UNIVERSIDADE DE SÃO PAULO - USP

PROGRAMA DE PÓS-GRADUAÇÃO EM ARQUITETURA E URBANISMO

ÁREA DE CONCENTRAÇÃO HABITAT

SARA VIEIRA ROSA

ACUMULAÇÃO E “VALORIZAÇÃO” PELA NATUREZA NO
PROCESSO DE PRODUÇÃO CAPITALISTA DA CIDADE DE

FORTALEZA 
ACUMULAÇÃO E “VALORIZAÇÃO” PELA NATUREZA NO PROCESSO DE PRODUÇÃO CAPITALISTA DA CIDADE DE FORTALEZA 


\section{ACUMULAÇÃO E “VALORIZAÇÃO” PELA NATUREZA NO PROCESSO DE PRODUÇÃO CAPITALISTA DA CIDADE DE FORTALEZA}

Tese apresentada a Faculdade de Arquitetura e Urbanismo da Universidade de São Paulo para obtenção do título de Doutor em Ciências.

Área de Concentração: Habitat Orientador: Prof. Maria Camila D’Ottaviano

EXEMPLAR REVISADO E ALTERADO EM RELAÇÃO À VERSÃO ORIGINAL SOB RESPONSABILIDADE DA AUTORA E ANUÊNCIA DA ORIENTADORA. 
Autorizo a reprodução e divulgação total ou parcial deste trabalho, por qualquer meio convencional ou eletrônico, para fins de estudo e pesquisa, desde que citada a fonte.

Rosa, Sara Vieira Rosa

Acumulação e "Valorização" pela Natureza no processo de produção capitalista da cidade de Fortaleza / Sara Vieira Rosa Rosa; orientadora Maria Camila Lofredo D'ottaviano. São Paulo, 2019.

$352 \mathrm{p}$.

Tese (Doutorado) - Faculdade de Arquitetura e Urbanismo da Universidade de São Paulo. Área de concentração: Habitat.

1. Natureza. 2. Acumulação Por Espoliação. 3. Valorização. 4. Mercantilização da Natureza. I. D'ottaviano, Maria Camila Lofredo, orient. II. Título.

Elaborada eletronicamente através do formulário disponível em: $\langle$ http://www.fau.usp.br/fichacatalografica/ $>$ 
Nome: ROSA, Sara Vieira

Título: Acumulação e "Valorização" pela Natureza no processo de produção capitalista da cidade de Fortaleza

Tese apresentada a Faculdade de Arquitetura e Urbanismo da Universidade de São Paulo para obtenção do título de Doutor em Ciências.

Área de Concentração: Habitat

Aprovado em:

I I

\section{Banca Examinadora}

1.

Instituição

Julgamento

2.

Instituição

Julgamento

3.

Instituição

Julgamento

4.

Instituição

Julgamento

5.

Instituição

Julgamento 
ACUMULAÇÃO E “VALORIZAÇÃO” PELA NATUREZA NO PROCESSO DE PRODUÇÃO CAPITALISTA DA CIDADE DE FORTALEZA 
a todos os seres espoliados e explorados 
ACUMULAÇÃO E “VALORIZAÇÃO” PELA NATUREZA NO PROCESSO DE PRODUÇÃO CAPITALISTA DA CIDADE DE FORTALEZA 


\section{Agradecimentos}

Ao meu querido companheiro, amante e amigo, Rafael, por trazer paz e tranquilidade a minha vida, pela paciência de todos os dias, em especial na reta final de produção dessa tese. Também pela revisão do texto, mesmo que enviado aos pedaços, trancos e barrancos.

Aos queridos amigos do cativeiro da tese que libertam. Hulda, Camila, Victor, Pedro, Larissa, Rerisson, e Fernanda, pela companhia, debates, cervejas, risadas, lágrimas e apoio, etc.

A Cecilia, Celso e Levi pelos momentos de alegria e esperança. Aos quais peço desculpas pela pouca presença esses últimos meses.

A Regina Lins por me receber em sua casa. Por seu apoio e companhia. Pelas sopas deliciosas e pela descontração nas aulas de yoga e saídas.

Ao amigo e eterno orientador, Renato Pequeno, sempre presente e paciente. A este agradeço pela oportunidade de iniciação científica na graduação e por todo o percurso como pesquisadora no LEHAU e LEHAB, tão importantes na minha formação. As conversas, mesmo que rápidas, sobre a tese e sobre a vida. E por encarar a coordenação do LEHAB e oferecer um espaço tão importante para a formação dos alunos e para a cidade.

A orientadora Camila, por seu apoio e confiança. Por encarar e apoiar uma mudança de tema no meio do doutorado. Pela predisposição, alegria e capacidade de sempre conseguir encaixar um horário na sua agenda.

A grande família Hulda, Pedro, Otacilio e Violeta pelas hospedagens, apoio e momentos de descontração.

A minha prima Cris e meus tios, também pela hospedagem, preocupação, atenção e carinho.

A Camila A., pela leitura e comentários desta tese, mesmo que com o texto ainda bastante incompleto. A ela e ao Rafael também agradeço pelos momentos de debates delirantes sobre a terra e a fórmula trinitária no primeiro semestre do doutorado. 
Ao professor Paulo Cesar e Beatriz Rufino, pelas disciplinas e debates desafiadores e empolgantes. Agradeço a aproximação a conceitos que embasaram essa tese. A oportunidade de participar de algumas reuniões, da rede de pesquisa articulada pelo professor Paulo Cesar, com outros professores que também olham a natureza. A Bia também agradeço toda a tenção, acolhimento e momentos de conversa sobre a tese. Ao professor Paulo pela troca de e-mails, conversas sobre a terra, sobre natureza, sobre os textos. Esses momentos foram muito importantes para o desenvolvimento desse trabalho.

A todos os professores e funcionários da FAUUSP, em especial aos professores da disciplina da monitoria, Raquel, Beatriz, Lu Royer, Nabil e em especial Paula com quem tive mais contato, quem agradeço também toda a dedicação e entusiasmo.

Benjamin e Lilica pela companhia nas madrugadas de escrita.

Ao Eder pelo repasse de imagens áreas antigas de Fortaleza.

A Neiliane e as demais bibliotecárias da biblioteca do curso de arquitetura da UFC pelo acesso aos mapas.

Um agradecimento especial aos amigos(as), colegas e companheiros(as) de luta por uma cidade mais justa e habitável. A Valéria, Breno, Renato, Adriana, Marcela, Marcelo, Dona Fátima, Vivi, Bia, João, e tantos outros, entre estes os integrantes da Assembleia Popular pelo Direito à Cidade, da Frente de Luta por moradia, das zeis, do movimento ambiental, e não podia deixar de incluir aqui também todos aqueles que passaram pelo LEHAB e parceiros.

A minha família e a família do Rafael

Não podia deixar de agradecer a todas as amigas e amigos que se preocuparam comigo nessa reta final, que mesmo distante estiveram presentes e sempre oferecendo ajuda e carinho.

O presente trabalho foi realizado com apoio da Coordenação de Aperfeiçoamento de Pessoal de Nível Superior - Brasil (CAPES) - Código de Financiamento 001 


\section{Resumo}

ROSA, Sara Vieira. Acumulação e "Valorização" pela Natureza no processo de produção capitalista da cidade de Fortaleza. Tese (Doutorado) - Faculdade de Arquitetura e Urbanismo da Universidade de São Paulo. Área de concentração: Habitat, 2019

A conformação do capitalismo, desde suas origens até os dias de hoje, está baseada sobretudo na apropriação privada e violenta da natureza em processos de acumulação por espoliação, mais do que na busca da valorização no processo de produção em si. A história do Brasil, desde a colonização, é marcada pela apropriação privada e indevida de suas terras e de seus recursos, incluindo o roubo/sequestro do próprio homem (também natureza). Quando a natureza é obscurecida pela forma mercadoria, perdemos sua essência e passamos a enxergála apenas como valor, como mercadoria que pode ser trocada pela mercadoria dinheiro. Quem não tem dinheiro para comprar passa a não ter acesso, nem direito de uso sobre a natureza. Quem pode comprar compra a propriedade privada sobre esta, que lhe confere, no caso da terra, um duplo monopólio, incluindo o direito de degradar. Contraditoriamente, no mundo das mercadorias, se algo não tem valor não tem reconhecimento social. As crises ambientais da segunda metade do século XX, levaram ao surgimento de teorias econômicas que passaram a incorporar a preocupação com a questão ambiental e a contestar o modelo neoclássico convencional. Desde então, tem-se por vezes uma tentativa de conciliar o crescimento econômico com a preservação ambiental. No campo do planejamento e do direito urbano, houve uma evolução da legislação ambiental. Passou-se a adotar, entre outras medidas, a demarcação de áreas ambientalmente mais frágeis ou de maior relevância ambiental e a regulamentar restrições no seu uso. Esses pedaços de natureza demarcados passariam a ter reconhecimento social, porém nem sempre o têm e permanecem ora como obstáculo à expansão de processos acumulativos, ora como oportunidade de potencializar capitalização de rendas. A presente tese tem como hipótese que a natureza entra como categoria importante no processo de acumulação e valorização do capital imobiliário urbano, pautado muito mais na capitalização de valor do que na produção de valor, resultando em processos espoliativos atuantes desde as origens do capitalismo até os dias de hoje. Tomando como análise o caso da cidade de Fortaleza, nosso objetivo é compreender os processos de acumulação e valorização do capital imobiliário a partir da natureza. Para isso, procuramos: 1 - Identificar e analisar os casos de acumulação por espoliação de bens comuns (natureza), no quadro da história recente de Fortaleza; 2 - Compreender o papel da mercantilização da natureza no processo de valorização imobiliária em Fortaleza; 3 -Compreender as estratégias, ferramentas e mecanismos, dentro do marco do planejamento urbano, que têm sido utilizadas para apropriação privada da natureza, bem como potencialização de processos de acumulação, valorização e capitalização.

Palavras chaves: 1. Natureza. 2. Acumulação Por Espoliação. 3. Valorização. 4. Mercantilização Da Natureza 


\section{Abstract}

ROSA, Sara Vieira Rosa. Acumulação e "Valorização" pela Natureza no processo de produção capitalista da cidade de Fortaleza. Tese (Doutorado) - Faculdade de Arquitetura e Urbanismo da Universidade de São Paulo. Área de concentração: Habitat, 2019

The conformation of capitalism, from its origins to the present day, is based above all on the private and violent appropriation of nature in processes of accumulation by spoliation, rather than in the search for valorization in the process of production itself. The history of Brazil since colonization is marked by the private and undue appropriation of its lands and resources, including the robbery / abduction of man himself (also nature). When nature is obscured by commodity form we lose its essence and we see it only as value, as commodity that can be exchanged for commodity money. Once it is a commodity, access to it happens to be only by the exchange of commodity, commodity money. If you do not have the money to buy it, you do not have access or use rights over it. Whoever can buy, buys private property on this, which gives it dual monopoly, including the right to degrade. On the other hand, in the world of commodities, if something has no value, it has no social recognition. The environmental crises of the second half of the twentieth century, especially those of the 1970s, led to the emergence of economic theories that began to reincorporate concern about the environmental issue and to challenge the conventional neoclassical model. Since then, there has been an attempt to reconcile economic growth with environmental preservation. In the field of planning and urban law there has been an evolution of environmental legislation since then that has adopted, among other measures, the demarcation of environmentally more fragile areas or of greater environmental relevance and to regulate restrictions of use in these. The present thesis assumes that nature enters as an important category in the process of accumulation and valorization of urban real estate capital, based much more on the capitalization of value than on the production of value and resulting, therefore, in spoliation processes that cross from the beginning of capitalism to the present day. Taking as an analysis the case of the city of Fortaleza has as general objective to understand the processes of accumulation and valorization / capitalization of real estate capital from nature, and as specific objectives: 1 - Identify and analyze the cases of accumulation by spoliation of common goods nature), within the recent history of Fortaleza; 2 - Understand the role of the commodification of nature in the real estate valuation process in Fortaleza; 3 - Understand the strategies, tools and mechanisms, within the framework of urban planning, that have been used for the private appropriation of nature, as well as potentialization of accumulation, valorization and capitalization processes.

Key words: 1. Nature. 2. Accumulation by Spoliation. 3. Valuation. 4. Nature Merchanization 


\section{Lista de figuras}

Figura 1. Região Metropolitana de Fortaleza. 42

Figura 2. Levantamento dos assentamentos precários por tipo e dos vazios urbanos, segundo Plhisfor (2012) 45

Figura 3. Porcentagem de domicílios não ligados a redegeral de esgoto (IBGE, 2010 - setores censitários) 46

Figura 4. Renda média mensal domiciliar (IBGE, 2010 - setores censitários) 46

Figura 5. Bacias Hidrográficas de Fortaleza. 47

Figura 6. Hipsometria - fortaleza 48

Figura 7. Sistemas Ambientais de Fortaleza 49

Figura 8. Linha do Tempo com os principais marcos regulatórios mencionados no capítulo sobre os índios. 86

Figura 9. Loteamentos aprovados em Fortaleza entre as décadas de 1930 e 2000. 91

Figura 10. Salinas do Cocó / Postal Salinas Diogo 96

Figura 11. Bairro Vila Velha, antiga Salina Vila Velha. 96

Figura 12. Carta da Cidade de Fortaleza e Arredores em 1945. 97

Figura 13. Ortofoto de Fortaleza na década de 1950, possível ano de 1958 98

Figura 14. Mosaico de imagem aérea do Google Earth, 2018. 99

Figura 15. Avenida Aguanambi no ano de sua inauguração, 1972 102

Figura 16. Riacho Água Nambi e Riacho Tauape 102

Figura 17. Riacho Água Nambi e Riacho Tauape 1945 versus loteamentos e malha urbana atual 103

Figura 18. Riacho Água Nambi 103

Figura 19. Lagoa do Tauape - sobreposição hidrografia de 1945 com imagem aérea de 2018 105

Figura 20. Lagoa do Tauape 105

Figura 21. Lagoa do Tauape e loteamentos do entorno - sobreposição hidrografia de 1945 com imagem aérea de 2018 106

Figura 22. Planta de parcelamento do Sítio Cocó de propriedade da imobiliária Antônio Diogo 107

Figura 23. Coco e dunas do Papicu, 1958 108 
Figura 24. Dunas do Mucuripe e do Papicu - 1981. 109

Figura 25. Dunas do Mucuripe e do Papicu - 2018. 109

Figura 26. Salinas do Cocó e Shopping Iguatemi. 110

Figura 27. Salinas Diogo 111

Figura 28. Trecho do Rio Coco mostrando a retificação de seu leito - 1972 112

Figura 29. Foto do Shopping Iguatemi na segunda metade da década de 1980. 113

Figura 30. Loteamentos aprovados pertencente a membros da família Jereissati segundo base da PMF 115

Figura 31. Iguatemi - expansão dos loteamentos por década e seus proprietários 119

Figura 32. Loteamentos segundo base da PMF no entorno da Av. Washington Soares. 119

Figura 33. Loteamento José de Alencar (parque sobre a Lagoa da Sapiranga) 120

Figura 34. Localização do Bairro Sabiaguaba e identificação de seus sistemas ambientais 121

Figura 35. Núcleo de casas na Sabia-naba, levantadas em 1945. 125

Figura 36. Núcleo de casas na lagoa da Jaraberaba, levantadas em 1945. 126

Figura 37. Cartografia social do uso do território da Sabiaguaba 129

Figura 38. Localização Comunidades Tradicionais identificadas durante o trabalho 131

Figura 39. Sabia-naba (Sabiaguaba) - Levantamento segundo Carta de Fortaleza e arredores de 1945. 132

Figura 40. Levantamentos na Sabiaguaba e arredores da década de 1930 a 20000. 133

Figura 41. Loteamento da Praia Sabiaguá - Sabiaguaba (praia) aprovado em 1971. 134

Figura 42. Zoom Loteamento Praia da Sabiaguaba. 134

Figura 43. Loteamento Parque Entre Rios 136

Figura 44. Plano Diretor Hélio Modesto - levantamento acidentes naturais, áreas livres, locais de interesse paisagístico 152

Figura 45. Plano Diretor da Cidade de Fortaleza, elaborado por Hélio Modesto, 1962. 154

Figura 46. LUOS 1975 155

Figura 47. Zoneamento - LUOS de 1979 155

Figura 48. Macrozoneamento e zonas especiais do PDDU (1992) e LUOS (1996) 158

Figura 49. Macrozona urbana e macrozona ambiental do PDP-2009 de Fortaleza. 159

Figura 50. Áreas especiais ambientais - PDDU-1992/LUOS-1996 166

Figura 51. Zonemento Ambiental do PDP-2009 166 
Figura 52. Operações Urbanas Consorciadas em Fortaleza, aprovadas e com lei publicada no Diário Oficial do Município, entre 2000 e 2017.

Figura 53. Localização das OUC frente ao zoneamento ambiental do município segundo Zoneamento do PDP-2009.

Figura 54. OUCs aprovadas frente ao zoneamento ambiental do município segundo PDDU de 1992 e LUOS de 1996.

Figura 55. Parque Otacílio Teixeira Lima Neto - Bisão (Riacho Maceió) e Terreno 185

Figura 56. Anexo I da lei 8503/2000. Zoneamento segundo PDDU 1992 e LUOS 1996 para a área da OUC do Riacho Maceió

Figura 57. Anexo II da lei 8503/2000. Zoneamento proposto pela OUC do Riacho Maceió 188 Figura 58. Comparação zoneamento ambiental PDDU-1992 e PDP-2009 sobre o Riacho Maceió 188

Figura 59. OUC Riacho Maceió e limite do terreno de marinha 190

Figura 60. Anexo da lei 8.915/2004. Zoneamento segundo PD 1992 e LUOS 1996 para a área da OUC Dunas do Cocó 191

Figura 61. Concentração de venda de imóveis prediais segundo registros de transações do ITBI (2009 a março de 2016) e valor do solo residencial segundo IPTU (2015) 195

Figura 62. Transações de imóveis prediais (ITBI) + valor do solo + empreendimentos de empresas capital fechado. 197

Figura 63. Transações de imóveis prediais (ITBI) + valor do solo + empreendimentos de empresas capital aberto. 197

Figura 64. Preço do $\mathrm{m}^{2}$ do imóvel residencial em Fortaleza segundo IPTU de 2015. 198

Figura 65. Preço do $\mathrm{m}^{2}$ do imóvel territorial em Fortaleza segundo IPTU de 2015. 198

Figura 66. OUC Riacho Maceio e OUC Lagoa do Papicu frente a dinamização do mercado imobiliário. 200

Figura 67. Imagem aérea do terreno a OUC do Riacho Maceió, ainda com as últimas casas por serem removidas. 201

Figura 68. Vila de pescadores do Mucuripe na década de 1930. 203

Figura 69. Assentamentos Precários (PLHIS-FOR, 2012) e OUCs aprovadas. 206

Figura 70. OUC Riacho Maceió. Ocupações prévias à Operação. Removidas. 208

Figura 71. Localização atual de moradia de algumas famílias removidas da OUC Riacho Maceió utilizadas como exemplo pela Norpar. 210 
Figura 72. Evolução da OUC do Riacho Maceió. 210

Figura 73. Fotos da área do Parque do Riacho Maceió mostrando o resto de construções demolidas. 211

Figura 74. Trecho da Comunidade Areias que ocupava parte do leito viário da Rua César Fonseca 213

Figura 75. Conjunto do Reassentamento do Gengibre. 213

Figura 76. Localização comunidade das Areias e Conjunto de HIS do Reassentamento da comunidade do Gengibre. 214

Figura 77. Projeto Lagoa do Papicu - HABITAFOR/PAC - Programa de Aceleração do Crescimento do Governo Federal 217

Figura 78. evolução da ocupação da comunidade do Pau Fininho - Lagoa do Papicu 217

Figura 79. Shopping Rio Mar e Urbanização da Lagoa do Papicu. 219

Figura 80. Anexo 2 da Lei Complementar n. 202 de 2015. 232

Figura 81. Sobreposição da base cartográfica referente a ZPA1 da Lei do Plano Diretor aprovada em 2009 e base cartográfica disponibilizada pela SEUMA em 2015 em seu site. 233 Figura 82. Zoneamento Ambienta de Fortaleza segundo PDP 2009 236

Figura 83. Espacialização a partir das coordenadas geográficas da ZRA publicada no DO no 14.020 - Lei $62 / 2009$ 236

Figura 84. Macrozoneamento Lei no 250/2018. 238

Figura 85. APA da Sabiaguaba e Zoneamento Ambiental segundo PDP 2009 260

Figura 86. Vista da CE 010 em construção, sentido Sabiaguaba-Eusébio. 263

Figura 87. Vista de terrenos a venda dentro do Parque das Dunas da Sabiaguaba cortado pela CE 010 263

Figura 88. Ocupações recentes na beira da CE 010 em construção. 263

Figura 89. Vista de parte do Parque das Dunas da Sabiaguaba da CE 010. 264

Figura 90. Operações Urbanas Consorciadas aprovadas e propostas em Fortaleza 267

Figura 91. Operações urbanas selecionadas pelo município como prioritárias 269

Figura 92. Ideia de OUC para área do 23 batalhão, ReCS Architects. Cliente: sinduscon 269 Figura 93 271

Figura 94. Cruzamento do zoneamento ambiental do PDP de Fortaleza com o número de registro de vendas de imóveis prediais e territoriais que deram entrada no ITBI entre os períodos de 2009 a setembro de 2016. 
Figura 95. Transações imobiliárias em área de ZRA - ITBI 2009 a setembro de 2016.

Figura 96. Transações imobiliária territoriais e prediais nas ZRAs do Iguatem e Cocó e entorno.

Figura 97. Transações imobiliária territoriais e prediais na área da OUC do Riacho Maceió e entorno. 275

Figura 98. Transações imobiliária territoriais e prediais no bairro Presidente Kennedy e entorno.

Figura 99. Transações imobiliária territoriais e prediais na área da OUC Osório de Paiva e entorno. 276

Figura 100. Transações imobiliárias em área de ZIA - ITBI 2009 a setembro de 2016 277

Figura 101. Transações imobiliárias em área de ZIA da Praia do Futuro e Cocó - ITBI 2009 a setembro de 2016 278

Figura 102. Transações imobiliárias em área da OUC da Lagoa da Sapiranga - ITBI 2009 a setembro de 2016 278

Figura 103.Dunas da ZIA do Cocó. 279

Figura 104. Transações imobiliárias na ZIA e APA da Sabiaguaba - ITBI 2009 a setembro de 2016 280

Figura 105. Dunas da APA da Sabiaguaba. 280

Figura 106. Imóveis territoriais a venda na Sabiaguaba. 281

Figura 107. Ocupações ao longo da Rodovia que está sendo aberta pelo município na APA da Sabiaguaba. 283

Figura 108. Transações imobiliárias em área de ZPA - ITBI 2009 a setembro de 2016 283

Figura 109. Identificação dos lotes com cobrança de ITBI na ZPA da Sabiaguaba, foz do rio Cocó. 284

Figura 110. Identificação dos lotes com cobrança de ITBI na ZPA e APA da Sabiaguaba. ITBI 2009 a set. de 2016 . 284

Figura 111. Transações imobiliárias territorial e predial dentro da APA da Sabiaguaba 285

Figura 112. Iguatemi Tower 288

Figura 113. Interface mostrando o processo de marcação dos pontos de controle 316

Figura 114. Relatório gerado automaticamente pelo J Rectifier descrevendo e identificando os pontos de controle e opções escolhidas para o georreferenciamento. 317

Figura 115. Levantamento empreendimentos de empresas de capital fechado 322 
Figura 116. Levantamento empreendimentos de empresa de capital aberto 323

Figura 117. Levantamento empreendimentos de empresa de capital aberto tipo incorporação 323

Figura 118. Levantamento empreendimentos de empresa de capital aberto tipo construção 324

Figura 119. Concentração de transações de imóveis prediais segundo dados do ITBI (2009 a março de 2016) 344

Figura 120. Concentração de transações de imóveis prediais segundo ITBI ao longo da Av. Santos Dumont. 345

Figura 121. Concentração de transações de imóveis prediais segundo ITBI /Av. W. Soares/Luc. Cavalcante 345

Figura 122. Concentração de transações de imóveis prediais segundo dados do ITBI /Av. W. Soares/Sapiranga e Cambeba. 346

Figura 123. Diferença do limite municipal do PDP-2009 para 2015 347

Figura 124. Localização das OUC frente ao zoneamento ambiental do município segundo Zoneamento do PDP-2009 atualizado pela SEUMA em 2015. 356

Figura 125. IBI por valor e outorgas 357 


\section{Lista de quadros}

Quadro 1. Loteamentos pertencentes à família Jereissati registrados na base da Prefeitura 114

Quadro 2. Comparação dos parâmetros urbanos das zonas de proteção ambiental da versão da minuta do PDP de 2007/P.L. enviada à Câmara em 2008 e versão da lei publicada no Diário Oficial do Município em 2009. 163

Quadro 3. Comparação de parâmetros das áreas de proteção e preservação do PDDU1992/LUOS-1996 e PDP-2009 165

Quadro 4. Parâmetros urbanos para a área de orla marítima segundo PDDU-1992 e LUOS 1996. 165

Quadro 5. Operações Urbanas Consorciadas (OUCs) aprovadas em Fortaleza até 2015 _ 175

Quadro 6. Objetivos das OUCs aprovadas. 178

Quadro 7. OUCs e zoneamento ambiental (PDP-2009) 181

Quadro 8. Sistematização da flexibilização trazida com cada OUC aprovada em Fortaleza 193 Quadro 9. Atores das OUC. Setor público e setor privado vinculados nas Leis de cada OUCs. 201

Quadro 10. Comunidades atingidas pelas OUCS 205

Quadro 11. Comparativo entre os I.A. básico e máximo definidos pelo Plano Diretor Participativo (2009) 239

Quadro 12. Enquadramento da Minuta de Decreto em análise. Fonte: Lei 10.335/2015; lei 10.431/2015; minuta de decreto de 2016. 249

Quadro 13. Indicação do uso da Outorga Onerosa de Alteração do Uso e do Direito de Construir para o macrozoneamento urbano, segundo PDP 2009 252

Quadro 14. Definição, objetivos e instrumentos previstos pelo PDPFor para as Zonas de proteção ambiental ZIA e ZRA. Fonte: Fortaleza/PDPfor, 2009 258

Quadro 15. Parâmetros urbanos das zonas de proteção ambiental segundo PDP 2009 286

Quadro 16. Total de imóveis prediais registrados na Base de dados do ITBI após a aprovação do PDP (13/03/2009) por número de pavimentos da edificação. 286

Quadro 17. Padrão das edificações que tiveram ITBI cobrados em áreas de proteção ambiental no período de 2009 a setembro de 2016 segundo a SEFIN 289

Quadro 18. Exemplo levantamento inicial. 320 
Quadro 19. Instrumentos indicados pelo PDP para cada zona, macrozoneamento ambiental e zonas especiais de interesse social 339

Quadro 20. Instrumentos indicados pelo PDP para cada zona, macrozoneamento urbano 340

Quadro 21. Obrigações do setor público e setor privado que assinam as Operações 341 


\section{Lista de tabelas}

Tabela 1. População residente estimada - Fortaleza 1980 a 2018.

Tabela 2. Porcentagem de domicílios por rendimento per capita, em salário mínimo (IBGE, 2010) - \% 45

Tabela 3. Total de imóveis registrados no ITBI dentro das zonas ambientais de Fortaleza, por ano de registro. 272

Tabela 4. Total de imóveis registrados no ITBI dentro das zonas ambientais de Fortaleza, por ano e tipo de imóvel. 272

Tabela 5. Tipo de ocupação do imóvel edificado vendido 272

Tabela 6 289 


\section{Lista de Siglas e abreviações}

AEA - área especial aeroportuária do zoneamento do PDDU-1992

AIA - área de interesse ambiental do zoneamento do PDDU-1992

AP - área de preservação do zoneamento do PDDU-1992

APA - Área de Proteção Ambiental - categoria de Unidade de Conservação definida pelo

Sistema Nacional de Unidades de Conservação

APE - área de proteção do zoneamento do PDDU-1992

APP - Área de Preservação Permanente definida pelo Código Florestal

ARIE - Área de relevante Interesse Ecológico

AOM - área de orla marítima do zoneamento do PDDU-1992

CF - Constituição Federal de 1988

CGS - Conselho Gestor da Sabiaguaba

COMAM - Conselho Municipal do Meio Ambiente de Fortaleza

CPAC - Certificado de Potencial Adicional de Construção

CPPD - Comissão Permanente de Avaliação do Plano Diretor

CRI - Certificados de recebíveis imobiliários

HIS - Habitação de Interesse Social

I.A. - Índice de Aproveitamento

IBGE - Instituto Brasileiro de Geografia e Estatística

IPTU - Imposto Predial e Territorial urbano

ITBI - Imposto de Transferência de Bens e imóveis

IVV - Índice de Velocidade de Venda 
L.C. - Lei Complementar

LEHAB - Laboratório de Estudos da Habitação da Universidade Federal do Ceará

LUOS - Lei de Uso e Ocupação do Solo

LPUOS - Lei de Parcelamento, Uso e Ocupação do Solo

LO - Lei Orgânica do Município de Fortaleza

MCMV - Minha Casa Minha Vida

ONU - Organizações das Nações Unidas

OUC - Operação Urbana Consorciada

PAC - Programa de Aceleração do Crescimento (Governo Federal)

PDP - Plano Diretor Participativo de Fortaleza aprovado em 2009 e vigente até a data da presente tese

PDDU - Plano Diretor de Desenvolvimento Urbano

PDCF - Plano Diretor da Cidade de Fortaleza (Plano de Hélio Modesto de 1963)

P.L. - Projeto de Lei

PLANDIRF - Plano de Desenvolvimento Integrado da Região Metropolitana de Fortaleza de 1972

PLHIS - Plano Local de Habitação de Interesse Social

PLHISFor - Plano Local de Habitação de Interesse Social de Fortaleza

PMCMV - Programa Minha Casa Minha Vida

PMF - Prefeitura Municipal de Fortaleza

PNMDS - Parque Natural Municipal das Dunas de Sabiaguaba

RMF - Região Metropolitana de Fortaleza

SEMA - Secretaria Estadual de Meio Ambiente do Ceará 
SEMACE - Superintendência Estadual do Meio Ambiente

SEUMA - Secretaria de Urbanismo e Meio ambiente de Fortaleza

SEFIN - Secretaria Municipal de Finanças de Fortaleza

SEINF - Secretaria Municipal de infraestrutura

SINDUSCON-CE - Sindicato da Indústria da Construção Civil do Estado do Ceará (sindicato das construtoras)

SNUC - Sistema Nacional de Unidades de Conservação (Lei Federal n 9985, de 18 de julho de 2000)

UC - Unidades de Conservação

UH - Unidade habitacional

ZEIS 1 - Zonas Especiais de Interesse Social tipo ocupação definida pelo PDP de 2009

ZEIS 2 - Zonas Especiais de Interesse Social tipo conjuntos habitacionais definida pelo PDP de 2009

ZEIS 3 - Zonas Especiais de Interesse Social tipo vazios definida pelo PDP de 2009 destinadas para a construção de HIS

ZIA - Zona de Interesse Ambiental definida pelo PDP de 2009

ZPA - Zona de Preservação Ambiental definida pelo PDP de 2009

ZRA - Zona de Recuperação Ambiental definida pelo PDP de 2009

ZU.4 = zona urbana 4 do zoneamento do PDDU-1992

ZO4 - zona de orla 4 do zoneamento do PDP-2009

ZRU - zona de requalificação urbana do zoneamento do PDP-2009

ZOP - zona de ocupação prioritária do zoneamento do PDP-2009 


\section{SUMÁRIO}

INTRODUÇÃO

Sobre Fortaleza: apresentação geral

41

CAP.01. ACUMULAÇÃO PELA NATUREZA 53

1.1. A natureza no processo de acumulação primitiva 55

Natureza: riqueza comum 55

Natureza: riqueza apropriada privativamente - o papel da terra e do ser humano no processo de acumulação primitiva

Quebra do metabolismo e alienação 60

O surgimento da economia como sistema fechado e isolado da natureza 62

A reincorporação da natureza nas teorias econômicas 67

1.2. A natureza no processo de acumulação em Fortaleza - espoliação de um bem comum 72

Apropriação privada da terra no Ceará: Para além da Lei de Terras, genocídio etnocídio e embraquecimento dos índios no século XIX 77

Acumulação por espoliação no imobiliário em Fortaleza no século XX, expansão dos loteamentos e negação da natureza

Consolidação de um mercado de terras e expansão dos loteamentos em Fortaleza 88

Natureza como barreira a ser dominada, apropriada privativamente e ocupada. 93

1.3. Considerações sobre o capítulo 01 136

CAP. 02. "VALORIZAÇÃO” PELA NATUREZA 141

2.1. O fetiche da mercadoria natureza 142

2.2. Desmercantilização estatal da mercadoria Natureza 144

Correntes ecológicas e rebatimento sobre a regulamentação urbana 147

A conservação da natureza no marco normativo urbano municipal 149

2.3. Do antivalor ao valor: $\mathrm{O}$ caso das Operações Urbanas Consorciadas aprovadas em Fortaleza 168

Operações Urbanas Consorciadas aprovadas em Fortaleza 173

Do antivalor à possibilidade de valor e remercantilização estatal de áreas de proteção e preservação ambiental 180 
Áreas de "valorização" imobiliária - potencialização da capitalização ou Inserção em áreas de valorização imobiliária e alto valor de troca ou concentração de geração de valor 193

Os espoliados e esquecidos no processo de acumulação e valorização pela natureza 202

2.4. Considerações finais do capítulo 02

\section{CAP. 03. APERFEIÇOAMENTO E EXTENSÃO DAS ESTRATÉGIAS DE ACUMULAÇÃO E "VALORIZAÇÃO" PELA NATUREZA}

\subsection{O zoneamento ambiental em Fortaleza e sua constante (des)regulamentação para potencializar} processos de acumulação e "valorização" pela natureza.

Proposta de alteração dos índices das Zonas do PDPfor 238

Sobre a Comissão Permanente de Avaliação do Plano Diretor (CPPD)

3.2. Outorga Onerosa do Direito de Construir e do Direito de Alterar Uso do Solo

Outorga Onerosa de Alteração de Uso do Solo - Lei no 10.335, de 01 de abril de 2015 e lei no 10.431, de 22 de dezembro de 2015

Minuta do Decreto da Outorga Onerosa de Alteração do Uso do Solo 254

Minuta de decreto de outorga onerosa de alteração de uso altera características essenciais da APA da Sabiaguaba

3.3. As novas Operações Urbanas: A cidade como uma grande operação urbana 266

Venda de imóveis em Zona de Recuperação Ambiental (ZRA) 273

Vendas de imóveis em Zona de Interesse Ambiental (ZIA)

Venda de imóveis em Zonas de Preservação Ambiental (ZPA) 281

Inadequação dos imóveis edificados em áreas de proteção 285

O padrão dos imóveis prediais vendidos dentro das áreas de proteção ambiental 288

3.5. Considerações finais do capítulo 03

I. Nota metodológica: Georreferenciamento Carta da Cidade de Fortaleza e Arredores de 1945 levantada e desenhada pelo Serviço de Geografia do Exército 316

II. Nota metodológica: Atualização base SIG de loteamentos da PMF a partir de cartografias 318

III. Nota metodológica: Levantamento empreendimentos de empresas de capital fechado e capital aberto. 
IV. Nota metodológica: Identificação da supressão das duas áreas de ZRA do Cocó do mapa de zoneamento divulgados pela SEUMA.

V. Roteiro das entrevistas realizadas.

VI. Instrumentos por zona do macrozoneamento urbanos de Fortaleza, segundo o Plano Diretor Participativo de Fortaleza, PDP-2009. 339

VII. Obrigações do setor público e setor privado que assinam as Operações 341

VIII. Mapas extras - dinâmica da produção imobiliária de mercado 344

\section{Anexos}

I. Decreto n. 426 de 24 de julho de 1845 - Regulamento acerca das missões de catechese e civilização dos índios. 349

II. Planta XXXXXXXXXXXXX 354

III. Planta XXXX 355

IV. OUCs e macrozoneamento ambiental do PDP-2009 atualizado e disponibilizado pela SEUMA em 2015 356 
ACUMULAÇÃO E "VALORIZAÇÃO” PELA NATUREZA NO PROCESSO DE PRODUÇÃO CAPITALISTA DA CIDADE DE FORTALEZA 
Se nós (entendido, aqui, como a civilização humana) entramos numa fase da história do capitalismo em que as consequências ambientais da acumulação no quadro da dominação mundial do capital financeiro tendem a materializar-se sob formas extremamente graves e num ritmo que se acelera, os mecanismos que levaram essa situação estavam presentes desde as origens do capitalismo (CHESNAIS e SERFATI, 2003, p. 40. Grifo meu). 


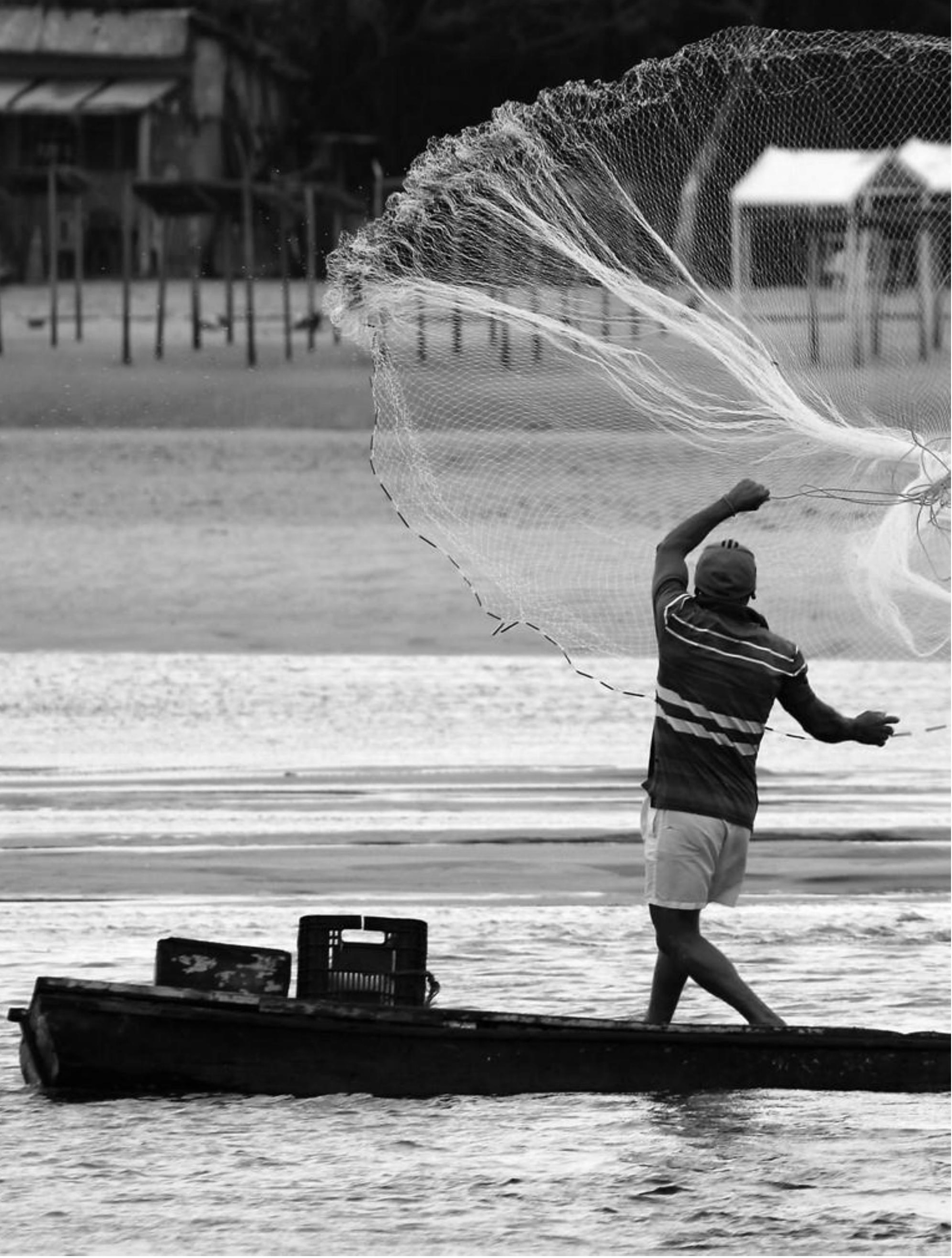




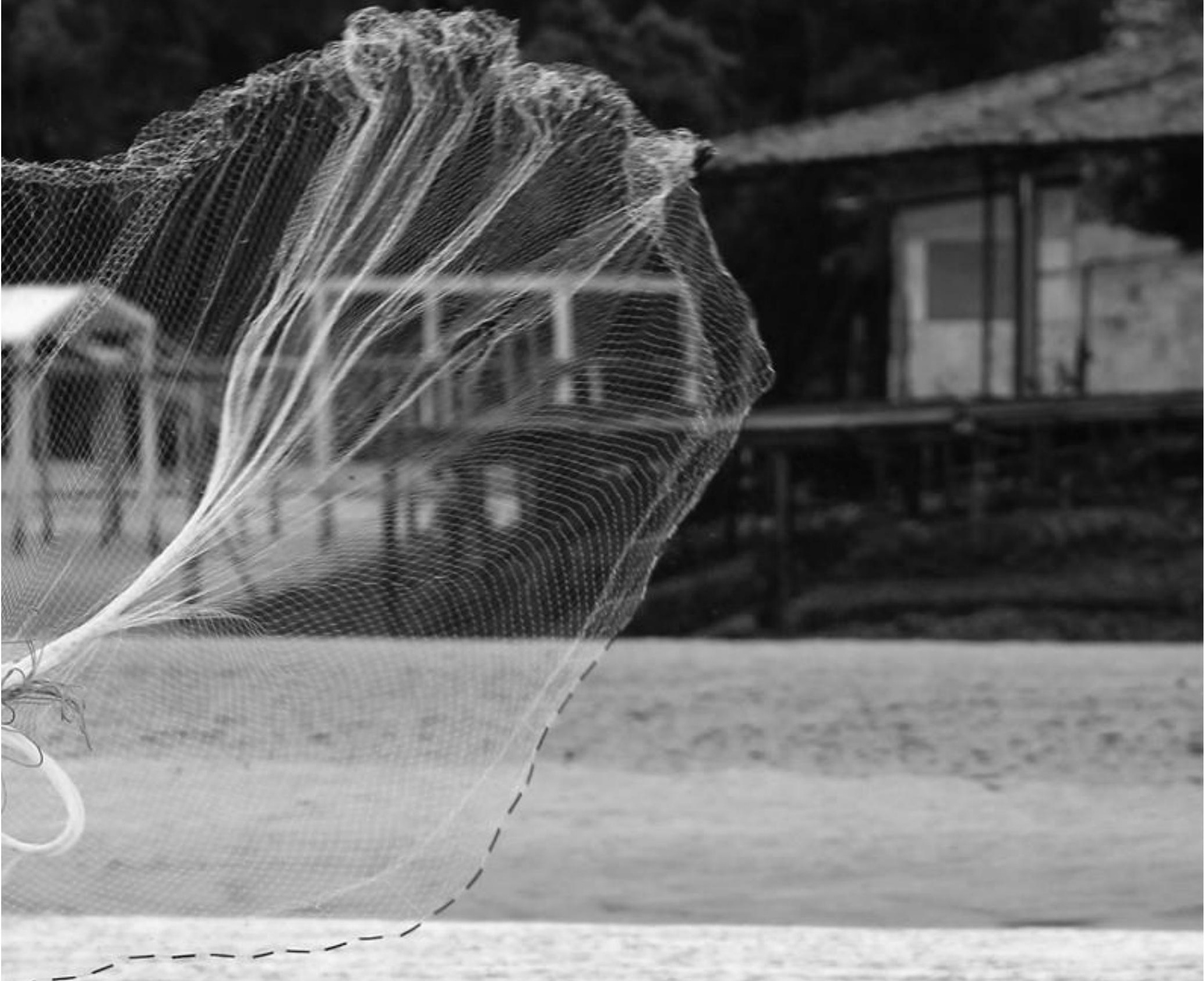

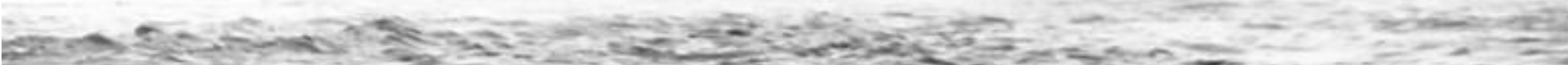

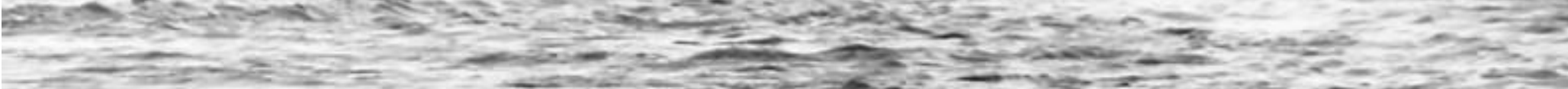
D.

20

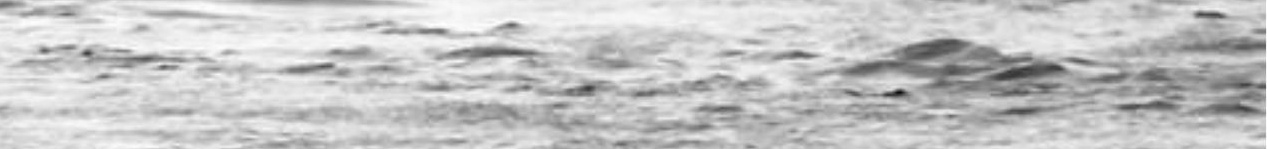


ACUMULAÇÃO E "VALORIZAÇÃO” PELA NATUREZA NO PROCESSO DE PRODUÇÃO CAPITALISTA DA CIDADE DE FORTALEZA

FOTO: SARA VIERA ROSA, 2017

PESCADOR DA BOCA DA BARRA

LOCAL: FOZ DO RIO COCÓ (BOCA DA BARRA) - SABIAGUABA - FORTALEZA, CE 


\title{
INTRODUÇÃO
}

\begin{abstract}
"A produção capitalista só desenvolve a técnica [...] esgotando as duas fontes das quais jorram toda a riqueza: a terra e o trabalhador" (MARX, Livro I, apud CHESNAIS e SERFATI, 2003, p. 49)
\end{abstract}

A conformação do capitalismo, desde suas origens até os dias de hoje, está baseada sobretudo na apropriação privada e violenta da natureza em processos de acumulação por espoliação, mais do que na busca da valorização no processo de produção em si. A história da formação do Brasil não é diferente, desde sua colonização, é marcada pela apropriação privada e indevida de suas terras e de seus recursos, incluindo o roubo/sequestro do próprio homem (também natureza).

Assim, para se desenvolver e se manter, o capital destrói a base que lhe sustenta. Ao mesmo tempo que ele é capaz de conseguir seu próprio pressuposto por meio de processos contínuos de acumulação por espoliação, ele destrói a base da sua acumulação capaz de fornecer riquezas, a natureza (a terra e o ser humano). Ou seja, ao conseguir seu pressuposto ele o destrói. Essa contradição do capitalismo foi apontada por Marx e vem sendo posta em destaque por autores, como Chesnais (2003) e Harvey (2016; 2018). Este último dedica uma seção inteira às "contradições perigosas" no seu livro "17 contradições e o fim do capitalismo".

Adiantamos que não se pretende nesta tese propor soluções ou maneiras de superar o possível esgotamento da terra e do homem, nem prever o seu fim. A ideia é tentar avançar um pouco mais na compreensão desta contradição e, à medida do possível, deixar subsídios para pensar as suas consequências no que tange à produção da cidade de Fortaleza.

Para isto, a terra, enquanto natureza, é um elemento chave que foi trabalhado ao longo dos capítulos, tentando não esquecer os seres que vivem sobre ela, sobretudo o homem, entendido aqui também como natureza.

A privatização da terra e a atribuição de um preço a ela mascaram o fato de que a sua existência independe de qualquer tempo de trabalho social necessário para sua produção. Mascaram o fato de que a terra é natureza, é algo que existia antes do ser humano e 
independe de sua força de trabalho. A moderna propriedade privada da terra mascara a expropriação de um bem de uso comum e necessário à sobrevivência de todos e, por sua vez, permite que toda a sociedade concorde em conferir a seu proprietário o direito de ser o único a usufruir deste. Mascara também a atribuição de preço (no caso, preço de monopólio MARX, 2017, p. 835-836) sem a necessária produção de valor, sobrecarregando outros setores de produção. Mascara processos extremamente violentos que sempre estiveram aí e permanecem até os dias de hoje.

Quando a natureza é obscurecida pela forma mercadoria, perdemos sua essência e passamos a enxergá-la como valor $^{1}$ (mesmo que não o seja) que se concretiza na forma mercadoria. Passamos a enxergá-la como mercadoria que pode ser trocada pela mercadoria dinheiro. Quem não tem dinheiro para comprar passa a não ter acesso, nem direito de uso sobre a natureza. Quem pode comprar compra a propriedade privada sobre ela la moderna propriedade privada), que lhe confere, no caso da terra, um duplo monopólio (monopólio do direito de exploração da terra com o fim de reprodução ou de extração, e o monopólio do espaço $)^{2}$, incluindo muitas vezes o direito de degradar.

Contraditoriamente, no mundo das mercadorias, se algo não tem valor, não tem reconhecimento social, pois as relações sociais se baseiam na troca de mercadorias. Assim, a natureza passa a ser socialmente reconhecida quando é atribuído valor a ela, fazendo com que o seu reconhecimento seja ao mesmo tempo o caminho para o seu esgotamento.

Esse processo de mercantilização da natureza, e sua consequente valoração, evolui à medida que a sociedade se transforma e muda seu conceito sobre a natureza, entendendo aqui o conceito de natureza como uma produção social, assim como à medida que o conceito do que é natureza evolui e muda, modifica-se o processo de mercantilização da natureza.

A natureza, enquanto meio biofísico que sustenta a vida, sempre esteve atrelada à produção da cidade - nos diferentes modos de produção (escravista, feudal, capitalista) e nas suas diferentes formas de produção (autoconstrução, estatal e de mercado - JARAMILLO, 1982) -

\footnotetext{
1 Marx (2011; 2013) explícita três tipos de valor, o valor de uso, o valor de troca e o valor. Este último é uma determinação social que cola no produto produzido pelo trabalho humano e é expresso na forma do valor de troca.

2 "Cabe aí considerar dois aspectos: a exploração da terra com o fim de reprodução ou de extração, e o espaço, elemento necessário a toda produção e a toda atividade humana. E a propriedade fundiária cobra seus tributos nos dois domínios." (Marx, Ed. Civilização Brasileira, p. 888).
} 
seja dando suporte à produção, oferecendo o espaço onde se constrói, seja dando suporte por meio dos materiais necessários a sua produção, insumos como areia, barro, ferro, pedra, etc. Contudo, com a consolidação da forma de produção imobiliária de mercado, sobretudo sob a forma incorporação (RUFINO, 2016), a natureza, enquanto conceito socialmente produzido, natureza simbólica, espaços verdes ${ }^{3}$, tem sido tão ou mais importante no processo de produção e valorização do capital imobiliário, quanto como meio biofísico que sustenta a produção. A concepção do que é natureza muda ao longo do tempo e das diferentes sociedades, ajustando as formas de acumulação de capital, assim como as necessidades de ajustes das formas de acumulação e de reprodução de capital mudam a concepção do que é natureza.

Cada vez mais, a concepção que a sociedade tem do que é natureza, do que deve ser ou não protegido e preservado, implica no maior ou menor preço de um produto imobiliário e na maior velocidade de sua venda, de sua concretização enquanto mercadoria. Seja na facilidade ou entraves de aprovação ou regularização de um empreendimento, ou no maior ou menor potencial construtivo de um terreno que as restrições ambientais aportam ao controle do uso e ocupação do solo; seja na maior ou menor incorporação de valor (mesmo que fictício) que a presença e o conceito de natureza trazem para um empreendimento aumentando seu preço de venda. Há um movimento tanto de transformação e destruição da primeira natureza para a produção de uma segunda natureza, urbana, como de reprodução de uma natureza simbólica enquanto primeira natureza (LEFEBVRE, 1999). Desta forma, "o espaço natural torna-se raridade que se especializa e gera desigualdades" (FERRARA, 2018, p. 138).

Assim, esta tese tem como hipótese que a natureza se constitui como categoria importante no processo de acumulação e valorização do capital imobiliário urbano, pautado muito mais na capitalização de valor do que na produção de valor, resultando em processos espoliativos que agem desde as origens do capitalismo aos dias de hoje.

Tomando como análise o caso da cidade de Fortaleza, tem-se como objetivo geral compreender os processos de acumulação, valorização e capitalização de capital no imobiliário a partir da natureza, e como objetivos específicos:

\footnotetext{
3 LEFEBVRE, 1999.
} 
1 - Identificar e analisar os casos de acumulação por espoliação de bens comuns (natureza), no quadro da história recente de Fortaleza;

2 - Compreender a importância da mercantilização da natureza no processo de valorização imobiliária em Fortaleza;

3 - Compreender as estratégias, ferramentas e mecanismos, dentro do marco do planejamento urbano, que têm sido utilizadas para apropriação privada da natureza, bem como na potencialização de processos de acumulação, valorização e capitalização.

O trabalho está dividido em três capítulos principais, além da introdução e das considerações finais, nos quais apresentamos os avanços obtidos em relação a cada objetivo específico. Deste modo, o capítulo 01, intitulado Acumulação pela natureza, busca fazer um resgate de conceitos como acumulação primitiva, acumulação por espoliação, apropriação privada versus apropriação coletiva e individual, espoliação e o rebatimento destes na Natureza. A partir deste ponto, é realizado um breve resgate histórico a partir de casos representativos de processos acumulativos que apropriaram privativamente a natureza (incluindo o ser humano), estabelecendo pressupostos para o desenvolvimento capitalista da cidade de Fortaleza. Todos os casos apresentados, desde a Coroa Portuguesa, às regras dos primeiros loteamentos, guardam a semelhança de serem baseados em processos espoliativos de apropriação privada da natureza e já apontavam o Estado como fundamental para a sustentação e naturalização desses processos.

As crises ambientais da segunda metade do século XX levaram ao crescimento de correntes ecológicas e ao surgimento de teorias econômicas que passaram a incorporar a preocupação com a questão ambiental e a contestar o modelo neoclássico convencional. O meio ambiente e a natureza passaram então a ser uma questão também de Estado. No campo do planejamento urbano e do direito, houve uma evolução da legislação ambiental e urbana que, desde então, passou a adotar, entre outras medidas, a demarcação de áreas ambientalmente mais frágeis ou mais relevantes e a regulamentar restrições ao seu uso e ocupação. Restrições estas que entraram em conflito com o duplo monopólio pertencente aos proprietários privados dessas terras, monopólio da natureza e do espaço, ferindo o direito socialmente construído de obter, a partir da propriedade privada, renda fundiária, extrativista e imobiliária. Observa-se então mobilizações do setor privado em busca de estratégias que 
permitam que se continue construindo e extraindo mais-valor nestas áreas, ao mesmo tempo em que buscam estratégias que permitam que as áreas preservadas, assim como a ideia de natureza e sustentabilidade, agreguem valor aos seus terrenos e empreendimentos imobiliários.

No segundo capítulo, "Valorização" pela natureza, sem esquecer os processos de acumulação (por espoliação), que permanecem, busca-se focar nos processos de valorização, investigando a ideia de que a valorização no imobiliário não ocorre somente por meio da produção, mas cada vez mais é baseada também em processos fictícios, que não envolvem trabalho, tendo a natureza como uma categoria importante. Toma-se como análise para ilustrar esses processos o caso das Operações Urbanas Consorciadas (OUCs) já aprovadas em Fortaleza.

No último capítulo, reforça-se a ideia da acumulação e valorização do capital imobiliário pela natureza, tentando compreender as estratégias, ferramentas e mecanismos, dentro do marco do planejamento urbano, que têm sido utilizadas atualmente para intensificação desses processos.

Para o desenvolvimento desta tese foram utilizadas diferentes estratégias e procedimentos metodológicos. O início, mais como pesquisa exploratória, foi marcado por estratégias de observação participante e pesquisa-ação, junto às atividades do LEHAB (Laboratório de Estudos em Habitação da Faculdade de Arquitetura e Urbanismo da Universidade Federal do Ceará) ${ }^{4}$, em pesquisa sobre o Direito à Cidade com metodologia que permitia um envolvimento maior com o objeto de pesquisa, incluindo a incidência nos processos, conselhos e assessoria técnica a algumas comunidades. Inicialmente, foram acompanhados o Conselho Municipal de Habitação Popular de Fortaleza (COMHAP); a Comissão Permanente

\footnotetext{
${ }^{4}$ O laboratório é coordenado pelo professor Renato Pequeno da UFC. Destaca-se que a inserção do laboratório com outras redes e núcleos de pesquisa também foi importante para o enriquecimento da experiência durante os processos de pesquisa e análise. Entre as parcerias ao longo do percurso, destacamos: o INCT Observatório das Metrópoles, o LabCidade da FAUUSP; o IPPUR/UFRJ no Rio de Janeiro; o Práxis e o Indisciplinar, da FAU/UFMG, em Belo Horizonte; além de parcerias locais com grupos de pesquisa, extensão e instituições de defesa dos direitos humanos, entre eles: Escritório de Direitos Humanos e Assessoria Jurídica Popular Frei Tito de Alencar (EFTA), Escritório de Direito Humanos e Assessoria Jurídica Popular Dom Aloísio Lorscheider (EDHAL), Núcleo de Habitação e Moradia da Defensoria Pública do Estado do Ceará (NUHAM), NIGÉRIA produções audiovisuais, Instituto Brasileiro de Direito Urbanístico (IBDU), entre outros.
} 
do Plano Diretor (CPPD) ${ }^{5}$, com projetos de lei que alteravam o Plano Diretor; comunidades demarcadas como ZEIS (Zonas Especiais de Interesse Social), entre outros.

Esse procedimento de pesquisa-ação que, por vezes, provoca embates, em especial com o Estado e o setor privado, foi parcialmente responsável pelo aumento da dificuldade na concessão de informações e de algumas entrevistas. Por outro lado, permitiu um constante contato com o objeto de estudo e com atores envolvidos, suprindo em muitos casos a dificuldade de acesso a informações e, muitas vezes, iluminando atores e alianças que não seriam revelados com outras estratégias.

Durante esse processo de acompanhamento, chamou atenção a constante e crescente desvirtuação dos instrumentos urbanísticos e da interpretação do Plano Diretor do município para legalizar projetos em desacordo com os parâmetros urbanísticos dispostos na legislação urbana vigente. Muitas vezes, a área em questão envolvia terrenos dentro das zonas de proteção e preservação ambiental, gerando conflitos socioambientais e políticos importantes na cidade. Noutros casos, observava-se a utilização do discurso sobre meio ambiente e sustentabilidade para justificar a aprovação de empreendimentos imobiliários em desacordo com a legislação e que suprimiam áreas de proteção ambiental.

Dentre os atores que ganhavam destaque nesses espaços estavam o mercado imobiliário, representado pelo Sindicato da Industria e da Construção Civil (SINDUSCON-CE), o governo municipal e o estadual. Esses dois grupos de atores trabalhavam muitas vezes juntos, contudo, em ocasiões de maior exposição pública, como em audiências públicas, o SINDUSCON atuava como observador, cabendo ao Estado fazer a defesa de suas propostas. Outros atores que apareciam nos processos eram as comunidades diretamente afetadas, a universidade e alguns movimentos sociais e ambientais.

Neste momento, foram formuladas as primeiras questões que nortearam a pesquisa desta tese que, depois de melhor trabalhadas, levaram à formulação da hipótese aqui apresentada. Dentre algumas das questões iniciais que apareceram, podemos destacar:

\footnotetext{
${ }^{5}$ Em Fortaleza a CPPD tem cumprido o papel do Conselho Municipal de Desenvolvimento Urbano (CMDU). Tem função consultiva e deliberativa, com representação do estado e da sociedade civil, porém as instituições e vagas foram elencadas pelo município sem passar por um processo de formação e eleição dentro de uma conferência com participação popular.
} 
- Quais são as principais áreas da cidade flexibilizadas e quais são os principais tipos de flexibilização? Existe flexibilização nas áreas de proteção e preservação ambiental? Que instrumentos urbanos estão sendo regulamentados, a quê e a quem eles atendem? Que leis para alterar a legislação urbana e ambiental estão sendo propostas? Elas flexibilizam os parâmetros existentes? Seu conteúdo é legal?

- Que impactos essa flexibilização poderá trazer para o território e para os diferentes atores envolvidos na produção do espaço de Fortaleza? Como essa flexibilização urbana e ambiental do território impacta nos processos de acumulação e reprodução do capital imobiliário?

- As leis que flexibilizam a legislação vigente são propostas por quem? Quem apoia? Quem teve a ideia? Quem são as pessoas/grupos que consomem a natureza como mercadoria em Fortaleza?

- Como foi o processo de acumulação primitiva em Fortaleza? Como se deu o processo inicial de formação do capital imobiliário de Fortaleza? Existiu um processo de acumulação pela natureza? Outros processos de acumulação por espoliação permaneceram?

- A intensificação da mercantilização de áreas de proteção e preservação ambiental deve-se ao fato de existir pouca terra bem localizada na cidade ou ao fato de que a natureza tem, cada vez mais, transformando-se em uma mercadoria que agrega valor aos empreendimentos imobiliários?

- De que forma o Estado tem corroborado ou até mesmo incentivado esse processo de mercantilização da natureza em Fortaleza?

- A intensificação da mercantilização da natureza levará a extinção do valor de uso desta?

As estratégias de observação participante e pesquisa-ação em alguns processos permaneceram até o final da tese, porém, à medida que a hipótese e os objetivos foram sendo melhor formulados, foi-se priorizando o acompanhamento de alguns espaços e comunidades mais específicos e ligados a questões ambientais. Intensificou-se o acompanhamento à CPPD, pois nesta passavam a análise e a aprovação dos projetos especiais, das minutas dos projetos de leis complementares de alteração do plano diretor, minutas de leis específicas de regulamentação de instrumentos urbanos, dentre outros. Como espaços novos, passou-se a 
acompanhar as reuniões do Conselho Gestor da Área de Proteção Ambiental (APA) da Sabiaguaba; do Conselho Municipal de Meio Ambiente (COMAM); do processo de revisão da Lei de Uso e Ocupação do Solo (LUOS); do Projeto Orla; e da comunidade da Sabiaguaba.

A revisão bibliográfica e documental, aliada a levantamentos de campo e realização de entrevistas exploratórias e entrevistas semiestruturadas, também foram de extrema importância no desenvolvimento da tese.

Dentro do levantamento documental, destacamos o levantamento e a análise de legislação pertinente; de atas das reuniões dos conselhos; cartografias e fotos aéreas antigas. Para as análises destas informações, destacamos a espacialização das informações no território e a utilização de sistema de informação geográfica para elaboração de mapas temáticos, o cruzamento das informações e a geração de novas informações. Maiores informações individualizadas para cada um desses procedimentos podem ser encontradas nas "notas metodológicas" dos apêndices dessa tese.

As entrevistas ocorreram, em sua maioria, com a utilização de roteiros semiestruturados para guiar os pontos que haviam interesse em serem abordados, porém algumas, de carácter mais exploratório, foram realizadas sem roteiro, a fim de que a conversa ocorresse com mais fluidez e permitisse ao entrevistado seguir suas memórias e lembranças. Destaca-se que muitas delas foram realizadas juntamente com a equipe do LEHAB e serviram para subsidiar tanto as pesquisas do laboratório como o desenvolvimento desta tese.

Dentre as entrevistas, destacamos aquelas realizadas: com agentes públicos da gestão municipal e estadual; com a Empresa Terra Brasilis responsável pela Operação Urbana Consorciada (OUC) do Riacho Maceió; e com moradores e ex-moradores de comunidades em risco de remoção por empreendimentos privados ou públicos que interferem na flexibilizações da legislação de proteção ambiental ou por demarcação de parques, com destaque para as comunidades do entorno da OUC do Riacho Maceió, OUC do Rio Mar, Foz do Rio Cocó e bairro Sabiaguaba. No apêndice, podem ser consultados a lista e os roteiros semiestruturados das principais entrevistas que entraram no escopo da tese.

Por fim, não se pode deixar de mencionar a matriz teórica utilizada na análise e construção dessa tese. Para isto, merecem destaque as disciplinas assistidas durante o período do doutorado, em especial a disciplina Da Construção da Casa à Indústria Imobiliária: Espaço e 
Política, ministrada pelo professor Paulo Cesar Xavier e Beatriz Rufino, e a disciplina Renda da Terra, ministrada pelo professor Paulo Cesar Xavier. A aproximação aos conceitos de valor, renda, preço, mercadoria, capitalização x produção, espoliação x exploração, capital fictício, somada aos debates na própria sala de aula ou em algumas reuniões, em que me foi dada a oportunidade de participar, da rede de pesquisa articulada pelo professor Paulo Cesar, com outros professores que também olham a natureza, como a professora Luciana Ferrara e o professor Rodrigo Hidalgo, foram de extrema importância para a definição e desenvolvimento desta tese.

\section{SOBRE FORTALEZA: APRESENTAÇÃO GERAL}

A cidade de Fortaleza é a sede da Região Metropolitana de Fortaleza (RMF), localizada ao norte do estado do Ceará. Criada na década de $1970^{6}$, era formada inicialmente pelos municípios de Fortaleza, Caucaia, Maranguape, Pacatuba e Aquiraz. Hoje conforma um aglomerado, com definições muito mais políticas do que de fato (PEQUENO, 2009), de 19 municípios, contando com a sede. Os últimos municípios foram adicionados a partir da criação do Complexo Industrial e Portuário do Pecém em São Gonçalo do Amarante, quando a região metropolitana recebeu o acréscimo, em 2014, de mais 4 municípios, a saber, Paracuru, Paraipaba, Trairi e São Luís do Curu ( CEARÁ, 2014)7.

Até meados do século XVII, a então província de Fortaleza não possuía grande importância econômica e política no Ceará, ficando atrás de cidades como Sobral, Crato, Icó e Quixadá. Fortaleza começa a ganhar importância somente no século XIX com a política do Império de fortalecimento das capitais das províncias, somada à mudança na economia cearense, até então baseada na criação de gado voltada para o abastecimento interno, para a produção de

\footnotetext{
${ }^{6}$ Instituída e definida originalmente pela Lei Complementar no14 de 6 de junho de 1973, pelos municípios Fortaleza, Caucaia, Maranguape, Pacatuba e Aquiraz. Posteriormente, são integrados à RMF: em 1986, pela lei no 52, o município de Maracanaú; em 1991, pela lei no 11.845, os municípios de Eusébio e Guaiuba; em 1999, pela lei no 18, os municípios de Itaitinga, Chorozinho, Pacajus, Horizonte e São Gonçalo do Amarante ( DANTAS e SILVA, 2009).

${ }^{7}$ Art. 10 Altera o item 1, do inciso I do art. 10, bem como o item 2, do inciso II do art. 1o da Lei Complementar no 03 , de 26 de junho de 1995, alterada pela Lei Complementar no 18, de 29 de dezembro de 1999, com alteração posterior pela Lei Complementar no 78, de 26 de junho de 2009, que passa a vigorar com a seguinte redação: "Art. 10 ... I - Regiões Metropolitanas: 1. Aquiraz, Caucaia, Eusébio, Fortaleza, Guaiúba, Itaitinga, Maracanaú, Maranguape, Pacatuba, Pacajus, Horizonte, Chorozinho, São Gonçalo do Amarante, Pindoretama, Cascavel, Paracuru, Paraipaba, Trairi e São Luís do Curu (lei complementar n.․ 144, DE 04.09.14, D.0. 08.09.14).
} 
algodão para exportação, quando Fortaleza despontou como porto exportador. (COSTA e AMARAL, 2013).

Fortaleza teve parte do seu crescimento demográfico atrelado à migração de refugiados da seca que, frente a essa adversidade natural, somada a grande concentração fundiária, buscavam na capital melhores condições de sobrevivência. Até o ano de 1900, Fortaleza possuía uma população de aproximadamente 48 mil habitantes, vinte anos depois, com uma taxa de crescimento de mais de $62 \%$ durante esse período, o município já apresentava um total de 78.536 habitantes. De 1950 a 1960 o município quase dobrou o número de sua população, passando de um pouco mais de 270 mil habitantes para mais de 510 mil. Na década de 1980 Fortaleza ultrapassa a marca de mais de um milhão de habitantes. Nas últimas décadas a taxa de crescimento populacional do município tem diminuído, mas este já possui atualmente aproximadamente 2 milhões e seiscentos mil habitantes (ver Tabela 1. População residente estimada - Fortaleza 1980 a 2018.).

Figura 1. Região Metropolitana de Fortaleza.

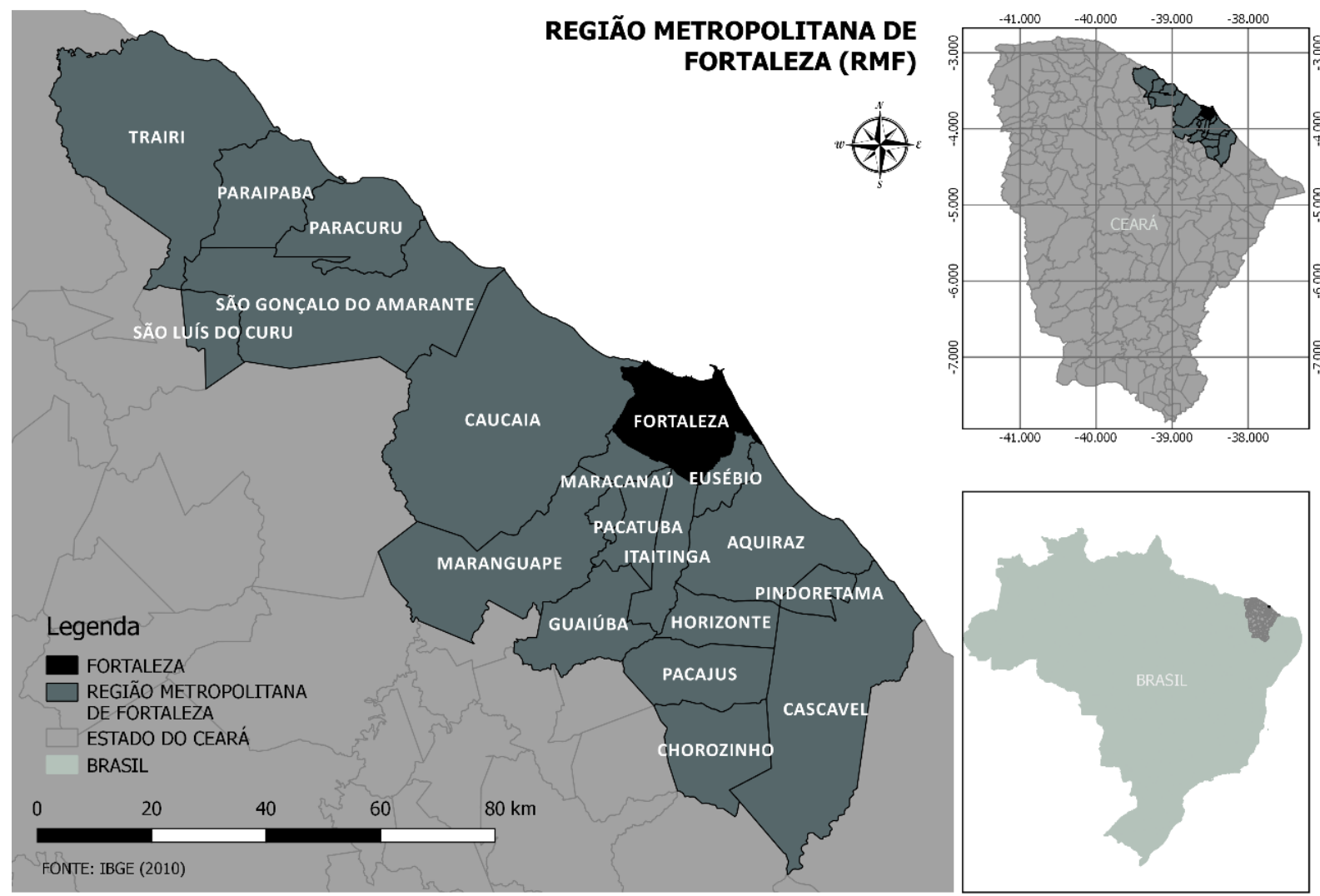

Elaboração: Rosa, 2018. Fonte: IBGE, 2010; D.O., 2014 ((lei complementar n. 144, DE 04.09.14, D.O. 08.09.14). 
Tabela 1. População residente estimada - Fortaleza 1980 a 2018.

\begin{tabular}{rrr}
\hline Ano & População & Taxa de crescimento* \\
\hline 1890 & 40.902 & $18,3 \%$ \\
1900 & 48.369 & $62,4 \%$ \\
1920 & 78.536 & - \\
1930 & $N D^{1}$ & $129,4 \%$ \\
1940 & 180.185 & $49,9 \%$ \\
1950 & 270.169 & $90,6 \%$ \\
1960 & 514.813 & $66,7 \%$ \\
1970 & 857.980 & $52,6 \%$ \\
1980 & 1.308 .919 & $35,1 \%$ \\
1991 & 1.768 .637 & $11,1 \%$ \\
1996 & 1.965 .513 & $11,1 \%$ \\
2001 & 2.183 .612 & $10,7 \%$ \\
2006 & 2.416 .920 & $2,5 \%$ \\
2011 & 2.476 .589 & $5,4 \%$ \\
2016 & 2.609 .716 & $1,3 \%$ \\
\hline
\end{tabular}

Fonte: IBGE - Estimativas de População e Dantas e Silva (2009, p. 11). Sistematização e cálculo: Sara V Rosa, 2019.

**Taxa de crescimento populacional calculada a partir do ano de referência anterior existente na tabela.

${ }^{1}$ ND: Não disponível.

Atualmente, com uma população de mais de dois milhões e seiscentos mil habitantes, o município apresenta conurbação urbana forte com Caucaia e Maracanaú, conhecidos como municípios dormitórios, os quais receberam grandes conjuntos de habitação de interesse social (HIS) nas décadas de 1970 e 1980, como ações vinculadas ao Programa Integrado de Desfavelamento $^{8}$, e ao estabelecimento de distritos industriais na RMF ( PEQUENO e FREITAS, 2012; MÁXIMO, 2012). Também é possível verificar uma conurbação urbana, porém mais dispersa, com Itaitinga, Eusébio e Aquiraz, sendo esses dois últimos municípios, como apontado por Pequeno, vetores de expansão do mercado imobiliário.

Sem fugir à regra das cidades brasileiras, Fortaleza apresenta extrema desigualdade socioeconômica ${ }^{9}$. Em 2010, foi classificada pela ONU como a 13 cidade mais desigual do mundo ${ }^{10}$, já em 2013 subiu para a 5o mais desigual. Esta desigualdade pode ser percebida nos indicadores urbanos. Pequeno (2002 apud MOURA, 2017) estimava que no final do século XIX aproximadamente $30 \%$ das habitações do município eram precárias. Mais de um século

\footnotetext{
8 "[...] data de 1973 o primeiro levantamento de favelas de Fortaleza, quando foram identificadas 81 favelas, somando 34 mil domicílios onde viviam mais de 205 mil pessoas, correspondendo a cerca de $20 \%$ da população do município. No primeiro plano de desfavelamento proposto pela Fundação do Serviço Social de Fortaleza, 32 áreas (14.500 famílias) seriam alvo de erradicação total, em sua maioria associadas à implantação do sistema viário principal” ( PEQUENO e FREITAS, 2012, p. 487). ${ }^{9}$ Em 2013 foi classificada pela ONU (relatório das Nações Unidas State of the World Cities 2010/2011: Bridging the Urban Divide) como a quinta cidade mais desigual do mundo. Fonte: http://diariodonordeste.verdesmares.com.br/editorias/metro/entre-crescimento-e-contrastes-que-fortaleza-a-populacaoconhece-1.1299583

10 https://www.gazetadopovo.com.br/vida-e-cidadania/cinco-cidades-brasileiras-integram-lista-das-mais-desiguais-domundo-289ip4tf7gr70xp5s0uhycd3i/
} 
depois, com uma população de aproximadamente dois milhões e seiscentos ${ }^{11}$, estimativas mais recentes do Plano Local de Habitação de Interesse Social (PLHISfor-2012), apontam que mais de $40 \%$ da população viva em assentamentos precários. São mais de um milhão de pessoas vivendo ao todo em 843 assentamentos precários, entre favelas (622, no total), cortiços, loteamentos informais e inclusive produção estatal de habitação de interesse social ( FORTALEZA, 2012)

Outro dado alarmante é o número de famílias inscritas nos programas de habitação de interesse social do município que gira na ordem de mais de cento e trinta mil famílias, apontando que aproximadamente $20 \%$ da população encontra-se em situação de déficit habitacional ( HOLANDA e ROSA, 2017b).

Apesar do município atualmente possuir um atendimento quase universal no que tange aos serviços de água e energia elétrica, ainda possui (segundo dados do último censo demográfico do IBGE, 2010) mais da metade do seu território sem cobertura de saneamento sanitário (Figura 3). As porções mais ao sul do município que apresentam cobertura deste serviço não possuem ligação à rede, que ainda é inexistente nessas áreas, apresentando apenas soluções de tratamento de esgoto individualizadas, como são, em geral, os casos dos grandes conjuntos implantados na área, como o Conjunto Ceará, o Conjunto Palmeiras e o Conjunto Prefeito José Walter. A solução de estação de tratamento individual continua sendo utilizada nestas áreas também na implementação de novos Conjuntos de HIS e habitação popular, como os do Programa Minha Casa Minha Vida (PMCMV) ( ROSA, PEQUENO e SILVA, 2014).

A população com maior poder aquisitivo está localizada principalmente no setor leste da cidade (como pode ser observado na Figura 4), com destaque para os bairros Meireles, Aldeota, De Lourdes, Cocó, Guararapes e, de forma geral, um pouco mais dispersas, nos bairros ao longo do eixo viário das avenidas Santos Dumont e Washington Soares. Nestes bairros, a renda média das famílias ultrapassa dez salários mínimos, enquanto em quase todo o resto da cidade a renda média fica entre zero e três salários mínimos. É também ao longo do eixo da avenida Washington Soares onde estão localizados grande parte dos terrenos ainda vazios, não construídos ou subutilizados (Figura 2).

\footnotetext{
$11 \mathrm{ftp}: / / \mathrm{ftp}$. ibge.gov.br/Estimativas_de_Populacao/Estimativas_2015/estimativa_dou_2015_20150915.pdf 
Tabela 2. Porcentagem de domicílios por rendimento per capita, em salário mínimo (IBGE, 2010) - \%

\begin{tabular}{|c|c|c|c|c|c|c|c|c|c|c|}
\hline & $1 / 8$ & $1 / 8$ A $1 / 4$ & $1 / 4$ A $1 / 2$ & $1 / 2$ A 1 & $1 \mathrm{~A} 2$ & $2 \mathrm{A3}$ & 3 A 4 & 3 A 5 & 5 A 10 & MAIS DE 10 \\
\hline FORTALEZA & 2,18 & 7,78 & 21,54 & 29,19 & 17,57 & 6,04 & 5,57 & 4,36 & 1,93 & 3,84 \\
\hline CEARÁ & 10,52 & 13,38 & 25,26 & 27,91 & 10,75 & 2,96 & 2,40 & 1,67 & 0,70 & 4,47 \\
\hline
\end{tabular}

Sistematização: Sara V. Rosa, 2019. Fonte: Censo demográfico do IBGE.

Análises feitas por Pequeno (2002 e 2003) e Zanella, Costa, Panizza e Rosa (2009), a partir dos dados censitários e características geomorfológicas do território municipal, identificaram que as populações socialmente mais vulneráveis estão localizadas também em áreas ambientalmente mais vulneráveis, sujeitas a inundações constantes ou deslizamentos de encosta, conformando um forte quadro de vulnerabilidade socioambiental no município.

Figura 2. Levantamento dos assentamentos precários por tipo e dos vazios urbanos, segundo Plhisfor (2012)

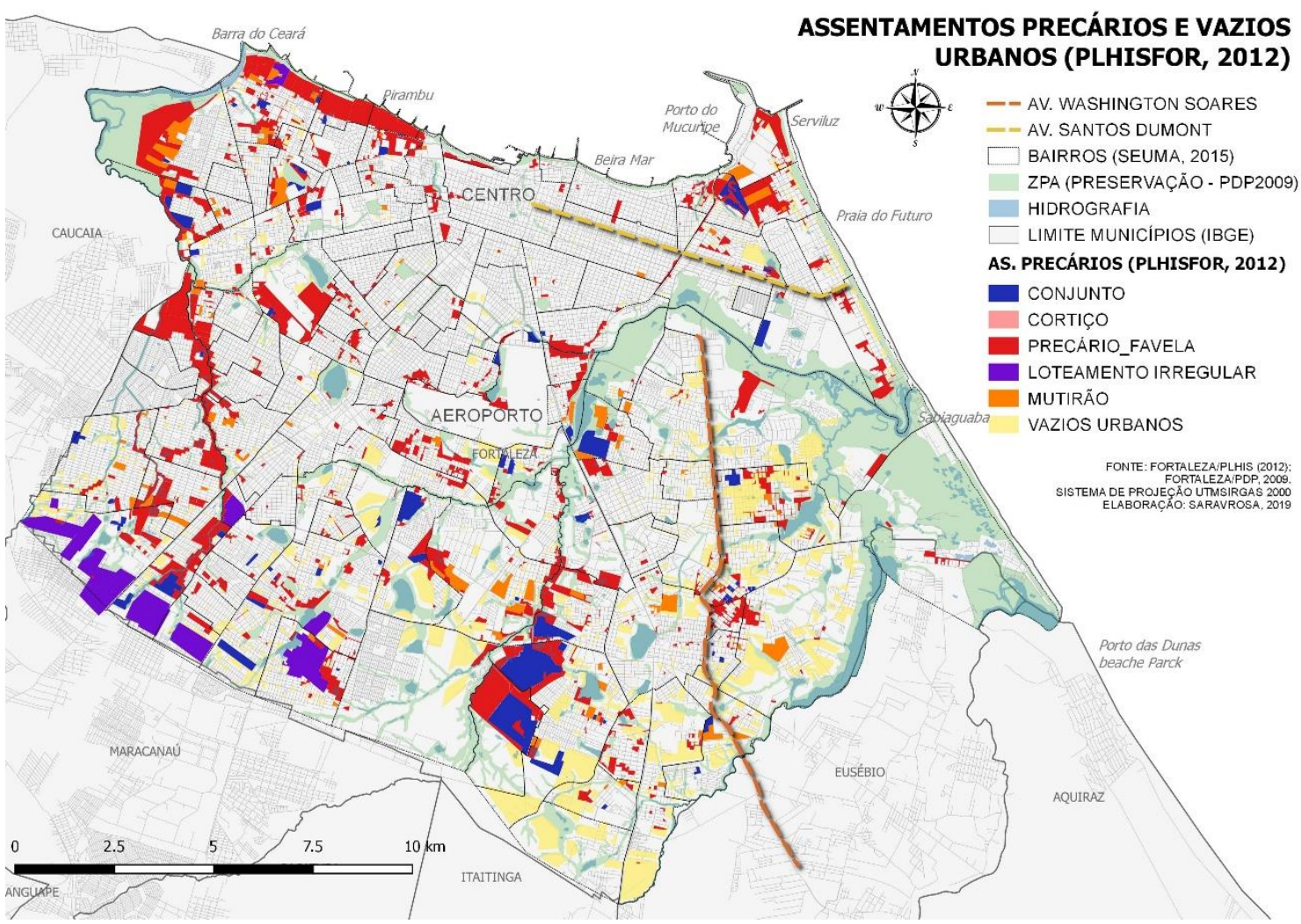

Elaboração: Rosa, 2019. Fonte: FORTALEZA/PLHIS (2012); FORTALEZA/PDP (2009). 
Figura 3. Porcentagem de domicílios não ligados a redegeral de esgoto (IBGE, 2010 - setores censitários)

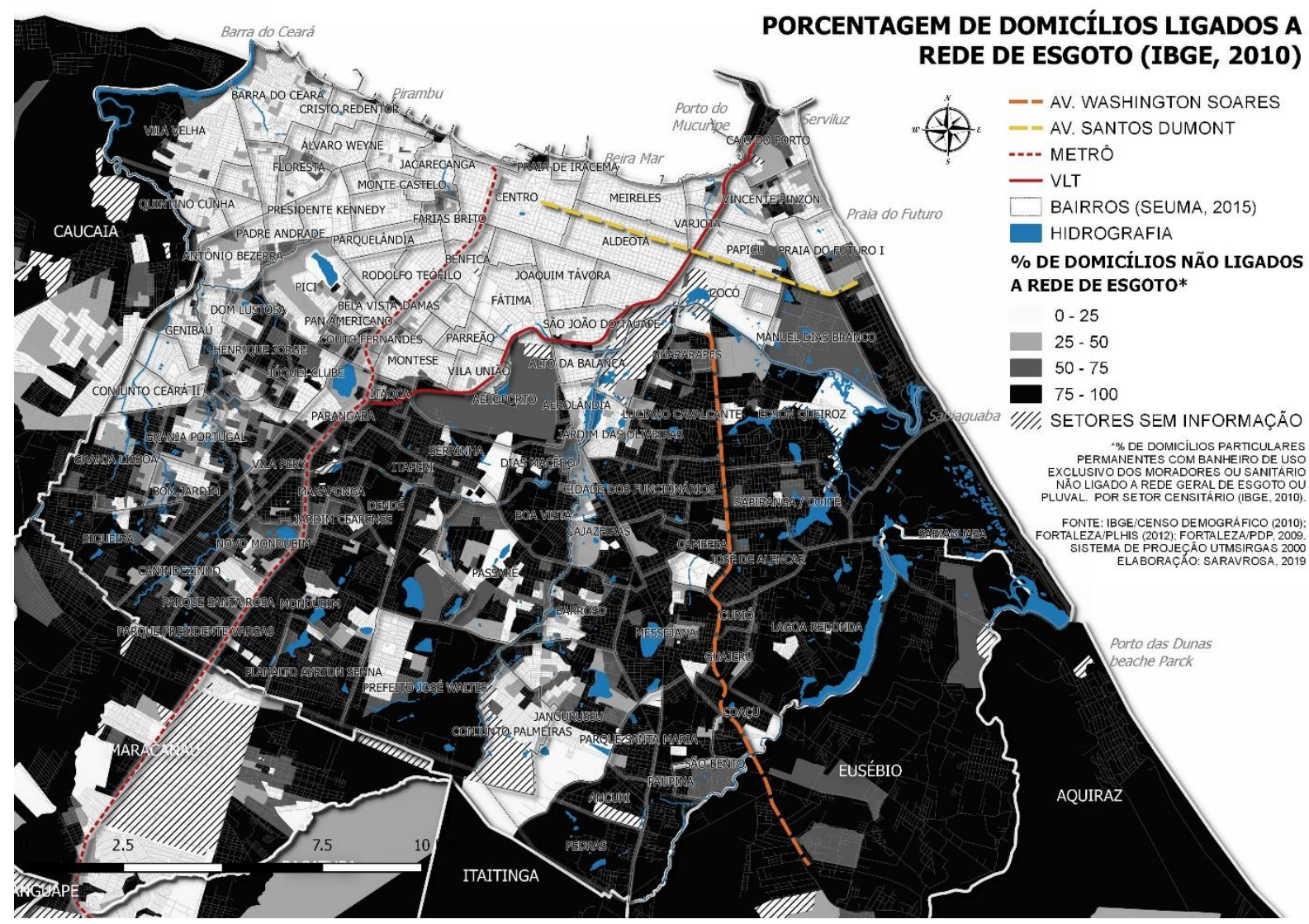

Elaboração: Rosa, 2019. Fonte: IBGE (2010). Mapa apresentado no ICA.

Figura 4. Renda média mensal domiciliar (IBGE, 2010 - setores censitários)

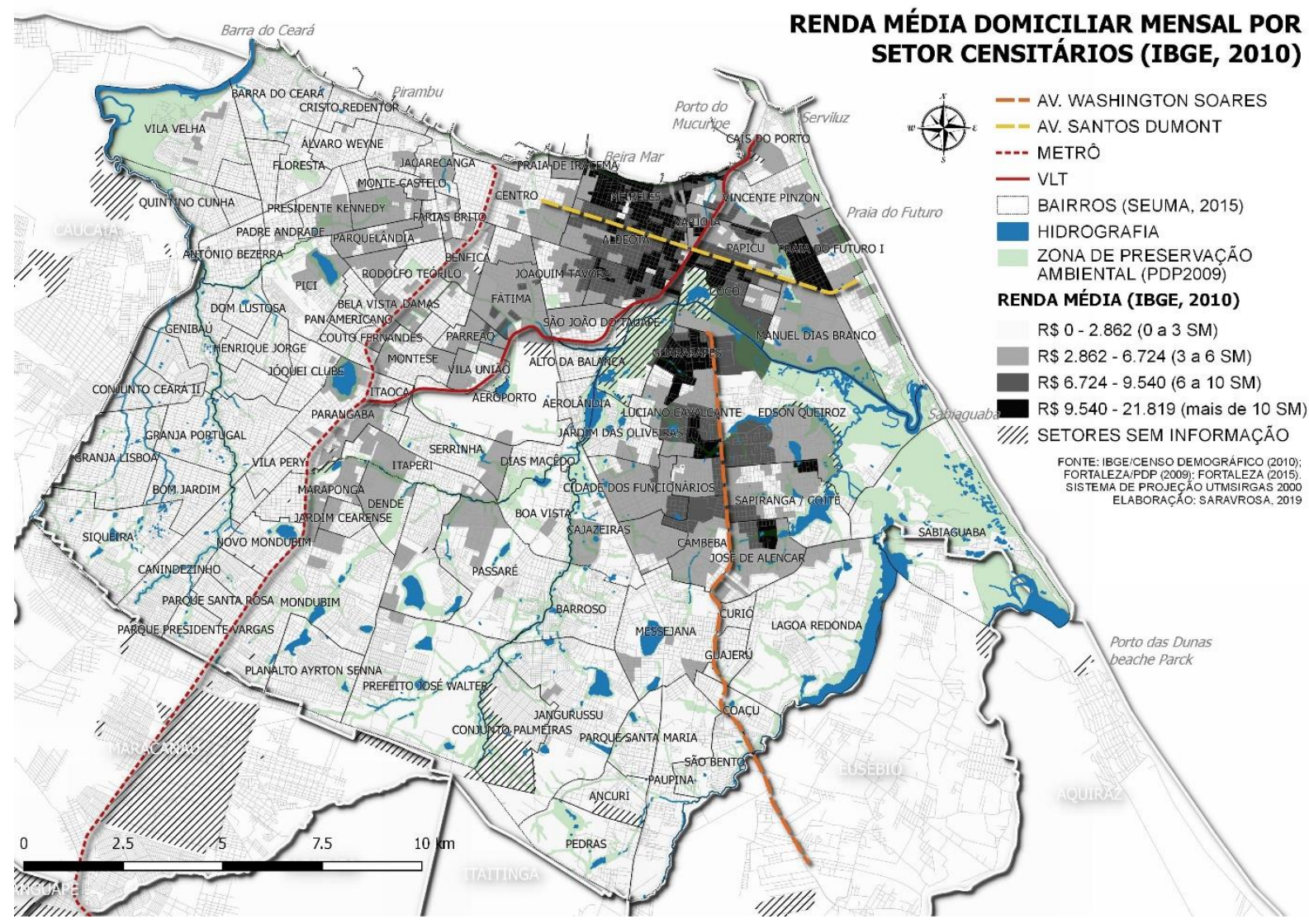

Elaboração: Rosa, 2019. Fonte: IBGE (2010). Mapa apresentado no ICA. 
Do ponto de vista geoambiental, Sales destaca que o município possui, em seus limites norte e leste, "35km de litoral formado por praias, dunas e pequenos estuários" (SALES, 2010, p. 449), cuja porção norte é extremamente ocupada e suas características anterior de dunas e pequenos estuários já são quase imperceptíveis. Já a faixa litorânea leste possui uma ocupação urbana mais dispersa e ainda preserva alguns campos de dunas móveis e fixas, assim como de vegetação típica desse sistema e dos estuários aí presentes (Figura 7).

O município está inserido entre as fozes de dois rios, a oeste, tem-se a foz do Rio Ceará, e ao sudeste, a do rio Pacoti. Já seu interior é dividido em três bacias hidrográficas, Bacia Hidrográfica Vertente Marítima (ao norte), Bacia Hidrográfica do Rio Maranguapinho (ao oeste) e Bacia Hidrográfica do Rio Cocó. Ainda integra, no extremo sudeste, um fragmento da Bacia Hidrográfica do Rio Pacoti (Figura 5).

A Bacia Vertente Marítima drena uma área completamente urbanizada, tendo como principais recursos hídricos o Riacho Pajeú, o Riacho Jacarecanga e o Riacho Maceió (ZANELLA, COSTA, et al., 2009), sendo os dois primeiros importantes recursos na formação inicial de Fortaleza no período colonial.

Figura 5. Bacias Hidrográficas de Fortaleza.

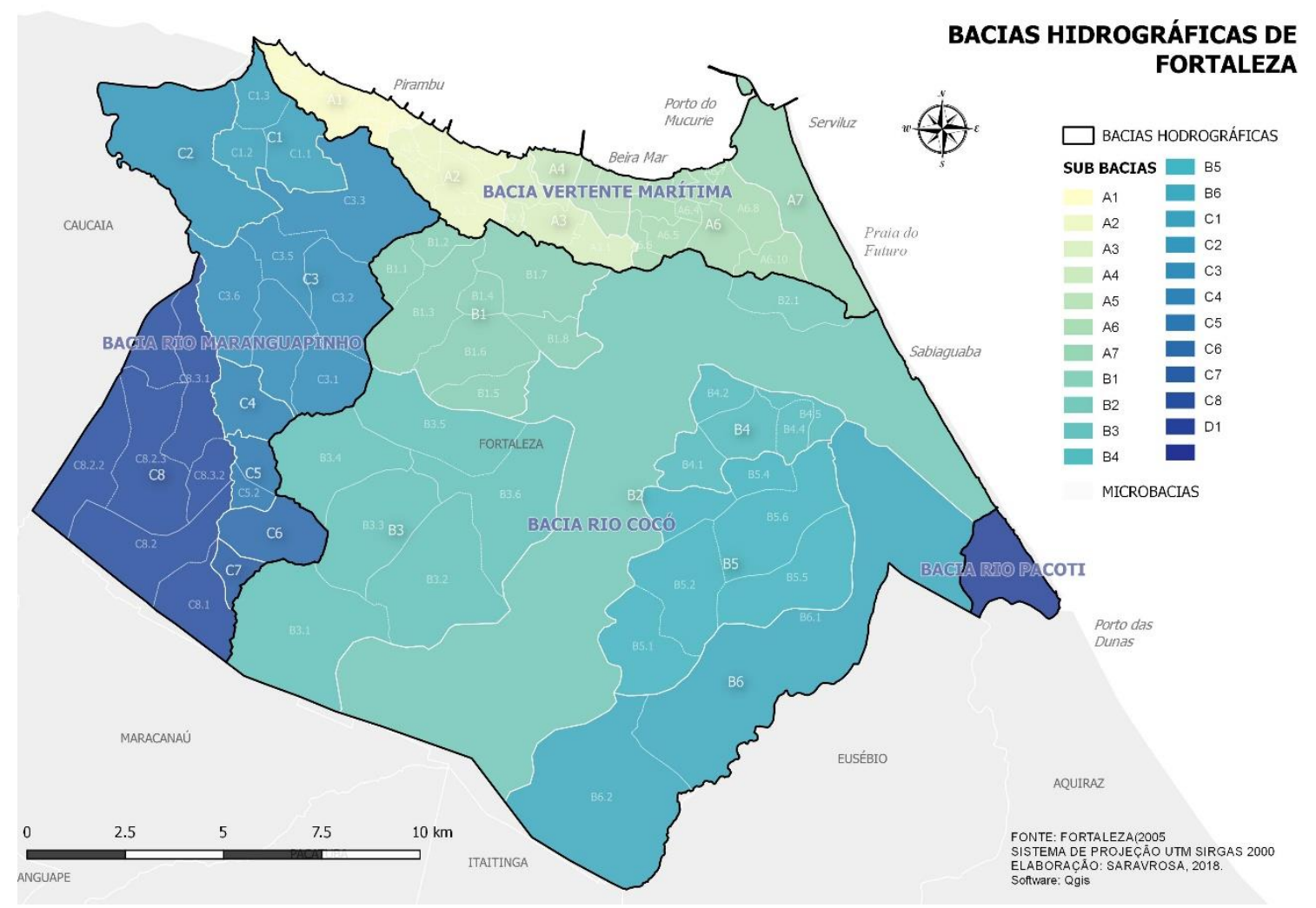

Elaboração: Rosa, 2018. Fonte: FORTALEZA, 2006. 
Figura 6. Hipsometria - fortaleza

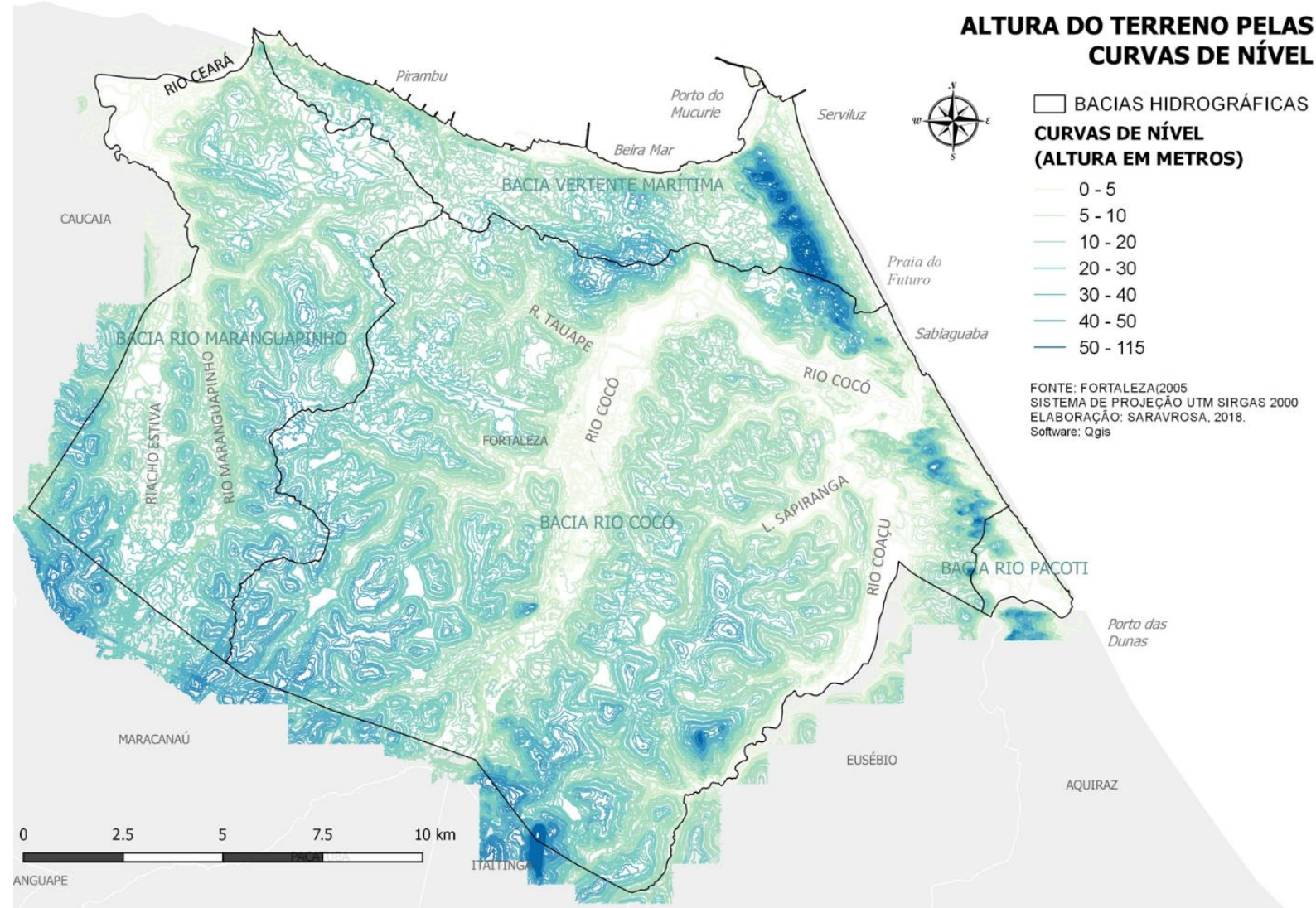

Elaboração: Rosa, 2018. Fonte: FORTALEZA, 2006.

As bacias do Rio Maranguapinho e do Rio Cocó, em seus médios e baixos cursos (trechos que cortam Fortaleza) drenam a maior parte do tabuleiro costeiro do município, sendo esse sistema a ocupar a maior porção do território municipal (Figura 7). Tanto a mata de tabuleiro dessas bacias como a vegetação ciliar das planícies fluviais, onde predominava a carnaúba, destes dois rios e dos rios menores que conformam as duas bacias, encontram-se atualmente, em grande medida, substituídas por ocupação urbana. As planícies fluviais encontram-se ocupadas principalmente por população de baixa renda (Figura 4) submetidas às constantes inundações nos períodos chuvosos. ( ZANELLA, COSTA, et al., 2009). 


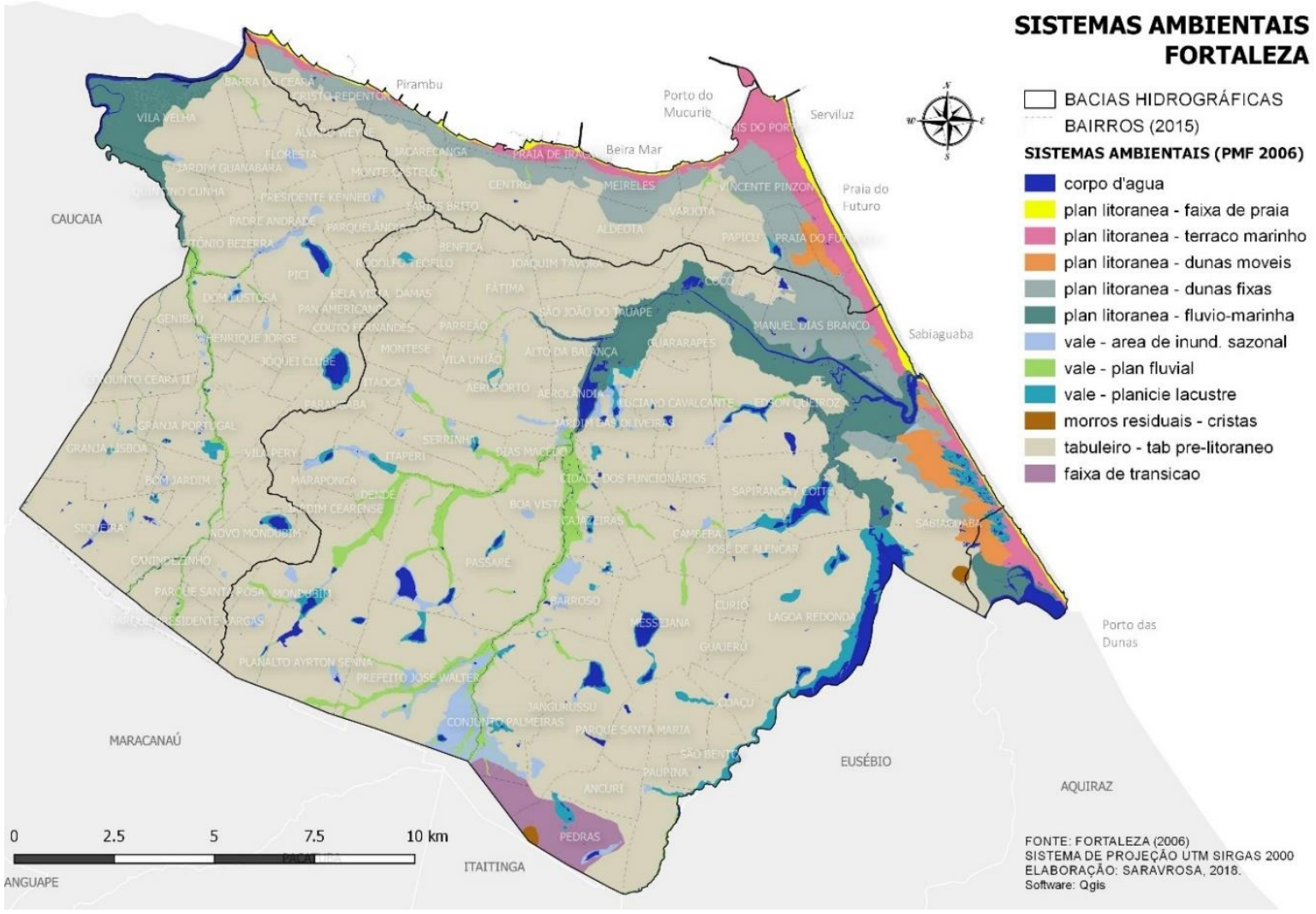

Elaboração: Rosa, 2018. Fonte: FORTALEZA, 2006

A Bacia do Cocó é a que ocupa a maior porção do território e abriga o principal rio da cidade, o Rio Cocó, aproximadamente dois terços (Figura 5). Este rio, possui cerca de $49 \mathrm{~km}$ de extensão, cortando e drenando quatro municípios, três deles da RMF, incluindo Fortaleza, tendo sua nascente na Serra de Baturité, em Pacoti. É também o rio com maior porção relativamente preservada, onde ainda é possível observar uma grande área de vegetação de manguezal, sobre a qual incide proteção por meio de criação de um parque estadual desde o final da década de 80, Parque Ecológico do Cocó de $1989^{12}$.

As desembocaduras desses dois rios, Cocó e Marangapinho-Ceará, conformam planícies flúvio-marinhas (Figura 7) com vegetação tipo mangue ( ZANELLA, COSTA, et al., 2009). Parte dessas planícies também se encontram ocupadas ou em processo de ocupação, porém, ainda é possível observar a presença de manguezais, mesmo que sob pressão da poluição e do avanço da mancha urbana.

\footnotetext{
12 Sales ( SALES, 2010, p. 449) destaca que eram cerca de 1.600 ha de vegetação preservada.
} 


\section{T.}

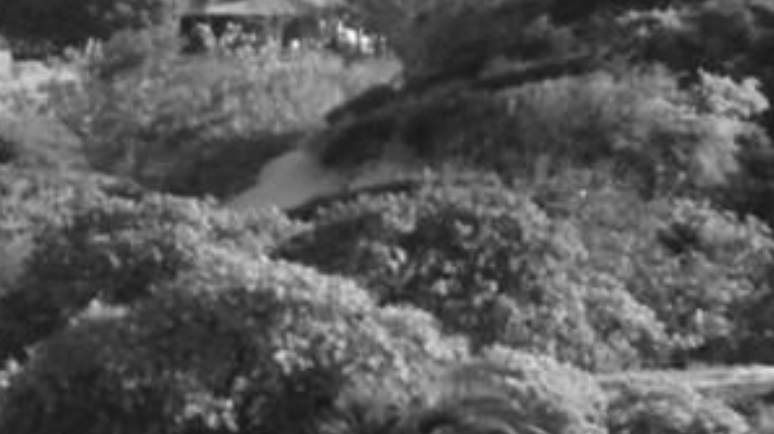

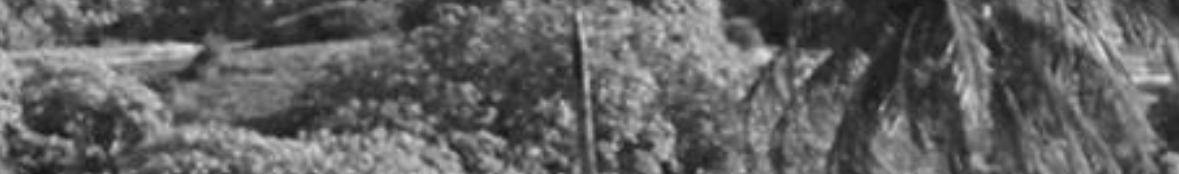

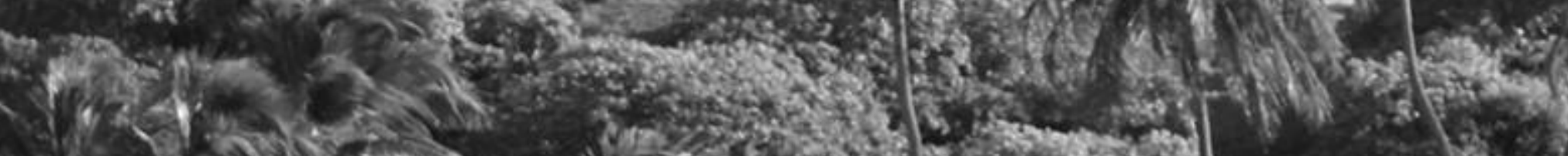

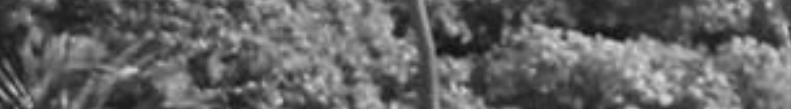
S.

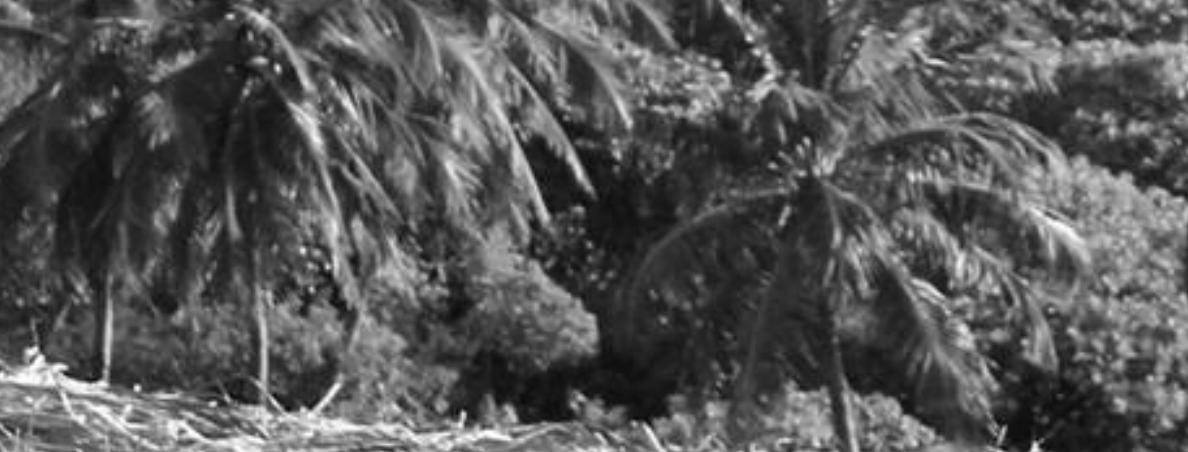

$1=72$.

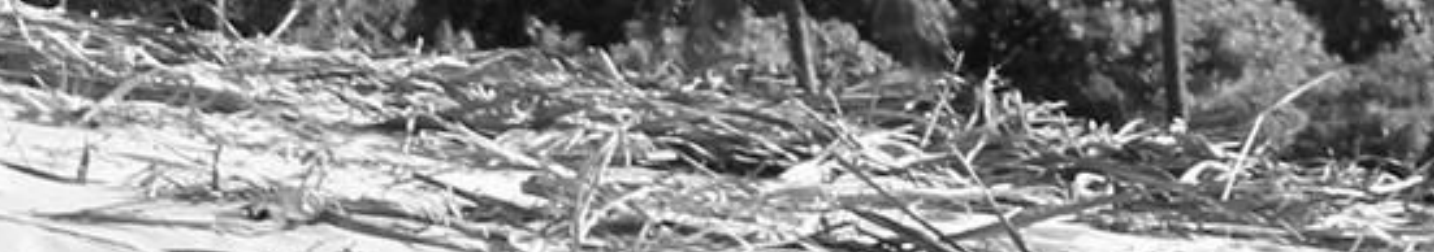
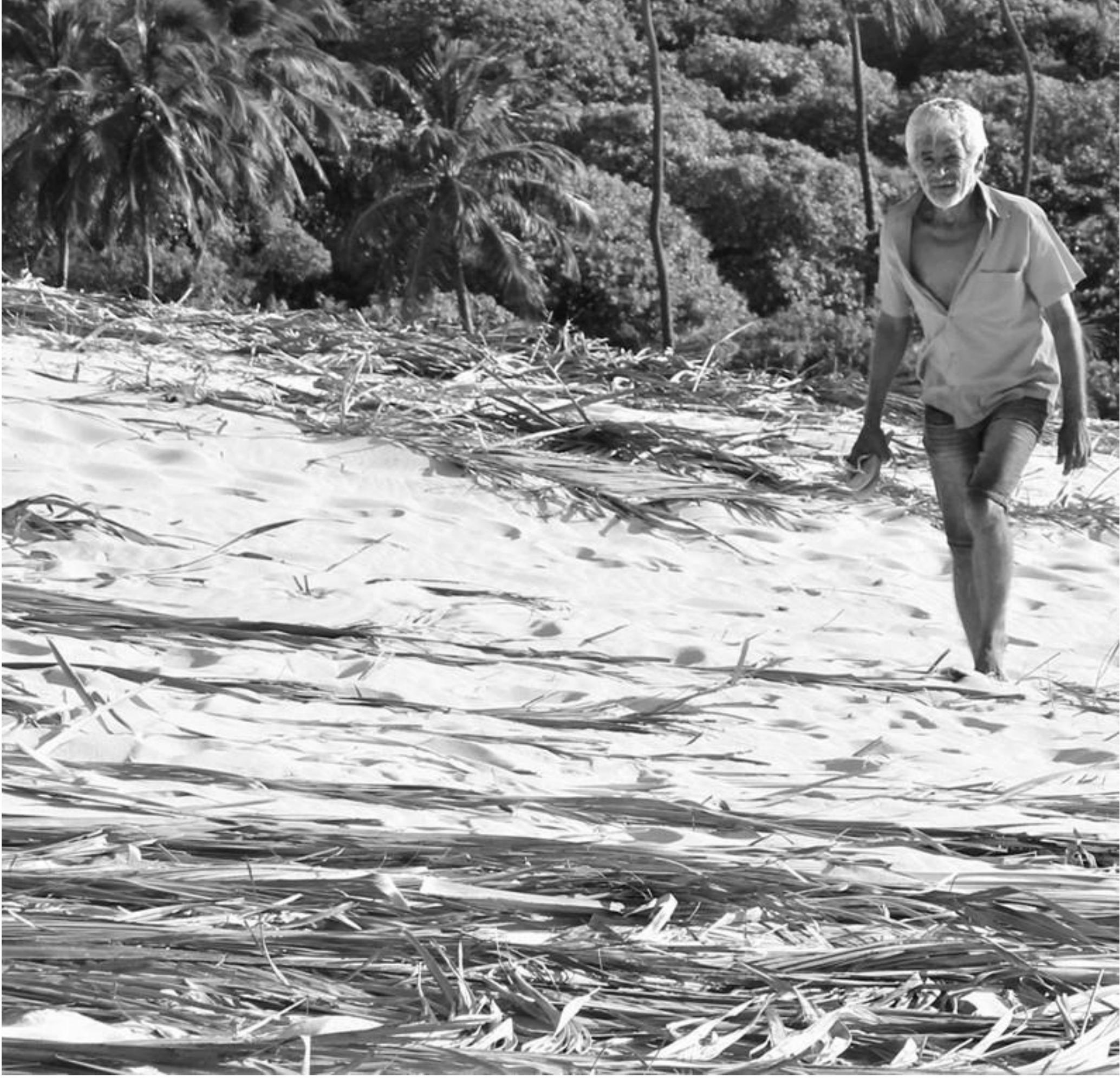
FOTO: SARA VIERA ROSA, 2017

MORADOR ANTIGO CAMINHANDO SOBRE AS DUNAS APÓS MOSTRAR LOCAL ONDE EXISTIU A CASA DE SUA AVÓ LOCAL: DUNAS DA SABIAGUABA - PARUE DAS DUNAS DA SABIAGUABA - FORTALEZA, CE 


\section{CAP.01. ACUMULAÇÃO PELA}

\section{NATUREZA}

história do Brasil e do Ceará desde a colonização é marcada pela apropriação
indevida, pelo roubo, de suas terras e de seus recursos, incluindo o roubo/sequestro
do próprio homem (também natureza). Tivemos a invasão e apropriação privada das terras e riquezas locais, marcadas por genocídio, etnocídio e expulsão dos que aqui habitavam para outros territórios, até serem expulsos novamente, e novamente, e novamente; tivemos ainda o sequestro dos Africanos trazidos para servirem no trabalho escravo. Como apontam Lencioni ( 2012) e Harvey (2013), tanto o roubo das terras locais como o trabalho escravo continuam até os dias de hoje, assim como a biopirataria que continua levando nossas riquezas. Os roubados e espoliados no processo de formação das cidades capitalistas brasileiras são quase sempre os mais pobres que, quase sempre, são também os descendentes dos indígenas locais e dos africanos ${ }^{13}$.

Neste capítulo e ao longo de toda a tese, concordando com Harvey (2016) e Lencioni (2015), perpassa a ideia de que a conformação do capitalismo, desde suas origens até os dias de hoje, está baseada sobretudo na apropriação privada e violenta da natureza, mas do que a busca da valorização no processo de produção em si.

Este primeiro capítulo está dividido em duas partes principais. A primeira procura fazer uma reflexão sobre a matriz teórica utilizada para a realização da análise dos dados empíricos demonstrados a seguir. Deste modo, é feita uma pequena discussão sobre conceitos de riqueza; apropriação individual ou coletiva versus apropriação privada; acumulação primitiva/acumulação por espoliação; e alienação. Procuramos aqui destacar o papel crucial da natureza, representada pela terra e pelo ser humano, nesses processos que visam à acumulação de capital e o quão importante foi a quebra no metabolismo, separando o homem

\footnotetext{
${ }^{13}$ Maetínez Alier (2009), destacando os processos de roubo no período colonial somados aos processos que se seguiram de acumulação capitalista e uso desigual de recursos naturais, propõe que não seja paga a dívida externa dos países do Sul, pois a dívida ecológica dos países do Norte com os do Sul é tão elevada que já a pagaria.
} 
da terra, forçando uma visão alienada de que o homem não é natureza e que, como tal, deveria dominá-la e não apenas se apropriar de seus elementos para seu usufruto.

Na segunda parte, a partir de fatos históricos, material cartográfico e documental, procuramos descrever e demostrar que o processo de produção da cidade de Fortaleza foi baseado na apropriação privada e violenta da natureza. Fazemos um breve resgate histórico de processos ocorridos no período colonial e imperial para demonstrar que a riqueza acumulada pelos capitalistas locais provém de um longo e violento processo de roubo e apropriação privada da natureza, subjugando, explorando e, sobretudo, espoliando o índio e o negro, até chegar no século XX, quando, a partir da consolidação de um mercado de terras em Fortaleza, a terra começa a despontar como capital fictício e novos processos de espoliação entram em marcha.

A apropriação privada da terra concentra-se neste período nas mãos de poucos, como riqueza entesourada. O loteamento dessas terras passa a ser uma atividade importante e expande horizontalmente a cidade, deslocando populações, soterrando lagoas, encobrindo dunas e desviando rios, mesmo que não exista demanda com capacidade de pagamento para ocupar esses lotes.

Os grandes marcos naturais, como rios mais volumosos e dunas, são neste momento barreiras que contêm e impedem a expansão urbana, a expansão dos loteamentos. A natureza é compreendida por estes proprietários de terra e rentistas como barreiras a serem superadas e incorporadas como capital (fictício). Assim, ao mesmo tempo em que a natureza se apresenta como possibilidade de renda, ela é barreira e, ao mesmo tempo em que é barreira, é possibilidade de renda. A postura então foi de dominá-la, de transformar locais não propícios à ocupação e construção, como dunas móveis, áreas de inundação (planícies flúvio-marinhas, fluviais, lacustres), e até mesmo o leito de lagoas e rios em terrenos propícios à construção e obtenção de renda, ou em avenidas-canais que, ao mesmo tempo que dão acesso a essas terras, contêm as águas, possibilitando que os lotes lindeiros sejam ocupados. A renda imobiliária, neste momento, era obtida de forma extensiva e envolvendo processos de espoliação que capturam riquezas comuns, sem ou com o aval do Estado, ilegais, ou já legalizados pelo direito à propriedade privada, mas sempre imorais. 


\subsection{A nATUREZA NO PROCESSO DE ACUMULAÇÃO PRIMITIVA ${ }^{14}$}

Neste primeiro ponto do capítulo 1, trazemos para reflexão a matriz teórica utilizada para a embasar análise dos dados históricos e empíricos trabalhados no segundo ponto para os casos de Fortaleza e do Ceará entre o século XVIII e XIX. Deste modo, é feita uma pequena discussão sobre os conceitos de riqueza; apropriação individual ou coletiva versus apropriação privada; acumulação primitiva e acumulação por espoliação; e alienação. Procuramos aqui destacar o papel crucial da natureza, representada pela terra e pelo ser humano, nos processos que visaram à acumulação de capital e o quão importante foi a quebra no metabolismo, separando o homem da terra, forçando uma visão alienada de que o homem não é natureza e que, como tal, deveria dominá-la e não apenas se apropriar de seus elementos para seu usufruto.

\section{Natureza: riqueza comum}

Marx atribui riqueza a algo material com valor de uso destinado ao consumo individual ou ao produtivo. Para ele, esta matéria com valor de uso advém de matéria natural (água, terra, minério, semente, etc.) e do trabalho que transforma essa matéria natural para adequá-la ao uso do ser humano. O trabalho, portanto, para este autor é uma atividade produtiva "[...] que adapta matérias naturais específicas a necessidades humanas específicas [...] criador de valores de uso [...]" é, assim, uma "condição de existência do homem, independente de todas as formas sociais, eterna necessidade natural de mediação do metabolismo entre homem e natureza e, portanto, da vida humana". (MARX, 2013a, p. 167).

Tomando como exemplo a produção de um casaco para o abrigo de um ser humano, Marx cita:

Os valores de uso casaco, linho etc., em suma, os corpos das mercadorias, são nexos
de dois elementos: matéria natural e trabalho. Subtraindo-se a soma total de todos
os diferentes trabalhos úteis contidos no casaco, linho etc., o que resta é um substrato
material que existe na natureza sem a interferência da atividade humana. Ao produzir,
o homem pode apenas proceder como a própria natureza, isto é, pode apenas alterar
a forma das matérias. Mais ainda: nesse próprio trabalho de formação ele é
constantemente amparado pelas forças da natureza. Portanto, o trabalho não é a

${ }^{14}$ Acumulação primitiva é a tradução pela editora Boitempo. Outras editoras, como a Nova Cultura, utilizam o termo acumulação originária. 
única fonte dos valores de uso que ele produz, a única fonte da riqueza material. 0 trabalho é o pai da riqueza material, como diz William Petty, e a terra é a mãe. (MARX, 2013a, p. 167. Grifo meu).

Interessante o destaque que Marx dá à natureza (matéria natural e terra) logo no início do primeiro livro de O Capital. Assim, compreendemos que qualquer valor criado pela ação do trabalho humano só é possível porque existe uma riqueza prévia ao trabalho que é a natureza sem acréscimo de trabalho humano, a matéria sem interferência do homem.

Disto, entendemos que a riqueza existe também fora da forma mercadoria. Porém, num sistema capitalista, como bem destaca Marx, toda riqueza tende a ser transformada em mercadoria, assim "a riqueza das sociedades onde reina o modo de produção capitalista aparece como uma enorme coleção de mercadorias, e a mercadoria individual como sua forma elementar" (MARX, 2013a, p. 157). A forma mercadoria mascara a riqueza comum, enquanto valor de uso de todos. Como também destaca Aldigueri (2017), a partir de Marx, nem toda riqueza é mercadoria, mas toda mercadoria é riqueza apropriada e ressignificada como tal.

Destaca-se que a natureza, enquanto riqueza, é anterior ao sistema capitalista, e sempre foi riqueza social a partir do momento em que o ser humano passou a apropriar-se dela individualmente ou coletivamente, seja em atividades extrativistas e coletoras de subsistência, seja no desenvolvimento da agricultura ou como abrigo. Sua existência, não como riqueza, mas como natureza, é anterior ao próprio homem. Seu surgimento não depende do homem, este, não esqueçamos, é parte dela e, portanto, também natureza.

Harvey ( 2016) chama a atenção para a distinção entre apropriação individual ou coletiva e apropriação privada. Segundo o autor, a propriedade privada "estabelece o direito de posse exclusiva de uma coisa ou processo, quer seja usado ativamente ou não" (p. 47. Grifo meu), conferindo ao proprietário o "direito de vender aquilo que possui" (p.48). Ou seja, o proprietário tem o monopólio sobre aquela propriedade e o direito de decidir quem pode usála ou não. No caso da terra, um duplo monopólio (MARX), monopólio da natureza e monopólio do espaço. Já a apropriação, seja ela coletiva ou mesmo individual, está ligada ao uso ativo, "nos apropriamos de coisas à medida que as usamos ativamente. Aproprio-me dos alimentos quando os como [...]" (p.47). A apropriação está associada, como destaca Harvey, ao usufruto. 
Podemos dizer então que a apropriação está relacionada ao valor de uso e a apropriação privada ao valor de troca.

\begin{abstract}
Ao se afirmar que a propriedade privada é uma não-apropriação, pode-se compreender que isso significa que esta propriedade limita a apropriação individual ou coletiva e não a apropriação privada, porque desvia e domina as formas apropriativas pautadas exclusivamente no uso, no consumo improdutivo, formas apropriativas em prol da existência e da manutenção da vida. Assim, a moderna propriedade privada capitalista trata-se de uma forma de restrição à apropriação concreta, na medida em que "la propiedad (privada) del suelo, simula y caricaturiza la apropiación. Lleva a la destrucción" (LEFEBVRE, 1983, p.182) (ALDIGUERI, 2017, p. 97).
\end{abstract}

Assim, para esta Tese, temos como entendimento que todo o meio biofísico, que não é originário da ação do trabalho humano, é riqueza comum, ou bem comum, podendo (devendo) ser apropriada (de maneira não privativa) para satisfazer necessidades de uso individuais e/ou coletivas.

Natureza: riqueza apropriada privativamente - o papel da terra e do ser humano no processo de acumulação primitiva

[...] o processo que cria a relação capitalista não pode ser senão o processo de separação entre o trabalhador e a propriedade das condições de realizar seu trabalho, processo que, por um lado, transforma em capital os meios sociais de subsistência e de produção e por outro, converte os produtores diretos em trabalhadores assalariados. A assim chamada acumulação primitiva não é, por conseguinte, mais do que o processo histórico de separação entre produtor e meio de produção. Ela aparece como "primitiva" porque constitui a pré-história do capital e do modo de produção que lhe corresponde. ( MARX, 2013a, p. 961, grifo meu)

No capítulo 21, Marx traz uma discussão extremamente importante para entender o surgimento e desenvolvimento do sistema capitalista, "a então chamada acumulação primitiva", que tem dois elementos da natureza envolvidos, a Terra e o Ser Humano (enquanto trabalhador "livre"). É por meio da expropriação de um que se origina o outro. É a partir da expropriação da terra dos trabalhadores rurais, retirando assim seus meios de produção e subsistência, que o Ser Humano se constitui enquanto trabalhador livre, mas obrigado a vender sua força de trabalho (MARX, 2013a). “[...] esses recém-libertados só se convertem em vendedores de si mesmos depois de lhes terem sido roubados todos os seus meios de produção, assim como todas suas garantias de sua existência que as velhas instituições feudais Ihes ofereciam" (MARX, 2013a, p. 962), sendo assim trabalhadores livres "no duplo sentido de 
que nem integram diretamente os meios de produção, como os escravos, servos, etc., nem Ihes pertencem os meios de produção,[...], mas então, antes, livres e desvinculados desses meios de produção" (MARX, 2013a, p. 961).

É através da acumulação primitiva que o ser humano enquanto trabalhador livre, proletariado, surge de fato e em quantidade suficiente para rodar o sistema. "A acumulação primitiva diz respeito às origens históricas desse trabalho assalariado, assim como à acumulação nas mãos do capitalista dos recursos necessários para empregá-lo" (HARVEY, 2013, p. 279).

Porém, Marx dá grande destaque a outro aspecto também, ao qual queremos dar maior ênfase aqui, a relação entre o trabalhador livre assalariado e a propriedade privada da terra. É por meio da extorsão das terras comunais e estatais do agricultor e produtor que se liberará o homem para vender sua força de trabalho, nas palavras de Marx (2013a, p. 963), “a expropriação da terra que antes pertencia ao produtor rural, ao camponês, constitui a base de todo o processo".

De fato, a terra e o homem, ou melhor, a natureza e o trabalho social, têm papel fundamental na origem do sistema capitalista, não à toa, são as duas formas, vistas anteriormente, capazes de criar riqueza. Há então uma apropriação privada e violenta da natureza, representada pela terra, que é riqueza, e apropriação do trabalho, capaz de produzir riqueza a partir da natureza. Podemos dizer, inclusive, que pela apropriação do trabalho e privatização dos meios de produção há uma apropriação do próprio homem, também natureza. Assim, observamos não somente uma acumulação de riqueza nas mãos de poucos, como também uma concentração dos meios que produzem novas riquezas e criam valor.

Sem acesso à terra, aos meios de produção de sua subsistência, o homem se vê forçado a adquirir os alimentos, vestuários, dentre outros objetos, que antes ele mesmo produzia, exclusivamente por meio do mercado, sendo necessário assim vender sua força de trabalho. Então, ao mesmo tempo que se obtém a mão de obra necessária para a produção capitalista, adquire-se também uma demanda para parte dessa produção.

Esse processo de monetização e mercantilização deu impulso a uma "revolução agrícola" no campo, permitindo que o capital utilizasse o solo de determinada maneira. $\mathbf{O}$ capital circulava através do solo, da natureza, exatamente do mesmo modo que circulava através do corpo do trabalhador como capital variável. 0 impacto dessa revolução agrícola, diz Marx no item 5, teve dois lados: liberou não só uma grande quantidade de trabalho, mas também meios de subsistência que 
antes eram consumidos diretamente da terra. Ele mercantilizou a oferta de alimentos. 0 mercado para bens e mercadorias cresceu, em parte porque menos pessoas podiam subsistir por sua própria conta. $O$ resultado foi a expansão das trocas e o crescimento do mercado. Enquanto isso, o capital destruiu grande parte dos negócios subsidiários artesanais e domiciliares não apenas na Índia, como também na Grã-Bretanha. (HARVEY, 2013, p. 284.Grifo meu)

Esses processos violentos de extorsão não se restringiram somente à Grã-Bretanha e ao restante da Europa. Marx ( 2013a) e Harvey ( 2013 e 2016) chamam atenção para os saques, roubos e escravização cometidos durante o período colonial, que foram de extrema importância e fundamentais no processo de acumulação primitiva. "[...] as colônias garantiam um mercado de escoamento e uma acumulação potenciada pelo monopólio do mercado. Os tesouros espoliados fora da Europa diretamente mediante o saqueio, a escravização e o latrocínio refluíam à metrópole e lá se transformavam em capital" (MARX, 2013a, p. 1001)

Lencioni (2012) chama atenção para o fato de a acumulação primitiva ser um processo que resulta na criação de um capital novo por meio da espoliação. “[...] acumulação primitiva está relacionada à espoliação e à produção de um capital novo, enquanto [...] o de reprodução do capital está relacionado à exploração e tem como ponto de partida um capital já constituído" (LENCIONI, 2012, p. 1). Tanto a autora citada como Harvey (2013 e 2016) concordam que não é um processo que historicamente desapareceu, pois, processos de acumulação por meio de espoliação persistem nos dias atuais. A espoliação foi de extrema importância para a transição do feudalismo para o capitalismo, mas é também de extrema importância para o desenvolvimento e manutenção do sistema.

Vários exemplos de rapinagem dos recursos naturais são dados, incluindo-se aí a biopirataria. Também é destacada a escravidão por dívida, como uma forma violenta de espoliação, uma forma de acumulação primitiva de capital em que o trabalhador livre, pelos mecanismos de sujeição ao qual está submetido, perde sua liberdade. 0 roubo de terras se constitui num outro exemplo de acumulação primitiva dessa sociedade contemporânea. ( LENCIONI, 2012, p. 1. Grifo meu)

Harvey ( 2016) destaca a enorme capacidade e flexibilidade do capital para a apropriação da riqueza comum, seja ela criada pelo trabalho social, seja ela natureza (riqueza "natural" previa a qualquer trabalho social), evidenciando a acumulação por espoliação ${ }^{15}$ como a característica fundamental do que define o capital. Falando sobre as formas de espoliação, o autor destaca:

\footnotetext{
15 "uma reavaliação geral do papel contínuo e da persistência das práticas predatórias de "acumulação primitiva" ou "original" no âmbito da longa geografia histórica da acumulação do capital é por conseguinte muito necessária, como observaram bem vários comentadores. Como parece estranho qualificar de "primitivo" ou "original" um processo em andamento, substituirei a seguir esses termos por "acumulação por espoliação" (HARVEY, 2004, p. 121).
} 
Não só foram centrais para os aspectos mais vis do colonialismo, como até hoje as políticas de espoliação (administradas em grande parte por uma aliança terrível entre o poder corporativo e o poder estatal) do acesso à terra, à água, e aos recursos naturais geram movimentos maciços de inquietação global. (HARVEY, 2016, p. 63)

Por fim, destacamos que as formas de espoliação vão ao longo do tempo sendo incorporadas pelo Estado, institucionalizadas e legalizadas. Foi assim desde a acumulação primitiva na Europa, descrita por Marx, quando as Leis aplicadas pelo Estado (Leis de Cercamentos) passaram a legitimar a tomada de terras comunais e de trabalhadores rurais: "[...] que a própria lei se torna, agora, o veículo do roubo das terras do povo, embora os grandes arrendatários também empreguem paralelamente seus pequenos e independentes métodos privados" (MARX, 2013a, p. 971). Foi assim na invasão e apropriação privada das terras na América. Foi assim no Brasil Império, com a Lei de Terras e a definição de terras devolutas, e continua sendo assim no Brasil República.

\section{Quebra do metabolismo e alienação}

A descrição de Marx sobre a passagem do feudalismo para o sistema capitalista pode parecer um tanto romantizada, como também destaca Harvey (2013). Havia exploração, servidão e outras tantas formas de exploração no sistema feudal, todavia o quase exagero de Marx nos faz atentar para algo muito importante que o desenvolvimento do capitalismo encobriu. 0 homem assalariado não é mais livre que o servo, é na verdade, um ser talvez menos autônomo e, com certeza, mais alienado que o servo. A venda da força de trabalho, a naturalização e disseminação do contrato mediante salário encobriram outros processos, como a exploração, a espoliação e sobretudo a perda de autonomia, a perda dos meios de produção que passaram a ser cada vez mais concentrados. É sobretudo a separação do homem da terra, o que Marx chamou de quebra do metabolismo ${ }^{16}$.

A acumulação primitiva, como visto anteriormente, libertou o ser humano dos seus meios de produção e voltou-o para o trabalho assalariado, ou, como também se refere Marx, trabalho alienado. "O conceito marxiano de 'trabalho alienado' (ou trabalho assalariado) é inseparável de sua ideia de que a forma social determinada da atividade produtiva, que traz a 'valorização

\footnotetext{
${ }^{16}$ Marx considera que o ser humano é parte da natureza, "definindo a relação historicamente primária entre o ser humano e a natureza como relação da natureza consigo mesma” (MÉSZÁROS, 2016, p. 116).
} 
do mundo das coisas' ao preço da 'desvalorização do mundo dos homens' [...]" ( MÉSZÁROS, 2016, p. 118).

A divisão social do trabalho, disseminada através da teoria dos economistas clássicos, foi uma forma de alienação, pois separou o homem da terra, o trabalho da natureza, contribuindo para a quebra do metabolismo identificada por Max, que, segundo a interpretação de Foladori (s/d, p. 106), refere-se ao "processo por meio do qual a sociedade humana transforma a natureza externa, e, ao fazê-lo, transforma sua natureza interna. A ação de transformar a natureza externa constitui o processo de trabalho, e o seu efeito sobre a natureza interna se manifesta na forma como se estabelecem as relações sociais de produção". Dessa forma, o avanço das ideias econômicas neoclássicas, representariam uma intensificação dessa fratura metabólica e da alienação que esta provoca.

“[...] o trabalhador assalariado [...] é livre, mas essa liberdade deve ser entendida como isolamento, alienação com respeito a natureza externa; é livre porque foram esgarçados os laços do metabolismo com o meio ambiente. É livre no sentido isolado" (FOLADORI, s/d, p. 108). Esta separação faz com que o homem, alienado, enxergue a si mesmo como algo distante da natureza. "La naturaleza ya no es vista como cuerpo inorgánico del hombre, sino como depósito primordial de víveres o arsenal primordial de medios de trabajo" (MUNOZ, 2015, p. 21).

O trabalho alienado alimenta o desconhecimento dos materiais e do trabalho empregado nos processos de produção das mercadorias ( HARVEY, 2013). Assim, a forma mercadoria acaba por encobrir processos de exploração e espoliação empregados no seu desenvolvimento. A relação do consumidor é com a mercadoria pronta, com o objeto. A mercadoria assume então uma forma fantasmagórica, é um mistério, um fetiche, "o fetiche da mercadoria" ( MARX, 2013a). Não enxergamos as relações sociais que possibilitaram sua existência, enxergamos apenas o objeto mercadoria e pagamos por ele preços que não necessariamente representam seu valor.

O fetiche sustenta o sobrepreço de muitas mercadorias, sustenta inclusive que coisas que não são resultado de trabalho, por isso não possuem valor, possuam preço, a representação do valor. É o caso, por exemplo, da natureza, da terra. A alienação e o fetiche da mercadoria naturalizam a propriedade privada da terra, naturalizam e concebem o direito do proprietário 
de obter renda da natureza sem trabalho empregado, naturalizam o fato do trabalhador que constrói casas não ter uma porque não tem dinheiro para comprá-la, mesmo que durante sua vida tenha produzido o valor de centenas de casas.

Importante ressaltar que ao mesmo tempo que a alienação encobre os processos de exploração do trabalhador, ela encobre também a espoliação da natureza, levando à degradação dos recursos ambientais que sustentam o próprio sistema (terra, água, ar, vegetação, e o próprio homem).

Esse processo de alienação e separação do homem da natureza é acompanhado pelo surgimento e desenvolvimento da economia clássica e neoclássica que exercem influência até os dias de hoje nas atividades e produção de nossas cidades. Teorias, estas, que compreendem a economia como um sistema fechado e isolado da natureza, e que implementaram a divisão do trabalho, com o objetivo de aumentar a produção e manter um crescimento econômico constante.

O surgimento da economia como sistema fechado e isolado da natureza

O surgimento da economia é atribuído a um grupo de pensadores franceses do século XVIII, conhecidos como fisiocratas ${ }^{17}$, mais tarde reconhecidos como a primeira escola de economia (NAREDO, 2004; CECHIM, 2010; SÁNCHEZ, 2014). Antes disso, as atividades econômicas eram desenvolvidas por filósofos, advogados, empresários e funcionários públicos (CECHIM, 2010).

Este grupo acreditava que o conjunto formado pela biosfera e pelos recursos naturais estavam relacionados entre si e que cada criatura ou componente físico tinham uma função (NAREDO, 2016). Defendia que a verdadeira riqueza estava associada à natureza, mais precisamente à agricultura, e não ao comércio e acumulação de metais preciosos, como era acreditado até então ${ }^{18}$ (CECHIM, 2010). Também acreditava que o trabalho e a indústria eram "aniquiladoras de riqueza", pois eram incapazes de repor o desperdício gerado durante suas atividades, afirmando assim, como tese principal de sua obra, que "[...] la agricultura era la única

\footnotetext{
${ }^{17}$ Fisiocrata traduzido do grego significa "domínio da natureza" (NAREDO, 2004; CECHIM, 2010)

18 Vale destacar que antes dos fisiocratas, séc. XV ao XVIII, os países europeus passavam pelo mercantilismo, considerando como riqueza o montante de ouro e prata, e o comércio como fonte de crescimento da riqueza" (CECHIM, 2010).
} 
actividad verdadeiramente productiva, ya que sólo através de ésta era posible la generación de um produto neto ${ }^{19 \prime \prime}$ (SÁNCHEZ, 2014, p. 65).

Ao associar a riqueza à agricultura, os fisiocratas estavam condicionados a variações do clima e do tempo, não podendo estar afastados de uma concepção e percepção de ligação entre a economia e o meio físico. Desenvolveram, assim, o que hoje é chamado de uma economia da natureza, tendo assim as leis do mundo físico como base para orientar os princípios da economia monetária (NAREDO, 2004).

Todavia, foram estes mesmos autores que desenvolveram incialmente a ideia de interdependência entre os vários processos produtivos e de equilíbrio do sistema econômico, e a representação das trocas econômicas como um fluxo circular de bens e dinheiro entre vários setores econômicos. E foram estas últimas ideias, de sistema econômico e fluxo circular de bens e dinheiro que acabaram ganhando força e sendo disseminadas e incorporadas pelos economistas clássicos (NAREDO, 2004; CECHIM, 2010).

Diferente dos fisiocratas, os economistas clássicos acreditavam que a verdadeira riqueza era criada pelo trabalho, ou seja, pela transformação de recursos da natureza. Deste modo, a ênfase dada à agricultura foi transferida para o setor manufatureiro. Essa mudança de enfoque somada ao pensamento de que era necessário garantir um crescimento econômico, levou a que esses economistas incentivassem o aumento da produtividade através da especialização em tarefas cada vez mais específicas, conduzindo à divisão social do trabalho e à acumulação de capital. Foi a partir deste momento que a economia começou a se afastar de assuntos ligados à religião, ética e natureza (NAREDO, 2004; CHECHIM, 2010). "La economía se ocuparía sólo del estadio de la interacción entre los hombres, dejando de lado la relación de estos con los otros seres vivos y con el planeta ${ }^{20 "}$ (SÁNCHEZ, 2014, p. 63).

Apesar do afastamento da natureza, Naredo (2004) destaca que os economistas clássicos reconheciam que este crescimento econômico tinha um limite imposto pela disponibilidade de recursos naturais ${ }^{21}$ e que, a longo prazo, levaria o crescimento econômico a um estado

\footnotetext{
19 "[...] a agricultura era a única atividade realmente produtiva, já que somente por meio desta era possível a geração de um produto líquido" (SÁNCHEZ, 2014, p. 65. Tradução própria).

20 "A economia se ocuparia apenas da interação entre os homens, deixando de lado a relação destes com outros seres vivos e com o planeta" (SÁNCHEZ, 2014, p. 63. Tradução própria).

${ }^{21}$ Naredo (2004, p. 87 e 88) destaca que: "Hay que recordar que a finales del siglo XVIII e principios del XIX la geodesia, la mineralogía y la química modernas desautorizaron la antigua idea del crecimiento de los minerales y de la Tierra misma [...]
} 
estacionário. Para Cechim (2010), alguns autores deste período, como Adam Smith, não estavam muito preocupados com este limite, pois o visualizavam a um futuro muito distante, e acreditavam que, até a aproximação deste momento, a sociedade já haveria evoluído a ponto de sobrepor estas dificuldades. Já outros, como David Ricardo e Thomas Malthus ${ }^{22}$, demostravam bastante preocupação com o tema e acreditavam que, mesmo com a aplicação de trabalho crescente na terra, o produto por trabalhador diminuiria, implicando a queda no padrão de vida e um estado estacionário, com a população vivendo em um estado de subsistência.

Alguns economistas, como Jonh Stuart Mill, viam este estado estacionário como algo positivo e natural: "até a chegada do estado estacionário, o progresso técnico já teria possibilitado satisfazer as vontades materialistas da humanidade, e a sociedade estaria livre para perseguir outras metas sociais" (CECHIM, 2010, p. 30). Esta visão positiva, sobre parar o crescimento, levou Naredo (2004) a afirmar que até este momento a "[...] mitologia atual do crescimento como uma chave incontestável para o progresso" (NAREDO, 2004, p. 88. Tradução própria) ${ }^{23}$ ainda não estava completamente estabelecida.

Serían los economistas llamados neoclásicos de finales del siglo XIX y principios del $\mathrm{XX}$, los que acabarían vaciando de materialidad la noción de producción y separando ya por completo el razonamiento económico del mundo físico, completando así, la ruptura epistemológica que supuso desplazar la idea de sistema económico, con su carrusel de la producción y el crecimiento, al mero campo de valor, donde seguiría girando libremente, hasta que las recientes preocupaciones ecológicas o ambientales demandaran nuevas conexiones entre lo económico y el físico (Ibid., 2004, p. 88. Grifo meu) ${ }^{24}$.

Deste modo, os neoclássicos ${ }^{25}$ seguiram com a postura acrítica de progresso baseado na produção e crescimento econômico, tendo este como a chave para o sucesso e como algo

\footnotetext{
los economistas clásicos no pudieron menos que aceptar que el crecimiento de la población, la producción y los consumos (materiales) resultaba inviable a largo plazo si la Tierra no crecía".

${ }_{22}$ Autor da teoria Malthusiana onde a população cresceria em uma progressão geométrica enquanto a produção de alimentos em uma aritmética, e apontava como uma das principais soluções o controle da natalidade.

23 "mitologia actual del crecimiento como llave inequívoca de progreso" (NAREDO, 2004, p. 88).

24 "Seriam os chamados economistas neoclássicos do final do século XIX e início do XX, que acabariam esvaziando de materialidade a noção de produção e separando completamente o raciocínio econômico do mundo físico, completando assim a ruptura epistemológica que supostamente deslocaria a ideia de sistema económico, com o seu carrossel de produção e crescimento, para o mero campo de valor, onde continuaria a rodar livremente, até que as recentes preocupações ecológicas ou ambientais exigissem novas ligações entre o económico e o físico" (NAREDO, 2004, p. 88. Tradução própria).

${ }^{25}$ Foi neste momento que a economia como ciência se afirmou separando-se do mundo físico e do político, antes a economia era tratada como "economia política" e passou a ser somente economia (NAREDO, 2004; CHECHIM, 2010).
} 
positivo para todo o mundo. A noção de sistema econômico ${ }^{26}$ autossuficiente e isolado da natureza se sobrepôs às ideias de economia da natureza. Nesse sistema, a natureza não era vista como um limite, pois, apesar do reconhecimento da finitude dos recursos naturais, acreditava-se que estes poderiam ser melhor aproveitados ou substituídos por outras fontes, a partir dos avanços das ciências e das tecnologias. A transformação da terra e do trabalho em mercadorias teve grande importância para o desenvolvimento dessa corrente, como aponta Naredo (2004, p.88): "[...] a ideia de que tanto a terra como o trabalho eram substituíveis por capital, permitiu fechar o raciocínio econômico no universo do valor, abstraindo o mundo físico, ao considerar o capital como o fator limitante final para a produção de riqueza"27.

Assim, ao considerar a economia como um sistema fechado, a tradição neoclássica "não reconhecia que problemas ambientais pudessem, sistematicamente, interferir no funcionamento eficiente do mercado" (MULLER, 2004, p. 106). A ideia da economia como um sistema circular e fechado, representado nos livros de fundamentos da economia por um diagrama circular (CHECHIM, 2010) pressupõe um sistema econômico funcionando como se:

(1) existissem fontes inesgotáveis de insumos materiais e de energia para alimentar o funcionamento do sistema; (2) no processo de produção todos os insumos materiais fossem inteiramente convertidos em produtos, não ficando nenhum resíduo indesejado; (3) no consumo, todos os produtos desaparecessem inteiramente, sem deixar vestígios; (4) as instituições da sociedade assegurassem com que todos os atributos ambientais relevantes pertencessem a alguém, sendo livremente transacionados em mercados competitivos. Considerava-se, pois, a economia um sistema isolado, autocontido, cabendo à teoria econômica concentrar-se na análise dos fluxos de troca circulando no seu interior, entre empresas e famílias. (MULLER, 2004, p. 106).

Naredo (2004) aponta que o segredo do sucesso da ideologia implementada pelos neoclássicos, que dominou todo o século XX e continua sendo a corrente hegemônica, devese ao fato da crença de que "a los fuertes les promete liberdad absoluta en el ejercício de su fuerza y a los débiles la esperanza de algún día llegar a ser fuertes" (TAWNEY, 1921, Apud NAREDO, 2004, p. 85) ${ }^{28}$. Desta forma, esse modelo apontava a um crescimento econômico

\footnotetext{
26 “[...] la versión de sistema económico adoptada por los autores neoclásicos a finales del siglo XIX y utilizada hasta el momento como objeto de representación (de las contabilidades nacionales de flujo) y de reflexión de los economistas, explica el divorcio entre la economía y ecología que ahora se trata de paliar" (NAREDO, 2004, p. 89).

27 Tradução própria. "[...] la idea que la tierra como el trabajo, eran substituibles por capital, permitió cerrar el razonamiento económico en el universo del valor haciendo abstracción del mundo físico, al considerar el capital como el factor limitativo último para la producción de riqueza" (NAREDO, 2004, p.88)

28 "Aos Fortes se lhes promete liberdade absoluta de suas forças e aos fracos a esperança de algum dia chegarem a ser fortes" (TAWNEY, 1921, Apud NAREDO, 2004, p. 85. Tradução própria).
} 
constante e mistificador dos problemas e das tendências em curso que na verdade caminhavam para uma minimização do ecológico e uma polarização social (NAREDO, 2004).

Schmidt (1962), Burkett (1999), Foster (2000), Foladori (s/d), Riechman (2011), entre outros autores, vêm resgatando o conceito de metabolismo social colocado por Marx. Destacam que os escritos de Marx possuem uma rica fonte metodológica para se tratar a questão ambiental (FOLADORI, s/d), como trabalhado por Burkett em seu livro "Marx and Nature, a red and green perspective", e Foster no livro "Marx's ecology, materialism ${ }^{29}$ and nature". Inclusive, como pôde ser visto no ponto anterior, Marx coloca a terra (natureza) e essa separação do homem da terra como o ponto de partida para a acumulação de capital e geração de massa de trabalhadores livres para a indústria necessárias para o desenvolvimento inicial do capitalismo.

Segundo Foladori (s/d, p. 107) e Muller (2004) os que criticam Marx com relação a seu desinteresse pela natureza procuram na verdade explicações de como funciona a relação do homem com a natureza e respostas para os problemas ambientais. Mas Marx não tentava responder estas questões, o que ele tentava entender e explicar era como se deu o processo histórico no qual "se separa - aliena-se - a existência humana dos condicionantes necessários para reproduzir-se" (FOLADORI, p. 107), ou seja, as formas como esse metabolismo com a natureza vai sendo quebrado e modificado.

Segundo Muñoz (2015), Marx já apontava a eterna e completa dependência do homem, e demais seres vivos, do meio ambiente natural, relação homem/natureza ${ }^{30}$, e que já adiantava que o sistema capitalista desregulava o metabolismo entre o homem e a terra (natureza) e separava o campo da cidade.

A acumulação primitiva e a divisão social do trabalho, como visto anteriormente, foram formas de alienação, pois separaram o homem da terra, o trabalho da natureza, contribuindo para a quebra do metabolismo identificada por Marx, que, segundo a interpretação de

\footnotetext{
29 "[...] materialism claims that the origins and development of what eves exists is dependent on nature and "matter", that is, a level of physical reality that is independent of and prior to thought" (FOSTER, 2000, p. 02)

30 O termo "homem versus natureza", pode ser interpretado como uma alienação resultante da quebra do metabolismo social, que tende a ver o homem como um ser alienígena à natureza, quando na verdade o homem também é natureza. "[...] el hombre vive de la naturaleza quiere decir que la naturaliza es su cuerpo, con lo cual ha de mantenerse en proceso continuo para no morir (MUNOZ, 2015, p. 20). Se esclarece aqui que foi mantida o termo, por ser assim a forma como o autor estruturou sua fala.
} 
Foladori (s/d, p. 106), refere-se ao "processo por meio do qual a sociedade humana transforma a natureza externa, e, ao fazê-lo, transforma sua natureza interna. A ação de transformar a natureza externa constitui o processo de trabalho e o seu efeito sobre a natureza interna se manifesta na forma como se estabelecem as relações sociais de produção". Dessa forma, o avanço das ideias econômicas neoclássicas representaria uma intensificação dessa fratura metabólica e da alienação que esta provoca.

Esta separação faz com que o homem, alienado, enxergue-se a si mesmo como algo distante da natureza. "La naturaleza ya no es vista como cuerpo inorgánico del hombre, sino como depósito primordial de víveres o arsenal primordial de medios de trabajo" (MUNOZ, 2015, p. 21)

Segundo Naredo (2007), os economistas neoclássicos conseguiram enterrar a ideia de estado estacionário colocada pelos clássicos, baseados na ideia de que a Terra juntamente com todos seus recursos, "podría ser sustituida sin problemas por una entidad, abstracta llamada capital, presentando a éste como el factor limitativo último y cerrando así el discurso económico em mero campo de los valores pecuniarios, sin necesidad de incómodas conexiones con el mundo físico" (NAREDO, 2007, p. 37).

A alienação do homem não se dá apenas na sua separação da natureza. O homem aliena-se de si mesmo já que também é natureza e passa a construir uma ciência fragmentada, especializada, como a divisão do trabalho, e uma sociedade também fragmentada, levada cada vez mais ao individualismo. O tipo de visão acima descrita levou a ilusões dentro do campo da economia, como a de que os problemas ambientais seriam externalidades do sistema e que os mesmos poderiam ser facilmente reversíveis, e a ilusão talvez mais grave da suposta substituição dos recursos naturais por capital.

\section{A reincorporação da natureza nas teorias econômicas}

Problemas ambientais mais recentes, do final do século XIX e XX, têm forçado as ciências a buscarem novas interpretações e novos modelos que respondam aos problemas atuais. Muller (2004) destaca entre estes eventos a acentuação da poluição no primeiro mundo; a 
crise do petróleo na década de 1970, a criação do Clube de Roma e a publicação, em 1972, de "The limits of growth"31.

Dentro da economia surgiram correntes teóricas que tentaram revisar o modelo hegemônico neoclássico, aportando a reflexão sobre a natureza, que estava sendo mantida de fora. Dentre estas, destacam-se mais duas: (1) a economia ambiental ou economia verde, e (2) a economia ecológica.

A economia ambiental é considerada como parte ou subdisciplina da economia neoclássica (FOLADORI, 1999; NAREDO, 2004; MULLER, 2004; CECHIM, 2010; CAJAMAR 2010). Assim como os economistas clássicos, os adeptos da teoria ambiental, também reconhecem que os recursos naturais são finitos, não só pelo fim de terras férteis para agricultura, mas também o reconhecimento do fim de fontes de energias fósseis, dentre outros recursos não renováveis. Todavia, veem os problemas ambientais, os quais reconhecem como maléficos para a humanidade, como externalidades do sistema, que não representam um limite real à economia, pois podem ser corrigidos a partir do avanço da ciência, das tecnologias e da adoção de medidas de estímulo do mercado, que preveem a internalização dos custos ambientais nos cálculos dos agentes geradores através de taxação (MULLER, 2004; CECHIM, 2010). Defendem, assim, a possibilidade de compatibilizar crescimento econômico com preservação da natureza a partir de medidas mitigadoras, do aperfeiçoamento e substituição de técnicas e materiais, apropriando-se e disseminando o conceito de desenvolvimento sustentável.

Afirmavam, por meio de alguns casos (que não davam conta da realidade), que o crescimento econômico, a partir de certo nível de riqueza, seria benéfico ao meio ambiente, disseminando a ideia de que "o crescimento inicial degrada o meio ambiente, porém a continuidade do crescimento resolve os problemas ambientais" (CECHIM, 2010, p. 136). Assim, a população poderia ser tranquilizada através de medidas econômicas e políticas com "imagem verde" classificadas como sustentáveis. A banalização e a degradação ambiental poderiam ser ocultadas, sem necessariamente mudar os critérios de gestão, nem os comportamentos

\footnotetext{
31 "Os Limites do Crescimento", famoso relatório produzido por equipe liderada por Dennis Meadows e Donella Meadows a pedido do Clube de Roma que previa o esgotamento dos recursos naturais em 100 anos.
} 
daqueles que os originam (NAREDO, 2007). É o que Naredo (2007) vai chamar de reconciliação virtual entre economia e natureza, à qual faz enorme crítica.

\begin{abstract}
¿Hasta qué punto los vientos que soplan a favor de la reconciliación virtual entre economía y naturaleza conseguirán eclipsar a aquellos otros que buscan su reconciliación real? [...] ¿Hasta cuándo las políticas de imagen verde podrán seguir contentando a la población, ocultando, así, una posible reconciliación real? Ello dependerá, en parte, del vigor que alcancen las denuncias de la función mistificadora que ejerce el discurso económico dominante en este campo...o de que se cubra el vacío actual de conocimiento sobre los rasgos esenciales del metabolismo de la civilización industrial que son fuente simultánea de desarrollo económico y deterioro ecológico (NAREDO, 2007, p. 51).
\end{abstract}

Os integrantes dessa corrente defendem, em relação às medidas de reconciliação (virtual) entre economia e natureza, a importância de dar preço e monetizar os recursos naturais e a degradação gerada ao meio ambiente. Assim, poderiam ser geradas receitas a partir de taxas de mitigação por degradação e poluição para mitigar outros problemas ambientais, além de acreditarem que a visualização do serviço ambiental ou da degradação ao meio ambiente em valor monetário funcionaria como educação ambiental para a população e empresas, fazendo com que estas vejam a importância de preservar esses recursos.

Contudo, ao monetizar recursos e serviços ambientais, incluímos de vez estes no mundo do fetiche das mercadorias. As pessoas em seus trabalhos alienados, vivendo em uma segunda natureza ${ }^{32}$, já possuem dificuldades de compreender e visualizar as relações e o funcionamento dos sistemas e serviços ambientais. No momento em que não só a terra e o trabalho, mas também os serviços ambientais - ciclo da água, renovação do oxigênio pela vegetação e degradações ambientais como poluição do solo, ar e água - passam a ser convertidos em dinheiro, a ter um preço, a relação do ser humano com estes passa a ser o dinheiro necessário para comprá-lo, obscurecendo mais ainda o funcionamento desses serviços ambientais e os impactos da degradação. O limite não parece ser mais o mundo físico, mas o montante de capital que posso desprender.

Inclusive, isso vem se transformando em um novo e extremamente lucrativo nicho de mercado, onde ações de sequestro de carbono são negociadas inclusive no mercado financeiro.

\footnotetext{
32 LEFEBVRE, 1999
} 
Assim, concordando com Naredo (2016), a economia ambiental ou economia verde reforça a lógica econômica dominante de valoração econômica de tudo "[...] estirando a vara de medir do dinheiro (critério do dinheiro) para capturar componentes do meio ambiente com a finalidade de levá-los ao curral dos valores monetários [...] (ibidem, 2016, p. 10).

Com inspiração na economia ambiental, na ecologia humana, na antropologia ecológica, na ecologia urbana, entre outras correntes, a econômica ecológica ${ }^{33}$ remonta ao final da década de 1980, com a deliberação da fundação do ISEE (International Society for Ecological Economics), em 1987. Neste mesmo ano, foi lançado o primeiro livro trazendo em seu título o termo economia ecológica e dois anos depois, em 1989, a ISEE publica o primeiro número da revista acadêmica Ecological Economics ( NAREDO, 2016). Contudo, as ideias desta corrente já vinham sendo trabalhadas, segundo Cechim (2010), desde a década de 60, por autores como Georgrscu-Roegen, que defendia a retração econômica a partir de um determinado momento para garantir o desenvolvimento humano.

Para essa corrente, a "economia humana está incrustada na natureza e os processos econômicos devem ser vistos também como processos de transformação biológica, física e química" (NAREDO, 2010, p. 138). Defendem que os danos ambientais causados pela economia não são facilmente reversíveis e parte das alterações são irreversíveis, tratando a economia como um ser vivo, que intercambia energia e matéria com seu meio exterior (MULLER, 2004). Assim, estão preocupados com os limites biofísicos e com a absorção e assimilação dos resíduos pela natureza, defendendo que, a partir de certo ponto, o crescimento econômico (que segundo eles não é capaz de garantir felicidade, nem bem-estar) deixa de ser benéfico e passa a comprometer o futuro das próximas gerações (CECHIM, 2010).

Neste sentido, avançam ao reconhecer os limites físicos do crescimento econômico e na defesa da necessidade de que, mesmo com desenvolvimento tecnológico e científico, em determinado ponto (ainda não definido) é necessário desacelerar o crescimento econômico e produtivo até um estado estacionário. Mesmo mantendo este estado estacionário, nomeado por eles mais como "desenvolvimento sustentável"34 (CECHIM, 2010), acreditam que

\footnotetext{
33 Para maiores detalhes sobre Economia Ambiental e Economia Ecológica consultar: Cechim (2010); Klink e Alcántara (1994); Cajamar (2010).

34 Martínez Alier (2009) ressalta que a maioria dos economistas ecológicos rejeitam o termo "crescimento sustentável", porém aceitam o "desenvolvimento sustentável". Contudo, para o autor, o termo "desenvolvimento" ainda carrega uma forte denotação de crescimento econômico, deste modo prefere usar apenas a palavra "sustentabilidade".
} 
continuem existindo limites, pois os recursos não renováveis em certo momento se esgotarão e seus substitutos também. Deste modo, para estes, o que se pode é garantir por mais tempo, mas não de forma indeterminada, o futuro das próximas gerações.

Apesar de muitos integrantes da economia ecológica também possuírem pretensões de atribuir valores monetários aos serviços e às perdas ambientais, Martínez Alier ( 2009) defende que isto é apenas um pequeno fragmento da corrente. O autor destaca que esta busca proporcionar uma visão sistêmica das relações econômicas e o meio ambiente, incorporando também avaliações físicas e sociais das contribuições da natureza, destacando entre essas avaliações a construção de indicadores que tentam medir a insustentabilidade. Assim, o grupo contesta a sustentabilidade da economia tanto pelo crescimento demográfico como pelos impactos ambientais devido a demandas de energia e materiais cada vez maiores com o aumento do consumo.

Naredo ( 2016) também destaca como pontos positivos da Economia Ecológica o fato desta buscar uma abordagem multidisciplinar, buscado em ciências que já vinham estudando e analisando o mundo físico, o meio ambiente, seus sistemas, biomas e interrelações como a ecologia, considerando o sistema econômico como "un ecosistema más cuyo metabolismo cabe analizar, con todos sus flujos de energía, materiales... y dinero y con sus interacciones con el medio físico" (ibidem, p. 11). O autor, e aqui concordamos com ele, considera a economia ecológica um avanço em relação a economia ambiental, pois a primeira, por mais que incorpore a natureza, ainda trava uma leitura do homem separado da natureza, enquanto a ecológica entende que homem faz parte da natureza e, como em outros exemplos de animais, podem haver simbioses da espécie humana com o meio físico ou outras espécies que sejam interessantes e importante para a manutenção de ambos.

Reconhecemos os vários avanços da economia ecológica destacados por Martínez Alier e Naredo, porém, por mais que a economia ecológica tente defender a visão de que homem é natureza, que os recursos ambientais como o crescimento econômico têm um limite, e que reconheça o fetiche das mercadorias, no momento em que não rompem com os sistemas de valoração monetária e taxação dos recursos e degradação ambiental, a natureza continuará aos olhos do homem como mercadoria. 


\title{
1.2. A NATUREZA NO PROCESSO DE ACUMULAÇÃO EM FORTALEZA - ESPOLIAÇÃO DE UM BEM COMUM
}

\begin{abstract}
A formação da base capitalista da sociedade cearense, assim como a brasileira, é marcada por constantes e violentos processos de roubo e apropriação privada ${ }^{35}$ da natureza, riqueza antes
\end{abstract} comum. Esse processo de apropriação privada de riquezas comuns para acumular novos capitais é chamado por Marx ( 2013a) como acumulação primitiva, e foi de extrema importância na formação do modo de produção capitalista. Harvey ( 2004), observando que esse é um processo que não foi exclusivo da gênese do capitalismo, e segue até os dias de hoje, passou a chamá-lo de acumulação por espoliação, por se tratar de um processo em que se acumula capital por meio da espoliação e apropriações ilícitas.

Tivemos desde o roubo de toneladas de metais preciosos, que foram mais importantes no processo de acumulação de capitais da Europa do que do Brasil, passando pela invasão e apropriação privada das terras locais, antes apropriadas (não-privadas) de forma individual ou coletiva pelos que aqui habitavam, até mesmo o rapto e apropriação privada do próprio ser humano (também natureza), escravizado e subjugado a uma vida que não mais Ihe pertencia. Como já apontava Marx em O Capital, o sistema colonial, além de extremamente violento, foi um dos momentos fundamentais da acumulação primitiva que possibilitou a passagem da produção feudal para a capitalista na Europa:

A descoberta das terras auríferas e argentíferas na América, o extermínio, a
escravização e o soterramento da população nativa nas minas, o começo da
conquista e saqueio das Índias Orientais, a transformação da África numa reserva para
a caça comercial de peles-negras caracterizam a aurora da era da produção
capitalista. Esses processos idílicos constituem momentos fundamentais da
acumulação primitiva. A eles se segue imediatamente a guerra comercial entre as
nações europeias, tendo o globo terrestre como palco. [...] Os diferentes momentos
da acumulação primitiva repartem-se, agora, numa sequência mais ou menos
cronológica, principalmente entre Espanha, Portugal, Holanda, França e Inglaterra. Na
Inglaterra, no fim do século XVII, esses momentos foram combinados de modo
sistêmico, dando origem ao sistema colonial, ao sistema da dívida pública, ao moderno
sistema tributário e ao sistema protecionista. Tais métodos, como, por exemplo, o
sistema colonial, baseiam-se, em parte, na violência mais brutal. Todos eles, porém,

\footnotetext{
${ }^{35}$ Aqui fazemos questão de diferenciar apropriação de apropriação privada: “[...] observa-se, na obra de Lefebvre, a ideia de apropriação em oposição ao conceito de propriedade privada. Para este autor (1996) a propriedade é um ato de possessão de desvio das atividades apropriativas (do tempo, do espaço, do corpo, do desejo) que buscam atender às necessidades. A apropriação é posta por Lefebvre como expressão do uso. O uso seria o movimento contrário a forma mercadoria que se realiza na propriedade. Trata-se, portanto, da apropriação individual (ou coletiva) e não apropriação privada, sendo esta última associada à propriedade privada". (ALDIGUERI, 2017, p. 96.)
} 
lançaram mão do poder do Estado, da violência concentrada e organizada da sociedade, para impulsionar artificialmente o processo de transformação do modo de produção feudal em capitalista e abreviar a transição de um para o outro. ( MARX, 2013a, p. 998. Grifos meus)

Como também destaca Pereira ( 1988, p. 19) , no Brasil, "a organização da economia colonial viabilizava o desenvolvimento do capitalismo industrial europeu e embotava a divisão do trabalho na Colônia ao permitir aqui uma acumulação de riquezas, mas não de capital", e "[...] do ponto de vista do capital mercantil em expansão, o controle monopolista da produção colonial identificava-se com o processo de separação do trabalho e da propriedade que lá estava ocorrendo, ambos voltados para a acumulação primitiva de capital”. Estes processos foram de extrema importância não só para a formação do sistema capitalista na Europa, mas também foram base para o capitalismo no Brasil. Tanto o roubo das terras dos que aqui habitavam e delas se apropriavam para sua subsistência como o rapto daqueles que aqui não habitavam de suas terras (a terra roubada e os roubados de suas terras) iniciaram o processo de alienação da população, separaram esses homens de suas terras e criaram a base dos futuros trabalhadores assalariados ${ }^{36}$ (de "baixos salários" - MARICATO, 1995) que "se convertem em vendedores de si mesmos depois de lhes terem sido roubados todos os seus meios de produção, assim como todas suas garantias de sua existência" ( MARX, 2013a, p. 962). Vale destacar que o índio não tinha a noção de propriedade privada, o que facilitou o roubo inicial dos colonos tanto de suas terras como de outras riquezas, como metais preciosos e madeira ( LIMA e MARQUESAN, 2017).

Durante o período Colonial, a terra ainda não tinha tanta importância, importava o que era produzido ou extraído e, portanto, o que importava era a mão de obra escravizada, o ser humano escravizado era a mercadoria importante. "A terra sem escravos pouco valia. O valor representado pela propriedade imobiliária, fosse ela fazenda ou edifício urbano era muito pequeno" (PEREIRA, 1988, p. 19). Tomando o caso de São Paulo como exemplo, o mesmo autor destaca:

A propriedade imobiliária, devido ao seu pequeno valor, pouco é mencionada na documentação da época; os inventários, muitas vezes, são omissos e as escrituras só são mencionadas com frequência na segunda metade do século XVIII. A terra como propriedade imóvel pouco valia, nem mesmo precisava ser bem demarcada em seus

\footnotetext{
${ }^{36}$ Essa massa de trabalhadores assalariados foi inicialmente formada pelos imigrantes europeus, com destaque para os italianos, sobretudo em São Paulo e Rio de Janeiro. Ver PEREIRA, 1988.
} 
limites, tanto que eram distribuídas propriedades a quem solicitasse. ( PEREIRA, 1988)

A distribuição de terras, sesmarias, ocorreu inclusive para população indígena durante o período colonial. Diversos trabalhos mais recentes que têm analisado bibliografia documental desta época têm encontrado relatos de solicitações por parte de indígenas e distribuição para estes de sesmarias. Podemos mencionar os trabalhos de Melo ( 2007); Antunes ( 2012); e $\operatorname{SILVA}(\mathrm{s} / \mathrm{d})$.

De fato, a riqueza na Colônia era medida pela quantidade de escravos, "o aumento do número de escravos implicava o aumento do excedente, enquanto o acréscimo na extensão de terras nem sempre significava aumento no excedente" (PEREIRA, 1988, p. 33). O escravo representava a renda capitalizada a partir da projeção futura da renda que seu proprietário iria adquirir com a produção realizada por este (PEREIRA, 1988). A terra vai adquirir essa propriedade de renda capitalizada e capital fictício no Brasil ( ALDIGUERI, 2017) mais precisamente a partir da Lei de terras (1850), quando esta, assim como o escravizado, passa a ser tratada como mercadoria e a possuir um preço, mesmo que seu valor não seja real.

Assim como na Europa, onde o Estado e o quadro normativo desenvolvido por este tiveram um importante papel no processo de acumulação primitiva - incluindo a apropriação privada das terras dos produtores rurais e camponeses, como descreve Marx ( 2013a) $)^{37}$ - , também no Brasil e no Ceará, o Estado desempenhou importante papel desde o período do Império. Uma das ações mais conhecidas vinculadas a esse processo, no Estado brasileiro ainda em formação, é a já mencionada Lei de Terras, aprovada em 1850, a partir da qual ficou definido que o acesso à terra seria mediante a propriedade privada, adquirida por meio de sua compra e venda, e transferida por contrato ou herança. Assim, por mais que a terra estivesse disponível, sem uso, sem ocupação, sem apropriação individual ou coletiva, torna-se inacessível, pois "[...]a propriedade da terra só podia ser adquirida de forma onerosa, tornando-se equivalente de capital, isto é, renda capitalizada" (PEREIRA, 1988, p. 54). "A

\footnotetext{
37 O progresso alcançado no século XVIII está em que a própria lei se torna, agora, o veículo do roubo das terras do povo, embora os grandes arrendatários também empreguem paralelamente seus pequenos e independentes métodos privados. [...] A forma parlamentar do roubo é a das "Bills for Inclosures of Commons" (leis para o cercamento da terra comunal), decretos de expropriação do povo, isto é, decretos mediante os quais os proprietários fundiários presenteiam a si mesmos, como propriedade privada, com as terras do povo. (MARX, 2013a, p. 971. Grifo meu).
} 
propriedade privada capitalista da terra ressignifica a apropriação individual (ou coletiva) onde emerge a apropriação privada da riqueza comum" (ALDIGUERI, 2017, p. 95).

A lei de terras e o abandono do trabalho cativo para o assalariado transferem a riqueza do escravo para a propriedade da terra ( PEREIRA, 1988). A transferência de riqueza que falamos aqui é riqueza atrelada à mercadoria, enquanto renda capitalizada, pois enquanto riqueza comum a terra sempre o foi.

No caso do Ceará, como se utilizava pouco trabalho escravo, a transferência se deu principalmente a partir de outras atividades, como o gado ( ALDIGUERI, 2017), o algodão e o comércio.

O capital que era imobilizado no gado como forma de riqueza e meio de acumulação, aos poucos passa a ser imobilizado na terra, tanto que a terra ganha condições que a torna capaz de assegurar garantia de empréstimos em bancos para a safra de algodão. A terra ia metamorfoseando-se em equivalente de capital, conforme podemos constatar através de Silva (2000, p. 82): "[..] as várias fazendas e imóveis sob hipoteca, para o grupo em questão dizem respeito aos empréstimos fornecidos através do comércio da Casa Comercial para a safra do algodão [...]". Nesse sentido, é que o monopólio da terra, que já se formava no Ceará pecuarista, se consolida como um poder econômico novo. ( ALDIGUERI, 2017, p. 115 e 116).

A privatização da terra e a atribuição de um preço a ela mascara o fato de que a sua existência independe de qualquer tempo de trabalho social necessário para sua produção. Mascara o fato de que a terra é natureza, é algo que existia antes do ser humano e independe da força de trabalho deste, e "sigue siendo aquel sustrato tan a menudo destacado por Marx, 'que está presente sin constribuición del hombre"' ( SCHMIDT, 2011, p. 78). A terra, assim como a água, assim como o ar que respiramos, é antes de tudo natureza, estava aí antes do ser humano (que também é natureza) e são essenciais para sua (nossa) sobrevivência. A propriedade privada da terra, e dos demais elementos (recursos) ${ }^{38}$ naturais, mascara a expropriação de um bem de uso comum e necessário a sobrevivência de todos e, por sua vez, permite que toda a sociedade concorde em conferir ao seu proprietário o direito de ser o único a usufruir deste.

\footnotetext{
${ }^{38}$ A categoria recurso puxa muito a noção econômica, mais próximo da corrente ecológica nomeada por Alier como "evangelho da ecoeficiência", talvez não seja a melhor forma de nomear. Harvey (2018) vem utilizando as vezes a expressão "dádivas da natureza", assim como Marx.
} 
Note que o processo de alienação descrito anteriormente, separando a concepção de homem e natureza, assim como as teorias econômicas hegemônicas, são extremamente importantes para a implantação e manutenção da propriedade privada.

A propriedade privada da terra confere então, ao seu proprietário, um duplo monopólio (MARX, 2013a), monopólio do espaço e monopólio dos elementos naturais da terra ( MARX, 2013a; PEREIRA, 2017). Marx indica que o preço de monopólio é definido pelo desejo da demanda de ter aquela mercadoria até o limite do que essa demanda pode pagar pela mercadoria que deseja. Deste preço de monopólio, Marx afirma que, é gerado o sobrelucro (ou lucro suplementar ou ainda lucro extraordinário), que seria o excedente, que se converte em renda. A renda por sua vez, segundo Marx, gera preço de monopólio, que gera renda, que gera preço de monopólio... assim por diante. Assim sendo, só obtenho renda se tenho um lucro extraordinário, uma vez que necessitaria um preço além do valor da mercadoria, para além do preço de produção. Porém, se a terra é uma mercadoria sem valor (valor gerado pela exploração do trabalhador da produção da mercadoria), por sua vez, sem preço de produção, qualquer preço atribuído a ela está acima de seu valor, então teria sempre um preço de monopólio, um sobrelucro e, por sua vez, renda. "No reino das mercadorias, é o preço que faz pressupor o valor, inclusive o (in)existente na propriedade terra (PEREIRA, 2017, p. 201).

Assim, a terra é uma mercadoria que tem sempre a potencialidade de gerar renda, pois apesar de não ter valor gerado pelo trabalho tem valor de troca, e o preço atribuído a esta sempre está atrelado ao desejo dos consumidores e a suas capacidades de pagamento. Se a sociedade está sempre aumentando o desejo pela terra, pela casa própria, e sempre criando novas formas crédito, o preço da terra sempre aumentará, independentemente de haver produção aí ou geração de valor, o que por sua vez, sempre deixará uma parcela da sociedade que não tem capacidade de pagamento, nem acesso a créditos, excluída da terra. 


\title{
Apropriação privada da terra no Ceará: Para além da Lei de Terras, genocídio etnocídio e embraquecimento dos índios no século XIX
}

Desde que a espada e a cruz desembarcaram em terras americanas, a Conquista europeia castigou a adoração da Natureza, que era pecado ou idolatria, com penas de açoite, forca ou fogo. A comunhão entre a Natureza e a gente, costume pagão, foi abolida em nome de Deus e depois em nome da civilização. Em toda a América, e no mundo seguimos sofrendo as consequências desse divórcio obrigatório. (GALEANO, apud ACOSTA, 2016, p. 105).

Para que a Lei de Terras $^{39}$ de 1850 surtisse o efeito que teve, vários outros aspectos normativos, anteriores e posteriores a esta, foram importantes durante o Brasil Imperial, muitos deles, como no caso do Ceará, ligados à espoliação e ao genocídio da população indígena. Todo o processo de aculturação e extermínio da cultura original e do povo indígena, passando pelas políticas indigenistas do período imperial até a constituição de 1891, somaram-se de forma significativa à Lei de Terras no processo de apropriação privada e concentrada das terras brasileiras.

Entre finais do século XVIII e meados do século XIX, havia discordância sobre o tratamento que devia ser dado à população indígena por parte dos colonizadores.

\begin{abstract}
"travou-se um intenso debate sobre o uso da brandura ou violência no seu tratamento, discutindo-se se a solução deveria ser a exterminação dos índios 'bravos', 'desinfestando' os sertões - solução propícia aos colonos - ou se cumpre civiliza-los e incluí-los na sociedade política - solução em geral propagada por estadistas e que supunham sua possível integração como mão-de-obra" ( SILVA, 1996, p. 236)
\end{abstract}

Após a queda do Regime Pombalino, por exemplo, no final do século XVIII, houve a proibição da prática de expedições para a captura de índios e sua escravização, porém, em 1808, com a chegada de D. João VI ao Brasil e a promulgação das Cartas Régias, de 13 de maio de 1808, que defendiam a repressão e guerra contra os índios botocudos e quaisquer índios bravos ${ }^{40}$.

\footnotetext{
39 Lei no 601 de 18 de setembro de 1850.

40 “[...] tendo-se verificado na minha real presença a inutilidade de todos os meios humanos, pelos quaes tenho mandado que se tente a sua civilisação e o reduzil-os a aldear-se e a gozarem dos bens permanentes de uma sociedade pacifica e doce, debaixo das justas e humanas Leis que regem os meus povos; e até havendo-se demonstrado, quão pouco util era o systema de guerra defensivo que contra elles tenho mandado seguir, [...] ordenar-vos, em primeiro logar: Que desde o momento, em que receberdes esta minha Carta Regia, deveis considerar como principiada contra estes Indios antropophagos uma guerra offensiva que continuareis sempre em todos os annos nas estações seccas e que não terá fim, senão quando tiverdes a felicidade de vos senhorear de suas habitações e de os capacitar da superioridade das minhas reaes armas de maneira tal que movidos do justo terror das mesmas, peçam a paz e sujeitando-se ao doce jugo das leis e promettendo viver em sociedade, possam vir a ser vassallos uteis, como ja o são as immensas variedades de Indios que nestes meus vastos Estados
} 
Já no final da primeira metade do século XIX, sob a influência de José Bonifácio, iniciou-se uma política mais "branda" no tratamento do índio, ocorrendo em 1831 a revogação das cartas régias de 1808 e 1809. ( MELO, 2007).

Ainda na primeira metade do século XIX, José Bonifácio escreveu dois documentos intitulados “Lembranças e apontamentos do Governo Provisório para os Senhores Deputados", em 1821, e "Apontamentos Sobre a Civilização dos Índios Bravos do Império do Brasil”, em 1823, que influenciaram a política indigenista da segunda metade do século XIX e início do século XX (MELO, 2007 e SILVA, 1996).

Segundo Silva (1996), o projeto de Bonifácio para o Brasil tinha como questão central a integração e unificação da nação, sendo necessária uma homogeneização da população. Como grande parte do território era ocupada por índios “bravos"41, José Bonifácio considerava os índios um obstáculo para a integração e desenvolvimento econômico do país ${ }^{42}$. Para ele, o Estado deveria ter a "função de integrar e civilizar o índio, tornando índio e brasileiros uma nação homogênea" (BONIFÁCIO, apud SILVA, 1996, p. 229)

Para que a integração ocorresse, Bonifácio defendia a formulação de uma política de terras, acompanhada por uma política econômica, visando o desenvolvimento da agricultura e do comércio, atendendo também a uma missão civilizatória ${ }^{43}$ do índio (SILVA, 1996).

\footnotetext{
do Brazil se acham aldeados e gozam da felicidade que é consequencia necessaria do estado social: Em segundo logar sou servido ordenar-vos que formeis logo um Corpo de soldados pedestres escolhidos [...] os quaes terão o mesmo soldo que o dos soldados Infanteas; e sendo Indios domesticos, poderá diminuir-se o soldo a 40 réis, como se faz na guarnição dos Presidios [...] terá mais meio soldo aquelle Commandante que no decurso de um anno mostrar, não sómente que no seu districto não houve invasão alguma de Indios Botocudos, nem de outros quaesquer Indios bravos, de que resultasse morte de Portuguezes, ou destruição de suas plantações; mas que aprisionou e destruiu no mesmo tempo maior numero, do que qualquer outro commandante; [...]" (DOM JOÃO VI, 1808).

${ }^{41}$ No período, a documentação "oficial" branca, costumava classificar os índios em duas categorias, os "bravos" e os "domésticos" ou "mansos". Os "mansos" eram aqueles grupos em que a Coroa havia consegui estabelecer relações políticas e econômicas de dominação, englobavam principalmente as etnias Tupi e Guarani. Já os "bravos", eram aqueles grupos em que não se conseguiu criar laços de dominação, sendo constantes as guerras e disputas por suas terras, eram conhecidos, tinham "reputação" de "indomáveis e ferozes" e englobavam genericamente os Botocudos. (CUNHA, 1992, apud, SILVA, 1996, p. 229)

42 Os negros escravizados também eram considerados por José Bonifácio naquela época como um obstáculo para a integração e desenvolvimento econômico do país, que considerava esta prática uma das principais causas da heterogeneidade e por isso um risco ao seu projeto de integração do país (SILVA, 1996). "Na verdade, podemos dizer que a própria presença do negro na sociedade brasileira decorria da especificidade do escravismo colonial, sobre cujas bases esta sociedade fundou-se: o fato deste estar inserido nos quadros mais gerais do processo de acumulação de capital nas economias europeias e, neste sentido, encontrar no tráfico de africanos uma fonte adicional de lucro na dinamização deste processo. Dessa forma, o problema do negro, enquanto obstáculo à homogeneização populacional do país, desvendava um dos aspectos contraditórios da escravidão em relação ao projeto nacional de José Bonifácio" (SILVA, 1996, p. 226).

43 "Tenho pois mostrado pela razão e pela experiência, que a pesar de serem os índios bravos uma raça de homens inconsiderada, preguiçosa e em grande parte desagradecida e desumana para conosco, que reputam seus inimigos, são contudo capazes de civilização, logo que se adotam meios próprios, e que há constância e zelo verdadeiro na sua execução" (BONIFÁCIO, 1823, apud, SILVA, 1996, p. 229).
} 
Considerava, assim, ser primordial '[...] desenvolver nos índios a 'ideia de propriedade' e o desejo de 'distinções e vaidades sociais', que são as molas poderosas que põem em atividade o homem civilizado [...]" (BONIFÁCIO, apud SILVA, 1996, p. 237. Grifo meu).

Silvia destaca que a forma principal como essa integração se revela é pela política de aldeamentos proposta por Bonifácio, "a qual tinha como fundamentos básicos a reunião e sedentarização dos índios, submetendo-os às leis e ao trabalho" (1996, p. 244). De fato, como destaca Cunha (1992, apud SILVA, 1996), a prática do aldeamento já era utilizada no século $\mathrm{XVI}$, permitindo a retirada dos índios de regiões onde havia disputa por frentes agrícolas e pastoris. Assim, esse processo de "civilização" do índio acarretou que aos poucos estes deixassem de ser nômades e integrassem a força de trabalhadores "livres" da nação.

O extermínio da cultura, do modo de vida e de existência do índio e seu "embranquecimento" guardam estreitas relações com a formação da propriedade privada da terra no Brasil e no Ceará, pois, ao forçar a mudança de uma cultura nômade de subsistência, que empregava como meios para isto a caça, a pesca, a coleta, a extração, e forçar a fixação do índio em um determinado terreno, em concentrações de aldeamentos, cultivando seu alimento, faz com que estes povos passem a ocupar e necessitar de extensões muito menores de terras, diminuindo os embates e disputas por terras com os invasores brancos e posteriormente com seus descendentes.

Dessa forma, ao atacar a cultura e o povo indígena, provocou-se um duplo movimento cujos impactos são sentidos até hoje: 1) a alienação, separação, de parte dos habitantes originários da América, da natureza - destruição de uma cultura que interpretava e interpreta o homem como parte integrante da natureza; 2) a liberação de terra que depois seria apropriada privativamente pelo homem branco invasor e transformada em reserva de valor.

Contudo, como aponta Silva (sd), Antunes (2012) e Melo (2007), parte desses índios se "adaptaram" à cultura imposta (etnificação e etnogênese) ${ }^{44}$ e foram capazes inclusive de

\footnotetext{
44 “Uma vez obrigados à convivência com o colonizador (clérigos, elite, gestores e potentados locais), que impõe seus padrões culturais (etnificação), os grupos indígenas reagem a este estímulo forçado com adaptações e recriações (etnogênese) de novas tecnologias de saber, gerando poder de transformar suas condições de vida e seus valores a partir da situação adversa" ( ANTUNES, 2012, p. 11).
} 
disputarem politicamente e legalmente por terras, a partir da troca de serviços, em especial, serviços militares e de escolta ${ }^{45}$.

Estes autores, dentre outros ${ }^{46}$, relatam as solicitações e concessões de sesmarias para lideranças e grupos indígenas. Assim, quando a Lei de Terras foi lançada em 1850, algumas terras importantes para o processo de acumulação de capital estavam sob domínio legal de indígenas, seja nos aldeamentos com seus terrenos de cultivo, seja em terrenos mais amplos de sesmarias utilizados para pesca e coleta. Então, nesse momento, foram necessárias medidas também legais para respaldar os novos processos de espoliação dessas terras. Quem cumpriu em parte com este papel foi a política indigenista iniciada no princípio do século XIX.

A "nova" política de aldeamentos trazia agora a figura dos padres Capuchinhos no lugar dos Jesuítas e pregava um tratamento "brando" e "amigável" com índio, segundo as orientações de José Bonifácio, porém encobria estratégias de espoliação das terras dos índios que, somadas aos processos de sedentarizarão mencionados anteriormente, provocaram grande impacto.

Em 24 de julho de 1845, é decretado o "Regulamento acerca das Missões de catequese e civilização dos índios" (Decreto n. 426 de 24 de julho de 1845) ${ }^{47}$. Este decreto definiu e regulamentou, para todas as províncias, a existência de um Diretor Geral dos índios nomeado pelo Imperador.

Segundo o Decreto 426/1845 ( BRASIL, 1845), entre as atribuições do diretor estavam as de criar, remembrar ou extinguir aldeamentos; designar terras destinadas para plantações comuns, para usos particulares e para arrendar; definir se as terras dos aldeamentos e de índios estão sendo bem utilizadas para a agricultura e, se não estiverem, tomá-las e designálas para arrendamento; definir se os índios possuem "bom comportamento" e

\footnotetext{
45 “[...] era interesse do Império luso conceder benefícios aos índios em troca de serviços prestados à Coroa. Esses serviços eram variados: iam desde trabalhos manuais até as elevações de construções de grande porte como igrejas, cidades e fortificações. Um dos mais relevantes serviços prestados pelos índios à Coroa era sem dúvida os militares, que possibilitaram pacificar tribos inimigas e proteger fronteiras de ataques de estrangeiros. Com isso os índios foram transformados em súditos reais e como tais recebiam direitos de terra, benesses e títulos que souberam reivindicar, manter e perpetuar para seus ascendentes e descendentes. Portanto os índios aldeados adquiriram o direito às suas possessões territoriais coletivas de acordo com os costumes e leis do antigo regime e essa lógica comunal chega viva ao século XIX. Foi essa lógica que tornou possível que os povos indígenas da atualidade reivindiquem seus territórios, tendo como base a memória ancestral de seus antigos aldeamentos." ( ANTUNES, 2012, p. 16).

${ }^{46}$ Relatos deste tipo também são feitos no Plano de Manejo da APA da Sabiaguaba: FORTALEZA. Plano de Manejo do Parque Natural Municipal das Dunas de Sabiaguaba (PMNDS)) e da Área de Proteção Ambiental de Sabiaguaba (APA), 2010

${ }^{47}$ Conferir texto do decreto na íntegra em anexo.
} 
desenvolvimento industrial, em caso negativo, o Diretor poderia tomar suas terras, em caso afirmativo, este poderia premiar os indígenas outorgando-lhes concessões de terras separadas da aldeia para uso particular que, depois de doze anos de bom aproveitamento da terra no uso da agricultura, poderiam obter carta de sesmarias ${ }^{48}$. O Diretor Geral tinha inclusive poder de dar voz de prisão e de representar o presidente da província ( BRASIL, 1845, art. 10 e 2 ㅇ). Assim,

[...] em 1845 a política indigenista parece ter objetivos: a primeiro, pôr fim aos choques armados nas áreas de expansão da sociedade nacional. A atração e o aldeamento dos índios retira-os da linha de fogo dos que avançam sobre seu território. A sua sedentarização libera terra para a ocupação dos nacionais. $O$ segundo objetivo patente no novo Regimento é a questão da destinação das terras indígenas. As que estavam abandonadas deviam ser indicadas pelo Diretor do Governo, sugerindo o destino a ser dado às mesmas. Aos índios que não cultivassem suas terras, essas deviam ser retiradas. Os pequenos grupos deviam ser reagrupados. A terra não utilizada numa determinada aldeia devia ser arrendada. (Beozzo 1983, p.79-80, Apud MELO, 2007, p. 32)

A partir destes pontos, podemos entender que a Política de Aldeamentos do século XIX além de adotar a estratégia de confinamento dos índios, mudando sua cultura, antes nômade e baseada em grande parte na coleta e pesca, e liberando terras de interesse dos colonos; coloca o destino das terras indígenas de toda uma província nas mãos, decisões e julgamentos de uma única pessoa. Assim, a criação e a extinção de aldeamentos, a definição ou não de terras indígenas, a tomada de terras, apesar de rotuladas por uma legislação, estavam sujeitas a decisões arbitrárias de interesse político, econômico e de particulares.

Assim, quando a Lei no 601 (Lei de Terras) é aprovada em $1850^{49}$, já existia uma "brecha" legal para expropriação de terras indígenas e entrada destas no mercado de terras que começou a se formar a partir deste marco legal.

\footnotetext{
${ }^{48}$ Apesar do sistema de sesmarias ter sido suspenso em 1822, o decreto 426 de 24 de julho de 1845 , traz em seu texto a menção da possibilidade de obtenção de carta de sesmaria, em seu artigo 10, § 15: "Informar ao Governo Imperial ácerca daquelles Indios, que, por seu bom comportamento e desenvolvimento industrial, mereção se lhes concedão terras separadas das da Aldêa para suas grangearias particulares. Estes Indios não adquirem a propriedade dessas terras, senão depois de doze annos, não interrompidos, de boa cultura, o que se mencionará com especialidade nos relatorios annuaes; e no fim delles poderão obter Carta de Sesmaria. Se por morte do concessionario não se acharem completos os doze annos, sua viuva, e na sua falta seus filhos, poderão alcançar a sesmaria, se, além do bom comportamento, e continuação de boa cultura, aquella preencher o tempo que faltar, e estes a grangearem pelo duplo deste tempo, com tanto que este nem passe de oito annos, e nem seja menos de quinze o das diversas posses."

49 "Dispõe sobre as terras devolutas no Império, e acerca das que são possuídas por titulo de sesmaria sem preenchimento das condições legais. bem como por simples titulo de posse mansa e pacifica; e determina que, medidas e demarcadas as primeiras, sejam elas cedidas a titulo oneroso, assim para empresas particulares, como para o estabelecimento de colonias de nacionaes e de extrangeiros, autorizado o Governo a promover a colonisação extrangeira na forma que se declara" (BRASIL. LEI No 601, DE 18 DE SETEMBRO DE 1850).
} 
Logo em seu primeiro artigo, a Lei 601/1850 define que ficam proibidas as aquisições de terras devolutas ${ }^{50}$ que não sejam por outro título que não seja o de compra e, em seu artigo segundo, define como crime os que assim o fizerem. Seus artigos quatro e cinco reforçam que as terras devem estar sendo cultivadas, ignorando a cultura indígena de coleta e pesca.

Art. 40 Serão revalidadas as sesmarias, ou outras concessões do Governo Geral ou Provincial, que se acharem cultivadas, ou com principios de cultura, e morada habitual do respectivo sesmeiro ou concessionario, ou do quem os represente, embora não tenha sido cumprida qualquer das outras condições, com que foram concedidas.

Art. 5o Serão legitimadas as posses mansas e pacificas, adquiridas por occupação primaria, ou havidas do primeiro occupante, que se acharem cultivadas, ou com principio de cultura, e morada, habitual do respectivo posseiro, ou de quem o represente, guardadas as regras seguintes:

$\S 1$ 을 Cada posse em terras de cultura, ou em campos de criação, comprehenderá, além do terreno aproveitado ou do necessario para pastagem dos animaes que tiver $o$ posseiro, outrotanto mais de terreno devoluto que houver contiguo, comtanto que em nenhum caso a extensão total da posse exceda a de uma sesmaria para cultura ou criação, igual ás ultimas concedidas na mesma comarca ou na mais vizinha.

$\S 20$ As posses em circumstancias de serem legitimadas, que se acharem em sesmarias ou outras concessões do Governo, não incursas em commisso ou revalidadas por esta Lei, só darão direito á indemnização pelas bemfeitorias.

Exceptua-se desta regra o caso do verificar-se a favor da posse qualquer das seguintes hypotheses: 1a , o ter sido declarada boa por sentença passada em julgado entre os sesmeiros ou concessionarios e os posseiros; 2a , ter sido estabelecida antes da medição da sesmaria ou concessão, e não perturbada por cinco annos; $3 \mathfrak{a}$, ter sido estabelecida depois da dita medição, e não perturbada por 10 annos.

( BRASIL, 1850, art. 4 e 5)

No artigo doze da Lei 601/1850 e nos artigos setenta e dois e setenta e três do decreto no 1.318 , de 30 de janeiro de $1854^{51}$, abre-se a possibilidade para que as terras definidas como devolutas também pudessem ser destinadas à colonização dos indígenas. Note-se que não é um reconhecimento dos direitos dos índios de se apropriar de terras designadas para eles, são terras destinadas a manter a política de aldeamento, "civilização" desses povos. Ainda assim, há um reconhecimento de terras para os índios, na forma dos aldeamentos (Lei 601/1850, art.

\footnotetext{
${ }^{50}$ Art. 3ㅇ São terras devolutas:

$\S 1$ 을 As que não se acharem applicadas a algum uso publico nacional, provincial, ou municipal.

$\S 2$ ㅇ As que não se acharem no dominio particular por qualquer titulo legitimo, nem forem havidas por sesmarias e outras concessões do Governo Geral ou Provincial, não incursas em commisso por falta do cumprimento das condições de medição, confirmação e cultura.

$\S 3$ 3 As que não se acharem dadas por sesmarias, ou outras concessões do Governo, que, apezar de incursas em commisso, forem revalidadas por esta Lei.

§ 4으 As que não se acharem occupadas por posses, que, apezar de não se fundarem em titulo legal, forem legitimadas por esta Lei.

${ }^{51}$ Regulamenta e manda executar a Lei no 601, de 18 de setembro de 1850.
} 
12) ou na forma de ocupação primária (Lei 601/1850, art. 5ㅇ), desde que cumpram com as exigências de serem cultivadas e seus ocupantes serem civilizados (Decreto 426/1845).

Art. 12. O Governo reservará das terras devolutas as que julgar necessarias: 1ำ, para a colonisação dos indigenas; $2^{\circ}$, para a fundação de povoações, abertura de estradas, e quaesquer outras servidões, e assento de estabelecimentos publicos: 3ㅇ, para a construção naval. ( BRASIL, 1850, art. 12)

Art. 72. Serão reservadas terras devolutas para colonisação, e aldeamento de indigenas nos districtos, onde existirem hordas selvagens.

Art. 73. Os Inspectores, e Agrimensores, tendo noticia da existencia de taes hordas nas terras devolutas, que tiverem de medir, procurarão instruir-se de seu genio e indole, do numero provavel de almas, que ellas contêm, e da facilidade, ou difficuldade, que houver para o seu aldeamento; e de tudo informarão o Director Geral das Terras Publicas, por intermedio dos Delegados, indicando o lugar mais azado para o estabelecimento do aldeamento, e os meios de o obter; bem como a extensão de terra para isso necessaria. ( BRASIL, 1854, art. 72 e 73)

No caso da província do Ceará, a dificuldade dos índios de manterem a apropriação de suas terras, e até mesmo das terras dos aldeamentos, foi agravada, por um "decreto" de 1963 que declarava a extinção dos índios no Ceará. Todavia, como descreve Antunes (2012), esse decreto de fato nunca existiu. Segundo Antunes (2012), o famoso decreto de 1863 do presidente da província (José Bento Cunha Figueiredo Junior), que declarou a extinção dos índios, era na verdade um relatório rotineiro e burocrático do Império ${ }^{52}$, sem caráter jurídico, mas que se tornou uma declaração simbólica tão enfática ao ponto de ser propagada como um decreto. Já que a legislação até então, apesar de espoliar fortemente essa população, garantia a posse de terras, desde que os índios cumprissem com as condutas de comportamento e econômicas exigidas, "passou-se a ignorar a existência desses sujeitos" (SILVA, 2009 apud ANTUNES, 2012, p. 17)

Neste relatório, o presidente da província afirma "não existirem índios vivendo na província cearense, nem como aldeados, nem muito menos como índios bravos" e que seu desaparecimento já vinha sendo declarado desde o início do século XIX (ANTUNES, 2012, p. 12).

Já não existem aqui índios aldeados ou bravios. Das antigas tribus de Tabjaras, Cariris e Potiguaris, que habitavam a província, uma parte foi destruída, outra emigrou e o resto constituiu os aldeamentos da Serra da Ibiapaba, que os Jesuítas no principio do seculo passado formaram em Villa Viçosa, S. Pedro de Ibiapina, e S. Benedicto com os índios chamados Camussis, Anacaz, Ararius e Acaracú, todos da grande família

52 "Relatório produzido pelo governo como resultado da gestão do ano de 1862 enviado no dia 09 de abril de 1863 para ocasião da abertura dos trabalhos da Assembleia Legislativa" ( ANTUNES, 2012, p. 12). 
Tabajara. Com a extinção dos Jesuitas, que os governavam theocraticamente, decahiram esses aldeamentos, e já em 1818 informava um ouvidor ao governador Sampaio que os índios iam-se extinguindo na Ibiapaba, onde tinham aqueles religiosos um celebre hospicio no lugar denominado Villa Viçosa, que com os outros acima indicados abrangem a comarca deste nome. E nelles que ainda hoje se encontram maior numero de descendentes das antigas raças; mas andam-se hoje misturados na massa geral da população, daí a caracterização de critérios de indianidade, da forma como está contido no relatório de 1863. (FIGUEREDO JUNIOR, 1863, apud, ANTUNES 2012, p. 12)

Segundo relatos de Thomaz Pompeu Sobrinho ${ }^{53}$ (apud, FORTALEZA, 2010), mesmo antes do relatório ("decreto") de 1863, são encontrados vários registros que relatam protestos de índios que reclamavam contra a (des)apropriação de suas terras no Ceará por parte de posseiros, que justificavam a ação dizendo que esses índios estavam confundidos com a massa da população civilizada.

É perceptível o processo de apropriação das terras indígenas que estava em andamento no século XIX nas terras dos antigos aldeamentos, sob as alegações de que estavam confundidos na massa da população civilizada. Em 1839, houve a supressão da vila de índios da Messejana. Se até este momento, há indícios acerca das tentativas de obrigação de índios a uma disciplina do trabalho e sua fuga e dispersão das vilas, a partir daqui, são as denúncias e perseguições que aparecerão junto com a disputa pelas terras da Vila, outrora ocupadas e consideradas, então, como 'terras devolutas'. ( FORTALEZA, 2010, p. 140)

Anteriormente a 1839, diversos aforamentos de terras já haviam sido feitos nas terras indígenas do antigo aldeamento de Paupina, para "proprietários de casas, sítios e demais terras foreiras", além dos indígenas que nela habitavam, como afirma a lei provincial que extingue a vila de Messejana. Neste processo, as perseguições aos índios, as fugas das vilas, o esbulho de terras e as denúncias ao Governo imperial dinamizam as relações de conflito e resistência à usurpação agenciada pelos índios da Messejana, na interlocução com as diversas instâncias dos contextos local, regional e imperial. ( FORTALEZA, 2010, p. 140)

Todavia, o relatório de 1863 é extremamente contraditório, pois, no mesmo documento onde é afirmada a extinção dos índios, vários gastos da província são justificados e atribuídos a ações realizadas para os índios, assim como também são computadas o total de posses de terras legitimadas pelo governo a índios, um total de 120 das 145 até o fim de 1862 (ANTUNES, 2012). ${ }^{54}$ Ainda assim, a ideia de extinção dos índios se propagou, o que para Antunes deveu-

\footnotetext{
53 Thomaz Pompeu Sobrinho, nasceu em Fortaleza em 1880, formou-se em engenharia, fundou a faculdade de agronomia e o Instituto de Antropologia da Universidade Federal do Ceará, foi também escritor, presidente do Instituto do Ceará, e Membro da Academia Cearense de Ciências.

54 Do primeiro de fevereiro de 1861 até 31 de dezembro de 1862, a despesa com todo o serviço montou 11.933 .866 incluindo a quantia de 7.332 réis 299 tostões em importância de empréstimos feitos pela fazenda pública aos índios pobres na conformidade das ordens imperiais. [...] o próprio gestor se contradiz quando assume a vultuosa quantia gasta em despesas com os mesmos índios que acabara de negar a existência. Ainda ao longo das linhas desse documento, o governo reconhece posses de terras que foram legitimadas para índios, como nos informa Silva (2009, p.12): "Até o fim do ano de 1862 legitimaram-se 145 posses incluindo-se neste número 120 para índios e 06 aforamentos", ou seja, das terras que foram
} 
se principalmente ao projeto ideológico e político de consolidação do Império Brasileiro, mencionado anteriormente, que trazia a ideia de unificação e homogeneização da nação e a ideia de mudança fundiária com metas de centralização, controle e regularização da situação fundiária no país; e a situação econômica do Ceará, que passava no momento pelo boom da produção algodoeira e necessitava de novas terras para expansão.

No mesmo ano do relatório do presidente da província que afirmava a extinção dos índios, um mês depois, em quatro de março de 1863, foi apresentado pelo engenheiro Antônio Gonçalves Justa Araújo o "Relatório das Terras Públicas e da Colonização". Este relatório, resultado da Lei de Terras (601/1850), visava identificar e medir as terras devolutas no Ceará, e, neste caso, a declaração oficial de não existência de índios no território era muito conveniente para a demarcação de terras em posse de indígenas como terras devolutas.

O relatório dá conta da situação das terras dos aldeamentos indígenas em várias províncias, identificando terras devolutas, com o objetivo de, incorporando-as aos "próprios nacionaes", aforá-las e vendê-las para particulares. As principais informações contidas neste relatório dizem respeito à medição e demarcação das terras devolutas da extinta vila de Messejana. Reiterando o clima tenso das relações entre posseiros, foreiros e indígenas por conta das disputas de terras, o relatório expõe que a medida tomada pelo governo imperial visava a minimização da situação de conflito. O relatório é um documento que situa o momento em que, ao mesmo tempo em que os conflitos por terras se acirravam, com as denúncias recorrentes feitas por índios e outros, o Governo Imperial, assumindo sua posição favorável ao esbulho das terras indígenas, mede, identifica e demarca as terras não-ocupadas por indígenas, passando a denominá-las de devolutas - incorporando-as aos 'proprios nacionaes', consequentemente, oficializando e tornando legal a sua transferência para particulares, posseiros, foreiros e compradores. (POMPEU SOBRINHO, apud FORTALEZA, 2010, p. 141)

A partir do que foi visto, podemos perceber que com a política, considerando os marcos legais elaborados e as ações empregadas pelo governo brasileiro no século XIX, não havia o que pudesse ser feito para que os indígenas permanecessem com as terras que se apropriaram desde sua existência. Se estes lutavam para manter seu modo de vida original, ou o mais próximo do período anterior ao contato com o colonizador e invasor europeu, eram classificados como "bravios", e, como tais, considerados pelo governo como não-civilizados e sem direito à terra. Para ter direito legal à terra, estes deveriam contribuir com o projeto unificação e homogeneização do país, deviam ser civilizados, adotar os modos de vida e a produção capitalista nascente, ser trabalhadores úteis e prestar serviços para a "nação". Uma

legitimadas pelo governo só naquele ano, pelo menos $80 \%$ pertenciam aos índios, mais uma confirmação de existência através das práticas sociais, daqueles que o discurso político e ideológico teimava em negar. ( ANTUNES, 2012, p. 12-13). 
vez civilizados, são considerados misturados e não mais índios, como "não são" índios, não possuem direito legal à terra que ocupam e estas Ihe são expropriadas.

\begin{abstract}
No século XIX, ocorre a extinção das vilas de índios, a usurpação e o aforamento de suas terras, realizados com a conivência da política indigenista do Império Brasileiro, apesar das reclamações e protestos dos grupos indígenas. Considerando que a disputa pela terra já pode ser percebida desde o início do século XVIII, no caso das sesmarias analisadas (de 1707, 1708 e 1722), este processo de luta continua ocorrendo e chega a um ponto crítico no fim do século XIX. Dar-se-á atenção ao esbulho de terras indígenas a partir da vila de Messejana (antigo aldeamento de Paupina), percebendo via documentação, como os indígenas mantiveram-se ativos até, pelo menos, a década de 1860, apesar da reiterada 'extinção' dos índios no Ceará, indicada em documentação oficial, sob o argumento de que estavam 'miscigenados' e 'confundidos' na 'massa da população civilizada'. Há íntima relação entre o processo de dispersão dos grupos para longe das vilas, a imposição de uma disciplina para o trabalho, a negação da presença indígena no Ceará (reafirmada continuamente a partir de 1850), o processo de esbulho e apropriação de terras dos aldeamentos e o silenciamento, a partir de 1860, destes grupos na Província do Ceará. FORTALEZA, 2010, p. 136. Grifo meu)
\end{abstract}

No final do século XIX, já no Brasil república, a constituição de 1891 trazia, em seu artigo 64, a transferência das terras devolutas para os Estados. Dentro das terras devolutas estavam os aldeamentos que haviam sido extintos, porém, como a extinção de muitos aldeamentos ocorreu de forma fraudulenta e abusiva, muitos índios permaneciam nessas terras até então e foram expulsos (CUNHA, 1987, apud, MELO, 2007). Melo (2007) afirma ainda que houve confusão quanto à definição do que eram as terras devolutas, disseminando-se à época que as terras indígenas como um todo passariam para propriedade do Estado.

Figura 8. Linha do Tempo com os principais marcos regulatórios mencionados no capítulo sobre os índios.

\begin{tabular}{|c|c|c|c|c|c|c|c|}
\hline $\begin{array}{l}\overline{0} \\
\vdots \\
0 \\
0 \\
\vdots \\
\vdots \\
\vdots \\
z\end{array}$ & $\begin{array}{l}1808 \\
\text { Cartas Régias de } \\
13 \text { de maio de } \\
1808 \text { defendia a } \\
\text { repressão e } \\
\text { guerra contra o } \\
\text { índio bocotudos } \\
\text { e quaisquer } \\
\text { índios bravos }\end{array}$ & $\begin{array}{l}1822 \\
\text { Relatório } \\
\text { de José } \\
\text { Bonifácio } \\
\text { Apontam } \\
\text { tos Sobre } \\
\text { Civilizaçã } \\
\text { dos Índio } \\
\text { Bravos do } \\
\text { Império c } \\
\text { Brasil }\end{array}$ & $\begin{array}{l}1831 \\
\text { Revogaçã } \\
\text { da carta } \\
\text { régia de } \\
1808\end{array}$ & & $\begin{array}{l}\text { 6 de 24/06 } \\
1850 \\
\text { Lei de Terra } \\
\text { de } 18 / 07 \text { ) } \\
\qquad \begin{array}{l}185 \\
\text { Dec. } \\
\text { sobr } \\
\text { regu }\end{array}\end{array}$ & $\begin{array}{l}501 \\
\text { de 30/01 - Dispõe } \\
\text { taçãão e da Lei de Terras }\end{array}$ & $\begin{array}{l}1891 \\
\text { Constituição } \\
\text { de 1891- } \\
\text { Transferênc } \\
\text { ia para o } \\
\text { Estado de } \\
\text { Terras } \\
\text { devolutas }\end{array}$ \\
\hline & 1810 & 1820 & 1830 & 1840 & 1850 & $1870>$ & 1900 \\
\hline & BRASIL COLÔNIA & & & & BRASIL IM & & LICA \\
\hline 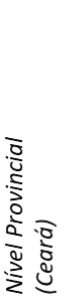 & & & $\begin{array}{l}\text { Portaria ao } \\
\text { diretor de } \\
\text { Messejana } \\
\text { para recolher } \\
\text { a sua direção } \\
\text { todos os } \\
\text { índios que } \\
\text { tiverem } \\
\text { desertado } \\
\mathbf{1 8 2 9}\end{array}$ & $\begin{array}{l}\text { Supressão da } \\
\text { vila de índios } \\
\text { da Messejana } \\
1839\end{array}$ & & $\begin{array}{l}\text { Relatório de José Bento Cunha } \\
\text { Figueiredo Junior (Relatório que } \\
\text { ganhou status de decreto quanto a } \\
\text { afirmação da extinção dos índios no } \\
\text { Ceará) } \\
\text { Relatório das Terras Públicas e da } \\
\text { Colonização do engenheiro Antônio } \\
\text { Gonçalves Justa Araújo } \\
1863\end{array}$ & \\
\hline
\end{tabular}

Elaborado pela autora, Rosa, 2018 
O fato de $90 \%$ dos municípios cearenses possuírem nomes de origem indígena nos dá uma ideia de quão importante e forte era a presença dessa população no Ceará, que atualmente possui apenas quatro aldeias indígenas oficialmente reconhecidas e demarcadas pelo governo federal ( ANTUNES, 2012). Também nos dá uma ideia do quanto esse povo foi expropriado ao longo dos séculos e permanecem em constantes processos de espoliação até hoje, que se dá tanto pela permanente expropriação de suas terras (como veremos no caso da Sabiaguaba), como pela necessidade imposta de terem que pagar para poderem ter um espaço para morar, uma terra para plantar, água para beber, peixe para comer (cada vez mais caros) e, para tanto, ser também explorado, ao vender sua força de trabalho.

\section{Acumulação por espoliação no imobiliário em Fortaleza no século XX, expansão dos loteamentos e negação da} natureza

As terras do estado do Ceará, expropriadas da população indígena, permitindo uma acumulação por espoliação, vão ter sua primeira potencialização enquanto capital fictício ${ }^{55}$ (utilizando a definição de Aldigueri, 2017), ou capital aparente, a partir da consolidação do mercado de terras, que em Fortaleza se dá a partir da década de 1930.

Uma mercadoria só se realiza enquanto mercadoria no sistema capitalista se ela estabelece relações de troca de compra e venda (MARX, 1934). Assim, a consolidação de um mercado de terras em Fortaleza foi de extrema importância para a firmação da terra-natureza como mercadoria na região. Por sua vez, o título de propriedade privada (moderna propriedade privada) conferiu a legalidade e mascarou os processos de espoliação e captura de valor na transformação da natureza em mercadoria.

A seguir apresentamos um breve resgate sobre o processo de consolidação do mercado de terras em Fortaleza, já trabalhado por outros autores como Silva (2000) e Aldigueri (2017).

\footnotetext{
55 “A terra se manifesta em sua aparência fetichista capaz de autovalorização, como se constituísse capital real independente do processo de produção, mas assim como nos juros, rendimento do capital dinheiro, trata-se de um valor puramente ilusório/fictício, porém real, dotado de preço, porque somos forçados a responder pela renda da terra em decorrência do significado econômico e político que a terra adquiriu como propriedade privada. A terra como propriedade privada pode ser vendida, transferida, possibilitando a riqueza-terra circular como se fosse capital" ( ALDIGUERI, 2017, p. 121-122).
} 
Aqui, em um primeiro momento, apenas como base de informação para explicitar processos que serão descritos ao longo da tese.

\section{Consolidação de um mercado de terras $^{56}$ e expansão dos} loteamentos em Fortaleza

Durante o século XIX e início do XX, tivemos no Ceará também uma grande transformação com relação a sua principal atividade econômica que, somada às mudanças nas políticas fundiárias descritas anteriormente, teve grande impacto na forma de apropriação da terra no Ceará e em Fortaleza.

A atividade principal da província do Ceará durante todo o século XVIII era a agropecuária, que ocorria no interior, principalmente ao longo dos rios Jaguaribe, Acaraú e Coreaú. "Os principais centros urbanos decorrentes da pecuária extensiva foram Aracati e Icó (à margem dos rios Jaguaribe e Acaraú) e Sobral (ao lado do Rio Acaraú)" ( ANDRADE e JUCÁ NETO, 2014). Até então, Fortaleza não fazia parte desse circuito $^{57}$ e só começa a ganhar importância na região com crescimento da atividade algodoeira. Essa economia, gado-algodão, em especial o algodão, como aponta Silva apud Aldigueri (2017), guarda extrema relação com a formação urbana da cidade de Fortaleza, que se desenvolveu como porto exportador do produtonatureza algodão e centralizou os investimentos de capital originados a partir da acumulação de riqueza espoliada da natureza (meio biofísico + homem).

Em 1810, Fortaleza, então Vila do Forte, torna-se capital da província do Ceará e principal porto de embarque de algodão para o mercado internacional, passando à condição de único porto a manter relações comerciais com o mercado inglês, em 1811, favorecendo a exportação do algodão. No mesmo ano, a então vila, ultrapassa as demais vilas cearenses no tocante ao volume total de exportação do produto, concentrando mais de quarenta porcento do total e, em 1823, é elevada à categoria de cidade. Em 1830, a nova cidade supera Aracati em importância econômica, sendo somente a partir da primeira metade do século XIX que

\footnotetext{
56 Para maiores detalhes ver ALDIGUERI, 2017.

57 “Fortaleza, mesmo elevada à condição de vila em 1726, não passava de um pequeno núcleo distante da atividade pastoril desenvolvida no interior da Capitania. [...] em 1810 era uma vila de pequena importância, centro captador e exportador do algodão para o mercado externo, principalmente inglês, implantada em solo de areal frouxo, que dificultava a sua expansão física" ( ANDRADE e JUCÁ NETO, 2014, p. 6).
} 
Fortaleza passa a despontar com hegemonia econômica, política e administrativa na região (ANDRADE e JUCÁ NETO, 2014).

Na década de 1860, a economia algodoeira do Ceará experimenta um grande crescimento, sendo este um período de prosperidade econômica e de profundas transformações urbanas em Fortaleza. É nesta época que a cidade recebe os primeiros planos de expansão da malha urbana e uma série de códigos de postura. Com destaque para o plano de Aldofo Herbster que propunha uma expansão da cidade até sete vezes maior do que a área desta (ANDRADE e JUCÁ NETO, 2014, p. 16-17).

No final do século XIX, a extração da renda da terra ${ }^{58}$, no urbano, em Fortaleza, dava-se sobretudo por meio do mercado de aluguel (que se estende até início do século XX, por volta de 1920). O embrionário mercado de terras nessa época começava a realizar o parcelamento de sítios, com a venda de lotes até bem distantes do núcleo de Fortaleza e mesmo fora dos planos de expansão ( ANDRADE, 2012; ALDIGUERI, 2017).

É a partir de 1920, segundo aponta Aldigueri (2017), que o mercado de terras começa a se desenvolver de forma mais efetiva em Fortaleza, começando a se consolidar na década de 1930. Até a década de 1970, com base nas informações de Aldigueri (2017) e Andrade (2012), a atividade associada ao loteamento se limitava à venda de terrenos e lotes, predominando então a extração de renda. A produção imobiliária de mercado começa a ganhar força só depois desse período.

Nota-se que, desde as primeiras décadas de registro de loteamentos aprovados em Fortaleza ${ }^{59}$, (Figura 9) além do entorno imediato da área urbana consolidada, há loteamentos aprovados em áreas bem afastadas, já próximas dos atuais limites do município. São, em especial, os entornos de antigos aldeamentos indígenas, como Messejana e Parangaba, que também na época já possuíam alguma ocupação resultante do período dos aldeamentos. Loteamentos nestas áreas aparecem na base de dados do município desde a década de 1930. Outra área loteada, "precocemente", é a Praia do Futuro que, diferentemente de Messejana

\footnotetext{
58 "Cabe aí considerar dois aspectos: a exploração da terra com o fim de reprodução ou de extração, e o espaço, elemento necessário a toda produção e a toda atividade humana. E a propriedade fundiária cobra seus tributos nos dois domínios." (MARX. Ed. Civilização Brasileira, p. 888)

${ }^{59}$ Base de dados da Prefeitura Municipal de Fortaleza/SEFIN, com registro de aprovação dos loteamentos, já trabalhada por Santos (2015) e também Aldigueri (2017). É uma base incompleta, com lacunas de informações, mas que permite ter uma ideia da expansão dos loteamentos em Fortaleza.
} 
e Parangaba, segue com ocupação menos densa até os dias de hoje. No caso da Praia do Futuro, na época do registro do loteamento, década de 1940, ainda era necessário vencer toda a barreira e distância de atravessar o campo de dunas da Praia do Futuro/Cocó para se chegar aos lotes (Figura 9). Essa barreira só será vencida, em parte, três década depois, quando é feito o prolongamento da Avenida Santos Dumont.

Santos (2015) e Aldigueri (2017) destacam a década seguinte, 1950, como o período em que se verificou o maior número de loteamentos de acordo com os registros do município, como também pode ser observado na Figura 9. A partir daí, os loteamentos se estendem por quase todo o território do município.

Inclusive áreas mais isoladas, como o Bairro da Sabiaguaba, têm loteamento aprovado ainda na década de 1970, localizado entre a foz do Rio Cocó e o campo de Dunas da Sabiaguaba (Dunas da Barra). Este loteamento, no entanto, é registrado também em cartório do Município de Aquiraz e começa a ser ocupado na década de 1980, por casas de veraneio. A ocupação do tipo segunda residência (veraneio) nos dá uma ideia do quanto estes espaços eram distantes, na época, do núcleo efetivamente ocupado.

A seguir, apresentaremos alguns casos desses loteamentos para exemplificar como estes foram se expandindo, desconsiderando a terra e seus recursos enquanto natureza. Veremos que também na atividade rentista de loteamentos a relação social com a natureza é de dominação e desconsideração desta. 
Figura 9. Loteamentos aprovados em Fortaleza entre as décadas de 1930 e 2000.
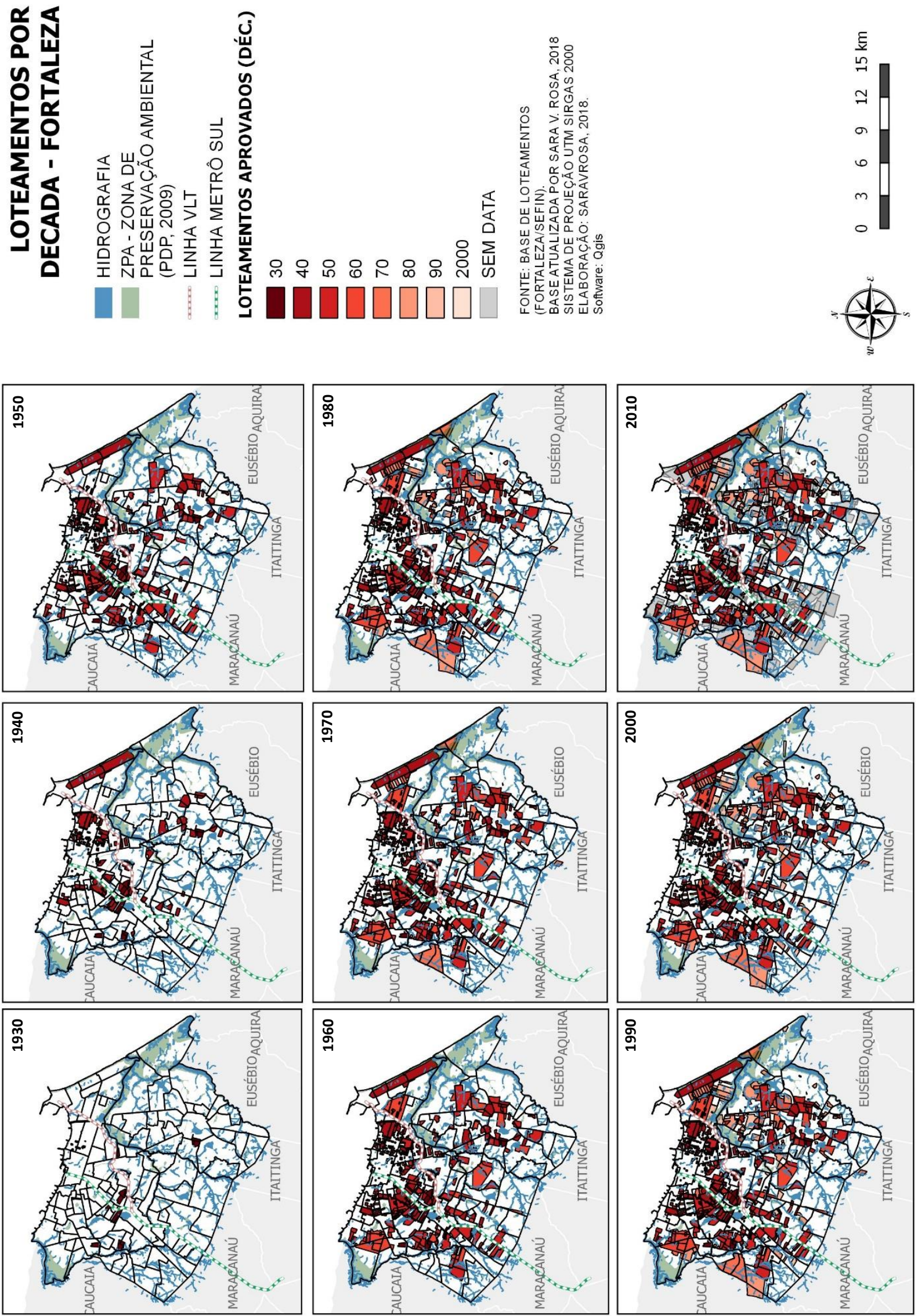

Elaboração/projeto cartográfico: Rosa, S. V. (2018). Fonte: FORTALEZA/SEFIN, 2017 (base de loteamentos com registro de 1931 a 2002) com atualizações a partir de pesquisa cartorial realizada pela autora. Obs.: Loteamentos aprovados no bairro da Sabiaguaba na década de 70/80 foram registrados no cartório do município de Aquiraz. 


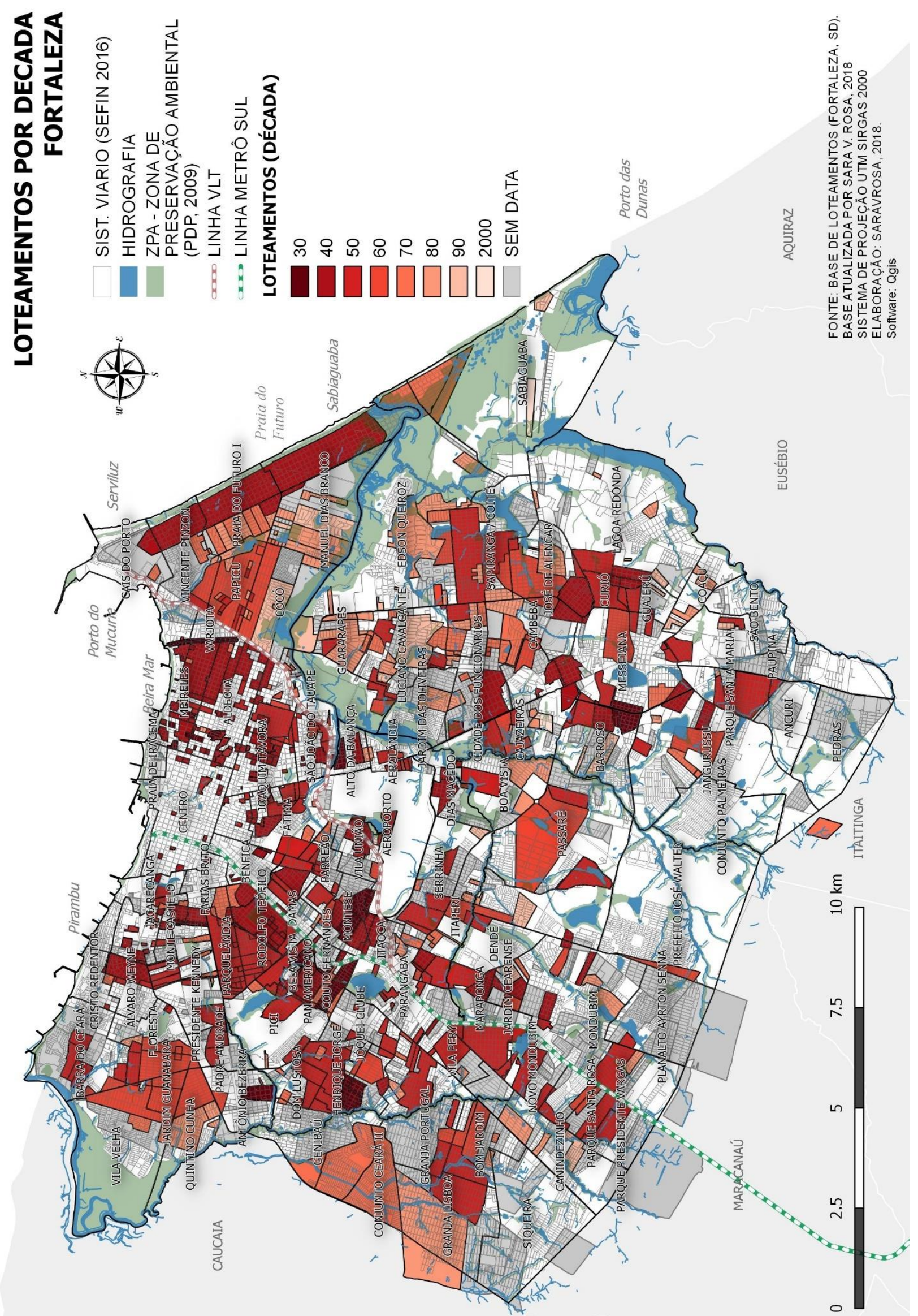

Elaboração/projeto cartográfico: Rosa, S. V. (2018). Fonte: FORTALEZA/SEFIN, 2017 (base de loteamentos com registro de 1931 a 2002) com atualizações a partir de pesquisa cartorial realizada pela autora. Obs.: Loteamentos aprovados no bairro da Sabiaguaba na década de 70/80 foram registrados no cartório do município de Aquiraz. 
Nesta secção, fazemos breve resgate histórico do processo de expansão urbana da cidade de Fortaleza a partir da apropriação da natureza, destacando processos de acumulação por espoliação da natureza que levaram ao desaparecimento de recursos hídricos e à privatização do comum, retirando meios de produção de comunidades tradicionais ou pobres e acirrando ainda mais as desigualdades socioeconômicas e espaciais da cidade. Para isto, utilizaremos como procedimento metodológico a análise de cartas, ortofotos e imagens aéreas antigas da cidade que foram tratadas e georreferenciadas, permitindo a sobreposição das informações antigas e atuais. Destacamos neste processo a Carta de Fortaleza e Arredores de 1945 (levantamento do Serviço Geográfico do Exército) ${ }^{60}$; Ortofotos do final da década de 1950 (provavelmente 1958 ou 1959); Ortofotos de 1972; Ortofotos de 2001; e imagens do GoogleEarth de $2018^{61}$.

Elementos da natureza, como hidrografia e relevo, no caso de Fortaleza, rios e dunas, apresentaram-se muitas vezes como uma barreira ao processo de expansão da urbanização do município. Foi o caso do Riacho Pajeú, até início do século XX, como aponta Fuck Jr. (2002 apud RUFINO, 2016), e posteriormente o Rio Cocó, até a década de 70 ( RUFINO, 2016). O cordão de dunas móveis que se estende(ia) do Mucuripe até o Rio Cocó também representou uma importante barreira a expansão urbana até o final dos anos 60 e início dos 70 . Essas barreiras foram aos poucos sendo ultrapassadas, muito por meio de ações do Estado, como a abertura de vias e pontes e, por vezes, com a implementação de conjuntos habitacionais sobre dunas e áreas de mangue, permitindo que agentes imobiliários abrissem loteamentos sobre estas. Assim, áreas antes rurais, com presença de lagoas e vegetações importantes, ou sítios e culturas foram aos poucos sendo transformadas em vastos loteamentos, mesmo sem demanda real (alguns permanecem com baixo percentual de ocupação até hoje), e aos poucos sendo incorporadas à malha urbana da cidade.

\footnotetext{
60 A Carta impressa original encontra-se na mapoteca da Biblioteca de Arquitetura e Urbanismo da UFC. A partir deste trabalho, foi disponibilizado CD para a biblioteca com as imagens tiradas das folhas em alta resolução.

${ }^{61}$ Destaca-se que estas imagens, principalmente as da década de 1950 e 1970, não contemplavam todas as áreas do município o que dificultou a análise de alguns trechos. Detalhes sobre o processo de tratamento e georreferenciamento das imagens pode ser consultado nos apêndices desta tese.
} 
Partindo da Carta de Fortaleza e Arredores, cartografia de 1945 (Figura 12), é possível observar que, em pouco mais de 60 anos, as transformações na paisagem e no território de Fortaleza foram gigantescas. Nesse período, ainda era possível observar um grande cordão de dunas móveis, tanto no litoral norte, com as Dunas da Barra do Ceará - atual Grande Pirambu, quanto no litoral leste, com o cordão de dunas que ia do Mucuripe até a foz do Rio Cocó, Dunas do Mucuripe, Dunas do Papicu e Dunas da Barra, cruzando a Foz do Cocó. Na então Sabia-naba (atual Sabiaguaba), era observado outro cordão de dunas, também denominado no mapa como Dunas da Barra pela proximidade com a Barra do Cocó. Este último conjunto de dunas, do Mucuripe à Sabia-naba62, era mais expressivo, tanto em dimensões de comprimento como em altura, tendo dunas com cotas superiores aos 60 metros.

Apesar da base cartográfica de loteamentos do município apontar a aprovação de loteamento em toda a extensão da Praia do Futuro, ainda na década de 1930 e até 1945, a faixa de praia da Praia do Futuro, logo após o cordão de dunas do Mucuripe, Papicu e Barra, segundo o levantamento do Serviço de Geografia do Exército, ainda não apresentava ocupações, exceto o antigo Farol do Mucuripe (hoje, bem tombado) e do Porto, construído no final dos anos 1930 e começo dos 1940, já no Mucuripe.

Observando uma imagem aérea atual da cidade, ano 2018, (Figura 14), é possível perceber que atualmente apenas o setor sudoeste do campo de Dunas da Barra, atual Parque das Dunas da Sabiaguaba, permanece parcialmente preservado. As demais foram sendo ocupadas por conjuntos habitacionais promovidos pelo Estado, por "assentamentos irregulares" de população de baixa renda, por galpões industriais, por barracas de praia, por habitações tipo mansões (atual bairro De Lourdes), por condomínios fechados para classe média, alguns hotéis, casas de praia, dentre outros tipos de ocupação.

Além do conjunto de dunas móveis, é possível perceber na cartografia de 1945 a representação de dunas fixas com vegetação contíguas às dunas móveis do setor leste, com maior destaque para aquelas contíguas às Dunas da Barra e do Papicu, representadas como Matas do Cap. Moura, onde também se localiza o sítio da Família Diogo, que posteriormente aparece nos registros de loteamentos da prefeitura como proprietário de toda essa porção da cidade compreendida pelas Matas do cap. Moura, dunas do Mucuripe, Papicu, Barra, até a

\footnotetext{
62 Sabia-naba é como a localidade Sabiaguaba aparece no registro da base cartográfica de 1945 analisada. 
praia e a foz do Cocó. Grande parte destas já foram ocupadas, principalmente por habitações verticalizadas para classe média, onde hoje se situa o bairro do Cocó e pelo conjunto habitacional Cidade 2000. Todavia, existe uma importante porção ainda não ocupada no atual bairro M. Dias Branco, onde está localizada a Operação Urbana Consorciada Dunas do Cocó e um outro pequeno trecho onde está localizada a ARIE $^{63}$ do Cocó. Estes dois casos serão melhor trabalhados no decorrer do trabalho.

Outra importante alteração na paisagem da cidade foi a supressão das áreas ao longo dos recursos hídricos com vegetação, com presença de grandes carnaubais, como é possível observar pela cartografia de 1945, ao sul do Rio Cocó, Rio Maranguapinho, Riacho Estiva e Rio Ceará. Hoje, para visualizar esse tipo de vegetação, é necessário sair dos limites da cidade, pois essas áreas encontram-se densamente ocupadas, em especial no entorno do Rio Maranguapinho e Riacho Estiva (Figura 14).

Parte das planícies de inundação do Rio Cocó e do Rio Ceará, compreendidas entre os carnaubais e a foz, eram apropriadas por grandes salinas, onde os proprietários destas glebas de terrenos auferiam renda de extração pela exploração do sal. Na década de 1940, no Rio Ceará, estavam localizadas as salinas Margarida, Vila Velha, Soledade, Santa Rita, São José e Guaié. Já no Rio Cocó, localizavam-se as salinas Salina Velha, Dendê e Cocó (S3, S2 e S1 respectivamente, Figura 12 ).

A Salina Diogo, também localizada no Rio Cocó, a qual ficou mais conhecida e da qual se tem mais registros históricos e fotográficos, ainda não aparecia demarcada nessa cartografia, vindo a ser implantada posteriormente ${ }^{64}$.

Após a desativação das salinas, parte desses leitos de rios foram aos poucos se regenerando pela ação da própria natureza e dando lugar a mangue, no caso do Cocó, inclusive em áreas onde não foi demarcada a presença deste tipo de vegetação no levantamento de 1945 , fato talvez desencadeado pelas salinas, que provocaram o aumento de áreas alagáveis com água salobra, como é possível observar no atual bairro Salinas, que dava lugar, em 1945, à Salinas do Cocó (Figura 12) e parte do atual Bairro do Cocó, onde estavam localizadas as Salinas Diogo. Outras partes foram ocupadas pelo avanço da urbanização. As salinas do Vila Velha (Figura

\footnotetext{
63 Área de Relevante Interesse Ambiental, criada pela Lei no 9502, de 07 de outubro de 2009.

${ }^{64}$ provavelmente no final dos anos 50 e início 60, pois os registros fotográficos encontrados são do início dos 60 e anos 70 .
} 
12), por exemplo, dão lugar hoje ao bairro Vila Velha (Figura 11), caracterizado por ocupação popular, com presença de conjuntos habitacionais e favelas, onde as famílias sofrem constantemente com problemas de inundação e de umidade do terreno que sobe para a estrutura das casas.

Figura 10. Salinas do Cocó / Postal Salinas Diogo
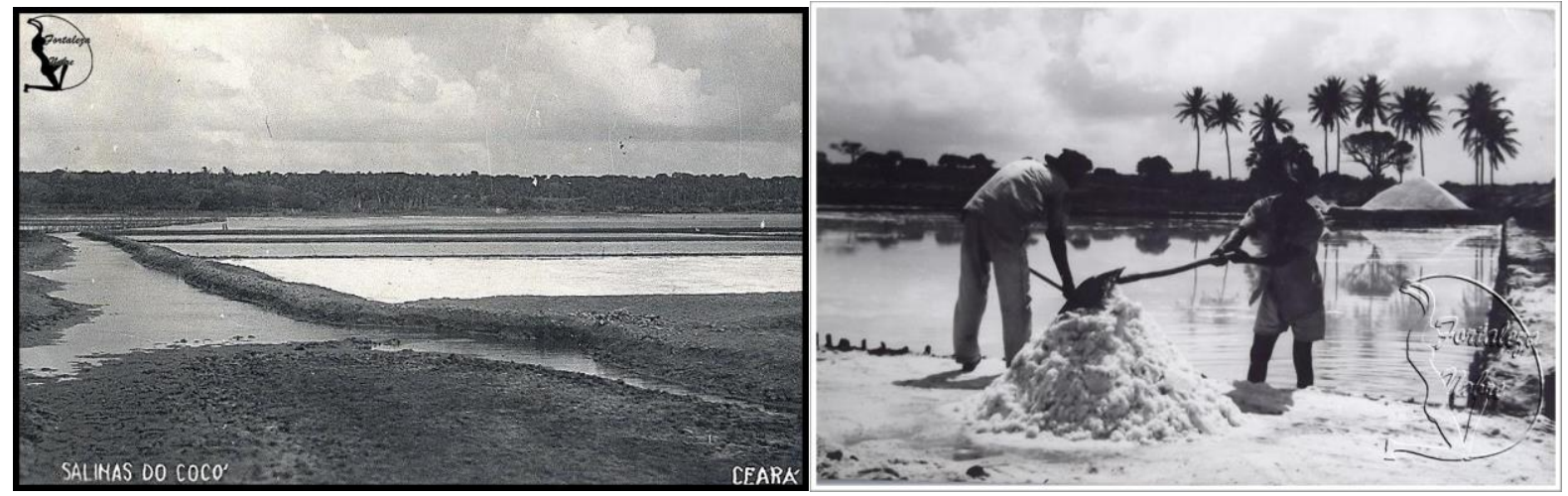

Foto esquerda: Salinas Cocó, Arquivo Carlos Juaçaba. Fonte: site Fortaleza Nobre, disponível em: <https://www.facebook.com/Fortalezanobreoficial/photos/a.1111694512191973/1111694795525278/?type=3\&theater>
Foto
direita:
Salinas
Diogo.
Fonte:
site
Fortaleza Nobre,
disponível
em:

<http://www.fortalezanobre.com.br/2009/11/shopping-center-iguatemi.html>

Figura 11. Bairro Vila Velha, antiga Salina Vila Velha.

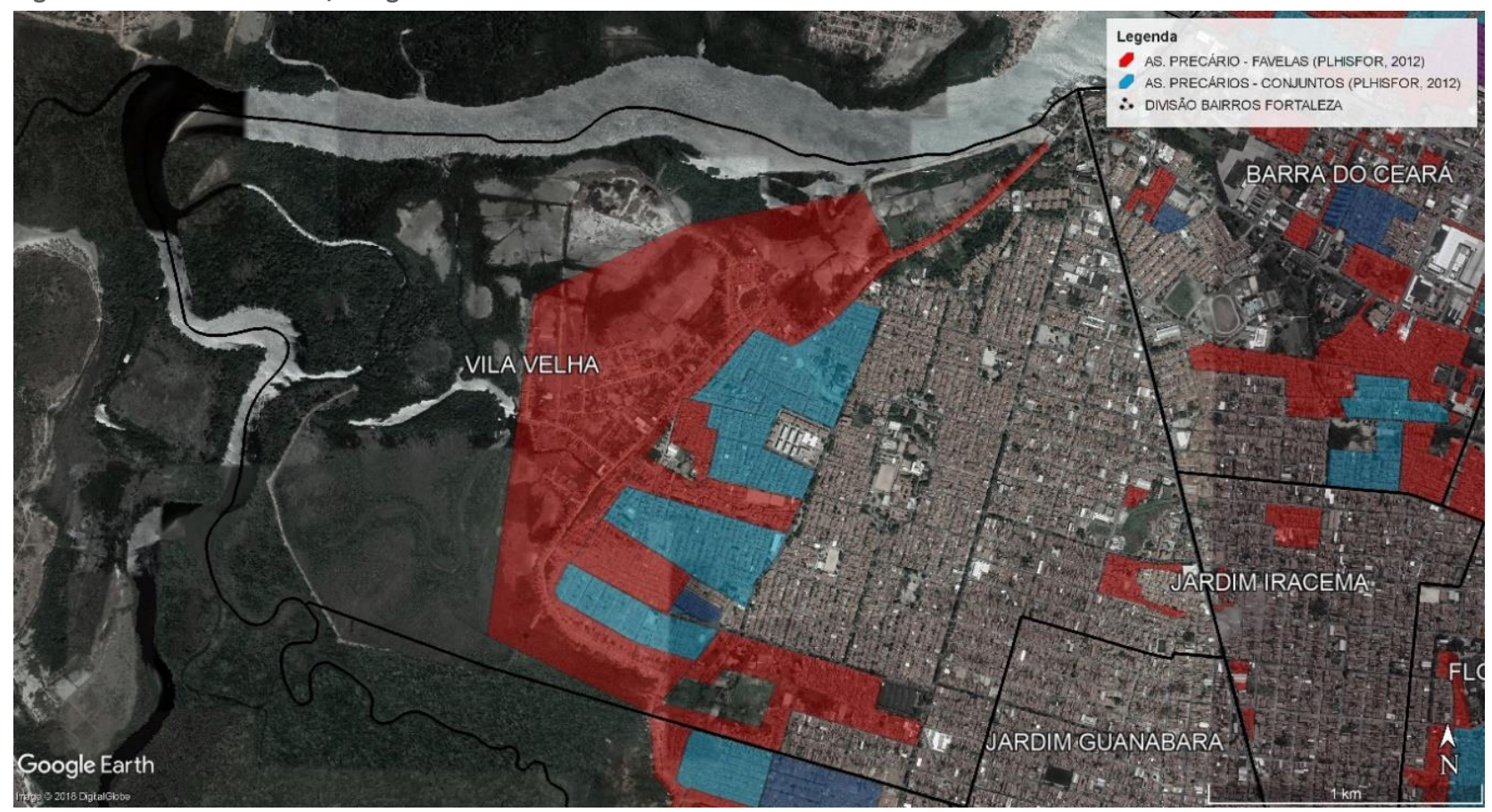

Elaboração Rosa, 2018. Imagem aérea (Google Earth, 2018), divisão de bairros (SEUMA, 2015), Assentamentos precários (PLHISFOR, 2012). 
Figura 12. Carta da Cidade de Fortaleza e Arredores em 1945.

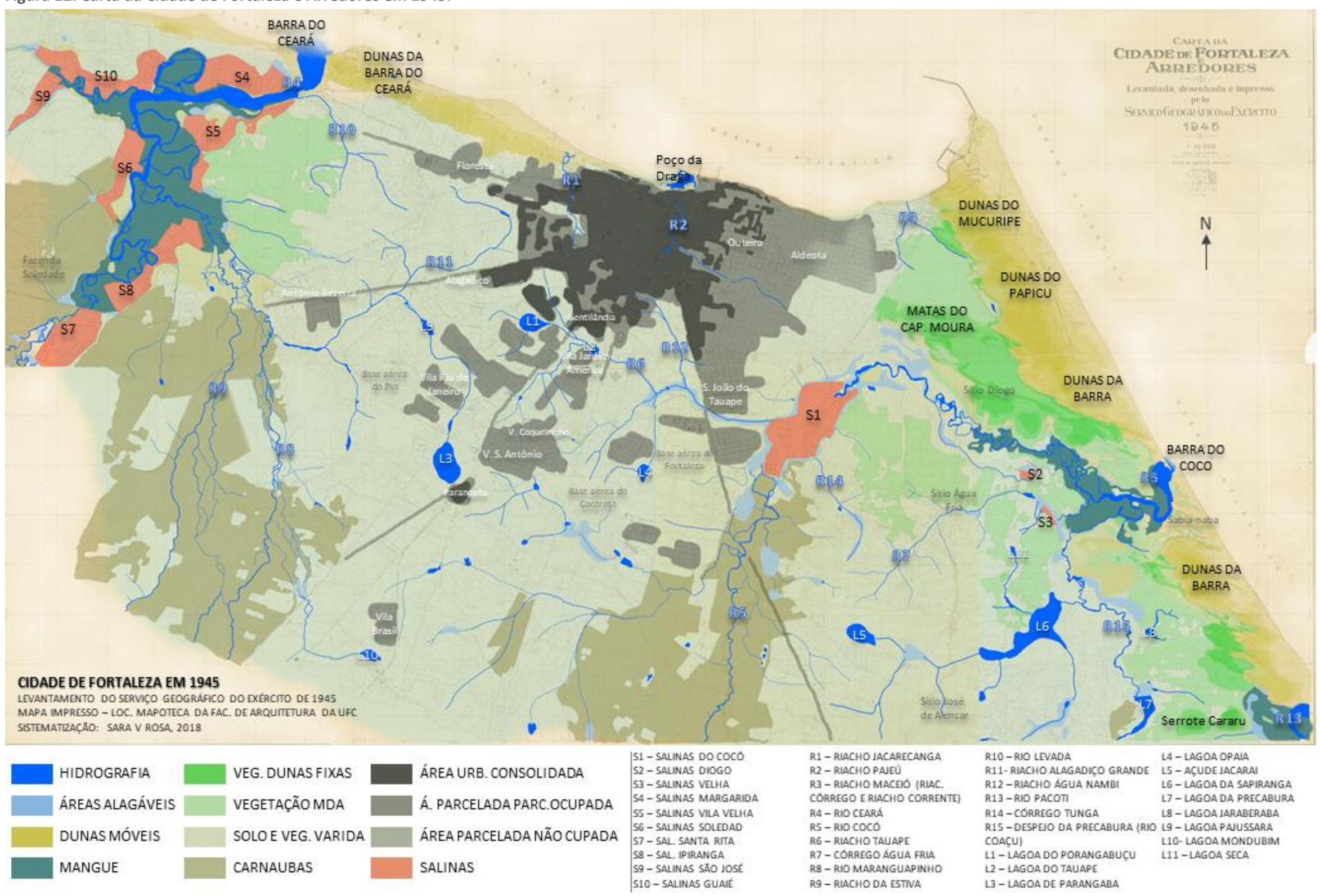

Fonte: Carta da Cidade de Fortaleza em 1945 - levantamento do Serviço Geográfico do Exército, adaptado pela autora. 
Figura 13. Ortofoto de Fortaleza na década de 1950, possível ano de 1958

S9

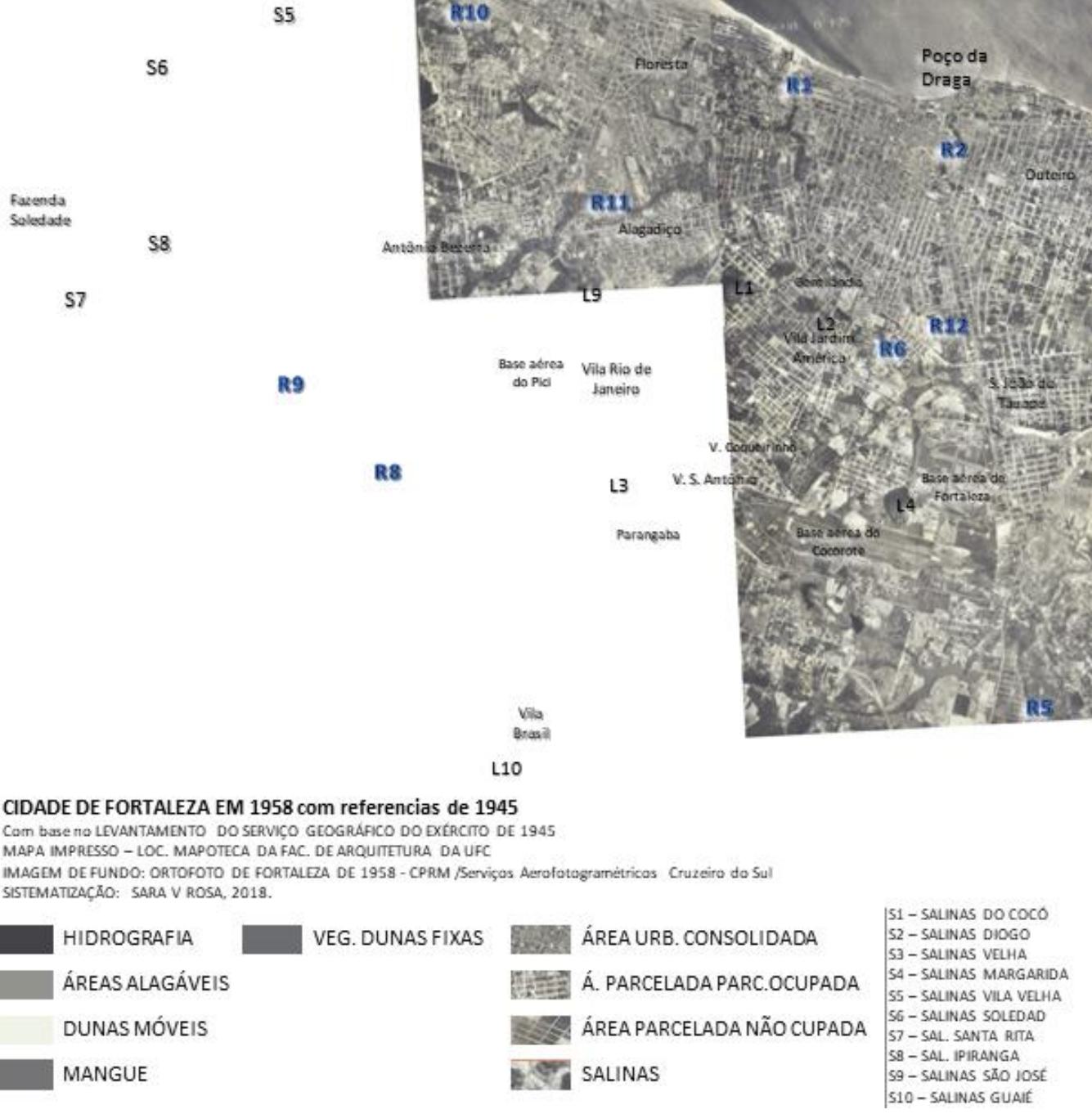

54

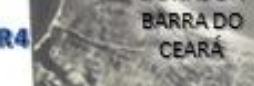

$\$ 5$

ACUMULAÇÃO E “VALORIZAÇÃO” PELA N
Figura 13. Ortofoto de Fortaleza na
$\$ 10$

$$
\text { BARRAD }
$$<smiles>CCCCCC(C)(C)O</smiles>

$$
\text { DUNASDA }
$$
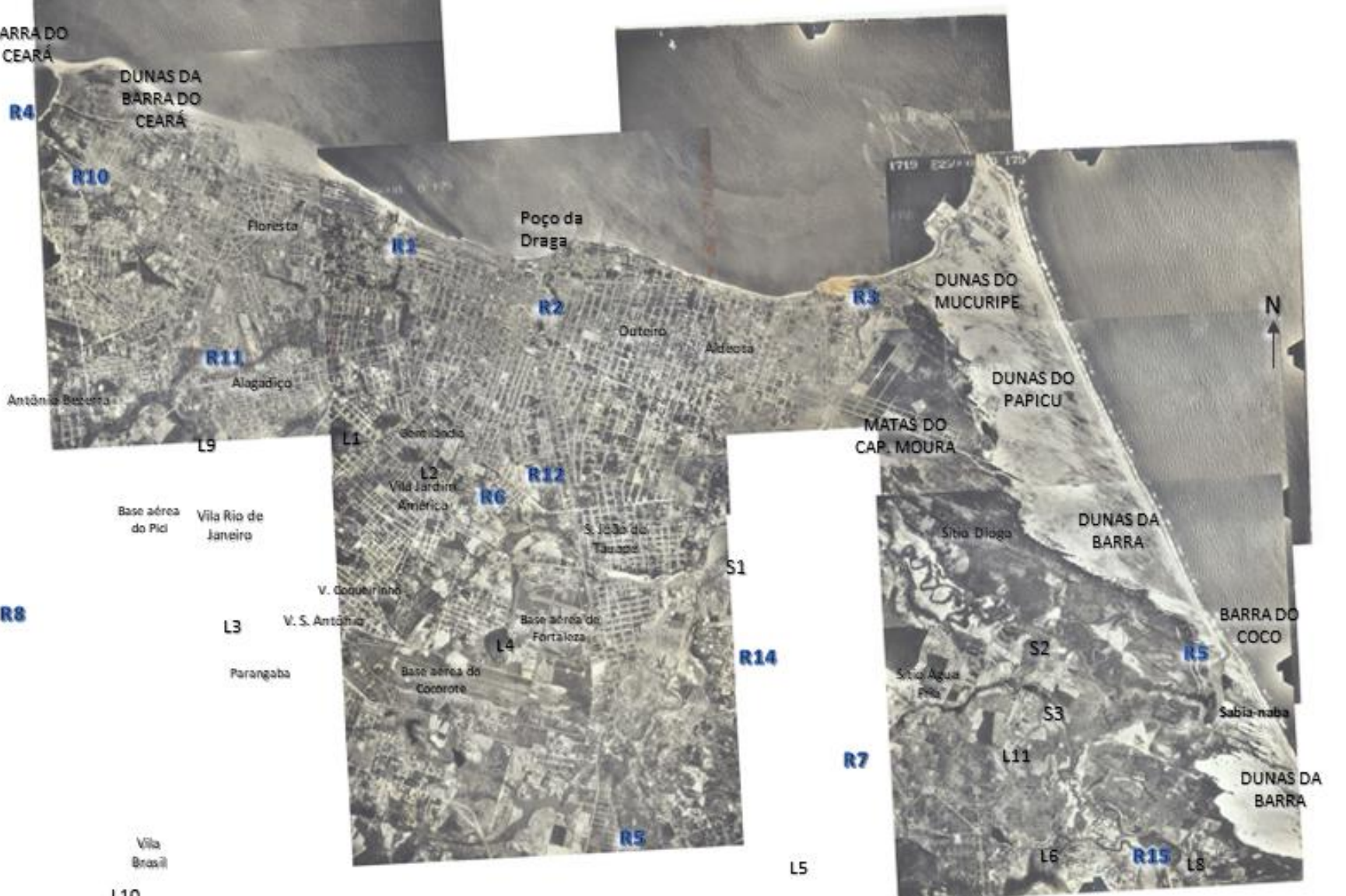

L5

$$
\begin{aligned}
& \text { Sitio José } \\
& \text { de Alencar }
\end{aligned}
$$$$
17
$$

Serrote Cararu

R1 - RLACHO JACARECANGA R2 - RLACHO PAEÚ
R3 - RLACHO MACEO IRLAC CORREGO E RLACHO CORRENTI RA - RIO CEARA
R5 - RIO COCO RG- RLACHO TAUAPE R7 - CORREGO AGUA FRLA RB - RIO MARANGUAPINH

R10-RIO LIVADA L4- LAGOA OPALA R11- RLCCHO ALAGGAICO GRANDE I5 - ACUDE IACARAI R12 - RLACHO AGUUA NAMEA
P13 - RIO PACOT LAGOA DA SAPIRANGA

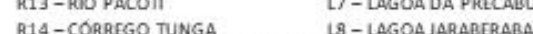

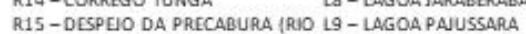
COACU) L10- LAGOAMONDURAIM L1- LAGOA DO PORANGABUCCU LI1-LAGOA SECA. L2- LAGOA DO TAUAPE R9-RIACHO DA ESTA L3- LAGOA DE PARANGARA

Sistematização: autora (2018) a partir de Carta da Cidade de Fortaleza em 1945 - levantamento do Serviço Geográfico do Exército. Ortofoto: Fortaleza, 1958 Página 98 | CAP. 01 - ACUMULAÇÃO PELA NATUREZA 
Figura 14. Mosaico de imagem aérea do Google Earth, 2018.

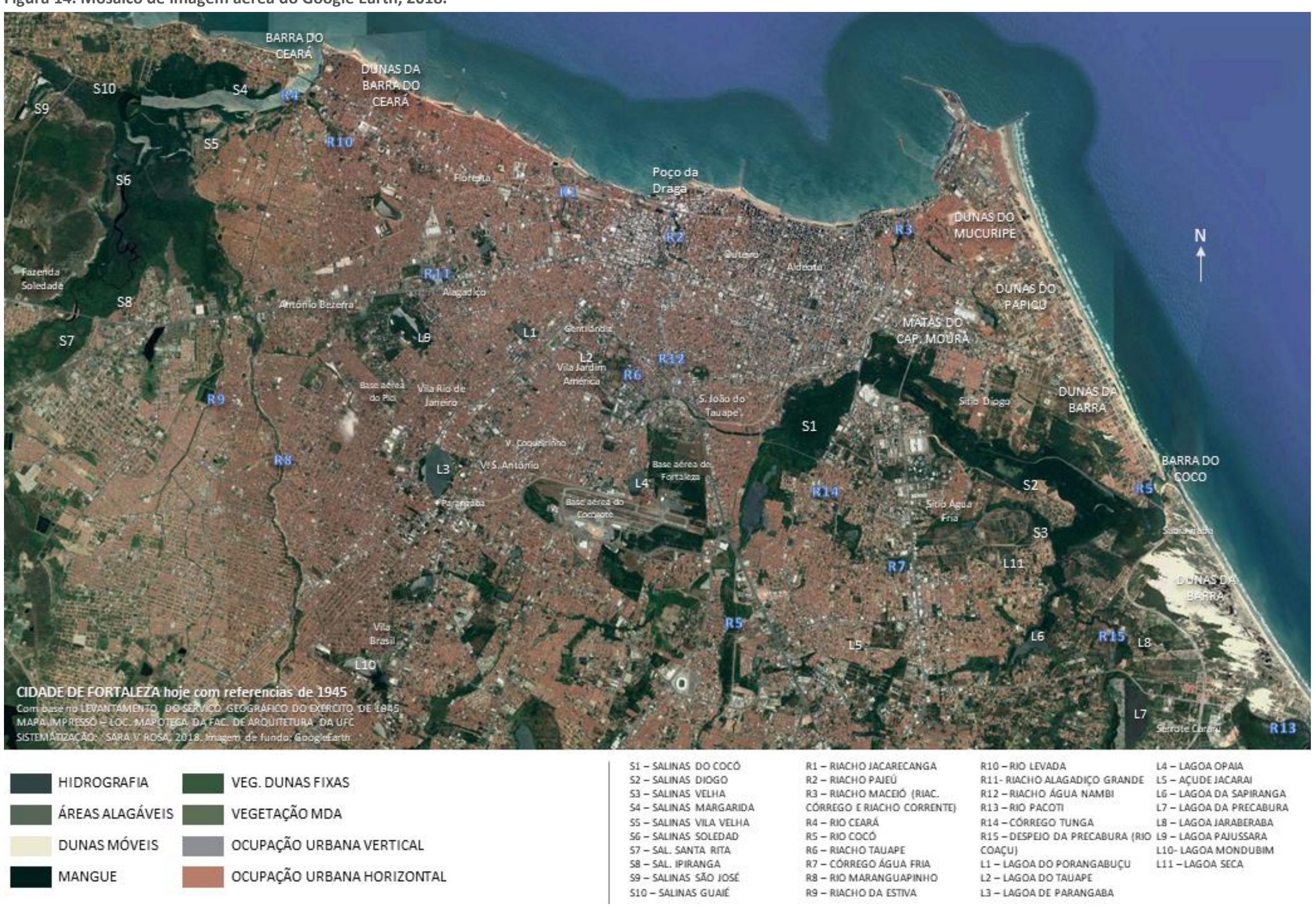

Sistematização: autora (2018) a partir de Carta da Cidade de Fortaleza em 1945 - levantamento do Serviço Geográfico do Exército.. Imagem aérea: GoogleEarth, 2018. 


\section{Riacho Tauape e Riacho Água Nambi - por aqui já passou um rio}

O Riacho do Tauape e o Riacho Água Nambi fazem parte da Bacia Hidrográfica do Rio Cocó. Hoje, encontram-se canalizados e seus leitos dão lugar às avenidas Eduardo Girão e Aguanambi, respectivamente, passando desapercebidos pela maior parte da população, ou sendo percebidos apenas como canal de esgoto.

Afluentes do Rio Cocó, estes dois rios tinham uma importante função de drenagem da região que cortavam. O local onde eles se cruzam, hoje totalmente coberto para dar lugar a Rotatória da avenida Aguanambi, que faz a ligação desta com a avenida Borges de Melo e BR-116, dava lugar em 1945 ao Sítio Canadá, que abrigava um açude com o mesmo nome no leito do Tauape e um pouco acima o sítio Gameleira. Todo o entorno do Água Nambi (atual Bairro de Fátima) e todo entorno do Tauape até a lagoa do Tauape (atual bairro Benfica) eram completamente desocupados na época. A área da atual Av. Borges de Melo, ao longo do Riacho do Tauape, juntamente com a água que recebia do Água Nambi, até desaguarem no Rio Cocó, conformava uma grande área alagável conhecida na época como Alagamar do Tauape (Figura 16), área ainda sob influência das mares do oceano Atlântico ${ }^{65}$. Neste local, no Alagamar, logo abaixo do núcleo urbano que já se formava na década de 40 no Bairro do Tauape, consolidou-se a comunidade Lagamar ${ }^{66}$, cujos relatos sobre sua formação destacam a importância da instalação das famílias nas margens do riacho, já que eram famílias vindas do interior, que tinham o costume de utilizar o rio como local de banho, bem como para lavagem de roupas e utensílios. A comunidade sofre constantemente com problemas de inundação devido ao local que ocupou ser originalmente uma área alagável e pela intensificação da impermeabilização do entorno e canalização dos dois riachos, aumentando a vazão da água que se concentra na parte mais baixa, no Alagamar do Tauape.

A canalização do Riacho Água Nambi e a abertura da Avenida Aguanambi, no início da década de $70^{67}$, possibilitaram a extensão da urbanização da área central da cidade para essa região, ligando a av. Dom Manuel à av. Borges de Melo e viabilizando diversos loteamentos que

\footnotetext{
${ }^{65}$ A linha de preamar e a linha de área de marinha, definidas em 1931, avançam do rio Cocó pelo riacho Tauape até o início da BR-116.

66 Segundo Gondim (2012) a ocupação do lagamar se deu no início da década de 30 juntamente com o surgimento das primeiras favelas de Fortaleza, todavia, outros autores como Aguiar (2016) apontam a década de 50.

${ }^{67}$ A Avenida Aguanambi foi inaugurada em junho de 1972 na gestão do prefeito Vicente Fialho, ligando a Avenida Dom Manuel à Avenida Borges de Melo. (FORTALEZA EM FOTOS - http://www.fortalezaemfotos.com.br/2011/10/o-governovicente-fialho-e-construcao.html) .
} 
tiveram aprovação ainda no final da década de 1940 e década de 1950 em todo o entorno dos dois riachos.

Segundo a Base de Loteamentos da Prefeitura de Fortaleza, podemos verificar os seguintes loteamentos aprovados na área a partir da década de 40, no entorno imediato do encontro do riacho Água Nambi com o riacho Tauape: Canadá (Sítio) Trecho Aeroporto - Sem informação sobre o proprietário e ano; Canadá (Sítio) - Quadra "Q" - proprietário CONSIBEL Const. Belchior Ltda. - ano 1976; Canadá (Sítio) - proprietário Pergentino Ferreira - ano 1956; Ubirajara Parque - Sem informação sobre o proprietário e ano; Tomazlândia - proprietário Jerônimo Vale Sampaio e outros - ano 1954. Ao longo da Av. do Riacho Água Nambi (av. Aguanambi): 13 de maio (Parque) - proprietário José Leon Coelho de Vasconcelos - ano 1952; Santa Terezinha (Parque) - proprietário Herds. José Euclides Coelho e Osória Sales Coelho ano 1958; Pergentino Ferreira (Terreno) - proprietário Pergentino Ferreira - ano 1956; Leão XIII (Parque) - proprietário Imobiliária Pedro Filomeno Ltda; Fernandes (Vila) - proprietário José Fernandes de Carvalho - ano 1950; Ernest Goldschmidt - proprietário Ernest Goldschmidt - ano 1951; José Gondim Chaves (Terreno) - proprietário José Gondim Chaves ano 1957; Trindade (parque) - proprietário Imobiliária José Gentil S/A - ano 1949; Aratanha (parque) - proprietário Empresa de Terrenos Ltda - ano 1949; Artur Wichmann (Sítio Ubirajara) - proprietário Artur Wichmann - ano 1946; Empresa de Terreno Ltda - Sem informação sobre o proprietário e ano; Ubirajara (Parque) - proprietário Gladstone Lima Almendra - ano 1947. Ao longo do Riacho Tauape, nos bairros Alto da Balança e São João do Tauape: margem sul do riacho, São Sebastião do Tauape - proprietário Manuel Sátiro - ano 1938; e na margem norte, loteamentos São Luiz (Parque) - proprietário Empresa de Terrenos - ano sem informação; Santo Antônio (Parque) - proprietário Empresa de Terrenos Ltda - ano 1950; Imbuí (Parque) - proprietário Faustino Nascimento - ano 1950.

A canalização de recursos hídricos era a resposta dada na época para a solução de problemas de inundação das áreas ocupadas nas cotas mais baixas da proximidade destes. Ainda assim, mesmo com a canalização dos dois riachos e a urbanização até o limite dos canais, em períodos de chuvas mais intensos estas áreas são constantemente inundadas, principalmente no leito das avenidas. No momento, a Avenida Aguanambi está passando por uma remodelagem que inclui o tamponamento do que restou do riacho e uma nova rede de drenagem paralela ao riacho (canal) para ajudar na captação da água da sub-bacia do riacho 
Água Nambi, levando até o Riacho Tauape. O tamponamento, além de ajudar a apagar a memória do riacho e a invisibilizar os problemas de poluição deste, junto com a nova drenagem, poderá aumentar ainda mais a vazão dessa sub-bacia, que sobrecarregará o Alagamar do Tauape, afetando as famílias que aí residem, além de retirar um território que, mesmo poluído e estreitado, é reduto de aves migratórias.

Figura 15. Avenida Aguanambi no ano de sua inauguração, 1972

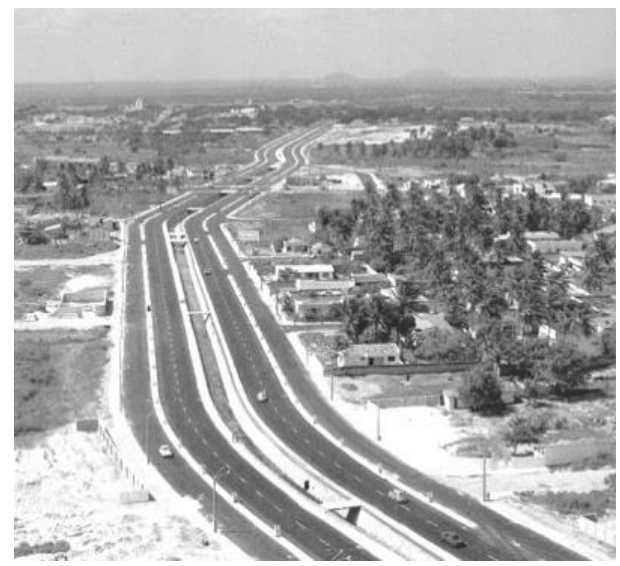

Foto: Arquivo Nirez. Fonte: https://eraumavezumrio.wordpress.com/2016/07/02/um-novo-pajeu/

Figura 16. Riacho Água Nambi e Riacho Tauape

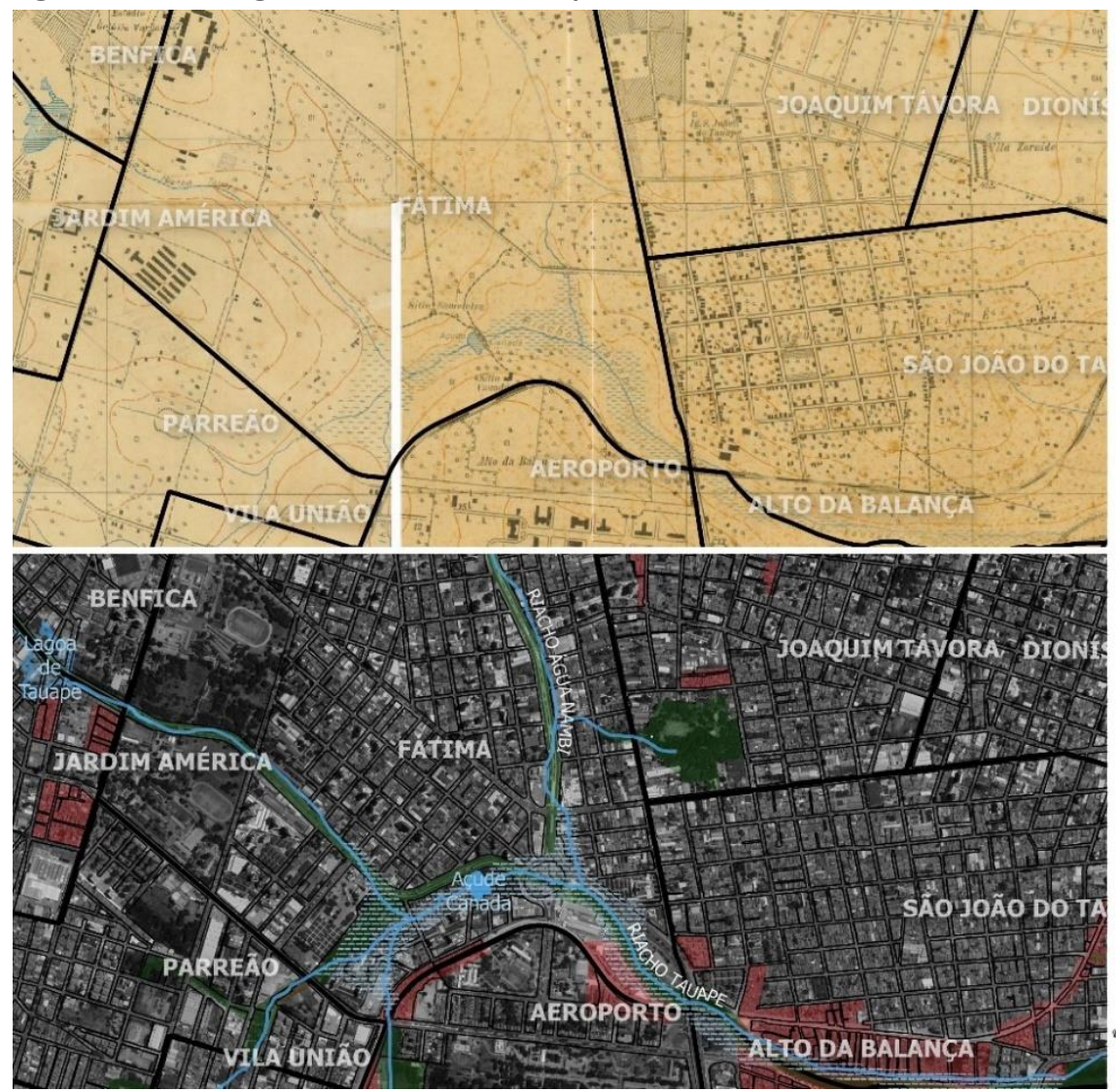

RIACHO ÁGUA NAMBI E RIACHO TATUAPE sobreposição carta 1945 e quadras atuais

$\square$ HIDROGRAFIA(LEV. 1945) AREA ALAGAVEL

(ALAGAMAR DO TAUAPE)

CURVAS DE NIVEL (LEV. 1945)

$\square$ BAIRROS ATUAIS (SEUMA 2016)

$\square$ QUADRAS ATUAIS (SEFIN 2016) ZPA - ZONA DE PRESERVAÇÃO
AMBIENTAL (PDP 2009)

AS. PRECÁRIOS

Fortal45_EPSG31984_v9

(LEV. EXERCITO 1945)

FONTE: CARTA CIDADE DE FORTALEZAE ARRED OAES DE DI945 (SERVICO DE GEOGRAFIA DO EXERCITO, 1945):
OUADRAS EAIRROS (FORTALEZ, 2010 CUADRAE EAIRROS (FORTALEZA, 2016
FORTALEA.PDP. 2009: OUTORG: PROC.

969422015

SISTEMA DE PROJECAO UTM SIRGAS 2000

ELABORACCAO: SARAVROSA, 201

Sofware: Qgis

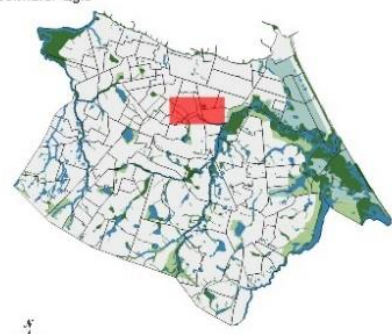

d. $0 \quad 200 \quad 400 \quad 600 \quad 800 \mathrm{~m}$

Elaboração: Sara V. Rosa, 2018. Fonte: Carta de Fortaleza em 1945 (Serviço Geográfico do Exército). 
Figura 17. Riacho Água Nambi e Riacho Tauape 1945 versus loteamentos e malha urbana atual

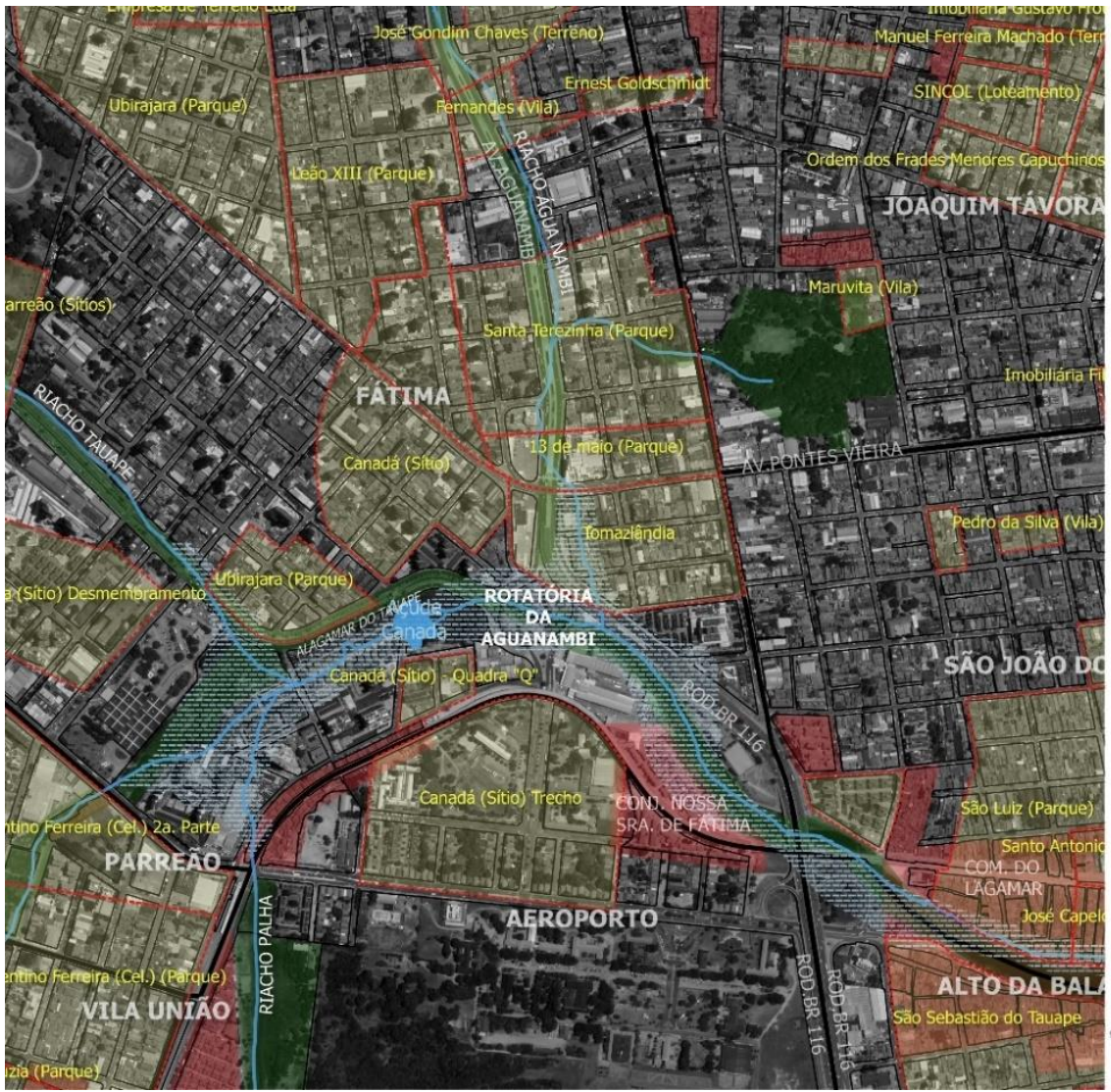

\title{
RIACHO ÁGUA NAMBI E \\ RIACHO TATUAPE \\ hidro 1945, quadras atuais, plhisfor e loteamentos
}

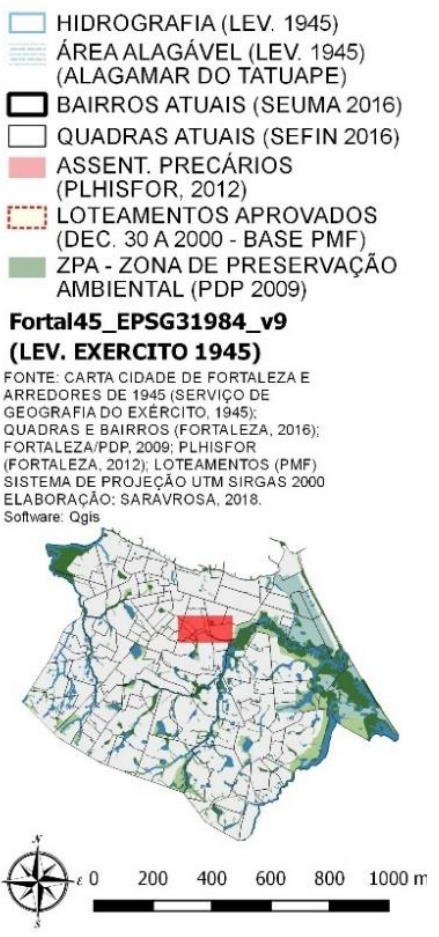

Elaboração: Sara V. Rosa, 2018. Fonte: Carta de Fortaleza em 1945 (Serviço Geográfico do Exército); Loteamentos (SEFIN).

Figura 18. Riacho Água Nambi

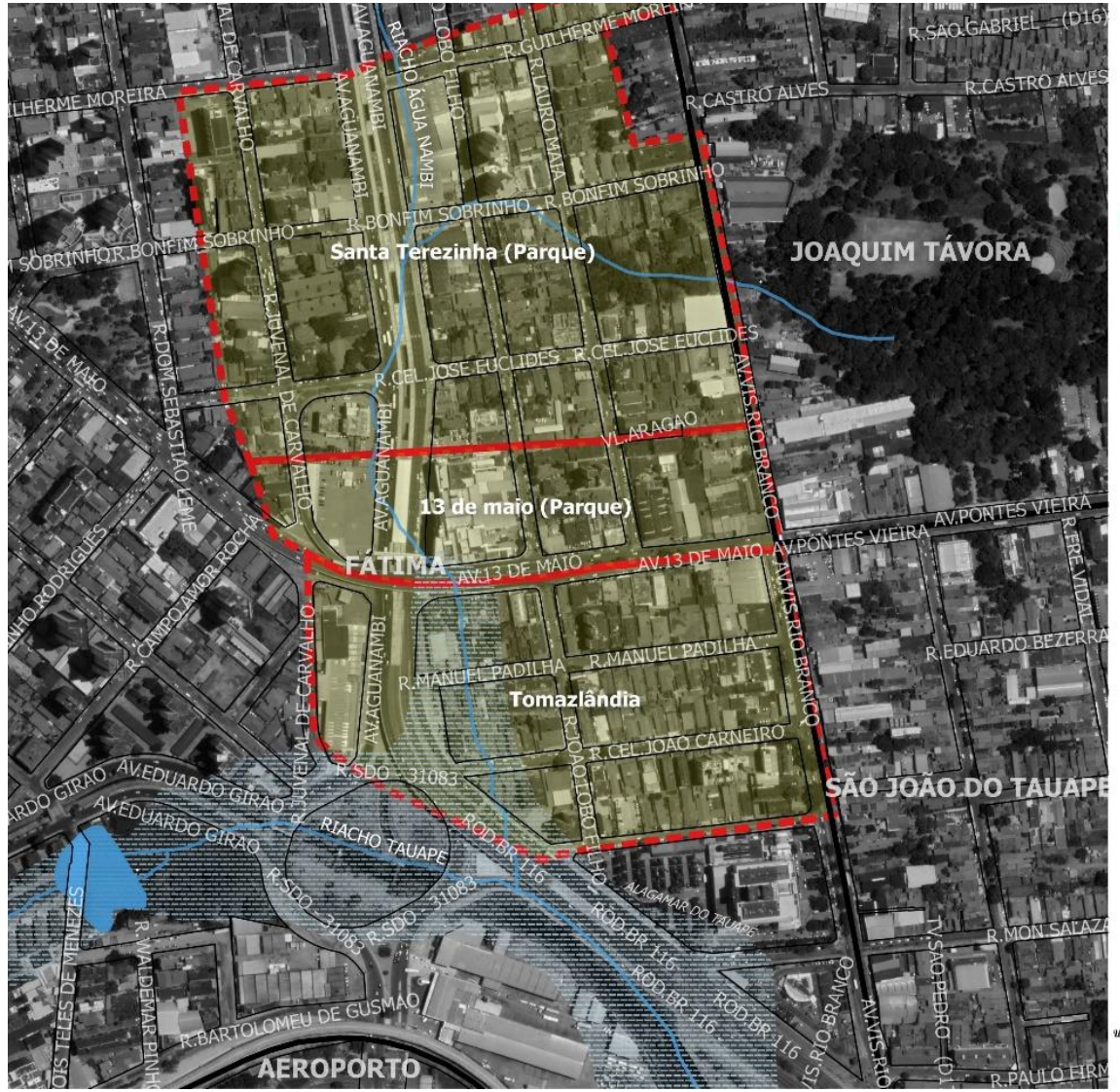

\section{LOTEAMENTOS SOBRE 0 RIO ÁGUA NAMBI déc. 1950}

\author{
FE LOTEAMENTOS SOBRE O \\ BAIRROS ATUAIS (SEUMA 2016) \\ QUADRAS (SEFIN 2016) \\ - HIDROGRAFIA (LEV. 1945) \\ ” LAGOAS (LEV. 1945) \\ ÁREAS ALAGẢVEIS (LEV. 1945)
}

FONTE: CARTA DE FORTALEZA E ARREDOES DE 1045 (SIST. DE GEOGRAFIA DO EXÉRCITO, 1945): QUADRAS

(2009) SISTEMA DE PROJECAO UTM SIRGAS 2000 ELABORAC,AO: SARAVROSA. 2018.

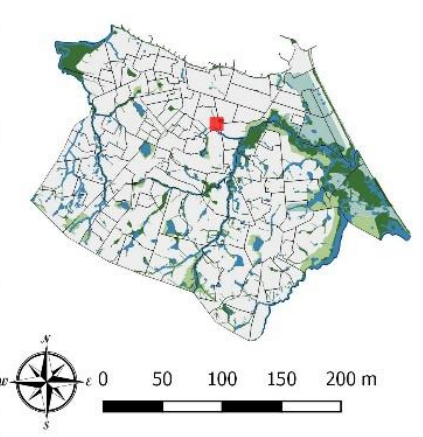

Elaboração: Sara V. Rosa, 2018. Fonte: Carta de Fortaleza em 1945 (Serviço Geográfico do Exército); Loteamentos (SEFIN). 
A Lagoa do Tauape (Figura 19 e Figura 12 - L2) é um dos exemplos de recursos hídricos que "desapareceram" no processo de urbanização de Fortaleza. Ela é retratada na cartografia de 1945 do Exército como lagoa alimentada pelo Riacho Tauape (afluente do Rio Cocó) e que se ligava também à Lagoa de Porangabuçu, alimentada pelo mesmo rio. Apresentava na época um pouco mais de $200 \mathrm{~m}$ de diâmetro, todavia, segundo relados do site Fortaleza em Fotos ${ }^{68}$, a lagoa chegou a ocupar uma área de aproximadamente dez hectares, "compreendida entre o que são hoje as avenidas dos Expedicionários e João Pessoa, entre as Ruas Marechal Deodoro e Jorge Dummar e a Avenida Eduardo Girão" e que a partir da década de 1940 teve início seu aterramento. De fato, na cartografia analisada, em 1945 já é possível observar o estrangulamento do corpo hídrico pelo sistema viário (atual Rua Jorge Dummar) e a proximidade da expansão do bairro Gentilândia (atual Benfica) e do loteamento Vila Jardim América (atual bairro Jardim América) já se sobrepondo à lagoa.

Assim, a lagoa, que já foi uma reserva de água doce e prestadora de serviços ambientais, hoje dá lugar, considerando a extensão anterior, da década de 1940, a trechos dos bairros Benfica (na época, trecho registrado como Gentilândia), Fátima, Jardim América e Damas. O leito da lagoa foi expropriado do uso comum da população, conformando, a partir da década de 1930, loteamentos privados que levaram ao desaparecimento por completo da lagoa, são estes: Loteamento Jardim América - proprietário: Sociedade de Terrenos LTDA; Loteamento Sítio Benfica - proprietário João Batista Maia; Loteamento Flórida e Parreão (sítios) - proprietário: Empresa Matadouro Modelo; Loteamento Otávio Menescal da Frota (Terreno) - proprietário: Otávio Menescal da Frota; Loteamento Imobiliária Boris Feres LTDA - proprietário: Imobiliária Boris Feres (Figura 21) ${ }^{69}$. A parte específica ainda retratada na cartografia de 1945 abriga hoje um prédio da Prefeitura de Fortaleza, Posto de Saúde Dr. Luís Costa, edifício da FAEC/SENARCE (Federação de Agricultura e Pecuária do Estado do Ceará) e alguns galpões de empresas.

O bairro Benfica recebeu no fim do século XIX e primeira metade do século XX a elite de Fortaleza que antes residia na Jacarecanga. Hoje, no Benfica e demais bairros do leito e entorno da lagoa do Tauape, mencionados acima, predomina população de classe média-

\footnotetext{
68 https://www.facebook.com/fortalezaemfotos/?tn-str=k*F

${ }^{69}$ Base de Loteamentos de Fortaleza da década de 30 a 2000 da Prefeitura Municipal de Fortaleza.
} 
média e média-baixa, e se observa a gradual substituição de casas, ou lotes ainda vazios, por habitações verticalizadas que vêm sendo ocupadas por famílias de classe média de um estrato um pouco mais alto do que as que aí residem.

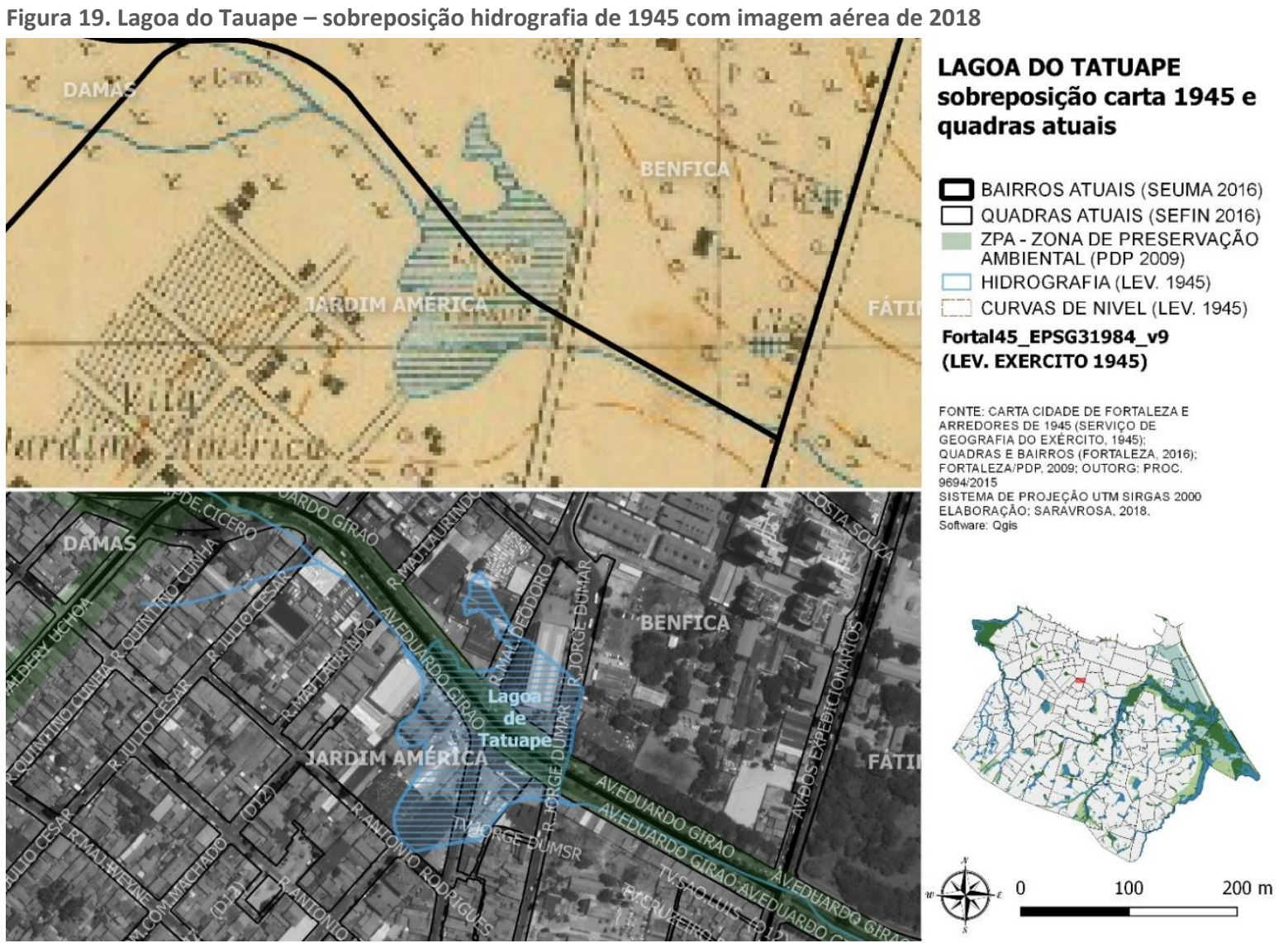

Elaboração: Sara V. Rosa, 2018 a partir de lev. do Serviço de Geografia do Exército (Carta de Fortaleza e Arredores de 1945);

Figura 20. Lagoa do Tauape

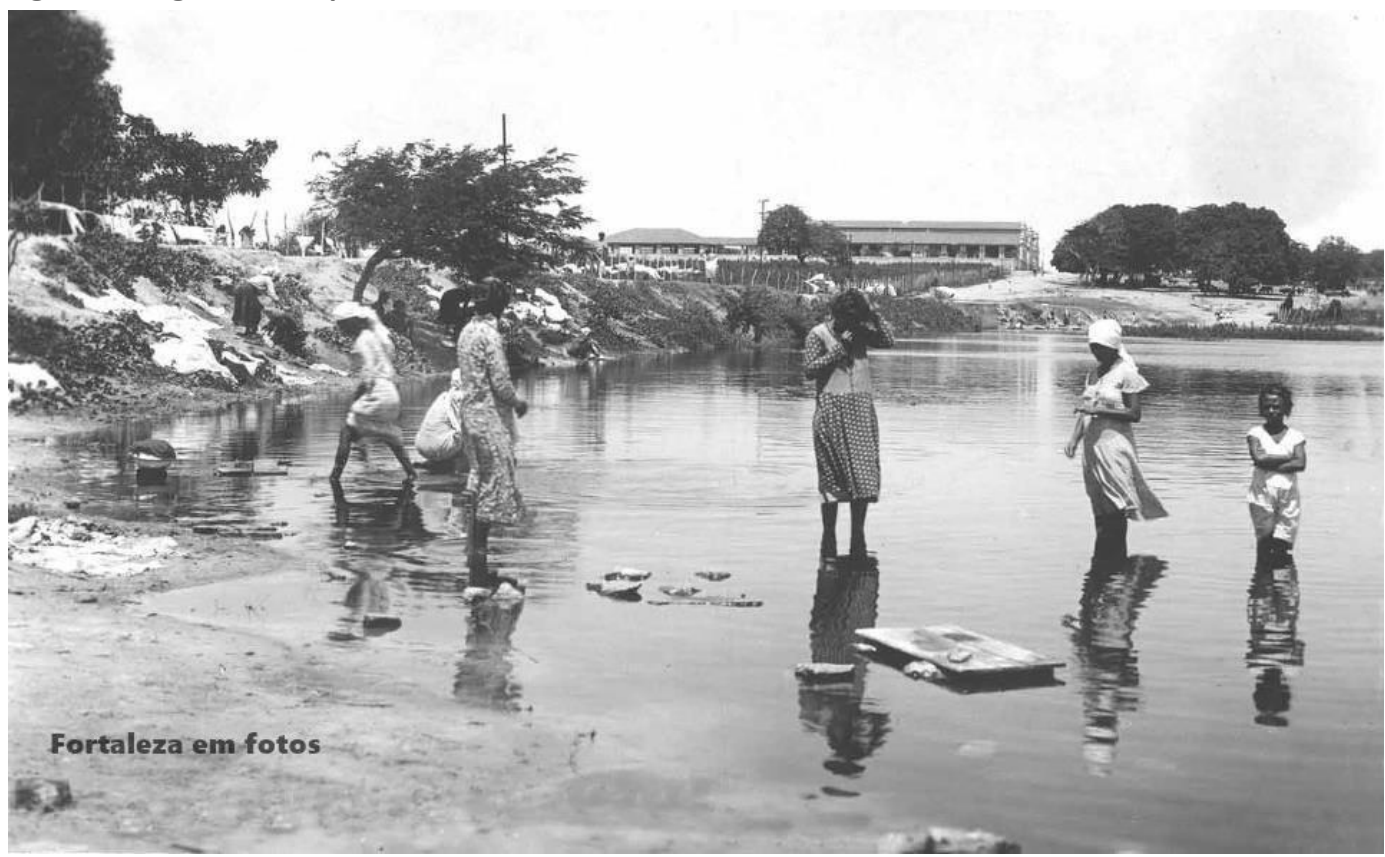

Foto Arquivo Nirez. Fonte: https://www.facebook.com/fortalezaemfotos/?tn-str=k*F 
Figura 21. Lagoa do Tauape e loteamentos do entorno - sobreposição hidrografia de 1945 com imagem aérea de 2018

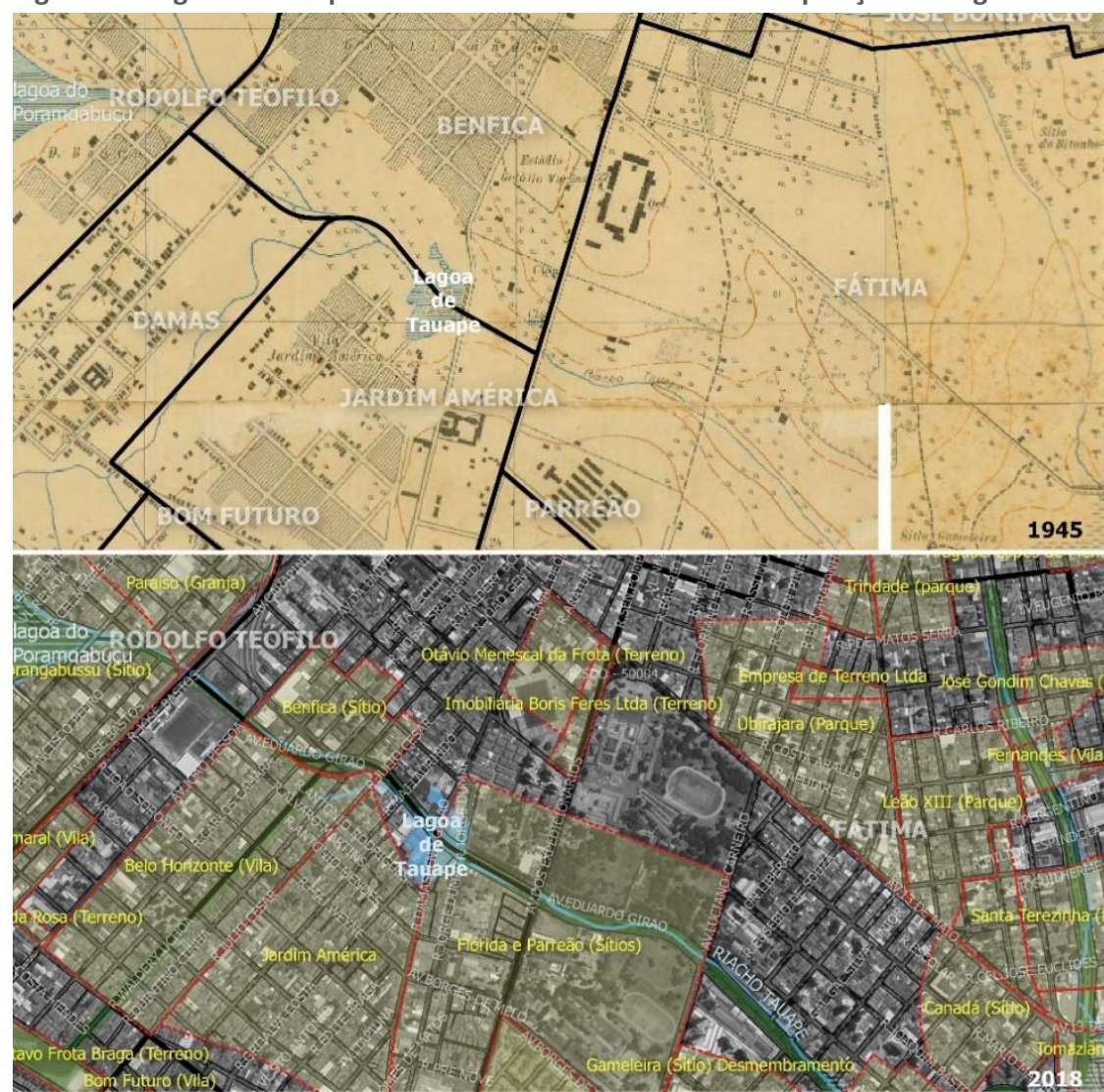

\section{LAGOA DO TAUAPE E LOTEAMENTOS sobreposição carta 1945 e} quadras atuais

$\square$ HIDROGRAFIA (LEV. 1945) = LAGOAS (1945)

CURVAS DE NIVEL (LEV. 1945)

Fortal45_EPSG31984_v9

(LEV. EXERCITO 1945)

LOTEAMENTOS APROVADOS

$\square$ BAIRROS ATUAIS (SEUMA 2016)

$\square$ QUADRAS ATUAIS (SEFIN 2016) ZPA - ZONA DE PRESERVAÇÃO
AMBIENTAL (PDP 2009)

FONTE: CARTA CIDADE DE FORTALEZAE ARREDORES DE 1945 (SERVICO DE
GEOGRAFIA DO EXERCITO, 1945 ): OUADRAS E EAIRROS (FORTALEZA, 2016)
FORTALEZAPDP. 2009: LOTEAMENTSS

(FORTALEZA) SISTTMA DE PROJECÁA UTM SIRGAS 2000

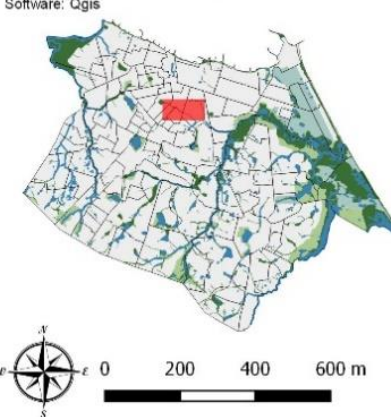

Elaboração: Sara V. Rosa, 2018. Fonte: levantamento do Serviço de Geografia do Exército (Carta de Fortaleza e Arredores de 1945); Base de Loteamentos da Prefeitura Municipal de Fortaleza.

Campo de dunas e faixa de praia do setor leste da cidade - do móvel ao imóvel

Toda a porção de terra localizada entre a linha de trem (atual VLT), ao oeste, a Beira Mar, ao norte, a Praia do Futuro ao Leste, e o Rio Cocó ao sul, faziam parte do Sítio Diogo, uma grande gleba de propriedade do Coronel Antônio Digo. Toda a área englobava as Matas do Cap. Moura e as Dunas da Barra, do Papicu e do Mucuripe, como registado na Planta de Fortaleza de 1945 (Figura 12). Essa área, segundo Costa (1988, apud ALDIGUERI, 2017, p. 130), "era explorada por agricultura de subsistência e pesca pelos posseiros que viviam no local, pela criação de gado, agricultura e produção de sal por parte do proprietário, Coronel Antônio Diogo", que adquiriu a gleba provavelmente antes da década de 1930, já que veio a falecer em $1932^{70}$.

\footnotetext{
70 Pelo registro de loteamentos da Prefeitura de Fortaleza, é possível verificar que parte da gleba, referente à faixa de praia dos atuais bairros Praia do Futuro I e II, teve loteamento registrado ainda na década de 1940, mesma época em que grande parte da atual Aldeota, porção mais contígua à mancha urbana ocupada na época, também tem loteamento registrado na base da prefeitura.
} 
O loteador enfrentaria uma grande dificuldade para poder extrair renda dessas terras, uma vez que o traçado ortogonal da planta de parcelamento do Sítio Diogo (Figura 22), não representava o relevo acidentado do terreno que deveria ser superado enquanto barreira. Para tanto, seria necessário o investimento de grandes somas de capital, mas o proprietário contou com a ajuda do Estado para isso. A inserção de conjuntos habitacionais de interesse social sobre as dunas do Mucuripe, para reassentamento de famílias já expropriadas de outros locais, assim como a construção do conjunto Cidade 2000, construção e prolongamento da Av. Santos Dumont, foram de extrema importância para superar a natureza-barreira.

A Planta de parcelamento do Sítio Diogo (Figura 22), com loteamentos aprovados/registrados na base de dados do município entre as décadas de 1940 e 1960. De lá para cá, a naturezabarreira foi superada a partir de processos que implicaram a expropriação de populações que praticavam usos não mercantis dessas terras, como o objetivo de subsistência. Implicou também alterações profundas na paisagem, assim a natureza-barreira foi suplantando a terranatureza, fazendo com que hoje, em grande parte dos terrenos, já não se reconheça mais os elementos naturais que antes tinham valor de uso de subsistência e marcavam a paisagem (Figura 23, Figura 24 e Figura 25).

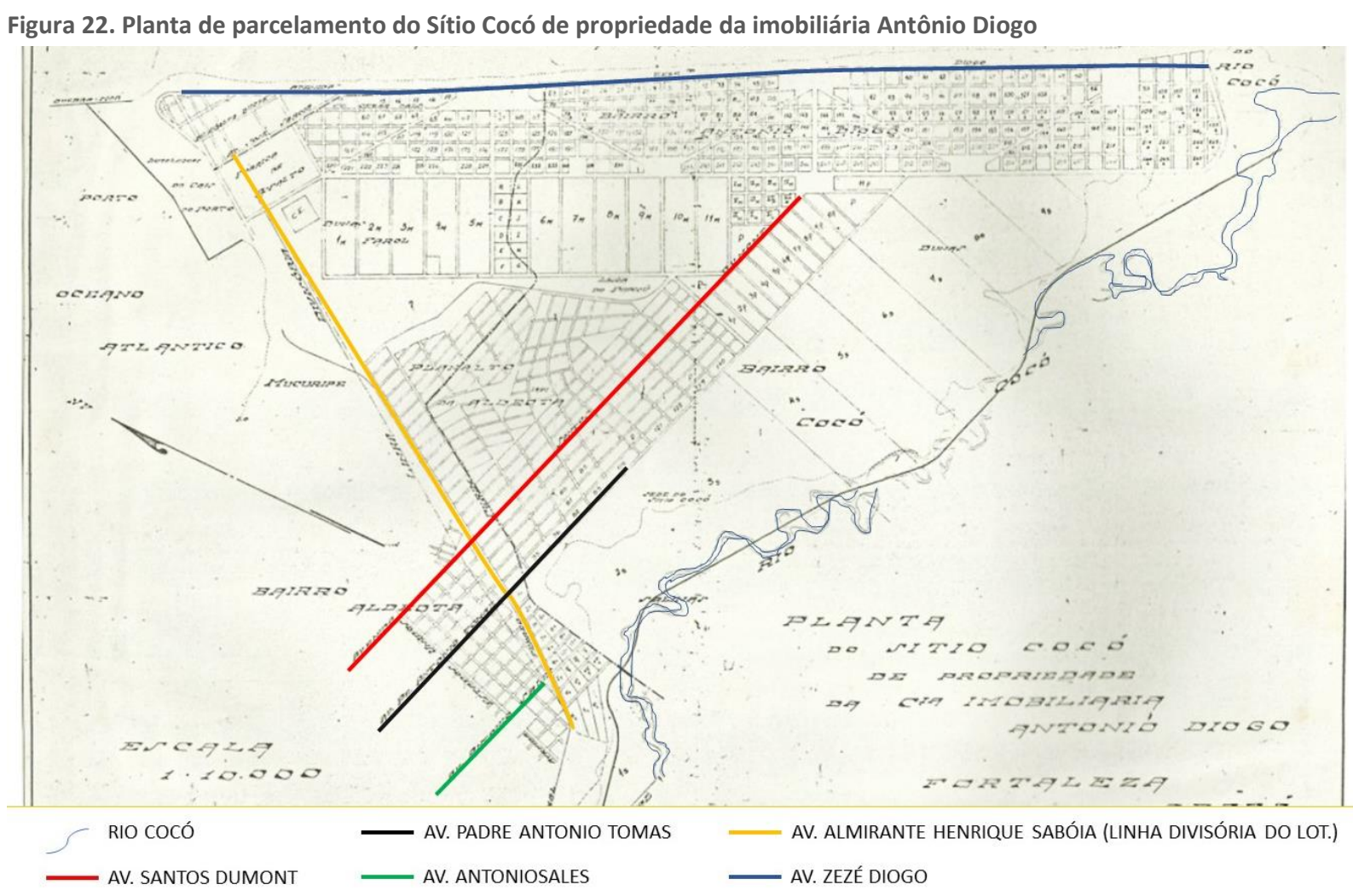




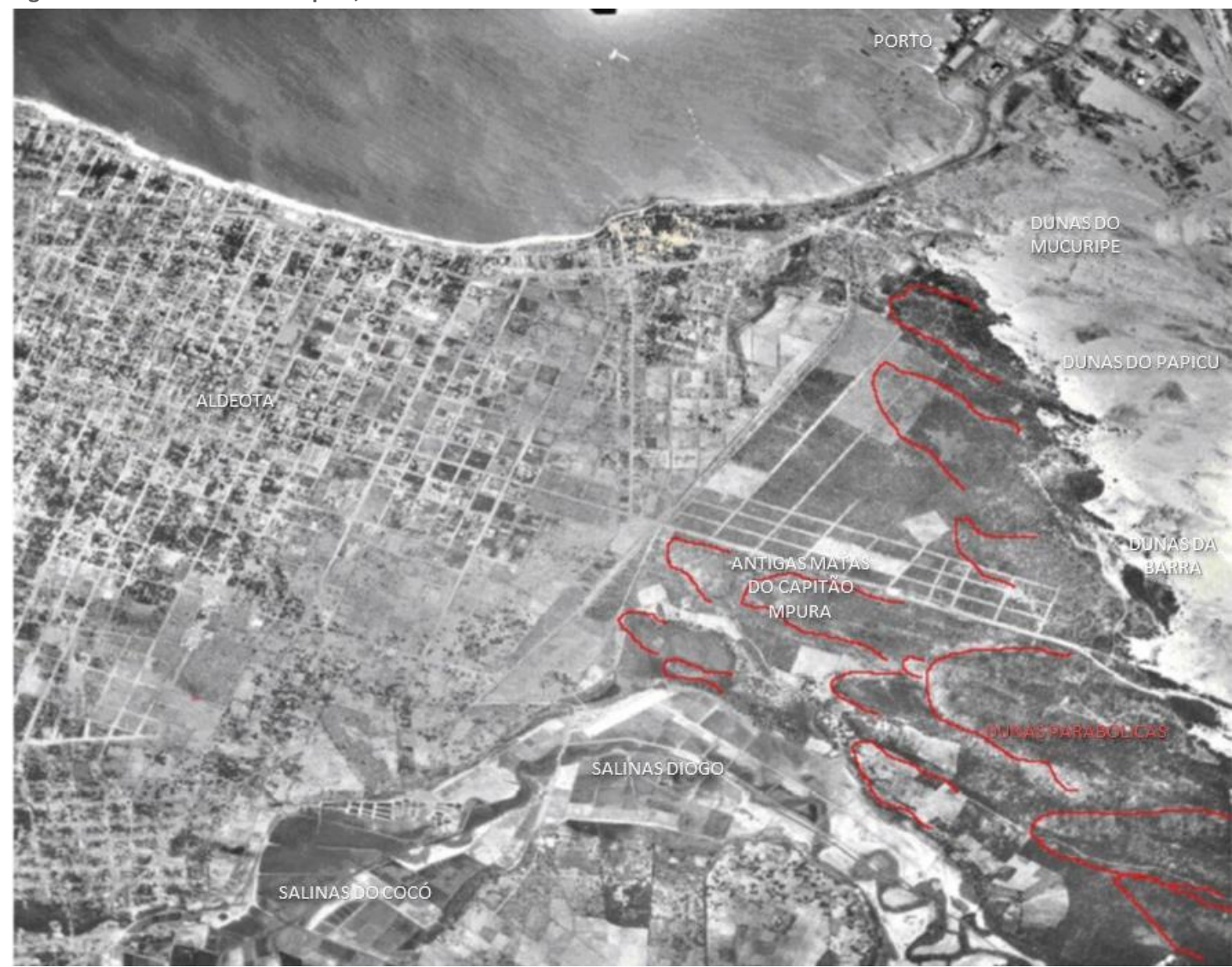

Fonte: SALES (2010, p. 452), adaptado por Rosa (2018). Em vermelho Sales destaca o campo de dunas parabólicas 'hairpin'. 
Figura 24. Dunas do Mucuripe e do Papicu - 1981.

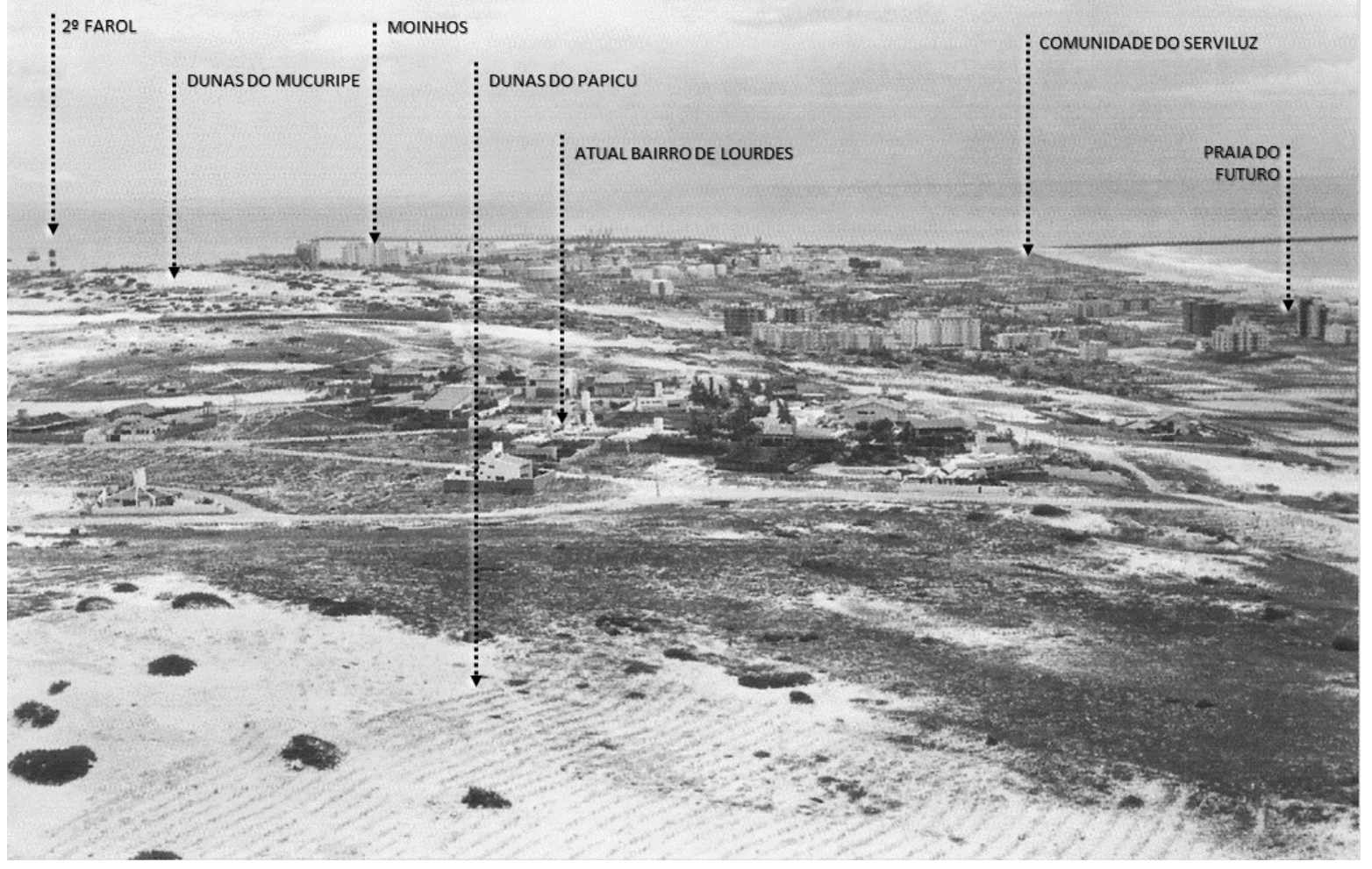

Foto: Primeiros Registros de urbanização da zona leste de Fortaleza (foto de Gentil Barreira - livro Fortaleza Viva). Fonte: http://www.fortalezaemfotos.com.br/2013/02/da-salina-diogo-ao-parque-do-coco.html. Sistematização: sara v rosa, 2018.

Figura 25. Dunas do Mucuripe e do Papicu - 2018.

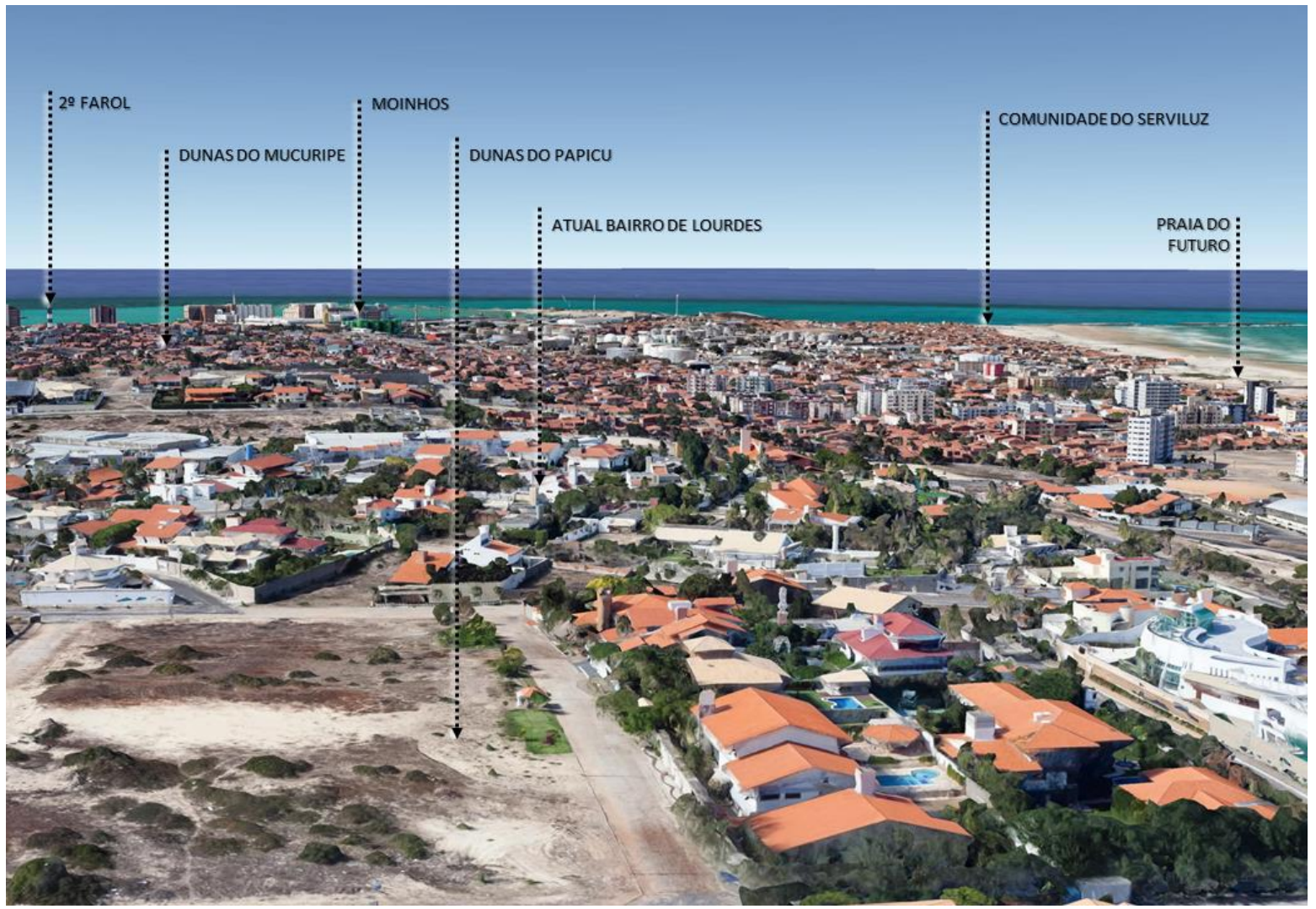

Foto: GoogleEarth 3D, 2018. Sistematização: sara v rosa, 2018. 


\section{Shopping Iguatemi e córrego Água Fria (atual bairro Edson Queiroz)}

O Shopping Iguatemi está localizado na planície litorânea-flúvio-marinha do estuário do Rio Cocó, no atual bairro Edson Queiroz. Apesar de já bastante modificado na década de 1940 devido à extração de sal pelas Salinas do Cocó, Salinas Velha e Salinas do Dendê, até 1945, segundo o levantamento do Exército, o terreno de implantação do shopping se encontrava bastante preservado. Ainda era possível verificar a presença sinuosa do Rio cocó (mais tarde retificado) e de uma grande área alagável, cercados em parte por vegetação e manque, e por vegetação de dunas fixas (Matas do Capitão Moura) ao norte, como pode ser observado na Figura 26 e Figura 28.

Figura 26. Salinas do Cocó e Shopping Iguatemi.

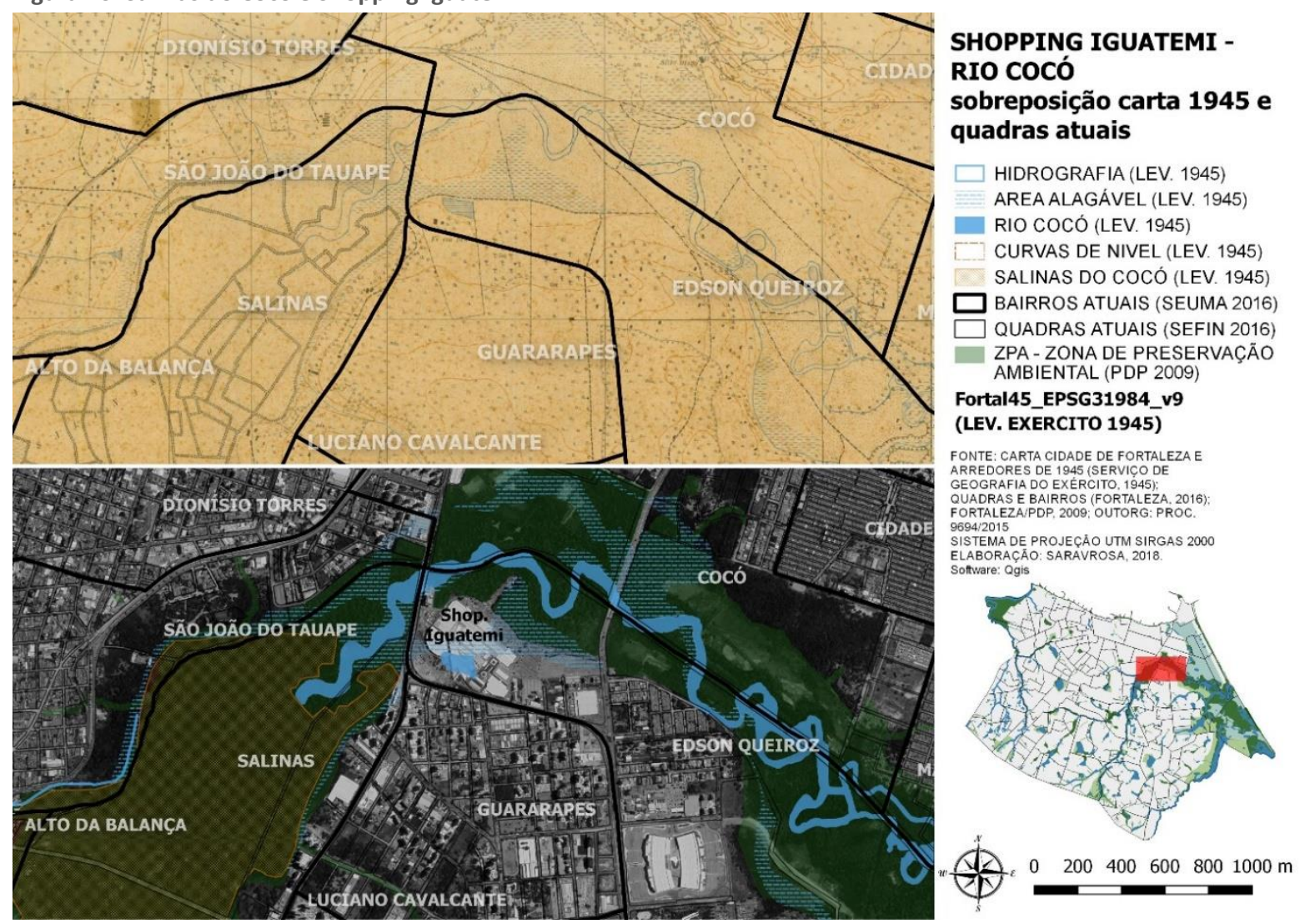

Elaboração: Sara V. Rosa, 2018 a partir de levantamento do Serviço de Geografia do Exército (Carta de Fortaleza e Arredores de 1945);

Posteriormente, esse trecho do rio também passa a ser apropriado para a extração de renda a partir da exploração do sal. As salinas aí implantadas recebem o nome de Salinas Diogo $^{71}$ e aparecem em imagens aéreas do final da década de 1950 (Figura 23), levando a crer que as

\footnotetext{
${ }^{71}$ Não foi encontrada data exata de início das atividades na Salinas Diogo. Relatos no site Fortaleza em Fotos mencionam que na década de 1960 a área já era ocupada pela Salinas. De fato, a Salinas em quentão já aparece em ortofoto de 1958, levando a crer que a instalação desta se deu na década de 1950.
} 
atividades aí se iniciaram nesta década. O nome Diogo vem do antigo proprietário de terras dessa área, senhor Antônio Diogo de Siqueira, que possuía o Sítio Diogo, com edificação identificada na Carta de Fortaleza de 1945, localizado entre o Rio Cocó e as Matas do Capitão Moura (Figura 12) e na foto aérea de 1958 (Figura 13), onde ainda era possível, apesar das interrupções das áreas de salinas, verificar a sinuosidade do rio. Nas ortofotos de 1972, já se observa a alteração do leito do rio, bem como nas imagens aéreas do Google Earth, onde permanece tal alteração.

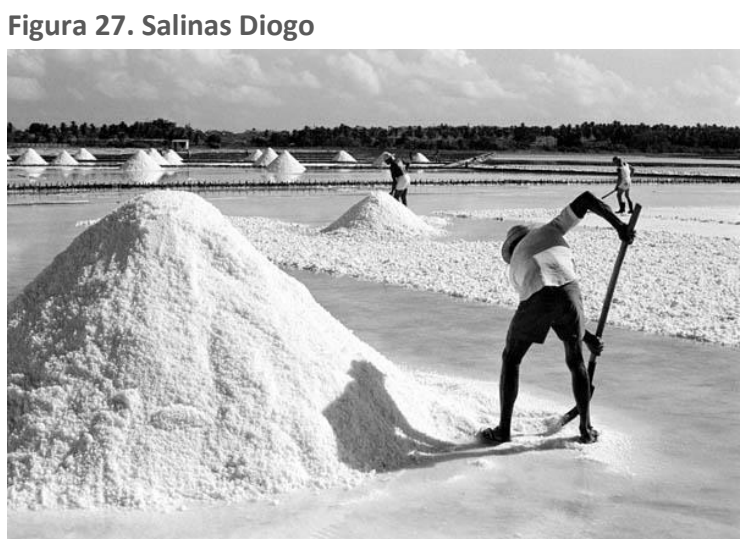

Foto de Elian Machado. Fonte: http://www.fortalezaemfotos.com.br/2013/02/da-salina-diogo-ao-parque-do-coco.html

A atividade das salinas começa a entrar em declínio no final da década de 1970. Segundo relatos disponíveis no site Fortaleza em Fotos ${ }^{72}$, a Salinas Diogo encerra suas atividades por completo em 1980. Em fotos da segunda metade da década, já é possível observar parte do terreno das Antigas Salinas do Cocó (bairro Salinas) preenchida por vegetação de manguezal (Figura 29). Com o declínio da produção de sal, parte do mangue do estuário do Rio Cocó voltou a se regenerar e as áreas anteriormente ocupadas pelas salinas foram dando lugar à vegetação de mangue, que se intensificou após 1989, com a criação do Parque Ecológico do $\operatorname{Cocó}^{73}$ (SEMA, sd).

A inauguração do Shopping Iguatemi, pertencente ao grupo Jereissati ${ }^{74}$, deu-se em 1982, após o declínio da atividade salineira em área anteriormente ocupada por parte da Salinas Diogo.

\footnotetext{
72 http://www.fortalezaemfotos.com.br/2013/02/da-salina-diogo-ao-parque-do-coco.html.

73 DECRETO № 20.253, de 05 de setembro de 1989 e DECRETO N²2.587, 08 de junho de 1993.

74 "A Jereissati Participações S.A. ("Companhia" ou "Grupo Jereissati”) é uma companhia aberta, registrada na CVM sob o n.으 00867-2 e com ações negociadas na BM\&FBOVESPA, cujas principais receitas advêm de participações societárias no capital de outras sociedades e da prestação de serviços de assessoria e consultoria econômica, financeira e tributária.

O Grupo Jereissati, cujas origens remontam ao início do século no Estado do Ceará, com atividades no comércio têxtil, diversificou seus interesses através da criação da Companhia Imobiliária Jereissati em 12 de março de 1946 e da compra da Metalúrgica La Fonte, em 19 de setembro de 1960. A partir de então, o Grupo Jereissati expandiu sua participação em outros setores da economia, sendo hoje um dos maiores grupos privados do país, com expressiva participação no setor de shopping centers e participação no setor de telecomunicações e Contact Center e Serviços.
} 
Todavia, segundo Soares (2005), a área do Shopping Iguatemi, apesar de ser uma antiga salina, já se encontrava parcialmente coberta por mangue na data de sua implantação. Como podemos observar em foto da década de 1980 (Figura 29), a margem sul, onde está localizado o Shopping, já se apresentava bastante recuperada em comparação com outras áreas das Salinas Diogo. Mesmo que não estivesse recuperada, como pode ser observada na Figura 26, representa área originalmente de inundação do Cocó, sendo importante para a conservação de seu ecossistema de estuário.

Figura 28. Trecho do Rio Coco mostrando a retificação de seu leito - 1972

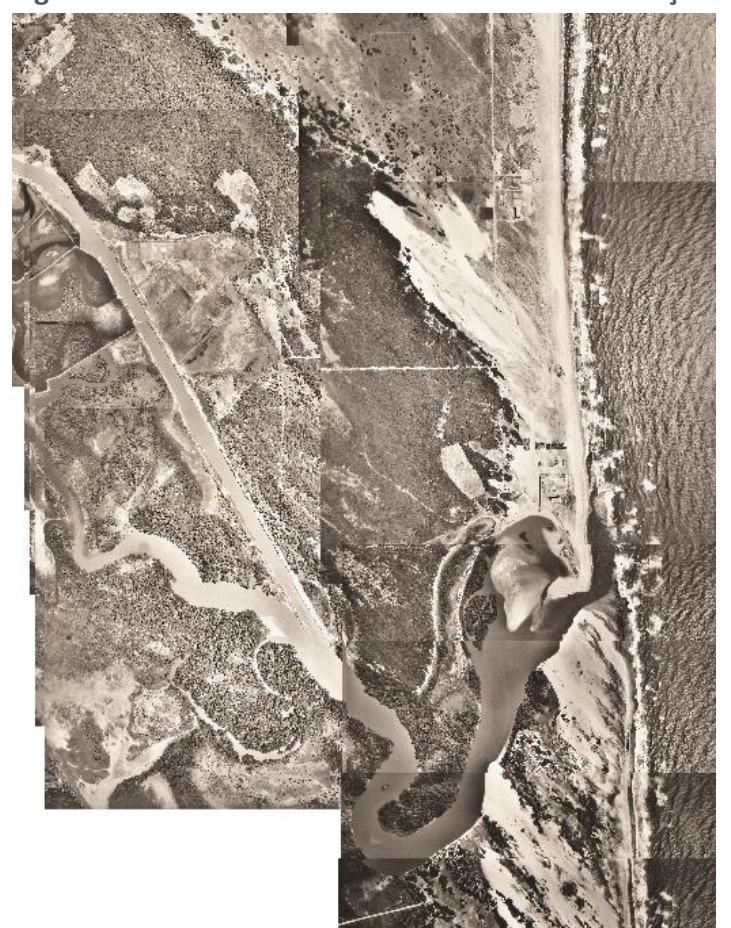

Fonte: Ortofoto de Fortaleza de 1972

Assim, com o exemplo das Salinas e do Iguatemi, podemos observar um processo de acumulação primitiva por meio de espoliação da natureza, a qual é utilizada por seu proprietário (na época, família Diogo) para a obtenção de renda de extração por meio da atividade de extração de sal que, com o seu declínio, é convertida em renda imobiliária, com a venda do terreno para o Grupo Jereissati, que continua obtendo renda imobiliária com o shopping e atualmente também investe no capital financeiro. 
Figura 29. Foto do Shopping Iguatemi na segunda metade da década de 1980.

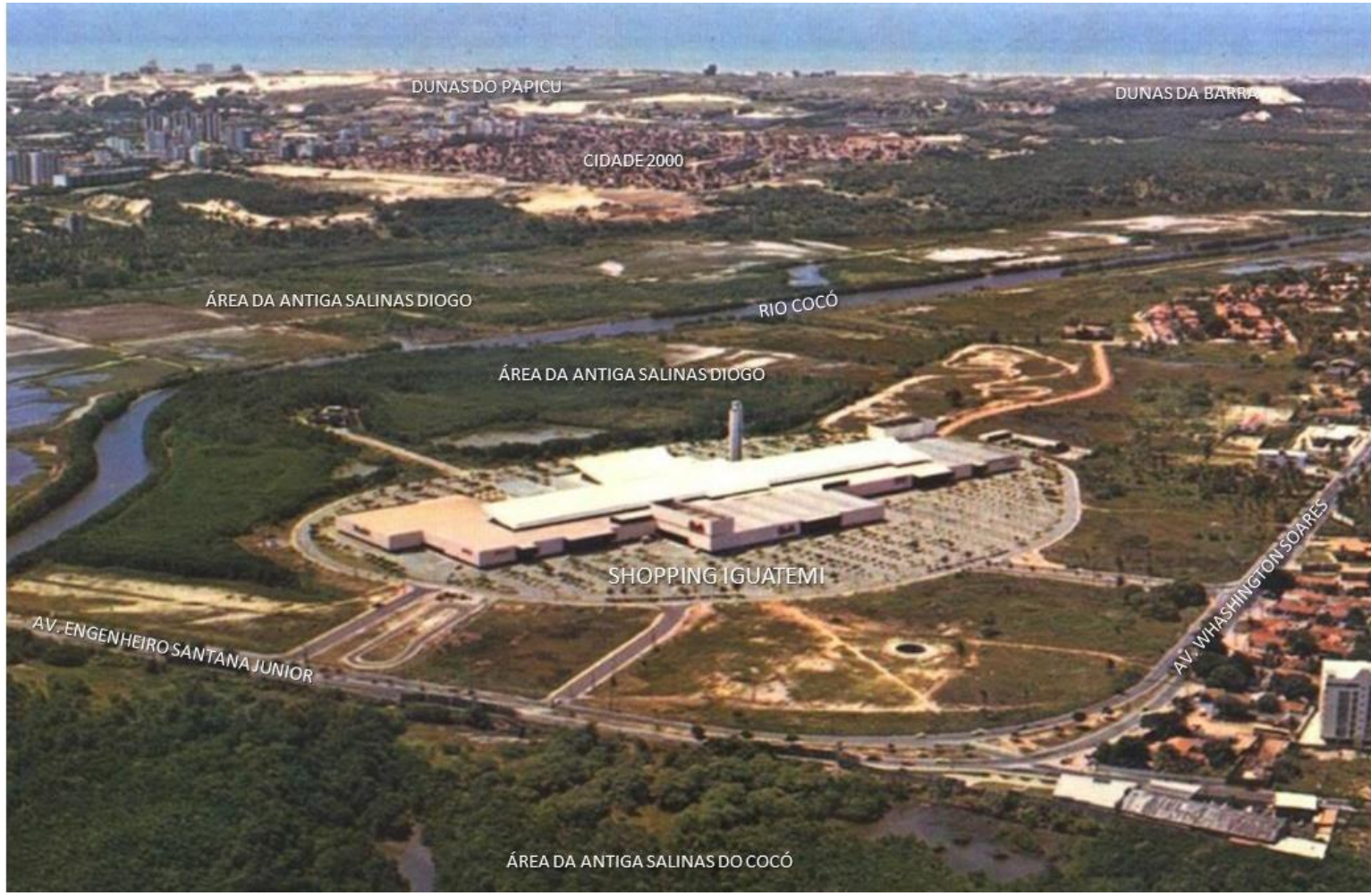

Foto: Arquivo Nirez. Fonte: http://www.fortalezaemfotos.com.br/2013/02/da-salina-diogo-ao-parque-do-coco.html. Adaptada pela autora.

O capital inicial do grupo Jereissati provém do comércio de bacalhau e de tecidos, segundo relatos do próprio grupo em seu site ${ }^{75}$, que depois migra para o setor agrícola e industrial, seguido pelo imobiliário através da criação da Companhia Imobiliária Jereissati, em 12 de março de 1946, fundada por Carlos Jereissati ${ }^{76}$, mesma década em que a nova empresa registra loteamento na Aldeota (Quadro 1 e Figura 31). Além deste loteamento no nome da Imobiliária, na base de loteamentos da Prefeitura Municipal de Fortaleza (PMF) são registrados outros três loteamentos no nome de Francisco Jereissati ${ }^{77}$, são estes: Santa Cecília (sítio), Sabiaguaba (Parque Entre Rios), Nova Aldeota (planalto), localizados respectivamente nos bairros Siqueira, Sabiaguaba e Papicu (Figura 30). O loteamento Sabiaguaba, que aparece

\footnotetext{
75 http://www.jereissati.com.br/

${ }^{76}$ Carlos Jereissati (1917-1963) era filho de imigrante libanês que se estabeleceu em Fortaleza em 1908, acumulando fortuna no comércio de bacalhau e de tecidos. Com o falecimento do pai, "assumiu a chefia de sua firma comercial, mudando o nome para Carlos Jereissati \& Cia., e ampliou as atividades para novos setores, industriais, agrícolas e imobiliários, o que lhe permitiu acumular uma das maiores fortunas particulares do Ceará. Estendeu a atuação da empresa a outros estados, principalmente São Paulo, atingindo projeção nacional nos negócios de metalurgia, hotéis e shopping centers. A partir de 1950, dominou o comércio de linho estrangeiro no Nordeste". Exerceu também carreira política, assim como seu filho Tasso Jereissati. Foi deputado federal pelo Ceará por dois mandatos consecutivos, de 1955 a 1962, pelo PTB, deixou a Câmaras dos Deputados em 1962 para assumir como Senador pelo Estado, vindo a falecer no ano seguinte, em 1963. (https://pt.wikipedia.org/wiki/Carlos_Jereissati).

77 Atribuímos que Francisco Jereissati, seja o Carlos Francisco Ribeiro Jereissati, nascido em Fortaleza em 1946, um dos seis filhos de Carlos Jereissati, empresário e dono da Jereissati Participações S.A e da empresa alimentícia do Grande Moinhos Cearense S.A.
} 
na base de dados da prefeitura sem data e pertencente a Francisco Jereissati, tem planta de loteamento registrada em Aquiraz, pertencente a Paulo Roberto de Carvalho, com data de aprovação de 1975. Foi realizada uma pesquisa de matrícula de terreno pertencente a este loteamento e o nome do proprietário encontrado bate com Paulo Roberto de Carvalho ${ }^{78}$.

Apesar de inaugurado em 1982, o terreno do Iguatemi aparece registrado na base da Prefeitura apenas no ano 1990, no nome de Tasso Jereissati, então governador do Estado na época ${ }^{79}$.

Hoje, a empresa responsável pela administração do Shopping é a Iguatemi Empresa de Shopping Centers S.A (CNPJ 51.218.147/0001-93), do grupo Jereissati Participações S.A (CNPJ 60.543.816/0001-93), ambas empresas de capital aberto (Sociedade Anônima Aberta). A primeira, com CNPJ aberto em 07/06/1979, possui um capital social declarado na faixa de R\$ 1.261.727.567, $12^{80}$ (um bilhão, duzentos e sessenta e um milhões, setecentos e vinte e sete mil e quinhentos e sessenta e sete reais e doze centavos). A Jereissati Participações S.A., com CNPJ aberto em 21/07/1966, possui um capital social declarado de $\mathrm{R} \$ 741.986 .608,51^{81}$ (setecentos e quarenta e um milhões e novecentos e oitenta e seis mil, seiscentos e oito reais e cinquenta e um centavos), e firmou parceria com o Fundo Vinci Shopping Center FII que, segundo matéria do O POVO, adquiriu, em 2018, 15\% de participação no Shopping Center Iguatemi Fortaleza por R\$ 185 milhões. “O Iguatemi Fortaleza é agora o $9^{\circ}$ imóvel no portfólio do Vinci Shopping Centers FII, que passa a ser o maior fundo imobiliário do segmento de shopping da B3 (antiga Bovespa) em número de propriedades" ( POVO, 2018) ${ }^{82}$.

Quadro 1. Loteamentos pertencentes à família Jereissati registrados na base da Prefeitura

\begin{tabular}{llcl}
\hline LOTEAMENTO/TERRENOS & BAIRRO & ANO & PROPRIETARIO \\
\hline Santa Cecília (Sítio) & Siqueira & Sem informação & Francisco Jereissati \\
Grande Cocó (Shop. Center Iguatemi) & Edson Queiroz & 1990 & Tasso Jereissati
\end{tabular}

\footnotetext{
${ }^{78}$ Aqui ficou incerto se houve erro da base de dados do município de Fortaleza, ou se este está registrado inicialmente apenas como terreno e depois desaparece nos históricos da matrícula pesquisada, ou ainda se foi registrado duas vezes. Como adiantado anteriormente, a base de loteamentos da PMF é incompleta e pode conter imprecisões. Até o final desta tese não foi possível ter certeza do que de fato ocorreu.

79 Tasso “governou o estado do Ceará em três gestões: 1987-1990, 1995-1998 e 1999-2002. Em 2002, foi eleito para seu primeiro mandato parlamentar como Senador pelo Estado do Ceará, no período de 2003 a 2011. Em 2014, foi novamente eleito e, atualmente, ocupa o $2^{\circ}$ mandato como Senador da República. Em 2017, foi eleito Presidente da Comissão de Assuntos Econômicos (CAE) e passou a integrar, como titular, o Grupo Parlamentar Brasil-Argentina, e como suplente, as Comissões de Desenvolvimento Regional e Turismo (CDR), Mista Permanente sobre Mudanças Climáticas (CMMC) e de Relações Exteriores e Defesa Nacional (CRE)". (fonte: https://www.senadortasso.com.br/perfil/).

${ }^{80}$ Segundo pesquisa do Cadastro Nacional da Pessoa Jurídica realizada no site da Receita em 18/12/2018.

81 Segundo pesquisa do Cadastro Nacional da Pessoa Jurídica realizada no site da Receita em 24/09/2018.

82 https://www.opovo.com.br/jornal/dom/2018/09/fundo-compra-15-do-shopping-iguatemi-fortaleza.html
} 


\begin{tabular}{|c|c|c|c|}
\hline Imobiliária Jereissati S.A. & Aldeota & 1949 & Imobiliária Jeressaiti SA \\
\hline Sabiaguaba ${ }^{83}$ & Sabiaguaba & $1975^{*}$ & Francisco Jereissati \\
\hline Nova Aldeota (Planalto) & Papicu & Sem informação & Francisco Jereissati \\
\hline $\begin{array}{l}\text { Sana Lúcia (Desmembramento das } \\
\text { Quadras) }\end{array}$ & Granja Portugal & Sem informação & Samir Jereissati \\
\hline
\end{tabular}

Fonte: Base de Loteamentos da PMF. Sistematização e atualização Sara V Rosa (2018). *O Loteamento Sabiaguaba, que aparece na base de dados da prefeitura sem data e pertencente a Francisco Jereissati, tem planta de loteamento registrada em Aquiraz pertencente a Paulo Roberto de Carvalho, com data de aprovação de 1975.

Figura 30. Loteamentos aprovados pertencente a membros da família Jereissati segundo base da PMF

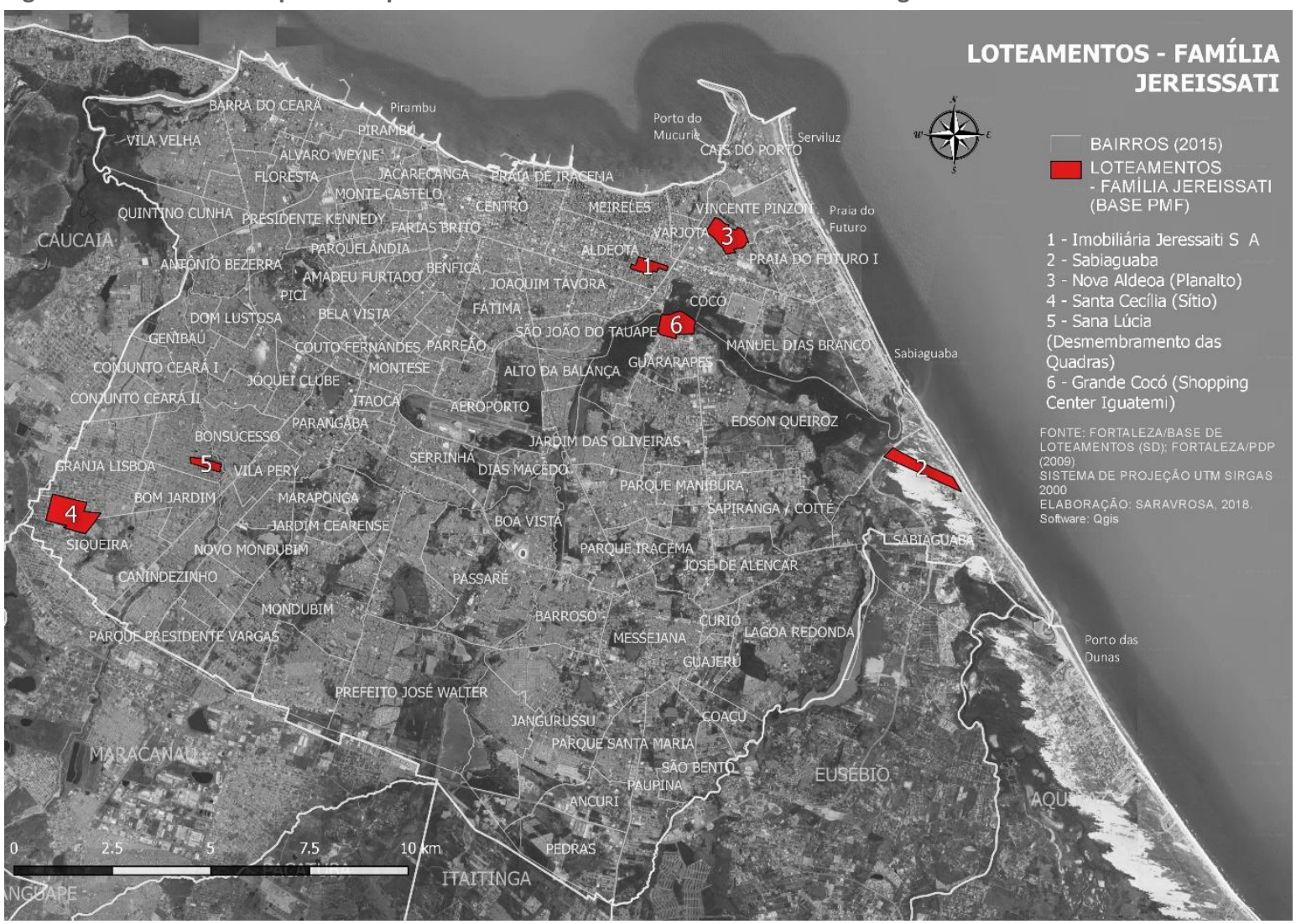

Elaboração: Sara V Rosa (2018). Fonte: Base de Loteamentos da Prefeitura Municipal de Fortaleza (sd). Imagem: GoogleEarth.

A valorização obtida com a construção do shopping, associada à valorização com a construção de importantes vias de acesso ao setor sudeste da cidade, cruzando o Rio Cocó, foi capitalizada pelos proprietários dos terrenos do entorno, viabilizando a implantação de loteamentos aprovados entre as décadas de 1940 e 1990, e a consolidação de bairros concentradores de população de classe média e média alta, que incluem quadras do final do bairro Aldeota e os atuais bairros Papicu, Cocó, Guararapes, Luciano Cavalcante, Edson Queiroz.

\footnotetext{
83 Mesmo terreno hoje configura-se como loteamento Parque Entre Rios, com planta de loteamento aprovada no município de Aquiraz em 1975, com proprietário identificado como Paulo Roberto de Carvalho, atual dono, segundo pesquisa cartorial. Ainda segundo pesquisa cartorial, o imóvel encontra-se em processo de venda para Fortaleza da Espanha Empreendimentos Imobiliários LTDA.
} 
Só no entorno do Shopping, segundo a base de loteamentos da Prefeitura, podemos destacar os seguintes:

Os primeiros loteamentos próximos ao Shopping Iguatemi, registrados na base de loteamentos da PMF, datam da década de 1940 e estão localizados no final do bairro Aldeota (antigo Outeiro) e do bairro Dionísio Torres, ambos atualmente ocupados por famílias de classe média. O primeiro ficou tão marcado como a nova área para onde os ricos saídos da Jacarecanga, Benfica e Centro estavam indo morar que seu nome foi atribuído a vários outros loteamentos por toda a expansão leste da cidade, como veremos adiante, a partir da identificação destes.

Na Aldeota, podemos citar: o Raimundo Oliveira Filho (Terreno) - proprietário Raimundo Oliveira Filho - ano 1948; o Imobiliária Jereissati S.A. - proprietário Imobiliária Jereissati S.A. - ano 1949; o Centro Aldeota - proprietário Patriolino Ribeiro de Souza - ano 1945. No Dionísio Torres: o Quitandinha (Parque), com mais da metade deste localizada no bairro vizinho, atual Joaquim Távora - proprietário Empresa de Terrenos Ltda - ano 1947; o Estância Castelo - proprietário Geórgia Castro Mota Torres - ano 1946.

Ao longo da Av. Washington Soares, a base de dados não traz registro dessa década. Somente mais perto de Messejana é que vão ser registrados outros loteamentos nessa área, como o José de Alencar (Parque) - proprietário Soc. Fomento Agro-Indusrial Ltda - ano 1949.

As décadas de 1950 e 1980 vão ser os períodos com maior concentração de loteamentos no entorno do Iguatemi e ao longo da Av. Washington Soares. Na primeira, vão ser registrados loteamentos em quase todos os bairros cortados pela av. Washington Soares. No Guararapes foi registrado o Encantado (Jardim) - proprietários José Monteiro Filho e Hiran dos Santos Monteiro - ano 1955; no Luciano Cavalcante, o Buenos Aires (Vila) - proprietários Raimundo Porvário de Lima - ano 1952, o Montevidéu (Parque) - proprietários Arruda Mota \& Cia - ano 1952, e, com grande parte no bairro Salinas, o São Luís (sítio) - proprietário Luiz de Mendes da Silva - ano 1958. No parque Manibura, o Ouro Branco (Parque) proprietário Patriolino Ribeiro de Souza - ano 1958; no bairro Sapiranga, tomando quase toda a dimensão atual do bairro, o Água Fria (Parque) - proprietários Péricles Moreira da Rocha e João Gentil Jr. - ano 1957. Há ainda registros de loteamento desta década nos atuais bairros Curió, Lagoa Redonda, Guajerú, Messejana, Paupina, e Parque Santa Maria. 
Na década de 1960, acima do Rio Cocó, temos o loteamento já apresentado no ponto anterior, Moderna Aldeota (Retif. dos terrenos de prop. Imob. A. Diogo) - proprietário Imobiliária Antônio Diogo - ano 1964. Descendo em direção a Av. Washington Soares, o Bernardo Bichucher (Terreno) - Bernardo Bichucher - ano 1960; e o Jardim São Paulo - proprietário Oswaldo Rizzato - ano 1963, ambos localizados no bairro atual Edson Queiroz Abaixo do Vilage Colosso. O Carrapicho (Sítio), localizado em terreno do sítio com a mesma denominação proprietário João Guimarães Duque - ano 1961. É dessa década também o loteamento José de Alencar (Parque) - proprietário Adolfo Campelo Gentil - ano 1963, localizado no antigo bairro Alagadiço Novo, hoje José de Alencar, onde antes era o sítio José de Alencar. Este se sobrepõe com suas quadras e arruamentos sobre parte da Lagoa da Sapiranga ${ }^{84}$, desconsiderando completamente esse corpo hídrico (Figura 33).

Na década de 1970, temos o registro de alguns pequenos desmembramentos, no tamanho de uma quadra, do Loteamento Moderna Aldeota da década anterior, em nome de outros proprietários. Os demais loteamentos desta época estão localizados dispersos mais ao longo da Av. Washington Soares, como o Amaralina (Parque) - proprietário Bernardo Bichucher ano 1976; Dias Branco (Loteamento) - proprietários Delberg Ponce de Leon e Angra R. Carvalho - ano 1975; Manibura (Parque), entre os bairros Luciano Cavalcante e Parque Manibura - proprietário Francisco Carvalho Pereira - ano 1979; No bairro Edson Queiroz, outro loteamento com a denominação de "Aldeota", o Aldeota (Jardim) - proprietário Escr. Tec. Administ. de Imóveis - ano 1970. Ainda nessa época, temos o Água Fria (Parque), localizado no atual bairro Sapiranga - proprietário Bernardo Bichucher - ano 1978; o Jacarey (Sítio) - Proprietário SIMBRA - ano 1970. Hoje a área é conhecida como Sítio Jacarey ou Lago do Jacarey, por conta da presença de um lago com o mesmo nome. Este lago, no Levantamento do Exército de 1945, aparece represado e intitulado como Açude do Jacarei, com uma área pelo menos 9 (nove) vezes maior do que a área que o lago hoje ocupa. Logo acima do Sítio Jacarey está o Jacarey (Parque) - proprietário Eduardo Antunes de Alencar ano 1979.

A década de 1980, década em que o Iguatemi foi inaugurado, é umas das que mais se tem registro com datas de loteamentos no entorno deste equipamento e ao longo da Avenida

\footnotetext{
${ }^{84}$ Maiores detalhes sobre os loteamentos no entorno da Sapiranga podem ser obtidos na tese de SANTOS, 2015.
} 
Washington Soares. Localizados no atual bairro Guararapes, temos o Rogaciano Leite (desmemb.) - proprietário DICOL - ano 1983; o Centro de Convenções (Planalto) proprietários Manuel Dias Branco/Fco. Tavares de Sá Dias Branco - ano 1984. Também é da mesma época o Loteamento Vilage Colosso - cujo proprietário dá o nome atual do bairro onde está inserido, Edson Queiroz - ano 1985 - que até hoje encontra-se completamente desocupado e é conhecido pela população como Sítio Colosso. Ainda nesse bairro, também foram registrados o Cidade Leste, localizado abaixo do Vilage Colosso - proprietário Imob. Vicente de Castro Ltda - ano 1984; e o Nacional (Parque) - proprietário Const. Adm. Imóveis Marajá Ltda - ano 1982. Além de outros que se seguem ao longo do eixo da Avenida Washington Soares, como o Carrapicho (Sítio - desmembramento), logo abaixo da Oliveira Paiva, em terreno do sítio com a mesma denominação - proprietário Oto Brasil de Sá Cavalcante - ano 1980; e também o Alagadiço Novo - proprietário João Gentil Júnior - ano 1981. No bairro Luciano Cavalcante, os Loteamentos Planalto Água Fria - proprietário Sociedade Mair LTDA - ano 1984; e Galiléia (Planalto) - proprietários Josefina Osório e filhos - ano 1985. É no final dessa década também que são registrados o loteamento Jardim das Oliveiras (Vila Verde), que hoje dá nome ao bairro - proprietário não identificado na base ano 1989.

Como mencionado anteriormente, apesar de inaugurado em 1982, o registro do terreno do shopping pela base da Prefeitura é da década de 1990, o Grande Cocó (Shopping Center Iguatemi) - proprietário Tasso Jereissati - ano 1990. Cruzando o Cocó, temos outro grande loteamento o Jardim Fortaleza (Waldir Diogo Ltda) - proprietário Construtora Waldir Diogo ano 1992 - localizado no atual bairro do Cocó, contém parte do terreno do parque do Cocó, onde estão os equipamentos e o terreno da ARIE (Área de Relevante Interesse Ecológico).

Outro grande loteamento desta década é o Tunga (Sítio) (Alpha Village) - proprietário Imobiliária Novo Euzébio - ano 1994. Parte do terreno deste, justamente o localizado no entorno da lagoa, era terreno municipal e hoje é alvo de Operação Urbana Consorciada que está em andamento e será abordada com maiores detalhes no capítulo 02. 
Figura 31. Iguatemi - expansão dos loteamentos por década e seus proprietários

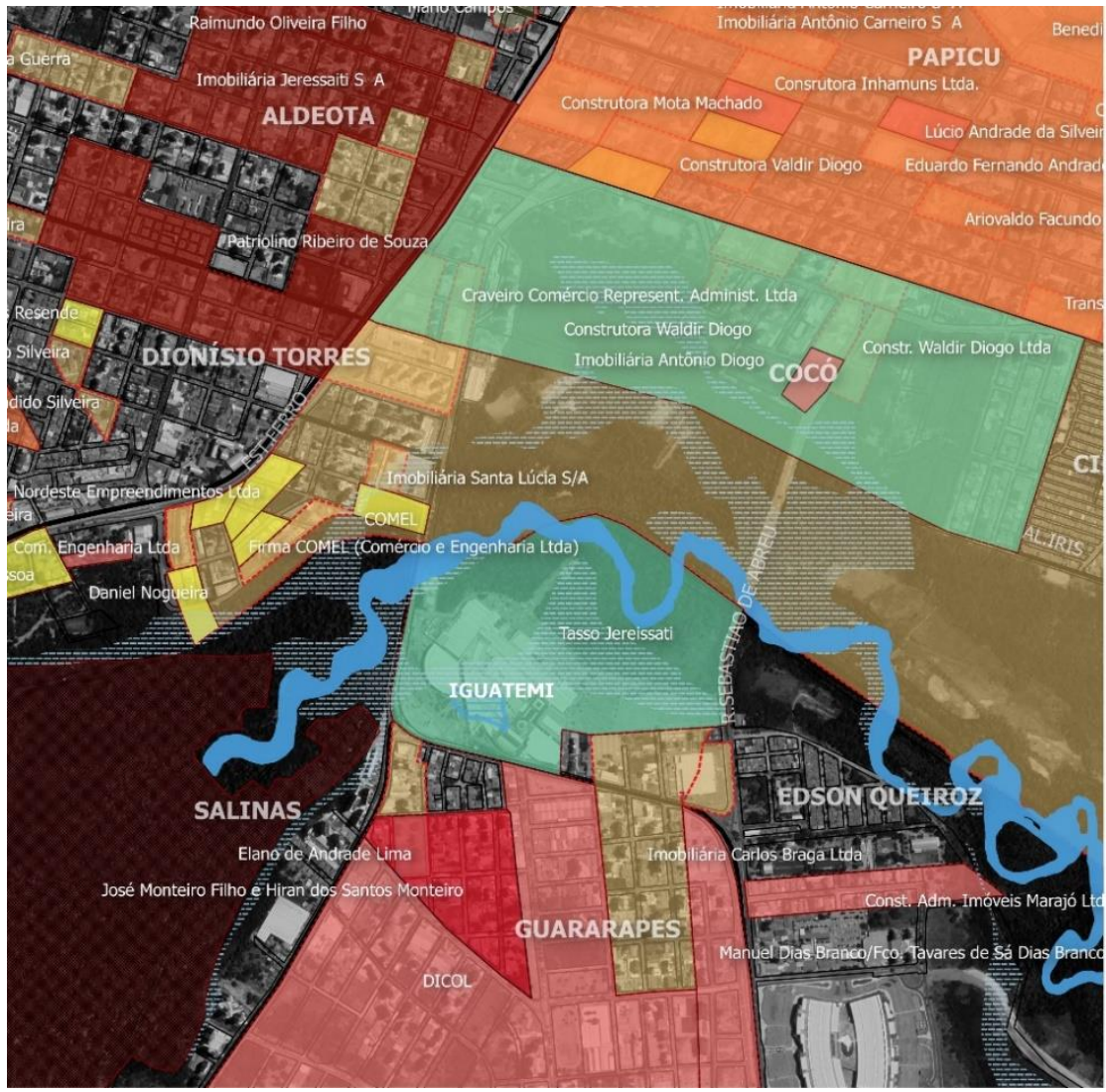

\section{IGUATEMI - RIO COCÓ} hidro 1945, quadras atuais e loteamentos

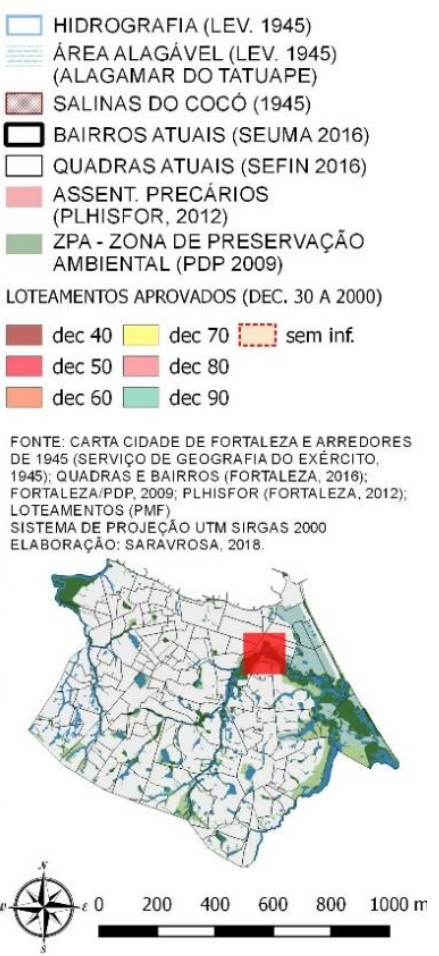

Elaboração Sara V. Rosa (2018). Fonte: Base de Loteamentos da Prefeitura Municipal de Fortaleza.

Figura 32. Loteamentos segundo base da PMF no entorno da Av. Washington Soares.

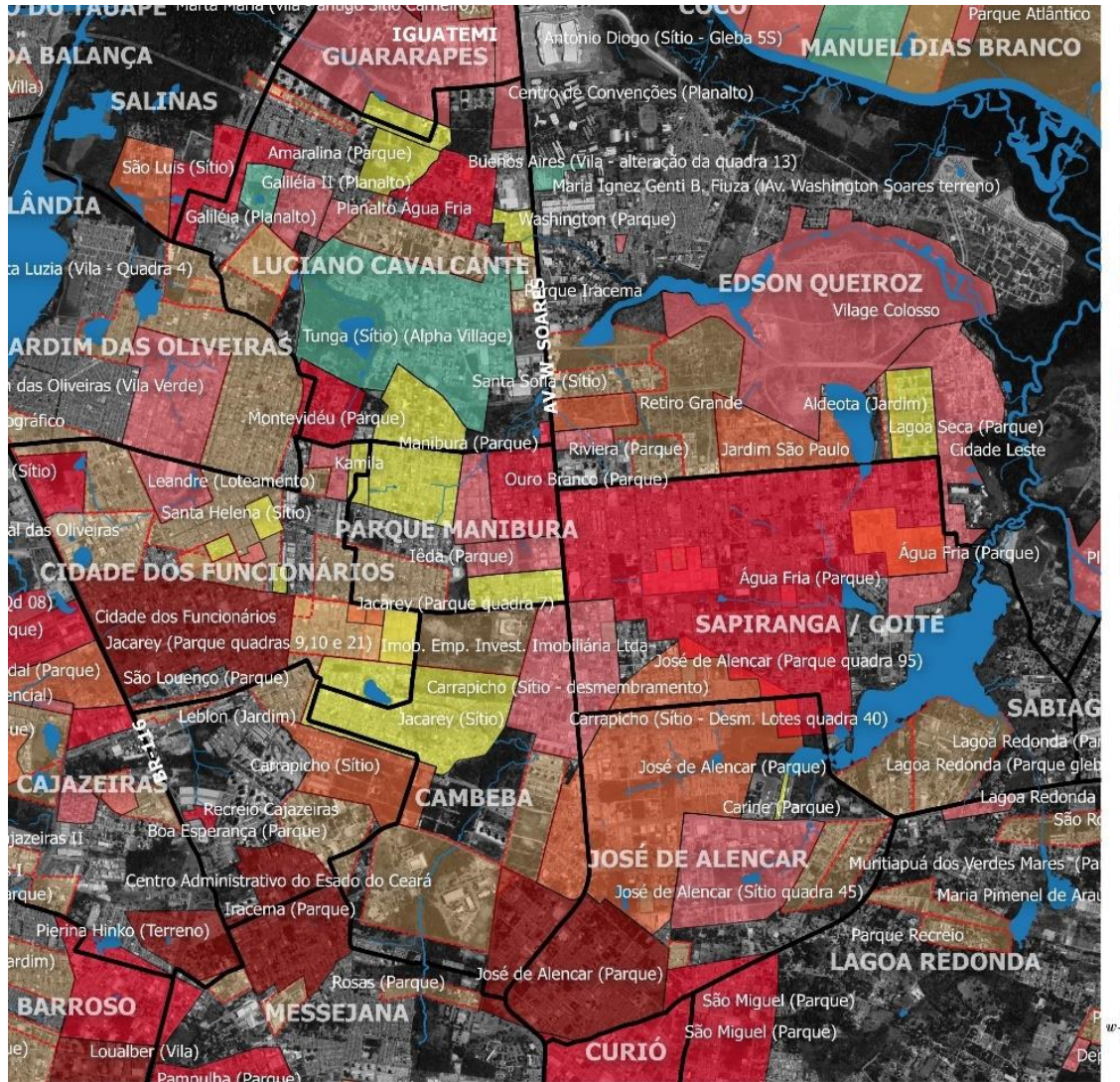

\section{LOTEAMENTOS AO LONGO DA AV. WASHINGTON SOARES}

$\square$ BAIRROS ATUAIS (SEUMA 2016)
$\square$ QUADRAS ATUAIS (SEFIN 2016)
HIDROGRAFIA (LEV. DEC. 2000)
LOTEAMENTOS APROVADOS (DEC. 30 A 2000)
$\operatorname{dec} 40 \square \operatorname{dec} 70$ dec sem inf.
dec $50 \square$ dec 80
dec $60 \square \operatorname{dec} 90$

FONTE: QUADRAS E BAIRROS (FORTALEZA, 2016): LOTEAMENTOS (PMF) SISTEMA DE PROJECAO UTM SIRGAS 2000
ELABORAÇAOO: SARAVROSA. 2018.

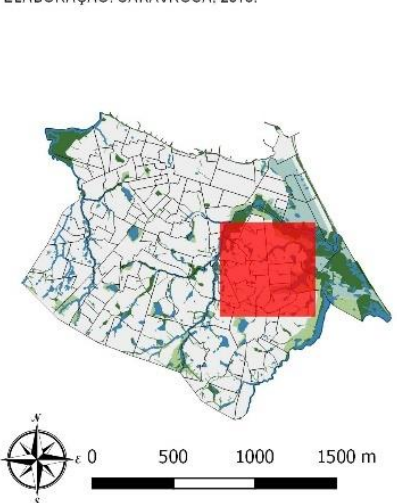

Elaboração Sara V. Rosa (2018). Fonte: Base de Loteamentos da Prefeitura Municipal de Fortaleza. 
Figura 33. Loteamento José de Alencar (parque sobre a Lagoa da Sapiranga)
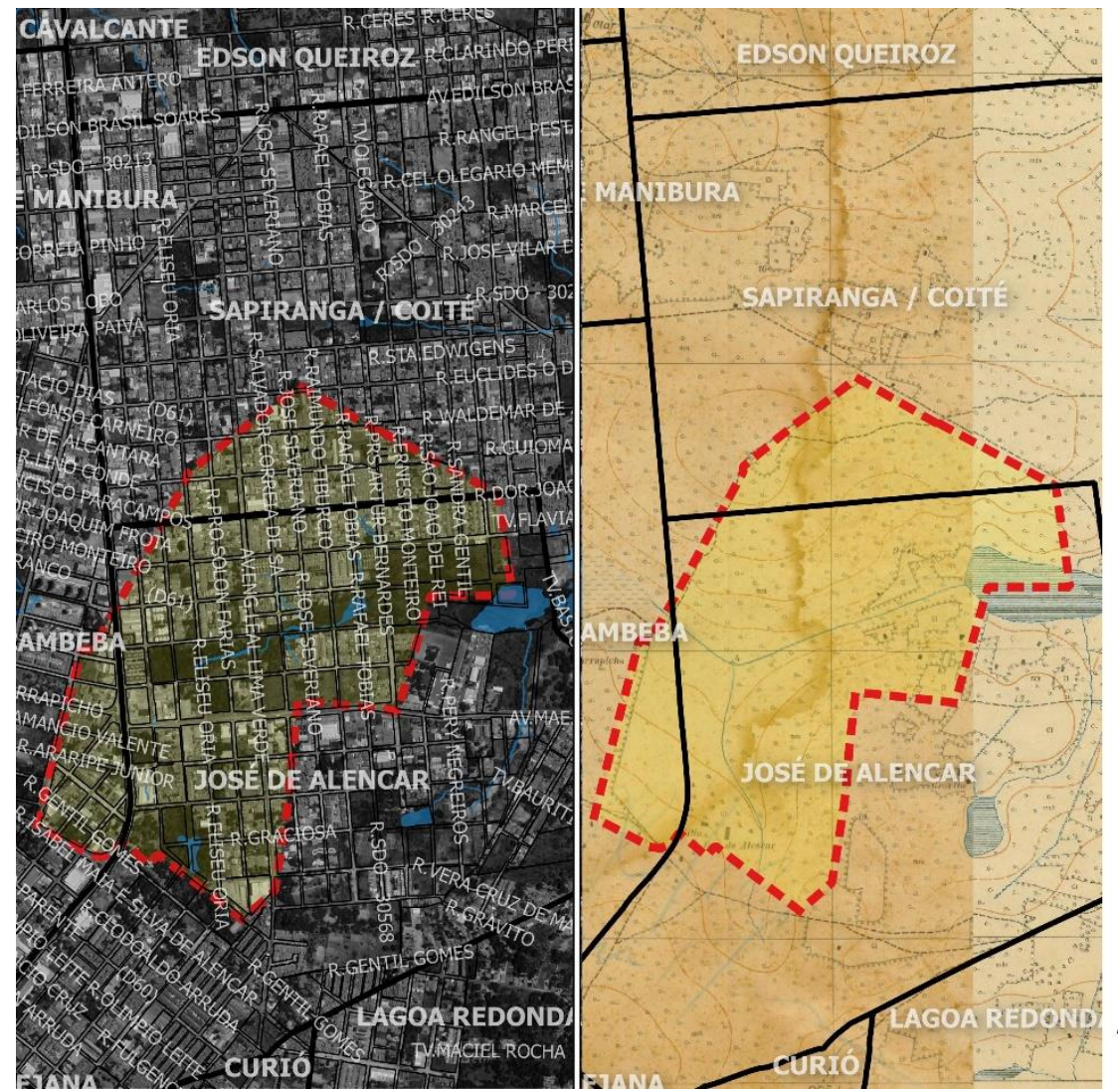

LOTEAMENTO JOSÉ DE ALENCAR (PARQUE) bairros Sapiranga e José de Alencar

= LoteAmENTO JOSÉ - LEALENCAR (PARQUE)

BAIRROS ATUAIS (SEUMA 2016) QUADRAS ATUAIS (SEFIN 2016) HIDROGRAFIA (I FV DFC, 2000)

- HIDROGRAFIA (LEV. 1945)

LAGOAS (LEV. 1945)

ÁREAS ALAGÁVEIS (LEV. 1945)

PROPRIETÁRIO: Adolfo Campelo Gentil

ANO: 1963 EM 1945 AO SÍTIO JOSÉ DE ALENCAR FONTE: CARTA DE FORTALEZA E ARREDOES DE 1045 (SIST. DE GEOGRAFIA DO EXÉRCITO, 1945); QUADRA (F) SISTEMA DE PROJECCAO UTM UIRGAS LOTEAMENTOS 2000 ELABORAÇAOO: SARAVROSA, 2018.

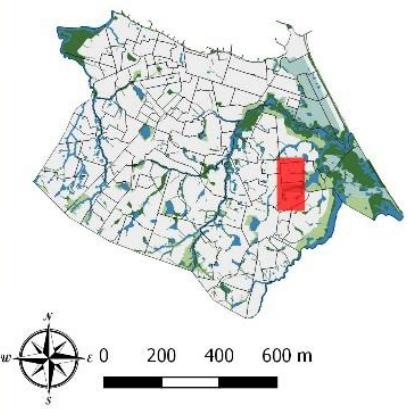

Elaboração: Sara V. Rosa, 2018 a partir de levantamento do Serviço de Geografia do Exército (Carta de Fortaleza e Arredores de 1945); Base de Loteamentos da Prefeitura Municipal de Fortaleza.

\section{Campo de dunas do setor sudeste: Sabiaguaba - o pequeno reduto}

Sabiaguaba é atualmente um bairro de Fortaleza localizado no extremo sudeste do território do município, entre o Rio Cocó e o Rio Pacoti, cuja maior parte se situa na bacia do Cocó e um pequeno pedaço na do Pacoti. É a porção do território do município que ainda se encontra com maior representatividade de seus sistemas ambientais parcialmente preservados, onde ainda é possível observar uma certa conservação de suas características de planície litorânea de faixa costeira, terraço marinho, dunas móveis e dunas fixas, além de abrigar parte da planície flúvio-marinha dos rios Coaçu e Pacoti (Figura 34).

Pela definição administrativa do bairro Sabiaguaba, a planície flúvio-marinha do Rico Cocó fica fora de seus limites, pertencendo ao Bairro Edson Queiroz (antigamente denominado Água Fria). Todavia, neste trabalho, quando falarmos de Sabiaguaba, estaremos fazendo referência ao Território da Sabiaguaba, reconhecido pela população tradicional que habita a região há 
mais de $300 \operatorname{anos}^{85}$, que inclui a parte das planícies flúvio-marinha do Cocó $^{86}$, do Pacoti e do Coaçu, bem como toda a faixa de tabuleiro pré-litonâneo e planície litorânea entre esses três rios. O que corresponderia, mais ou menos, a uma mescla dos limites do bairro com os limites da APA $^{87}$ da Sabiaguaba, definida em 2006 por Decreto Municipal ${ }^{88}$ (Figura 34).

Figura 34. Localização do Bairro Sabiaguaba e identificação de seus sistemas ambientais

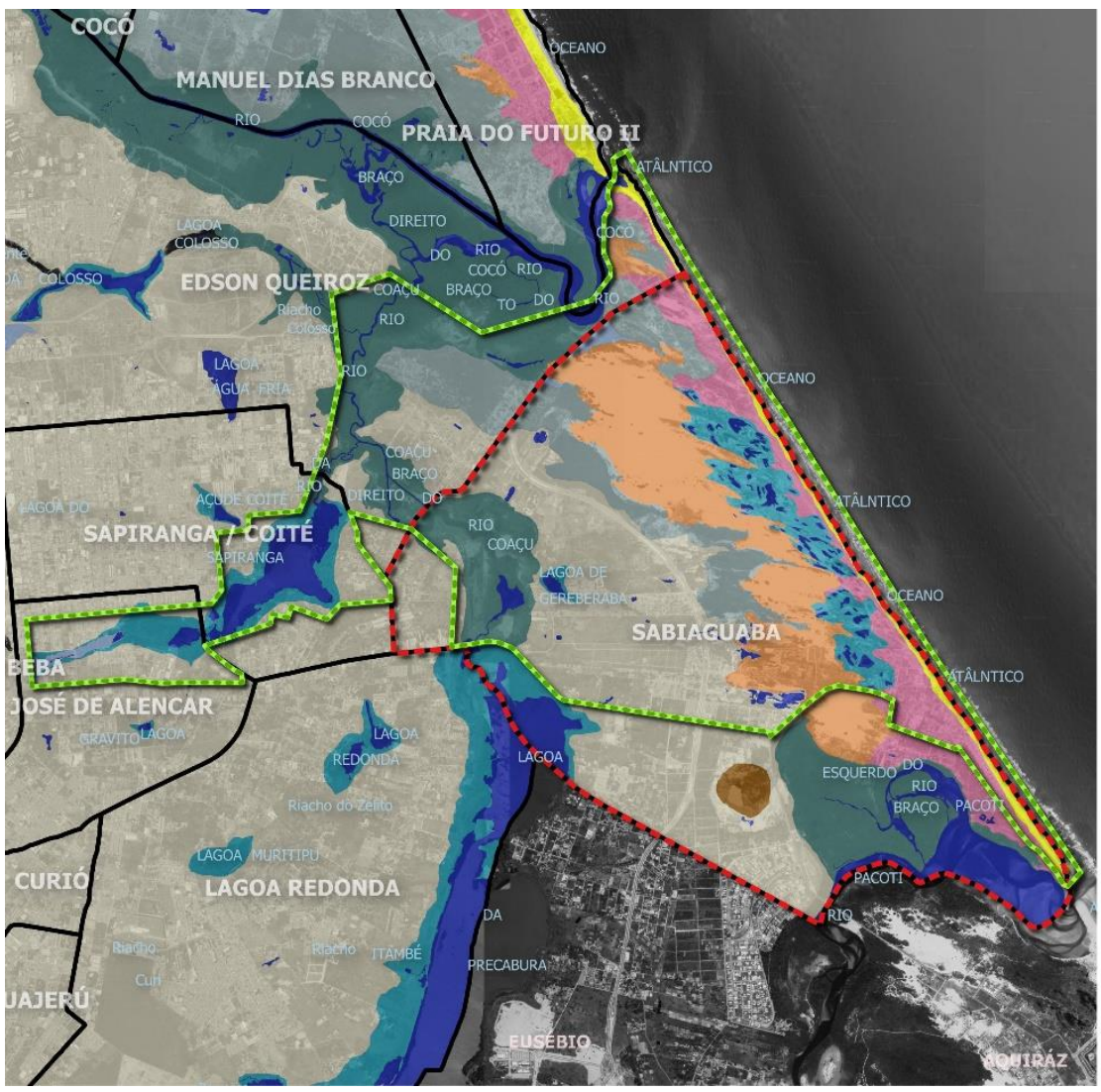

\section{SABIAGUABA SISTEMAS AMBIENTAIS}

BAIRROS ATUAIS (SEUMA 2016)

BAIRRO SABIAGUABA (SEUMA 2016")

APA DA SABIAGUABA

DEC. MUNICIPAL $11.987 / 2006$

sistemasambientais (PMF 2006)

corpo dagua

morros residuais - cristas

plan litoranea - dunas fixas

plan litoranea - dunas móveis

plan litoranea - faixa de praia

plan litoranea - terraco marinho

plan litoranea - fluvio-marinha

tabuleiro - tab pre-litoraneo

vale - area de inund. sazonal

vale - planicie lacustre

FONTE: SIST. AMBIENTAIS (FORTALEZA, 2006) BAIRRO (FORTALEZA, 2016) FORTALEZA:PDP, 2009: IMAG. AEREA (GOOOGLEARTH, 2018) ELABORAÇAO: SARAVROSA, 2018

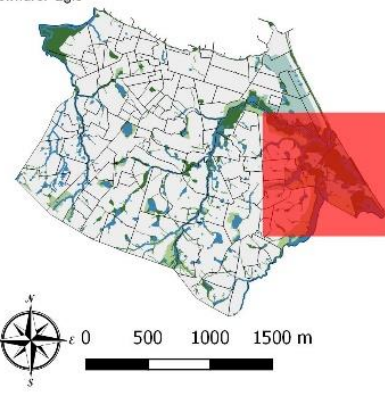

Elaboração: Sara V Rosa (2018). Fonte: FORTALEZA $(2006,2016)$. OBS. O limite de Fortaleza tem sido representado diferente ao longo das diferentes gestões. No trecho referente ao bairro Sabiaguaba, houve um acréscimo, englobando parte da CE020 e as antigas pedreiras representadas no mapa acima como morros residuais - cristais. Nos limites municipais das bases do IBGE de 2010, esse trecho ainda fazia parte do município Eusébio.

Apesar da falta de registros históricos sobre a Sabiaguaba anteriores ao século XX, a equipe que elaborou o Plano de Manejo da APA e do Parque das Dunas da Sabiaguaba ${ }^{89}$, a partir de estudos antropológicos, históricos e arqueológicos, coloca como hipótese que as

\footnotetext{
${ }^{85}$ Estudos antropológicos sobre a região apontam que as famílias que atualmente residem aí são descendentes de indígenas e puderam fazer um levantamento de pelo menos três gerações. Porém, as dunas da Sabiaguaba guardam os sítios arqueológicos mais antigos do Estado.

${ }^{86}$ Muitos moradores ficam surpresos ao descobrirem que o limite do bairro não inclui a foz ou acham que sua correspondência vem com o endereço errado, pois nas contas de água e luz vem o bairro Edson Queiroz para o destinatário. 87 APA: Áreas de Proteção Ambiental. Unidades de Uso Sustentável integrante do Sistema Nacional de Unidades de Conservação (SNUC).

88 Decreto no 11.987 de 20 de fevereiro de 2006

89 Parque Natural Municipal das Dunas de Sabiaguaba - PNMDS (decreto 11.986/2006); Área de Proteção da Sabiaguaba APA da Sabiaguaba (decreto 11.987/2006). Os dois são categorias de Unidades de Conservação definidas pelo SNUC (Sistema Nacional de Unidades de Conservação), Lei Federal n 9985, de 18 de julho de 2000.
} 
comunidades que hoje habitam o território da Sabiaguaba são descendentes de índios da etnia Potiguara (tronco linguístico do Tupi-Guarani), que migraram de aldeamentos da Messejana (antiga Paupina) onde estabelecem relações até hoje ( FORTALEZA, 2010).

Os autores do Plano citado (2010) trazem relatos encontrados em documentações portuguesas e holandesas dos séculos XVII, destacando trajetórias do chefe da etnia Potiguara no Siará-Grande ${ }^{90}$, Amanay, conhecido como Algodão ${ }^{91}$, ao qual atribuem relação com a formação de vários aldeamentos em Fortaleza e atual Região Metropolitana. Em um desses relatos, eles destacam uma passagem que contribui com a hipótese de que o território da Sabiaguaba era utilizado por seu povo.

Os potiguaras que descendem de Amanay passaram a ser conhecidos na documentação e nas crônicas coloniais como Algodões, e deles há registros nestes aldeamentos e vilas de índios nos séculos XVIII e XIX. Em Paupina ${ }^{92}$, por exemplo, seu neto, Thomé da Silva Campeliu (identificado como Chefe da nação Cabedelo) aparece solicitando data de sesmaria em 1708, entre o rio Cocó e a serra de Pacatuba, área em que deveriam morar e circular, em plantações, pescarias e habitações. (FORTALEZA, 2010, p. 131. Grifo meu).

[...] ciclo missionário jesuítico, entre 1656 e 1759, é importante para a contextualização do momento em que ocorreram os pedidos de sesmarias dos índios de Paupina, solicitando terras na região entre o rio Cocó e a serra de Pacatuba. Naquele momento, sem o auxílio de religiosos e em conflito direto com os militares portugueses moradores da Fortaleza de Nossa Senhora de Assunção, estes indígenas buscavam legalizar juridicamente a posse de espaços habitados e já utilizados por eles para atividades diversas. Na verdade, buscavam reafirmar acordos e alianças travadas no século precedente (MAIA, 2009) e resistir perante a ocupação destas terras. (FORTALEZA, 2010, p. 133. Grifo meu).

A tentativa de descendentes do líder Potiguara de solicitar sesmarias que incluíam o território da Sabiaguaba dão indícios que esse povo já ocupava e utilizava esse território em suas atividades. Essa hipótese levantada pelos autores do Plano de Manejo é respaldada com os estudos feitos também durante a elaboração do Plano e por outros trabalhos nos sítios arqueológicos encontrados na Sabiaguaba. Estes foram descobertos não faz muito tempo, durante as escavações para construir a ponte sobre o Rio Cocó em sua foz, na década de 2000, o que levou ao estudo e descoberta de outros sítios ao longo do campo de dunas móveis e

\footnotetext{
90 Siará-Grande era como era chamado o Ceará nos tempos coloniais.

91 "O chefe Algodão, também conhecido por Amanay, liderou a etnia potiguara no século XVII, nas terras do Siará-Grande, onde habitaram a partir do limiar entre os séculos XVI e XVII, vindos das terras invadidas da capitania do Rio Grande do Norte, após uma longa guerra contra os portugueses. No Siará, fundaram novas aldeias, entraram em novos embates" FORTALEZA, 2010, p. 131).

$92 \mathrm{Em} \mathrm{1760,} \mathrm{a} \mathrm{aldeia} \mathrm{de} \mathrm{S.} \mathrm{Sebastião} \mathrm{de} \mathrm{Paupina} \mathrm{passa} \mathrm{a} \mathrm{categoria} \mathrm{de} \mathrm{vila} \mathrm{com} \mathrm{título} \mathrm{de} \mathrm{Villa} \mathrm{Nova} \mathrm{de} \mathrm{Messejana} \mathrm{(} \mathrm{FORTALEZA,}$ 2010).
} 
soterrados por estas. Tudo isto se soma aos relatos orais dos moradores mais antigos da área, levantado pelos pesquisadores, que relatam práticas culturais ancestrais e relações antigas com Messejana. O próprio nome do local tem origem indígena, Sabiaguaba do tupi, sabiáguaba = comedouro de sabiá, segundo lista de palavras referentes a localidades do Ceará, oriundas do tupi e outras línguas indígenas apresentada pelo Diário do Nordeste, em 24 de abril de $2006^{93}$

Dentre as práticas culturais, destacam-se as atividades extrativistas, pesca artesanal, coleta entre outras, tanto para a subsistência como para a troca ou comercialização por outros produtos, principalmente outros alimentos que estes não obtinham. Como destaca Pompeu Sobrinho (1945, apud FORTALEZA, 2010, p. 139), referindo-se aos índios da Vila de Messejana e entorno, "Estes indígenas ocupavam-se de atividades extrativistas em locais onde pudessem coletar os mariscos designados (caranguejos, ostras e outros), nos quais, ou moravam próximos, ou percorriam e conheciam, as áreas que exploravam."

Dentro do território da Sabiguaba são identificados dois núcleos de comunidades tradicionais ${ }^{94}$ que, segundo o Plano de Manejo da APA, são provavelmente descendentes da etnia indígena potiguara, e reconhecidas como comunidades de pescadores, coletores e agricultores. São estas: a comunidade da Gereberaba e a comunidade da Sabiaguaba. Destas duas povoações se originou parte dos agrupamentos familiares que hoje ocupam espaços mais amplos, incluindo a Lagoa Redonda, Aubreulândia e Messejana ( FORTALEZA, 2010).

A comunidade da Gereberaba está localizada no entorno da Lagoa Gereberaba, antigamente nomeada Jaraberaba. A comunidade da Sabiaguaba, nomeada anteriormente Sabia-Naba ${ }^{95}$, localizava-se, segundo relatos dos descendentes, coletados durante trabalho de campo desta tese, de maneira mais dispersa, onde hoje se localiza loteamento ocupado por casas de veraneio. Atualmente, reconhece-se que parte desses descendentes hoje conformam a comunidade Boca da Barra, localizada na Foz do Rio Cocó.

\footnotetext{
$93 \mathrm{http}: / /$ diariodonordeste.verdesmares.com.br/editorias/verso/palavras-logica-e-sentido-1.237487

94“[...] grupos culturalmente diferenciados e que se reconhecem como tais, que possuem formas próprias de organização social, que ocupam e usam territórios e recursos naturais como condição para sua reprodução cultural, social, religiosa, ancestral e econômica, utilizando conhecimentos, inovações e práticas gerados e transmitidos pela tradição" (Decreto n. 6.040 , de 7 de fevereiro de 2007, artigo 3으, inciso I).

95 Estas nomeações antigas Jaraberaba e Sabia-naba foram observadas na cartografia da cidade de 1945 como a Carta de Fortaleza e Arredores levantada pelo serviço de geografia do exército.
} 
As construções anteriores aos loteamentos na área eram autoconstruções realizadas pelos próprios moradores e não mercantis. Segundo o senhor Rocimar, antigo morador nativo da Sabiaguaba e hoje morador da Gereberaba (apud FORTALEZA, 2010), as casas das famílias que residiam na Sabiaguaba antes da chegada dos loteamentos na década de 1970 "eram de palha e as casas feitas em cima das dunas fixas, algumas com palha até o chão de areia branca, outras, com paredes de taipa" e as "passagem de carroças ainda era muito complicada nestes caminhos, porque se tratava de uma mata fechada" ( FORTALEZA, 2010, p. 143).

Ainda segundo o mesmo morador, o Plano de Manejo aponta que:

É difícil se localizar, espacialmente, na Sabiaguaba de hoje com base nas lembranças de antanho, pois muitas das referências antigas já não mais existem, por conta das transformações da natureza e da ação humana no local. Este núcleo de povoação inicial se localizava num dos morros ainda hoje ocupados, concentrando-se pouco depois da atual praça, à margem direita da via que leva à praia, área que se encontra no interior da área do Parque Municipal de Dunas. Ali se concentravam as casas, as criações de bode e carneiro, pequenos roçados, alguns cajueiros sombreando. (FORTALEZA, 2010, p. 144).

O relato do senhor Rocimar sobre o local onde a comunidade estava instalada reflete a representação de um agrupamento, ainda que disperso, de pequenas casas levantadas pelo Exército na Carta de Fortaleza e Arredores (Figura 35). Nesta Carta, é possível observar aproximadamente 10 casas localizadas em dunas móveis mais baixas e já com presença de vegetação, entre a curva do Rio cocó, seu mangue, a praia e as dunas móveis mais altas. É possível observar também na mesma imagem o levantamento de áreas de pequenos cultivos. Este agrupamento de casas coincide exatamente com o local na carta onde está colocado o nome da localidade "Sabia-naba" (Figura 35) ${ }^{96}$. Mais ao sudoeste deste pequeno núcleo é possível observar mais duas casas sobre dunas, próximo às cotas de 21 e 22 metros.

Na mesma Carta, é possível também observar no entorno da lagoa de Gereberaba (Jaraberaba na carta) outro agrupamento, também disperso, de pequenas casas. São ao todo quase quarenta casas representadas entre a lagoa da Jaraberaba e a lagoa da Precabura de norte a sul e de leste a oeste entre o despejo da Precabura (atual riacho Coaçu) e as dunas móveis da Barra (atuais Dunas do Parque das Dunas da Sabiaguaba). Assim como na Sabia-naba, é possível observar também, na Carta, a presença de vários cultivos (Figura 36).

\footnotetext{
${ }^{96}$ Ver folha completa da Carta de toda a área em anexo.
} 
Tirando esses dois pequenos núcleos de casas e as pequenas áreas demarcadas como cultivo, todo o território da Sabiaguaba, como pode ser observado na Carta de Fortaleza e Arredores, até a década de 1940 era praticamente desocupado e com a presença de grande cordão de dunas móveis e fixas, lagoas, mangue e rios. Não havia abertura de vias ainda na região, apenas um pequeno caminho de terra que chegava próximo ao núcleo sabia-naba.

Figura 35. Núcleo de casas na Sabia-naba, levantadas em 1945.

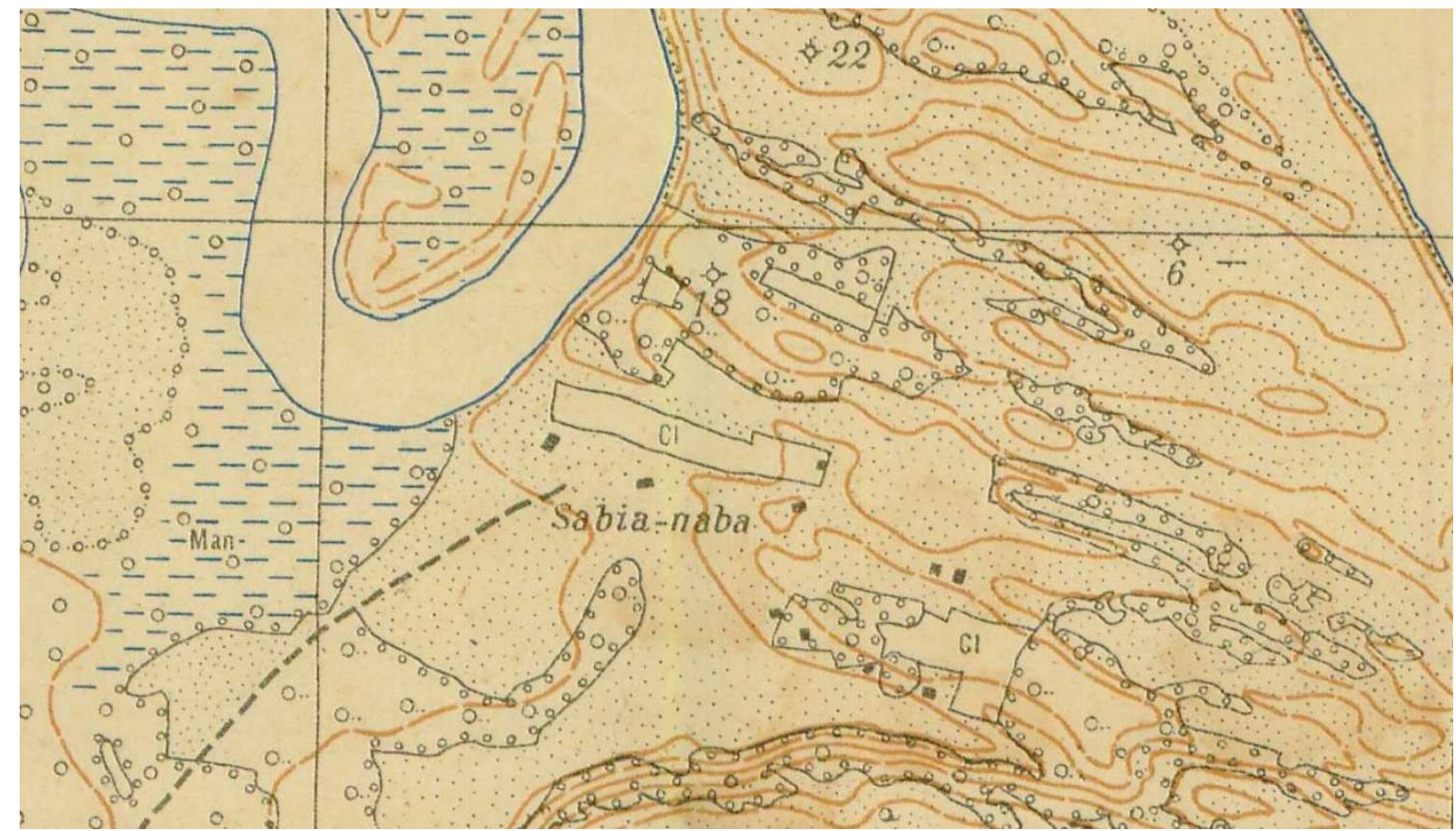

Fonte: levantamento do Serviço de Geografia do Exército - Carta de Fortaleza e Arredores de 1945. Digitalização: Sara V. Rosa, 2018. 
Figura 36. Núcleo de casas na lagoa da Jaraberaba, levantadas em 1945.

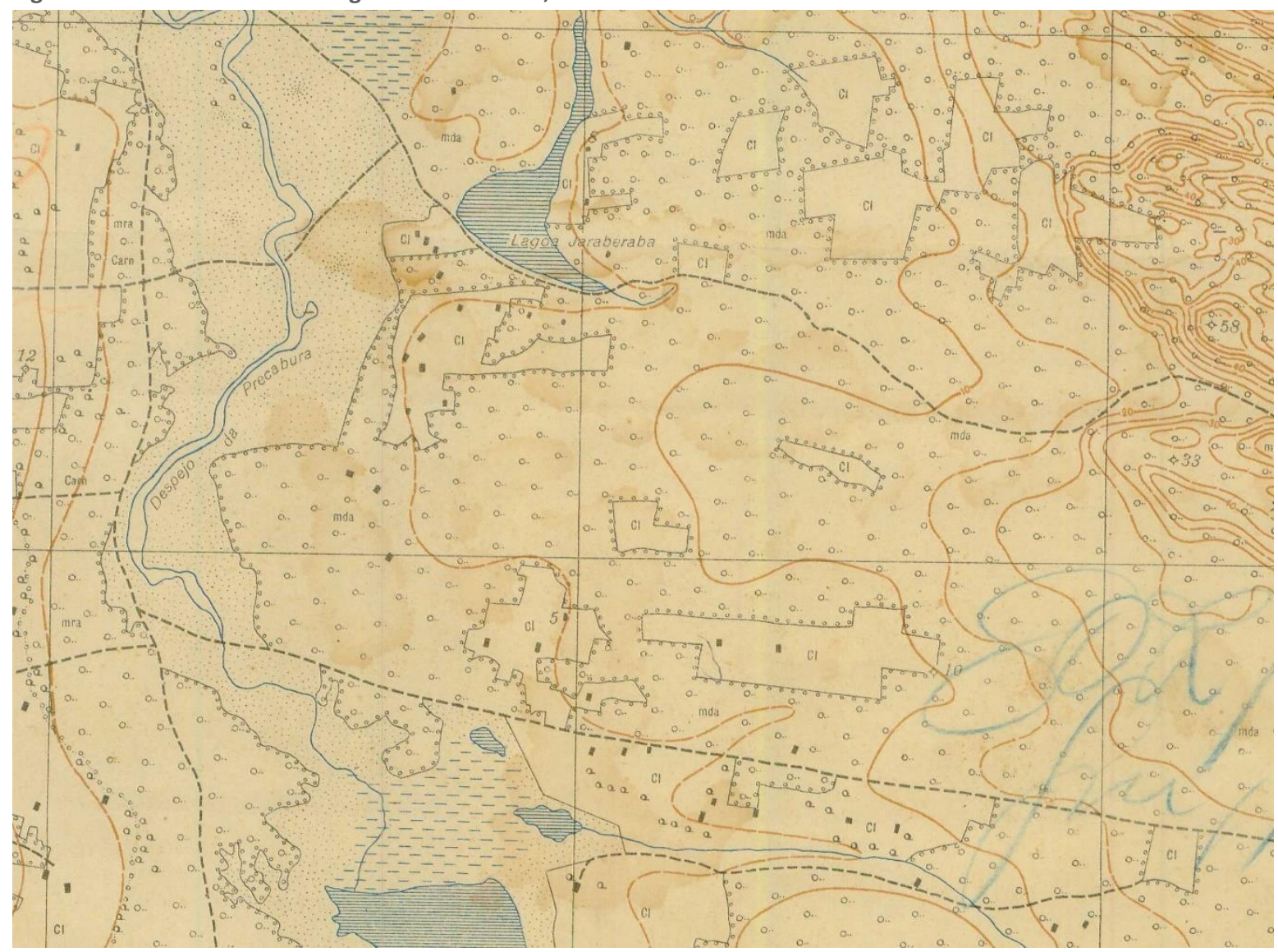

Fonte: levantamento do Serviço de Geografia do Exército - Carta de Fortaleza e Arredores de 1945. Digitalização: Sara V. Rosa, 2018.

Com relação às práticas sociais de trabalho e subsistência, os autores do Plano de Manejo da

APA (2010) descrevem:

A memória de todos os interlocutores está fortemente marcada pela pesca como prática social fundamental, de trabalho e relação com a natureza, imersa de significados para a identificação e entendimento da Sabiaguaba de antigamente e seus habitantes. Inclusive o sentido social do espaço estava intimamente relacionado com a pesca, enquanto atividade exercida neste e fundamental na sua significação por parte dos moradores. Deste modo, no espaço a pesca imprime a sua referência, em lugares que não mais existem, mas que constituíam importantes lugares de memória da pesca, de como esta era vivenciada, que possibilitam pensar sobre as transformações das relações mediante a transformação social do espaço. ( FORTALEZA, 2010, p. 144)

A extração de mariscos e a coleta de caju, da castanha e do murici constituem-se fundamentais para o modo de vida e sobrevivência, tanto da Gereberaba quanto da Sabiaguaba, com várias gerações criando seus filhos com a venda e troca deles e de seus derivados, como o mocororó. A comercialização, além do consumo, era fundamental para obter outros itens da alimentação necessária, como farinha e arroz ou feijão. Eram vendidos tanto os mariscos, como o mocororó e o murici, na safra de agosto a dezembro, junto com a do caju. A pesca e a coleta, junto a uma incipiente agricultura básica, eram os sustentáculos do modo de vida destas comunidades. Extraíam os alimentos e, de muitos deles, obtinham recursos para ter acesso ao que Ihes faltavam. ( FORTALEZA, 2010, p. 145) 
Durante a pesquisa desta Tese, verificou-se que algumas dessas práticas persistem até os dias de hoje, outras foram sendo substituídas por comércios, como barracas de praia, trabalhos assalariados e principalmente pela prestação de serviços na forma de "bicos". A pesca permanece. Alguns pescadores mais velhos continuam exercendo a atividade e alguns, mais novos, filhos de pescadores, exercem a pesca como complementação à renda de outros serviços. A mariscagem, que era uma atividade muito importante para estas famílias, exercida em especial pelas mulheres, as marisqueiras, hoje não existe mais por conta das transformações sociais, ambientais e territoriais na área, que incluem a poluição e a degradação das áreas de coleta de mariscos. Essas transformações estão atreladas ao adensamento da cidade, à falta de saneamento básico, à ocupação da planície fluvio-marinha do rio Cocó e, principalmente, à exploração mercantil dessas terras, com a chegada de loteamentos a partir da década de 1970.

Há ainda relatos de pescadores mais antigos de que houve um período em que se escondia que se era descendente de índio, porque era muito vergonhoso e corriam risco de serem mortos ${ }^{97}$. Assim, as gerações mais novas não recebiam a transferência cultural e histórica que os antigos receberam. As gerações atuais, com a pressão que vem ocorrendo para sua remoção da área, estão redescobrindo suas histórias e seus antepassados, durante o processo de resistência para permanecer em suas terras e resgatando tradições e festas antigas.

Em uma tentativa de resgatar o uso desse território pelas famílias do núcleo Sabia-naba, hoje comunidade Boca da Barra, realizou-se a construção de um mapa (cartografia-social) com a colaboração do irmão de seu Rocimar, o seu Ronivaldo (Zé Tartaruga), juntamente com seu filho, Roniele. O mapa final é o mostrado na Figura 37. O processo de sua elaboração e a conversa nesse momento, juntamente com conversas com outros moradores em outros momentos, permitiram não só o resgate da forma como aquele território era usado e a espacialização dessas atividades, bem como nos ajudou na compreensão das alterações do território e do modo de vida dessas famílias após o loteamento dessas terras.

A oficina para a construção da cartografia social, dispunha de fotos aéreas e mapa de arruamentos da porção do território compreendida pela faixa de praia, englobando a foz do

\footnotetext{
97 Seu Zé Tartaruga, antigo pescador menciona uma suposta lei que fez com que os índios fossem perseguidos e mortos, então que estes passaram a esconder suas origens. Durante a tese, não se teve tempo de verificar este fato, até porque esta tese não é histórica, nem antropológica.
} 
Rio Cocó, estendendo-se até quase chegar na Cofeco, sendo esta a área mais utilizada e explorada pelos moradores desse núcleo, apesar de se saber das relações até os dias de hoje com a Gereberaba, Lagoa Redonda e Messejana. O período retratado é aquele referente a lembrança de Seu Zé Tartaruga e de seu filho, que vão desde a geração do pai do Zé, seu Nirvado, até a geração do seu filho. Zé Tartaruga e seu filho destacam a pesca, a coleta de marisco e o extrativismo vegetal como principais atividades da comunidade antes da chegada dos loteamentos residenciais na praia. Sabe-se, e o próprio Zé já comentou em outros momentos, que os antigos moradores também cultivavam pequenos roçados com feijão, arroz, café bravo entre outros, porém estes não apareceram no dia da elaboração do mapa. Outro fato que também pode ter levado a isso é o roçado já não ter sido tão abundante na geração do seu Zé. A única área no mapa em que seu Zé Tartaruga destacou a utilização para a agricultura foi em um banco de terra formado entre os braços do Rio Cocó, conhecido por eles como o Alto da Rola, onde antigamente vivia um senhor apelidado de Rola que plantava e vivia no local.

Em relato posterior, seu Zé aponta um local entre as dunas onde ficava provavelmente a casa de sua bisavó. Local em que morava e tinha um roçado onde plantava "comida mais simples", que segundo ele, "era feijão, era tudo que ela plantava aí [...] e comida, coisa mais simples feijão, arroz". Ele comenta que o local era da época de sua tataravó, não chegou a ver a casa, mas ia no local olhar os "cacos de pratos, e panelas", "ninguém mexia, né [...] só eu que vinha [..] depois muita gente veio, mas ninguém sabe onde anda isso aí". Quando sua bisavó faleceu, sua avó foi morar na Lagoa Redonda. 
Figura 37. Cartografia social do uso do território da Sabiaguaba

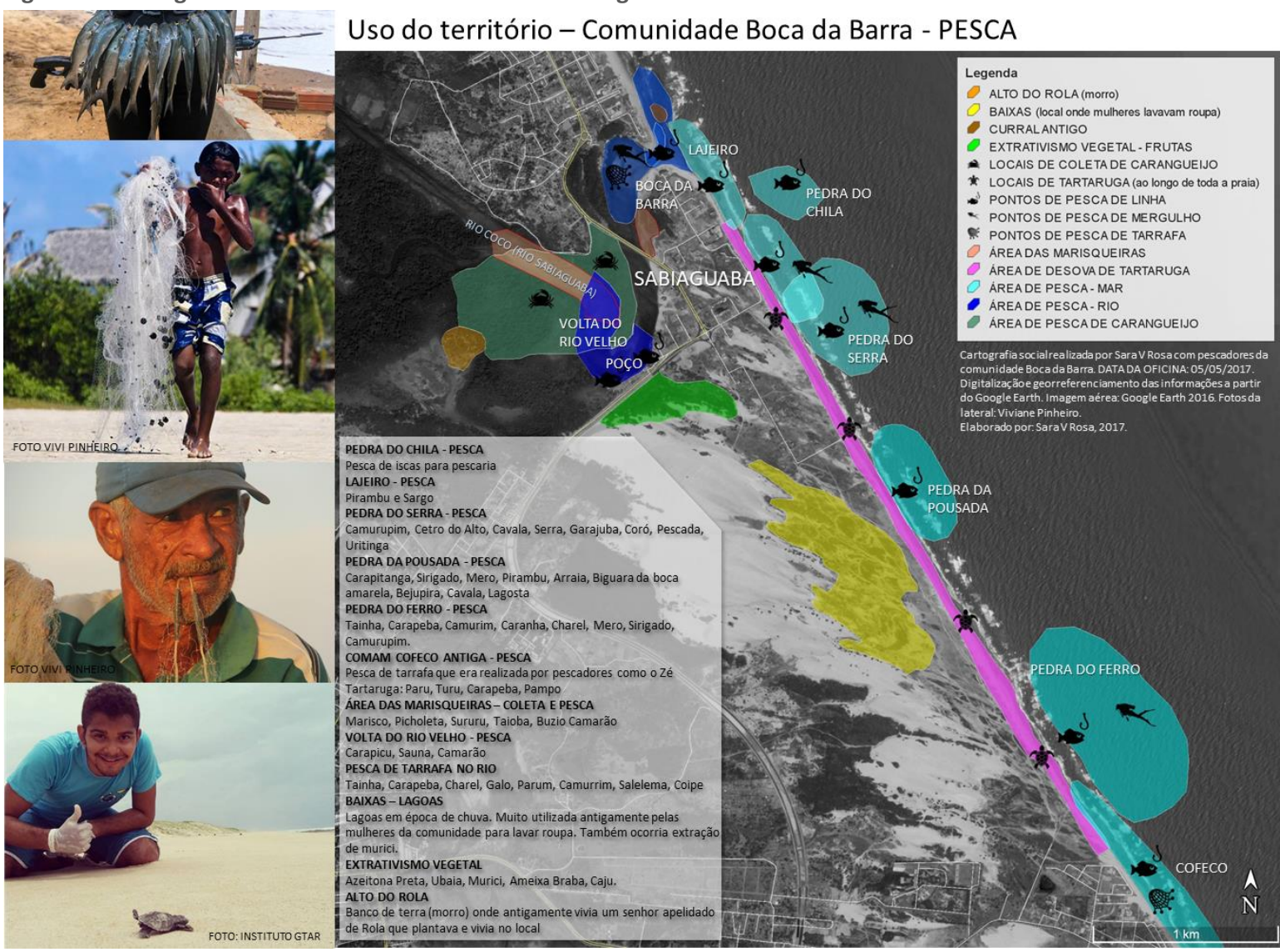

Cartografia social construída com pescadores, pai (Ronivaldo) e filho (Roniele) moradores da Boca da Barra da Sabiaguaba. Tentativa de resgatar o uso do território pela sua família e comunidade antes da chegada do loteamento de casas de veraneio. Elaboração Sara V Rosa (2017). Fotos Viviane Pinheiro (2016); Instituto Gtar (sd)

Seu Zé Tartaruga, que se refere ao rio Cocó como Rio Sabiaguaba ${ }^{98}$, conta da época em que o Rio era cheio de curvas tortuosas e que a retificação dele provocou grande impacto negativo, levando à diminuição de várias espécies de mariscos e de peixes. Destaca também que a pesca diminuiu depois do paredão do Porto do Mucuripe. Relata que a variedade e a quantidade de peixes diminuíram muito. Hoje, apesar de ainda poder encontrar outras espécies, a mais comum é o Cará.

Zé Tartaruga e seu filho destacaram três modalidades de pesca: a pesca de tarrafa, a pesca de mergulho e a pesca de linha. Havia o local onde se apanhavam as iscas para a realização da pesca, a Pedra da Chila, logo na desembocadura do Rio Cocó. Os pontos de pesca com tarrafa, na foz do Rio, onde até hoje é possível observar a sua realização em pequenas embarcações, ou de pé.

\footnotetext{
${ }^{98}$ Rio Cocó era assim denominado do Dendê para cima. Na foz, os moradores conheciam o rio como Rio Sabiaguaba.
} 
Ao longo de toda a faixa de praia, predominava mais a pesca de linha e a pesca de mergulho, essa última ainda praticada pelo seu filho, Roniele. Na altura da praia da atual Cofeco, já perto da foz do Rio Pacoti, tinha-se também a prática da pesca de tarrafa. Dentre as diversas espécies de peixes pescadas, eles destacam na PEDRA DO SERRA: Camurupim, Cetro do Alto, Cavala, Serra, Garajuba, Coró, Pescada, Uritinga; na PEDRA DA POUSADA: Carapitanga, Sirigado, Mero, Pirambu, Arraia, Biguara da boca amarela, Bejupira, Cavala, Lagosta; na PEDRA DO FERRO: Tainha, Carapeba, Camurim, Caranha, Charel, Mero, Sirigado, Camurupim; na COMAM (COFECO ANTIGA), pesca de tarrafa que era realizada por pescadores, como o Zé Tartaruga: Paru, Turu, Carapeba, Pampo

Roniele e seu pai, e outros moradores, destacam também que toda essa faixa de praia é local de desova de tartarugas. Atualmente existe uma ONG que trabalha na tentativa de preservação das tartarugas, a Verdeluz ${ }^{99}$, com seu grupo GTAR (Grupo de Estudos e Articulações sobre Tartarugas Marinhas - GTAR-Verdeluz).

Já na foz do Rio Cocó, além da pesca, desenvolvia-se a atividade de coleta de mariscos pelas marisqueiras, a "área das marisqueiras, onde se coletava e pescava Marisco, Picholeta, Sururu, Taioba, Buzio e Camarão". Havia a pesca de caranguejo na volta do "Rio Velho", onde se pescava também Carapicu, Sauna, Camarão. A pesca de tarrafa no rio pegava espécies, como Tainha, Carapeba, Charel, Galo, Parum, Camurrim, Salelema e Coipe (Figura 37).

Destacam ainda locais onde realizavam extrativismo vegetal, como a extração de Azeitona Preta, Ubaia, Murici, Ameixa Braba e Caju, bem como local onde as mulheres lavavam roupa, as Baixas. Nestas, existem a presença de lagoas intermitentes, formadas na época da chuva na planície lacustre, entre as dunas móveis e o terraço marinho. A área também era importante no extrativismo da fruta Murici (Figura 37).

${ }^{99}$ http://verdeluz.org/ 
Figura 38. Localização Comunidades Tradicionais identificadas durante o trabalho

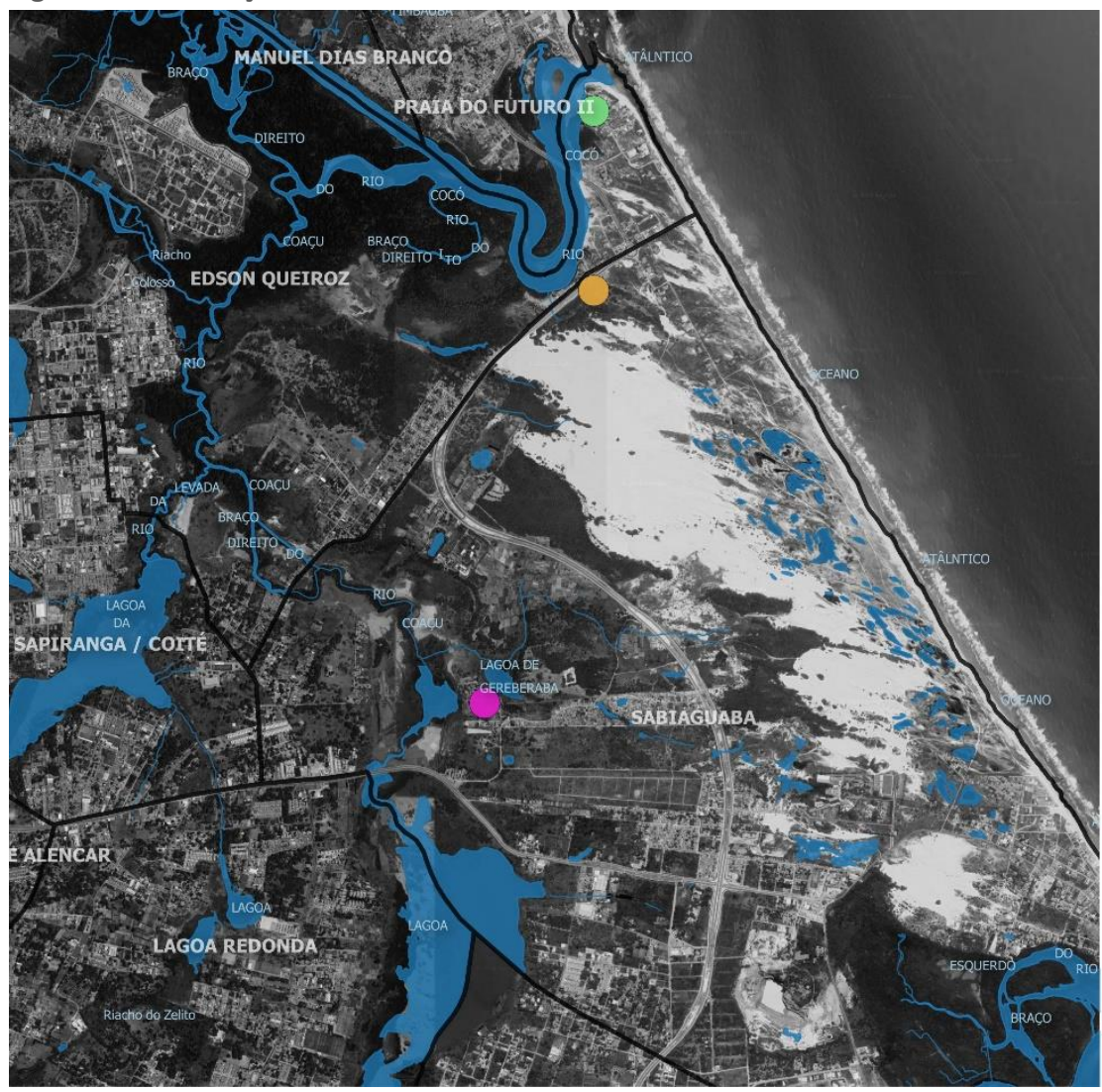

SABIAGUABA -

comunidades

imagem aérea 2018

$\square$ BAIRROS ATUAIS (SEUMA 2016)

HIDROGRAFIA (FORTALEZA, 2006)

COMUNIDADES SABIAGUABA

BOCA DA BARRA

Localização atual da comunidade descendente dos antigos moradores da Sabiaguaba (Sabia-naba)

JARABERABA

localização da comunidade Gereberaba antes e após os loteamentos

SABIA-NABA (núcleo sabiaguaba) antes da chegada do loteamento

FONTE: LEVANTAMENTO PRÓPRIO; BAIRROS
(FORTALEZA, 2016); IMAGEM AEREA (GOOGLEEARTH,

obs.: NOMES SABIA-NAMA E JARABERABA ESTÄO COM A TOPONOMIA DA CARTA DE FORTALEZAE DO EXÉRCITO)
SISTEMA DE PROJECEAO UTM SIRGAS 2000 ELABORACAOO: SARAVROSA, 2018

Software: Qgis

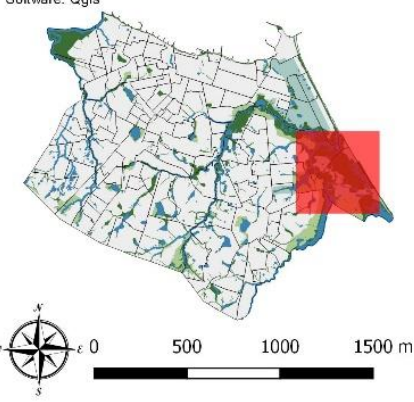

Fonte: Levantamento próprio. Imagem aérea GoogleEarth, 2018.

A dragagem e retificação do Rio Cocó provocou vários impactos no estuário do rio que, juntamente com a poluição, à medida que a cidade se tornava mais densa, repercutiram em alterações no modo de vida das populações tradicionais que viviam ainda primordialmente de pesca e coleta na Sabiaguaba. A atividade das marisqueiras era muito importante para as famílias desta região, que viram aos poucos sua fonte de subsistência ir diminuindo e desaparecendo do leito do Rio. Moradores da boca da Barra relatam que quando o Iguatemi despeja a água tradada no Rio Cocó é possível perceber sua chegada na foz e a morte de peixes devido aos produtos químicos utilizados para tratar a água e a rápida velocidade de escoamento desta, ocasionada pela retificação do leito do rio.

Assim, quando o loteamento Sabiaguaba chega na faixa de praia da Sabiaguaba, expulsando os moradores de suas áreas tradicionais de moradia e restringindo suas áreas de coleta, a diminuição dos mariscos contribui para que essas famílias abandonem suas atividades de subsistências tradicionais e passem a depender da venda de sua força de trabalho, inicialmente para os funcionários do loteamento e posteriormente para os proprietários das casas de veraneio que aí foram se instalando. 
Temos ao todo sete loteamentos registrados na Base da Prefeitura (da década de 1930 a 2000) dentro do território da Sabiaguaba. Planalto Aldeota Sul, Colina da Sabiaguaba, Sabiaguaba, Sabiaguaba (praia), Lago Dourado, Precabura (terreno). Há que se destacar de antemão que alguns destes loteamentos registrados na base da Prefeitura Municipal de Fortaleza possuem planta de aprovação e registro em cartório do município vizinho, Aquiraz, às vezes com informações divergentes das apresentadas na base de Fortaleza. Não sabemos se as informações incompatíveis se devem a problemas na base de dados, ou se o registro que nesta consta se refere apenas ao terreno anteriormente a seu loteamento e, posteriormente, o proprietário registrou o loteamento no município vizinho para fugir de alguma restrição; ou ainda se foram feitos dois registros de loteamentos em dois municípios diferentes (Figura 40).

Figura 39. Sabia-naba (Sabiaguaba) - Levantamento segundo Carta de Fortaleza e arredores de 1945.

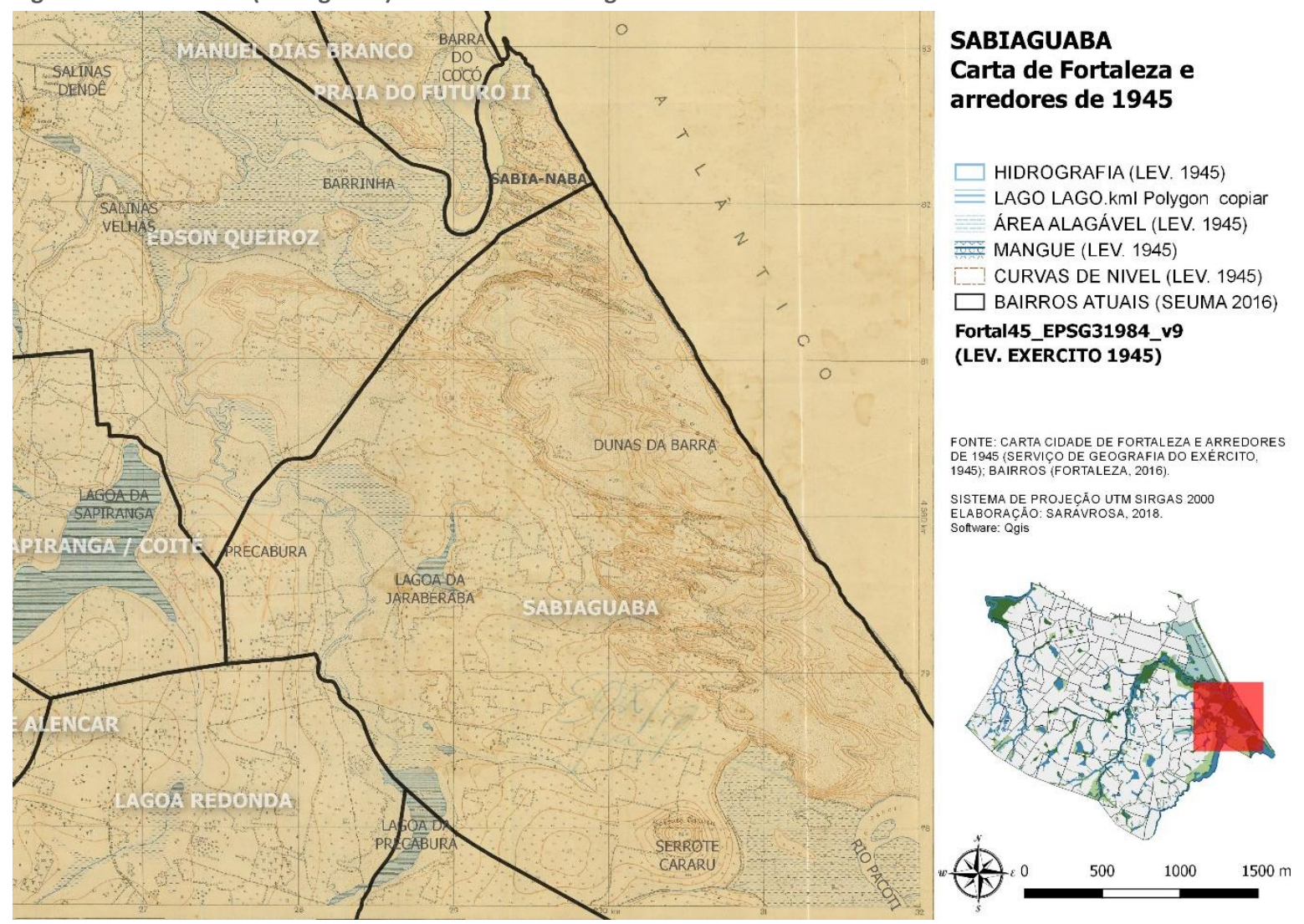

Elaboração: sara V Rosa (2018). Fonte: levantamento do Serviço de Geografia do Exército - Carta de Fortaleza e Arredores de 1945

Em 1971, segundo planta de loteamento registrada no município de Aquiraz, é aprovado para fins de construção o Loteamento "Praia da Sabiaguá" - "Sabiaguaba (praia)" pela base de loteamentos da Prefeitura Municipal de Fortaleza e "Parque Sabiaguá", segundo matrícula de terreno pertencente a este, de propriedade da Empresa de Terrenos LTDA (Figura 41). 
Figura 40. Levantamentos na Sabiaguaba e arredores da década de 1930 a 20000.

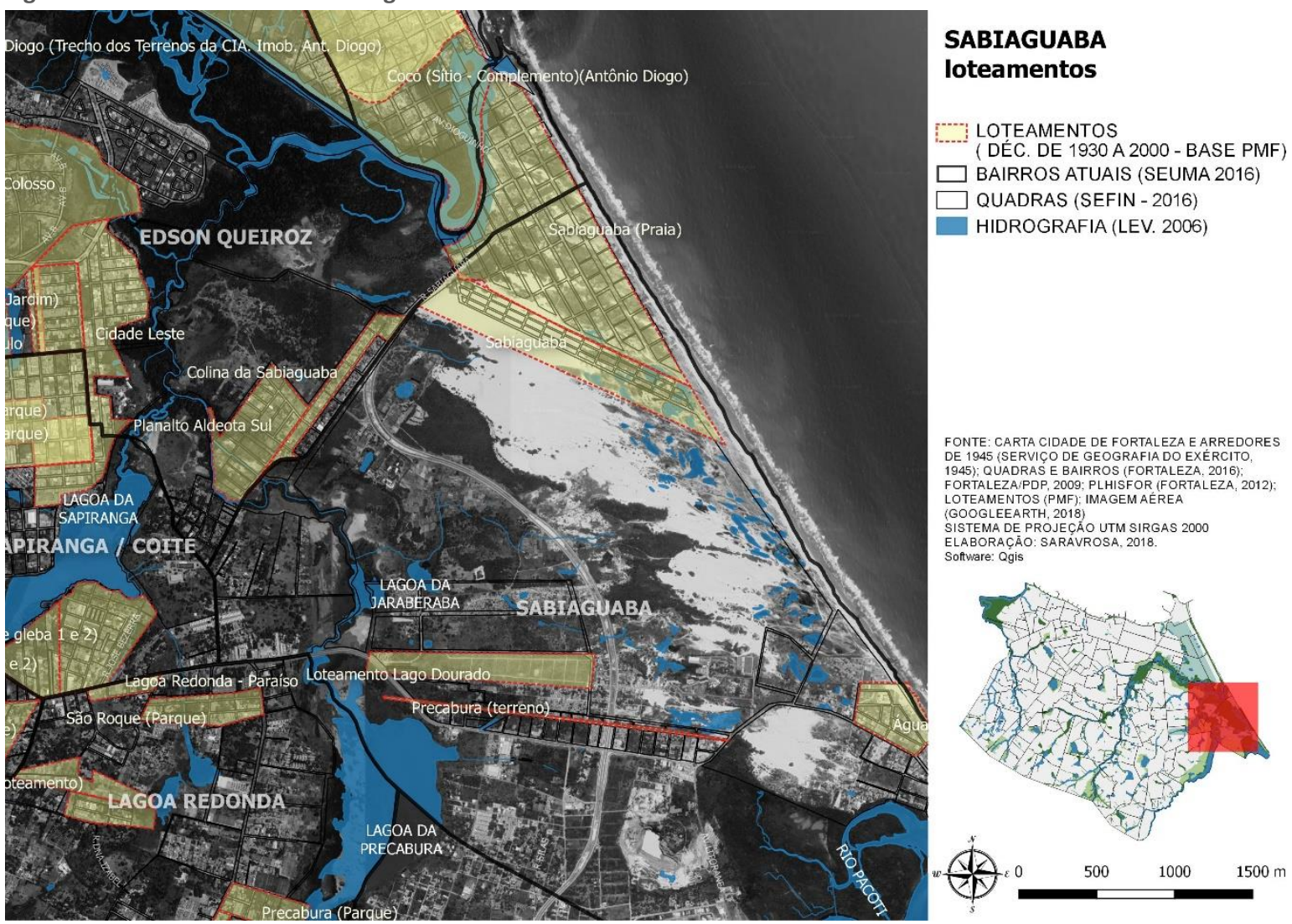

Elaboração: sara V Rosa (2018). Fonte: Base de Loteamentos da Prefeitura Municipal de Fortaleza.

Na forma de um trapézio, o loteamento se estende de onde hoje estão localizadas as barracas do Rio Cocó, na altura onde o campo de dunas, reivindicando seu lugar, avança em direção à estrada da Sabiaguaba, hoje CE-010, abrindo em direção à praia, ocupando uma área total de $1.145 .800 \mathrm{~m}^{2}$. Apresenta lotes grandes com dimensões que variam entre $20 \times 33 \mathrm{~m}, 15 \mathrm{X} 33 \mathrm{~m}$ e $17 X 50 \mathrm{~m}\left(660 \mathrm{~m}^{2}, 495 \mathrm{~m}^{2}\right.$ e $850 \mathrm{~m}^{2}$, respectivamente). Contando com os lotes irregulares, o de menor dimensão tem $457 \mathrm{~m}^{2}$ e o de maior ultrapassa os mil metros quadrados. Estes projetamse sobre a planície litorânea, incluindo a faixa de praia, dunas móveis e dunas fixas, estando quase totalmente em Área de Marinha.

Na planta de loteamento apresentada ao Município de Aquiraz, o loteamento "respeita" os limites do rio, porém os lotes são desenhados bem próximo a este, separados apenas por uma via, o que é pouco, principalmente para um rio destas dimensões. Ao verificar a base da Prefeitura Municipal de Fortaleza, onde aparece sem registro de data, tanto a base dos loteamentos como o desenho viário existente e proposto, o loteamento, seus lotes e suas vias passam por cima do rio, como pode ser observado na Figura 40 e na Figura 42. 
Figura 41. Loteamento da Praia Sabiaguá - Sabiaguaba (praia) aprovado em 1971.

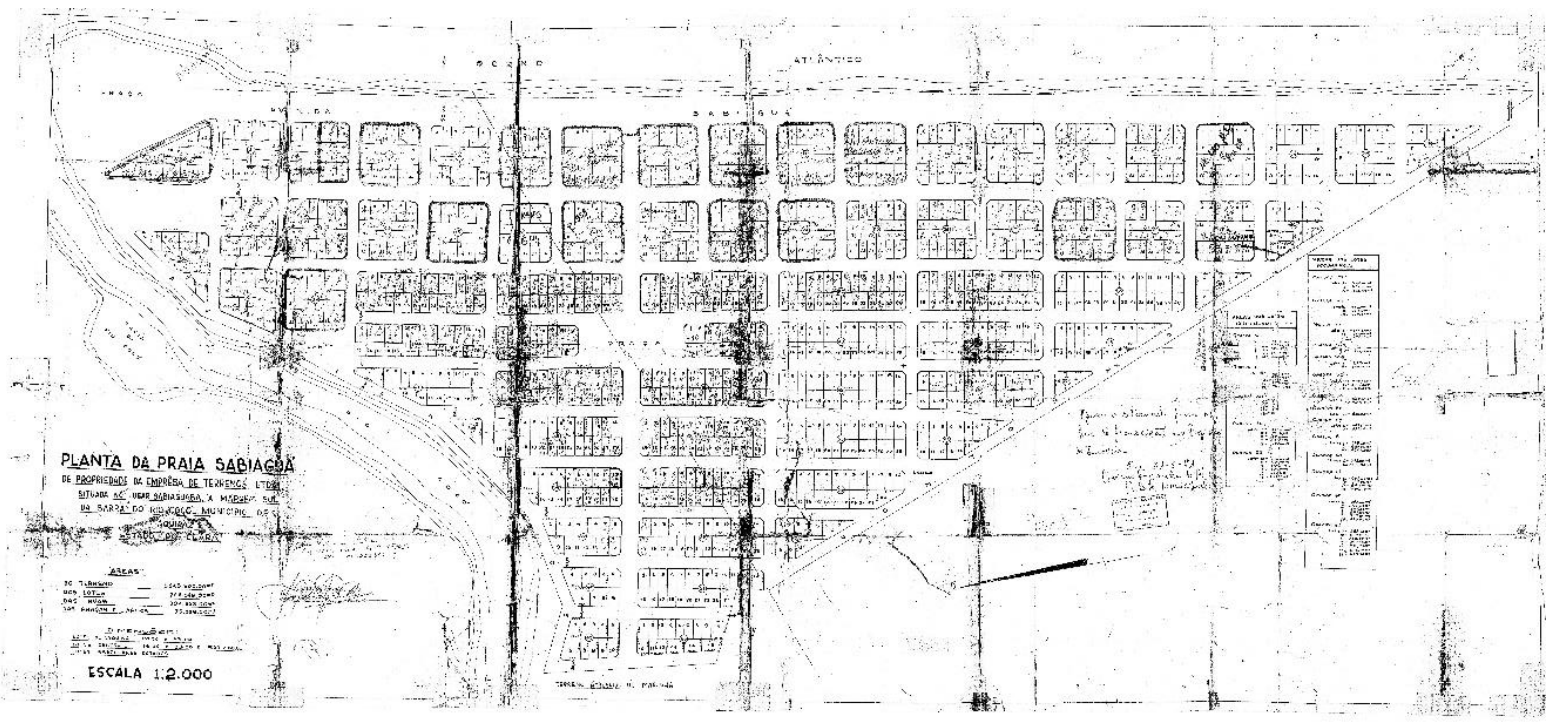

Fonte: SEFIN de Aquiraz. Disponível em: sefin.aquiraz.ce.gov.br/plantas. Imagem com melhor qualidade pode ser vista em anexo.

Figura 42. Zoom Loteamento Praia da Sabiaguaba.

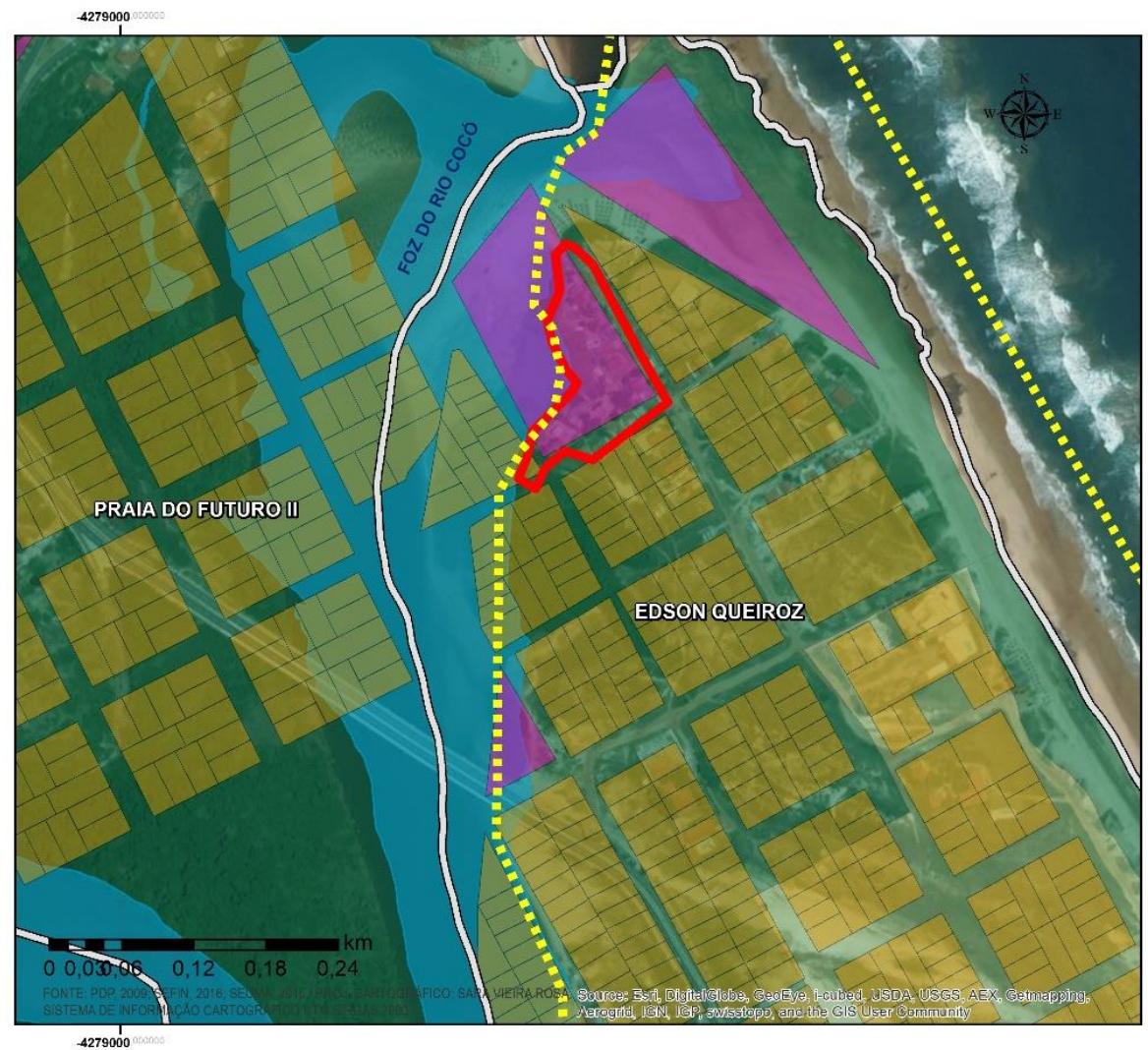

COMUN.E BOCA DA BARRA

LOTEAMENTO EXISTENTE- LOTES

COMUNIDADE BOCADA BARRA

APA DA SABIAGUABA

ZIA (Zona de Interesse

Ambiental - PDP2009)

ZPA (Zona de Preserv. Amb.

PDP2009)

$\square$ BairRos

HIDROGRAFIA

Patrimônio

Privado

Pub.Munic

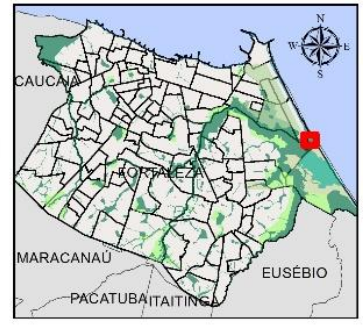

FONTE:

FORTALEZA/PDP, 2009

ORTALEZA/SEFIN, 2016 (LOTEAMENTO)

FORTALEZA/SEUMA, 2015 (BAIRROS)

PROJETO CARTOGRÁFICO:

SARA VIEIRA ROSA

SISTEMA DE INFORMAÇĀO CARTOGRÁFICA UTM SIRGAS 2000

Elaboração: Sara V Rosa (2017)

O início da implantação desse loteamento obrigou as famílias do núcleo Sabia-naba a saírem do local que habitavam. Parte delas reconstruiu suas casas ainda no território da Sabiaguaba, em porção de terreno público de doação obrigatória do parcelamento do loteamento, onde hoje é conhecida como comunidade Boca da Barra (Figura 42). A pesca e a coleta passaram a 
ser complementadas pela venda de almoço para os trabalhadores que estavam abrindo o loteamento. Com a finalização das obras do loteamento, a atividade de venda de refeição permanece, agora para as famílias que vão para suas casas de veraneio e para visitantes, por meio da abertura de barracas de praia e à beira rio. A primeira barraca de praia construída foi a do finado Seu Nirvado (pai do Zé Tartaruga). A pesca passa a ser substituída por trabalhos, como na construção de casas, caseiro, doméstica, bicos.

O loteamento Parque Entre Rios (Figura 43) possui planta de loteamento aprovada no município de Aquiraz, com data de aprovação de dois de dezembro de 1975 e proprietário Paulo Roberto Carvalho. Todavia, como comentado em ponto anterior, este mesmo loteamento aparece registrado na planta de loteamentos do Município de Fortaleza, sem data de registro e com propriedade no nome de Francisco Jereissati. Foi realizada uma pesquisa de matrícula de terreno pertencente a este loteamento e o nome do proprietário encontrado foi Paulo Roberto de Carvalho. Ficou a dúvida se houve um erro da base de dados do município de Fortaleza, ou se o loteamento está registrado inicialmente apenas como terreno e depois desaparece nos históricos da matrícula pesquisada.

Todavia, destacamos que o limitante sudoeste do loteamento aparece na planta do mesmo (Figura 43) como pertencente a Francisco Jereissati e que a matrícula em nome de Paulo Roberto de Carvalho, registrada no cartório da primeira zona de Fortaleza tem data de abertura de 1994, com registro anterior, a transcrição, registrada no Cartório de Registro de Imóveis de Aquiraz. Provavelmente, o registro da base de dados do município de Fortaleza é apenas do terreno, já que, pela planta de loteamento, terrenos lindeiros a este também eram de Francisco Jereissati e não do loteamento que deve ter sido feito já com o terreno em propriedade de Paulo Roberto Carvalho.

Com uma área total de duzentos e quarenta mil metros quadrados, o loteamento foi aprovado completamente sobre o campo de dunas móveis, hoje Parque Natural das Dunas da Sabiaguaba. Este segundo loteamento não teve o sistema viário implementado.

O Loteamento Planalto Aldeota Sul tem como proprietário a Imobiliária Etevaldo Nogueira Ltda, datado na base de dados da prefeitura como sendo de 1982, e o loteamento Colina da Sabiaguaba, sem data, de propriedade de Colina-Comércio de Imóveis Ltda, estão ambos localizados ao longo da lateral esquerda da estrada aberta para dar acesso ao loteamento da 
Praia Sabiaguá - Sabiaguaba (praia). O primeiro, Aldeota Sul, tem a maior parte de seu terreno sobre a planície flúvio-marinha do riacho Coaçu e teve até hoje poucos lotes ocupados. Já o Colina da Sabiaguaba e seu entorno estão completamente ocupados, de maneira informal, por população de baixa renda.

Figura 43. Loteamento Parque Entre Rios

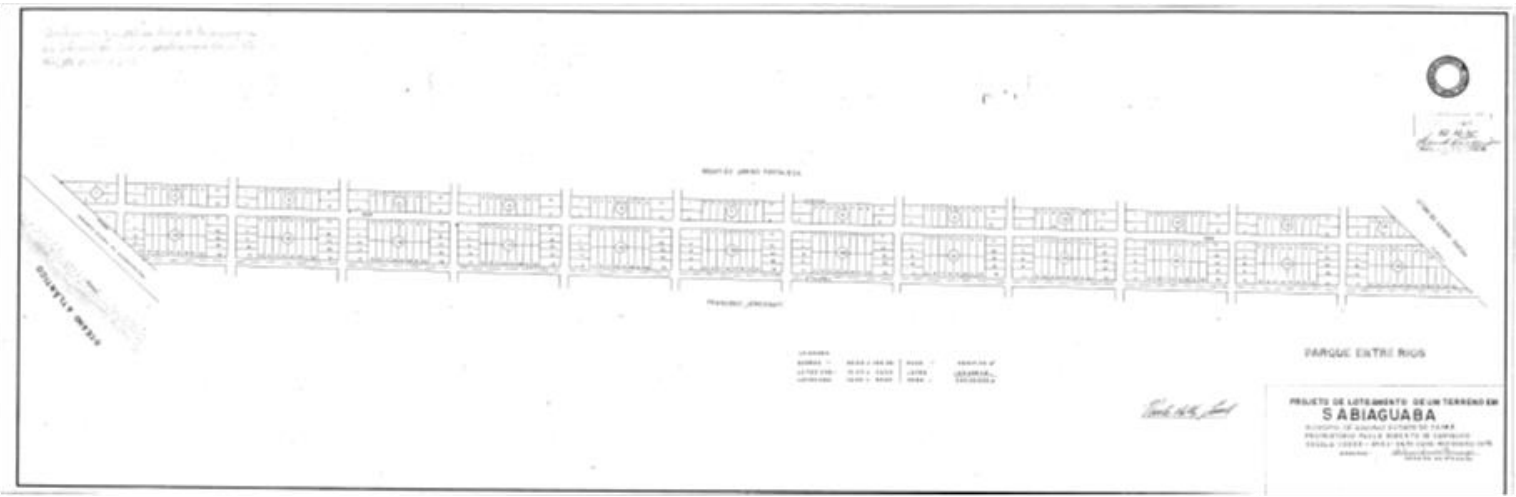

Fonte: SEFIN de Aquiraz. Disponível em: sefin.aquiraz.ce.gov.br/plantas. Imagem com melhor qualidade pode ser vista em anexo.

Em 1991, houve o registro do loteamento Água Marinha (Residencial) de propriedade de SINCOL na praia da Cofeco. Mais recentemente, em 2002, segundo a base de loteamentos da prefeitura, tivemos o Loteamento Lago Dourado, de propriedade de SERVETC Engenharia Ltda e Cequip Importação e Comércio, localizado nas proximidades da Gereberaba, com acesso pela via que foi aberta recentemente pelo Governo do Estado, a CE-010.

Existem outros terrenos parcelados no território, todavia não aparecem na base de dados de loteamentos da PMF que tínhamos disponível.

\subsection{CONSIDERAÇÕES SOBRE O CAPÍTULO 01}

Este capítulo apresentou como as bases capitalistas e de produção da cidade de Fortaleza foram formadas a partir de processos de acumulação por espoliação da natureza (base biofísica de sustentação da vida e próprio homem). Desde o período colonial até o início do século $X X$, a acumulação de capital e produção do núcleo urbano de Fortaleza foi pura acumulação por espoliação da natureza, ora explicitamente por meio de invasão, roubo e guerras violentas, ora "maquiadas" e impostas como um processo "justo" e "natural" pelo Estado, mediante um conjunto de regulamentos de políticas indigenista, econômicas e de terras. 
Demonstrou também que as práticas e estratégias primitivas de acumulação por espoliação da natureza no imobiliário, como a expansão de loteamentos, ainda permanecem até o final do século $\mathrm{XX}$, e até os dias atuais, espoliando a mesma população massacrada no período colonial, como elucidado no caso da Sabiaguaba.

A natureza aparece enquanto recurso e espaço. Enquanto recurso, extrai-se o sal, e enquanto espaço, constroem-se empreendimentos imobiliários, apagando os vestígios do que poderia ser considerado "natural", como o mangue e o estuário do Rio Cocó, como neste exemplo, ou como lagoas e rios, como no caso mostrado anteriormente, dos rios Tauape e Água Nambi. Neste momento, a capitalização inicial obtida pelo proprietário de terra se dá pela posse da moderna propriedade da terra.

No primeiro momento da atividade loteadora, onde quase não há geração de valor pela produção, a renda é capitalizada principalmente com a venda de terreno e lote. Foi utilizada como estratégia a expansão das áreas loteadas para aumentar a possibilidade de captura de valor. Nesse processo de expansão, a terra-natureza, representada por dunas móveis, áreas alagadiças, rios, etc., representam barreiras a essa expansão. A solução foi novamente a dominação da natureza.

Loteamentos dessa época, como por exemplo aqueles da década de 50 sobre o Riacho Água Nambi e da década de 60 sobre parte da lagoa da Sapiranga e seu sangradouro, avançam sobre a hidrografia, aterrando e transformando o que era leito de rio e lagoa em área para construção. Neste momento, a natureza constitui uma barreira à expansão que, uma vez superada, é completamente ignorada.

É uma apropriação privada da natureza enquanto riqueza a partir da dominação. Uma vez apropriada e transformada em mercadoria, perde-se a concepção social de natureza enquanto natureza. A natureza passa a ser barreira. O próprio meio biofísico espoliado para a acumulação de novo capital é, paradoxalmente, também barreira. A própria terra, riquezanatural, transformada (ou metamorfoseada - vide Aldigueri, 2017) em valor aparente, representa uma barreira física para a expansão da capitalização de valor.

Nos próximos capítulos, veremos que essas estratégias antigas de acumulação vão sendo somadas a novas estratégias também de acumulação, aliadas a estratégias de aparente valorização pela natureza. 


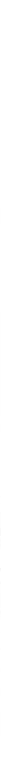




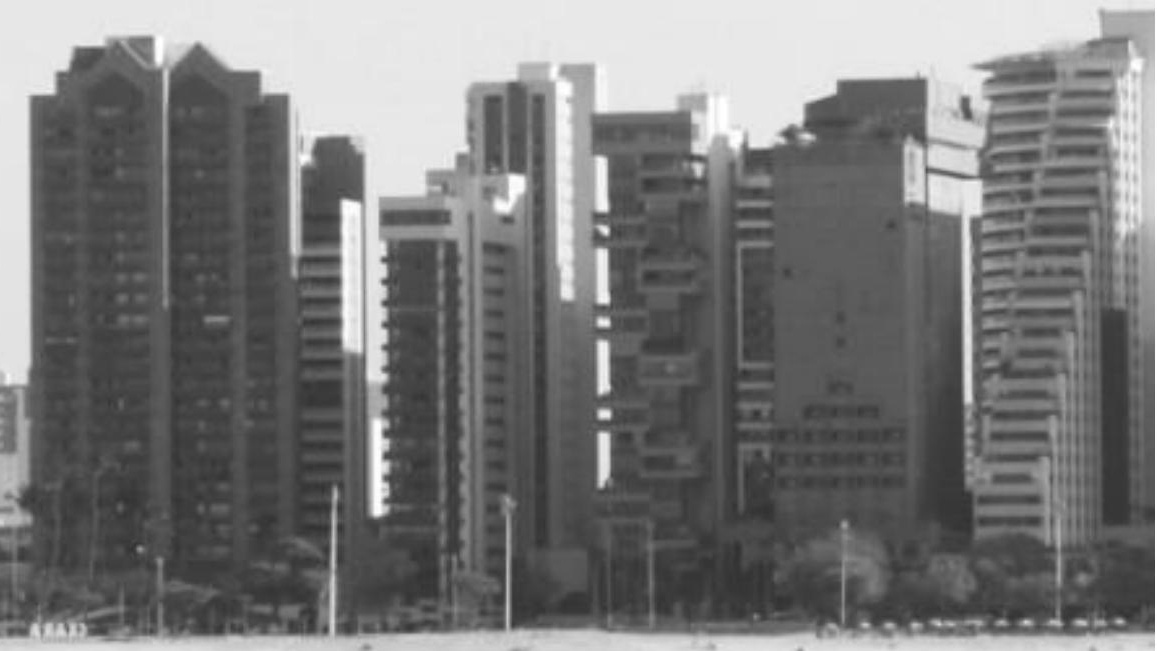

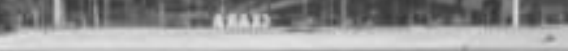


FOTO: SARA VIERA ROSA, 2015

JANELA DO RIACHO MACEIÓ

LOCAL: BEIRA MAR - FORTALEZA, CE 


\section{CAP. 02. "VALORIZAÇÃO" PELA}

\section{NATUREZA}

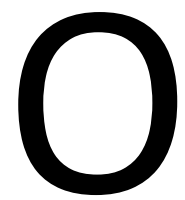

capítulo anterior descreve como a espoliação da natureza e do ser humano (também natureza), foi essencial para a conformação da sociedade capitalista europeia e brasileira. A partir de exemplos do século XIX e XX, demostramos como esses processos espoliativos foram importantes para a acumulação de capital e para a produção da cidade de Fortaleza.

Neste segundo capítulo, veremos que os processos de espoliação da natureza, gerando acumulação de capital, acumulação pela natureza, continuam ocorrendo no século XXI, ora com as mesmas estratégias anteriores, ora com estratégias novas e mais complexas. Contudo focaremos em como esses processos se desenvolvem, não só ao ponto de gerar acumulação pela natureza, mas também ao ponto de gerar valorização pela natureza, mesmo que seja uma aparente valorização ou valorização fictícia.

Assim, a valorização aparece no título do capítulo entre aspas, porque nem sempre ela vai ser uma valorização real. Em grande medida, ela é aparente (fictícia), e quando é real, ela não provém da natureza, como aparenta por puro fetiche, pois na realidade ela é produzida pela exploração da força de trabalho envolvida no processo. Quando não há trabalho envolvido, não há produção de valor, mas valores são capitalizados, gerando sobrepreços ainda mais elevados, mesmo sem produção alguma, e fazendo com que a aparente valorização, mas na verdade capitalização, termine reforçando processos espoliativos no total.

De agora em diante, focaremos na legislação ambiental e urbana municipal, no que tange especialmente à demarcação de zonas de proteção e preservação ambiental ${ }^{100}$, já que a

\footnotetext{
100 Faço esse recorte, apesar de entender a natureza como algo muito mais abrangente, que envolve qualquer porção de terra por si só e o ser humano, para compreender as implicações dessa categoria social, desse "contrato social" que define o que deve ser ou não protegido e preservado, o que é ou não natureza, nos processos de acumulação e valorização do capital imobiliário e nos processos de capitalização e espoliação. As crises ambientais da segunda metade do século XX, sobretudo as da década de 70 , levaram ao surgimento de teorias econômicas que passaram a reincorporar a preocupação com a questão ambiental e a contestar o modelo neoclássico convencional. Desde então tem-se, por vezes, uma tentativa de conciliar o crescimento econômico com a preservação ambiental. No campo do planejamento e do direito urbano, houve uma evolução da legislação ambiental desde então, que passou a adotar, entre outras medidas, a demarcação de áreas ambientalmente
} 
demarcação legal representa um reconhecimento ou acordo social do que seria natureza. Contudo veremos que esse reconhecimento nem sempre acontece.

Para exemplificar a suposta (aparente) valorização pela natureza, vamos utilizar o caso do instrumento urbano Operação Urbana Consorciada, que vem sendo idealizado no município desde o começo da década de 2000 , focando nos casos que se encontram em processo de implementação.

\subsection{O FETICHE DA MERCADORIA NATUREZA}

A natureza nem sempre é compreendida socialmente como natureza. Por vezes, apenas alguns elementos que estão sobre este substrato o são, como rios, flora e alguns tipos de fauna, considerando que o bicho homem quase sempre enxerga a si mesmo como algo à parte da natureza. Alguns tipos de relevo ou de terra também podem ser considerados natureza, como montanhas, encostas, dunas, entre outros. Isso varia conforme a época, a cultura e o estado de conservação desses elementos. Aquelas terras que abrigam exemplares de hidrografia, fauna e flora condizentes com uma "natureza intocável" (algo mais próximo do que seria uma primeira natureza) têm mais chances de serem consideradas natureza, enquanto um rio ou lago urbanos e poluídos podem ser vistos como esgoto e passíveis de soterramento porque já tiveram sua "dinâmica natural" alterada. E frequentemente uma natureza inventada (HIDALGO, et.al, 2016) (terceira natureza), como um parque urbano criado do zero com espécies exógenas, ou um lago cristalino artificial, pode ser considerada mais natureza que muitas áreas mais próximas de uma primeira natureza. A relação também com o que é considerado natureza muda conforme a época, a região e a cultura. Disso, podemos tirar que a natureza é uma categoria social.

La naturaleza es una categoría social, es decir lo que un determinado estadio del desarrollo social vale como naturaleza, el modo en que ocurre la relación entre esta naturaleza y el hombre y la forma en que se produce el ajuste entre éste y aquélla y, por lo tanto, lo que la naturaleza tiene que significar en lo que respecta a su forma

\footnotetext{
mais frágeis ou de maior relevância ambiental e a regulamentar restrições de uso nestas. No Brasil, destacam-se o Código Florestal (Lei Federal no 12.651) aprovada em 1962 e atualizada em 2012; mais recentemente o Sistema Nacional de Unidades de Conservação da Natureza (Lei n 9.985/2000); e a nível municipal os Planos Diretores e zoneamentos municipais.
} 
y contenido, su alcance y objetividad, está siempre socialmente condicionado (LUKÁCS, 1923, p. 240 apud SCHMIDT, 2011, p. 77 e 78. Grifo meu)

Quando a natureza é transformada em mercadoria, ela é "obscurecida pela forma mercadoria" ( MARX, 1934). Quando transformamos a natureza em mercadoria perdemos a essência da natureza, passamos a enxergá-la apenas como valor, como mercadoria que pode ser trocada pela mercadoria dinheiro. No entanto, no capitalismo, se o produto não vira mercadoria, não tem validade social. No momento que a natureza vira mercadoria, ela passa a ter validade social e importância, o que por um lado parece bom, mas por outro aliena ainda mais o ser humano. A natureza não é vista mais como natureza, ela é vista como valor. Uma vez sendo uma mercadoria, o acesso a ela passa a ser somente pela troca de mercadoria, mercadoria dinheiro. É necessário pagar um preço. Quem não tem dinheiro para comprá-la, passa a não ter acesso, nem direito de uso sobre a natureza. Quem pode comprar, compra a propriedade privada sobre esta, que lhe confere monopólio de uso... incluindo o direito de degradar.

Outro aspecto negativo é a relação social que se estabelece com a natureza quando esta assume a forma mercadoria. A relação passa a ser a de compra e venda, o ser humano se desconecta mais ainda (alienação). Utilizando o mesmo exemplo de Harvey, "é como a alface que parece vir do supermercado", ou da carne vermelha que vem também do supermercado embalada em uma bandeja de isopor. A natureza também começa a aparentar vir do mercado, e todo o processo e circuitos naturais, o tempo necessário e trocas de energia da própria natureza para conceber a si mesma, passam a ser desconhecidos do ser humano, assim como os processos de exploração no plantio e colheita da alface.

O fetiche ${ }^{101}$ da forma mercadoria ( MARX, 1934) obscurece ainda mais o processo de captura de valor de mercadorias que não tenham tempo de trabalho individual investido, que é o caso da natureza. Obscurece as relações sociais, criando a aparência de que o preço da terra provém do mérito de seu proprietário. Assim, o fetiche da mercadoria permite a criação da

\footnotetext{
101 O fetichismo seria a adoração de divindades puramente materiais: o fetichista é o homem que, por ignorância, medo, desejo e loucura, adora pedras, animais e toda espécie de matéria bruta e sórdida. O fetichista desconheceria a verdadeira causalidade física do mundo, as leis de Deus e as ideias de belo e de universal. Além disso, ele seria incapaz de figuração, isto é, de analogia, metáfora, de pensamento representacional, e por isto o fetichista, a partir de sua necessidade de superstição para se proteger de um mundo que não compreende nem domina, adoraria uma coisa qualquer, o mais vil ser que encontrasse no meio do mato. $O$ fetichista projetaria seus desejos sobre este objeto aleatório e se iludiria, imaginando que o objeto possui poder sobre a natureza e sobre a vida humana. Sobre esses objetos ele faz juramentos, contratos, estabelece toda uma ordem social aparentemente caótica, regulamentada pelos fantasmas que crê habitarem o mundo. (PIRES, 2014, p. 351)
} 
relação social em que um rentista continue sendo rentista, capturando o valor gerado pelo trabalho social investido por muitos, sem que ele mesmo não tenha investido trabalho nenhum. Ao mesmo tempo que a forma mercadoria da natureza obscurece os processos naturais, pondo em risco a sua existência, no mundo das mercadorias, a natureza parece só poder ter existência social se for transformada em mercadoria.

\subsection{DESMERCANTILIZAÇÃO ESTATAL MERCADORIA NATUREZA}

A regulamentação e o controle do uso do solo refletem no valor ${ }^{102}$ que poderá ser gerado, pois determinam o volume máximo de área construída sobre os terrenos. Assim, definem quais terrenos podem abrigar maior hora abstrata de trabalho social, resultando em empreendimentos construídos que abrigam maior ou menor valor, bem como maior extração de mais-valia pela exploração do trabalho aí contido.

Ao se restringir a área/volume total que pode ser construído em determinado terreno, restringe-se também a possibilidade de valor que poderá ser gerado (e por tanto, de mais valia-que poderá ser apropriada) no futuro, durante o processo de produção imobiliária. Se a restrição chega ao ponto de transformar o terreno em área não edificante, anula-se então a possibilidade de geração de valor dentro do processo de produção imobiliária (ao menos, em um cenário de produção legal). Se não há produção, não há geração de valor ${ }^{103}$.

Nesse caso, o valor de uso para a produção imobiliária é reduzido ou anulado, já que não pode haver produção imobiliária aí ${ }^{104}$, "[...] se ninguém quiser, precisar ou desejar um valor de uso em particular oferecido em determinado lugar e momento, isso significa que o produto não possui valor. Não é nem sequer digno de ser chamado mercadoria." ( HARVEY, 2018, p. 82).

\footnotetext{
102 Teoria do valor trabalho de Marx. "[...] o espaço como condição, meio e resultado dessa produção tem a terra um elemento indissociável, um valor de uso que privatizado e comercializado tem preço. Por isso, expressa valor de mercado, mas, por não ser um resultado do trabalho, não contêm tal substância, o seu "valor" é apenas uma expressão do seu preço" (Pereira, 2017, p. 186).

103 "[...] a base da produção e da apropriação de mais-valor está na exploração da força de trabalho vivo no processo de produção, não no mercado" ( HARVEY, 2018, p. 36).

${ }^{104}$ Nota-se que, apesar de perder o valor de uso para o setor de produção imobiliária, a terra-natureza pode permanecer com outros valores de uso mercantis ou não mercantis, como local de lazer, desfrute de paisagem, serviços ambientais, e moradia não-mercantil, como aponta Aldigueri (2017).
} 
Perde-se então a base que sustenta o valor, pois o valor só se realiza enquanto valor se existir valor de uso para terceiros ( HARVEY, 2018; MARX, 2011).

Diminui-se também a possibilidade de especulação de geração de valor futuro pela produção imobiliária futura e, consequentemente, a possibilidade desse valor futuro (que não existe mais, nem como possibilidade) de ser capitalizado no preço atual do terreno, reduzindo assim a possibilidade de aumento do preço deste e de aumento da renda $a^{105}$ do seu proprietário.

Neste caso, ocorreria uma redução do valor da mercadoria natureza-terra, mesmo que o valor reduzido seja um valor aparente, já que na essência ele é na verdade capitalização de valor futuro. Podemos dizer que há aí um processo de desvalorização da terra. Uma desvalorização aparente. Aparente, porque não é real de fato, assim como o valor da natureza e a valorização da terra não é real de fato, mas a forma fetichizada da mercadoria nos faz parecer que é. Então, estamos falando da perda de valor de algo que não tem valor na sua essência, apenas na sua aparência ${ }^{106}$.

Todavia não podemos esquecer que, além da capitalização de valor futuro, esse valor também pode ser capitalizado de outros setores. Desse modo, a desvalorização é aparente, não só porque estamos falando da perda de valor de uma mercadoria que não tem valor, mas porque, em geral, o preço do terreno não reduz de fato ${ }^{107}$. Contudo, a inviabilização de produção imobiliária no urbano, inviabiliza a realização do negócio com esse terreno, inviabiliza, de certo modo, o terreno enquanto mercadoria, embora o valor aparente inicial deste terreno permanece estocado esperando um dia ser resgatado.

Enquanto estocado, parado, é capital negado, mesmo sendo a natureza-terra capital fictício ${ }^{108}$. "O capital é valor em movimento, e uma pausa ou redução na velocidade desse

\footnotetext{
105 “[...] temos que toda renda "tem de constituir sempre fração da mais-valia", podendo ser fração da mais-valia da própria mercadoria ou "será por certo, fração da mais-valia de outras mercadorias, isto é, das mercadorias que se trocam por essa mercadoria que tem preço de monopólio"'” (MARX, [1894] s.d., L3, Apud PEREIRA, 2017, p. 189).

106 Poderíamos usar também o termo valorização e desvalorização fictícia, termo utilizado por Aldigueri (2017) e Marx ( 1934). Polanyi também utiliza o termo fictício ao se referir ao conceito de mercadoria fictícia ( POLANYI, 1980) geradas sem trabalho: terra, trabalho e dinheiro. Todavia, vamos dar preferência a explicação a partir do conceito do fetiche da mercadoria de Marx e procurar utilizar mais o termo aparente.

107 "[...] preço de mercado é o mesmo para todas as mercadorias da mesma espécie, por muito variem as condições de produção dos produtores individuais" (Max, [1865]1974, apud Pereira, 2017, p. 171).

${ }^{108} \mathrm{~A}$ tese de C. Aldigueri (2011) discute esse papel da terra funcionando enquanto capital fictício, pois mesmo sem ter valor (por isso a denominação de fictício) a terra tem funcionado como valor em circulação, assim como o capital dinheiro. "A instrumentalização da terra como capital fictício tornou-se mais evidente na atualidade, em decorrência do contexto de financeirização mundial e seus impactos na produção imobiliária, o que acarretou uma reestruturação na produção do urbano, consequentemente, na produção da favela na cidade. [...] Entretanto, a terra tem seu funcionamento como capital
} 
movimento, por qualquer razão que seja, significa uma perda de valor, que pode ser ressuscitado em parte ou in toto somente quando o movimento do capital é retomado" (HARVEY, 2018, p. 80-81).

Assim, ao limitar o valor e o valor de uso da natureza-terra, em um processo de desvalorização aparente, limita-se também a possibilidade dessa porção de natureza funcionar como mercadoria, mesmo que esta outrora o fora. Partindo do pressuposto de que uma mercadoria deixa de ser mercadoria, poderíamos falar de um processo de desmercantilização.

O conceito de desmercantilização já vem sendo trabalhado por outros autores como Pírez e Aldigueri. Aldigueri (2017) traz o conceito para uma discussão sobre a desmercantilização da terra. Pírez (2016) trabalha com o conceito dentro da temática de urbanização, com destaque para as infraestruturas urbanas, que por vezes também incluem o acesso ao solo urbanizado. Ele destaca que, mesmo dentro do sistema capitalista, às vezes é necessário que o Estado proveja certos serviços que tendem a ser oferecidos como mercadorias sem ônus para uma parcela da população, promovendo assim uma ação de "desmercantilização Estatal".

Para solucionar as contradições capitalistas com relação aos baixos salários, solvência e reprodução da força de trabalho, o Estado adotou, ou geralmente adota, duas medidas principais. Uma monetária que constitui o financiamento e subsídio público para o consumo de famílias de baixa renda. E uma outra não monetária, onde o Estado assume a produção e gestão de serviços também de maneira subsidiada, gratuita ou com baixos custos para famílias de baixa renda (PÍREZ, 2016, p. 139).

A degradação ambiental é também uma das contradições do capitalismo destacada por Harvey (2016) como uma das contradições perigosas, que poderia pôr em risco o próprio sistema. Desse modo, a partir também do surgimento de correntes ecológicas de conservação da natureza preocupadas com o futuro das espécies e do ser humano, foi sendo necessário um controle sobre o processo destrutivo do capital, refletindo na definição de porções de natureza que passariam a ser reconhecidas socialmente como natureza e que deveriam ser 
preservadas. O Estado passou então a normatizar e regulamentar pedaços de natureza que deveriam ser conservados, restringindo seu uso.

Ao restringir completamente a construção em um determinado terreno - o que ocorre na nossa legislação quando determinada área é socialmente identificada como ambientalmente importante, devendo então ser preservada - ademais do processo de desvalorização, no caso, mais precisamente, a possibilidade de criação de valor futuro é transfigurada para o presente como antivalor, ocorre também um processo de desmercantilização Estatal e a possibilidade de uma ressignificação desta enquanto riqueza comum, espaço de fruição pública a ser apropriado individualmente ou coletivamente e que presta serviços ambientais para o funcionamento saudável da cidade. Em alguns casos, como na criação de parques, há inclusive o processo anterior de desprivatização dessa terra, por meio da desapropriação, para que estas terras passem a ser estatais (públicas) e pertencentes ao parque e à sociedade, como é o caso, em Fortaleza, do Parque do Riacho Maceió, que será tratado nesse capítulo, e de outros parques, como o recente Parque do Cocó decretado em 2017.

Há que se fazer a ressalva de que essa desmercantilização estatal da natureza é frágil, uma vez que algumas vezes tem sido facilmente remercantilizadas, por meio de alterações na legislação, como demostraremos ao longo deste capítulo e no próximo. Assim, esse processo de desmercantilização estatal da natureza, a princípio bem intencionado, tem potencializado outros processos de valorização imobiliária a partir de novas estratégias e aperfeiçoamento de outras.

\section{Correntes ecológicas e rebatimento sobre a} regulamentação urbana

A crença no crescimento e econômico e as crises ecológicas, que se sucederam anos 1960 e 1970, desencadearam o crescimento de diversas correntes ecológicas ou ambientalistas. Martinez Alier destaca três, as quais denomina: o "culto à vida silvestre", o "evangelho da ecoeficiência", e a "justiça ambiental e o ecologismo dos pobres", destacando o predomínio, e, por vezes coexistência, principalmente das duas primeiras.

O "culto ao silvestre" agrupa os ecologistas que enxergam a natureza como algo sagrado, e a associam principalmente à natureza intocável, aos bosques primários e aos cursos d'água. 
Visam "[...] preservar e manter o que resta dos espaços da natureza original [...] manter reservas naturais, denominadas parques nacionais ou naturais, ou algo semelhante, livres da interferência humana" (MARTíNEZ ALIER, 2009, p. 22 e 24). Assim, enxergam a importância da natureza e das espécies, seres vivos, em si mesmo, defendendo o direito da existência de cada uma. Todavia, excluem o bicho homem, já que a natureza deve ser preservada sem a interferência humana, e os limites de áreas naturais delimitadas, como parques ou áreas de preservação, que não podem coexistir com habitações humanas.

Já a corrente do "evangelho da ecoeficiência" não reconhece o direito intrínseco das demais espécies existirem. Para ela, a conservação da natureza está associada à manutenção dos recursos necessários para a vida e a economia humana. A atuação de seus seguidores "[...] está direcionada para os impactos ambientais ou riscos à saúde decorrentes das atividades industriais, da urbanização e também da agricultura moderna" ( MARTíNEZ ALIER, 2009, p. 26). Natureza, para estes ambientalistas, está associada mais às ideias de recursos naturais, capital natural e serviços ambientais. Em geral, são adeptos da ideia de desenvolvimento sustentável e acreditam na possibilidade de um crescimento econômico sustentável, por meio de boa utilização dos recursos e da modernização ecológica.

A terceira corrente, mais recente, ora nomeada como justiça ambiental, ora como ecologismo dos pobres, ou ecologismo popular, ou ecologismo da sobrevivência humana, dentre outros nomes, apesar de, em alguns momentos e alguns lugares, reconhecer a sacralidade da natureza, está mais preocupada com a sobrevivência da espécie humana, em especial pela sobrevivência dos pobres humanos do presente, "sua ética nasce de uma demanda por justiça social contemporânea entre os humanos"( MARTínEZ ALIER, 2009, p. 34). Preocupa-se com os impactos e conflitos causados pelo crescimento econômico e pela desigualdade social, em especial pelos grupos de pessoas mais pobres e vulneráveis que sofrem mais com privação de acesso aos recursos e serviços ambientais, e com problemas de poluição e contaminação, como nos casos apontados pela literatura americana de racismo ambiental (MARTÍNEZ ALIER, 2009).

Dessas correntes e das bases científicas que as sustentam, houve uma transposição para uma conservação normativa, influenciando diversos tratados internacionais e legislações nacionais e a níveis municipais. No âmbito da legislação urbana, influenciaram a criação de normativas 
referentes a áreas de preservação permanente, parques, áreas de proteção e manejo sustentável.

O "Culto ao Silvestre", por exemplo, influenciou a regulamentação do uso, no caso do Brasil, de áreas de preservação, incluindo aí unidades de conservação integral, como parques, e as áreas de preservação permanente, a nível nacional ${ }^{109}$ e municipal. Nestes casos, o objetivo é a manutenção das características originais dessas áreas, sem influência humana, impossibilitando a permanência de ocupações dentro destes limites. Em alguns casos, essas medidas geram conflitos ambientais com populações tradicionais que habitam essas áreas há gerações, ou mesmo com populações mais recentes, pobres e excluídas do sistema do mercado de terras. Mais recentemente, sob influência de correntes mais ligadas ao ecologismo dos pobres, esses marcos normativos têm sido revisados e aberto exceções para casos de interesse social e de ocupações de populações tradicionais ${ }^{110}$.

A seguir apresentaremos uma breve descrição dos planos de ordenamento do uso do solo de Fortaleza para ilustrar essa evolução do caráter protecionista e preservacionista dentro do marco normativo urbano municipal, dando maior ênfase aos dois mais recentes, o Plano Diretor de Desenvolvimento Urbano (PDDU) aprovado em 1992 e que antecede o plano vigente, o Plano Diretor Participativo (PDP) aprovado em 2009, em especial este último que ainda vigora.

\section{A conservação da natureza no marco normativo urbano municipa|111}

No início da formação do mercado de terras em Fortaleza, décadas de 1930 a 1960 (cap. 01), o controle sobre o uso e ocupação do solo por parte do estado era bem pequeno, permitindo

\footnotetext{
109 No Brasil, podemos destacar dentro do marco da legislação ambiental nacional, mas que refletem a nível urbano nos municípios, a Lei que institui o Código Florestal Brasileiro, ainda em 1965 (Lei $n^{\circ} 4771$ de 1965), revogada e substituída pela Lei no 12.651, de 25 de maio de 2012, e o Sistema Nacional de Unidades de Conservação - SNUC (Lei no 9.985, de 18 de julho de 2000 e Decreto № 4.519, de 2002).

110 Martínez Alier destaca: "Os técnicos do setor ambiental já contam com alternativas para evitar o tão frequente conflito entre populações tradicionais e áreas destinadas à preservação. A expulsão de habitantes entre populações não cessou. Porém, instituíram-se formas de atenuar os impactos a partir do reconhecimento do mosaico de unidades de conservação, que permitem que determinadas atividades sejam mantidas sem prejuízo da conservação ambiental e da população que vive na região" ( MARTíNEZ ALIER, 2009, p. 11).

111 Não se tem o objetivo aqui de detalhar o marco regulatório urbano de Fortaleza, mas, apenas destacar a evolução das plantas de expansão aos zoneamentos que previam áreas de preservação, assim, como a chegada de unidades de conservação, e como estas áreas ora avançam em determinados espaços, ora recuam.
} 
com que o proprietário privado da terra tivesse liberdade em transformar quase todas as terras em mercadorias, incluindo natureza-não terra, como lagoas e rios que foram loteados e ocupados.

Os primeiros planos e plantas de Fortaleza pautavam principalmente questões relacionadas ao sistema viário e arruamento. Havia uma tendência à canalização da hidrografia e à transformação desta em avenidas canais, como a Av. Aguanambi, Av. Eduardo Girão e Av. Bezerra de Menezes, propostas no Plano Diretor para Remodelação e Expansão de Fortaleza /1947-1948, do urbanista Sabóia Ribeiro e no Plano Diretor de Fortaleza /1962-1963, do urbanista Hélio Modesto. É neste último, quando é feita a recomendação de transformar toda a orla marítima em avenida-parque à beira-mar, que tem origem o calçadão da Avenida Beira Mar, hoje, a área mais "valorizada", com um dos metros quadrados mais caros, da cidade.

A primeira planta com caráter de planejamento registrada para Fortaleza é a elaborada pelo engenheiro Antônio José da Silva Paulet, com base em seus levantamentos feitos entre 1812 e 1818 ( FORTALEZA, s/d).

A partir da década de 1960, com os Planos Diretores, o estado deixa de ser um mero regulador e disciplinador do uso do solo para desempenhar um papel de promotor do desenvolvimento do município (ACCIOLY, 2008). Até então, tanto o período entre 1824 e 1932, representado pelas plantas de expansão, os códigos de posturas e as intervenções setoriais, como aquele entre 1932 e 1963, expressos nos planos de melhoramentos e no primeiro código urbano (classificação de Accioly, 2008), ainda não há um reflexo direto no que tange ao caráter conservacionista da natureza.

Em 1963, é lançado o Plano Diretor da Cidade de Fortaleza (PDCF), elaborado pelo arquiteto e urbanista Hélio Modesto. Nota-se que, neste momento, ainda não há uma preocupação de viés protecionista do meio ambiente. A natureza, neste plano, é colocada mais como um espaço de lazer, turismo e contemplação paisagística. A questão ambiental, no plano, aparece no levantamento de "acidentes naturais" (Figura 44), discriminando as áreas livres, de arborização e interesse paisagístico. Quando transportada a proposta de zoneamento do plano, estas áreas aparecem como áreas de proteção paisagística.

Accioly (2008) cita a proposta elaborada por Hélio Modesto de criação de áreas de proteção y na Barra do Ceará, na praia do Farol do Mucuripe, nas dunas do Pirambu, nas Salinas do 
Cocó, no curso do Pajeú, no rio Jacarecanga, na Casa José de Alencar, no forte Fortaleza de Nossa Senhora da Assunção e no entorno das lagoas do Porangabussu, da Parangaba, do Opaia e da Messejana. Destaca ainda a intenção de tratamento paisagístico da avenida BeiraMar e do Parque Pajeú. “No Parque Barra do Ceará seriam incluídos o Jardim Zoológico e o Jardim Botânico, instalações esportivas, cívicas, e parques, arraial, pousadas, colônias de férias, coqueiral, na orla arborizada" ( ACCIOLY, 2008, p. 155) (Figura 45). Percebe-se aqui uma atenção dada ao caráter paisagístico do litoral, uma tentativa de ordenar e voltar parte do desenvolvimento da cidade para a faixa de praia, prevalecendo usos muito mais de caráter de turístico-econômico do que de caráter conservacionista.

Observando as plantas de levantamentos do estudo preliminar do plano, como o levantamento de acidentes naturais (Figura 44) e o zoneamento final (Figura 45), pode-se perceber também que houve uma maior preocupação com as áreas já ocupadas da cidade de Fortaleza, mesmo já existindo, nessa época, loteamentos aprovados em setores bem periféricos, como foi mostrado no cap. 01 (Figura 9). Pelo recorte dos mapas do levantamento, assim como apontado anteriormente, o Rio Cocó e as dunas da Praia do Futuro/Cocó aparecem como um limite físico para a expansão da cidade e seu planejamento. A escala dos mapas dos levantamentos só muda de forma a abranger todo o limite atual do município nas cartografias sobre circulação e transporte, considerando a conexão com o restante do estado. 
Figura 44. Plano Diretor Hélio Modesto - levantamento acidentes naturais, áreas livres, locais de interesse paisagístico

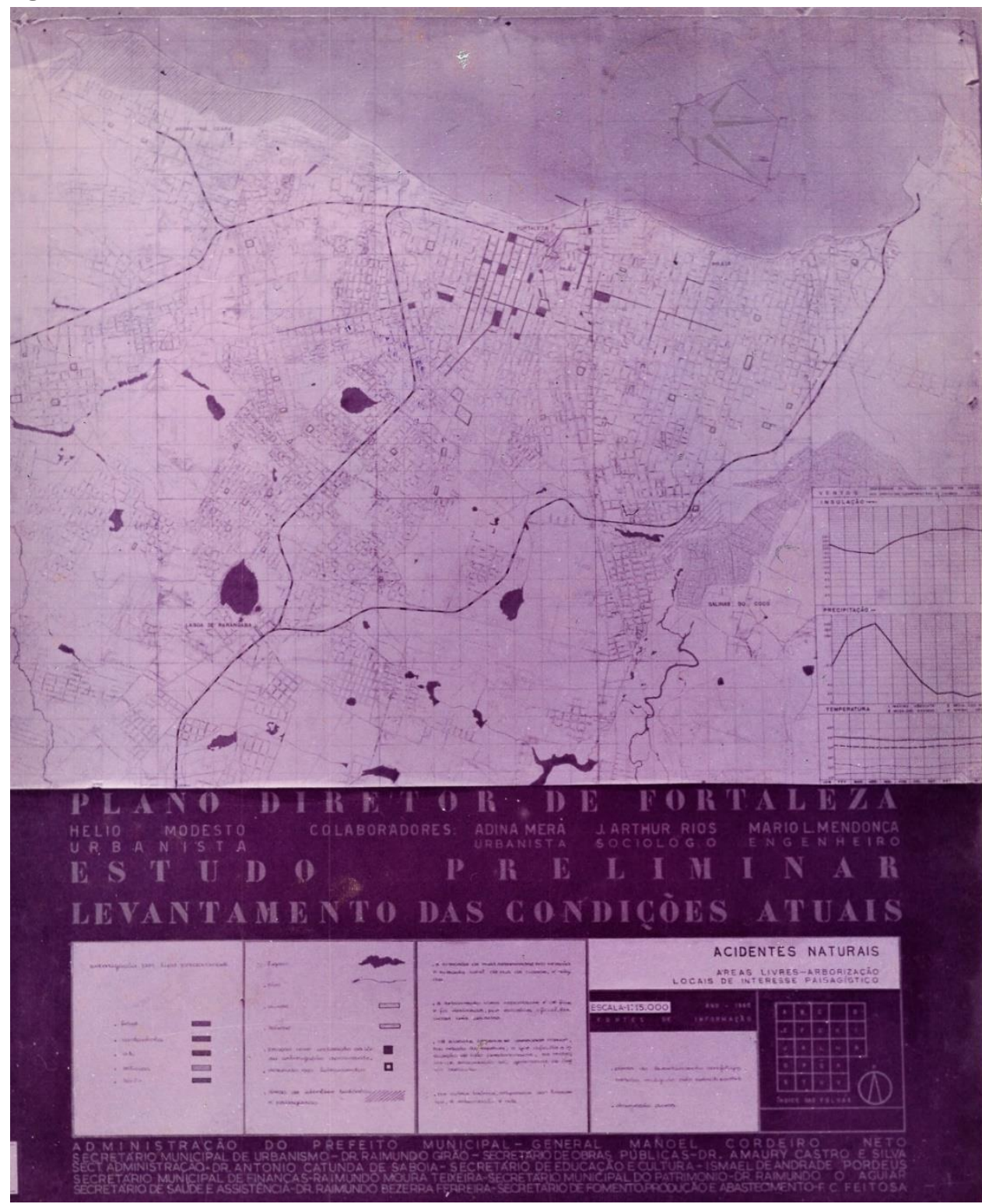

Fonte: Pranchas do Estudo preliminar do Plano Diretor de Fortaleza de Hélio Modesto, 1960.

Já no Plano de Desenvolvimento Integrado da Região Metropolitana de Fortaleza (PLANDIRF) de 1972 e na Lei de Parcelamento, Uso e Ocupação do Solo (LPUOS) de $1975^{112}$, é possível perceber um olhar para todo o município e um esboço do que viriam a ser as áreas classificadas como de preservação permanente nos planos mais recentes. Nesta legislação, estas áreas aparecem com a denominação de Zonas Especiais de Preservação Paisagística, Turística e Reserva Verde e passam a abranger toda a extensão, dentro do município, dos rios Maranguapinho e Cocó; pequeno trecho do Rio Maceió, já próximo a sua foz; e algumas

\footnotetext{
112 Lei Municipal no 4.486 de 1975.
} 
lagoas, como a Lagoa da Parangaba, a Lagoa de Messejana e a Lagoa da Precabura; pequenas porções da faixa de mangue da foz do Rio Ceará e Rio Cocó.

Apesar desse avanço, essas delimitações foram bem inferiores ao que já havia sido estabelecido a nível nacional pela Lei do Código Florestal, que desde $1965^{113}$ define faixas de preservação permanente (APPs) ao longo dos recursos hídricos, bem como ao longo das áreas com vegetações de mangue e de dunas. A LPUOS de 1975 deixou de fora grandes trechos de mangue do Rio Cocó e do Rio Ceará; pequenos olhos d'água que ajudam na manutenção do Cocó; diversos recursos hídricos, dos quais podemos citar, o Rio Coaçu, que liga a Lagoa da Precabura ao Rio Cocó, a Lagoa do Papicu e o Riacho Maceió/Papicu, e o Riacho Estivas, localizado a sudoeste do Rio Maranguapinho, que veio sendo apagado completamente das cartografias de Fortaleza (ver Figura 12 e Figura 14, cap. 01). Também não são demarcadas as faixas de dunas móveis, nem tão pouco a planície fluvial dos rios de maior porte, como o Cocó (ver Figura 6). Estas últimas áreas, apesar de não serem consideradas APP pela Legislação federal supracitada, são áreas de extrema importância para o contexto estadual de escassez hídrica. Há que se destacar que muitas destas áreas, apesar de já loteadas, como foi visto no capítulo 01, ainda não estavam ocupadas.

O zoneamento apresentado pela LUOS de 1979, já se parece um pouco mais com as áreas de preservação atuais, englobando maior quantidade de recursos hídricos (Figura 47 - E1), e incorporando também a categoria de proteção ambiental das zonas especiais referentes às dunas do Cocó/praia do Futuro e dunas da Sabiaguaba (Figura 47 - E6). Por outro lado, a zona

\footnotetext{
113 Lei Federal no 4.771 de 1965, Código Florestal, define: Artigo $2^{\circ}$ - Consideram-se de preservação permanente, pelo só efeito desta Lei, as florestas e demais formas de vegetação natural situadas:

a) ao longo dos rios ou de outro qualquer curso d'água desde o seu nível mais alto em faixa marginal cuja largura mínima seja: 1) de 30 metros para os cursos d'água de menos de 10 metros de largura; 2) de 50 metros para os cursos d'água que tenham de 10 a 50 metros de largura; 3) de 100 metros para os cursos d'água que tenham 50 metros a 200 metros de largura; 4) de 200 metros para os cursos d'água que tenham de 200 a 600 metros; 5) de 500 metros para os cursos d'água que tenham largura superior a 600 metros;

b) ao redor das lagoas, lagos ou reservatórios d'água, naturais ou artificiais;

c) nas nascentes, ainda que intermitentes e nos chamados "olhos d'água", qualquer que seja a sua situação topográfica, num raio mínimo de 50 (cinqüenta) metros de largura;

d) no topo de morros, montes, montanhas e serras;

e) nas encostas ou partes destas com declividade superior a $45^{\circ}$ equivalente a $100 \%$ na linha de maior declive;

f) nas restingas, como fixadoras de dunas ou estabilizadoras de mangues; (definidos em resolução do CONAMA)

g) nas bordas dos tabuleiros ou chapadas, a partir da linha de ruptura do relevo, em faixa nunca inferior a 100 (cem) metros em projeções horizontais;

h) em altitude superior a 1.800 (mil e oitocentos) metros, qualquer que seja a vegetação.

Parágrafo único - No caso de áreas urbanas, assim entendidas as compreendidas nos perímetros urbanos definidos por lei municipal, e nas regiões metropolitanas e aglomerações urbanas, em todo o território abrangido, observar-se-á o disposto nos respectivos planos diretores e leis de uso do solo, respeitados os princípios e limites a que se refere este artigo. (BRASIL, 1965, art. 2‥ Grifos meu)
} 
com maiores adensamentos construtivos definidos para a Aldeota e Meireles se estende até parte das Dunas do Cocó, incluindo trechos de dunas centenárias, como a quadra posteriormente definida, em 2009, como área de relevante Interesse Ambiental (ARIE) Dunas do Cocó ${ }^{114}$.

Em 1979, temos também a nível federal a Lei de Parcelamento do Solo, Lei no 6.766/79, que impõe a reserva de faixa não edificável, de 15 metros, ao longo das faixas de domínio público, bem como ao longo das águas correntes e dormentes, salvo maiores exigências da legislação específica. Aqui há um alinhamento da legislação urbana a legislação ambiental, porém na lei de Parcelamento, não é feita distinção das faixas não edificáveis pelo porte do recurso hídrico, como o é no Código Florestal.

Figura 45. Plano Diretor da Cidade de Fortaleza, elaborado por Hélio Modesto, 1962.

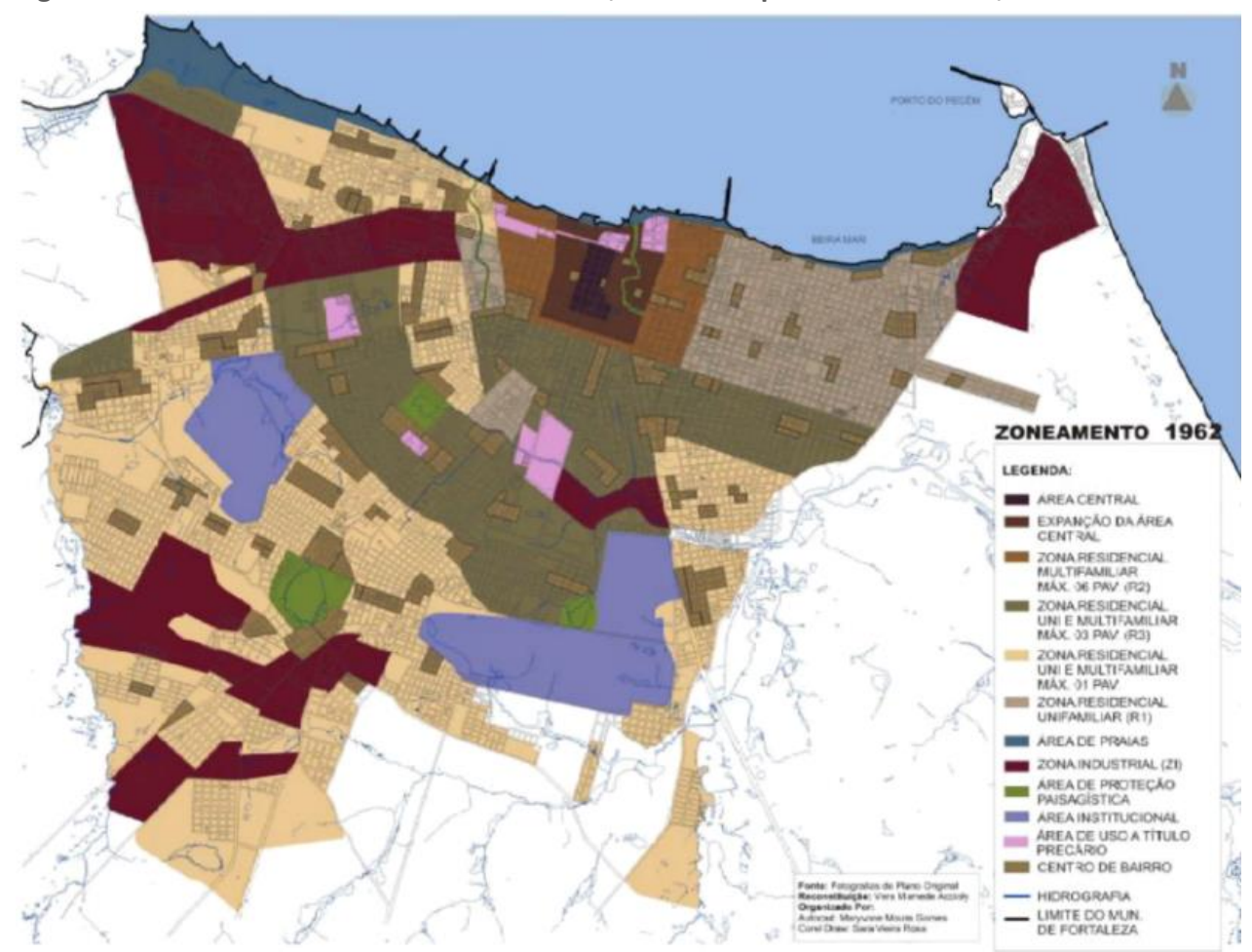

Fonte: ACCIOLY, 2008, p. 154

\footnotetext{
${ }^{114}$ Criada pela Lei Municipal n. 9502, em 2009, essa área, com loteamento aprovado, vem sendo alvo de importantes conflitos ambientais envolvendo, o governo, ambientalistas e proprietários, a pesar destes últimos não aparecem muito e serem mais representados pelo SINDUSCON.
} 

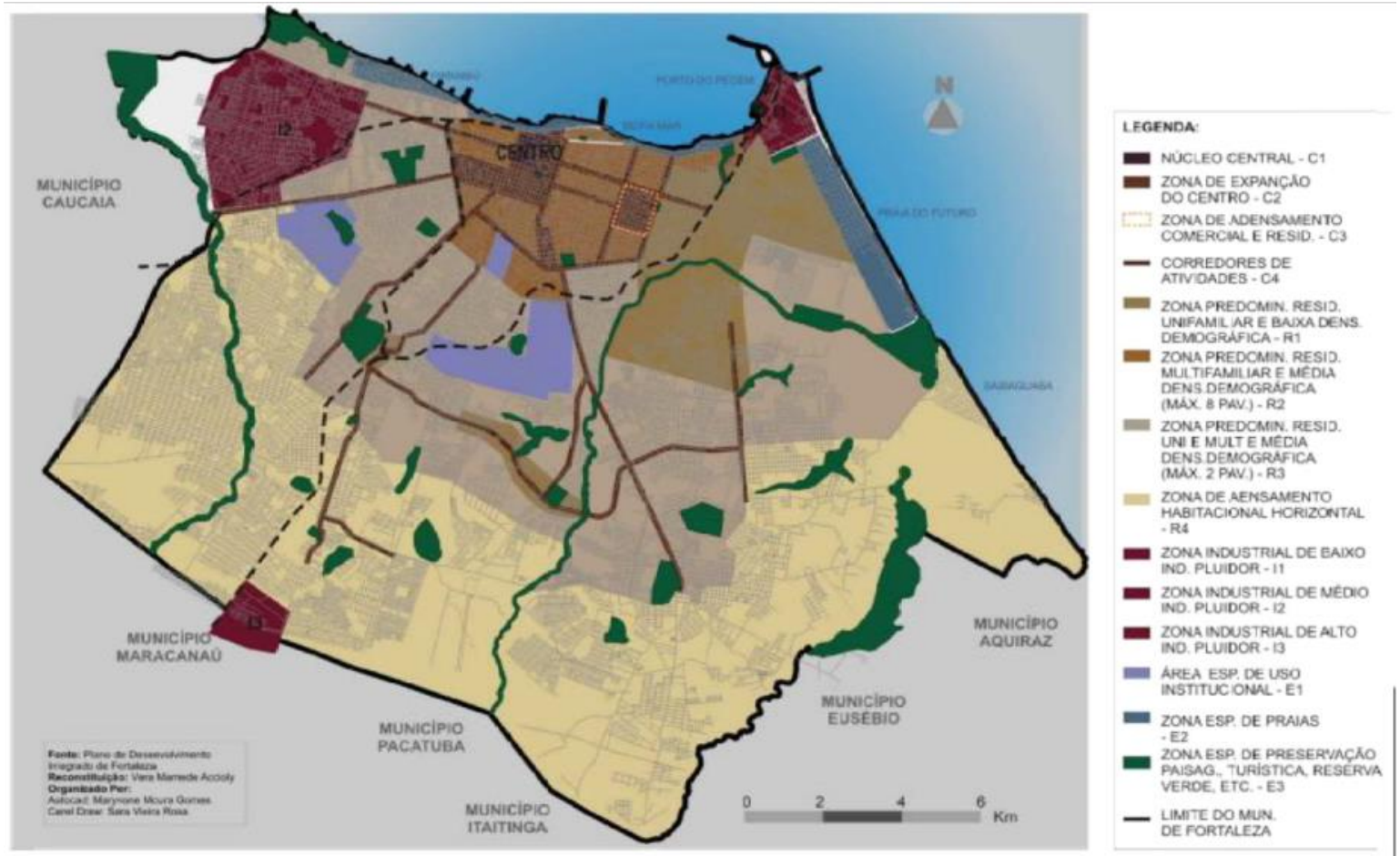

Fonte: ACCIOLY, 2008, p. 202

Figura 47. Zoneamento - LUOS de 1979

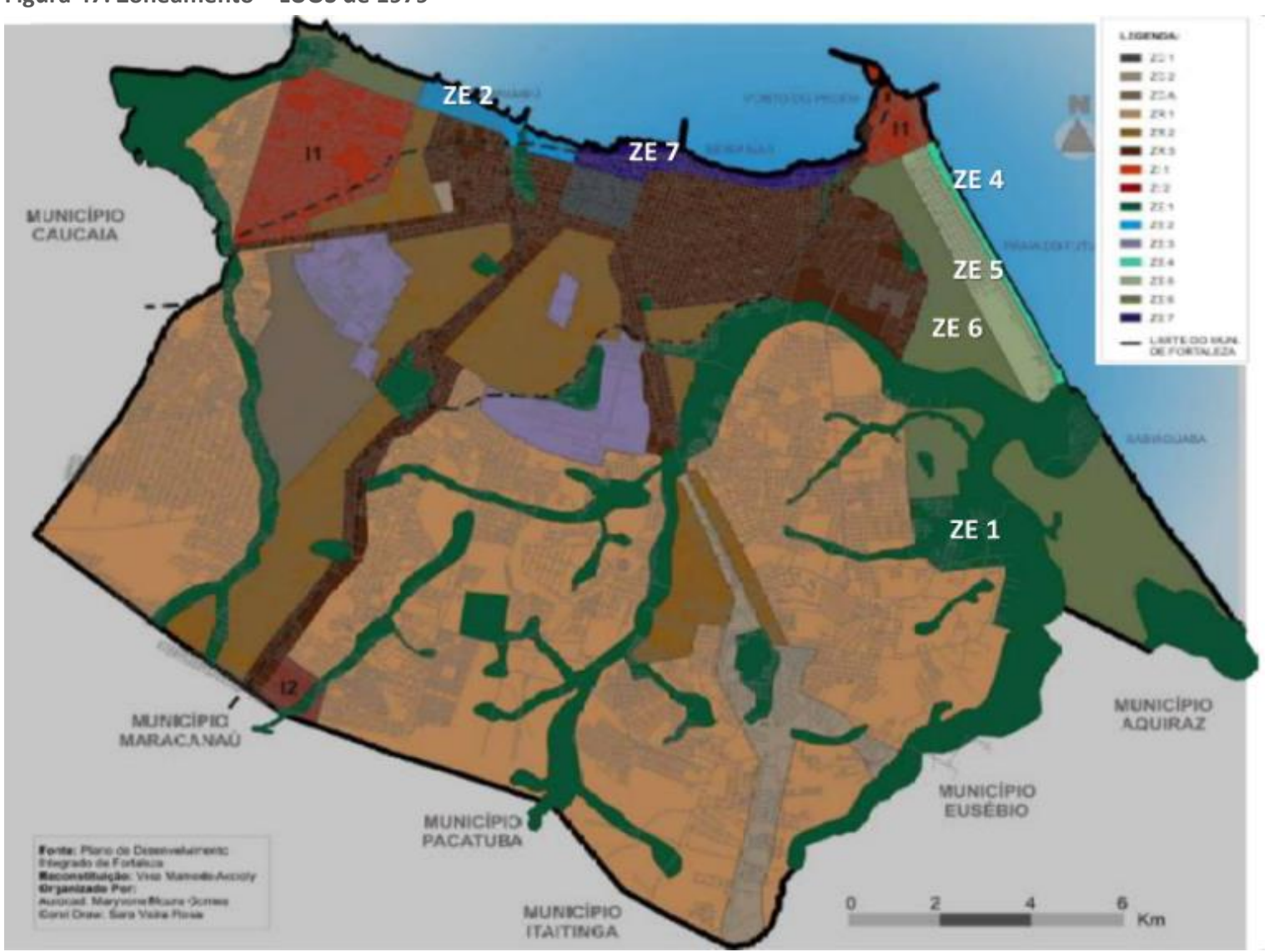

Fonte: ACCIOLY, 2008, p. 204. 
A Lei Orgânica Municipal (LO), em sua versão pós Constituição Federal (CF) ${ }^{115}$, seguindo esta, impõe com mais precisão alguns limites ao duplo monopólio da terra, passando, por exemplo, a estabelecer restrições de uso de áreas privadas para fins de proteção de ecossistemas (art. 206) e acesso público livre e franco às praias e lagoas (art. 209), por reconhecer o meio ambiente como bem de uso comum e de direito de todos (art. 194).

Juntamente com a CF/88, a LO de Fortaleza define como competência do município, a política urbana, o controle uso e ocupação do solo, incluindo a proteção, preservação e recuperação do meio ambiente natural e construído, dedicando um capitulo (capítulo III) inteiro para colocar tratar do meio ambiente.

Assim a LO e a CF, passaram a pautar e orientar os planos diretores e leis de parcelamento, uso e ocupação do solo, que seguiram a posteriori, incluindo diretrizes de preservação ambiental como essenciais no controle do uso e ocupação do solo, como por exemplo, o definido no art. 199: "A lei de uso e ocupação do solo urbano, integrante do plano diretor do Município e o código de obras e posturas, terá como diretriz geral o equilíbrio do meio ambiente, a preservação ecológica e a defesa da qualidade de vida" ( FORTALEZA, sd, art. 1999. Grifo meu). Define ainda que "as lagoas, as dunas, as praias, os mangues e as paisagens naturais notáveis são considerados de relevante valor ambiental, paisagístico e turístico, devendo sua delimitação, uso e ocupação serem definidas em lei"116 ( FORTALEZA, sd, art. 2000).

Dentre as obrigações impostas pela Lei orgânica ao município, em seu capítulo III, destacamos:

I - preservar e restaurar os processos ecológicos essenciais e prover o manejo ecológico das espécies e dos ecossistemas, de forma a garantir a preservação da natureza e a melhoria da qualidade de vida das populações;

II - preservar e restaurar a diversidade e a integridade do patrimônio genético, biológico e paisagístico, no âmbito municipal e fiscalizar as entidades de pesquisa e manipulação de material genético;

III - definir e implantar áreas e seus componentes representativos de todos os ecossistemas originais do espaço territorial do Município, a serem especialmente protegidos, preservados ou conservados, sendo a alteração e a supressão, inclusive

\footnotetext{
115 Lei Orgânica do município possuiu uma versão anterior a constituição Federal sob o número no 5930 de 13 de dezembro de 1984. Sua versão, pós constituição, e atualizada, pode ser consultada no site: <http://legislacao.fortaleza.ce.gov.br/index.php/Lei_Orgânica_do_Município>.

$116 \mathrm{O}$ art. 201, declara de relevante interesse ecológico, paisagístico, histórico e cultural: I - Os riachos Pajeú e Maceió, em especial suas nascentes; II - os rios Cocó, Ceará, Maranguapinho e Siqueira; III - a zona costeira e as faixas de proteção dos mananciais ( FORTALEZA, sd).
} 
dos já existentes, permitidas somente por meio de lei, vedada qualquer utilização que comprometa a integridade dos atributos que justifiquem sua proteção, preservação ou conservação, ficando mantidas as unidades de conservação atualmente existentes;

$[\ldots]$

VIII - estimular e promover o reflorestamento ecológico em áreas degradadas, objetivando especialmente a proteção dos recursos hídricos, bem como a consecução de índices mínimos de cobertura vegetal;

XVII - criar parques, reservas ecológicas, áreas de proteção ambiental e outras unidades de conservação, mantê-los sob especial proteção e dotá-los da infraestrutura indispensável às suas finalidades;

XX - recuperar a vegetação em áreas urbanas, segundo critérios definidos por lei.

( FORTALEZA, sd, art. 244. Grifo meu)

Em 1992, já sob o marco da CF e da LO, é aprovado o Plano Diretor de Desenvolvimento Urbano de Fortaleza (PDDUFOR), e, em 1996, a Lei de Uso e ocupação do Solo (LUOS) referente ao mesmo. Dentre os objetivos da política urbana estabelecidos pelo PDDUFOR, destacamos a "preservação, a proteção e a recuperação do ambiente natural e cultural", bem como "a recuperação de áreas deterioradas visando assegurar a melhoria do meio ambiente e as condições de habitabilidade" ( FORTALEZA, 1992, art. 2ㅇ).

A questão da preservação, proteção e recuperação ambiental, foi tratada no PDDU como um zoneamento especial (Figura 48 e Figura 50), juntamente com outras questões, totalizando nove classes de áreas especiais, sendo 5 delas relacionadas à questão ambiental: a) Áreas de interesse ambiental (dunas); b) Orla marítima; c) Faixas de praia; d) Áreas de preservação; e) Áreas de proteção; f) Áreas de interesse urbanístico; g) Áreas institucionais; h) Áreas de urbanização prioritária; i) Área industrial ( FORTALEZA, 1992, art. 26, parágrafo único. Grifo meu). As quais foram definidas como ${ }^{117}$ :

I - Área de interesse ambiental (dunas) - Áreas localizadas na zona urbanizada e adensável que, em razão de sua importância ambiental, exigem regulamentação de ocupação compatível com suas características físicas;

\footnotetext{
117 Na LUOS de 1996, estas áreas recebem a seguinte definição quanto ao uso: “- Na Área de Preservação, 'non aedificandi', permitir-se-ão apenas instalações relativas às atividades, que por sua natureza e porte não comprometem a função dessa área, tais como: esportes ao ar livre, excursionismo, pesca artesanal, esportes náuticos, florestamento e reflorestamento dando-se prioridade às árvores frutíferas; - Nas Áreas de Interesse Ambiental (dunas) e nas Áreas de Proteção, em função de suas peculiaridades físicas, o presente projeto estabelece a baixa densidade populacional; a horizontalidade na paisagem urbana, com o predomínio do uso residencial unifamiliar; o número restrito de atividades de comércio e serviços de apoio ao uso residencial, com pequeno porte e baixo afluxo de transporte; - Para a Orla Marítima, respeitadas as diferenças setoriais existentes, são propostos os usos condizentes à sua vocação para o turismo e lazer; - A Área da Faixa de Praia, subdividida em trechos, receberá tratamento diferenciado quando da implantação do projeto urbanístico" ( FORTALEZA, 1996).
} 
II - Orla Marítima - Áreas próximas à faixa de praia, passíveis de ocupação, respeitadas as condições do ambiente natural, a ocupação existente e a função na estrutura urbana;

III - Faixas de Praia - Áreas "non aedificandi" da orla marítima onde a implantação de equipamentos e pavimento só será permitida após análise específica;

IV - Áreas de Preservação - Áreas localizadas em quaisquer das macrozonas, que, por suas características físicas, paisagísticas, culturais ou ambientais, são consideradas "non aedificandi";

V - Áreas de Proteção - Áreas localizadas em quaisquer das macrozonas, adjacentes às áreas de preservação, que demandam tratamento específico;

( FORTALEZA, 1992, art. 57)

A área especial de "Orla Marítima", como veremos mais adiante, apesar da definição no PDDU exigindo sua ocupação atrelada ao respeito das condições do ambiente natural, recebem pela Lei de Uso e Ocupação do Solo propostas de usos condizentes à sua vocação para o turismo e lazer, com parâmetros de usos e ocupação do solo equivalentes aos de algumas das microzonas das áreas destinadas a urbanização e adensamento urbano, o que ocorre também para as áreas de interesse ambiental, mesmo sendo estas sobre dunas móveis ou fixadas por vegetação (Quadro 3 e Quadro 4).

Figura 48. Macrozoneamento e zonas especiais do PDDU (1992) e LUOS (1996)

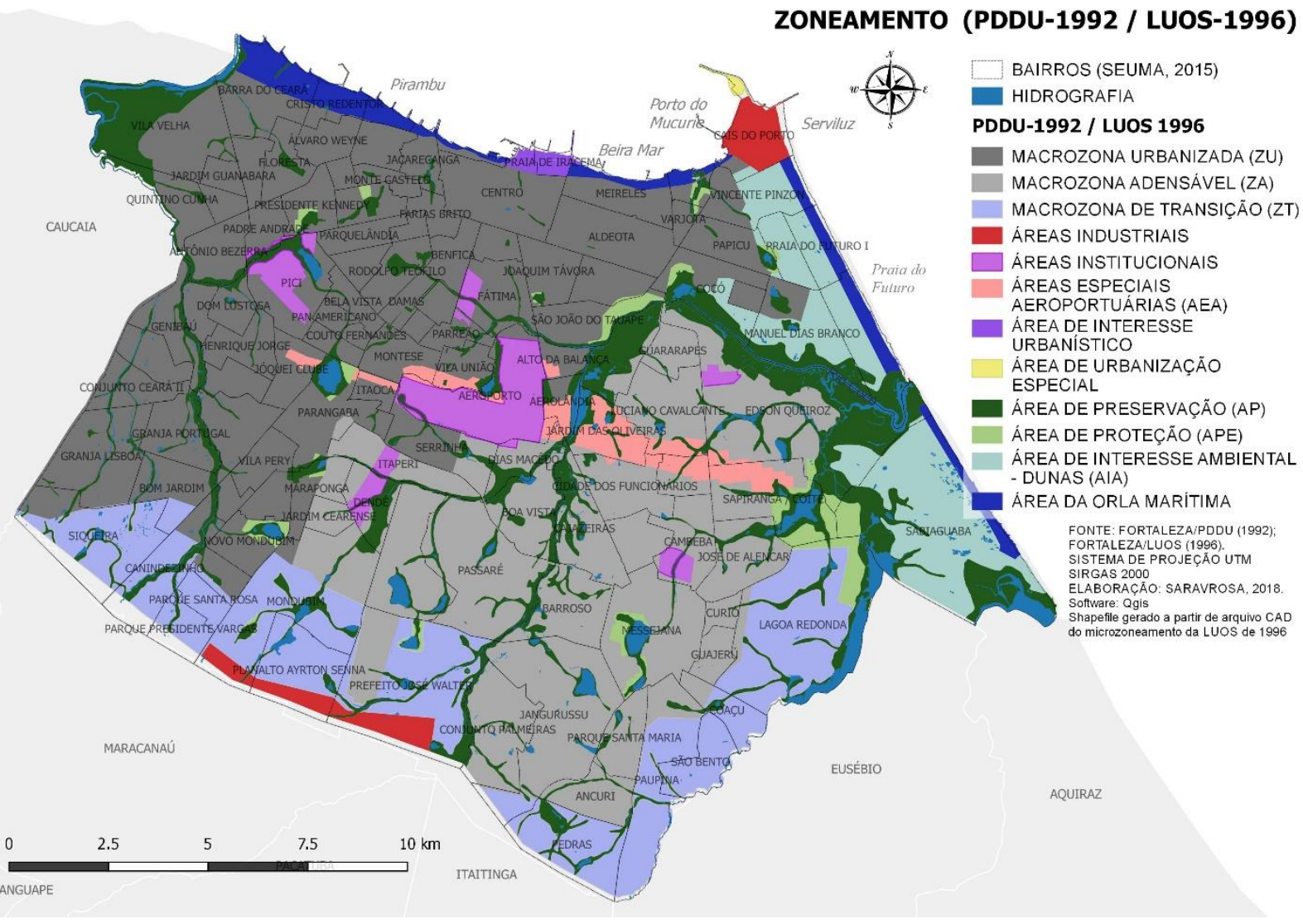

Fonte: Fortaleza/LUOS (1996). Elaboração: Rosa (2019). Software utilizado: QGis. 
Em 2006, o município recebe a demarcação de duas unidades de conservação no setor leste da cidade, o Parque Natural Municipal das Dunas de Sabiaguaba - PNMDS (decreto no 11.986/2006) e a Área de Proteção Ambiental da Sabiaguaba - APA da Sabiaguaba (decreto no 11.987/2006) (Figura 51). Posteriormente, em outubro de 2009, foi criada a Área de Relevante Interesse Ecológico (ARIE) Dunas Do Cocó (lei no 9.502, de 07 de outubro de 2009).

O plano diretor vigente, o Plano Diretor Participativo (PDP), é aprovado em fevereiro de 2009. É o primeiro a trazer, dentro do macrozoneamento, uma macrozona ambiental. Enquanto no PDDU todas as macrozonas são de caráter urbano (urbanizada, adensável e de transição) e as áreas de proteção e preservação aparecem como zonas especiais, no PDP-2009, há uma divisão entre macrozona urbana e macrozona ambiental (Figura 49).

Figura 49. Macrozona urbana e macrozona ambiental do PDP-2009 de Fortaleza.

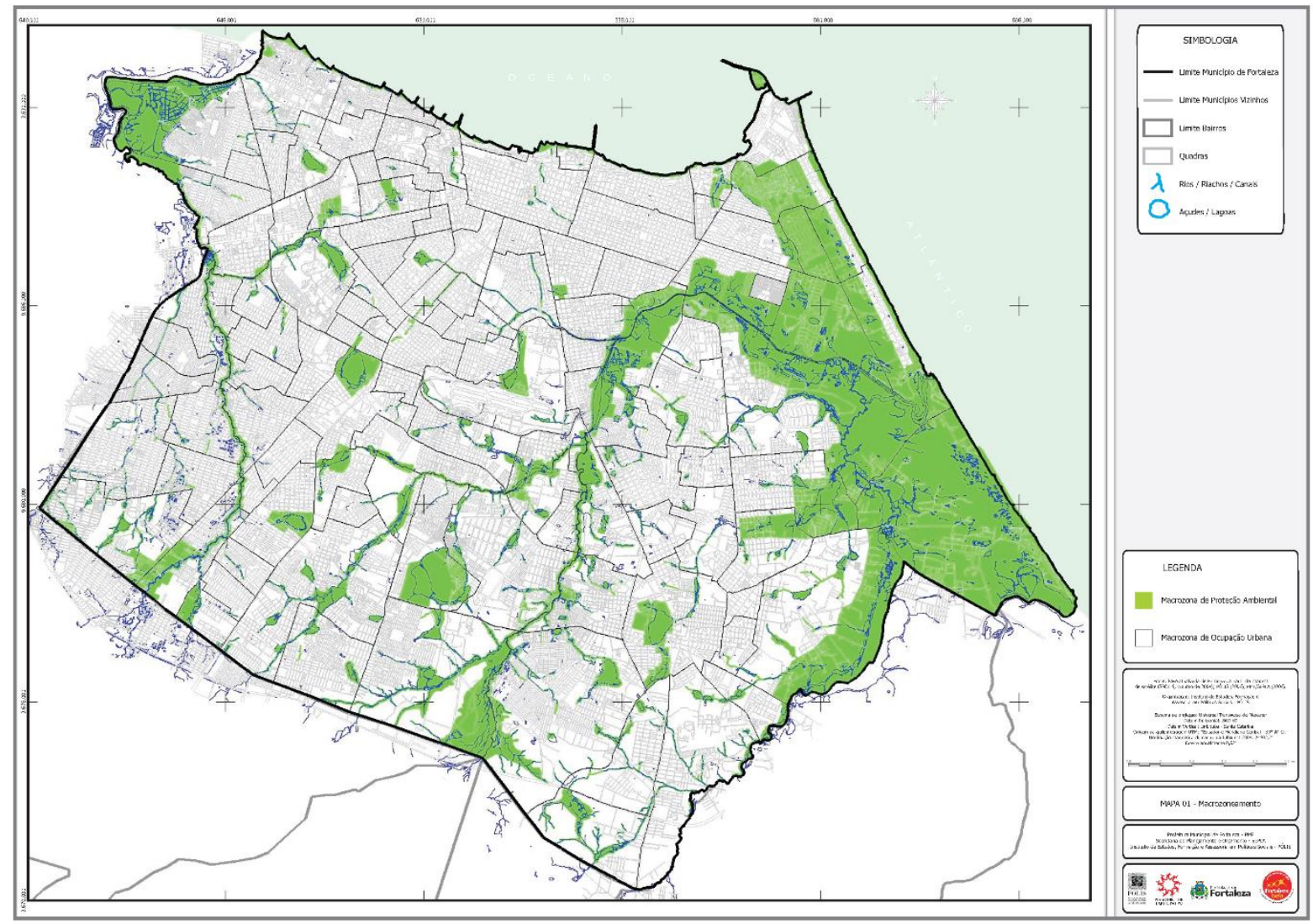

Fonte: FORTALEZA, 2009.

A Macrozona Ambiental do município definida e delimitada pelo PDP-2009, é dividida em 3 zonas: I - Zona de Preservação Ambiental (ZPA); II - Zona de Recuperação Ambiental (ZRA); III - Zona de Interesse Ambiental (ZIA). Conforma as áreas de proteção ambiental do município, desde a proteção com permissão de usos e construções de pequeno porte (ZIA e ZRA), até áreas de preservação permanente, não edificantes (ZPA). 
As Zonas de Preservação Ambiental (ZPAs), visam à preservação ambiental das áreas demarcadas, assim estas não podem receber construções e devem ter suas características preservadas o mais próximo possível do natural. São destinadas “à preservação dos ecossistemas e dos recursos naturais" (FORTALEZA, Lei Complementar n. 62, 2009, Art.63), Estão divididas em três tipos: ZPA 1 - Faixa de Preservação Permanente dos Recursos Hídricos; ZPA 2 - Faixa de Praia; ZPA 3 - correspondente à Unidade de Conservação do Parque Natural Municipal das Dunas de Sabiaguaba (FORTALEZA, Lei Complementar n. 62, 2009, Art.63, § 1ㅇ).

É importante destacar que a delimitação da ZPA1, assim como nos planos anteriores, não segue a rigor a legislação federal (Código Florestal - Áreas de Preservação Permanente, APP). Apesar de possuir áreas de ZPA1 que ultrapassam o mínimo exigido a nível federal para corpos hídricos, incorporando a vegetação do entorno, que também deve ser preservada, em alguns corpos, especialmente em algumas lagoas, ocorre o não atendimento pela legislação municipal do mínimo exigido no Código Florestal ${ }^{118}$.

Outras áreas de preservação permanente, APP segundo o Código Florestal, que não foram incorporadas no zoneamento ambiental do município, foram as dunas com vegetação ${ }^{119}$, com exceção daquelas existentes no bairro da Sabiaguaba que ficam dentro das unidades de conservação criadas em 2006, a Área de Proteção Ambiental (APA) da Sabiaguaba e o Parque Natural Municipal das Dunas da Sabiaguaba (PNMDS). As demais dunas existentes, ainda preservadas na Praia do Futuro e entorno do Rio Cocó, por exemplo, foram incorporadas apenas na categoria de proteção, como as ZIAs (Zonas de Interesse Ambiental). Estas áreas, mesmo protegidas desde 1965 pelo Código Florestal (Lei Federal º 4.771 de 1965), com categoria de preservação, continuam sendo ocupadas aos poucos, tanto por assentamentos precários quanto por loteamentos com padrão classe média, devido a uma "brecha" da legislação municipal.

\footnotetext{
118 Segundo o Código Florestal atual (Lei no 12.651/2012) Art. 4ํ, "considera-se Área de Preservação Permanente, em zonas rurais ou urbanas, para os efeitos desta Lei: I - as faixas marginais de qualquer curso d'água natural, desde a borda da calha do leito regular, em largura mínima de: a) 30 (trinta) metros, para os cursos d'água de menos de 10 (dez) metros de largura; b) 50 (cinquenta) metros, para os cursos d'água que tenham de 10 (dez) a 50 (cinquenta) metros de largura; c) 100 (cem) metros, para os cursos d'água que tenham de 50 (cinquenta) a 200 (duzentos) metros de largura; d) 200 (duzentos) metros, para os cursos d'água que tenham de 200 (duzentos) a 600 (seiscentos) metros de largura; e) 500 (quinhentos) metros, para os cursos d'água que tenham largura superior a 600 (seiscentos) metros" (BRASIL, Lei no 12.651, de 25 de maio de 2012, art. 4ㅇ)

${ }^{119}$ As dunas com vegetação são definidas como áreas de preservação permanente (APPs) já em 1965 no Código Florestal (Lei Federal º 4771 de 1965), e mantidas em sua versão atualizada de 2012 (Lei Federal o 12.651 de 2012).
} 
Esse detalhe abriu "oportunidades" para que o município aprovasse empreendimentos em áreas de preservação permanente (APP) que não estavam delimitadas nos mapas municipais consultados pelos técnicos de análise e aprovação de projetos. Todavia, a não demarcação destas áreas no Plano Diretor não exime o poder público municipal de respeitar e seguir a legislação federal, sempre e quando a lei municipal for menos restritiva. Assim, a "negligência" ou "erro" do município ao elaborar o zoneamento ambiental possibilitou que particulares se apropriassem de terras que haviam sido destinadas à reserva de "natureza" para garantir a qualidade ambiental da vida na cidade.

As Zonas de Interesse Ambiental (ZIA) foram definidas pelo PDP (2009) como "áreas originalmente impróprias à ocupação do ponto de vista ambiental, áreas com incidência de atributos ambientais significativos em que a ocupação ocorreu de forma ambientalmente inadequada" (FORTALEZA, Lei Complementar n. 62, 2009, Art.72). Foram divididas em 3 áreas com parâmetros distintos para cada uma: I - Cocó; II - Praia do Futuro; e III - Sabiaguaba.

Entre os objetivos definidos para estas zonas podemos citar: compatibilizar a conservação dos sistemas ambientais com o uso sustentável dos recursos naturais; assegurar a sustentabilidade dos recursos naturais; regular o uso admissível dessas áreas, de modo a compatibilizar com os objetivos de conservação da natureza (FORTALEZA, Lei Complementar n. 62, 2009, Art.72 e 73). Contudo, os parâmetros definidos para estas zonas não condizem com seus objetivos. A ZIA da Sabiaguaba possui parâmetros urbanísticos bem restritivos que realmente deveriam inibir e controlar a ocupação dessas áreas, com índices de aproveitamento e altura máxima da edificação bem baixos. Já a ZIA do Cocó e a da Praia do Futuro oferecem um potencial construtivo similar e até igual a muitas zonas urbanas onde se objetiva estimular a ocupação, propiciando assim um adensamento construtivo incompatível com seus objetivos.

Por exemplo, a ZIA do Cocó possui o índice de aproveitamento (I.A.) básico e máximo igual a 1,5, valor igual ao da Zona de Requalificação Urbana 2, pertencente ao Macrozoneamento Urbano do município. Mais permissivos ainda são os parâmetros da ZIA da Praia do Futuro, que estabelecem um índice de aproveitamento básico e máximo de 2,0, o mesmo I.A. básico definido para a Zona de Ocupação Preferencial 2. Para se ter uma ideia, 3,0 é o índice máximo (I.A. máximo) da Zona de Ocupação Preferencial 1, onde deve ser dada a máxima prioridade para adensamento e construção, segundo o PDP. 
Outro parâmetro que também merece destaque é a altura máxima da edificação que, tanto para a ZIA da Praia do Futuro como a do Cocó, é de 48m, o mesmo especificado para as Zonas de Requalificação Urbana 1 e 2, por exemplo.

Assim, a Zona de Interesse Ambiental, desde sua formulação em lei, apresenta contradições internas entre seus objetivos e seus parâmetros urbanos que põem em xeque a real possibilidade de proteção ambiental nestas áreas. Porém, aqui vale abrir um parêntese, pois os parâmetros para estas zonas aprovados e publicados no diário oficial não são os mesmos presentes na minuta da lei que vinha sendo discutida no processo participativo do PDP ${ }^{120}$ (Quadro 2).

Para a ZIA da Praia do Futuro, no lugar de I.A igual a 2, estava proposto na minuta do projeto de lei I.A. básico e máximo igual a 1 . A taxa de permeabilidade na minuta era de $50 \%$ e na lei aprovada, de $40 \%$. A taxa de ocupação era $40 \%$, na minuta, e $50 \%$, na lei aprovada. A altura máxima era de $36 \mathrm{~m}$, já na versão publicada, $48 \mathrm{~m}$ (Quadro 2).

A ZIA do Cocó também sofreu alterações da versão da minuta da lei para a versão da lei aprovada e publicada no Diário Oficial. Os índices de aproveitamento básico e máximo, por exemplo, eram de apenas 0,5, e não 1,5. A altura máxima da edificação era de apenas 15m e na lei aprovada o limite passou para 48m. A taxa de permeabilidade, assim como na Praia do Futuro, teve uma redução de $10 \%$, além da criação de uma taxa de ocupação do subsolo que antes não existia (Quadro 2), o que pode gerar grande problema para a manutenção dos lençóis freáticos e recursos hídricos da cidade, uma vez que, esses terrenos, ou são dunas, ou são planícies inundáveis contíguas ao Rio Cocó.

Por fim, as Zonas de Recuperação Ambiental (ZRA) são, em termos de definição e objetivos, bem parecidas com as ZIAs, tanto que na versão da minuta do PDP, em 2007, os parâmetros urbanísticos de ambas já eram bem parecidos, porém, para as ZRAs, há um destaque a ser realizado sobre o objetivo de recuperação do ambiente natural degradado.

\footnotetext{
120 Importante destacar aqui a fala de representante do SINDUSCON em reunião da Comissão Permanente de Avaliação do Plano Diretor (CPPD), onde se discutia a possibilidade de alterar os índices de aproveitamento definidos pelo PDP (2009): "sendo contra a alteração do índice básico, tendo em vista ter sido uma grande defesa pleiteada pelo SINDUSCON nas discussões do Plano Diretor Participativo - PDP e um direito adquirido [...] (FORTALEZA, 2014, p. 2. Ata da 58a reunião da (PPD).
} 
Como pode ser observado no Quadro 2, a ZRA também foi alvo de flexibilização durante o processo de aprovação do plano, contudo, menor do que a ocorrida nas ZIAs do Cocó e Praia do Futuro. Para a ZRA houve uma redução de $10 \%$ da taxa de permeabilidade e um acréscimo de 0,1 sobre a proposta inicial do índice de aproveitamento.

Já no processo de elaboração da lei do Plano Diretor Participativo, mesmo contrariando o acordado com a sociedade civil, verifica-se uma flexibilização das zonas ambientais por meio da aprovação da lei com parâmetros diferentes ao fechado no Projeto de Lei. Essas modificações de leis dentro da Câmara têm sido bem comuns em Fortaleza e foram observadas também em outros processos, como no de atualização da Lei de Uso e Ocupação do Solo (LUOS) ${ }^{121}$. A partir de negociações entre o mercado e o Estado (poder executivo e legislativo), são encaminhadas emendas, às vezes no mesmo dia da votação da lei, que trazem mudanças substanciais ao conteúdo da mesma.

Então, ainda no processo de elaboração da regulamentação que deve proteger as áreas da cidade que foram selecionadas, a nível federal e municipal, para garantir reservas de "natureza" e qualidade ambiental, expropriou-se tais áreas da coletividade da cidade, colocando-as à disposição do mercado, seja pela regulamentação de indicadores urbanos que contrariam seus objetivos, seja pela negação da existência destas áreas, quando parcelas de APP não são reconhecidas neste zoneamento.

Quadro 2. Comparação dos parâmetros urbanos das zonas de proteção ambiental da versão da minuta do PDP de 2007/P.L. enviada à Câmara em 2008 e versão da lei publicada no Diário Oficial do Município em 2009.

\begin{tabular}{|c|c|c|c|c|c|c|c|c|c|c|}
\hline VERSÃO DO PDP & Minut & PDP2009 (janeir & o de 2007) ${ }^{[1]}$ & P.L.C.009 (maio 2 & $08)^{[2]}$ & & Lei PDP200 & 9 (publicad & no D.O.M.) & \\
\hline ZONAS & ZPA & ZIA-sabiag. & ZIA-Cocó & ZIA-P. Futuro & ZRA & ZPA & ZIA-sabiag. & ZIA-Cocó & ZIA-P. Futuro & ZRA \\
\hline I.A. BÁSICO & 0 & 0,5 & 0,5 & 1 & 0,5 & 0 & 0,5 & $\underline{1,5}$ & $\underline{2}$ & $\underline{0,6}$ \\
\hline I.A. MÁXIMO & 0 & 0,5 & 0,5 & 1 & 0,5 & 0 & 0,5 & $\underline{1,5}$ & $\underline{2}$ & $\underline{0,6}$ \\
\hline I.A. MÍNIMO & 0 & 0 & 0 & 0 & 0 & 0 & 0 & 0 & 0 & 0 \\
\hline TAXA DE PERMEABILIDADE & $100 \%$ & $60 \%$ & $50 \%$ & $50 \%$ & $60 \%$ & $100 \%$ & $60 \%$ & $\underline{40 \%}$ & $\underline{40 \%}$ & $\underline{50 \%}$ \\
\hline TAXA DE OCUPAÇÃO & 0 & $30 \%$ & $40 \%$ & $40 \%$ & $30 \%$ & 0 & $30 \%$ & $40 \%$ & $40 \%$ & $\underline{33 \%}$ \\
\hline TAXA DE OCUP. DO SUBSOLO & 0 & - & - & - & - & 0 & & $\underline{40 \%}$ & - & $33 \%$ \\
\hline ALTURA MÁXIMA DA EDIF. & 0 & $15 \mathrm{~m}$ & $15 \mathrm{~m}$ & $36 \mathrm{~m}$ & $12 m$ & 0 & $15 \mathrm{~m}$ & $\underline{48 m}$ & $\underline{48 m}$ & $\underline{15 \mathrm{~m}}$ \\
\hline
\end{tabular}

Fonte: FORTALEZA/PDP, 2009; FORTALEZA/MINUTA PDP, 2007. Organização: Sara V. Rosa, 2016. [1] Documento impresso entregue nas discussões do PDP com a sociedade civil. [2] Projeto de Lei encaminhado à Câmara Municipal de Fortaleza.

Ao comparar o zoneamento do PDDU de 1992 com o do PDP de 2009, no que tange às áreas de proteção e preservação ambiental, com a ajuda dos mapas da Figura 50 e da Figura 51, é

${ }^{121}$ Ver: Artigo 05 do livro Cidade estado capital: reestruturação urbana e resistência em Belo Horizonte, Fortaleza e São Paulo (ROLNIK, R. Et.al, 2018). 
possivel perceber que, apesar de bem parecidos, em 2009 há uma expansão, em alguns trechos da cidade, das áreas de proteção e preservação. Ainda assim, é possível observar alguns estrangulamentos das áreas de preservação não edificantes, mas alguns destes casos foram alterações ainda sobre o PDDU de 1992 e sua Lei de Parcelamento Uso e Ocupação do Solo de 1996 que detalha e regulamenta o zoneamento.

Em 2009, as zonas de preservação ambiental, não edificantes, passam a cobrir parte da faixa de praia ao longo de todo o litoral do município, além de englobar também as dunas da Sabiaguaba, refletindo o limite do Parque Natural das Dunas da Sabiaguaba, criado em 2008. Na legislação anterior, o litoral, incluindo parte da atual ZPA-2 (faixa de praia), era classificado como Área de Orla Marítima (Figura 48) e recebeu parâmetros de uso e ocupação do solo equivalentes às Macrozonas Urbana e Adensável (Quadro 4).

Ainda que no PDDU-1992, houvesse a definição de faixa de praia como área especial não edificante, esta não aparece delimitada no mapa do microzoneamento, definido na LUOS1996, restando apenas a definição do que seria a área: “Art. 109. A Área da Faixa de Praia, parte da orla marítima do Município de Fortaleza, constitui-se da área coberta e descoberta periodicamente pelas águas marítimas, acrescidas da faixa de material detrítico, tais como areias, cascalhos, seixos e pedregulhos, até o limite onde se inicie a vegetação natural ou outro ecossistema, ou até o primeiro logradouro público e de acordo com o disposto nesta Lei (FORTALEZA, 1996).

Quanto às categorias de proteção, podemos perceber um leve aumento nas áreas de interesse ambiental das dunas da Praia do Futuro sobre o bairro Vincente Pinzon, assim como sobre o bairro Manuel Dias Branco, classificado no atual plano como Zona de Interesse Ambiental das Dunas do Cocó e recebendo parâmetros urbanos diferentes do restante das dunas da Praia do Futuro.

Há ainda um aumento da categoria de proteção, enquanto ZRA (Zona de Recuperação Ambiental) nos bairros Guararapes e Edson Queiroz, ao longo da faixa de proteção do Rio Cocó; no bairro José de Alencar, ao redor da Lagoa da Sapiranga; no bairro Lagoa Redonda, ao longo da Lagoa da Precabura, no setor sudeste do município; nos bairros José Walter e Conjunto Palmeiras, também ao longo da ZPA do Cocó, setor sul; no Canindezinho e Presidente Vargas, ao longo da ZPA do Rio Maranguapinho, setor sudoeste. 
Quanto aos parâmetros urbanos que regulam a taxa de permeabilidade e potencial construtivo dessas áreas, observa-se que houve uma tendência na manutenção desses valores, salvo os trechos correspondentes às dunas do Cocó e às dunas da Sabiaguaba. No novo plano, a área de interesse ambiental da Praia do Futuro foi dividida em duas, Zona de Interesse Ambiental da Praia do Futuro e Zona de Interesse Ambiental das dunas do Cocó. Em ambas há uma similaridade com os parâmetros definidos no PDDU-1992, onde o I.A. variava de 1 a 2, dependendo do tipo de uso do empreendimento, no caso da ZIA do Cocó houve uma pequena redução para um I.A. máximo de 1,5.

A ZIA da Sabiaguaba foi a que passou por maiores alterações. O índice de aproveitamento máximo dessa área passou a ser de 0,5, onde no PDDU-1992 era de 1. Também a taxa de permeabilidade aumentou de $40 \%$ para $60 \%$, sem contar que grande parte da área de interesse ambiental mudou para a categoria de preservação, com a delimitação da ZPA-3 dunas da Sabiaguaba.

Quadro 3. Comparação de parâmetros das áreas de proteção e preservação do PDDU-1992/LUOS-1996 e PDP-2009

\begin{tabular}{|c|c|c|c|c|c|c|c|c|}
\hline \multirow[t]{2}{*}{ PDDU 1992/LUOS 1996} & \multirow{2}{*}{$\begin{array}{l}\text { TAXA DE } \\
\text { PERMEAB }\end{array}$} & \multirow[t]{2}{*}{$1 . A * 1$} & \multirow{2}{*}{$\begin{array}{c}\text { ALTURA } \\
(\mathrm{m})\end{array}$} & \multirow[t]{2}{*}{ PDP 2009} & \multirow{2}{*}{$\begin{array}{l}\text { TAXA DE } \\
\text { PERMEAB }\end{array}$} & \multicolumn{2}{|c|}{$1 . A^{* 1}$} & \multirow{2}{*}{$\begin{array}{c}\text { ALTURA } \\
\text { (m) }\end{array}$} \\
\hline & & & & & & BÁSICO & MÁXIMO & \\
\hline ÁREA DE PRESERVAÇÃO & $100 \%$ & 0 & 0 & ZPA $(1,2$ e 3$)$ & 100 & 0 & 0 & 0 \\
\hline ÁREA DE PROTEÇÃO & $50 \%$ & 0,6 & 15 & ZRA & $50 \%$ & 0,6 & 0,6 & 15 \\
\hline \multirow[t]{2}{*}{ AIA - PRAIA DO FUTURO } & $40 \%$ & 1 a 2 & 48 & ZIA P. DO FUTURO & $40 \%$ & 2,0 & 2,0 & 48 \\
\hline & & & & ZIA COCÓ & $40 \%$ & 1,5 & 1,5 & 48 \\
\hline AIA - SABIAGUABA & $40 \%$ & 1 & 15 & ZIA SABIAGUABA & $60 \%$ & 0,5 & 0,5 & 15 \\
\hline
\end{tabular}

Sistematização: autora, 2019. Fonte: FORTALEZA (1996 e 2009) - Lei complementar no 062 , de 02 de fevereiro de 2009 e Lei no 7.987, de 23 de Dezembro de 1996. ${ }^{* 1}$ I.A. depende do tipo de uso.

Quadro 4. Parâmetros urbanos para a área de orla marítima segundo PDDU-1992 e LUOS -1996.

\begin{tabular}{|l|r|r|}
\hline PDDU 1992 & TAXA DE PERMEAB & I.A.*1 \\
\hline OM - POÇO DA DRAGA & $20 \%$ & 1,5 \\
\hline OM - MONS. TABOSA & $20 \%$ & 1 a 2,5 \\
\hline OM- CLUBE DO IATE & $30 \%$ & 1 \\
\hline OM - PRAIA DO FUTURO & $40 \%$ & 15 \\
\hline OM-SABIAGUABA & $40 \%$ & 1 a 2 \\
\hline AIU DA PRAIA DE IRACEMA*2 & $10 \%$ a $25 \%$ & 1 \\
\hline
\end{tabular}

Fonte: FORTALEZA, 1996 - Lei no 7.987, de 23 de Dezembro de 1996. Sistematizado pela autora, 2019. *1 I.A. depende do tipo de uso; *2 Parâmetros dependem do tamanho da testada do lote. 
Figura 50. Áreas especiais ambientais - PDDU-1992/LUOS-1996

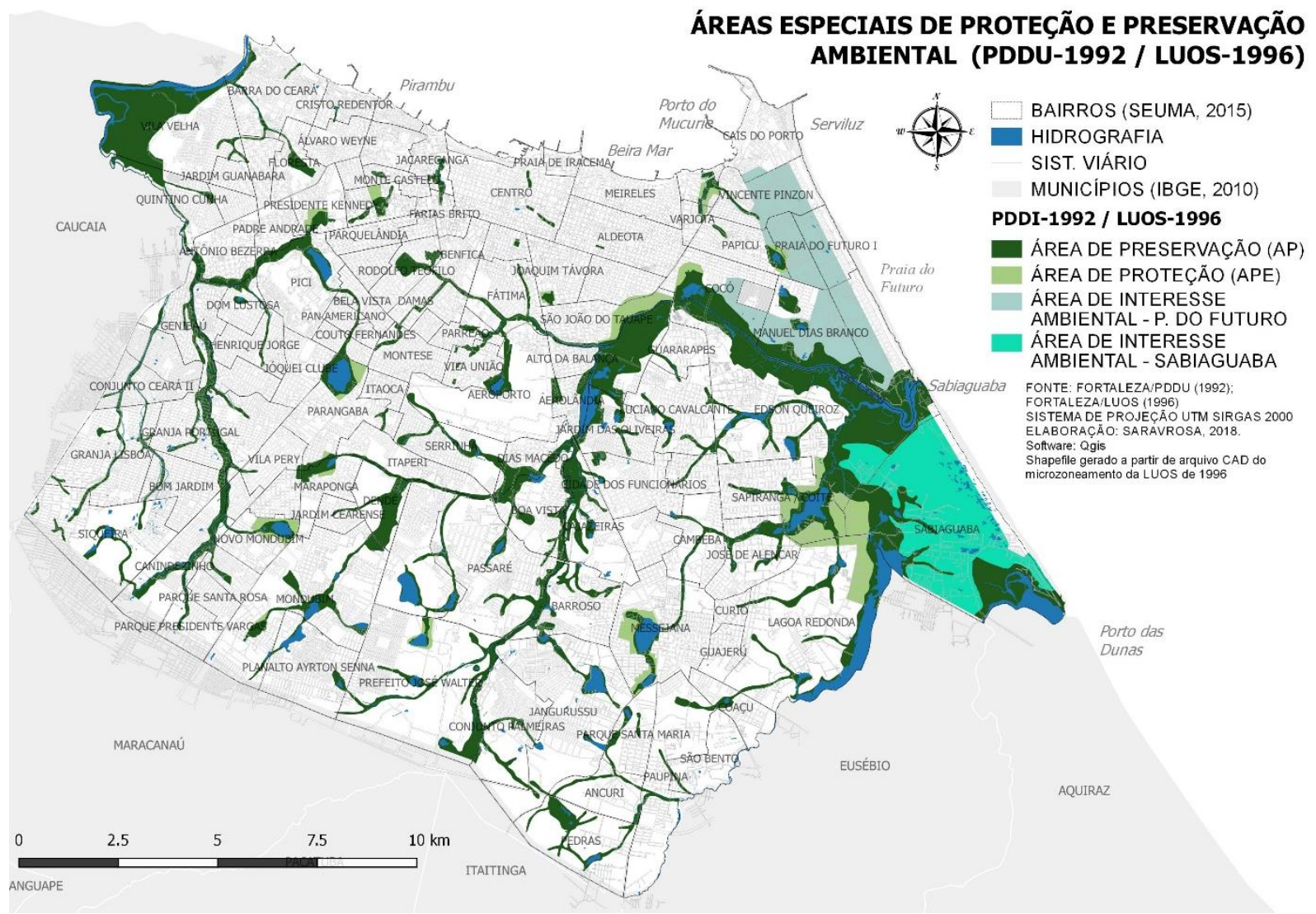

Elaboração: Autora, 2019. Fonte: FORTALEZA, 1996 - Lei no 7.987, de 23 de Dezembro de 1996.

Figura 51. Zonemento Ambiental do PDP-2009

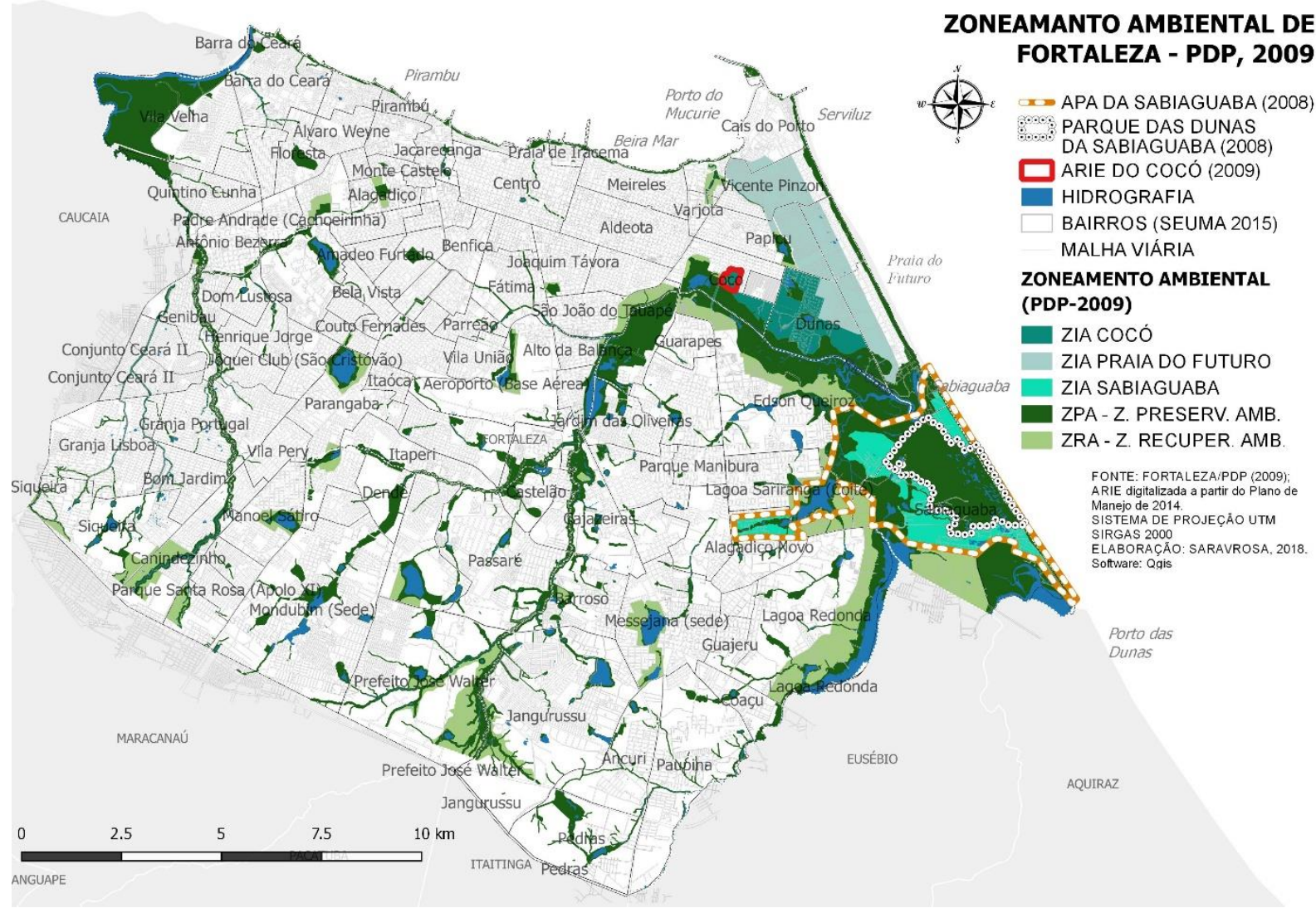

Elaboração: Autora, 2019. Fonte: FORTALEZA, 2009 - Lei complementar no 062, de 02 de fevereiro de 2009. 
A evolução das áreas de preservação, descrita nos planos mencionados, se por um lado é de extrema importância - seja por meio de uma visão que enxerga a natureza mais como algo sagrado, ressaltando o valor em si da natureza e das espécies, seja de uma visão que enxerga a natureza como um recurso, ressaltando o valor de uso e por vezes o valor de troca, por outro ela exclui em diversas ocasiões o homem (entendido nesta tese, também com natureza), seja ainda por uma visão de garantir às cidades de terceiro mundo um ambiente saudável e equilibrado para suas populações - por outro lado, não têm sido raros os casos de demarcação de áreas de preservação e parques que resultam na expulsão de moradores, em geral mais pobres, destas áreas.

É importante ressaltar que, como foi visto, a evolução, em termos de aumento da proteção e preservação, apesar de ter existido, não parece ter sido algo fácil. Houve trechos protegidos que o deixaram de ser na passagem de um plano diretor para o outro. Houve o desrespeito, em todos os planos revisados, com o que já havia sido definido pelo código florestal ainda da década de 1960. Por último, talvez o caso mais esclarecedor, houve a mudança dos parâmetros definidos para as zonas de proteção ambiental do PDP-2009, que, ao tentar propor índices mais condizentes com os objetivos de proteção definidos para estas, teve-os alterados no processo de aprovação da Lei dentro da câmara dos vereadores.

Muitas destas áreas que tiveram o potencial construtivo limitado ou anulado, a partir de sua demarcação como áreas de proteção ou preservação ambiental, sobretudo nos últimos planos, já possuíam loteamentos aprovados em décadas anteriores, como visto no capítulo anterior, alguns destes, incluindo lotes sobre áreas alagáveis, dunas móveis, dunas fixas, ou mesmo leito de rios e lagoas.

Fato é que, essa limitação do potencial construtivo, limita a possibilidade de uso do imóvel dentro do setor de produção imobiliária e, consequentemente, o seu valor de troca e o possível valor a ser gerado sobre este terreno no processo de exploração do trabalho utilizado na construção de possíveis edificações, criando assim conflito com os supostos ${ }^{122}$ proprietários da propriedade privada destes imóveis.

\footnotetext{
122 Uso aqui suposto porque, como ressaltado no primeiro capítulo, a formação da moderna propriedade privada da terra é pautada no roubo dessas terras e expulsão dos seus ocupantes. Também porque o registro fundiário de Fortaleza é extremamente desorganizado, sendo muitas vezes difícil identificar os proprietários dos terrenos. Além disso, há choque de
} 


\title{
2.3. DO ANTIVALOR AO VALOR: O CASO DAS OPERAÇÕES URBANAS CONSORCIADAS 123
}

\section{APROVADAS EM FORTALEZA}

\begin{abstract}
Con la consolidación de la reestructuración neoliberal se modificó el papel del Estado en la urbanización. De manera particular se sustituyeron las lógicas regulatorias redistributivas por lógicas competitivas (Nick, Peck y Brenner, 2009:2) configurando una "regulación dirigida por el mercado" (Ídem: 5). Las políticas estatales se orientan hacia el fortalecimiento general de las relaciones mercantiles, particularmente y la producción de la urbanización, promoviendo al mismo tiempo procesos crecientemente finaciarizados (Ídem). Aunque no se abandonen totalmente las acciones orientadas a la producción no mercantil o la desmercantilización, se consolidan diferentes formas de re-mercantilización de procesos de producción que habían sido desmercantilizados, así como de mercantilización de bienes y procesos que estaban fuera de las relaciones mercantiles. Dentro de esos procesos debe ser tenida en cuenta la particular reestructuración del sector inmobiliario (Lencioni 2014). (PÍREZ, 2016, p. 142 e 243. Grifo meu).
\end{abstract}

Como visto anteriormente, na perspectiva da produção urbana e do setor imobiliário, em um primeiro movimento, as terras de proteção e preservação ambiental poderiam representar uma barreira para o capital imobiliário, pois limitam o duplo monopólio da terra, limitando ou, às vezes, anulando sua possibilidade de extração de renda e de mais-valia. Tanto é que os processos de demarcação dessas áreas sempre geram conflitos com os proprietários e o setor imobiliário.

Porém, em um segundo movimento, essas terras-natureza passam a ser importantes elementos para acumulação e valorização de capital. Para isto, há um movimento tanto no sentido de resgatar o potencial construtivo dessas terras, portanto resgatar o valor aparente destas, por vezes, desqualificando-a enquanto natureza merecedora de preservação, como um outro movimento, no sentido de criar novos valores de uso da natureza (definida socialmente) associados ao imobiliário, criando desejo pelo consumo de natureza, somados à ideia de raridade desta, fazendo com que segmentos de consumidores com capacidade de pagamento estejam dispostos a pagar preços exorbitantes por empreendimentos que tenham agregado natureza (ou fragmentos desta) ${ }^{124}$. Nesse último caso, geralmente não há geração

\footnotetext{
matrículas, há loteamentos não formalizados que vendem o mesmo lote para pessoas diferentes, há loteamentos que foram registrados em cartório de municípios vizinhos, etc.

${ }^{123}$ Neste momento, trataremos apenas das Operações Urbanas Consorciadas (OUCs) aprovadas até 2015.

${ }^{124}$ Importante aqui destacar que, como ressalta Pereira (2017), apesar do preço ser a representação monetária do valor, ele não depende do valor. Tanto que a terra, como comentado, não tem valor, mas tem preço. 0 preço de mercado da terra, que
} 
de valor, mas a ideia de natureza é utilizada como estratégia/vetor para aumentar os processos de acumulação. Na aparência, há uma valorização por conta da presença da natureza, mas não existe aí valor gerando valor, apenas valor capitalizado de outros setores.

Há ainda um terceiro movimento, que é o de produção ou remodelação da natureza enquanto natureza, compreendida socialmente como natureza, a partir da criação/urbanização de um parque ou de um lago, por exemplo. Nas palavras de Hidalgo, Dattwyler, et al. ( 2016), "naturaleza inventada", que seria uma natureza produzida, não para ser cidade, não para ser outra coisa, mas para ser natureza ${ }^{125}$. Nesse caso, há trabalho envolvido e, portanto, extração de mais-valia, consequentemente, geração de valor. Valor este que é capitalizado na forma de renda para os terrenos e empreendimentos do entorno.

Estes três movimentos podem ocorrer isoladamente ou em conjunto e articulados. Em todos os casos, há quase sempre uma necessidade de associação entre capitalistas, rentistas e Estado para que sejam viabilizados.

No caso do primeiro momento, no qual se busca um resgate de valor a partir do resgate da terra, antes natureza, como terra local de produção imobiliária, essa necessidade de associação entre os capitalistas, rentistas e o Estado é ainda mais forte. Para que o direito à realização de produto imobiliário na terra-natureza-preservada seja possível, há uma necessidade de o Estado realizar um movimento contrário ao que havia feito anteriormente de desmercatilização, e revogar, alterar ou criar novas leis, descontruindo a ideia daquela terra enquanto natureza, e assim "devolver" ao proprietário privado dessas terras o direito de produção, potencializando novamente esta terra enquanto mercadoria.

Assim, o antivalor (da forma terra-natureza capital parado) pode ser resgatado na forma valor, a partir da abertura de alterações na legislação ou criação de novas regulações. Dessa forma, o próprio Estado que desmercantilizou essa terra e resgatou a possibilidade de seu significado enquanto riqueza comum, abre a possibilidade para sua remercantilização e realização do

\footnotetext{
é preço de monopólio, pode aumentar devido a outros fatores como "possibilidade de crédito, subsídio público e a própria instrumentalização financeira do produto imobiliário para obtenção de renda", podendo chegar "as nuvens no que depender do desejo e capacidade dos compradores" (ibidem, p. 198).

$125 \mathrm{Em}$, Aguas de ficción a la carta: la producción de naturaleza como nich de renta. Bienes comunes y espacio urbano en torno de las crystal laggons. HIDALGO, CAMUS, et al., 2016., os autores exploram a ideia da natureza como um bem de consumo, como um nincho de renda e como uma natureza inventada, como parte da acumulação capitalista e da exploração da renda imobiliária sobre espaços idílicos, a partir do estudo do caso das crystal lagoons, lagoas artificiais com tecnologia para permanecer com águas cristalinas, produzidas por uma empresa chilena e instalada em empreendimentos habitacionais.
} 
valor $^{126}$. "Qualquer desaceleração de valor em movimento acarreta uma perda de valor. Inversamente, acelerar o tempo de rotação do capital é um elemento fundamental para alavancar a produção de valor" ( HARVEY, 2018, p. 81).

Esse processo traz na sua aparência uma valorização, fazendo-se crer que o que se valorizou foi a terra-natureza, como se o valor brotasse da própria terra, reforçando a "ilusão do capital como um autônomo que se valoriza por si mesmo" (FRED MOSELEY, p. 526, apud HARVEY, 2018, p. 90)127. Mas essa ideia é puro fetiche. O que acontece, nesse caso, é a geração de possibilidade de criação de valor no futuro sobre este terreno (valor este ainda não realizado, por isso futuro) por meio do processo de produção imobiliário, que é capitalizado no presente e incorporado ao preço atual da terra.

Assim, a natureza, tomando aqui o caso da terra de proteção e preservação ambiental, socialmente definida como relevante, e seus recursos naturais, continua sendo apropriada por privados, retirando-se à força populações tradicionais que habitavam este espaço e negando às demais pessoas o direito de usufruir desse espaço como bem comum. Deste modo, observa-se que, além do processo de valorização (aparente), os processos espoliativos permanecem, tanto pela expropriação da terra, com valor de uso, de quem a habitava, como pela privatização e negação do uso comum (HARVEY, 2004; HIDALGO, 2016) ${ }^{128}$. Há ainda, como destaca Pereira (2017), os processos espoliativos gerados a partir da captura de maisvalia da produção de outras mercadorias destes novos processos de capitalização para formar estas rendas.

Esses processos espoliativos ocorrem inclusive quando a terra é mantida enquanto natureza preservada, pois parte da legislação, como comentado anteriormente, influenciada pelo culto ao silvestre, não consegue aliar a existência humana com a conservação da natureza. Também porque para que a natureza seja vista como bem de consumo é necessário que esta seja local

\footnotetext{
126 Às vezes há também a simples negação da legislação que limita o duplo monopólio de certa propriedade, por parte de particulares e de técnicos do município.

127 Neste caso, Capital seria a terra funcionando como capital fictício, nos termos como avançam as análises de ALDIGUERI, 2017.

128 “La privatización de la tierra, las expropiaciones, la expulsión de la población, la eliminación de las formas alternativas de producción, la apropiación de los recursos naturales y la invención de lo natural con fines turísticos, son formas en las que actualmente se manifiesta el cercamiento de los bienes comunes" (HIDALGO, Et al, p. 19, 2016).
} 
de natureza, mesmo que inventada, e não podendo ser local de apropriação não-mercantil ${ }^{129}$ por populações de baixa renda.

Tem-se então uma potencialização do sobrelucro. Primeiro, pelo aumento de preço dessas terras, pela permissão de construção onde não era permitido (capitaliza-se o valor futuro dessas construções onde antes não era esperado). Segundo, pela exploração da ideia de natureza "preservada", raridade, natureza bem de consumo, que faz com que alguns consumidores paguem mais ${ }^{130}$.

O fetiche ${ }^{131}$ nesses processos são extremos. A começar pela própria ideia da terra (natureza) enquanto mercadoria, da definição de preço e valorização para algo que na verdade não tem valor. Através de um mesmo elemento, trabalham-se concepções antagônicas, mas que se complementam para a realização da renda desta terra. Ora estes terrenos são vistos/trabalhados como área degradada, terreno baldio, mato, lugar de sujeira, esgoto, mosquito e esconderijo dos "marginais". Ora são vistos/trabalhados como natureza, raridade, vida, recurso hídrico, biodiversidade, lazer, lugar de contemplação e vistas cênicas. Há um jogo de rebaixar e exaltar o significado social de natureza. Um jogo entre categorias, como natureza $\mathrm{X}$ urbano, natural/preservado $\mathrm{X}$ degradado/poluído/ modificado. Este jogo permite que o Estado e o privado se justifiquem perante a sociedade, que não percebe que um bem, a terra (natureza), que deveria ser comum a toda a sociedade, está sendo apropriado privadamente. Quando muito, há uma suposta troca da permissão de construção em determinadas áreas pela criação de parques em outras. Perde-se parte das áreas protegidas e preservadas pela "criação de natureza" ou preservação em outras.

Também há fetiche na necessidade de se produzir natureza para que esta seja socialmente reconhecida como natureza. "Si se considera que la utopía de la naturaleza inventada se materializa sobre un ambiente construido, se debe señalar que el propósito de los ambientes urbanos del mercado inmobiliario presenta un nicho de renta seductor para una demanda cautiva" ( HIDALGO, CAMUS, et al., 2016, p. 20). A natureza começa a virar algo

\footnotetext{
129 Favela como apropriação não-mercantil da terra/ desmercantilização social: ver ALDIGUERI, 2017.

${ }^{130}$ A apropriação do valor de uso, que anteriormente não faziam parte da matriz do mercado imobiliário, como a prestação de serviços ambientais, assim como o reforço de valores de uso novos ou antigos que ganham importância com a ajuda de estratégias de marketing. Esses valores de usos passam a ser atrelados a valores de usos tradicionais utilizados pelo mercado imobiliário. Assim, não basta um imóvel para morar, o valor de uso de morar, habitar passa a ser atrelado ao valor de uso que os serviços ambientais proporcionam.

131 "o fetiche da mercadoria" MARX.
} 
fantasmagórico, não se sabe bem o que é, não a reconhecemos, apenas quando é produzida simulando condições idealizadas da primeira natureza, da natureza original.

Estabelecem-se duas análises: a ideia de natureza enquanto raridade e fetiche do "natural" que se soma à espiral do sobrepreço da terra, valorização fictícia; e uma valorização extra que se agrega ao produto imobiliário, aí designado devido ao valor gerado pelo trabalho social necessário para a produção dessa terceira natureza. Em ambos os casos, a categoria natureza aparece como elemento que potencializa a valorização aparente ou a real. Aparente, ou fictícia, no caso em que não há nenhum trabalho efetivo nessa terra, e real, quando há trabalho investido na criação de uma natureza inventada, gerando, de fato, valor.

Em resumo:

1) Mudança na legislação, oferecendo potencial construtivo onde antes não havia, porque era terra-natureza preservada (remercantilização da natureza):

a. Possibilidade de criação de valor real futuro no processo de produção imobiliária (apropriação de mais-valia).

b. Esse valor futuro é capitalizado no presente, transformado em renda e refletida no preço do terreno.

2) Natureza como bem de consumo é produzida enquanto natureza. Parte da terranatureza é urbanizada, transformada em parque, equipamentos, lagos.

a. Criação de valor real no processo de produção imobiliária do parque (apropriação de mais-valia).

b. Esse valor real criado pelo trabalho contido na produção da natureza é capitalizado pelos rentistas, refletindo no aumento do preço dos terrenos e empreendimentos do entorno. A valorização aparenta haver sido gerada pela presença da natureza; e na aparência, em verdade o foi, mas não da natureza em si, e sim da exploração do trabalho contido na criação desta natureza.

3) Natureza é consumida como bem de consumo, mesmo não sendo produzida.

a. Não há exploração do trabalho no imediato, portanto não há geração de valor.

b. No entanto, valores de outros setores são capitalizados e justificados pelo consumo da natureza. Na aparência, foi a presença da natureza que gerou valor. 
A seguir, tentaremos elucidar e exemplificar esses processos a partir do caso das Operações Urbanas Consorciadas (OUCs) aprovadas em Fortaleza, instrumento da política urbana que possibilita a alteração e flexibilização do uso do solo e que, no caso de Fortaleza, guarda a particularidade de terem sido implantadas quase que totalmente em áreas de proteção e preservação ambiental.

\section{Operações Urbanas Consorciadas ${ }^{132}$ aprovadas em} Fortaleza

O instrumento Operação Urbana Consorciada (OUC) aparece no marco regulatório de Fortaleza pela primeira vez no Plano Diretor de 1992 (PDDU, 1992) ${ }^{133}$. Todavia, o plano não chega a definir as áreas ou zonas onde o instrumento poderia ser utilizado, exigindo, para tanto, a elaboração de uma lei que o regulamentasse, a qual nunca foi publicada. Ainda assim, foram aprovadas três OUCs sob o marco do PDDU-1992.

A primeira delas, aprovada em 2000, um ano antes da publicação do Estatuto da Cidade ${ }^{134}$, que regulamentou o instrumento a nível nacional, foi a OUC do Riacho Maceió, localizada no atual bairro do Mucuripe, lei $n=8.503$, de 26 de dezembro de $2000^{135}$, na gestão do prefeito Juraci Magalhães ( HOLANDA e ROSA, 2017a; 2017b). Após a aprovação do Estatuto, mas ainda sob o marco do PDDU de 1992, o município teve mais duas OUCs aprovadas e publicadas em Diário Oficial: em 2004, a OUC Dunas do Cocó, localizada no atual bairro M. Dias Branco, lei no 8.915, de 23 de dezembro de 2004; e, em 2007, agora na gestão de Luizianne Lins, a OUC Jóquei Club, localizada no bairro de mesmo nome, Lei no 9.333, de 28 de dezembro de 2007 (Figura 52 e Quadro 5).

As OUCs aprovadas, já sob o marco do Plano Diretor Participativo vigente (PDP de 2009) (136 $^{136}$ foram: a OUC Sítio Tunga, aprovada em 2011, lei no 9.778, de 24 de maio de 2011, localizada no bairro Luciano Cavalcante; a OUC Lagoa do Papicu, aprovada no mesmo ano, lei no 9.857,

\footnotetext{
132 Neste momento trataremos apenas das Operações Urbanas Consorciadas (OUCs) aprovadas até 2015.

133 Lei Municipal no 7.061, de 16 de janeiro de 1992.

134 Lei Federal no 10.257, de 10 de julho de 2001.

135 D.O. do município de Fortaleza № 11.997, de 26 de dezembro de 2000. A mesma lei foi republicada no Diário Oficial do Município em 2002 (D.O. no 12.267, de 04 de fevereiro de 2002) para se adequar ao Estatuto da Cidade, porém sem modificações representativas no conteúdo da OUC

136 Lei Complementar Municipal no 062, de 02 de fevereiro de 2009.
} 
de 22 de dezembro de 2011, no bairro Papicu, ambas na gestão da prefeita Luizianne Lins. Em 2015, na primeira gestão de Roberto Cláudio, ainda sem nenhuma OUC concluída, foram aprovadas mais duas: a OUC Osório de Paiva, lei no 10.403, de 13 de outubro de 2015, localizada entre os barros Siqueira e Canindezinho; e a OUC Parque Urbano da Lagoa da Sapiranga, lei no 10.404, de 13 de outubro de 2015, no bairro Sapiranga. A localização de cada uma e informações gerais podem ser visualizadas na Figura 52 e Quadro 5.

Figura 52. Operações Urbanas Consorciadas em Fortaleza, aprovadas e com lei publicada no Diário Oficial do Município, entre 2000 e 2017.

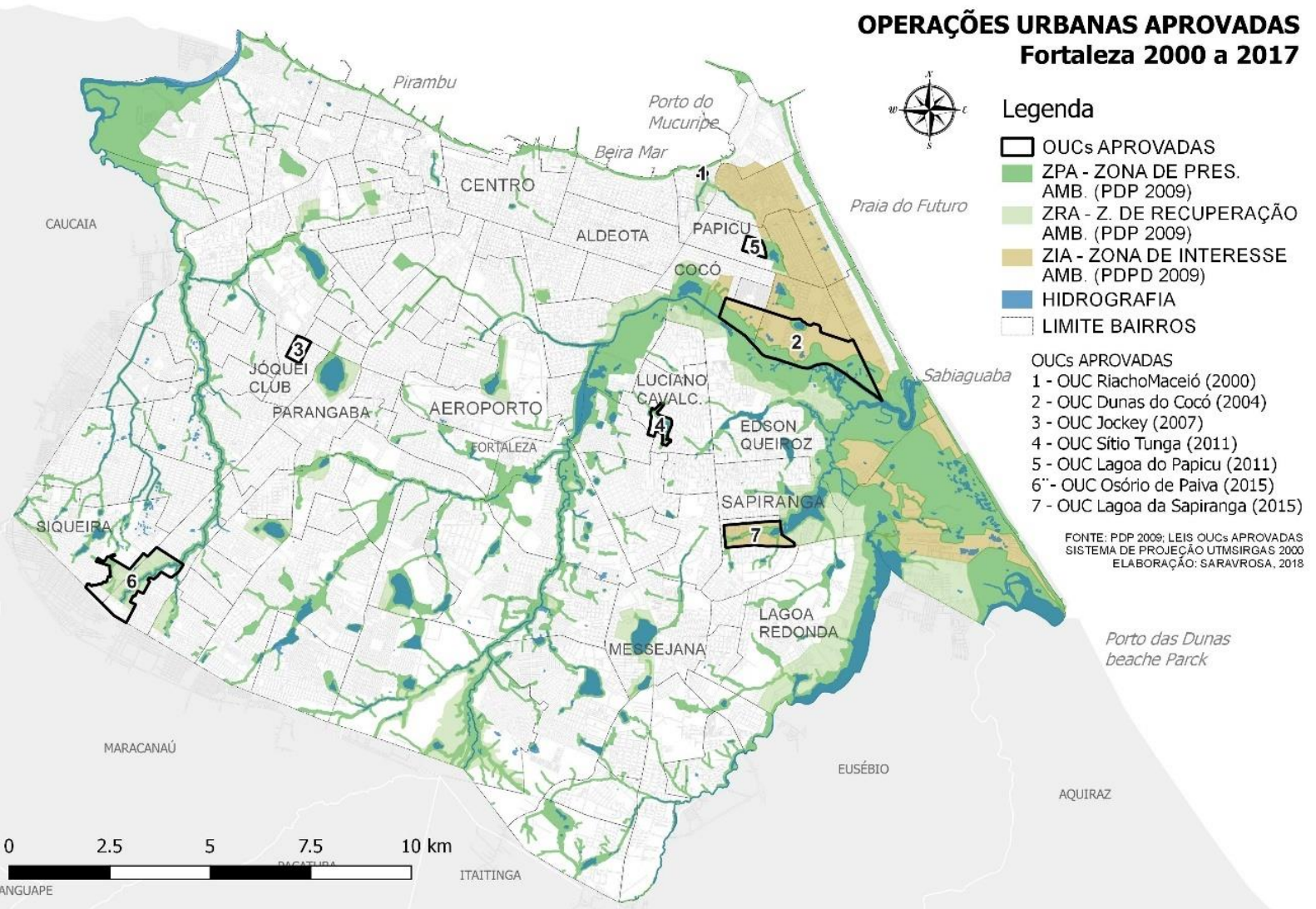

Elaboração: Rosa (2018). Fonte: FORTALEZA/PDP (2009); FORTALEZA LEIS: 8.503 (2000), 8.915 (2004), 9.333 (2007), 9.778 (2011), 9.857 (2011), 10.403 (2015), 10.404 (2015); limite dos bairros e do município: FORTALEZA/SEUMA (2015). Observação: Há uma diferença entre os limites do Município de Fortaleza publicados com o zoneamento do PDP em 2009, e os mapas que passaram a ser veiculados pela SEUMA a partir, principalmente, de 2015. No caso, por exemplo, o setor inferior da OUC Osório de Paiva (6), que aparece em branco no mapa, não constava como área de Fortaleza nos mapas de publicação do PDP em 2009.

Com porte bem diferente daquelas realizadas em São Paulo e Rio de Janeiro, as OUC firmadas em Fortaleza, até 2015, são mais pontuais, e em alguns casos destinadas à viabilização de um único empreendimento, porém têm apresentado uma evolução e uma diferenciação de seu conteúdo ao longo das diferentes gestões que as formularam. Nas gestões do prefeito Roberto Cláudio, esse instrumento, juntamente com outras possibilidades de parcerias público-privadas, tem ganhado papel de destaque como possível "solução de problemas 
urbanos" e requalificação urbana e ambiental, sendo anunciada em fóruns realizados na Câmara de Dirigentes Lojistas de Fortaleza - CDL e na Federação das Indústrias do Estado do Ceará - FIEC (HOLANDA; ROSA, 2017).

Contudo Maricato e Ferreira (2002), um ano após a publicação do Estatuto da Cidade, já chamavam atenção para a maleabilidade do instrumento da Operação Urbana Consorciada, que, em suas tentativas de aplicação no Brasil, principalmente em São Paulo, até a data, haviam funcionado muito mais como operações imobiliárias com fins lucrativos e pouca ou nenhuma melhoria social e ambiental. Os mesmos autores, assim como Fix (2011); Santoro e Rolnik (2017); Pequeno et al. ( 2018), têm afirmado que a aplicação desse instrumento, pelo município, obedeceu muito mais a uma lógica política que técnica na promoção de processos de valorização imobiliária excludente, proporcionando a flexibilização dos parâmetros urbanísticos, a mudança de uso do solo e "garantido ao setor privado vultosos lucros com o intuito de reabilitar setores da cidade". Entretanto, como destacam esses autores e Albuquerque ( 2015 ), o retorno para o município e para a cidade mostra-se reduzido ou mesmo inexistente, demonstrando que estes estão longe de serem utilizados como instrumentos de inclusão, resgate de mais-valia e redistribuição de riqueza, como às vezes são justificados.

Quadro 5. Operações Urbanas Consorciadas (OUCs) aprovadas em Fortaleza até 2015.

\begin{tabular}{|c|c|c|c|}
\hline OUC & ANO & LEI DE CRIAÇÃO & ÁREA $\left(M^{2}\right)^{* 1}$ \\
\hline Riacho Maceió & 2000 & Lei № 8503, de 26 de dezembro de 2000 & $30.248,08$ \\
\hline Dunas do Coco & 2004 & Lei № 8915, de 23 de dezembro de 2004 & $3.352 .339,68$ \\
\hline Jockey Club & 2007 & Lei № 9333, de 28 de dezembro de 2007 & $228.568,00$ \\
\hline Sítio Tunga & 2011 & Lei № 9778, de 24 de maio de 2011 & $246.840,31$ \\
\hline Lagoa do Papicu & 2011 & Lei № 9857, de 22 de dezembro de 2011 & $216.617,31$ \\
\hline Parque Urbano da Lagoa da Sapiranga & 2015 & Lei № 10404 , de 13 de outubro de 2015 & $877.747,13$ \\
\hline Osório de Paiva & 2015 & Lei № 10403 , de 13 de outubro de 2015 & $1.797 .490,06$ \\
\hline
\end{tabular}

Elaboração Rosa (2019). Fontes: Fortaleza/PDDU (1992); Fortaleza/LUOS (1996); Fortaleza/PDP (2009); leis de cada OUC. * Área calculada com software Qgis, a partir de shapefile gerado com base em arquivo KMZ disponibilizado no site da SEUMA, em 2017.

Destaca-se também como aspectos em comum entre as sete OUCs aprovadas, além do pequeno porte, a desconsideração das comunidades vulneráveis ou assentamentos precários localizados na poligonal destas ou em seu entorno, bem como a grande flexibilização que o instrumento traz à área onde incide quanto aos parâmetros urbanos, como índice de aproveitamento, taxa de ocupação, altura máxima das edificações, parcelamento, uso do solo e zoneamento (HOLANDA E ROSA, 2017a, 2017b). Essas alterações/flexibilizações dos 
parâmetros são ainda mais gritantes se considerarmos o fato de que quase todas elas estão localizadas em áreas de proteção e preservação ambiental. "Somando as áreas totais das sete operações, contata-se que em torno de $80 \%$ a $90 \%{ }^{137}$ deste total se encontra dentro do macrozoneamento ambiental" (HOLANDA e ROSA, 2017a, p.18), (Figura 52 e Figura 53).

Outro aspecto destacado por Holanda e Rosa (2017b) é o enorme descumprimento das exigências legais em todas as 7 operações. No artigo, os autores analisam o cumprimento das exigências legais quanto ao conteúdo mínimo definido pelo Estatuto da Cidade (lei federal no 10.257/2001), definidos em 7 pontos, e constatam que 5 deles não foram atendidos: 1) Não definição na lei da OUC, de maneira clara, da área da Operação. Em geral, as leis apresentam mapas distorcidos e de baixa resolução, sem descrição ou coordenadas geográficas da área exata da poligonal, tornando quase impossível a reprodução da área a partir das leis publicadas; 2) As OUCs Dunas do Cocó, Osório de Paiva e Sapiranga não apresentam programa básico de ocupação da área; 3) Nenhuma apresentou Programa de Assistência Econômica e Social para as Comunidade Diretamente Afetadas; 4) Nenhuma tampouco apresentou Estudo Prévio de Impacto de Vizinhança; 5) Nenhuma desenvolveu forma de controle da operação compartilhada com representantes da sociedade civil. O município criou Conselho Gestor da Operação em apenas uma, na Osório de Paiva. Todavia, não existe agenda, nem deliberações junto ao conselho.

As duas primeiras OUC aprovadas, Riacho Maceió (2000) e Dunas do Cocó (2004), foram voltadas para viabilizar uso hoteleiro e residencial, respectivamente, com parâmetros urbanos mais flexíveis do que o permitido no Plano Diretor do município. Na primeira, o objeto da lei prevê a construção de um apart hotel, sendo esta a menor operação aprovada em Fortaleza. A segunda, um loteamento unifamiliar localizado em áreas de Dunas. As operações que se seguiram passaram a mesclar diferentes tipos de usos.

As OUCs que se seguiram são: Jockey Club (2007), Sítio Tunga (2011), e Lagoa do Papicu (2011). Estas três, diferentes das duas primeiras, misturam usos comerciais e residenciais, com

\footnotetext{
137 Cálculo de Holanda em HOLANDA e ROSA, 2017a, chega ao resultado de mais de $88 \%$ da área todas das OUCs, juntas, dentro do macrozoneamento ambiental do município, considerando o zoneamento do PDP (2009) atualizado e publicado pela SEUMA em 2015. Se considerarmos o PDP-2009 em seu zoneamento ambiental, tal qual publicado em 2009, temos um resultado de aproximadamente $84 \%$ da área de todas das OUCs juntas dentro do macrozoneamento ambiental do município, segundo cálculo realizado por Rosa para esta tese. A alteração deve-se principalmente à diferença de área no limite do município nos mapas publicados a partir de 2015, que ultrapassam o limite da base de 2009 na área da OUC Osório de Paiva. Assim, ao utilizar o zoneamento publicado em 2009, parte da OUC da Osório de Paiva fica sem parâmetros.
} 
características de empreendimentos do tipo de complexos imobiliários. No caso do Jockey e da Lagoa do Papicu, ambas têm a semelhança de possuírem um grande equipamento comercial âncora, o Shopping Center Jockey Club na primeira e o Shopping Center RioMar na segunda.

As duas últimas Operações Urbanas Consorciadas aprovadas são a da Lagoa da Sapiranga e da Osório de Paiva. Ambas tiveram lei publicada em 2015 no mesmo Diário Oficial do Município e guardam uma certa semelhança com a OUC Dunas do Cocó, tendo como principal objeto da operação a possibilidade de reloteamento da área. A diferença entre elas é que as últimas buscam incentivar usos comerciais e de serviços na área, principalmente a da Osório de Paiva. Outro detalhe importante destacado por Holanda e Rosa ( 2017a) é que a OUC da Lagoa da Sapiranga é a primeira que traz, no corpo de texto da lei, a possibilidade de emissão de CEPAC $^{138}$. ( HOLANDA e ROSA, 2017a).

Passados quase vinte anos da primeira OUC aprovada, nenhuma das sete OUCs que tiveram leis de criação aprovadas, foi completamente finalizada. A OUC do Riacho Maceió teve a contrapartida do ente privado (a urbanização da foz do riacho) concluída somente em agosto de $2014^{139}$, mas segue aguardando para iniciar o empreendimento imobiliário que seria um apart hotel, atualmente a cargo da construtora Colmeia sob incorporação da Terra Brasilis ${ }^{140}$. A OUC da Lagoa do Papicu concluiu a construção do Shopping RioMar ${ }^{141}$ em agosto de 2014, porém, ainda não construiu todos os empreendimentos (torres residenciais e comerciais) das duas quadras anexas ao shopping. A OUC Jockey Club teve a obra do Hospital da Mulher concluída em agosto de $2012^{142}$, ainda na gestão da prefeita Luzianne Lins. O shopping desta

\footnotetext{
$138 \mathrm{Em} \mathrm{2015}$, a gestão do prefeito Roberto Cláudio, aprovou um número considerado de leis complementares e de regulamentação de instrumentos, além da lei de criação da OUC da Lagoa da Sapiranga e a da Osório de Paiva. Dentre essas leis, está a de no 10.333, de 10 de abril de 2015, que regulamenta a Transferência do Direito de Construir, conferindo ao município a opção de atrelar a emissão de CEPAC (Certificado de Potencial Adicional Construtivo) ao instrumento de Transferência do Direito de Construir. "Art. 60 - Quando a transferência do direito de construir for autorizada, sem a imediata indicação de um imóvel receptor do potencial construtivo, a Secretaria Municipal de Urbanismo e Meio Ambiente (SEUMA) emitirá o Certificado do Potencial Adicional de Construção (CEPAC). § 1 - Também será emitido o Certificado do Potencial Adicional de Construção (CEPAC), quando a transferência do direito de construir exigir a doação do imóvel ao Município de Fortaleza. § 2ㅇ - Cabe à Secretaria Municipal de Urbanismo e Meio Ambiente (SEUMA) fazer rigoroso cadastro e controle da emissão e uso do Certificado do Potencial Adicional de Construção (CEPAC)" (FORTALEZA, 2015. Lei 10.333).

139 O Parque recebeu o nome oficial do arquiteto "Otacílio Teixeira Lima Neto (Bisão)". https://www.fortaleza.ce.gov.br/noticias/prefeitura-de-fortaleza-inaugura-parque-do-riacho-maceio-nesta-sexta-feira-0. ${ }^{140}$ A assinatura da lei da OUC do Riacho Maceió foi realizada com a empresa NORPAR Participações e Empreendimentos S.A. A Terra Brasilis é uma das acionárias que compões a BORPAR, detendo $25 \%$ desta, juntamente com a empresa de capital aberto Tecnisa, que detém $75 \%$ das ações.

${ }^{141}$ A construção do Shopping teve início em meados de agosto de 2012, menos de um ano depois da publicação da Lei no Diário Oficial do Município.

${ }^{142}$ http://g1.globo.com/ceara/noticia/2012/08/ministro-participa-de-inauguracao-do-hospital-da-mulher-no-ceara.html.
} 
última OUC, North Shopping Jóquei, foi inaugurado pouco mais de um ano depois do hospital (que foi construído pelo município) ${ }^{143}$, em outubro de $2013^{144}$, já os empreendimentos verticais das quadras anexas integrantes da operação seguem em construção.

Em 2017, iniciou-se a construção do comércio atacadista de alimentos na OUC da Osório de Paiva, porém ainda não se tem conhecimento das demais ações da OUC. A OUC Sítio Tunga teve início de obras este ano. Já as OUCs Dunas do Cocó e Lagoa da Sapiranga seguem sem movimentações.

No quadro a seguir podem ser conferidos os objetivos definidos na lei de cada Operação Urbana Consorciada aprovada.

Quadro 6. Objetivos das OUCs aprovadas.

\begin{tabular}{|c|c|}
\hline nome & objetivo \\
\hline $\begin{array}{l}\text { Riacho } \\
\text { Maceio }\end{array}$ & $\begin{array}{l}\text { J - recuperação da foz do riacho Maceió, através da implantação dos seguintes projetos: a) execução das obras de drenagem, } \\
\text { canalização e saneamento da foz do riacho Maceió; b) delimitação das faixas de preservação e proteção especial; c) } \\
\text { construção e implantação do Parque Foz Riacho Maceió e seus respectivos acessos de integração com a circulação de seu } \\
\text { entorno; II - incrementar a ocupação ordenada do espaço urbano local, através da construção de empreendimento } \\
\text { imobiliário destinado à moradia e atividade hoteleira pelo grupo empreendedor privado co-participante, indicado nesta } \\
\text { Lei. }\end{array}$ \\
\hline $\begin{array}{l}\text { Dunas do } \\
\text { Coco }\end{array}$ & $\begin{array}{l}\text { I - dotar o Município de área com uso residencial exclusivamente unifamiliar a se implantar nos lotes existentes ou nos } \\
\text { parcelamentos a serem implantados, em forma de condomínio residencial de casas térreas ou assobradadas, autônomas } \\
\text { entre si com baixa densidade, assegurada assim uma ocupação rarefeita em área ambiental sensível; II - viabilizar a } \\
\text { implantação do Sistema Viário Principal para a área, estabelecido por diretrizes elaboradas pela SEINF e composto das } \\
\text { seguintes vias: prolongamento da Avenida Antônio Sales no trecho entre a Cidade } 2000 \text { e a Avenida Trajano de Medeiros; } \\
\text { abertura de avenidas paisagísticas que delimita a área de preservação do Rio Cocó no trecho entre a Avenida Sebastião de } \\
\text { Abreu e a Avenida Trajano de Medeiros; III - implantar o Parque Linear do Rio Cocó ao longo da via paisagística como forma } \\
\text { de garantir a preservação das margens do referido recurso hídrico; IV - implantar as atividades de atendimento ao público, } \\
\text { inerentes aos objetivos do Parque, com a oferta de seus serviços a promoções populares, a atividades escolares e à pesquisa } \\
\text { científica; V - incrementar, em seu espaço, a visitação pública, com objetivos turísticos, recreativos e educacionais; VI - } \\
\text { desenvolver em seu espaço técnicas pedagógicas de interação com o meio ambiente; VII - contribuir no sentido de } \\
\text { conscientizar o público que o frequenta da importância de preservação da natureza; VIII - oferecer aos seus usuários um } \\
\text { centro integrado de lazer e de incentivo de preservação ambiental, com experimentação de um modelo interativo de } \\
\text { incremento conservacionista da natureza, em compatibilidade e integração com os objetivos e propostas do Parque } \\
\text { Ecológico do Rio Cocó. }\end{array}$ \\
\hline $\begin{array}{l}\text { Jockey } \\
\text { Club }\end{array}$ & $\begin{array}{l}\text { I - Permitir o reparcelamento da área do Loteamento Parque São Cristóvam onde se situa o Jockey Clube Cearense e } \\
\text { promover o loteamento da gleba objeto da matrícula imobiliária no } 65.858 \text { do Cartório de Registro de Imóveis da } 3 \text { a Zona } \\
\text { desta capital; II - possibilitar a implantação do Hospital da Mulher em área localizada no perímetro do Loteamento Parque } \\
\text { São Cristóvam, situado na confluência da Avenida Lineu Machado com a Avenida Carneiro de Mendonça, estabelecida pelo } \\
\text { Município de Fortaleza, em decorrência das diretrizes do reparcelamento; III - a desafetação e permuta da área de praça e } \\
\text { ruas localizadas no Loteamento Parque São Cristóvam, com o fim de haver a relocação das áreas públicas e o novo traçado } \\
\text { viário; IV - incrementar a ocupação ordenada do espaço urbano local, através de construção residencial e de equipamento } \\
\text { de saúde; V - melhorar a fluidez do tráfego com a implantação de novas vias de circulação em toda a área objeto da presente } \\
\text { operação consorciada. }\end{array}$ \\
\hline
\end{tabular}

143 O ente privado entrou, como uma das contrapartidas da Operação, com a doação de um terreno de $7.175,25 \mathrm{~m}^{2}$ (FORTALEZA. Lei № 9333, de 28 de dezembro de 2007. Art. 9o, parágrafo II, inciso c.), porém a construção do hospital ficou a cargo do município. As demais contrapartidas do ente privado (formas de participação) são quase todas exigências já encontradas na lei de parcelamento nacional e municipal.

${ }^{144}$ https://www20.opovo.com.br/app/opovo/economia/2013/10/31/noticiasjornaleconomia,3155861/north-shoppingjoquei-e-inaugurado.shtml. 

público, através da construção, urbanização e iluminação da Avenida Pindorama, bem como de 2 (dois) outros trechos de vias locais, no bairro Luciano Cavalcante; Il - viabilizar a implantação de habitações de caráter social através da Fundação HABITAFOR; III - viabilizar a implantação de um parque público municipal, consoante diretrizes a serem definidas pelo poder público municipal, através da Secretaria Municipal de Desenvolvimento Urbano e Infraestrutura (SEINF), com a manutenção garantida com recursos privados; IV - incrementar a ocupação ordenada do espaço urbano local, integrante da Zona de Ocupação Moderada (ZOM 1), através da construção de empreendimento imobiliário predominantemente residencial; $V$ - permitir o parcelamento, o uso e a ocupação da área ora indicada de forma diferenciada; VI - definir o estoque de potencial construtivo da área contida no perímetro da OUC, a ser adquirida onerosamente por proprietários e empreendedores interessados, segundo as regras da outorga onerosa do direito de construir (art. 244, inciso II - PDP); e VII - proteger as áreas de preservação permanente existentes na área objeto desta OUC.

Lagoa do I - dotar o Município de Fortaleza de alternativas de sustentabilidade ambiental, social e econômica para aquela região, Papicu mediante construção de empreendimento de centro comercial de grande porte, tipo shopping center, e de edifícios de uso comercial e habitacional multifamiliar e de uso misto, [...]; II - realizar programa socioeducativo de capacitação profissional de 1.000 (mil) pessoas, objetivando a empregabilidade na indústria da construção civil e, preferencialmente, nas obras que se constituem objeto desta Operação Urbana Consorciada, [...]; III - manter e instalar unidade do Instituto João Carlos Paes Mendonça, pelo prazo de 10 (dez) anos, a contar após 20 (vinte) meses da concessão da licença de construção do empreendimento comercial de grande porte, tipo shopping center, objetivando a empregabilidade e exercício da cidadania da população a ser assistida; IV - realizar obras de interesse público, através do alargamento, urbanização e iluminação, às custas dos investidores privados, das Ruas Prisco Bezerra e Almeida Prado, [...], em área restrita aos imóveis de propriedade dos investidores privados; V - construir 75 (setenta e cinco) unidades habitacionais, de interesse social, nos padrões comumente utilizados pela Municipalidade, bem como seu arruamento, em área a ser cedida pelo Município de Fortaleza no prazo máximo de 180 (cento e oitenta) dias contados a partir da data da publicação desta Lei, destinadas estas unidades habitacionais aos atuais ocupantes do leito da Rua César Fonseca, entre o trecho que compreende a Rua Lauro Nogueira e a Avenida Santos Dumont, com posterior requalificação deste trecho com pavimentação devida; VI - implantar e construir eventuais equipamentos urbanos compatíveis, de área verde, em espaço de $9.891,79 \mathrm{~m} 2$ (nove mil, oitocentos e noventa e um metros e setenta e nove centímetros quadrados), localizada no imóvel do empreendimento, [...], e em substituição à área anteriormente destinada para praça, a qual totalizava 5.626,67m2 (cinco mil, seiscentos e vinte e seis metros e sessenta e sete centímetros quadrados) e com localização anterior ao lado leste do imóvel objeto desta Operação Urbana Consorciada, [...]; VII - construir o prolongamento da Rua Ari Barroso, a cortar, na direção oeste-leste, o imóvel objeto desta Operação Urbana Consorciada, [...]; VIII - fomentar a ocupação ordenada do espaço urbano local, integrante da Zona de Ocupação Prioritária (ZOP 2), através da construção de equipamentos de uso coletivo não habitacionais, edificações habitacionais multifamiliares e de uso misto e de centro comercial de grande porte, tipo shopping center; IX - permitir o parcelamento, o uso e a ocupação da área ora indicada de forma diferenciada, nos termos previstos na presente Lei; $X$ - instalar e manter, sob responsabilidade dos investidores privados, pelo período de 10 (dez) anos, após a construção, cercas de proteção do entorno da lagoa do Papicu e manutenção da calçada existente, a fim de servirem à melhor qualidade de vida e de espaço de lazer dos habitantes da região e do Município de Fortaleza, bem como a limpeza inicial do entorno da lagoa do Papicu; XI - limpeza sistemática da área do Parque da Lagoa do Papicu.

Parque I - Compatibilizar a conservação dos sistemas ambientais com uso sustentável dos recursos naturais; II - Incentivar a Urbano gestão compartilhada com a iniciativa privada das Áreas Verdes públicas; III - Promover a recuperação de áreas; verdes degradadas, de importância paisagístico-ambiental; IV - Regulamentar o disciplinamento do uso nos parques municipais, Lagoa da das atividades culturais e esportivas, bem como dos usos de interesse comercial e turístico, compatibilizando-os ao caráter Sapiranga público desses espaços; $V$ - Estabelecer a recuperação das áreas verdes, principalmente daquelas localizadas no entorno dos recursos hídricos; $\mathrm{VI}$ - Estabelecer parceria entre os setores público e privado, por meio de convênios, incentivos fiscais e tributários, para a implantação e manutenção de áreas verdes; VII - Implementar área componente do Sistema Municipal de Áreas Verdes; VIII - Disciplinar o processo de uso e ocupação do solo do entorno; IX - Melhorar a qualidade de vida da população residente, mediante orientação e disciplina das atividades econômicas locais; $X$ - Assegurar a sustentabilidade dos recursos naturais; XI - Regular o uso admissível dessas áreas, de modo a compatibilizar com os objetivos de conservação da natureza; XII — Fomentar e incentivar o ecoturismo sustentável e a educação ambiental; XIII — Preservar as culturas e as tradições locais.

Osório de I - Promover transformações urbanísticas estruturais e melhorias socioeconômicas na área da operação; II — Assegurar a paiva proteção e a valorização dos recursos ambientais existentes na Área de Preservação Permanente inserida na área objeto desta OUC; III - Compatibilizar a conservação dos sistemas ambientais com uso sustentável dos recursos naturais; IV Incentivar a gestão compartilhada com a iniciativa privada das Áreas Verdes públicas; V - Estabelecer parceria entre os setores público e privado, por meio de convênios, incentivos fiscais e tributários, para a implantação e manutenção de Áreas Verdes; VI - Disciplinar o processo de uso e ocupação do da área solo do entorno; VII - Melhorar a qualidade de vida da população residente no entorno, mediante orientação e disciplina das atividades econômicas locais; VIII - Assegurar a sustentabilidade dos recursos naturais; IX - Regular o uso admissível dessas áreas, de modo a compatibilizar com os objetivos de conservação da natureza; $X$ - Preservar as culturas e as tradições locais; XI - Assegurar o respeito ao interesse coletivo e à função social da cidade quanto aos limites, parâmetros de uso, ocupação e parcelamento do solo, estabelecidos no PDP e na legislação dela decorrente; XII - Dotar a porção sudoeste da cidade de áreas para instalação de equipamentos com grande potencial gerador de emprego e renda, aproveitando a infraestrutura viária existente; XIII - Permitir e estimular a instalação de atividades de comércio e serviços conjugadas à atividade residencial, nos termos do Anexo IV.

Fonte: FORTALEZA (2000; 2004; 2007; 2011a; 2011b; 2015a; 2015b) - Lei № 8503, de 26 de dezembro de 2000; Lei № 8915, de 23 de dezembro de 2004; Lei № 9333, de 28 de dezembro de 2007; Lei № 9778, de 24 de maio de 2011; Lei № 9857, de 22 de dezembro de 2011; Lei № 10404, de 13 de outubro de 2015; Lei № 10403, de 13 de outubro de 2015. Sistematizado pela autora. 
Do antivalor à possibilidade de valor e remercantilização estatal de áreas de proteção e preservação ambiental ${ }^{145}$

Como comentado anteriormente, as OUCs aprovadas em Fortaleza possuem a particularidade de estarem quase que completamente sobre terreno legalmente classificado como áreas de proteção e preservação ${ }^{146}$ ambiental definidas no zoneamento municipal. O Quadro 7 a seguir detalha para cada operação as zonas segundo o PDDU de 1992 e o PDP de 2009, assim como o total de suas áreas dentro das zonas que pertencem à categoria de proteção ambiental e às de preservação ambiental. Já o mapa da Figura 53 qualifica essa informação, ao mostrar espacialmente a sobreposição das OUCs com o zoneamento ambiental.

Os cálculos apresentados no Quadro 7 e a espacialização da Figura 53 foram produzidos a partir do zoneamento do Plano Diretor Participativo (PDP-2009), considerando a informação da publicação da lei no Diário Oficial do Município. Posteriormente, principalmente a partir de 2015, houve modificações no zoneamento ambiental do município. Todavia, para facilitar a compreensão e considerando que a maioria das OUCs é anterior a esta data, optou-se por fazer a análise, neste momento, considerando o zoneamento original.

A partir destas informações, é possível constatar que, das 7 operações firmadas, apenas duas delas, a da Lagoa do Papicu e a do Jockey Club, não se sobrepõem ao macrozoneamento ambiental. A Lagoa do Papicu, apesar de não englobar áreas de proteção ou preservação na sua poligonal original, está localizada ao lado da ZPA da lagoa do Papicu, e possui contrapartidas sobre esta área. Das 5 restantes, 3 delas (Riacho Maceió, Sapiranga e Osório de Paiva) têm toda sua poligonal totalmente dentro da Macrozona Ambiental (Figura 52).

\footnotetext{
${ }^{145}$ Aqui falaremos de maneira geral de todas as OUCs apresentadas, todavia detalharemos com maior atenção o caso da OUC Riacho Maceió por ser bem representativa das questões enunciadas e por ser umas das poucas que saiu do papel.

146 Por preservação ambiental entende-se aqui áreas com importância ambiental, segundo legislações e definições sociais, destinadas à preservação permanente, ou seja, não edificantes, e por proteção ambiental, entende-se áreas também de importância ambiental, segundo legislações e definições sociais, onde o seu uso e a construção nesta são controlados e restritos.
} 
Figura 53. Localização das OUC frente ao zoneamento ambiental do município segundo Zoneamento do PDP-2009.
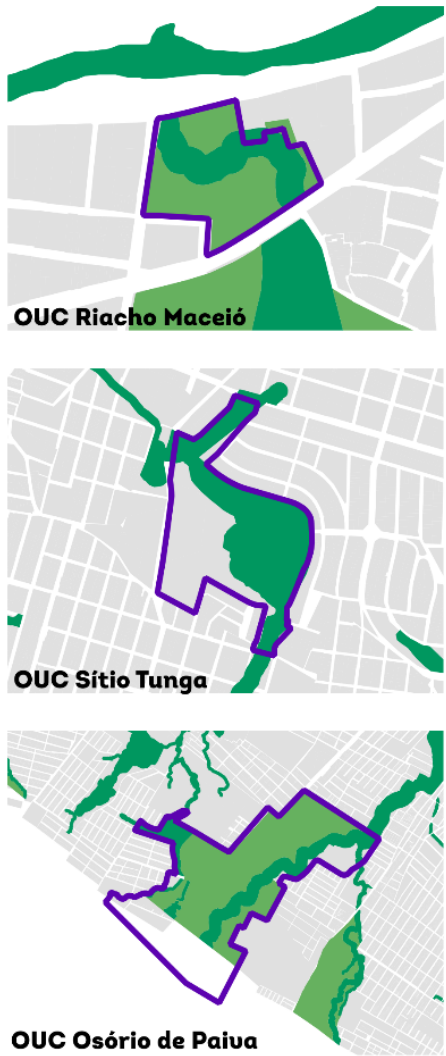
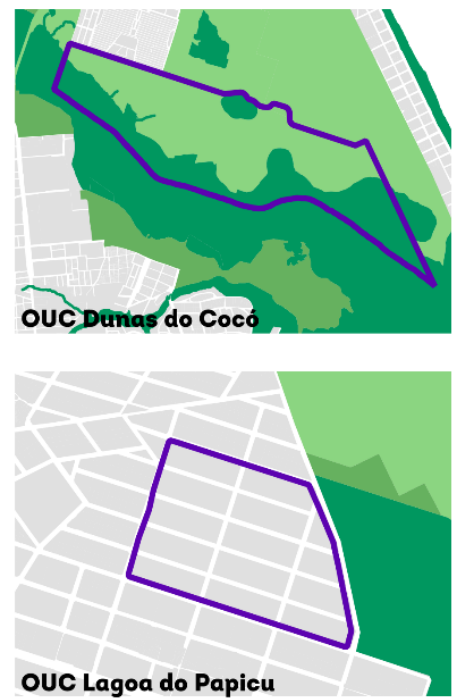

\section{OUCs}

\section{ESPECIFICAÇõES:}

Sistema de proj. geográfica /

FONTES:

(2009), SEFIN (2015) e LEHAB.

DATA:
03 de novembro de 2016 .
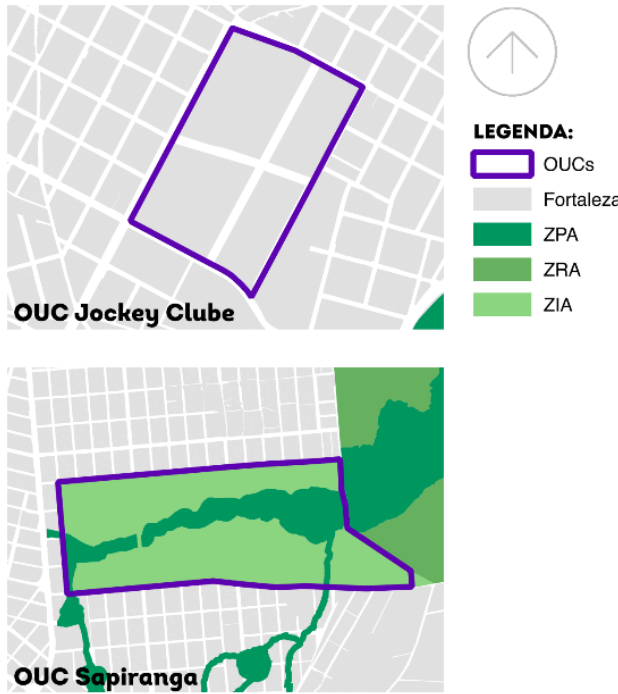

Macrozoneamento

Ambiental - PDP 2009

REALIZAÇÃo: APOIO:

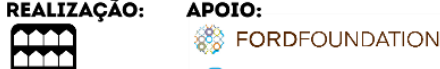

LEHAB @CNPq

Fonte: HOLANDA; ROSA, 2017. SEUMA, 2015/PDP, 2009; leis de criação das Operações Urbanas. Elaboração: HOLANDA/LEHAB, 2016. Mapa elaborado a partir do zoneamento do Plano Diretor Participativo (Lei Complementar № 62 de 2009), conforme publicado no Diário Oficial em 2009. Observação: O limite do município de Fortaleza e seus bairros, publicado junto com o mapa do zoneamento do PDP-2009, no Diário Oficial no, difere do limite das cartografias atuais adotadas pela prefeitura a partir de 2015. Mapa com a sobreposição das OUCs com o limite do município e zoneamento do PDP atualizado pela SEUMA em 2015/2017 pode ser visualizado no Anexo: Figura 121.

Quadro 7. OUCs e zoneamento ambiental (PDP-2009)

\begin{tabular}{|c|c|c|c|c|c|c|c|c|}
\hline OUC & $\begin{array}{l}\text { Recursos ambientais } \\
\text { envolvidos }\end{array}$ & $\begin{array}{l}\text { zoneamen } \\
\text { to (PDDU- } \\
\text { 1992) }\end{array}$ & $\begin{array}{l}\text { zoneamen } \\
\text { to (PDP- } \\
\text { 2009) }\end{array}$ & $\begin{array}{l}\text { AREA DA } \\
\text { OUC }\left(\mathrm{M}^{2}\right)^{* 1}\end{array}$ & $\begin{array}{l}\text { ÁREA }\left(\mathrm{M}^{2}\right): \\
\text { PRESERVAÇÃ } \\
0\end{array}$ & $\begin{array}{l}\text { ÁREA (M²): } \\
\text { PROTEÇÃO }\end{array}$ & $\begin{array}{l}\text { ÁREA }\left(M^{2}\right): \\
\text { TOTAL ZON. } \\
\text { AMB. }\end{array}$ & $\begin{array}{l}\text { \% ÁREA } \\
\text { EM } \\
\text { ZON. } \\
\text { AMB. }\end{array}$ \\
\hline $\begin{array}{l}\text { Riacho } \\
\text { Maceió }\end{array}$ & Riacho Maceió & $\begin{array}{l}\text { AP; APE; } \\
\text { AOM }\end{array}$ & $\begin{array}{l}\text { ZRA; ZPA; } \\
\text { ZO4 }\end{array}$ & $30.248,1$ & $11.414,0$ & $18.333,7$ & $29.747,6$ & $98 \% * 2$ \\
\hline $\begin{array}{l}\text { Dunas do } \\
\text { Coco }\end{array}$ & Dunas do Cocó; Rio Cocó & AP; AIA & ZIA; ZPA & $3.352 .339,7$ & $1.487 .242,8$ & $1.865 .096,9$ & $3.352 .339,7$ & $100 \%$ \\
\hline Jockey Club & - & ZU.4; AEA & ZRU 1 & $228.568,0$ & 0,0 & 0,0 & 0,0 & $0 \%$ \\
\hline Sítio Tunga & Recurso hídrico (lagoa) & $\begin{array}{l}\text { não } \\
\text { aplica }\end{array}$ & ZOM1; ZPA & $246.840,3$ & $142.779,5$ & & $142.779,5$ & $58 \%$ \\
\hline $\begin{array}{l}\text { Lagoa do } \\
\text { Papicu }\end{array}$ & $\begin{array}{l}\text { Lagoa do Papicu (fora da } \\
\text { poligonal) }\end{array}$ & $\begin{array}{ll}\text { não } & \text { se } \\
\text { aplica }\end{array}$ & ZOP & $216.617,3$ & 0,0 & 0,0 & 0,0 & $0 \%$ \\
\hline $\begin{array}{l}\text { Parque } \\
\text { Urbano da } \\
\text { Lagoa da } \\
\text { Sapiranga }\end{array}$ & $\begin{array}{l}\text { Lagoa da Sapiranga; } \\
\text { Unidade de conservação } \\
\text { (APA da Sabiaguaba) }\end{array}$ & $\begin{array}{ll}\text { não } & \text { se } \\
\text { aplica }\end{array}$ & $\begin{array}{l}\mathrm{ZIA} ; \quad \mathrm{ZPA} ; \\
\mathrm{APA}^{* *}\end{array}$ & $877.747,1$ & $195.247,4$ & $665.416,2$ & $860.663,6$ & $98 \% * 2$ \\
\hline $\begin{array}{l}\text { Osório de } \\
\text { Paiva }\end{array}$ & Rio Maranguapinho & $\begin{array}{l}\text { não } \\
\text { aplica }\end{array}$ & ZRA; ZPA & $1.797 .490,1$ & $367.519,3$ & $896.021,3$ & $1.263 .540,7$ & $70 \%$ \\
\hline área total & & & & $6.749 .850,6$ & $2.204 .203,0$ & $3.444 .868,1$ & $5.649 .071,1$ & $84 \%$ \\
\hline
\end{tabular}

Elaboração Rosa (2019). Fontes: Fortaleza/PDDU (1992); Fortaleza/LUOS (1996); Fortaleza/PDP (2009); leis de cada OUC. *1 Área das OUCs calculada com software Qgis a partir de shapefile elaborado com base em arquivo KMZ disponibilizado no site da SEUMA em 2017. *2 OUC Riacho Maceió e Lagoa da Sapiranga possuem, na realidade, 100\%, de sua poligonal dentro do Zoneamento Ambiental, as pequenas diferenças devem-se mais a problemas cartográficos de geração da informação, como escalas diferentes e imprecisão na delimitação. ${ }^{* 3}$ A OUC Osório de Paiva, quando sobreposta com o zoneamento e limites municipais utilizados pela SEUMA a partir de 2015, ano da sua aprovação, fica com quase $90 \%$ da sua poligonal dentro do zoneamento ambiental (ver anexo) Legenda das siglas: PDDU-1992: AP = área de preservação; APE = área de proteção; AOM = área de orla marítima; AIA = área de interesse ambiental; ZU.4 = zona urbana 4; AEA = área especial aeroportuária. 
PDP-2009: ZPA = zona de preservação ambiental; ZRA = zona de recuperação ambiental; ZIA = zona de interesse ambiental; ZO4 = zona de orla 4; ZRU = zona de requalificação urbana; ZOP = zona de ocupação prioritária. **APA = Área de Proteção Ambiental - categoria de Unidade de Conservação definida pelo Sistema Nacional de Unidades de Conservação.

Importante destacar que, das três OUCs aprovadas ainda sob a vigência do PDDU-1992 (Riacho Maceió, Dunas do Coco e Jockey Club), as duas primeiras, Parque Riacho Maceió e Dunas do Cocó aprovadas na gestão do então prefeito Juraci Magalhães, foram delimitadas já sobre zoneamento de proteção e preservação ambiental.

Quanto à localização nas áreas de proteção e preservação ambiental do PDP-2009, este, na sessão sobre as Operações Urbanas Consorciadas, estabelece o macrozoneamento ambiental como umas das áreas prioritárias para implantação destes instrumentos, mesmo que a lei não aponte para o uso destes em nenhuma delas, ao definir cada zona da macrozona ambiental (ver apêndice: Quadro 19). Essa contradição do plano abriu a possibilidade de que o uso desse instrumento entre em conflito com os objetivos destas zonas, uma vez que, para atingir os objetivos listados acima, essas áreas possuem potenciais de construção e taxa de ocupação baixíssimos, no caso das duas primeiras, e nulo no caso da última, e as OUCs permitem, entre outras medidas, "a modificação dos parâmetros e características de parcelamento, uso e ocupação do solo e subsolo" (FORTALEZA, 2009, PDP, art. 242).

Em quase todas as OUCs mencionadas há uma flexibilização (aumento) do potencial construtivo (representado pelo índice de aproveitamento no PDP), entre outras flexibilizações, incluindo a supressão de áreas de preservação permanente. Ou seja, áreas que antes tinham a possibilidade de uso de produção imobiliária negados, em prol de um uso de prestação de serviço ambiental para a sociedade, passam a tê-lo reduzido para possibilitar o uso de produção imobiliário. Assim, a OUC aparece em Fortaleza como uma possibilidade de resgatar o antivalor e alavancar a produção e capitalização de valor.

É o próprio Estado que provoca o primeiro processo de desvalorização (aparente ou fictícia, pois a terra não tem valor, mas real na aparência, porque ela tem preço), ou a partir do conceito de Pírez $(2016)^{147}$, comentado anteriormente, é o Estado que promove uma desmercatilização desta terra, desmercatilização estatal.

\footnotetext{
147 Las heterogéneas formas de producción y consumo de la urbanización latinoamericana, 2016.
} 
Quando estas áreas foram demarcadas como zonas ambientais no PDDU de 1992 e no PDP de 2009, retirou-se ou restringiu-se a possibilidade de construir nessas áreas, limitando então o valor de uso destas, ou mesmo, anulando, em especial para os capitalistas imobiliários. Assim, a terra que na aparência tinha um valor, também na aparência parece ter sido desvalorizada. Se não tem valor de uso, nem de troca, não se concretiza como mercadoria. Assim, o instrumento da OUC, em Fortaleza, tem, então, um papel chave na superação do antivalor e da desvalorização, mesmo que de um valor aparente.

Isso possibilita que o proprietário privado desta terra possa extrair renda a partir da sua comercialização, capitalizando valor (mais-valor) de outros setores, assim como também possibilita a geração de valor sobre este terreno (antes, legalmente e socialmente, definido como natureza), a partir da exploração do trabalho necessário para a construção de empreendimento imobiliário. Aqui podemos observar tanto um processo de acumulação por espoliação, na captura de riqueza comum (terra que deveria prestar serviço ambiental para toda a sociedade), como um processo de valorização, ao se aumentar o potencial construtivo dessas terras, aumentando, assim, a possibilidade de maior valor futuro, capitalizado para o preço da terra no presente.

Há que se destacar que esse processo de desmercatilização estatal vem acontecendo a nível federal desde a década de $1960^{148}$, se considerarmos a definição das áreas de preservação permanente (APP) na lei que instituiu o Código Florestal. Seguindo a legislação federal, na década de 1970, o governo estadual, por meio da lei no 10.147, de 1ㅇ de dezembro de 1977, dispôs sobre o disciplinamento do uso do solo para proteção dos recursos hídricos da Região Metropolitana de Fortaleza, incluindo a criação de faixas de proteção para os recursos hídricos de 1a e 2a categoria. Porém, somente em 1982, com o decreto no 15.274 , de 25 de maio, é que os limites das faixas de preservação são definidos, especificamente, para cada recurso hídrico do Município de Fortaleza.

${ }^{148}$ Código florestal brasileiro - Lei Federal n 4.771, de 15 de setembro de 1965. 
Figura 54. OUCs aprovadas frente ao zoneamento ambiental do município segundo PDDU de 1992 e LUOS de 1996.

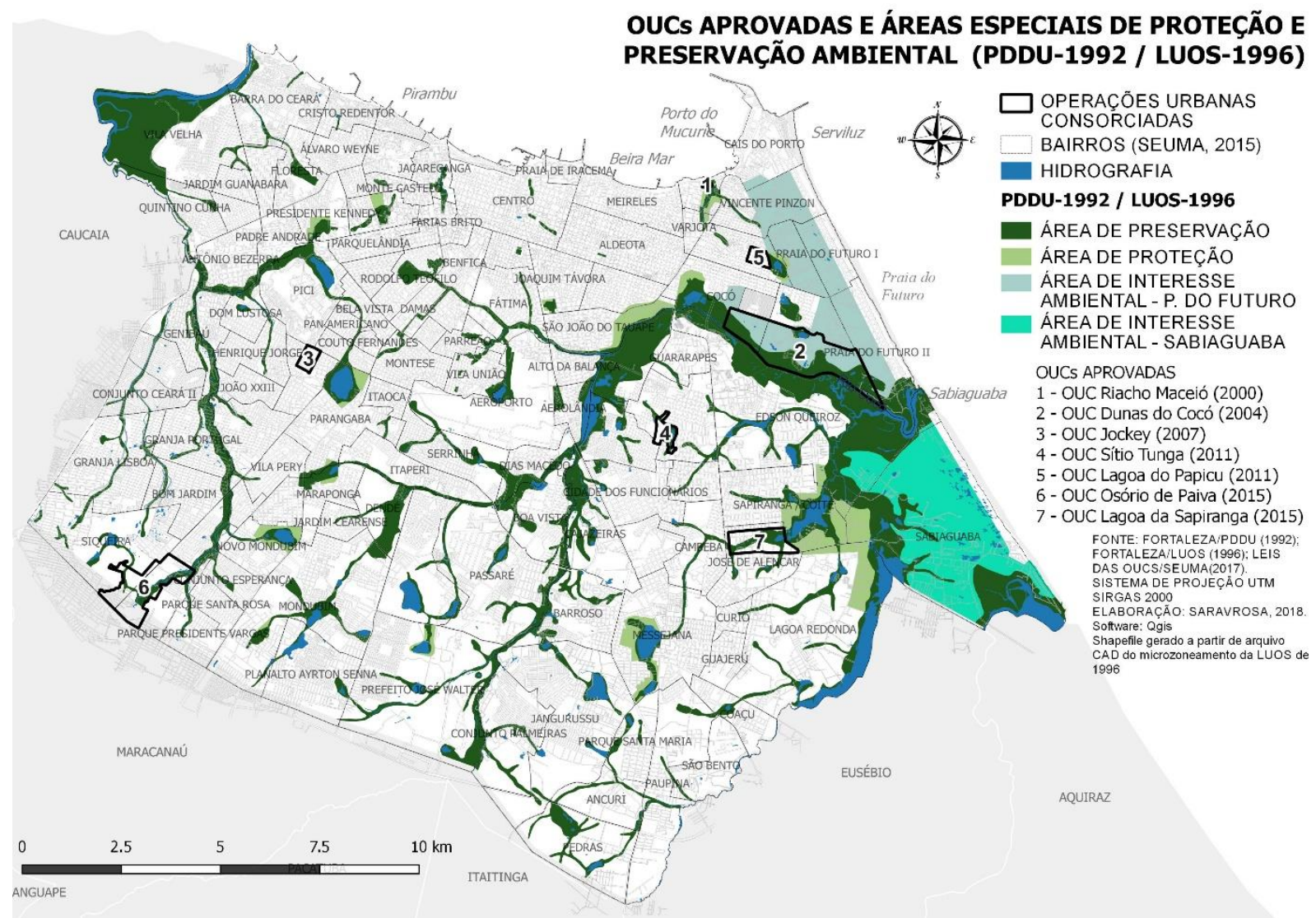

Elaboração: Rosa, 2019. Fonte: FORTALEZA, 1996

A Operação Urbana do Riacho Maceió localiza-se na foz do riacho de mesmo nome, entre a Avenida Beira Mar e a Avenida Abolição, no bairro do Mucuripe, litoral norte de Fortaleza (Figura 52). Conforme já mencionado, legislações de proteção e preservação ambiental incidem sobre o terreno da operação desde a década de 1960 a nível federal, e a nível estadual e municipal, desde a década de 1970. Especificamente para o Riacho Maceió, o decreto estadual $\mathrm{n}$ 15.274, de 25 de maio de 1982, estabeleceu as seguintes faixas de preservação e proteção, respectivamente: "1ạ Categoria: faixa simétrica com 30,0m (trinta metros) de largura, ao longo do eixo longitudinal, sendo 15,0m (quinze metros), para cada lado a partir do eixo; 2a Categoria: faixa com largura mínima de 300m (trezentos metros)" ( CEARÁ, 1982, art. 19). Estes limites foram depois atualizados pelo decreto № 24.831, de 26 de março de 1998, incluindo a ampliação da faixa de primeira categoria em vários trechos, passando a ser delimitada por sistema viário e calçadão existente ou projetado ${ }^{149}$.

\footnotetext{
149 Riacho Papicu-Maceió: Nova Redação dada pelo art. 10 do Decreto no 24.831, de 26 de março de 1998. a) Da Avenida da Abolição à via projetada: 1a Categoria: área compreendida nos seguintes limites: ao Norte pela avenida da Abolição; ao Sul
} 


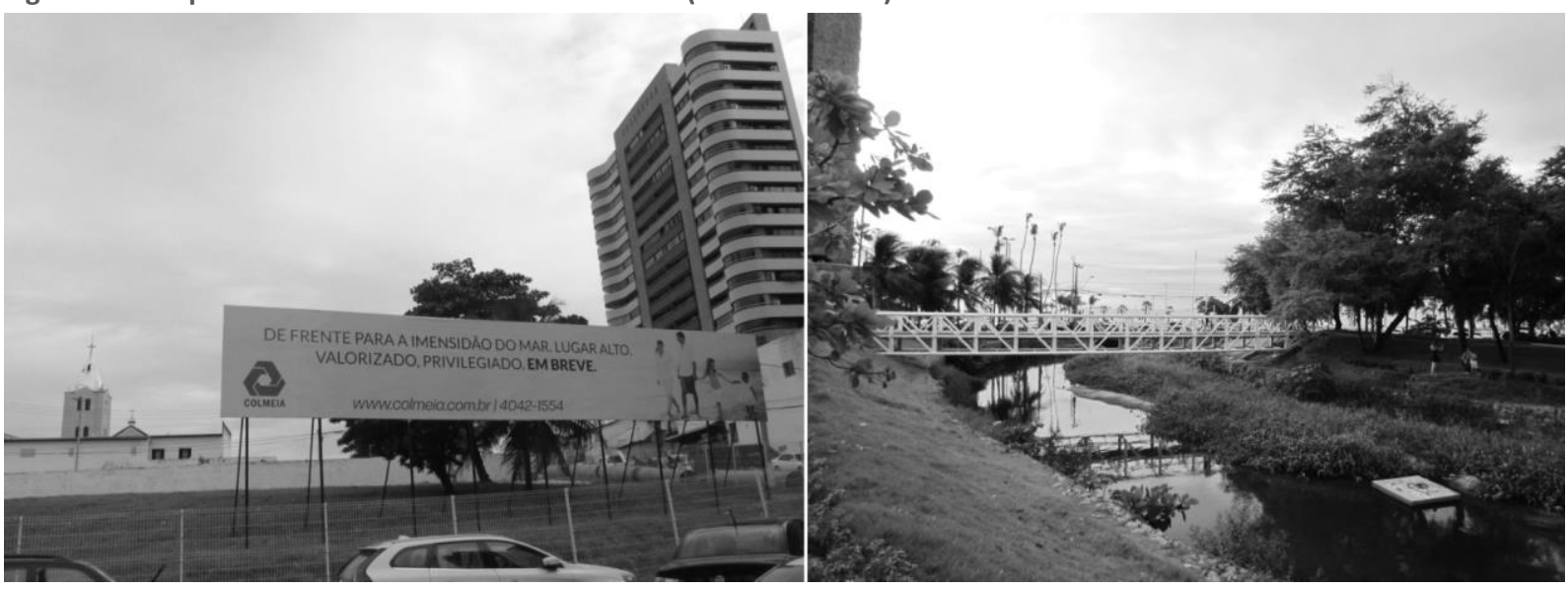

FOTO: Aline Medeiros/LEHAB, 2017. Fonte: http://www.lehab.ufc.br/wordpress/ouc-riacho-maceio-resulta-na-remocao-defamilias-na-senador-machado/

A nível municipal, o Plano Diretor Físico de Fortaleza de 1972 e a Lei de Parcelamento, Uso e Ocupação do Solo de 1979 definem a área do terreno da OUC como zona especial de proteção verde e paisagística. O plano diretor seguinte, o PDDU de 1992, legislação municipal vigente na data de promulgação da lei da OUC, também registra o terreno como área de preservação e proteção ambiental (Figura 56). Albuquerque ( 2015) destaca ainda que, na década de 1990, foi implementado, pela Secretaria de Desenvolvimento Urbano do Estado do Ceará (SDU), um parque ao longo deste recurso, incluindo a foz, que posteriormente foi passado para a administração do município ${ }^{150}$.

pela via Projetada; à Leste pelo calçadão paralelo à faixa de domínio da RFFSA e pela via projetada; à Oeste pela Rua Saporé; 2a Categoria: faixa com largura mínima de 300,0m(trezentos metros), medidos em projeção horizontal a partir da faixa de proteção de 1a Categoria; b) Da via Projetada à rua Álvaro Correia: 1ạ Categoria: área compreendida nos seguintes limites: ao Norte pela via projetada: ao Sul pela Rua Álvaro Correia; à Leste pelo prolongamento da Rua Alísio Mamede; à Oeste pelo prolongamento da Rua Umari; 2a Categoria: faixa com largura mínima de 300,0m(trezentos metros), medidos em projeção horizontal a partir da faixa de proteção de 1ạ Categoria; c) Da Rua Álvaro Correia à rua Jaime Vasconcelos: 1ạ Categoria: área compreendida nos seguintes limites: ao Norte pela Rua Álvaro Correia; ao Sul pela Rua Jaime Vasconcelos; à Leste pelo prolongamento da Rua Alísio Mamede e pelo calçadão projetado; à Oeste pela Rua Projetada e calçadão projetado; $2^{2}$ Categoria: faixa com largura mínima de 300,0m(trezentos metros), medidos em projeção horizontal a partir da faixa de proteção de 1a Categoria; d) Da Rua Jaime Vasconcelos à rua Dr. José Lino; 1ạ Categoria: faixa com largura mínima de $30,0 \mathrm{~m}$ (trinta metros) de largura, ao longo do eixo longitudinal, sendo $15,0 \mathrm{~m}$ (quinze metros) para cada lado, a partir do eixo; 2a Categoria: faixa com largura mínima de $300,0 \mathrm{~m}$ (trezentos metros), medidos em projeção horizontal a partir da faixa de proteção de 1a Categoria; e) Da Rua Dr. José Lino à Rua Tavares Coutinho 1a Categoria: faixa com largura mínima de $30,0 \mathrm{~m}$ (trinta metros) de largura, ao longo do eixo longitudinal, sendo 15,0m(quinze metros) para cada lado, a partir do eixo; 2a Categoria: faixa com largura mínima de $300,0 \mathrm{~m}$ (trezentos metros), medidos em projeção horizontal a partir da faixa de proteção de 1a Categoria; f) Rua Dr. Alisio Mamede: 1a Categoria: área compreendida nos seguintes limites: ao Norte pelo calçadão projetado; ao Sul pelo calçadão projetado; à Leste pela faixa de domínio da RFFSA e calçadão projetado e à Oeste pela Rua Alisio Mamede; 2a Categoria: faixa com largura mínima de 300,0m(trezentos metros), medidos em projeção horizontal a partir da faixa de proteção de 1a Categoria. (Fonte bibliográfica inválida especificada., art. 1ㅇ)

150 Nesta pesquisa não foi encontrado decreto ou lei de criação do parque mencionado, porém, o decreto no 24.831 , de 26 de março de 1998, ao atualizar as faixas de preservação e proteção do riacho menciona a existência de projeto de calçadões ao longo deste que passam a ser usados como limites para a definição da faixa de primeira categoria. Na área do riacho, fora da OUC, ainda é possível perceber restos de cerca e de calçada. 
Assim, quando a lei da OUC do riacho Maceió foi aprovada, em 2000, já insidia sobre o terreno diferentes categorias de proteção nas três esferas de governo, federal, estadual e municipal. Quase todo o terreno da OUC era definido pelo PDDU como Área de Preservação Ambiental, "non aedificandi". Este é exatamente o primeiro ponto de flexibilização urbana que a operação apresenta. O zoneamento do PDDU é alterado dentro da lei de criação da OUC, reduzindo a área de preservação permanente, que passa, assim como como a área de proteção, a permitirem os mesmos parâmetros urbanos dispostos para a Área de Orla Marítima Meireles/Mucuripe.

Nota-se que, ao definir a área como não edificante, o plano de 1992 promoveu uma "desvalorização" desses terrenos. O valor de uso para a produção imobiliária de mercado, deixa de existir (ao menos legalmente) no momento que o proprietário, apesar de ter a propriedade privada desta terra, não tem o direito de escolher o que fazer nela. A demarcação como área de preservação quebra a possibilidade de capitalização de um valor futuro gerado a partir do trabalho que seria empregado na geração/ produção de mercadorias imobiliárias. O valor é transformado então em antivalor e permanece esperando o momento de ser superado e voltar a circulação como valor. Já quando o município faz o movimento inverso, transforma a área, antes não edificante, em edificante, assegurando a volta deste terreno para o mercado de terras relacionados a produção imobiliária e a possibilidade de geração de valor futuro. A seguir, fala do ente privado responsável pela OUC demonstra como a área de preservação é um impedimento para a realização do terreno como mercadoria, que só acontece por meio da OUC.

Aquele terreno [...] um amigo dele [se referindo ao sócio da incorporadora Terra Brasilis] era dono do terreno, e tinha toda aquela situação de invasão e de preservação e o amigo dele disse "tá muito ruim essa situação desse terreno e eu não sei o que faço" [...] aí ele disse " eu vou fazer o seguinte: eu vou comprar, eu vou fazer um estudo e se for positivo eu compro" [...] aí ele acertou o preço e tudo. Ele fez a consulta com um consultor, que falou com uns analistas da prefeitura, isso há 20 anos atrás, 97 [...] e ele disse que dava para fazer se fizesse uma operação urbana consorciada [...] você doa umas áreas para o município, dá uma contrapartida e é possível determinadas coisas [...] a contrapartida da prefeitura foi essa, liberar índice para gente [...] o da Beira-Mar é três, mas se for flat pode ser 4, aí o nosso por conta da operação pode ser qualquer índice [...] a operação foi a seguinte: liberou esse índice e eu fiz a praça [...] (Representante da Terra Brasilis em entrevista concedida a Aldigueri. ALDIGUERI, 2017, p. 270. Grifos meu)

E aquele terreno ele tinha comprado em 1952 e há 20 anos atrás a gente adquiriu dele. Só que ele já tava com muita idade, e o terreno estava invadido. Nós tínhamos lá cadastradas mais de 87 famílias. Então a gente comprou o terreno sabendo disso, fez a operação urbana, ali tem uma parte do terreno que é área de preservação, 
mas...tem um valor venal. [...] o que nós pensamos para o terreno? Construir na frente da praia a gente não vai poder, na primeira linha da beira-mar, por conta do Riacho porque ele pega uma grande área de APP. Então a gente ficou com a parte mais de trás, e se a gente fizesse uma praça ali a gente teria vista pro mar. (Diretor da Terra Brasilis em entrevista concedida a equipe do LEHAB em 2016)

No trecho da segunda entrevista, nota-se na fala do representante da empresa Terra Brasilis que o terreno pode ser antivalor, mas nunca deixa de ter um preço. Ele pode ficar imobilizado como não-valor, mas com preço, porém não ser realiza enquanto mercadoria até aparecer um valor de uso para um terceiro que esteja disponível a pagar o preço do terreno. No caso do terreno da OUC, esse valor de uso para a produção imobiliária, só aparece quando é proposto a OUC.

Assim, para a realização do valor no terreno da OUC, foi feita uma grande alteração no zoneamento, suprimindo grande parte da área de preservação permanente do riacho, como pode ser verificado nas imagens da Figura 56 e Figura 57, que representam respectivamente, o zoneamento segundo o PDDU/LUOS vigente à época e o zoneamento proposto para a OUC. A partir das mesmas imagens, retiradas do projeto de lei da OUC, é possível observar também que a supressão de área de preservação não ficou restrita ao polígono da operação, abrangendo terrenos de faixa de praia que na época ainda estavam desocupados.

Figura 56. Anexo I da lei 8503/2000. Zoneamento segundo PDDU 1992 e LUOS 1996 para a área da OUC do Riacho Maceió

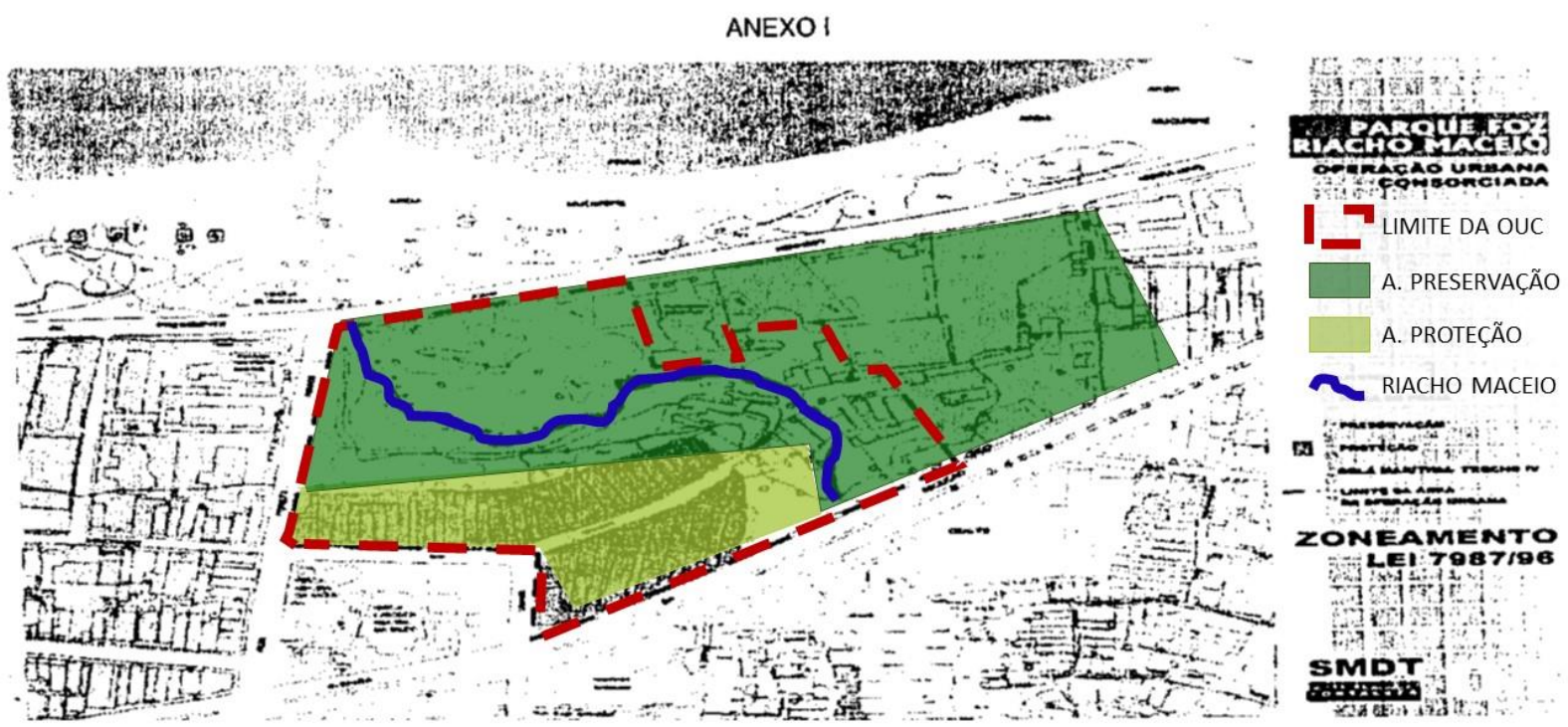

Fonte: Diário Oficial do Município, 04 de fevereiro de 2002, p. 03 (lei no 8503/2000). Modificado Sara Vieira Rosa. Obs.: devido a distorção da imagem, e por trabalhar com arquivo em PDF, as áreas de proteção e preservação, destacadas em verde, também podem apresentar distorções. 
Figura 57. Anexo II da lei 8503/2000. Zoneamento proposto pela OUC do Riacho Maceió

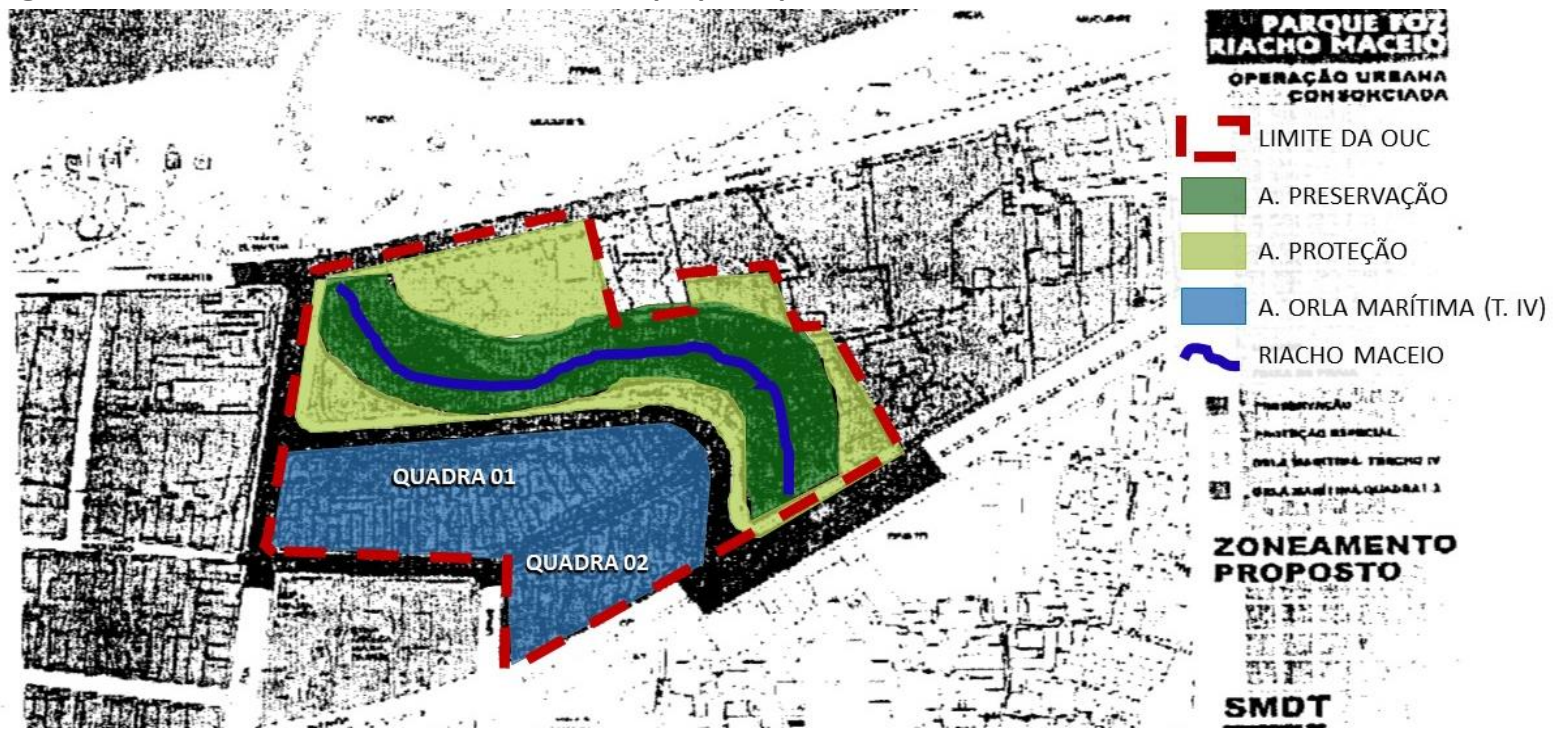

Fonte: Diário Oficial do Município, 04 de fevereiro de 2002, p. 03 (lei no 8503/2000). Modificado por Sara Vieira Rosa. Obs.: devido a distorção da imagem as áreas de proteção e preservação, destacadas em verde, também podem apresentar distorções.

Quando o PDP-2009 foi elaborado ele incorporou a supressão da área de preservação colocada pela lei da OUC, bem como, estreitou toda a faixa de preservação ao longo do riacho, como pode ser observado na figura.

Figura 58. Comparação zoneamento ambiental PDDU-1992 e PDP-2009 sobre o Riacho Maceió

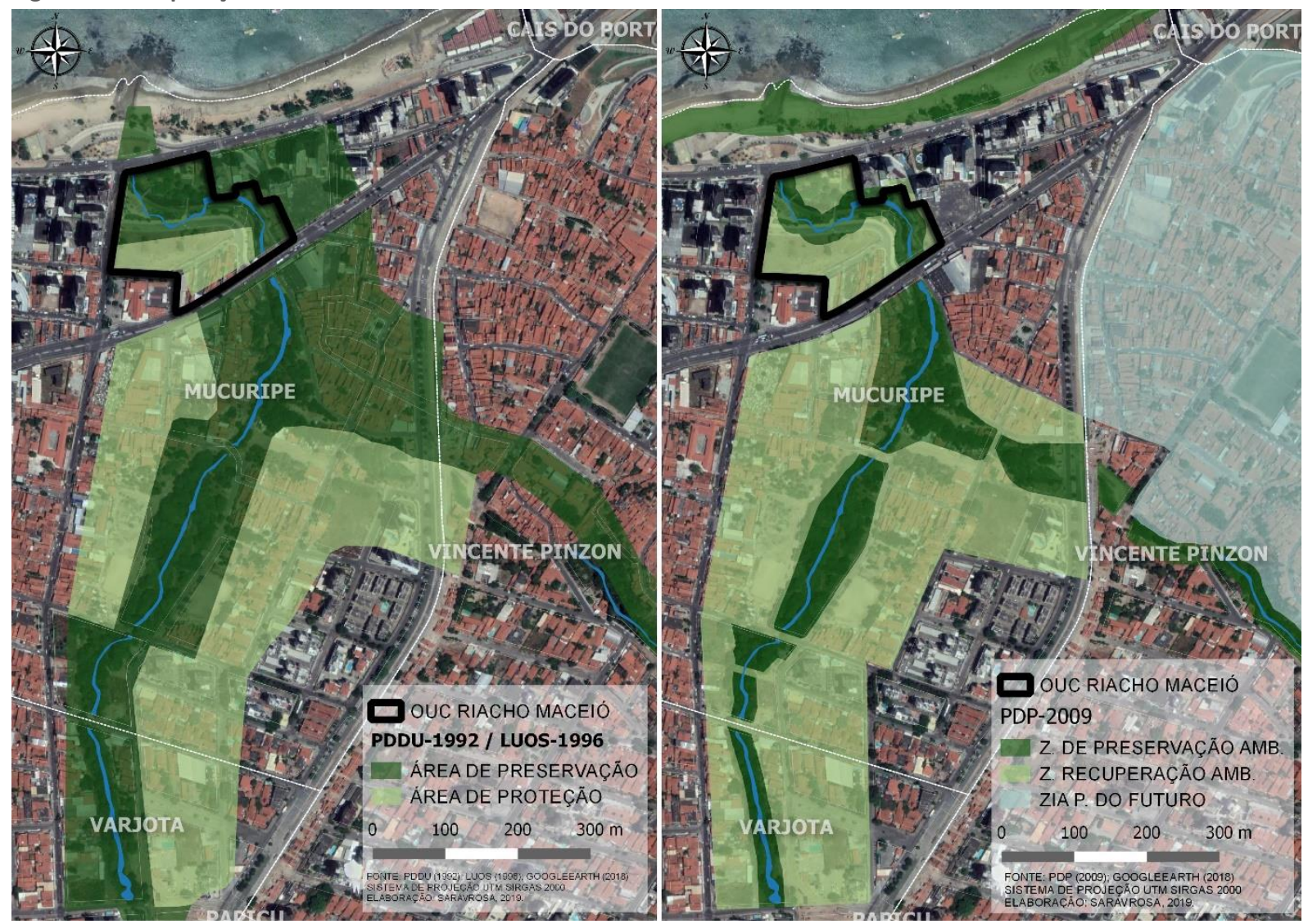

Elabrado por Rosa, 2019. Fonte: LUOS, 1996 e PDP, 2009. Imagem aérea: GoogleEarth, 2018. 
Oura grande flexibilização foi a mudança do zoneamento referente à área de proteção ambiental, que também foi suprimida e passou a ser regulamentada como área de Orla Marítima Meireles/Mucuripe, com índices de aproveitamento altos e voltada para edifícios hoteleiros de alto porte. Ocorreu aí a liberação do índice de aproveitamento (I.A.) para 4 (quatro), com a permissão, se o empreendedor assim o desejasse, para que seja computado ao I.A. o potencial construtivo "perdido" para abertura de via paisagística na área. Assim, considerando as áreas explicitadas nesta lei, o índice de aproveitamento ao qual se permitiu chegar no terreno foi de 5,42 ${ }^{151}$, lembrando que esta área era destinada à proteção ambiental e preservação ambiental, cujos I.A. eram 0,6 e 0 respectivamente ( HOLANDA e ROSA, 2017a).

Aqui, há não só o resgate do valor, como a garantia de extração de mais-valia no processo de produção imobiliária o edifício acima de qualquer outro terreno na região.

Dentre as flexibilizações para este caso, destaca-se também a permissão de construção de empreendimento do tipo hospedagem em vias locais, com porte acima do permitido pela Lei de Uso e Ocupação do Solo de 1996 (LUOS/1996) e em área onde era permitido apenas o uso unifamiliar.

Assim, quando executada em 2015, a OUC do Riacho Maceió seguiu tal e qual a flexibilização disposta na sua lei de criação que data do ano 2000, atualizada em 2002, mesmo com seu prazo máximo de vigência, de 10 anos, vencido em 2012. Deste modo, o município deveria ter adequado o convênio às exigências do novo Plano Diretor (PDP-2009), como por exemplo, a definição de índice de aproveitamento máximo de 4 (quatro) para as OUC, e o conteúdo mínimo da lei que não é contemplado.

Destaca-se ainda que a lei de criação dessa Operação nunca poderia ter acontecido antes do PDP de 2009, pois o plano diretor anterior atrelava a realização das Operações à aprovação de uma lei que regulamentasse o instrumento, incluindo a definição das áreas onde seria permitida a implantação destas parcerias (FORTALEZA, 1992, PD, art. 12), a qual nunca existiu.

A contrapartida oferecida pela empresa na operação, segundo sua lei de criação, foi a aquisição do terreno onde foi implementado o parque, a retirada e a indenização das famílias

\footnotetext{
${ }^{151}$ Fonte: Lei da Operação e entrevista do Diretor da Terra Brasilis concedida ao LEHAB em 2016.
} 
que moravam nessa quadra, a construção do parque e sua manutenção por 10 anos, e a doação do terreno para o município.

a) aquisição e doação ao Município de Fortaleza de um terreno de $17.874,91 \mathrm{~m} 2$ (dezessete mil, oitocentos e setenta e quatro metros e noventa e um centímetros quadrados), compreendendo $14.693,49 \mathrm{~m} 2$ (quatorze mil, seiscentos e noventa e três metros e quarenta e nove centímetros quadrados) para implantação da área do Parque e 3.181,42m2 (três mil, cento e oitenta e um metros e quarenta e dois centímetros quadrados) para o Sistema Viário Básico;

Segundo o relatado pelo representante da Terra Brasilis, o terreno de fato foi comprado: "e aquele terreno ele tinha comprado em 1952 e há 20 anos atrás a gente adquiriu dele". Contudo, o terreno em questão, como pode ser observado na Figura 59, é terreno de marinha ${ }^{152}$, ou seja, terreno pertencente à União. Assim, toda a renda obtida pelo proprietário anterior com a venda do terreno para a NORPAR/Terra Brasilis, foi obtida sobre um terreno de bem público. É um caso recente de apropriação indevida da natureza, acumulação por espoliação.

Figura 59. OUC Riacho Maceió e limite do terreno de marinha

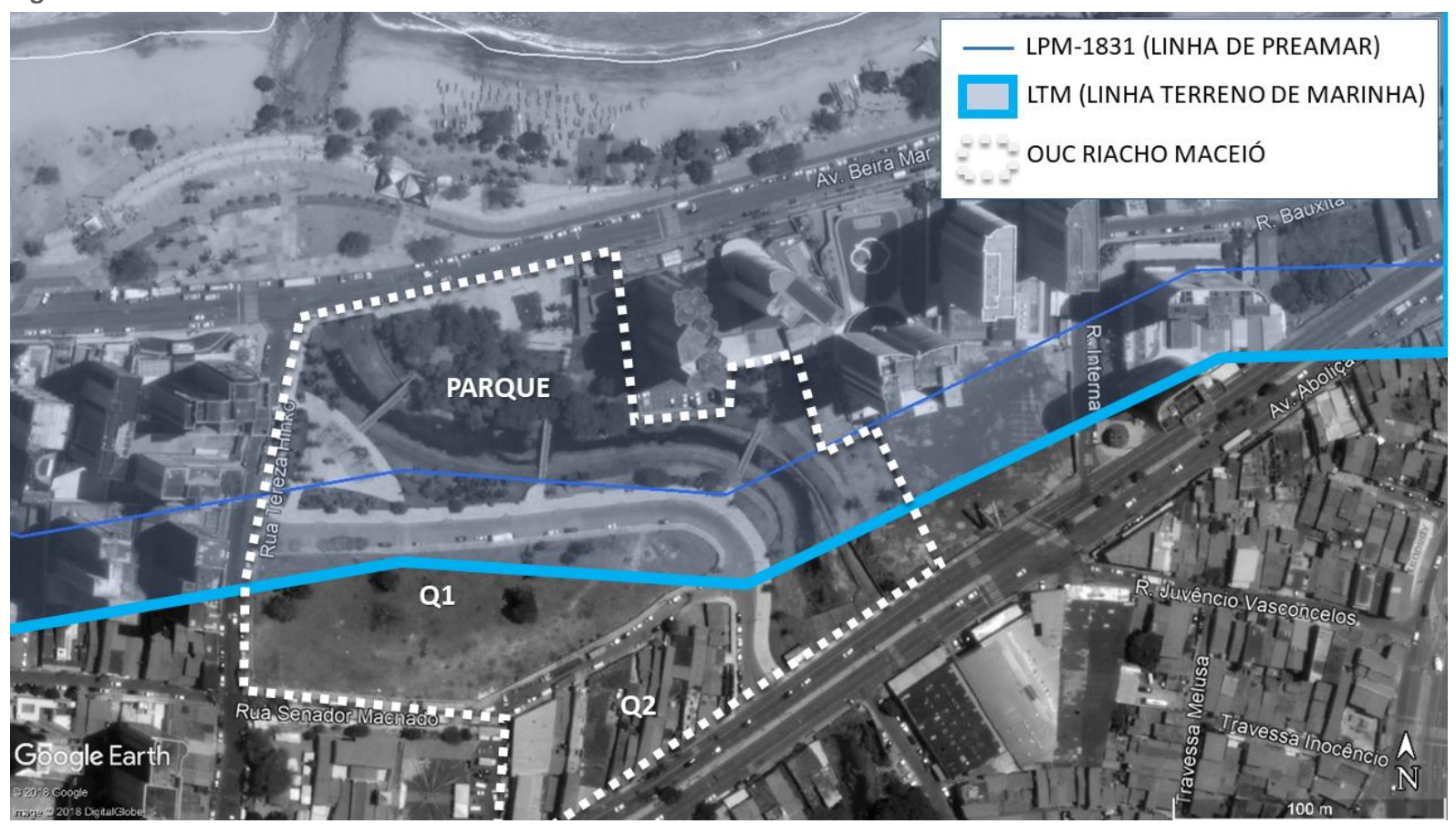

Elaborado pela autora. Fonte: SEUMA, 2018. Imagem aérea: GoogleEarth, 2018.

\footnotetext{
152 DECRETO-LEI № 9.760, DE 5 DE SETEMBRO DE 1946. “Art. 2o São terrenos de marinha, em uma profundidade de 33 (trinta e três) metros, medidos horizontalmente, para a parte da terra, da posição da linha do preamar-médio de 1831: a) os situados no continente, na costa marítima e nas margens dos rios e lagoas, até onde se faça sentir a influência das marés.
} 
As OUCs que se seguiram depois da do Riacho Maceió apresentaram, todas elas, flexibilizações urbanas, todavia é possível observar que a segunda Operação da gestão do Juraci (Dunas) e as duas que se seguiram na gestão da Luizianne (Jockey e Sítio Tunga) tiveram um menor número de alterações dos parâmetros urbanos definidos para a área, como pode ser observado na sistematização dessas alterações realizadas no Quadro. A OUC Dunas do Cocó, por exemplo, apesar de não apresentar grandes alterações no que se refere ao potencial construtivo definido para a zona, segundo o anterior PDDU-1992 e o atual PDP-2009, localizase sobre dunas. Grande parte destas dunas são APP (área de preservação permanente - pela lei federal do Código Florestal), que o município, nunca reconheceu em seus zoneamentos.

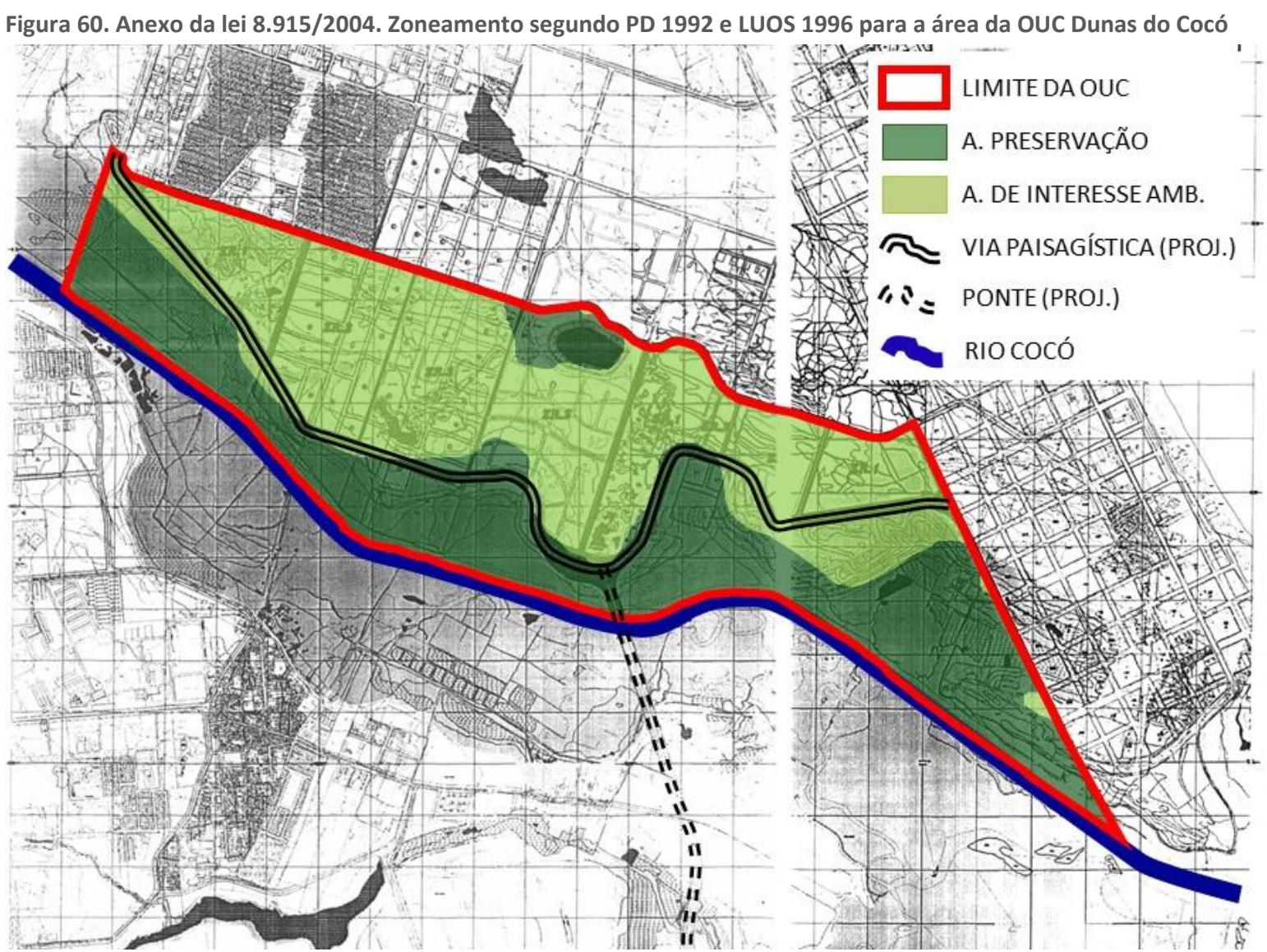

Fonte: Diário Oficial do Município, 04 de janeiro de 2005, p. 05 (lei 8.915/2004). Modificado por Sara Vieira Rosa. Obs.: devido a distorção da imagem, e por trabalhar com arquivo em PDF, as áreas de proteção e preservação, destacadas em verde, também podem apresentar distorções. Devido a difícil visualização da imagem do anexo da lei, as áreas de preservação e interessa ambiental foram demarcadas a partir de sobreposição do zoneamento segundo PDDU de 92 e LUOS de 96.

Pelo PDDU-1992, o terreno englobava área de preservação, onde não há flexibilizações pela lei de criação da OUC, e área especial de proteção da Praia do Futuro que possuía I.A. variando de 1 a 2, com altura máxima da edificação de 48m. Pelo PDP-2009, além da área de preservação (ZPA), a OUC engloba duas categorias de áreas de proteção, a ZIA do Cocó, que ocupa a maior extensão, e a ZIA da Praia do Futuro. Na Zia do Cocó, o I.A. básico e máximo é 
de 1,5 e na do Cocó, de 2, com altura da edificação também de até $48 \mathrm{~m}$. Em ambos os casos, os parâmetros definidos pelos planos diretores e LUOS, já são bastante flexíveis e equiparados a várias áreas fora do zoneamento ambiental.

Neste exemplo, apesar da classificação de áreas ambientais e de proteção, estes terrenosnatureza nunca passaram pelo processo de desmercantilização a nível municipal. A OUC entra aqui não para remercantilizar, ou resgatar valor, mas para garantir o valor, já que a legislação a nível municipal entra em conflito com a legislação a nível federal, trazendo insegurança para o proprietário e para e realização da renda.

A intensificação da flexibilização e alteração dos parâmetros começa a aparecer com mais intensidade na OUC da Lagoa do Papicu e nas duas últimas operações com convênio firmado e publicado em lei em 2015, na gestão do prefeito Roberto Cláudio.

Essas duas últimas Operações assinadas têm em comum: a data da divulgação da sua lei de criação, ambas publicadas no diário oficial do dia 19 de outubro de 2015; o conteúdo da lei, que possui o mesmo texto base; a não identificação nominal do parceiro privado, como acontece nas operações anteriores, nas quais o convênio é firmado entre a SEUMA e os proprietários dos terrenos localizados na área de que trata a Lei; o reloteamento para uso de residência, de comércio e de serviços; e, por último, a flexibilização de alguns parâmetros urbanos. Destacando-se o fato de que ambas estão inseridas quase que totalmente em áreas de proteção e preservação ambiental.

No caso da OUC da Lagoa da Sapiranga, o perímetro definido para a operação está completamente inserido dentro do macrozoneamento ambiental do PDP/2009, contemplando a Zona de Preservação ambiental (ZPA) do entorno da Lagoa da Sapiranga e pequeno afluente do Rio Cocó, e a Zona de Interesse Ambiental da Sabiaguaba (ZIASabiaguaba) do entorno da referida Lagoa. Destaca-se que a lei de criação da dita parceria modifica o índice de aproveitamento máximo da ZIA da Sabiaguaba de 0,5 para 1, ou seja, duplica o potencial construtivo da zona.

Já na Operação da Osório de Paiva, o índice de aproveitamento é quase triplicado na Zona de Recuperação Ambiental na qual está inserida a poligonal de intervenção, passando de 0,6 para 1,5. Neste caso, chama a atenção também pela alteração na altura máxima permitida para as edificações que, segundo o PDP-2009, é de apenas 15m e, com a OUC, passará para 25m e, 
em alguns trechos, para $48 \mathrm{~m}$. São alteradas também a taxa de ocupação, que passa de 33\% para $60 \%$, e a de permeabilidade, de $50 \%$ para $30 \%$.

Quadro 8. Sistematização da flexibilização trazida com cada OUC aprovada em Fortaleza

\begin{tabular}{|l|c|c|c|c|c|c|c|}
\hline Ouc & $\begin{array}{c}\text { Ouc } \\
\text { Maceió }\end{array}$ & $\begin{array}{c}\text { Ouc } \\
\text { Dunas }\end{array}$ & $\begin{array}{c}\text { Ouc } \\
\text { Jockey }\end{array}$ & $\begin{array}{c}\text { Ouc } \\
\text { Tunga }\end{array}$ & $\begin{array}{c}\text { OUC } \\
\text { Papicu }\end{array}$ & $\begin{array}{c}\text { Ouc } \\
\text { Osório }\end{array}$ & $\begin{array}{c}\text { Ouc } \\
\text { Sapiranga }\end{array}$ \\
\hline Zoneamento & & & & & & & $* *$ \\
\hline Índice de aproveitamento & & & & & & & \\
\hline Fração do lote & & & & & & & \\
\hline Taxa de ocupação & & & & & & & \\
\hline Taxa de ocupação do subsolo & & & & & & & \\
\hline Altura Máxima & & & & & & & \\
\hline Taxa de permeabilidade & & & & & & \\
\hline Dimensão máxima da quadra & & & & & & \\
\hline Testada mínima do lote & & & & & & \\
\hline Área mínima do lote & & & & & & & \\
\hline Profundidade mínima do lote & & & & & & \\
\hline Doação das áreas pub. fora do loteamento & & & & & & & \\
\hline Uso & & & & & & & \\
\hline Alterações no sistema viário & & & & & \\
\hline
\end{tabular}

Fonte: Legislação de criação de cada OUC (Lei 8503/2000/2002, Lei 8915/2004, Lei 9333/2007, Lei 9778/2011, Lei 9857/2011, Lei 10403/2015 e Lei 10404/2015). Sistematização LEHAB, 2016. (HOLANDA; ROSA, 2017) * Reloteamento permitindo áreas máximas dos lotes acima de $250 \mathrm{~m}^{2} \mathrm{com}$ base no loteamento anterior da área. ${ }^{* *}$ Apesar da lei de criação da Operação não especificar mudanças no Zoneamento, foi observado, a partir da comparação entre a base cartográfica do plano diretor publicada no Diário Oficial em 2009 e a base cartográfica atualizada e divulgada pela SEUMA em 2015, mudanças nos limites de algumas zonas, como a ZPA e a ZIA, não alterados por lei complementar ao PDP, mas que necessitam maiores investigações para confirmação.

Áreas de "valorização" imobiliária - potencialização da capitalização ou Inserção em áreas de valorização imobiliária e alto valor de troca ou concentração de geração de valor

Com exceção da OUC Osório de Paiva e da OUC Jóquei Club, as demais Operações aprovadas estão localizadas em áreas de tradicional interesse do mercado imobiliário e em eixos tradicionais de expansão do mercado imobiliário, ou ainda, como define Rufino (2009), nas áreas de valorização e expansão da valorização imobiliária. Análises feitas por Holanda e Pequeno (2018) e Pequeno et.al (2018) demostram também que essas áreas eram as mesmas, ou sua extensão, que mais receberam investimentos em infraestrutura viária por parte do governo nos últimos anos e que tiveram maior número de vendas e valores de vendas mais altos de imóveis, de acordo com o registro do ITBI (Imposto Territorial Predial) de 2009 a março de 2016. 
A seguir, procuramos detalhar um pouco melhor a dinâmica imobiliária recente no município, com a intenção de analisar as OUCs aprovadas em Fortaleza frente a essa dinâmica.

Os mapas da Figura $61^{153}$, onde é possível visualizar as áreas da cidade com maior concentração de transações de Imposto Territorial de Bens e Imóveis (ITBI), de 2009 a março de 2016, reforçam a tendência de dinâmica e valorização imobiliária identificadas por Rufino (2016), a partir dos dados de lançamento de imóveis dos Relatórios do índice de Velocidade de Vendas (IVV) do Sinduscon-CE para os anos de 2001, 2007 e 2010.

A partir dos dados do IVV, a autora acima citada pôde constatar tendência de uma maior distribuição territorial da produção de mercado ${ }^{154}$ para bairros mais periféricos e fora do núcleo e entorno tradicional Meireles-Aldeota, assim como a tendência de aumento no preço de venda desses imóveis tanto nas áreas tradicionais como nos bairros mais periféricos, incluindo os municípios vizinhos, que em alguns setores chegam a ter preços equivalentes às áreas de maior valorização imobiliária da capital.

O núcleo tradicional de produção de mercado de alto padrão, Meireles-Aldeota, e entorno imediato, é ainda dominado principalmente por produção de empresas locais de capital fechado, no qual se espacializa empreendimentos levantados a partir dos sites de grandes empresas de sociedade limitada (Itda.) e sociedade anônima fechada (s.a.) atuantes em Fortaleza ${ }^{155}$. Ainda assim, é possível perceber uma expansão da atuação dessas empresas para bairros mais periféricos, como Parque Iracema, entorno de Messejana e Passaré. Bairros que conformam a área identificada por Rufino (2016) como Consolidação da coroa imobiliária (segmento econômico).

\footnotetext{
${ }^{153}$ A análise desse mapa pode ser complementada com o mapa em anexo da Figura 113.

154 Ou promoção capitalista, segundo Jaramillo ( 1982), "La forma de producción de espacio construido que denomino promocional, la caracterizo aquí por su calidad de rama capitalista desarrollada: la relación fundamental que estructura la producción es la relación capital-trabajo asalariado, cuyo sentido general es la acumulación de capital a través de la apropiación de la plusvalía generada por los obreros del sector (aunque el mecanismo de la renta del suelo permite atraer plusvalía generada en otros sectores). Los agentes que detentan el control económico directo de la producción, aunque presentan distintas variantes [...] tienen el denominador común de ser agentes capitalistas. El control técnico, aunque existen conformaciones que se aparten de esta norma, es ejercido normalmente por agentes que son ellos mismos capitalistas, o extensiones del capital propiamente dicho. La producción se orienta hacia el mercado general en el cual el producto circula en forma de mercancía, y los procesos productivos tienden a ser repetitivos y continuos." ( JARAMILLO, 1982, p.186). Em seu texto Jaramillo faz um esforço para tentar classificar as formas de produção do espaço construído e chega as seguintes categorias: autoconstruccíon; produccíon por encargo; promocíon capitalista; produccíon estatal capitalista desvalorizada. 155 Levantamento realizado, em 2017, para trabalho do LEHAB, dos empreendimentos lançados pelas empresas: BSPAR, Diagonal, JCPM e Moura Doubex. Importante destacar que este levantamento não dá conta do universo de empresas atuantes no município, mas funciona como um dado exploratório para análises iniciais e complementares aos dados do ITBI e IVV.
} 
Figura 61. Concentração de venda de imóveis prediais segundo registros de transações do ITBI (2009 a março de 2016) e valor do solo residencial segundo IPTU (2015)

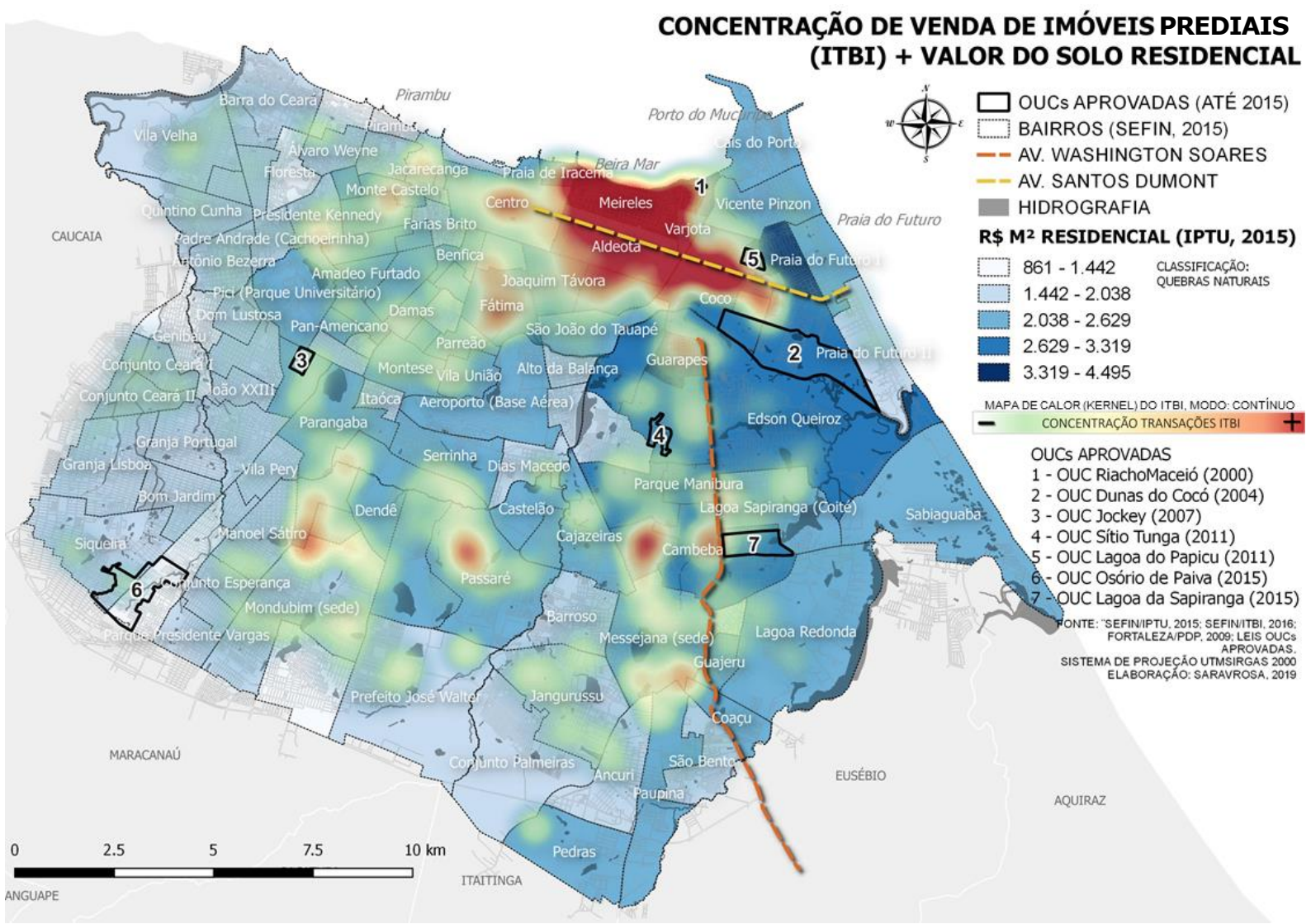

Elaboração: Rosa (2019). Fontes: ITBI (FORTALEZA/SEFIN, 2016); Valor do solo/IPTU (FORTALEZA/SEFIN, 2015); OUCs (SEUMA, 2017); Bairros (FORTALEZA/SEFIN, 2015). Mapa de Calor (mapa de densidade Kernel), foi elaborado a partir dos registros do ITBI (Imposto de Transação de Bens e Imóveis), onde para cada transação existia a coordenada geográfica do imóvel em questão. Os dados do ITBI correspondem aos registros dos anos de 2009 a março de 2016. Observação: Os limites dos bairros e do município apresentados com os dados da SEFIN/ITBI diferem dos limites dos bairros atualizados pela SEUMA em 2015.

Também é possível observar empreendimentos destas empresas no setor oeste de expansão da área de valorização imobiliária consolidada, como nos bairros de Fátima, Jacarecanga, Parquelândia e Presidente Kennedy, neste último os empreendimentos estão associados a um shopping center recentemente implementado na área ${ }^{156}$.

Já as empresas de capital aberto ${ }^{157}$, grandes empresas de incorporação nacional, que conseguiram entrar no mercado cearense, principalmente por meio de parcerias com as empresas locais, possuem empreendimentos com localização mais dispersa no território, porém sem fugir do núcleo Meireles-Aldeota, eixos de expansão das avenidas Santos Dumont e Washington Soares, e a faixa de consolidação da coroa imobiliária, segmento econômico,

\footnotetext{
156 Mapa com a discriminação das empresas pode ser conferido no Mapas extras - dinâmica da produção imobiliária de mercado.

${ }^{157}$ Foram identificadas um total de nove empresas de capital aberto que atuavam ou atuaram na produção imobiliária em Fortaleza e municípios do entorno, a saber: Cyrella, Direcional, MRV, Gafisa, Helbor, Rodobens, Rossi, Tecnisa, Viver. Levantamento realizado por Rosa e Moura, em 2017, para trabalho do LEHAB.
} 
identificada por Rufino (2016), formada por bairros mais periféricos e de expansão da produção de mercado (Figura 63).

Se isolarmos os empreendimentos de empresas de capital aberto que trabalham exclusivamente com incorporação, percebemos que estas permanecem no entorno do núcleo Meireles-Aldeota e nos eixos Santos Dumont-Washington Soares, com empreendimentos de alto padrão. Estes eixos, apesar de possuírem preço do solo relativamente mais baratos do que o núcleo tradicional (Figura 65), possuem preços de venda do imóvel construído semelhantes às áreas mais caras (Figura 64). Quando se distanciam um pouco mais desses eixos, fazem-no dentro de uma OUC vinculada à implantação de um shopping center, como é o caso da incorporadora Rossi, na OUC do Jockey Club. Os demais empreendimentos levantados fora do núcleo Meireles-Aldeota, desta classe de empresas, são todos da Rodobens. A Helbor ficou restrita ao núcleo. Já a Tecnisa, empresa que faz parte da SPE (Sociedade de Propósito Específico) da OUC do Riacho Maceió, juntamente com as empresas de capital fechado Norpar e Terra Brasilis, também ficou restrita ao núcleo com dois empreendimentos à beira-mar, porém possui atuação também fora de Fortaleza, no município de Aquiraz, onde também encontramos empreendimentos ligados à incorporadora Cyrella ${ }^{158}$.

Já as empresas de capital aberto que também trabalham com a produção (construção) do imóvel atuaram mais nos bairros periféricos, (coroa imobiliária - segmento econômico, RUFINO, 2016). São, em geral, empresas que conseguiram adentrar no mercado de Fortaleza por meio do Programa Minha Casa Minha Vida (PMCMV) do Governo Federal, construindo HIS e habitação popular. No caso, a empresa MRV tem o maior número de empreendimentos, seguida da Direcional. A incorporadora e construtora Rodobens vai atuar também para o segmento econômico popular, com empreendimentos do PMCMV, fora de Fortaleza, no município de Pacatuba. Dentro de Fortaleza, a empresa foca em empreendimentos para a classe média e em localizações próximas ao núcleo consolidado. Fugindo à regra da atuação para o segmento econômico e PMCMV, há ainda as empresas Gafisa e Viver, com empreendimentos de alto padrão/luxo no município de Aquiraz.

\footnotetext{
158 Mapa com a discriminação das empresas pode ser conferido no Mapas extras - dinâmica da produção imobiliária de mercado.
} 
Figura 62. Transações de imóveis prediais (ITBI) + valor do solo + empreendimentos de empresas capital fechado.

CONCENTRAÇĀO DE VENDA DE IMOVEIS PREDIAIAS (ITBI) +

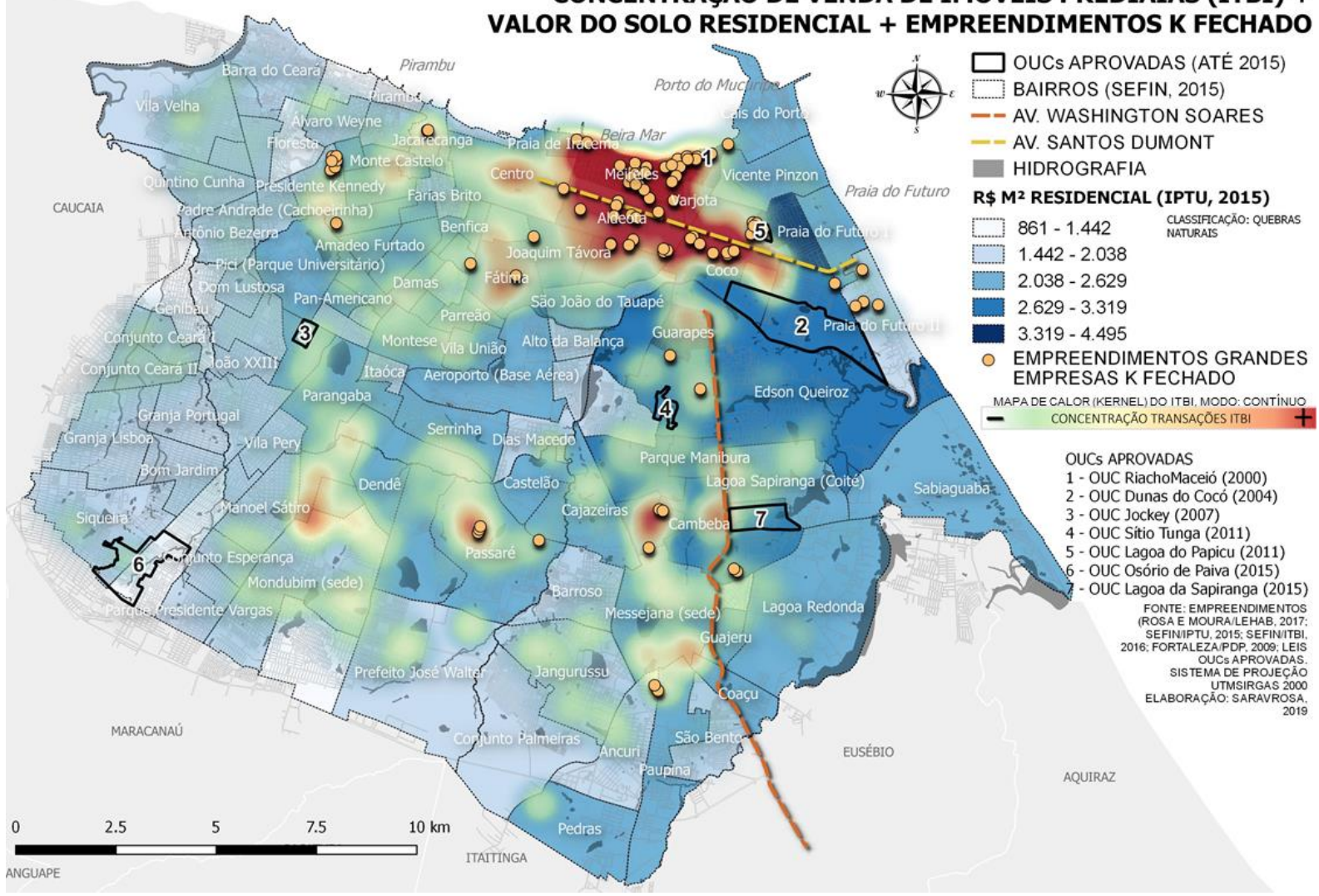

Elaboração: Rosa (2019). Fontes: EMP. (LEHAB/ROSA E MOURA, 2017); IPTU E ITBI (SEFIN, 2015 e 2016); OUCs (SEUMA, 2017).

Figura 63. Transações de imóveis prediais (ITBI) + valor do solo + empreendimentos de empresas capital aberto.

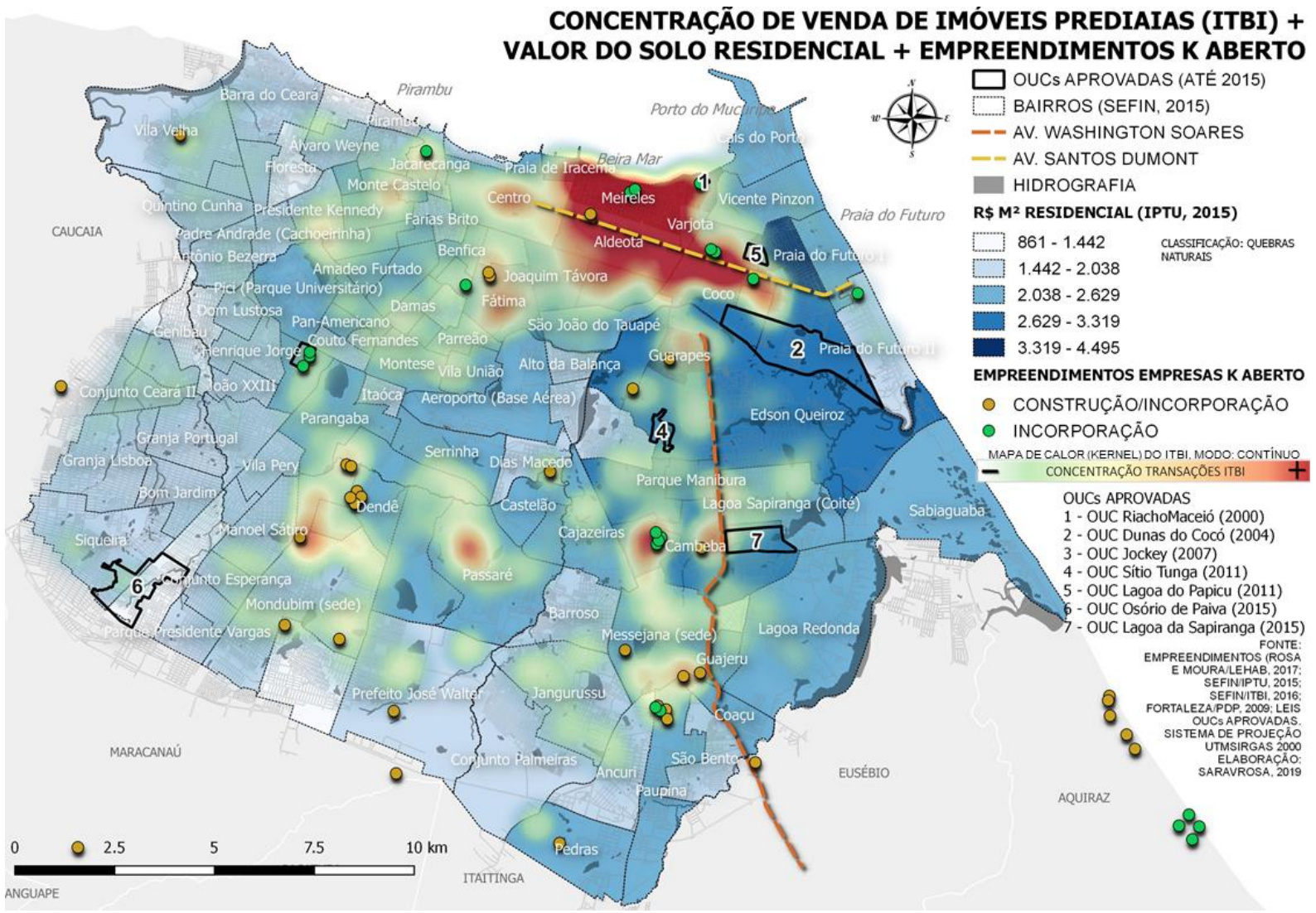

Elaboração: Rosa (2019). Fontes: EMP. (LEHAB/ROSA E MOURA, 2017); IPTU E ITBI (SEFIN, 2015 e 2016); OUCs (SEUMA, 2017). 
Figura 64. Preço do $\mathrm{m}^{2}$ do imóvel residencial em Fortaleza segundo IPTU de 2015.

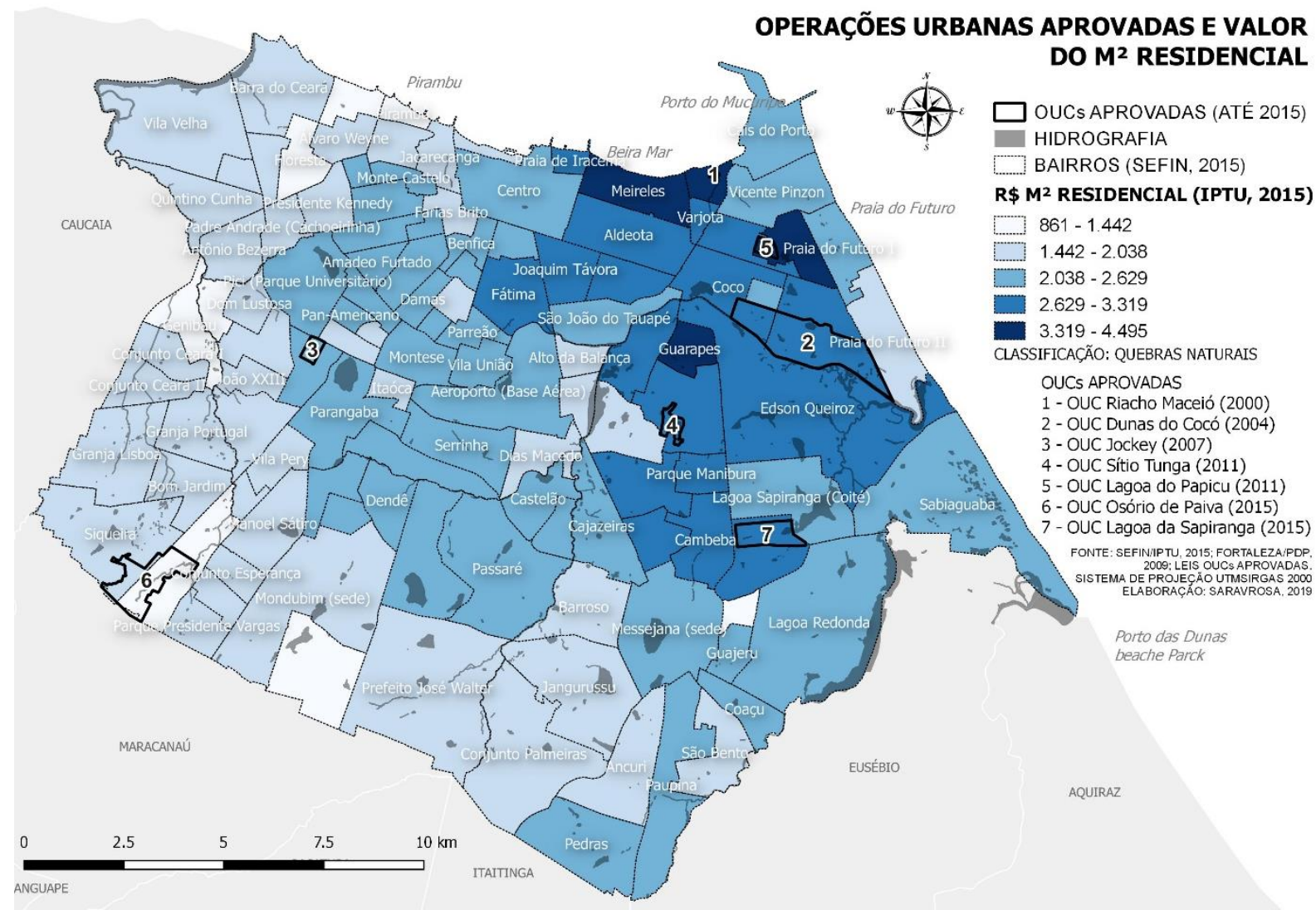

Elaboração: Rosa, 2019. Fonte dos dados: IPTU E ITBI (SEFIN, 2015 e 2016); OUCS (SEUMA, 2017).

Figura 65. Preço do $\mathrm{m}^{2}$ do imóvel territorial em Fortaleza segundo IPTU de 2015.

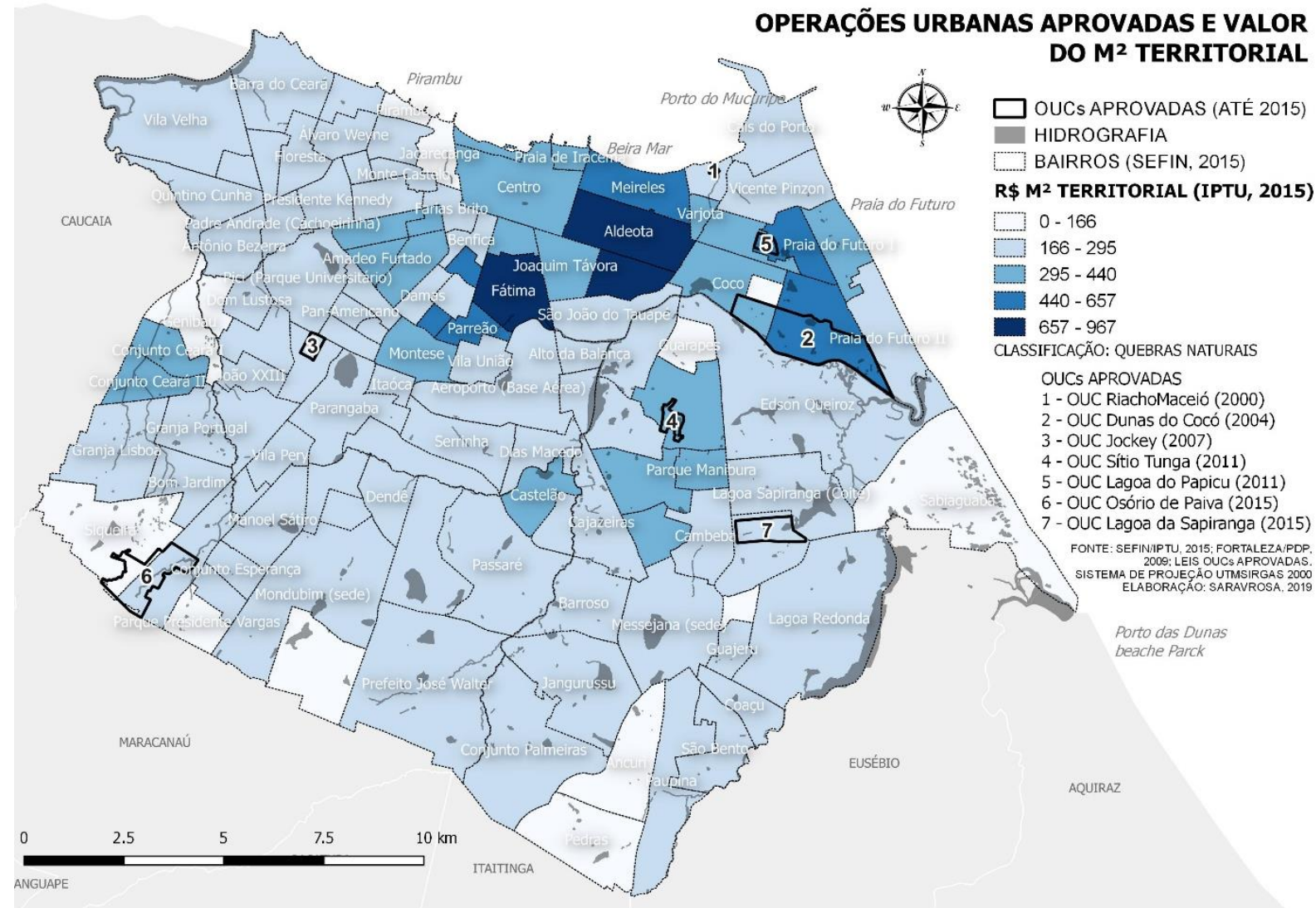

Elaboração: Rosa, 2019. Fonte: IPTU E ITBI (SEFIN, 2015 e 2016); OUCs (SEUMA, 2017). 
A partir da análise da Figura 64 e da Figura 65, é possível verificar que as OUCs (5,2,4 e 7), apesar de estarem localizadas em bairros com alto valor do metro quadrado residencial, ainda são áreas que não possuem uma dinâmica imobiliária tão intensa (considerando a venda de imóveis prediais a partir de dados do ITBI), como verificado nos bairros de maior tradição de investimento imobiliários, como Meireles e Aldeota. Ao mesmo tempo, também não são, necessariamente, os bairros com o preço do metro quadrado territorial mais caro.

Esse descompasso entre o preço do terreno e o preço do imóvel construído faz com que os investimentos imobiliários nesta área sejam altamente lucrativos e atrativos, pois a renda paga ao proprietário é pequena. Assim, as OUCs aprovadas, além de resgatarem o valor, mesmo que aparente, ou fictício, refletem também uma possibilidade de trazer dinamização e consolidar uma tendência de expansão do mercado de produção imobiliária em áreas nas quais os terrenos do entorno que foram adquiridos (previamente) a preços relativamente baixos e cujos produtos imobiliários podem ser comercializados entre os preços mais altos da cidade $^{159}$

Na Figura 66, é possível observar que tanto o parque do Riacho Maceió, como o Parque da Lagoa do Papicu, estão localizados exatamente no limite entre as áreas com maior concentração de transações de ITBI entre os anos de 2009 e março de 2016, bairros Aldeota, Varjota e eixo de expansão da av. Santos Dumont. Assim, os capitalistas e rentistas envolvidos, aproveitam espaços, às vezes, não reconhecidos socialmente como natureza ${ }^{160}$, apesar de serem legalmente espaços de preservação da natureza, e por meio da urbanização, geram valor, e reconhecimento social daqueles espaços como natureza, mesmo que seja uma natureza produzida, ou nos termos de Hidalgo, et al. (2016), "natureza inventada"161.

O reconhecimento social desses espaços como natureza funciona como contrapartida e justificativa para que partes da natureza-legal seja apropriada privativamente e receba novos

\footnotetext{
159 Como exemplo, podemos citar o caso da OUC Dunas do Cocó, que teve sua vigência renovada em nome da empresa DIAS BRANCO Administração e Participação Ltda (publicada do D.O. do município no 15.404 de 14 de novembro de 2014), pertencente ao grupo M Dias Branco, que além das térreas da poligonal da OUC, possui também outros terrenos no entorno e ao longo da Praia do Futuro. Daí inclusive a mudança do nome do bairro Dunas, para M Dias Branco.

160 Não reconhecido como natureza pela sociedade capitalista. Em entrevistas feitas a atores ligados ao empreendimento dos parques e ao estado, esses espaços eram sempre apontados como espaços perigosos e degradados, passando a serem reconhecidos como natureza, com reconhecimento do rio e da lagoa, somente após a urbanização e geração de valor. Por outro lado, em entrevistas feitas a moradores que foram desapropriados, ou moradores do entorno, que usam a terra como valor de uso de moradia não-mercantil, se referem ao lugar, antes da urbanização, como natureza, espaço de lazer, de pesca, etc.

161 Poderia ainda ser natureza símbolo, simulacro nos termos de Lefebvre.
} 
parâmetros de uso e ocupação do solo, permitindo novos e maiores empreendimentos imobiliários. E o valor gerado na produção dessa natureza reconhecida socialmente funciona como vetor de expansão da produção imobiliária de altos preços que acontecem nas proximidades, além de ser capitalizado nos empreendimentos previstos para os terrenos que ainda remanescem sem produto imobiliário construído.

Figura 66. OUC Riacho Maceio e OUC Lagoa do Papicu frente a dinamização do mercado imobiliário.

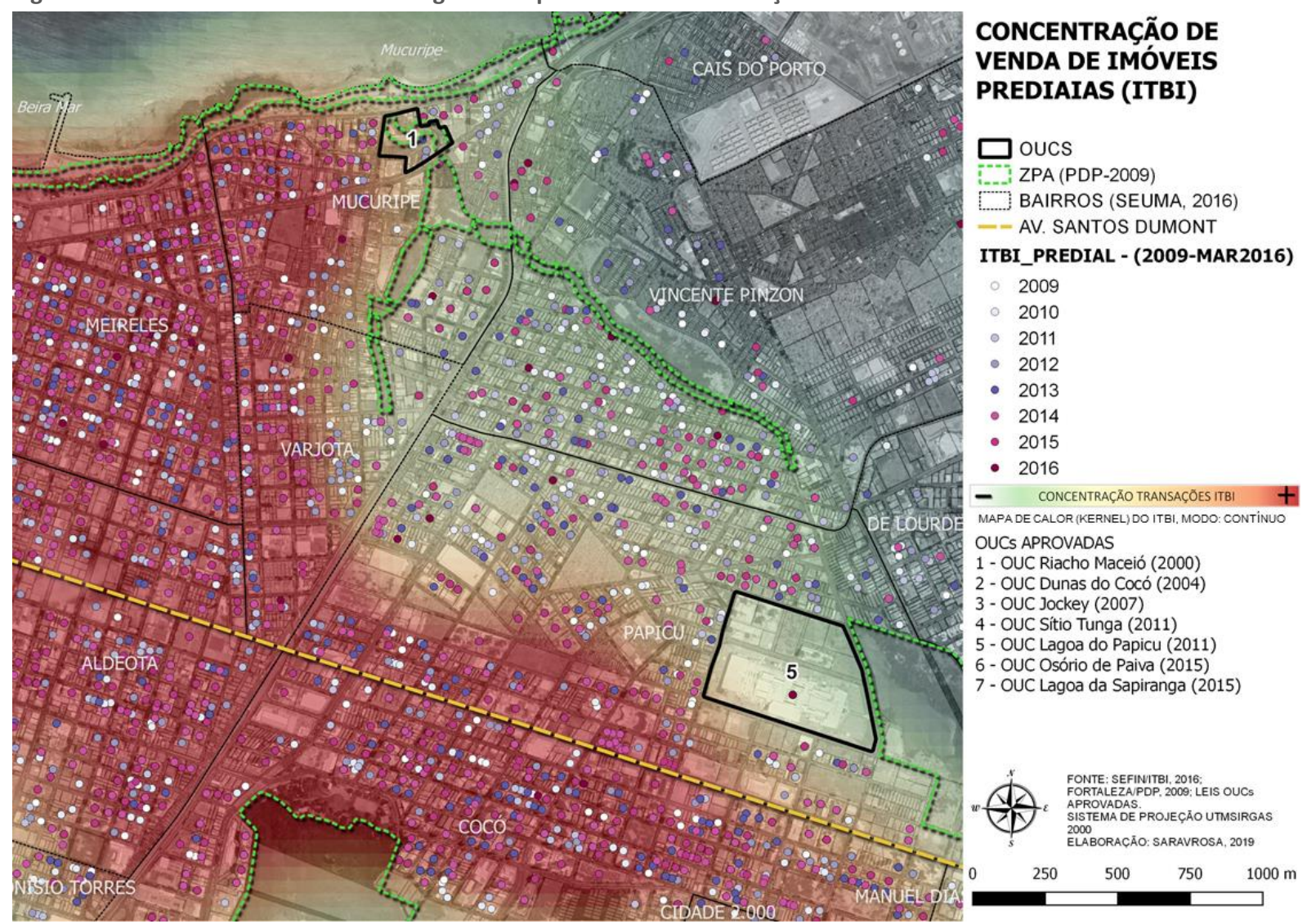

Elaboração: Rosa (2019). Fontes: ITBI (FORTALEZA/SEFIN, 2016); VALOR DO SOLO/IPTU (FORTALEZA/SEFIN, 2015); OUCS (SEUMA, 2017); BAIRROS (FORTALEZA/SEFIN, 2015). Mapa de Calor (mapa de densidade Kernel), foi elaborado a partir dos registros do ITBI (Imposto de Transação de Bens e Imóveis), onde para cada transação existia a coordenada geográfica o imóvel em questão. Os dados o ITBI corresponde os registros dos anos de 2009 a março de 2016. 
Figura 67. Imagem aérea do terreno a OUC do Riacho Maceió, ainda com as últimas casas por serem removidas.

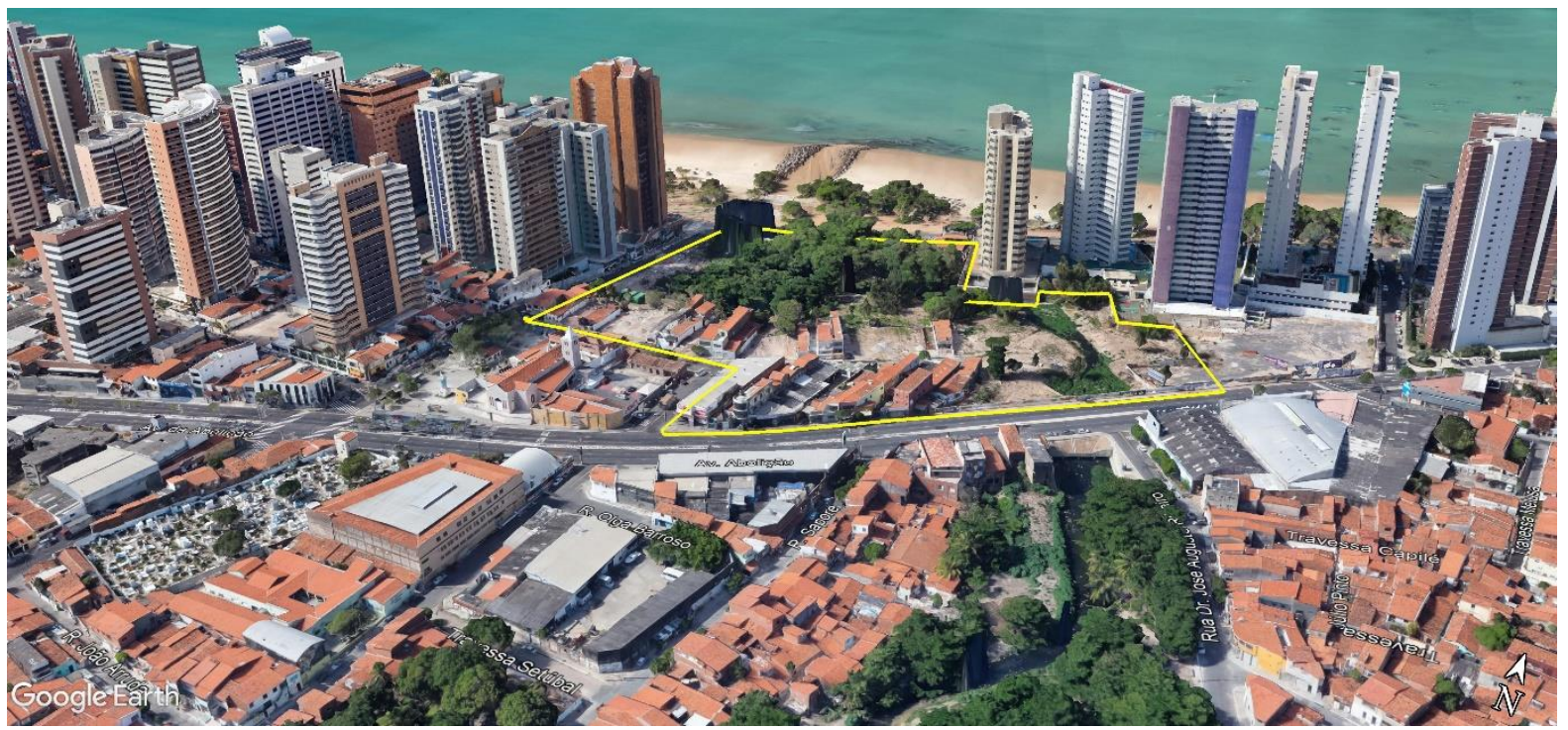

Foto: GoogleEarth, 3D.

Quadro 9. Atores das OUC. Setor público e setor privado vinculados nas Leis de cada OUCs.

\begin{tabular}{|c|c|c|c|c|}
\hline \multirow[t]{2}{*}{ OUC } & \multicolumn{2}{|c|}{ SETOR PÚBLICO } & \multicolumn{2}{|c|}{ SETOR PRIVADO } \\
\hline & Lei de criação & $\begin{array}{l}\text { Leis/decretos/notif. } \\
\text { Posteriores }\end{array}$ & Lei de criação & $\begin{array}{l}\text { Leis/decretos/notif. } \\
\text { Posteriores }\end{array}$ \\
\hline Riacho Maceió & $\begin{array}{l}\text { Secretaria Municipal } \\
\text { de Desenvolvimento } \\
\text { Territorial Urbano e } \\
\text { Meio Ambiente (SMDT) }\end{array}$ & & $\begin{array}{l}\text { Nordeste Participações Ltda } \\
\text { (NORPAR) }\end{array}$ & Terra Brasilis \\
\hline Dunas do Coco & $\begin{array}{l}\text { Secretaria Municipal } \\
\text { de Desenvolvimento } \\
\text { Urbano e } \\
\text { Infraestrutura (SEINF) }\end{array}$ & $\begin{array}{l}\text { Secretaria de } \\
\text { Urbanismo e Meio } \\
\text { Ambiente (SEUMA) }\end{array}$ & $\begin{array}{l}\text { Proprietários dos terrenos afetados } \\
\text { pela Operação (lei de criação) }\end{array}$ & $\begin{array}{l}\text { DIAS BRANCO } \\
\text { Administração e } \\
\text { Participação Ltda } \\
\text { (INSTRUMENTO } \\
\text { NOTIFICATÓRIO, D.O. } \\
14 \text { de novembro de } \\
\text { 2014) }\end{array}$ \\
\hline Jockey Club & $\begin{array}{l}\text { Secretaria Municipal } \\
\text { de Desenvolvimento } \\
\text { Urbano e } \\
\text { Infraestrutura (SEINF) }\end{array}$ & & $\begin{array}{l}\text { Proprietário dos terrenos } \\
\text { localizados na área (lei 9333/2007); }\end{array}$ & $\begin{array}{l}\text { SOCIEDADE JOCKEY } \\
\text { CLUB CEARENSE } \\
\text { (Protocolo de } \\
\text { intenções, D.O. } 11 \text { de } \\
\text { janeiro de 2008) }\end{array}$ \\
\hline Sítio Tunga & $\begin{array}{l}\text { Secretaria Municipal } \\
\text { de Desenvolvimento } \\
\text { Urbano e } \\
\text { Infraestrutura (SEINF) }\end{array}$ & & $\begin{array}{l}\text { FCM Comercial Ltda - proprietária } \\
\text { do terreno e ROOKFIELD MB } \\
\text { Empreendimentos Imobiliários S.A - } \\
\text { investidora (lei de criação } \\
9777 / 2011 \text { ) }\end{array}$ & \\
\hline Lagoa do Papicu & & & $\begin{array}{l}\text { MD CE NOVA ALDEOTA } \\
\text { EMPREENDIMENTOS LTDA (família } \\
\text { Moura Doubex) e RIOMAR } \\
\text { SHOPPING FORTALEZA S.A. }\end{array}$ & \\
\hline $\begin{array}{l}\text { Parque Urbano da } \\
\text { Lagoa da Sapiranga }\end{array}$ & $\begin{array}{l}\text { Secretaria Municipal } \\
\text { do Urbanismo e Meio } \\
\text { Ambiente (SEUMA) }\end{array}$ & & $\begin{array}{l}\text { Proprietários dos terrenos } \\
\text { localizados na área de que trata } \\
\text { esta Lei }\end{array}$ & \\
\hline Osório de Paiva & $\begin{array}{l}\text { Secretaria Municipal } \\
\text { do Urbanismo e Meio } \\
\text { Ambiente (SEUMA) }\end{array}$ & & $\begin{array}{l}\text { Proprietários dos terrenos } \\
\text { localizados na área de que trata } \\
\text { esta Lei }\end{array}$ & \\
\hline
\end{tabular}

Elaboração própria a partir das leis de cada OUC. 
Os espoliados e esquecidos no processo de acumulação e

valorização pela natureza

Ai!! Aqui era um sítio. Aqui atrás era um sítio que você nem imagina as frutas!?! Mas era assim!! Os pés de planta!! Cheio! Tinha de tudo, as melhores frutas!! Até fruta pão tinha aqui [...] E aí era um santuário de peixe, porque a maré entrava e deixava os peixes. E aí quando era o inverno... os invernos aqui eram rigorosos. Os invernos eram tão rigorosos que os pescadores não iam para o mar né... [...] morava meu tio que tinha uma jangada, e eles antes de irem pescar eles cozinhavam uma panelona de ferro com carne velha para o pessoal comerem né, era o café deles para eles irem pescar. Todo dia eles faziam isso. E eu me lembro que os pescadores ali com as roupas dele, [...]. Tinha outra coisa também, esse eu soube depois de muito tempo. Era um vento que chamavam de torrado... esse vento vinha lá da praia do futuro... e tinha um barulhinho assim: "huuuummmmmhummmmm" fazia esse barulho. Começava de madrugada e ia até umas $10 \mathrm{~h}$ da manhã. Aquele frio!! Mas era frio, era frio mesmo!! E aquele barulhinho... aí ficava assim nublado sabe... aí ia esquentando, esquentando $[\ldots]$

[...] o Mucuripe era assim um lugar... tinha muitas árvores, era um verde só e tinha poucas casas. E não era conhecido. Porque a entrada era difícil. Tinha um pouquinho...aí...onde tem um prédio... [...] então essa descida...tinha o casario do pessoal que mandava fazer as casas para passar as férias, tinha uns chalés...então essa descida não era conhecida também. E a Frei Mansueto, a Frei Mansueto ela vinha mais ou menos até a rua da paz. Da rua da paz para lá era sítio. E no meio da Frei Mansueto com a rua da paz tinha um pé de manga beem grande mesmo que tomava tudo! Quem era que ia saber que tinha isso aqui né? Só o pessoal que morava aqui. Só, que tinha outras pessoas mais curiosas né, que conseguiu passar por debaixo da mangueira e pegava a rua da paz e ficava conhecido aqui né. Que a gente até se assustava quando chegava alguém, aquele pessoal naqueles cavalos, bunitão assim. E na rua da abolição tinha um pé de cajueiro grande, antigo, que o pessoal dizia que ele já tava caducando, o cajueiro. E tinha também um pé de ipê, grande também, antigo também, devia ser centenário. E tinha essas casinhas que era onde eu morava. E aí eles aparecerem assim de repente né, aí a gente chega assim assustado de ver aquele pessoal ali... e eles queriam ver, conhecer tudo, e achavam muito bonito... e realmente era! Era uma aldeia de pescadores! Mas era muito bom, muito animado! ... tenho assim ... uma coisa assim... um encanto né?

...e aí minha filha, vi a passagem do século [..]

[...] é que foi essa luta danada. Era a especulação imobiliária. A especulação imobiliária que começou aqui nessa área. Eles chegavam na casa da gente, diziam que o terreno era deles e que a gente tinha que sair.

[...] Outra coisa que acho muito doloroso mesmo, é você por exemplo, você nasceu naquele espaço, mora ali, você não pretende sair. E de repente você vai para outro lugar aperreado... que vc não sabem nem.... Que você não quer! Se vocês andarem por aí, não tem mais praia que tenha pescador. E o pescador tem o direito de morar na praia porque é onde ele trabalha, [...]

[...] esse riacho ai era um rio caudaloso, ninguém se atrevia a atravessá-lo. E, foi acabando, acabando, acabando... ta aí, tem só uns metro d'água, que vc não sabe nem da onde veio... [...] dividiram o riacho todinho, e é podre a água, não cuidam, eu não acho que isso seja uma coisa boa. Daqui tem dia que o vento traz um fedor horrível! Porque essa água está empoçada e não é tratada. 
(MUNDINHA, 20176 Entrevista concedida a Sara V. Rosa e Camila Aldiguere/Lehab em 29 de outrubro de 2016).

Os relatos que brotam da memória de Dona Mundinha, moradora do Mucuripe, com 86 anos, de sua infância e de sua vida, são esclarecedores, no sentido de mostrar a passagem, mesmo em tempos mais recentes, de uma apropriação não privativa da natureza, não mercantil, para uma apropriação privada e mercantil ${ }^{162}$.

Os relatos iniciais de Mundinha ressaltam o valor de uso da natureza enquanto subsistência (moradia, alimentação), além de outros tipos de relação com a natureza que quase a humanizam - há a ideia de sagrado ("um santuário de peixe"), há características humanas ("cajueiro caducando"). Há também um conhecimento dos processos e do funcionamento da natureza, dos ciclos da maré, do clima. É uma relação social ainda não alienada (cap. 01).

Figura 68. Vila de pescadores do Mucuripe na década de 1930.

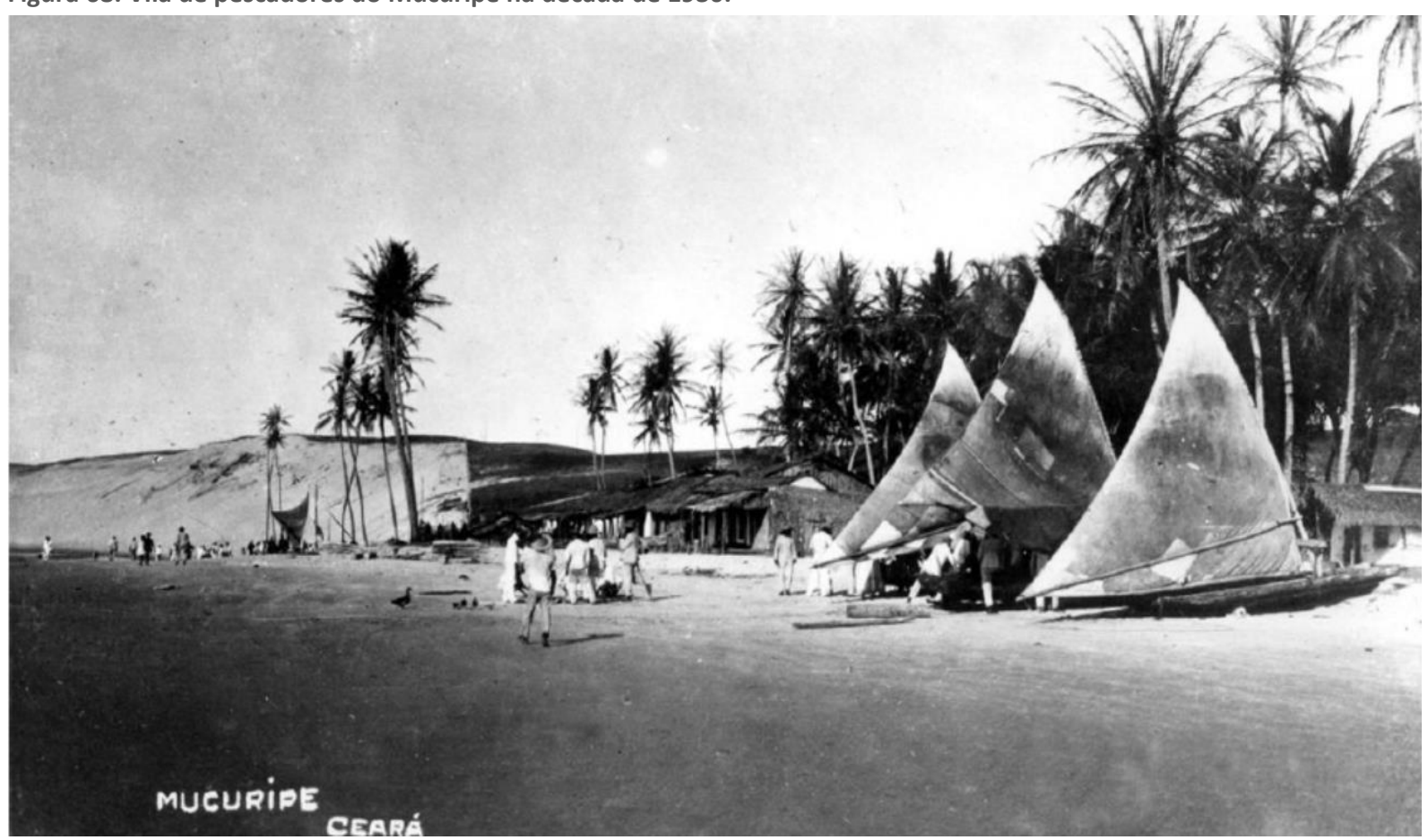

Foto: Arquivo Nirez. Fonte: Maia (2010, p. 69).

A moradora também relata o processo de apropriação privada desses espaços terra-natureza e a consequente expropriação dos que aí habitavam ("Eles chegavam na casa da gente, diziam

162 Aldigueri (2017), destaca o processo não mercantil de ocupação inicial do entorno da foz do Riacho Maceió, pautado mais no valor de uso que a terra, o rio e o mar representavam na apropriação das famílias que aí residiam. Segundo a mesma autora, com base nos conceitos de Pírez (2016), o processo representa uma desmercantilização social, uma vez que essas terras já se conformavam como moderna propriedade privada, e segundo relatos de Dona Mundinha (entrevista concedida à Sara V. Rosa e Camila Aldigueri em 2016), as pessoas iam pedindo permissão ao proprietário da época, Coronel Manuel Jesuíno, e iam construindo suas casinhas sem pagar pela terra. 
que o terreno era deles e que a gente tinha que sair"). Processo este que é anterior a OUC do Riacho Maceió. Em outros trechos da entrevista, Dona Mundinha comenta sobre a casa da infância menor, localizada onde hoje passa a avenida Abolição, e do motivo da mudança para a atual casa. Segundo ela, deveu-se à ampliação da avenida, que além de margear a casa, no entendimento do seu pai, seria impossível permanecer ali, porque estava se tornando um lugar apenas para pessoas ricas. Assim, a família mudou-se para mais perto do riacho.

Assim, os processos de acumulação por espoliação/expropriação vistos no primeiro capítulo, não cessam e permanecem inclusive nas OUCs descritas anteriormente, que têm se mostrado como importantes estratégias contemporâneas de manter processos espoliativos atrelados a processos de valorização real e aparente.

Dado que o porte das Operações Urbanas Consorciadas aprovadas em Fortaleza, até 2015, é, em geral, bem pequeno, como já demostrado anteriormente, estas incorporaram dentro de sua poligonal de atuação um número pequeno de comunidades (favelas), e quando ocorrem, são em geral comunidades bem menores do que as encontradas nos casos das OUCs de São Paulo e Rio de Janeiro. Todavia, algumas das OUCs possuem, adjacente a seus limites, várias comunidades, algumas grandes e densas, que por estarem fora da poligonal da OUC não podem receber investimentos da operação em prol de melhorias ${ }^{163}$, mas acabam sendo impactadas por reflexos, como aumento no preço dos aluguéis e venda das moradias. No caso de Fortaleza, houve inclusive remoção de comunidade fora da poligonal da OUC para permitir a realização do empreendimento da Operação, foi o caso da OUC da Lagoa do Papicu.

No Quadro 10, podemos ver um resumo por OUC das comunidades existentes dentro da poligonal, no ano de aprovação da lei da Operação e a situação mais recente. Das 7 OUCs aprovadas, as que possuem ou possuíam comunidades dentro da poligonal são: Riacho Maceió, Parque Urbano da Lagoa da Sapiranga; e Osório de Paiva. A OUC Dunas do Cocó, hoje, apresenta dois núcleos de ocupações no interior do seu limite. Uma ocupação que se expande a partir do Conjunto de HIS do reassentamento da comunidade da Lagoa do Gengibre, e a comunidade Terra Prometida 2.

\footnotetext{
${ }^{163}$ A Lei do Estatuto da Cidade que regulamenta o instrumento a nível nacional define que os recursos arrecadados em uma OUC só podem ser aplicados nas áreas inseridas na poligonal que define o limite da mesma.
} 
Nenhuma das OUC, com comunidades dentro de seus limites, tiveram qualquer menção a estas na lei de aprovação da Operação, com exceção da OUC do Riacho Maceió, que cita parcialmente ao transferir toda a responsabilidade das casas existente no terreno ao ente privado da operação, incumbindo a este a aquisição e desocupação desses imóveis ${ }^{164}$, sem qualquer diretriz de como isto deveria ser feito. Tampouco qualquer recurso foi destinado para a urbanização ou melhorias destas comunidades. Sequer exigências do Estatuto da Cidade, como elaboração de programa de assistência econômica e social para a população diretamente afetada, bem como a criação e funcionamento de conselho gestor para cada OUC, como forma de controle obrigatoriamente compartilhado com representantes da sociedade civil, foram cumpridas $^{165}$, deixando claro que estas famílias foram completamente ignoradas no processo de formulação e implementação da OUC.

Nesta seção, tentaremos detalhar um pouco os processos espoliativos que estas famílias, de comunidades dentro de OUCs, vêm sofrendo. Para tanto, utilizaremos o caso da OUC Riacho Maceió, única em desenvolvimento com ocupação dentro de sua poligonal, e a OUC Lagoa do Papicu, que implicou na remoção de parte de uma comunidade, mesmo estando fora dos limites da operação.

Quadro 10. Comunidades atingidas pelas OUCs

\begin{tabular}{|l|l|l|}
\hline \multicolumn{1}{|c|}{ OUC } & \multicolumn{2}{|c|}{ COMUNIDADES ATINGIDAS } \\
\cline { 2 - 3 } & No ano de criação da OUC & Atualmente (2018) \\
\hline Riacho Maceió & $\begin{array}{l}\text { Ocupação no entorno do riacho - Rua } \\
\text { Senador Machado }\end{array}$ & $\begin{array}{l}\text { Todas as casas da área da OUC foram } \\
\text { removidas através de indenizações }\end{array}$ \\
\hline Dunas do Coco & $\begin{array}{l}\text { Havia início das obras do conjunto de } \\
\text { HIS para reassentamento da } \\
\text { comunidade do Gengibre. Do lado da } \\
\text { Cidade Fortal (Loteamento Alto Aldeota }\end{array}$ & $\begin{array}{l}\text { Hoje existe ocupaço em processo de } \\
\text { consolidação no entorno do Conjunto } \\
\text { HIS de reassentamento do Gengibre; e } \\
\text { a Comunidade Terra Prometida 2 ao }\end{array}$ \\
& $\begin{array}{l}\text { I), há um pequeno núcleo de 5 ou seis } \\
\text { casas que pode ser uma pequena } \\
\text { lado da comunidade Caça e Pesca, esta } \\
\text { ocupação antiga com características } \\
\text { rurais que não aparece nos } \\
\text { levantamentos municipais. }\end{array}$ & última já fora da poligonal. \\
\hline Jockey Club & $\begin{array}{l}\text { Não havia ocupação no terreno. No } \\
\text { entorno imediato há a ocupação da Rua } \\
\text { Paulo Fortim, e a comunidade Fumaça - } \\
\text { Planalto Pici localizada dentro de uma } \\
\text { ZEIS de Ocupação. }\end{array}$ & \\
\hline
\end{tabular}

164 “(b) aquisição e desocupação dos imóveis, tais como prédios, benfeitorias e posses, localizados na Rua Senador Machado, lado norte, bem como aqueles existentes na área destinada ao Parque" (FORTALEZA, 2000. Lei 8503. Art. 8ㅇ, parágrafo II. D.O. no 11.997 de 26 de dezembro de 2000).

165 Para maiores detalhes dos descumprimentos legais das OUCs aprovadas em Fortaleza consultar: HOLANDA e ROSA, 2017b ( Las asociaciones público-privadas y el desarrollo urbano. Análisis de ilegalidades en la creación de operaciones urbanas consorciadas en fortaleza, ceará-brasil.). 


\begin{tabular}{|c|c|c|}
\hline Sítio Tunga & $\begin{array}{l}\text { Não havia ocupação dentro da } \\
\text { poligonal. }\end{array}$ & $\begin{array}{l}\text { Não há comunidades dentro da } \\
\text { poligonal }\end{array}$ \\
\hline Lagoa do Papicu & $\begin{array}{l}\text { Não havia ocupações dentro da OUC. } \\
\text { No entorno: Comunidade das Areias.; } \\
\text { Comunidade do Pau Fininho; } \\
\text { Comunidade Verdes Mares; } \\
\text { Comunidade Jardim Nova Esperança; } \\
\text { Telemar, entre outras }\end{array}$ & $\begin{array}{l}\text { Casas da comunidade das Areias } \\
\text { localizadas na rua César Fonseca foram } \\
\text { removidas (indenização). Moradores da } \\
\text { Comunidade Pau Fininho relatam } \\
\text { intensificação de ameaças de remoção } \\
\text { depois da OUC. Demais comunidades } \\
\text { do entorno imediato permanecem. }\end{array}$ \\
\hline $\begin{array}{l}\text { Parque Urbano da } \\
\text { Lagoa da Sapiranga }\end{array}$ & $\begin{array}{l}\text { Pequena ocupação na Rua Roseno } \\
\text { Lopes com Maestro Lisboa. Muitas } \\
\text { ocupações no entorno da poligonal da } \\
\text { operação, como a Comunidade Parque } \\
\text { Novo Paraiso; Comunidade do Alecrim; } \\
\text { Comunidade uruca, Comunidade Lagoa } \\
\text { do Coité; Comunidade Lagoa Seca, entre } \\
\text { outras }\end{array}$ & Idem \\
\hline Osório de Paiva & $\begin{array}{l}\text { Dentro da poligonal existem ocupações, } \\
\text { loteamentos informais e conjuntos } \\
\text { habitacionais classificados como } \\
\text { assentamentos precários pelo PLHISfor. } \\
\text { Comunidade Jardim Fluminense, } \\
\text { Planalto Canindezinho, Loteamento } \\
\text { Parque Nazaré, Loteamento Alto Alegre, } \\
\text { Conjunto/Comunidade } 8 \text { de Dezembro }\end{array}$ & Idem \\
\hline
\end{tabular}

Elaboração própria (2016) a partir das leis de cada OUC e levantamento por imagem aérea e de satélite via Google Earth e levantamento pelo PHISfor (2013).

Figura 69. Assentamentos Precários (PLHIS-FOR, 2012) e OUCs aprovadas.
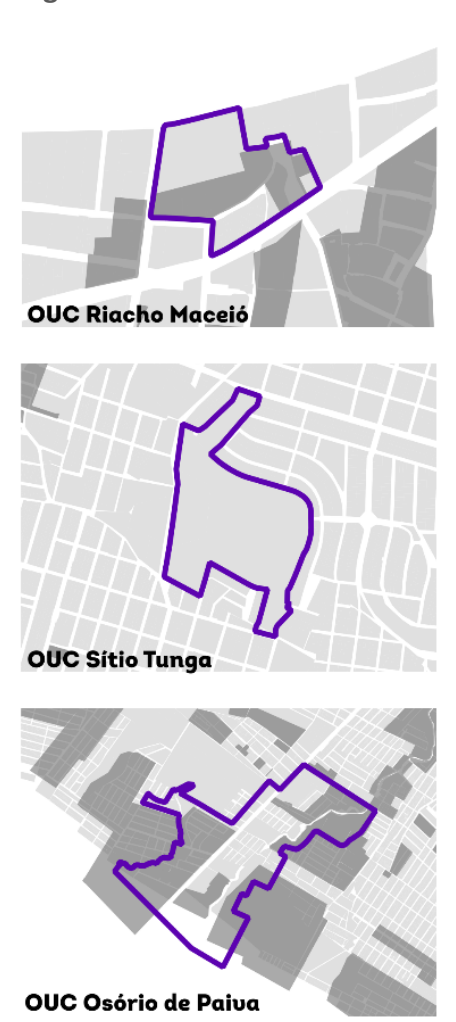

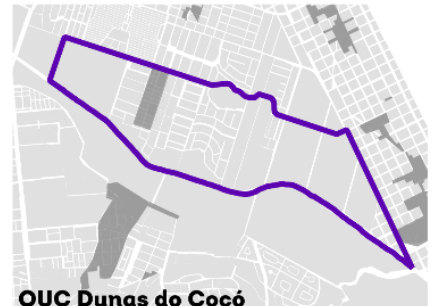

OuC Dunas do Cocó
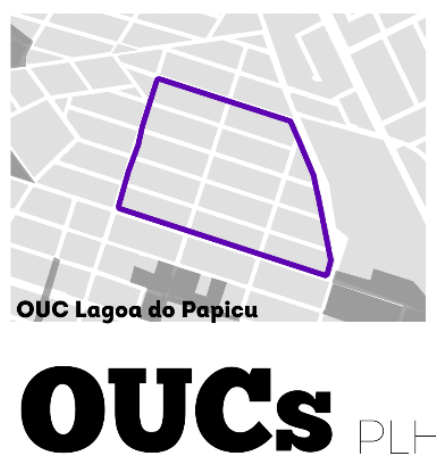

\section{ESPECIFICAÇõES:}

Sistema de proj. geográfica
DATUM SIRGAS 2000.

FONTES:

PLHIS (2012), SEFIN (2015) e LEHAB.

DATA:

03 de novembro de 2016
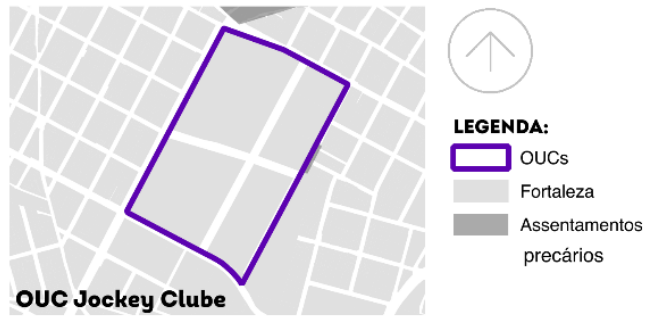

OUC Jockey Clube

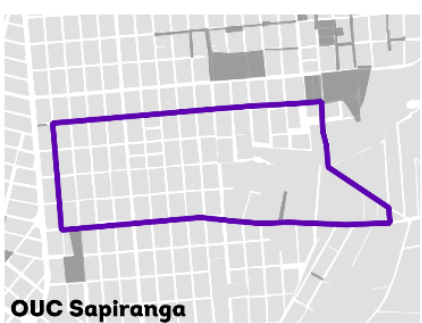

Ouc Sapiranga

Elaboração: HOLANDA/LEHAB, 2016. Fonte dos dados: PLHISFOR, 2012; SEUMA, 2015; PDP, 2009; leis de criação das Operações Urbanas. 
Além da espoliação que a população da cidade como um todo, e que a natureza/planeta terra como um todo, sofrem, de áreas preservadas que haviam sido "desvalorizadas" e desmercantilizadas para prestarem serviços ambientais e passam a serem remercantilizadas e valorizadas a partir da flexibilização do zoneamento e dos parâmetros de uso e ocupação do solo justificados pelas OUCs, tem-se ainda a espoliação e expulsão de população que moravam nestas áreas. A espoliação ocorre tanto em uma escala macro, como em uma escala local, e tanto em um nível global, como local ${ }^{166}$.

Na escala macro, pode ocorrer a supressão de uma área que poderia estar prestando um serviço ambiental ou de um espaço de lazer, contemplação para a cidade, o país, etc., que podem ocorrer pela substituição da terra-riqueza-natureza pela terra-valor-imobiliário ou pela privatização e restrição do acesso. Na esfera ou nível global, temos um aumento da espoliação urbana ${ }^{167}$ a partir dos sobrepreços gerados com o processo de valorização extrema (real ou não) proporcionado pela OUC. Na escala local, temos a expropriação direta da terra utilizada para moradia, às vezes também geração de renda, expropriação direta de áreas comuns e de riqueza natural. As comunidades inseridas dentro da OUC têm sido atingidas por todas essas escalas e níveis de espoliação.

A OUC do Riacho Maceió, tinha aproximadamente oitenta famílias que moravam na área onde foi implementado o parque, destas, aproximadamente metade, ocupavam terra demarcada como área de preservação e também identificada como área de risco. A outra metade, tinha suas casas em cota mais elevada na rua Senador Machado, já fora de risco, área classificada como de proteção ambiental (sendo permitida assim a ocupação com baixa densidade construtiva) e em casas mais estruturadas.

\footnotetext{
${ }^{166}$ Níveis e dimensões (LEFEBVRE, 1999).

167 Maiores detalhes sobre espoliação urbana ver KOWARICK, 1979.
} 
Figura 70. OUC Riacho Maceió. Ocupações prévias à Operação. Removidas.

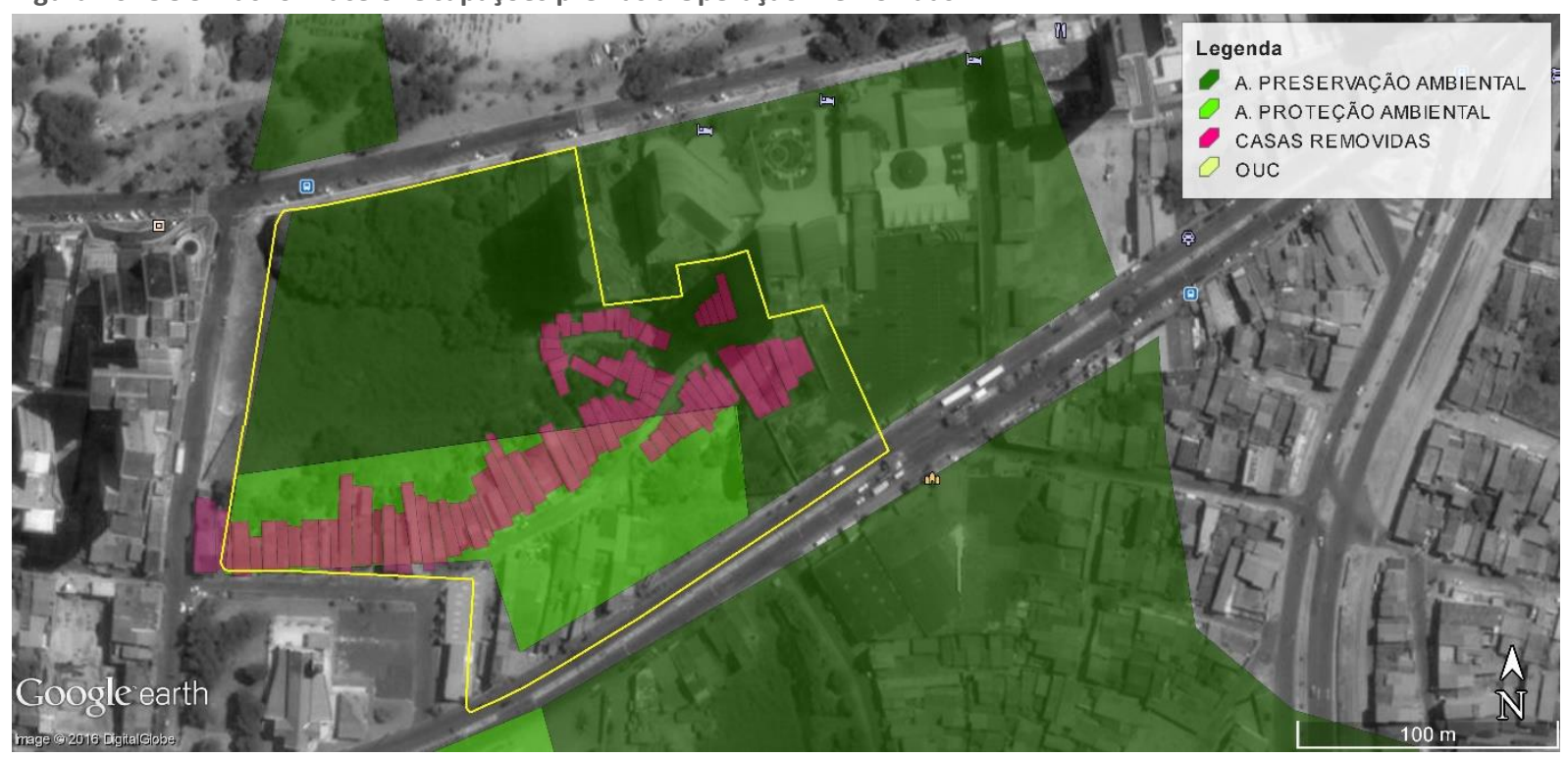

Fonte: FORTALEZA, 1992 (PD92). Imagem: Google Earth. Elaboração: Sara Vieira Rosa, 2017. Das mais de 80 famílias, 40 delas encontravam-se em área de risco segundo apresentação da Norpar ( NORPAR e FORTALEZA, sd)

Ao lembrar do conflito gerado pela implementação do parque/OUC com as famílias que residiam no local, Dona Mundinha relata:

[...] muita gente morreu, que tinha problema no coração e não aguentou. Choque! E foi se embora... outros da preocupação também, também do desgosto de morar tantos anos e depois sair, também ficou doente e morreu ... outros ainda estão vivos. Teve uma amiga minha que morava aí, foi só sair daqui, apareceu um Alzheimer, aí tá lá, não sabe quem é ninguém, não sabe nem quem é ela. (MUNDINHA, 20176 Entrevista concedida a Sara V. Rosa e Camila Aldiguere/Lehab em 29 de outrubro de 2016).

Outros moradores que também concederam entrevista para o LEHAB relatam esse processo, lembrando de casos de semelhantes "[...] os mais idosos entraram em depressão, minha mãe foi uma, apesar de a gente morar aqui [perto], minha mãe sentiu muito" (Ex-moradora da rua Senador Machado. Entrevista concedida à Aline Medeiros e Sara V. Rosa, pelo LEHAB, em setembro de 2017).

A empresa utilizou-se de estratégias, que são comuns ${ }^{168}$, porém cruéis, e em desacordo com legislações urbanas ${ }^{169}$, ao deixarem por anos no terreno todo o entulho de cada casa que iam

\footnotetext{
168 O próprio Estado adota essa prática. Como exemplo podemos citar a obra do VLT (veículo leve sobre trilhos) de Fortaleza, onde o Estado à medida que ia negociando com uma família, demolia sua casa e deixava o entulho para fazer pressão as famílias que ficavam ou para que a área não fosse ocupada novamente.

169 Proprietário de terreno tem obrigação de manter seu terreno limpo e dar correto destino a lixos, como entulho e material de demolição.
} 
conseguindo desapropriar e demolir, aumentando os riscos de saúde física e mental de quem permanecia, como é possível perceber na fala de ex-moradora do local:

\begin{abstract}
Eles começaram desse jeito, primeiro se conciliando com algumas pessoas da rua, algumas pessoas foram... aí depois eles viram que não dava, alguns moradores cederam, os outros não... mas todo mundo foi na questão mesmo do psicológico, aquela coisa que você é obrigado a sair ou a gente vem e derruba, mais ou menos nesses termos. [...]Foi obrigado a sair. Assim, não chegaram a botar a faca no pescoço, nem essas coisas, mas tipo, eles compravam as casas salteadas, derrubava casa, fazia coisa... teve uma amiga minha que foi até uma das últimas a saíram também e foi assaltada por conta dos escombros da casa, tu tá entendendo... tipo assim, para quem ficou por último, ficou uma zona meio que ruim, sabe?, principalmente para quem morava para a banda de lá, ficou uma coisa meio que ruim. Eles meio que ficaram utilizando de várias estratégias para poder fazer as pessoas cederem pro propósito deles. (Ex-moradora da rua Senador Machado. Entrevista concedida à Aline Medeiros e Sara Rosa, pelo LEHAB, em setembro de 2017).
\end{abstract}

O relato da ex-moradora contrasta com a fala do representante da empresa Terra Brasilis que comandou o processo de indenização das famílias e implementação do parque:

Não tem uma pessoa que saiu que possa dizer que saiu à força, que saiu com a faca no pescoço. Não. Foi sempre em negociação, às vezes em grupo, às vezes individual [..] (Diretor da Terra Brasilis, em entrevista concedida a equipe do LEHAB em 2016).

Em apresentação feita pela empresa (NORPAR e FORTALEZA, sd), em parceria com a Prefeitura de Fortaleza, ela mostra relatos de ex-moradores que saíram da área e foram indenizados. Segundo documento da apresentação, os moradores ficaram satisfeitos com a mudança, "[...] olha, quem saiu de lá está satisfeito [...]"; "Compramos uma casa excelente, muito melhor que a de antes!"; "Na casa nova temos registro do imóvel, antes era só posse. [...]. A casa que a gente tinha não era nossa, agora meu pai se foi mais deixou minha mãe com uma casa própria." (ex-moradores Maceió, apud NORPAR e FORTALEZA).

Apesar dos relatos registrados pela Norpar, os novos locais de residências, conseguidos a partir da indenização, dos três moradores que a empresa usa como exemplo, estão situados todos em áreas classificadas pelo Plano Local e Habitação de Interesse Social (PLHIS) como Assentamentos Precários. Dois deles são identificados como favelas parcialmente em área de risco (Comunidade do Saporé, localizada também as margens do Riacho Maceió, Comunidade Terra Mar); e o outro como conjunto de mutirão (Comunidade Castelo Encantado). Todas essas três áreas, identificadas na Figura 73, não possuem regularização fundiária, nem mesmo os conjuntos de HIS produzidos pelo Estado. O papel da casa que o morador relata na citação acima é provavelmente um contrato de compra e venda da casa, permanecendo este sem segurança quanto à propriedade do terreno. Ainda segundo as informações do PLHIS, a 
Comunidade do Saporé não possui atendimento de rede de esgoto e tanto a comunidade Terramar como a Castelo Encantado possuem atendimento via rede apenas parcial.

Figura 71. Localização atual de moradia de algumas famílias removidas da OUC Riacho Maceió utilizadas como exemplo pela Norpar.

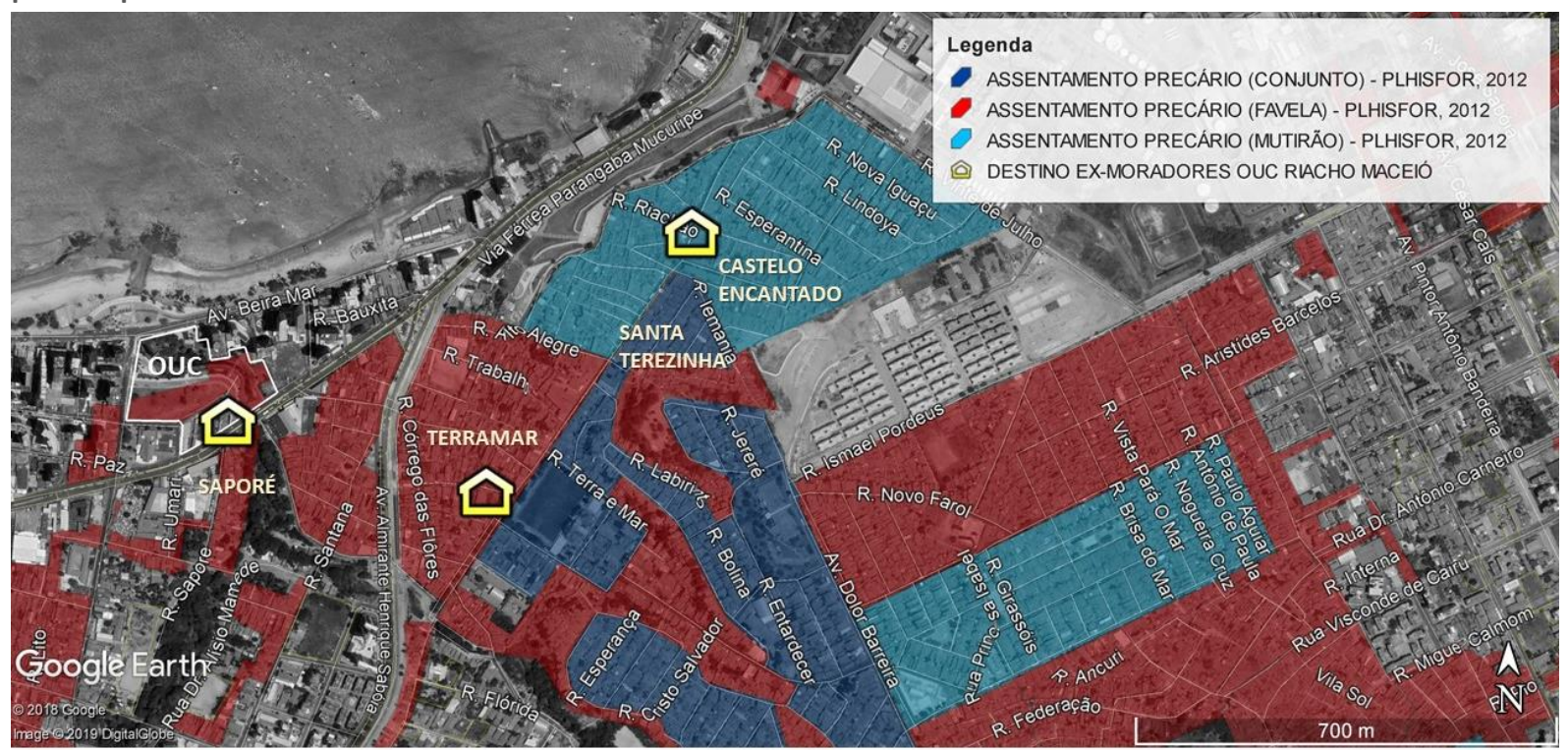

Elaboração: Sara V. Rosa (2019). Fonte: Norpar/Fortaleza (sd - apresentação pdf); Plhisfor (2012). Imagem aérea: GoogleEarth, 2018.

Segundo relato de ex-morador, a grande maioria das famílias que morava na rua Senador Machado foi para o Castelo e Conjunto Santa Terezinha (Assentamentos Precários segundo PLHIS - Figura 71). Uma ou outra família para o bairro da Varjota, e outros, foram morar bem distante. "Teve gente que foi morar na Cidade dos Funcionários, Messejana, esse pessoal aqui foi para a Sapiranga" ${ }^{170}$, estamos falando de até $12 \mathrm{~km}$ de distância, em linha reta, em uma cidade que tem entre 17 e 23 km de diâmetro.

Figura 72. Evolução da OUC do Riacho Maceió.

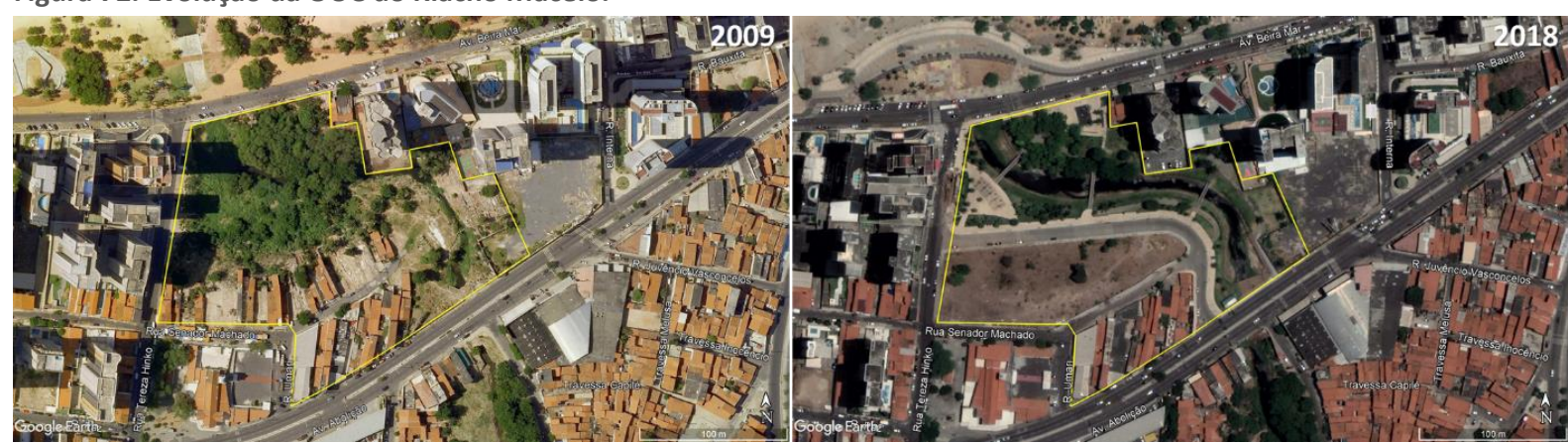

Imagem: GoogleEarth, 2009 e 2018.

\footnotetext{
170 Ex-moradora da rua Senador Machado. Entrevista concedida à Aline Medeiros e Sara Rosa (LEHAB), em setembro de 2017
} 
Figura 73. Fotos da área do Parque do Riacho Maceió mostrando o resto de construções demolidas.

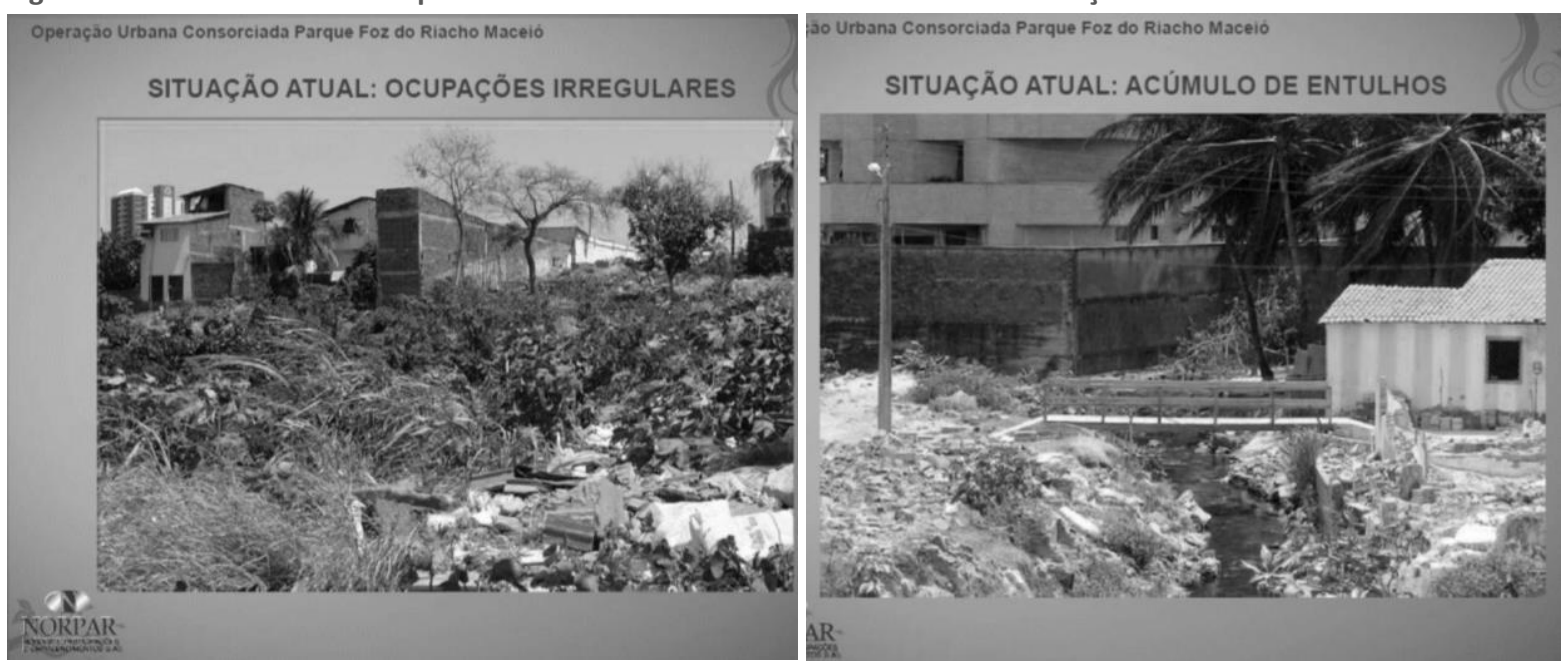

Fonte: NORPAR, sd. Fotos do ente privado da operação, Norpar.

A OUC da Lagoa do Papicu definia em sua Lei uma poligonal restrita ao terreno onde funcionava antiga fábrica inativa que foi demolida para dar lugar ao Shopping e às torres residenciais e comerciais, não englobando dentro da sua poligonal inicial nenhuma comunidade. Não obstante, o entorno da OUC é repleto de ocupações tipo favela ${ }^{171}$ (Figura 76), cuja obra do Shopping causou impacto direto, incluindo remoção de famílias.

A comunidade que teve famílias removidas para possibilitar a implantação do Shopping, foi a pequena Areias (favela Dazareias) localizada na rua César Fonseca, a partir década de $1980^{172}$, cuja parte de algumas casas foram construídas ocupando o espaço da calçada e parte do leito viário (Figura 74). A rua Cesar Fonseca liga a Avenida Santos Dumont ao Centro da quadra onde foi construído o shopping, sendo definida como o principal acesso ao empreendimento. Para tanto, foram necessários a recuperação e o alargamento do leito viário, implicando na remoção de parte da comunidade. A Lei da Operação previa essa obra e colocava como uma das contrapartidas da empresa responsável pela OUC seria justamente a construção de unidades habitacionais para as famílias removidas, em terreno que seria cedido pelo

\footnotetext{
171 “É, na verdade é assim Zareia, Pau Finim, aí tem a Cidade 2000, Morro do Gengibre, que é esse aqui. Com os Barreiros, que é novo, que é essa Cidade 2002 que chamam. Aí pra lá é que tem o Buraco, o Pilão, Morro Santa Terezinha, Conjunto São Pedro... do lado de cá tem os Trilhos, os Canos, e a Teleceará. São essas comunidades que tem em volta. A gente circulou em todas elas em toda a nossa infância e adolescência, por várias situações." (Felipe. Entrevista realizada em 25/01/2017)

172 Data aproximada do começo da formação da comunidade foi obtida junto a entrevista realizada em 2017 por Valéria Pinheiro, Sara V. Rosa e Breno Holanda (LEHAB) a ex-moradores da comunidade: "A gente nasceu lá, temos 29 anos de idade, e foi logo quando a gente nasceu que a comunidade começou a ser construída. A minha mãe, o meu pai conta, que quando eles chegaram lá, minha mãe já tava grávida de mim, eles tavam tipo invadindo o espaço, que era um terreno ao léu, baldio, só areia, por isso o nome DAS AREIAS, mas pelo fato do popular mesmo, ficou favela Dazareias...".
} 
Município, um total de 75 casas $^{173}$. Todavia, as casas nunca foram construídas e, segundo informações declaradas pela Secretária da SEUMA, Águeda Muniz, no lugar da construção foram pagas indenizações ${ }^{174}$. As indenizações foram confirmadas em entrevista realizada com ex-moradores, os quais afirmaram que o valor pago variou entre $5 \mathrm{mil}, 10 \mathrm{mil}$ a $30 \mathrm{mil}$, e alguns casos $50 \mathrm{mil}^{175}$.

Os entrevistados informaram que a maior parte das famílias removidas foram morar no Conjunto Farol Novo/Gengibre (Figura 75 e Figura 76), construído pelo governo do Estado para reassentar famílias removidas da área de risco e ZPA (Zona de Preservação Ambiental) da favela do Gengibre. Vale ressaltar que a área do Conjunto é ZIA (Zona de Interesse ambiental) pelo Plano Diretor do Município, porém, segundo o Código Florestal, ela é classificada como APP (Área de Preservação Ambiental), pois trata-se de duna com vegetação, sendo parte do conjunto das Dunas do Cocó (antiga Matas do Cap. Moura e Dunas da Barra - Figura 7, cap. 01), e está dentro da poligonal da OUC Dunas do Cocó. O próprio conjunto se adensou muito e hoje várias casas foram verticalizadas e subdivididas em unidades habitacionais menores para aluguel ou venda (Figura 75).

Apesar do Conjunto não ficar tão distante do local de origem das famílias, em um raio aproximado de $2 \mathrm{~km}$, o conjunto é classificado pelo Plano Local de Habitação como um assentamento precário (Figura 75 e Figura 76).

Então, não se observa melhora na qualidade da moradia dessas pessoas, em muitos casos há inclusive uma piora. No caso, as famílias estão morando em localização mais periférica, apesar de relativamente próxima da anterior, mais distantes de corredores viários principais com

\footnotetext{
$173 \mathrm{~V}$ - construir 75 (setenta e cinco) unidades habitacionais, de interesse social, nos padrões comumente utilizados pela Municipalidade, bem como seu arruamento, em área a ser cedida pelo Município de Fortaleza no prazo máximo de 180 (cento e oitenta) dias contados a partir da data da publicação desta Lei, destinadas estas unidades habitacionais aos atuais ocupantes do leito da Rua César Fonseca, entre o trecho que compreende a Rua Lauro Nogueira e a Avenida Santos Dumont, com posterior requalificação deste trecho com pavimentação devida. Parágrafo Único - A edificação pelos investidores privados das unidades de que trata o inciso $\mathrm{V}$ deste artigo terá início no prazo de até 120 (cento e vinte) dias, contados após a concessão da licença de construção do empreendimento comercial de grande porte, tipo shopping center, e das unidades habitacionais de que trata o presente dispositivo, e prazo de 16 (dezesseis) meses, após seu início, para a conclusão. (LEI № 9857 DE 22 DE DEZEMBRO DE 2011, art. 3ㅇ)

174 Informações declaradas pela Secretária, após pergunta sobre o tema, em palestra realizada no auditório da Reitora da UFC no dia 21/10/2015, durante o Fórum Hélio Duarte.

175 Entrevista realizada no dia 25/01/2017, concedida a equipe do LEHAB (Valéria Pinheiro, Sara v. Rosa e Breno Holanda). entrevistados: Felipe Rima - ex-morador das areias e Mariano (morador das Areias).
} 
acesso a maior variedade de transporte público, e em situações de adensamento, construção da casa e ofertas de serviços muito semelhantes.

Figura 74. Trecho da Comunidade Areias que ocupava parte do leito viário da Rua César Fonseca
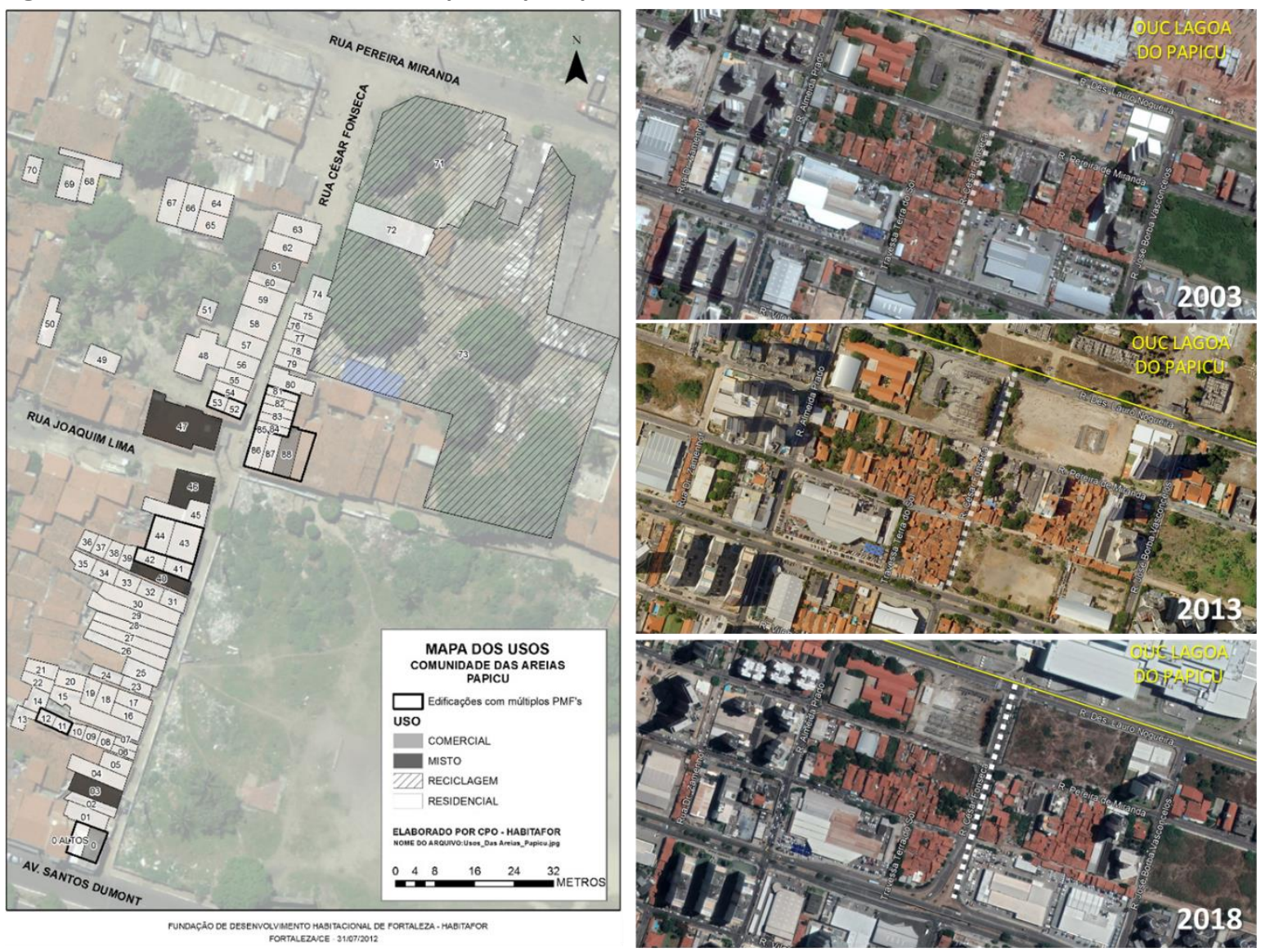

Fonte: Mapa: Fortaleza/HABITAFOR (2012)176; Imagens aéreas: GoogleEarth (2003;2013;2018)

Figura 75. Conjunto do Reassentamento do Gengibre.
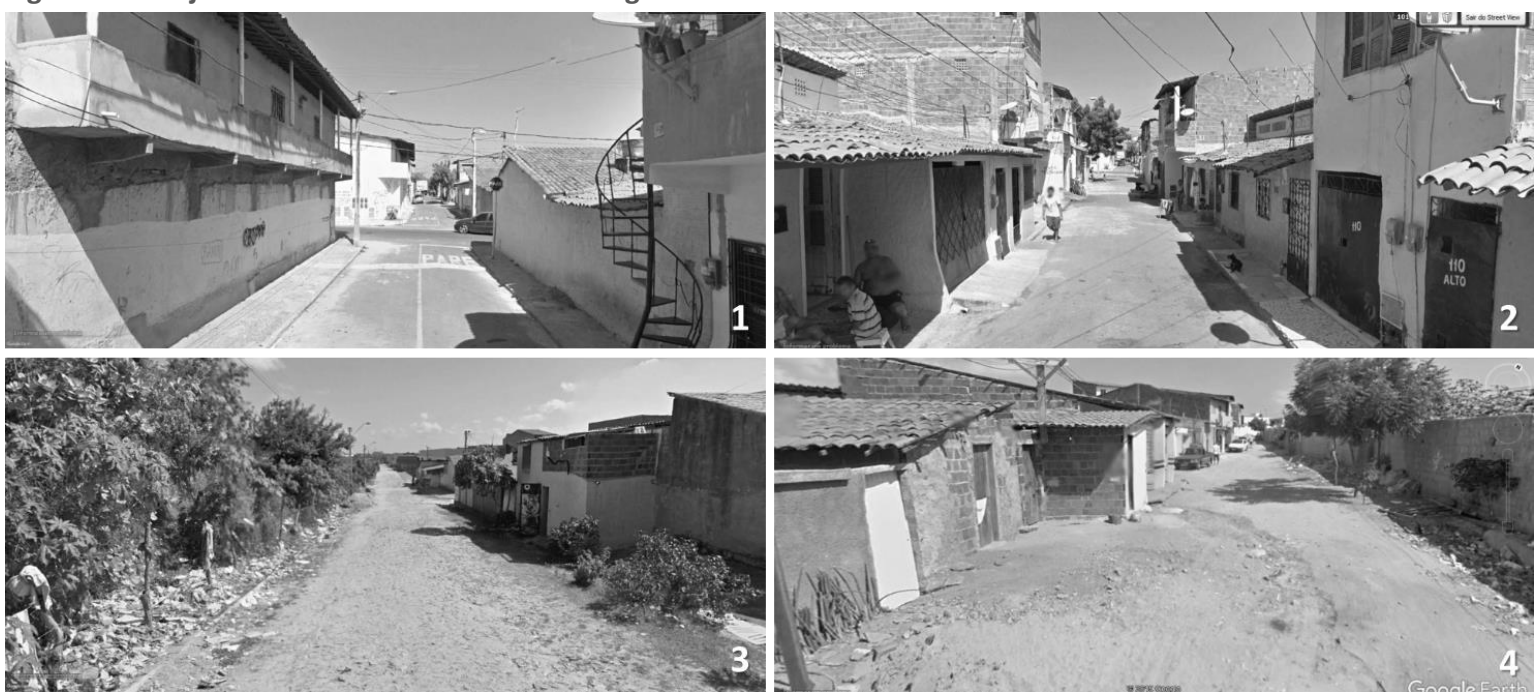

Fotos: GoogleEarth. 1 e 2: áreas densas do conjunto; 3: lateral leste do conjunto; 4: áreas de expansão informal do conjunto.

176 Material de análise da HABITAFOR, não publicado. 
Figura 76. Localização comunidade das Areias e Conjunto de HIS do Reassentamento da comunidade do Gengibre.

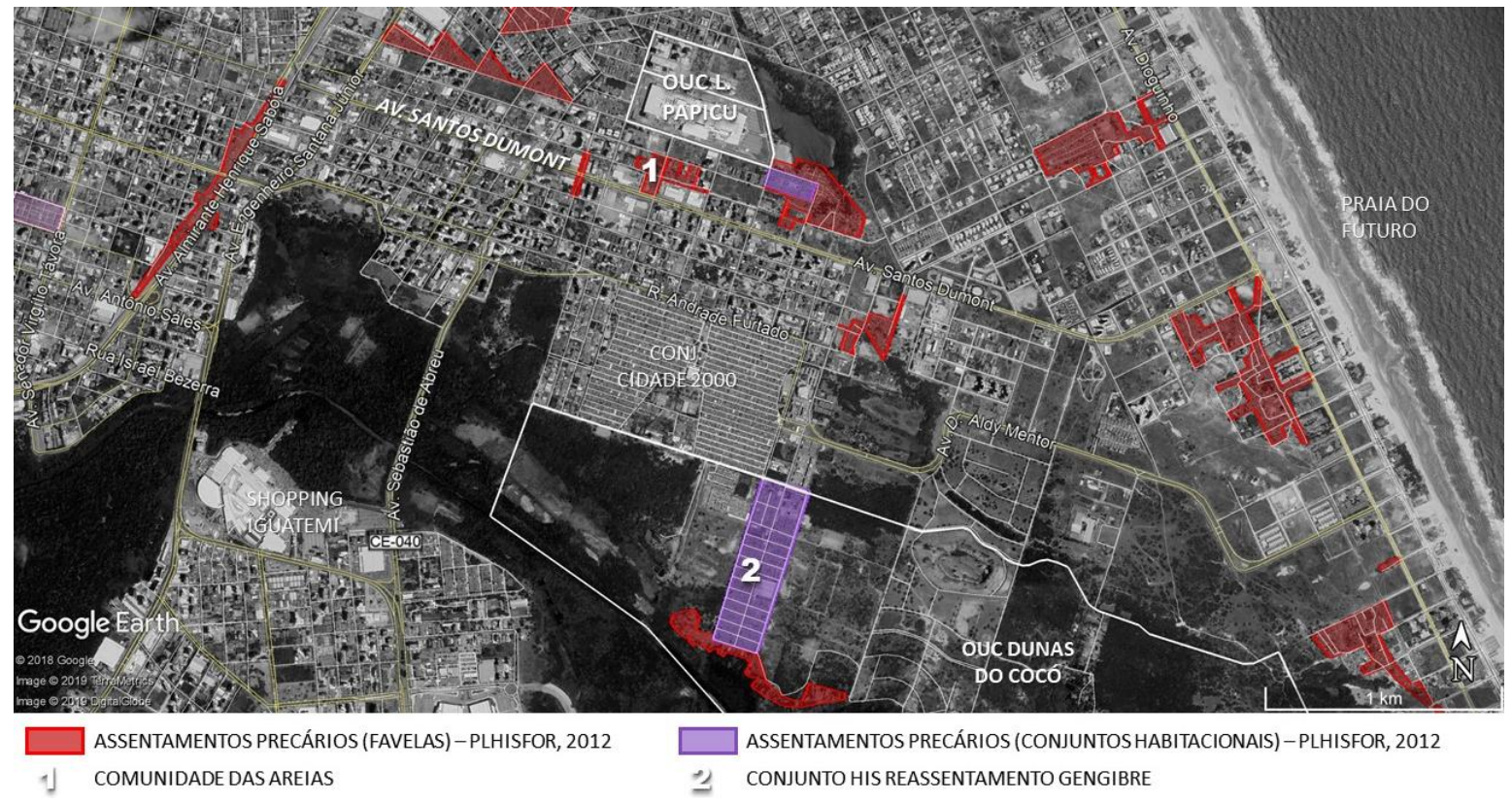

Imagem aérea: GoogleEarth, 2018. Fonte: Plhisfor, 2012. Elaboração: Rosa, 2019.

Outra comunidade que vale a pena destacar nesse processo, é a comunidade do Pau Fininho,

localizada às margens da Lagoa do Papicu.

[...] eu lembro que uma vez eu passei... fui pra despedida da xxxx [...] não sei se foi em 2005 ou 2007... 2007 ou 2009 mais ou menos... a despedida dela... eu entrei errado naquela rua que é a Coronel Matos Dourado Bezerra ${ }^{177}$, que vai sair lá na Alberto Sá, [...] E eu vivi momentos de pânico e terror, sete horas da noite, não tinha nada... a luz do carro não conseguia iluminar onde eu tava passando... "Meu Deus se eu sair do outro lado eu vou ser grata pelo resto da vida..." Porque ali tem o Pau Fininho, né... era tudo preto, escuro... E, um dia desses, eu tive que ir numa festa no La Maison e eu passei ali, o shopping já funcionando, eu passei era dez e meia da noite... a iluminação da lagoa, a lagoa toda iluminada, um monte de menino e de cara jogando futebol na quadra, na área verde... Monte de gente saindo do trabalho na parada de ônibus... E eu fiquei satisfeita, digo até um pouco emocionada, porque ali as pessoas estavam retomando aquele espaço pra elas. E assim, as pessoas continuam morando ali, [...] então ela realmente é um instrumento transformador... (MUNIZ, Secretária da SEUMA, 2014. Entrevista realiza pela equipe do LEHAB em 04 de maio de 2014).

Esse discurso da secretária sobre a OUC da Lagoa do Papicu é repetido em todo evento público que ela participa onde temas como OUC e Parcerias Público-privadas são tratados, criando uma aparência de que foi a OUC a responsável pela limpeza e urbanização da lagoa, que incluiu a quadra de futebol, a iluminação e a retirada das casas. De fato, em sua aparência o foi, mas se estivermos dispostos a olhar com mais atenção, podemos perceber que isso é a expressão apenas de parte da realidade. O campo de futebol e a utilização das margens da lagoa como

\footnotetext{
${ }^{177}$ Aqui a Secretária se referia provavelmente a Rua Dr. Francisco Matos e seu prolongamento Rua Prisco Bezerra, que é a rua que fica entre a comunidade do Pau finim e o Shopping Riomar e que liga a Av. Santos Dumont a Av. Eng. Alberto Sá. A rua Coronel Matos Bezerra está localizada em outro bairro da cidade, Antônio Bezerra, distante da OUC tratada.
} 
área de lazer é anterior a OUC. A lagoa ficou poluída com a chegada da antiga Fábrica da Brahma (terreno atual da OUC) e pelo processo de urbanização da cidade, mas o campo permaneceu e sempre foi utilizado pelos moradores.

[...] a Lagoa era uma área de lazer e tem um campo ali do lado, a gente ia pescar, o pessoal pescava nessa lagoa... lavava roupa.... buscar peixe beta, tomar banho e tal... até que a cervejaria Brahma poluiu a lagoa onde ficou impossível de usar [...] aí ficou toda coberta com aguapés, a gente via os peixes boiando... achava legal, "oh, os peixes nadando de costas..." Ele tava morrendo.... (Morador da comunidade Das Areia Entrevista realizada em conjunto com equipe do LEHAB no dia 25/01/2017)

Já a urbanização da Lagoa do Papicu foi realizada pela Secretaria de Habitação de Fortaleza, na época ainda Fundação Habitacional de Fortaleza, HABITAFOR, com recursos do Governo Federal, como parte do Programa do PAC-favela (Programa de Aceleração do Crescimento voltado para a urbanização de favelas). O contrato foi assinado com a CAIXA em 26/10/2007 e previa um repasse do governo federal de $\mathrm{R} \$ 12.300 .000,00$ (doze milhões e trezentos mil reais), com uma contrapartida do município de $\mathrm{R} \$$ 5.590.293,46 (cinco milhões quinhentos e noventa mil e duzentos e noventa e três reais e quarenta e seis centavos), totalizando um investimento público total de $\mathrm{R} \$ \mathbf{1 7 . 8 9 0 . 2 9 3 , 4 6}$ (dezessete milhões oitocentos e noventa mil duzentos e noventa e três reais e quarenta e seis centavos) ${ }^{178}$.

A obra teve início em 2008, quando começaram a limpeza da lagoa e a construção de muro de contenção, o qual serviu de fundação para a posterior implantação das cercas, uma das contrapartidas do ente privado responsável pela OUC. O projeto previa também, além da urbanização da lagoa com instalação de equipamentos públicos, o reassentamento das famílias que ocupavam a área de preservação da lagoa e áreas de risco para dois terrenos ao lado, melhoria habitacional para unidades habitacionais da comunidade que não tivessem a necessidade de reassentamento, regularização fundiária, e obras de saneamento básico (Figura 77).

A previsão para finalização da obra era fevereiro de $2009^{179}$, porém, ela se estendeu até 2012/2013 e nunca foi completamente finalizada. As unidades habitacionais para o reassentamento foram construídas apenas no terreno maior (Figura 77), e os últimos blocos não foram finalizados e foram ocupados na mudança da gestão da prefeita Luzianne Lins para

\footnotetext{
${ }^{178}$ Relatório da Caixa Econômica Federal de situação do processo do contrato do financiamento para o projeto de urbanização da Lagoa do Papicu, de 30/07/2008.

179 Ibidem.
} 
a do prefeito Roberto Cláudio. O segundo terreno (terreno menor para reassentamento Figura 77), posteriormente, foi lançado em chamada pública para interessados em construir pelo Programa do MCMV ( MOURA, 2017), mas segue até hoje sem contratação.

Como nem todas as UH foram construídas, muitas casas permaneceram na área de risco e de preservação da lagoa. Hoje temos uma densidade e extensão de ocupação na área de preservação ainda maior do que no início das obras em 2008, como pode ser observado na sequência de imagens aéreas da Figura 78.

Apesar de não concluído em sua totalidade, a urbanização realizada na lagoa, parceria entre o município e o governo federal foi suficiente para a produção de valor extra, além de proporcionar que o trecho com acesso direto pela Rua Prisco Bezerra, a qual também faz limite a OUC, fosse urbanizado.

O valor gerado pelo trabalho explorado, necessário para a urbanização da lagoa e construção do conjunto habitacional, impulsionado pelo investimento público, foi capitalizado pelos investidores da OUC (MD CE Nova Aldeota Empreendimentos Ltda - da Família Moura Dubeux; e Riomar Shopping Fortaleza S.A), contribuindo para a realização de preços mais elevados dos seus empreendimentos e dos novos empreendimentos que passam a surgir no entorno, que também capitalizam esse valor. Ademais do valor capitalizado, os investidores da OUC contaram com um cenário paisagístico mais "apropriado" para a realização do seu empreendimento, aumentando as chances de sucesso da OUC e melhorando a velocidade de venda das unidades comerciais e habitacionais. 
Figura 77. Projeto Lagoa do Papicu - HABITAFOR/PAC - Programa de Aceleração do Crescimento do Governo Federal

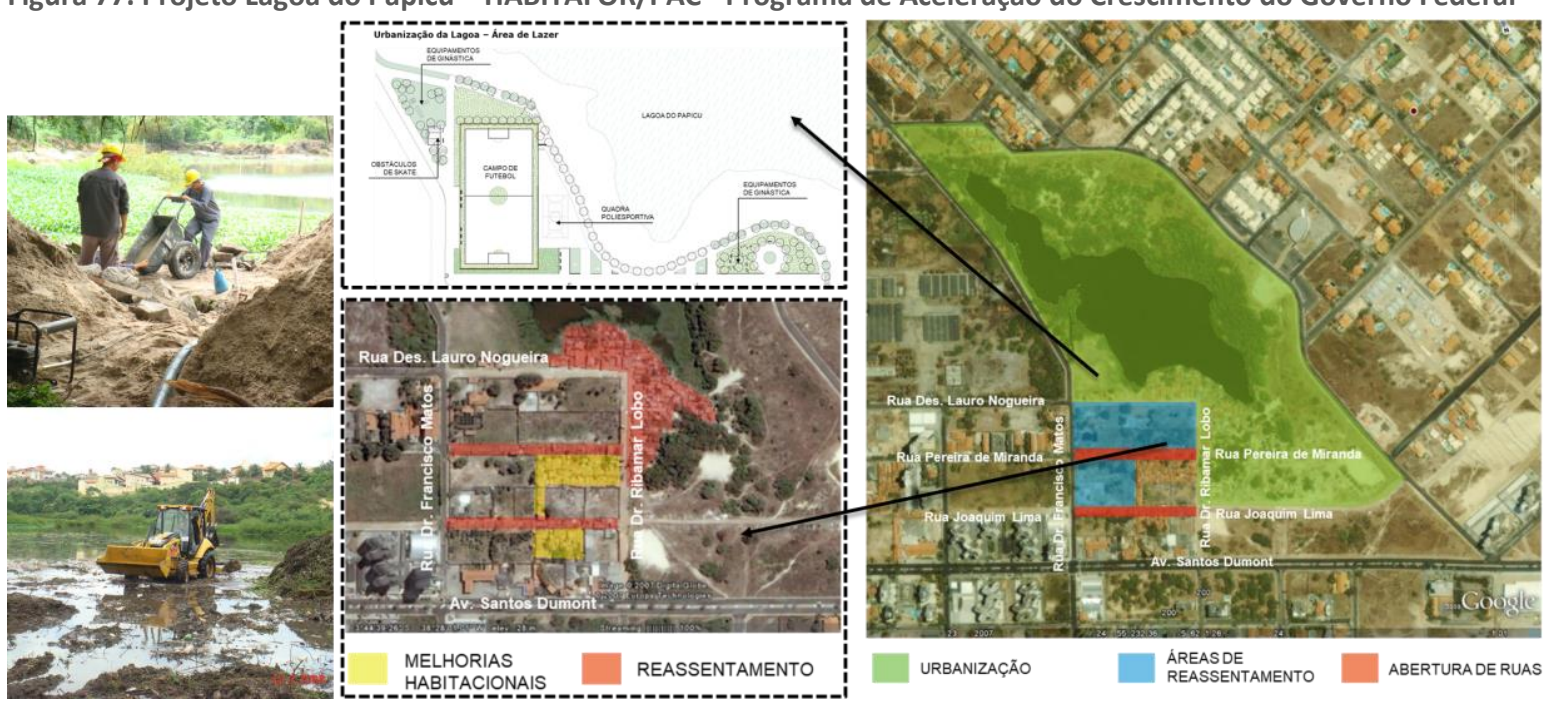

Fonte: HABITAFOR, 2009. Fotos: HABITAFOR, 2008. A área demarcada como "urbanização" no mapa corresponde à ZPA1 do zoneamento do PDP-2009. Das UH a serem construídas nas áreas de reassentamento (em azul na imagem à direita), foi realizada apenas a construção do terreno maior, o segundo terreno teve seu projeto transferido para o Programa Minha Casa Minha Vida e até hoje não foi realizado (MOURA, 2017).

Figura 78. evolução da ocupação da comunidade do Pau Fininho - Lagoa do Papicu

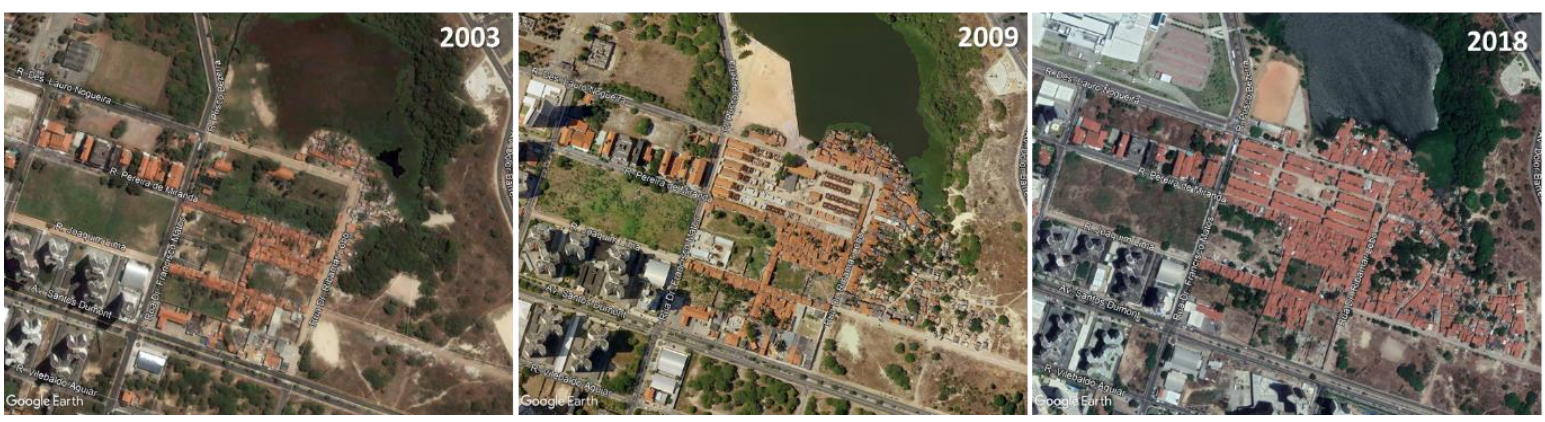

Imagens aéreas: GoogleEarth, 2003; 2009 e 2018

Mesmo com as contrapartidas que o ente privado da OUC tem que prestar, supostamente para equilibrar essa captura de valor, como visto anteriormente, no caso da OUC do Papicu, estas, foram quase todas obrigações que as legislações referentes ao parcelamento, assim como mitigações pelo impacto viário do equipamento de grande porte, já obrigariam o empreendedor a realizar. E quanto a contrapartida de manutenção e limpeza da urbanização da Lagoa pelo período de 10 anos $^{180}$, não tem sido cumprida satisfatoriamente. Em visitas ao local é possível observar a grade que circunda a lagoa quebrada em várias partes, canteiros sem capinar, e pavimentação das calçadas quebradas e soltas (fotos 3 e 4 da Figura 79). Sem

$180 \mathrm{X}$ - instalar e manter, sob responsabilidade dos investidores privados, pelo período de 10 (dez) anos, após a construção, cercas de proteção do entorno da lagoa do Papicu e manutenção da calçada existente, a fim de servirem à melhor qualidade de vida e de espaço de lazer dos habitantes da região e do Município de Fortaleza, bem como a limpeza inicial do entorno da lagoa do Papicu; XI - limpeza sistemática da área do Parque da Lagoa do Papicu (LEI № 9857 DE 22 DE DEZEMBRO DE 2011, art. $3^{\circ}$ ). Incisos dos objetivos, pegar os das obrigações do ente privado! 
contar o fato de que a prefeitura seguiu realizando trabalhos de manutenção e limpeza logo nos primeiros meses de vigência da OUC ${ }^{181}$.

Outro ponto "interessante" deste processo foi a construção do 22 Batalhão da Polícia Militar dentro da área de urbanização da Lagoa (foto 2 da Figura 79), também área de área de preservação ambiental não edificante, ZPA1 (Zona de Preservação Ambiental de Recursos Hídricos).

Este equipamento que não constava no programa do projeto de urbanização, sendo negociado depois da assinatura da OUC. A presença da Polícia Militar na área visa atender um valor de uso, muito mais relacionado a sensação de segurança dos usuários do Shopping Rio Mar, e dos novos edifícios comerciais e residenciais de médio e alto padrão que surgem no entorno, do que atender as demandas da comunidade do Pau Fininho.

Assim, além de ir em contra a legislação municipal, a construção do edifício expropria riqueza comum (natureza) de todo o bairro e da cidade (escala macro que atinge também a escala local), expropria área de lazer da comunidade Pau Fininho e demais comunidades do entorno (escala local), pois, a edificação da Polícia Militar ocupa área do terreno que, segundo projeto executivo da HABITAFOR, estava destinada ao redesenho e ampliação do campo de futebol, adequação de dimensão e posição, mantendo este em areia, e jardim margeando o mesmo (Figura 77).

\footnotetext{
${ }^{181}$ https://www.fortaleza.ce.gov.br/noticias/prefeitura-realiza-limpeza-na-lagoa-do-papicu
} 
Figura 79. Shopping Rio Mar e Urbanização da Lagoa do Papicu.
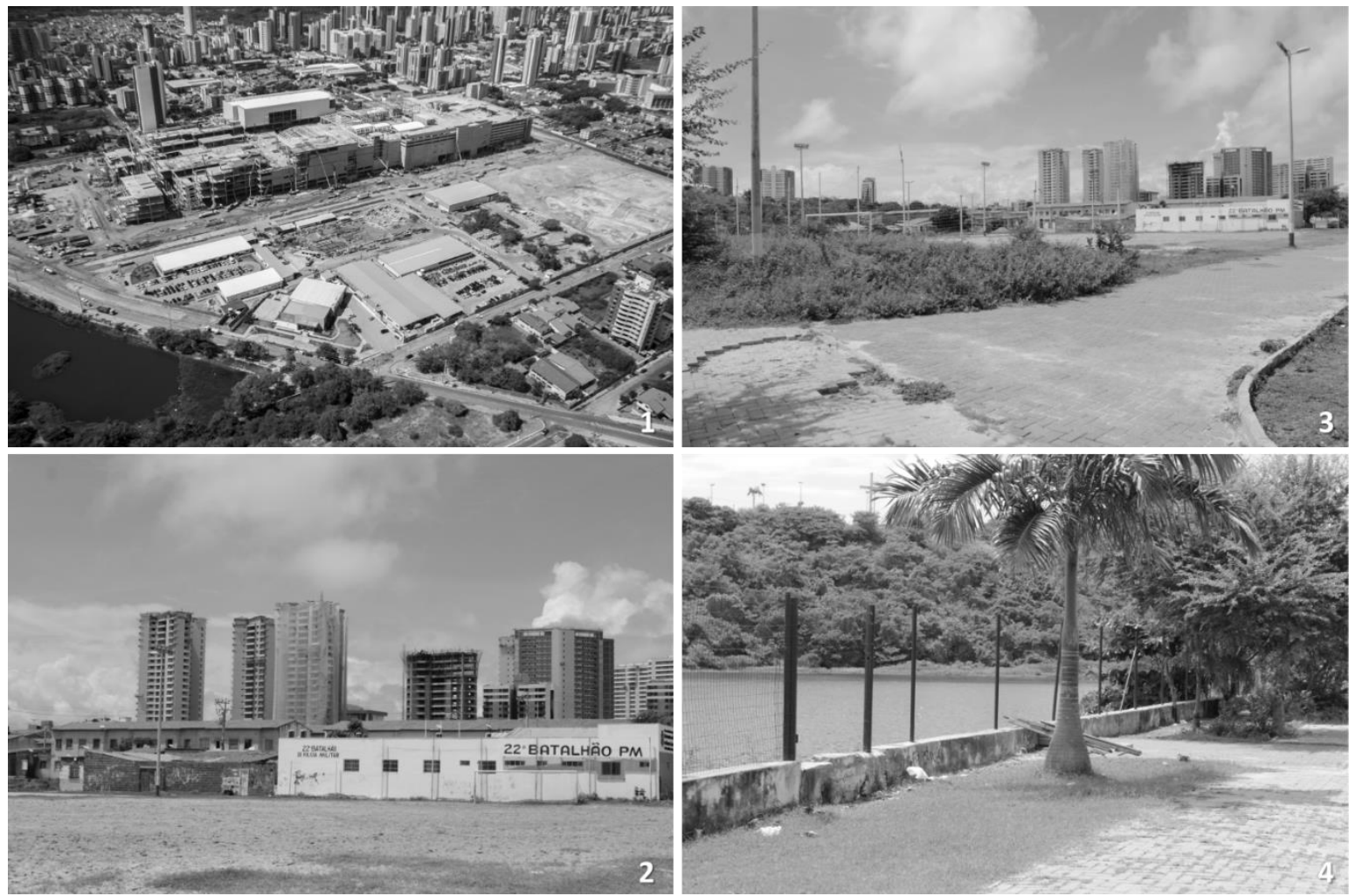

1 - Foto aérea do período da construção do Shopping RioMar. Fonte: http://www.tea.com.br/?p=1830. 2, 3, 4 - Fotos da urbanização da Lagoa do Papicu realizada pelo Município de Fortaleza, projeto de urbanização da favela do Pau Fininho com recursos do PAC- Gov. Federal, cuja manutenção da urbanização da lagoa está a cargo da JCPM, ente privado que celebrou a OUC. Foto 2: É possível observar o edifício do 22 으 batalhão, construído dentro da área de urbanização da lagoa e também Zona de Preservação Ambiental. Ao fundo, a cortina de edifícios que vêm surgindo no entorno do shopping e da Av. Santos Dumont. Fotos 3 e 4: Pode-se visualizar a falta de manutenção da urbanização da lagoa, sob responsabilidade do ente privado da OUC. Fotos: Rosa, 2016.

Há ainda a espoliação ocasionada pela elevação geral dos preços dos imóveis na área. 0 aluguel, mesmo dentro da favela, acompanha esse aumento de preço e quem mora de aluguel passa a ter mais dificuldade de se manter no local. Quem não consegue se manter, provavelmente, passa a buscar moradia em áreas mais afastadas, com menor oferta de serviços e equipamentos, ficando também mais distantes dos locais de emprego e estudo.

Por mais que a chegada de um grande empreendimento comercial, como o shopping aí instalado, traga um aumento na oferta de emprego na área, estas vagas são também disputadas por trabalhadores de outros bairros. Além disso, são empregos que pagam baixos preços pela mercadoria força de trabalho contratada. Ao ser questionado sobre o reflexo da chegada do Shopping dentro da comunidade e sobre as vagas de emprego ofertadas, um morador da comunidade das Areias respondeu:

Não mudou nada, não chega a ser um reparo. Na moral, assim. As pessoas que pelo ciclo trabalham no RioMar são as que trabalhavam na cidade 2000. Se elas não trabalhassem no setor de zeladoria do RioMar, elas iam trabalhar no setor de zeladoria de algum edifício, sendo doméstica em alguma casa de família... Porque o fato do 
RioMar, como fundação, ter proposto cursos pra atender sua demanda já tá colocando aí em si a frase: atender à sua demanda. E não a demanda da comunidade. Então, por exemplo, a longo prazo, isso não vai ter retorno nenhum pra comunidade. Daqui a dez anos, não vai acontecer nada, não vai mudar nada, ninguém da comunidade vai desenvolver o seu empreendedorismo trabalhando como zelador, ou servindo outras pessoas no RioMar. Então a interferência ela é mais pro próprio, como Mariano falou, "para o que o RioMar precisa do que o que a comunidade precisa?". Vamos entender que primeiro eles partiram o lugar [...] O que vai acontecer com essas pessoas que tem seu emprego no RioMar? Elas vão, daqui 10 anos, poder subir a casa, vão poder construir alguma casa melhor, vão poder dar uma alimentação melhor pros seus filhos, e vão poder se desenvolver, pagar seu estudo, sua faculdade? porque não dá. Então é um reparo que não é suficiente [...] Os moleques estão morrendo no crime, porque o crime é melhor do que ir pro RioMar pra alguns, os outros cidadão de bem, né, que é isso que é passado pras pessoas, que se você tem uma carteira assinada no RioMar você é um cidadão de bem, vão continuar naquele mesmo patamar de vida, onde eles vão servir uma comida no RioMar que não vão poder comer. Aí, a gente vai entender que o RioMar resolveu o problema dele e o nosso continua do mesmo jeito. Aliás, pior, porque mexeu com o nosso polo de entretenimento, de encontro, de comércio. Mexeu. Mexeu. Não é do mesmo jeito mais. Então, agora a gente não tem mais essa capacidade empreendedora da tia do churrasco, da mulher da coxinha, dos pratinhos de comida, ela não tem mais onde botar essa banca, porque não tem mais nem gente. Então fica meio... tem duas ou três bodegas, pra um lugar onde só no centro ali tinha oito. Recheadas de bagulho... então é mais ou menos o que a gente pode dizer do que é resultado mesmo. (Moradores da comunidade Das Areia - Entrevista realizada em conjunto com equipe do LEHAB no dia 25/01/2017)

Por último, podemos falar de espoliação de paz de espírito do ser humano, aqui entramos na reprodução da vida na dimensão total apontada por Lefebvre ( 1999), provocada pelo aumento da pressão e das ameaças de remoção das famílias que permanecem no local à medida que a área vai tendo o uso do solo transformado e ocupado por empreendimentos com maior produção de valor e maior valor de troca, como pode ser observado na fala de morador da área.

[...] a história que coisa lá, é que o Gilmar quer tirar tudo... quer limpar a área.... (Quem é Gilmar?) Gilmar é o Shopping. (Ah, o Shopping RioMar?) É, o shopping, é que eu não sei dizer a palavra correta. É ele, o chefão lá, que quer fazer a limpeza na favela. Na favela mora umas 3 mil pessoas ou quatro, ou mais... (O senhor tem escutado isso lá agora?) É, a gente escutou na época que tava derrubando lá... Nada oficial, coisa de boca... os bichão chega assim, de gravata, no carrão, chega "a gente vai derrubar tudo isso aqui... até aqueles barracos que a prefeita fez ${ }^{182}$, as casa... vamo derrubar tudo que é pra urbanizar a área"... Aí, a história que nós tem é que eles querem derrubar pra fazer os apartamento... o bichão, a imobiliária, né... aquelas casas que tem lá em cima do morro, pra descendo, fazer as casas, tirar a favela... ${ }^{183}$ (Morador da comunidade do Pau Fininho. Entrevista realizada por Valéria Pinheiro pelo LEHAB em 11/05/2017)

\footnotetext{
${ }^{182}$ Aqui faz referência provavelmente ao conjunto de HIS construído dentro do projeto de Urbanização da Lagoa do Papicu para reassentamento das famílias removidas da beira da lagoa. A "prefeita", seria a Luizianne Lins, em cuja gestão o projeto foi feito.

183 Entrevista realizada por Valéria Pinheiro (LEHAB) em 2017 com ex-morador da comunidade do Pau Fininho.
} 
O fetiche da mercadoria presente aí faz com que os capitalistas e rentistas, bem como os representantes do Estado, que coordenam esses processos de espoliação e exploração desapareçam. O shopping é personificado. Na citação acima, por um problema de dicção de quem dá a entrevista, ou dificuldade de entender para quem escuta, ganha até nome de gente, o "Gilmar". Na aparência, é o shopping ou por conta dele que as coisas acontecem, é o shopping quem comanda os processos, ele (shopping) passa a ter vontades e quereres, "o Gilmar quer tirar tudo... quer limpar a área" (morador da comunidade Pau Fininho, 2017). Ele (shopping) também tem necessidade e é capaz de atuar e resolver problemas, além de ser comparado com outros seres humanos, "para o que o RioMar precisa do que o que a comunidade precisa?", "aí a gente vai entender que o RioMar resolveu o problema dele e o nosso continua do mesmo jeito", ocultando de fato as pessoas que na realidade exploram e espoliam umas às outras.

A pressão de que amanhã você possa ser removido e não ter onde morar, os embates e disputas pelo território, espoliam pouco a pouco a essência do ser humano. Quem é forçado a sair, principalmente quando é reassentado longe do local de origem ou recebe indenização aquém do preço de uma residência perto, também é profundamente impactado, não é apenas sua terra e sua casa que estão sendo expropriadas. Há uma expropriação do modo de vida, dos amigos, dos vizinhos, da rede de apoio construída na comunidade, das lembranças, que às vezes a pessoa não está preparada, levando inclusive à cama por problemas de depressão ou surgimento repentino de Alzheimer, ou mesmo à morte, principalmente dos moradores mais antigos e mais idosos, como afirma Dona Mundinha, moradora do Mucuripe, sobre o processo de remoção da OUC "morreu gente.[...] Pessoas idosas, bastante idosas, não resistiram porque não queriam sair", "[...] muita gente morreu, que tinha problema no coração e não aguentou. Choque! E foi se embora... outros da preocupação também, também do desgosto de morar tantos anos e depois saíram, também ficou doente e morreu [...]. Esse relato de Dona Mundinha sobre problemas de doença e morte provocados pelo impacto da mudança também foi escutado em entrevista realizada com moradores removidos pela Operação do Riacho Maceió, são relatos que vez ou outra se escuta em conversas com 
moradores afetados em outros processos de remoção, em outras partes da cidade e do estado $^{184}$.

\subsection{CONSIDERAÇÕES FINAIS DO CAPÍTULO 02}

Neste capítulo, observamos um processo anterior de desvalorização na aparência da natureza, por meio de uma desmercantilização estatal, na qual se qualifica o espaço enquanto natureza importante (seja como beleza, seja pelo valor intrínseco da natureza, seja como natureza original, seja como recurso), devendo ser preservada, para que então seu valor seja resgatado e revalorizado por meio de uma remercantilização estatal associada ao setor privado, na qual o espaço é agora qualificado enquanto natureza degradada, poluída, descaracterizada, necessitando de intervenção e urbanização. Pela legislação se desmercantiliza, e também pela legislação se remercantiliza.

Assim, a natureza legalmente preservada nem sempre é reconhecida socialmente enquanto natureza, ou enquanto algo importante. No mundo das mercadorias, onde as coisas são humanizadas e as relações sociais coisificadas ${ }^{185}$, tudo passa a ser intermediado pela forma mercadoria. Assim, a natureza é coisificada, assim como o homem (também natureza) é coisificado, e a natureza meio biofísico que sustenta a vida também o é.

Quando transformamos a natureza em mercadoria, perdemos sua essência, passamos a enxergá-la apenas como valor, como mercadoria que pode ser trocada pela mercadoria dinheiro. Por isso, muitas vezes a natureza, não mercantilizada, no meio urbano, não é socialmente reconhecida, sendo com frequência associada a local sujo, área de risco, local de bandido se esconder, e vários outros adjetivos negativos, que terminam por justificar apropriações privativas desses espaços para acumulação de capital de particulares. Uma vez

\footnotetext{
184 O caso no Ceará provavelmente mais conhecido é o da cidade de Nova Jaguaribara. Cidade planejada e construída para abrigar as famílias removidas da cidade de Jaguaribara, que foi inundada para dar lugar à construção do Açude Castanhão, o maior do estado. Em visita à área, ainda nos tempos da graduação, foi possível perceber o impacto, principalmente nos mais idosos, a partir do grande número de casos de depressão (acima do normal) e os relatos de saudades dos vizinhos e do rio. $\mathrm{O}$ caso ficou conhecido e foi até noticiado em matérias de jornais. Maiores detalhes podem ser conferidos na tese de Bertini (2014), disponível em: http://repositorio.ul.pt/bitstream/10451/18329/1/ulsd70890 td Fatima Bertini.pdf.

185 Coisificação das relações sociais e personificação das coisas (MARX, 2013a).
} 
natureza criada, "natureza inventada", a natureza é socialmente reconhecida, pois ela se torna valor.

As OUCs funcionam como formas contemporâneas de expropriação, de acumulação por espoliação. Sustentando a tese de que o sistema capitalista não é apenas, ou principalmente, produção/exploração. Seu pressuposto inicial foi gerado por acumulação por espoliação, como visto no capítulo 1 , e tudo indica que só se sustenta em constante crescimento se mantiver processos de espoliação combinados com o de exploração. Não basta reproduzir o capital, é necessário produzir, constantemente, novos capitais. 


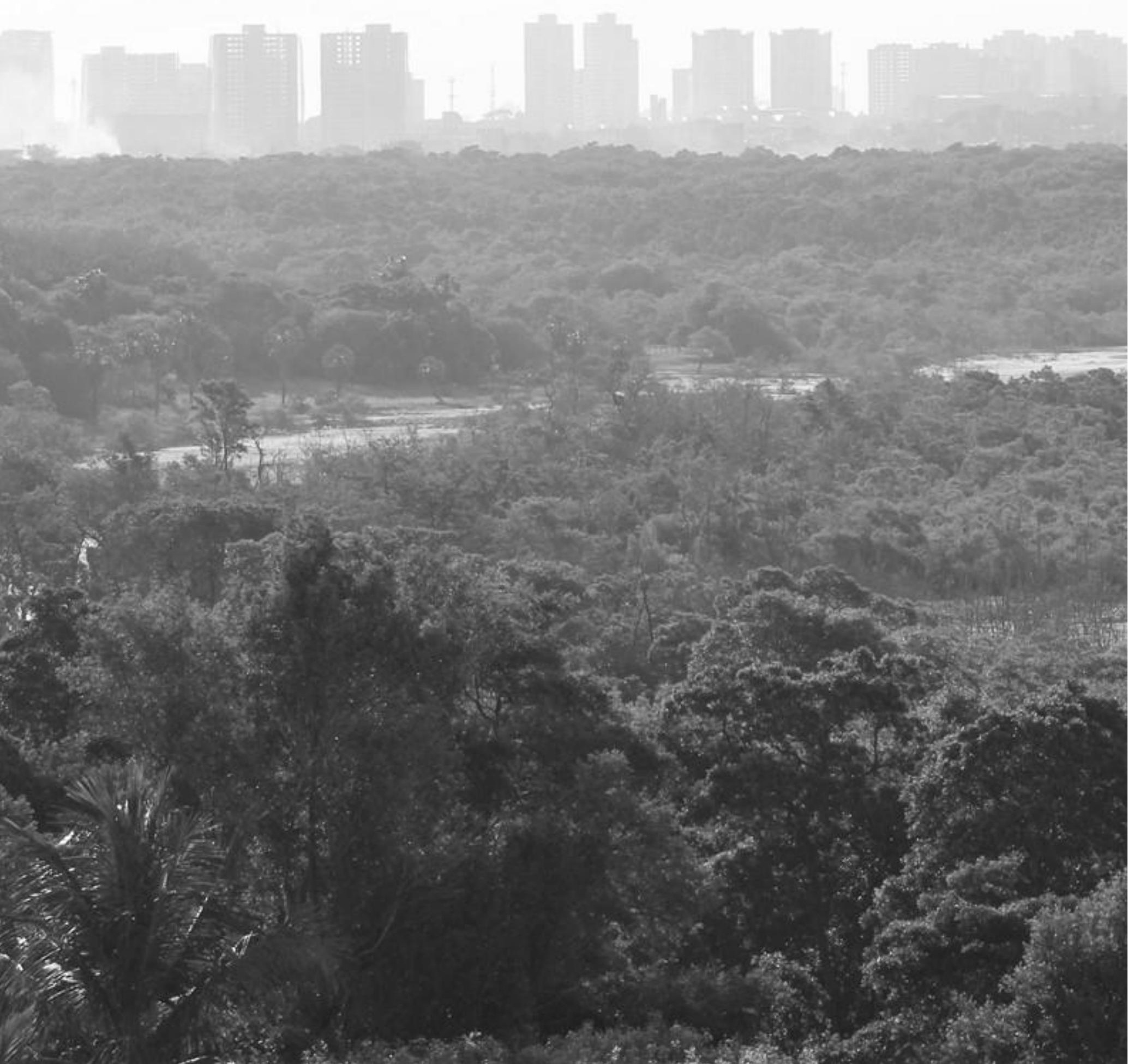




\section{1/}

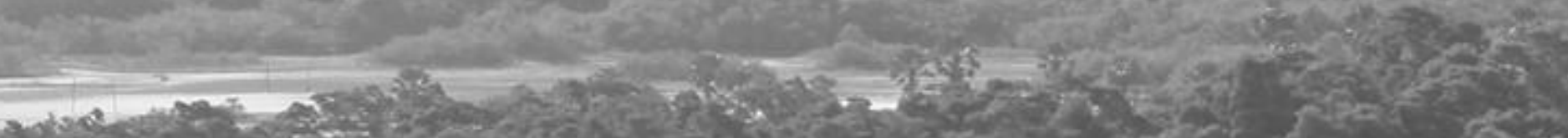

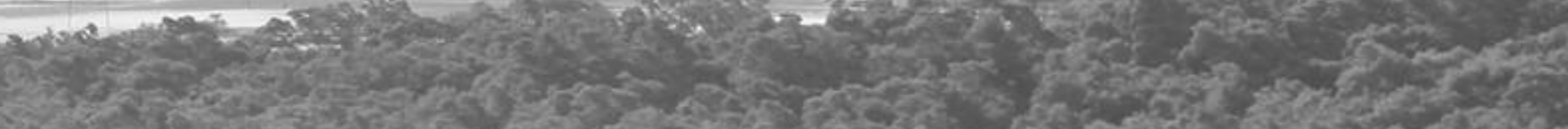

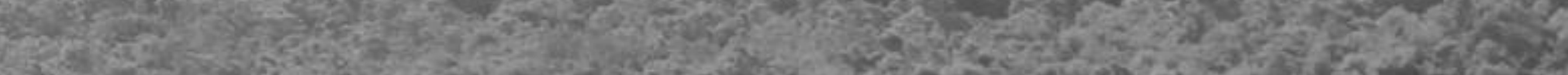

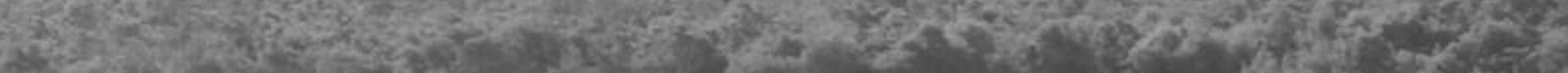

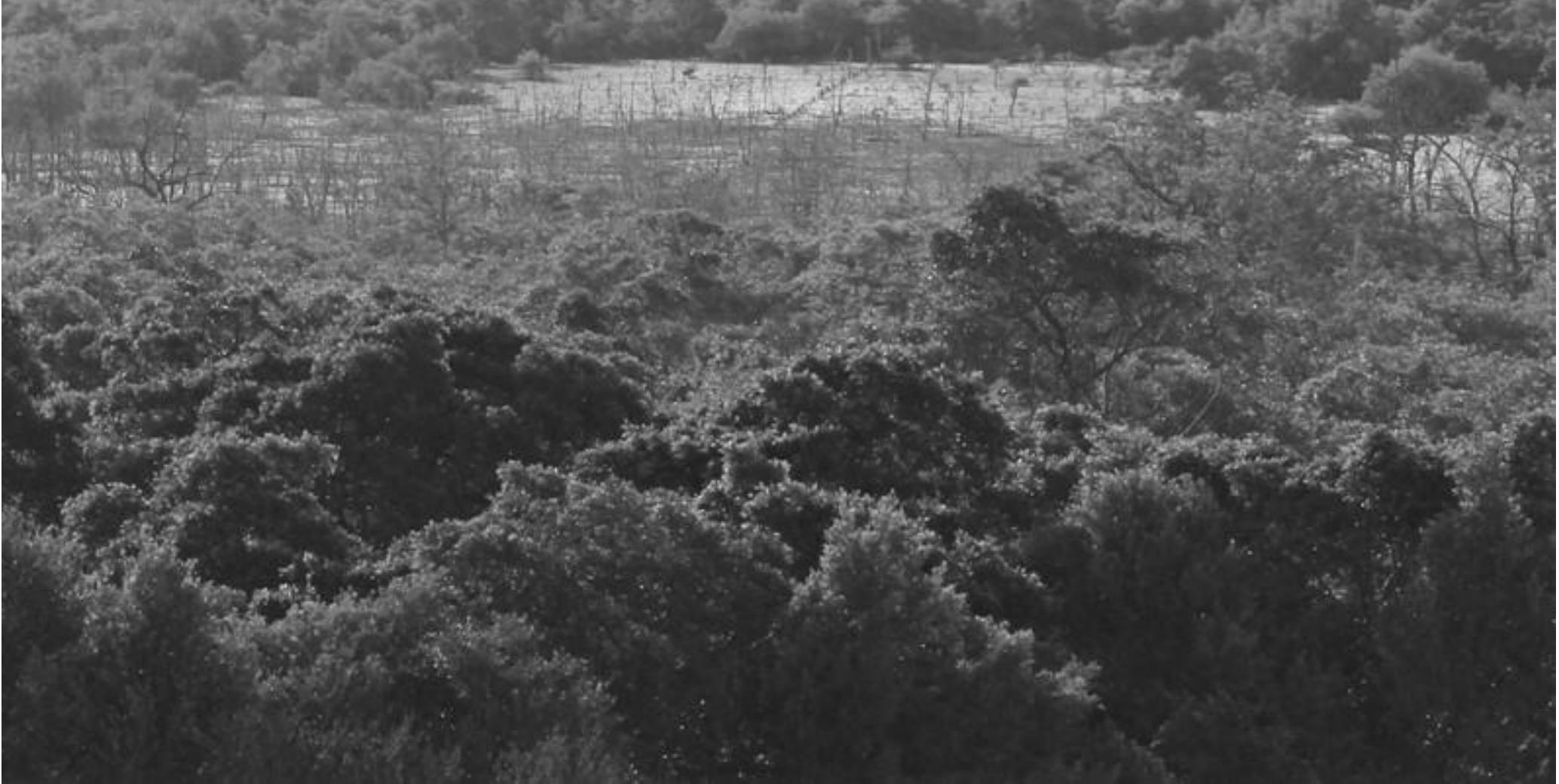


FOTO: SARA VIERA ROSA, 2018

VISTA PARA O RIO COCÓ

LOCAL: DUNAS DA SABIAGUABA - PARUE DAS DUNAS DA SABIAGUABA - FORTALEZA, CE 


\section{CAP. 03. APERFEIÇOAMENTO E EXTENSÃO DAS ESTRATÉGIAS DE ACUMULAÇÃO E "VALORIZAÇÃO" PELA NATUREZA}

$\mathrm{N}$ este capítulo, prosseguimos com o que vinha sendo abordado no anterior, porém chamando atenção para o incremento de estratégias de acumulação e valorização pautados em marcos legais que vêm se intensificando, a partir de 2015, e ganhando uma dimensão que engloba quase a totalidade do município. Não são mais casos isolados e restritos a uma pequena porção do território, como vinha sendo feito com as pequenas OUCs aprovadas até então. Percebe-se um maior imbricamento do Estado e setor privado na formulação de estratégias legais, ao mesmo tempo em que velhas práticas permanecem.

Observa-se uma consolidação de adaptação do setor imobiliário que, no século XX (cap. 01), simplesmente ignorava a natureza e agora passa a ter que lidar com este tema, buscando cada vez mais formas mais aprimoradas de permanecer acumulando e reproduzindo capital, mesmo com as "barreiras" impostas pela preservação e proteção ambiental. Por um lado, há uma tentativa de resgate da terra como "não natureza" através da criação de novos marcos legais que desregulamentem o caráter protecionista e preservacionista desses terrenos. Por outro, buscam-se acordos para manter trechos como áreas de preservação desde que outros tenham seu potencial construtivo potencializados. Exalta-se a natureza como valor de uso para potencializar vendas de imóveis e justificar sobrepreços, chegando-se à criação de "natureza" como produção imobiliária.

Como veremos mais adiante, há um corte temporal para consolidação dessas estratégias em Fortaleza, a partir do ano de 2015. Por isso, sem esquecer dos casos anteriores das Operações Urbanas, que também se encaixariam, de certa maneira, aqui, prosseguiremos neste capítulo 
apresentando estratégias implementadas a partir de 2015. Para isto, tomaremos como exemplos: a regulamentação dos instrumentos urbanos da Outorga Onerosa de Alteração do Uso do Solo e da Outorga Onerosa do Direito de Construir; as constantes alterações no zoneamento ambiental do município; e, de maneira breve, as últimas OUCs que vêm sendo propostas para Fortaleza, guardando particularidades com as anteriores que reforçam o foco deste capítulo.

Em seguida, tendo como base os registros do ITBI, demostraremos como essas terras, onde incidem legislações de proteção e preservação ambiental, mesmo com o processo de desvalorização estatal (cap.02), continuaram sendo comercializadas e sendo espaço pra produção de edificações, porém em proporções menores que os demais terrenos. Ressaltamos que, dentro do mercado formal, essas terras atendem a uma demanda de produção imobiliária de alto e altíssimo padrão.

Aalbers (2016, p.2) aponta que as "práticas neoliberais não implicam um recuo institucional", assim como o neoliberalismo não é sinônimo de desregulação. Na prática, o mercado precisa e deseja regulação e regulamentação, pois é como este consegue garantias legais de seus privilégios. Utilizando o exemplo de Aalbers (2016, p. 3), “[...] simplesmente precisam de regulamentação para poder reivindicar a maior parte da torta, ampliar o tamanho absoluto da torta ou poder assar uma torta em primeiro lugar".

Harvey chama atenção para a participação cada vez maior e íntima de negócios e corporações com governos, inclusive chegando a "assumir um forte papel na redação de leis, na determinação das políticas públicas e na implementação de estruturas regulatórias (que são vantajosas principalmente para eles mesmos)" (Harvey, 2014, p. 87). Assim, por mais que alguns segmentos do setor privado tenham ganhado cada vez mais importância na produção das cidades neoliberais, isso só tem sido possível graças ao intenso papel desempenhado pelo Estado.

É assim, por meio do Estado, que o mercado consegue viabilizar todo o marco regulatório para sua atuação. No caso do mercado imobiliário, é como este tem conseguido garantir territórios e instrumentos que vão ajudar a justificar e potencializar processos de acumulação, inclusive 
por expropriação, valorização e capitalização186 “até sem o 'necessário' consumo imobiliário, pois os negócios começam muito antes da obra que vai demorar anos para terminar" (PEREIRA, 2016, p. 135).

A seguir, descreveremos como este processo de desregulamentação regulamentada tem acontecido no município de Fortaleza nas áreas onde incide o zoneamento ambiental, de preservação ou proteção, e como isso se atrela a processos de acumulação por espoliação, bem como valorização real e valorização fictícia.

O ano de 2015 foi um ano de aprovação de vários marcos da legislação municipal, no sentido aqui trabalhado. Foram regulamentados dois importantes instrumentos de retorno financeiro previstos no Estatuto da Cidade e no PDP de 2009: a Transferência do Direito de Construir e a Outorga Onerosa do Direito de Alterar o Uso do Solo. Foi também a partir deste ano que a câmara municipal passou a aprovar uma série de Leis Complementares que alteraram o Plano Diretor, grande parte sendo alterações no zoneamento ambiental do município.

\subsection{O ZONEAMENTO AMBIENTAL EM FORTALEZA E SUA CONSTANTE (DES)REGULAMENTAÇÃO PARA POTENCIALIZAR PROCESSOS DE ACUMULAÇÃO E "VALORIZAÇÃO" PELA NATUREZA.}

O instrumento Operação Urbana Consorciada (OUC), visto no capítulo anterior, não foi a única estratégia para garantir a flexibilização ou exclusão de proteção e preservação de áreas que já haviam sido garantidas a partir da aprovação de lei federais, estaduais e municipais. A partir de 2015, o município de Fortaleza, sob a gestão do Prefeito Roberto Cláudio, com a arquiteta Águeda Muniz na SEUMA (Secretaria de Urbanismo e Meio Ambiente do Município de

\footnotetext{
186 Para uma análise mais aprofundada sobre valorização e capitalização associada à terra, recomendo os textos de Paulo César Xavier Pereira, "A reprodução do capital no setor imobiliário e a urbanização contemporânea: o que fica e o que muda" In: Reconfigurações das Cidades Contemporâneas, 2016; e "Preço e Valor na Financeirização da Produção do Espaço" In: O Espaço Metropolitano: cotidiano e ação, 2017.
} 
Fortaleza), empreendeu uma série de alterações no Plano Diretor vigente (PDP-2009), incluindo a supressão de áreas de protegidas e preservadas.

O município seguiu alterando a regulação definida no Plano por meio de novas leis complementares ou ordinárias, algumas destas específicas para instrumentos previstos no Estatuto da Cidade, como as Operações Urbanas Consorciadas e as Outorgas Onerosas do Direito de Alterar o Uso do Solo. Estas alterações estiveram quase sempre atreladas a mudanças de parâmetros urbanos, prevendo aumento do potencial construtivo dos terrenos e do gabarito (altura máxima permitida) das edificações em determinadas áreas da cidade. Alguns casos incluíram também mudanças nos limites de zonas estabelecidas no PDP-2009. Importante destacar que algumas dessas leis aprovadas contrariam os princípios e objetivos do próprio PDP-2009, mesmo assim foram aprovadas e implementadas.

A aprovação de leis que alteram o PDP-2009 sem competência jurídica para tanto foi ainda mais grave. Até 2017, foram pelo menos 6 (seis) leis complementares (L.C.) ao PDP-2009 que trazem maior flexibilização ao zoneamento urbano, ambiental e especial. Três delas interferem diretamente no zoneamento ambiental ${ }^{187}$. A priori, trataremos apenas das leis complementares de nㅇ 101/2011 e de no 202/2015.

A Lei Complementar 101, de 30 de dezembro de 2011, dentre as alterações no zoneamento do município, traz mudanças nos limites da Zona de Preservação Ambiental dos Recursos Hídricos (ZPA-1). Alterações sutis, mas importantes, como a inclusão de dois novos parágrafos no artigo 61 do PDP-2009. Seu novo parágrafo segundo traz a seguinte redação: "§ 2ㅇ A localização e os limites da Zona de Preservação Ambiental - ZPA-1, de que trata o art. 63 desta Lei, são constantes do anexo - limites das áreas de preservação dos recursos hídricos do município de Fortaleza".

O anexo "limites das áreas de preservação dos recursos hídricos do município de Fortaleza" não existia na Lei Complementar no 62, aprovada em 2009. Esta trazia com relação ao zoneamento ambiental apenas o Anexo 2 (Mapa 2) e o Anexo 2-A. O primeiro corresponde ao

\footnotetext{
187 Lei Complementar n. 79/2010; Lei Complementar n. 101/2011; Lei Complementar n. 108/2012; Lei complementar $202 / 2015$
} 
mapa com as zonas do macrozoneamento ambiental (ZPA, ZRA, ZIA) e o segundo corresponde às coordenadas geográficas de cada uma delas.

Importante destacar que este novo anexo, a que se refere o $2^{\circ}$ parágrafo da lei complementar de 2011, não faz parte do corpo desta e somente vem a ser apresentado quatro anos depois, em 2015, pela Lei Complementar n. 202/2015. Na verdade, o anexo é um quadro com descrições das diretrizes adotadas para a alteração do limite, não deixando claro como ficou o desenho final, tampouco traz as coordenadas desses novos limites, assim permanece em conflito com o anexo 2-A do PDP que traz as coordenadas dos limites das ZPAs, segundo o que foi definido em 2009 e com o próprio mapa (Anexo 2 - mapa, do PDP) que não foi substituído.

A L.C. de 2015 traz também um outro anexo, este sim, um mapa. O mesmo não é referenciado no corpo do texto da lei, mas podemos interpretar que é a espacialização destas alterações (Figura 80). Todavia não traz todas as áreas de ZPAs, ficam de fora toda as ZPAs do setor norte do Rio Cocó e de diversas lagoas e riachos, deixando em dúvida se estas, aí representadas, são apenas aquelas que "sofreram alterações" segundo o anexo do quadro acima mencionado. Porém, note-se que o nome no mapa deste anexo é "ZPA1 - Zonas de Preservação Ambiental (faixa de preservação permanente dos recursos hídricos)", fato que gera uma enorme confusão, uma vez que este não traz todas as áreas da ZPA 1. 
Figura 80. Anexo 2 da Lei Complementar n. 202 de 2015.

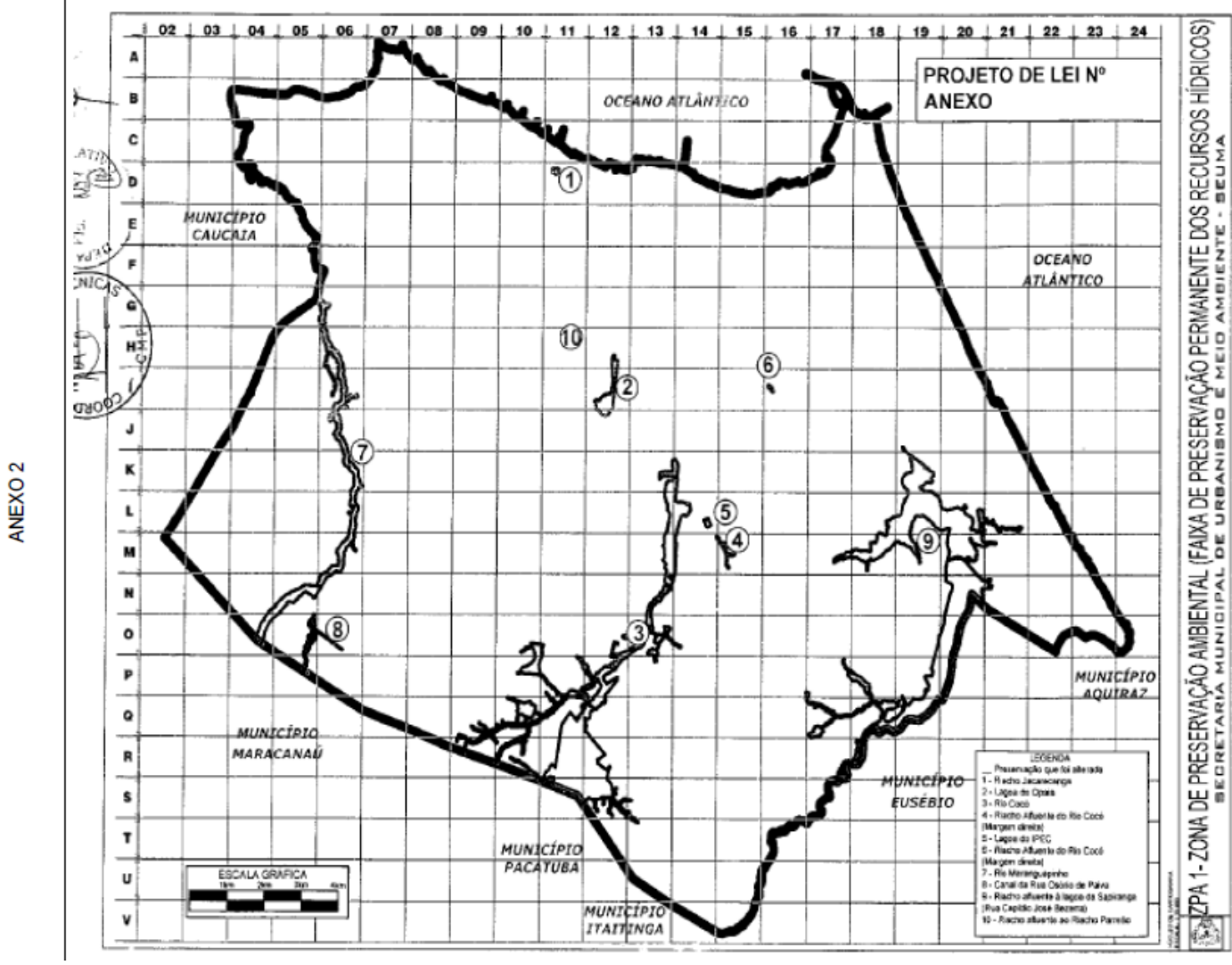

Fonte: Fortaleza (2015), Lei Complementar 0202 de 2015. DOM no 15.523, de 18 de maio de 2015, p. 13.

Fato é que, a partir de 2015, o Site da SEUMA ${ }^{188}$ (Secretaria Municipal de Urbanismo e Meio Ambiente de Fortaleza) passou a divulgar mapa do zoneamento do município com limites diferentes do aprovado e descritos nas coordenadas do anexo 2-A do Plano Diretor, incluindo alterações também em trechos que não aparecem no anexo 2 do mapa da L.C. 202/2015. Em geral, essas alterações são pequenas, mas guardam uma enorme relação com a viabilização de abertura de novas vias e pontes sobre o Rio Cocó, permitindo ligações viárias fundamentais para a reestruturação territorial. Na Figura 81, é possível observar pequenas alterações no limite da ZPA no setor norte do Rio Cocó que abrem espaço para a aberturas de novas vias, que vão aparecer mais tarde no mapa de sistema viário da Lei de Parcelamento, Uso e Ocupação do Solo (LUOS), aprovada em 2017. 
Figura 81. Sobreposição da base cartográfica referente a ZPA1 da Lei do Plano Diretor aprovada em 2009 e base cartográfica disponibilizada pela SEUMA em 2015 em seu site.

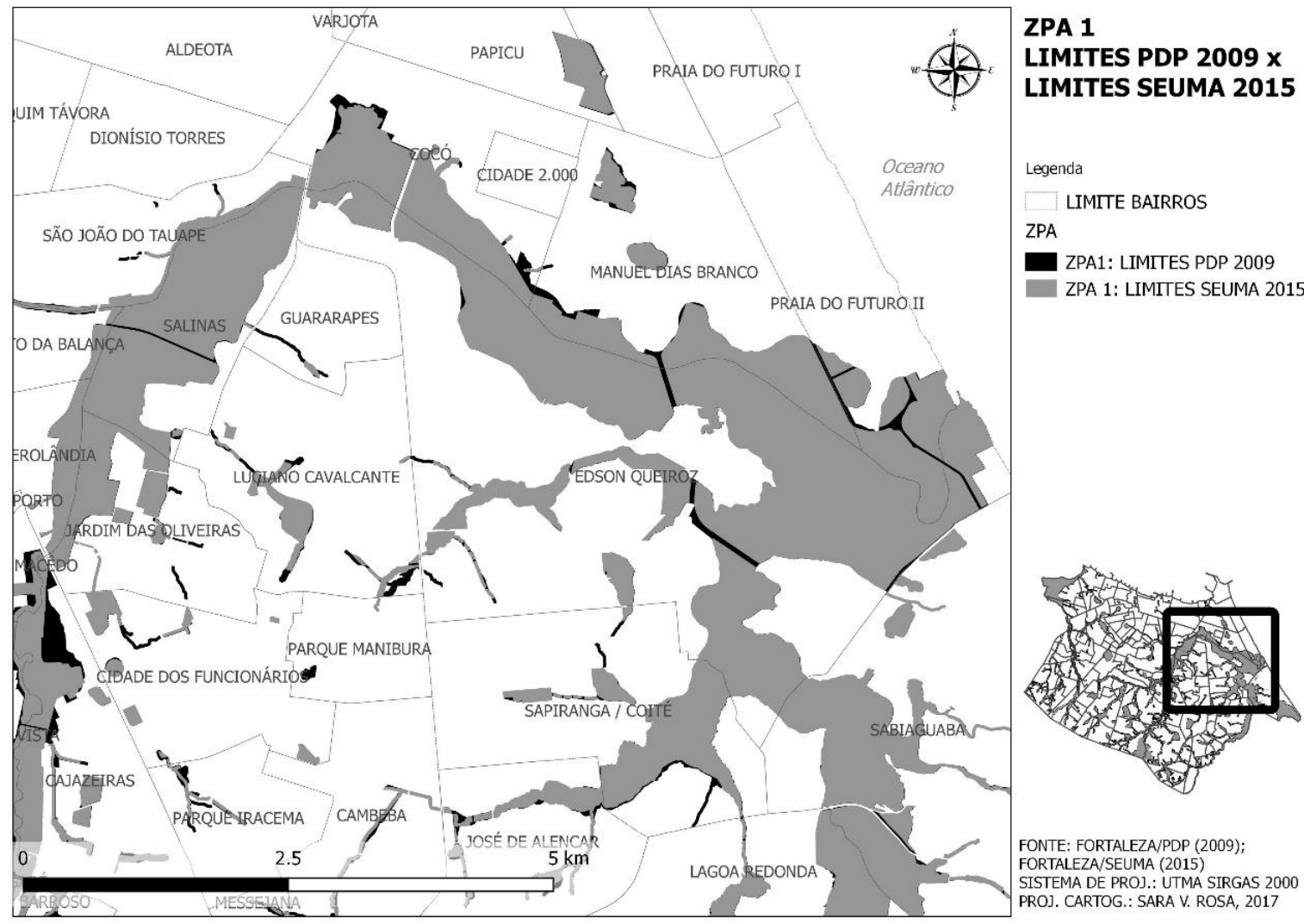

Fonte: FORTALEZA/PDP, 2009; FORTALEZA/SEUMA, 2015. Elaboração: Sara V. Rosa, 2016

Esse mesmo material divulgado e utilizado pela SEUMA, a partir de 2015, traz também uma importante alteração com relação a Zona de Recuperação Ambiental. Ele suprime duas importantes áreas localizadas abaixo da ZPA-1 do Rico Cocó, setor Norte (ver Figura 83, na qual nomeamos ZRA 1 e 2 para efeito de análise). Importante ressaltar que não existe lei retirando estas duas áreas do zoneamento ambiental. Todavia, em 2017, foi aprovada a nova Lei de Parcelamento, Uso e Ocupação do Solo (LPUOS), que, ao reproduzir o mapa do PDP, o fez considerando essas duas áreas como partes integrantes do macrozoneamento urbano, Zonas Moderadas 1 e 2.

Ainda em 2016, essa alteração foi questionada pelo Laboratório de Estudos da Habitação (LEHAB), do curso de Arquitetura e Urbanismo da UFC, à Secretaria de Urbanismo e Meio Ambiente (SEUMA). Esta respondeu que o mapa oficial publicado no Diário oficial do município como anexo da Lei do Plano Diretor não possuía estas áreas ${ }^{189}$.

189 Este questionamento foi enviado por e-mail no dia 31/10/2015, através de um relatório de questões sobre a minuta da Lei de Parcelamento, Uso e Ocupação do Solo que estava sendo desenvolvida pela SEUMA, cujos mapas do zoneamento deveriam ser fiéis ao do PDPfor2009, observando a ausência destas duas áreas. A resposta dada pela Secretária da SEUMA 
Todavia, o mapa da publicação do plano apresenta-se distorcido e pouco legível (anexo 2 da Lei), sendo, neste caso, as coordenadas geográficas, também publicadas em anexo da lei (anexo 2-A da Lei), material tecnicamente mais válido. A validade das coordenadas geográficas é reiterada quando são mencionadas no próprio corpo do texto da lei para espacializar as zonas ali definidas: “§ 10 A localização e os limites das zonas de que trata este artigo são os constantes das delimitações georreferenciadas do Anexo 2 (Mapa 2) e Anexo 2-A, desta Lei" (FORTALEZA, 2009, Art.61).

Utilizando-se de softwares de sistema de informação geográfica (Global Mapper e Arcgis), foi realizada a espacialização das coordenadas geográficas dispostas no anexo 2-A da L.C. 62/2009, publicada no Diário Oficial do Município no 14.020, de 13 de março de 2009. A partir das coordenadas devidamente espacializadas, pôde-se fazer a reconstrução do mapa da ZRA, comprovando a existência das duas áreas apontadas.

É importante destacar que, de fato, o mapa publicado no Diário Oficial do Município realmente deixa dúvidas quanto à representação dessas duas áreas de ZRA, o que poderia validar o argumento do município de que estas não fazem parte do mapa oficial. Todavia, vale ressaltar que o próprio município utilizava o mapa com a representação dessas duas áreas, segundo apresentações recentes da prefeitura, em 2016, realizadas por funcionários de carreira da própria SEUMA, que continham a representação dessas duas áreas ${ }^{190}$.

A hipótese para essa discordância entre o mapa e as coordenadas publicadas no diário oficial é que, assim como os parâmetros urbanos das áreas de proteção, mencionados no ponto anterior, a alteração ocorreu durante a aprovação da Lei na Câmara de Vereadores. Sem conhecimento da população, essas duas áreas foram retiradas do mapa, assim como outras alterações no texto da lei, todavia esqueceram de alterar as coordenadas.

Fato é que esta área vem sendo tratada pelo município como Zonas de Ocupação Moderada 1 e 2, do Macrozoneamento Urbano. O licenciamento de empreendimentos vem sendo feito

\footnotetext{
foi enviada por e-mail, no dia 23/12/2015, e repetida em entrevista posterior realizada com a mesma e a equipe de elaboração da minuta da LPUOS: "Quanto ao questionamento sobre uma eventual alteração da Zona de Recuperação Ambiental - ZRA do Cocó, percebe-se nos mapas oficiais publicados no PDP que a área citada não corresponde a ZRA, mas a uma Zona de Ocupação Moderada 2 (ZOM 2), de acordo com a publicação do Diário Oficial do Município de 13 de Março de $2009 "$.

190 Reunião da comissão da ZEIS. Na reunião representante da SEUMA, Regina Costa e Silva, em fala que visava oferecer capacitação aos moradores de comunidades classificadas como ZEIS, apresentou o zoneamento ambiental com mapa oficial da prefeitura contendo as duas áreas de ZRA em questão.
} 
com parâmetros de zonas urbanas, refletindo na descaracterização e perda gradual da área de proteção ambiental, que facilitam a implementação de outro projeto, a Ponte Estaiada sobre o Rio Cocó, do Governo do Estado do Ceará. A ponte cairá sobre a ZRA (ZRA 2 - Figura 83) e será ligada a outros loteamentos da cidade por meio de via que será ampliada rasgando a Comunidade do Dendê. As famílias removidas pela abertura da via e para retirada de parte da população que está dentro do Parque Estadual do Cocó, decretado em 2017, serão reassentadas em conjunto habitacional que está sendo construído dentro da ZRA suprimida (ZRA 2 - Figura X). Apesar do processo de licitação da ponte se arrastar desde 2012 e ter sido suspenso pelo MPCE em 2016 por suspeita de irregularidade, o traçado viário da mesma está previsto na LPUOS (2017) e a via - que passa dentro da ZPA e Parque Estadual do Cocó, a qual receberá a ponte, já está com obras em andamento.

A LPUOS/2017 também trouxe artigo que revogou a ARIE (Área de relevante Interesse Ambiental) Dunas do Cocó, criada pela Lei n. 9502/2009. Esta área que possui estudos destacando a importância histórica e ambiental da duna está localizada em bairro com um dos preços do solo mais alto da cidade e para onde existe um loteamento aprovado ${ }^{191}$.

Ainda na LPUOS é possível observar a alteração da taxa de ocupação do solo da ZIA da Praia do Futuro de $40 \%$ para $50 \%$ e a criação de uma taxa de ocupação de subsolo de $40 \%$, quando o PDP não definia taxa nenhuma para a ocupação do subsolo. É importante destacar aqui que essa nova regulação das taxas de ocupação da ZIA da Praia do Futuro, apesar de ter uma lei aprovada, nunca poderia ter sido regulamentada, pois a LPUOS não pode alterar o PDP ${ }^{192}$. Assim como todas as demais alterações mencionadas, mesmo que "regulamentadas", pois ferem o princípio constitucional de proibição do retrocesso ambiental, pelo qual se entende que novas leis não podem nunca flexibilizar ou diminuir a proteção ambiental já garantidas por leis anteriores.

\footnotetext{
191 A revogação da ARIE foi posteriormente suspensa por meio de Ação Civil Pública encaminhada pelo MPCE. "[...] MPCE alegou que o artigo 283 da Lei 236/2017 revogou a Lei 9.502/2009 sem observar as regras constitucionais e o princípio da proibição do retrocesso ambiental, [...], além de violar a legislação que institui o Sistema Nacional de Unidades de Conservação da Natureza (Lei $n^{\circ} 9.985 / 2000$ ), segundo a qual a desafetação ou redução dos limites de uma unidade de conservação só pode ser feita mediante lei específica" (http://www.mpce.mp.br/2017/10/17/justica-atende-pedido-dompce-e-suspende-revogacao-da-arie-dunas-do-coco/).

192 A LPUOS, enquanto lei subordinada ao PDP, deve detalhar e complementar aquilo que o Plano Diretor não o fez, não podendo nunca o alterar. Não vamos aprofundar este ponto aqui, pois não é objetivo do artigo fazer uma discussão jurídica dessas leis.
} 
Figura 82. Zoneamento Ambienta de Fortaleza segundo PDP 2009

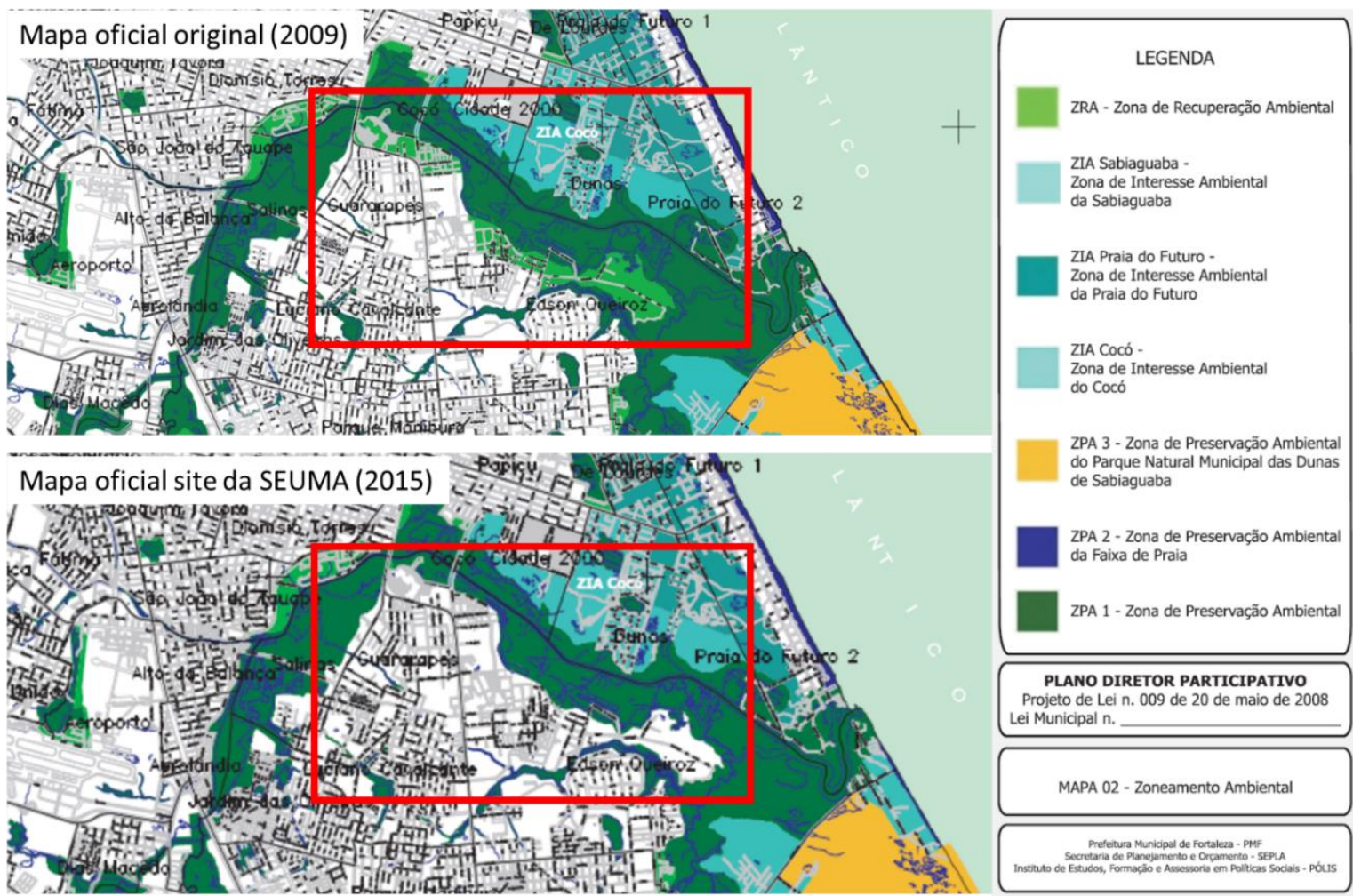

Fonte: FORTALEZA, 2009. Mapa obtido junto a HABITAFOR no ano de 2012; FORTALEZA 2015: Mapa baixado do site da SEUMA. Organização própria. Retângulo em vermelho destaca a área onde houve supressão de ZRA.

Figura 83. Espacialização a partir das coordenadas geográficas da ZRA publicada no DO № 14.020 - Lei 62/2009

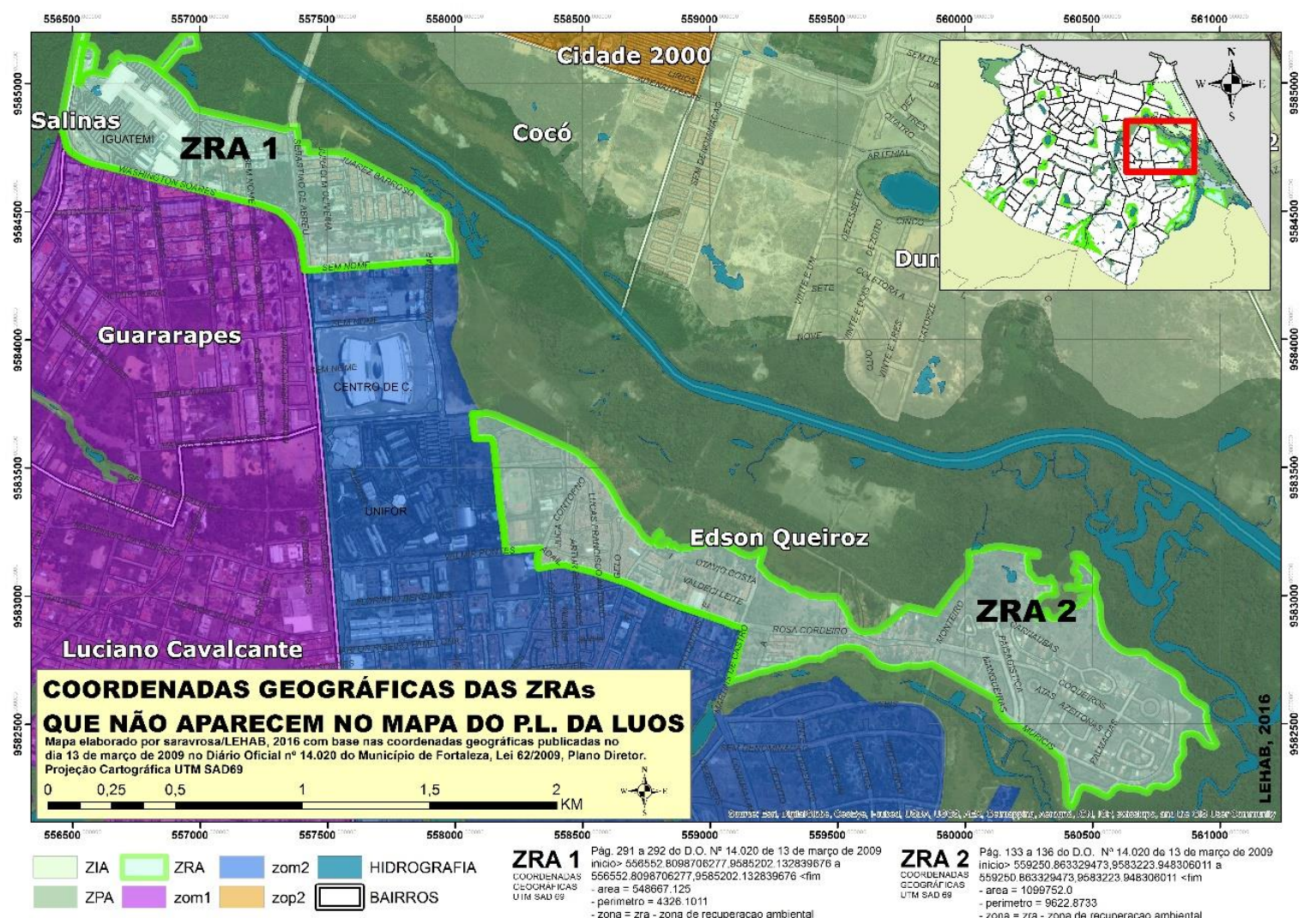

Fonte: FORTALEZA. DIÁRIO OFICIAL DO MUNICÍPIO № 14.020 de 13 de março de 2009. Lei 62/2009; LEHAB, 2016. Elaboração Sara V. Rosa, 2016. 
Em junho de 2018, foi aprovada nova Lei complementar alterando zoneamento ambiental do município (Figura 84), Lei no 250/2018 ${ }^{193}$. Assim como nas leis apontadas anteriormente há pequenas alterações e ajustes ao longo de todo o limite da ZPA1 (de recursos hídricos), em geral bem pequenas configurando mais ajustes cartográficos, mas seria necessário análise mais detalhado.

O que chama a atenção nessa LC de 2018, não e na verdade a supressão de áreas de conservação, mas a inclusão de três novas pequenas poligonais referentes a ZPA-3 (Zona de Preservação Ambiental de Dunas, dentro do limite da OUC Dunas do Cocó).

A OUC Dunas do Cocó, como mencionado anteriormente, encontra-se inteiramente sobre área de dunas, que conformam APP pela legislação federal, não reconhecido até hoje pelo município. Parte desta área já foi desmatada, e parcelada como pode ser observado na figura a seguir, mas desde sua aprovação a OUC segue parada, tendo sua vigencia renovada recentemente junto a imobiliária pertencente ao grupo M Dias Branco.

A proteção das dunas da Praia do Futuro e, em especial do Cocó, têm sido demanda dos movimentos ambientalistas do município a muito tempo. Recentemente o conflito foi acirrado com a demarcação do novo Parque do Cocó que deixou de fora várias áreas consideradas pelo movimento importantes, incluindo áreas de ZPA1 já preservadas a nível municipal. A área também tem sido alvo de intervenções do Ministério Público.

Contudo, a ARIE do Cocó (Área de Relevante Interesse Ecológico das Dunas do Cocó), que como comentado acima, tentou-se suprimir por meio de um artigo solto dentro do PL da LPUOS enviada para votação na câmara dos vereadores. De todas as áreas de dunas do município, está é talvez a que tem recebido maior demanda do movimento ambientalista, além de ser APP e AIRE, ainda assim não foi incluída nessa revisão a demarcação das áreas de dunas com vegetação do Cocó.

Aqui, podemos afirmar que há uma nova estratégia dos capitalistas e rentistas ligados ao mercado imobiliário. Se em um primeiro momento havia, principalmente, uma tentativa de retroceder a conservação ambiental de modo a recuperar ou obter maiores potenciais

\footnotetext{
${ }^{193}$ Até o presente momento só tivemos tempo hábil de analisar o mapeamento em KMZ disponibilizado pela SEUMA, não
} tendo sido feitas análises mais detalhadas sobre o conteúdo no texto da Lei. 
construtivos para os terrenos em questão, agora, aparentemente, esses atores estão dispostos a inclusive aumentar espaços de preservação, em troca de potenciais contrutivos em outros. Assim, apesar de perderem potencial construtivo em determinados terrenos, o potencial adiconal que receberão nos terrenos remanescentes será capaz de uma maior produção e maior geração de valor, além da possibilidade de captalizarem valores adicionais a partir de uma aparente valorização de seus terrenos e empreendimentos por conta da presença das dunas preservadas. Valorização (fictícia) pela natureza.

Figura 84. Macrozoneamento Lei no 250/2018.

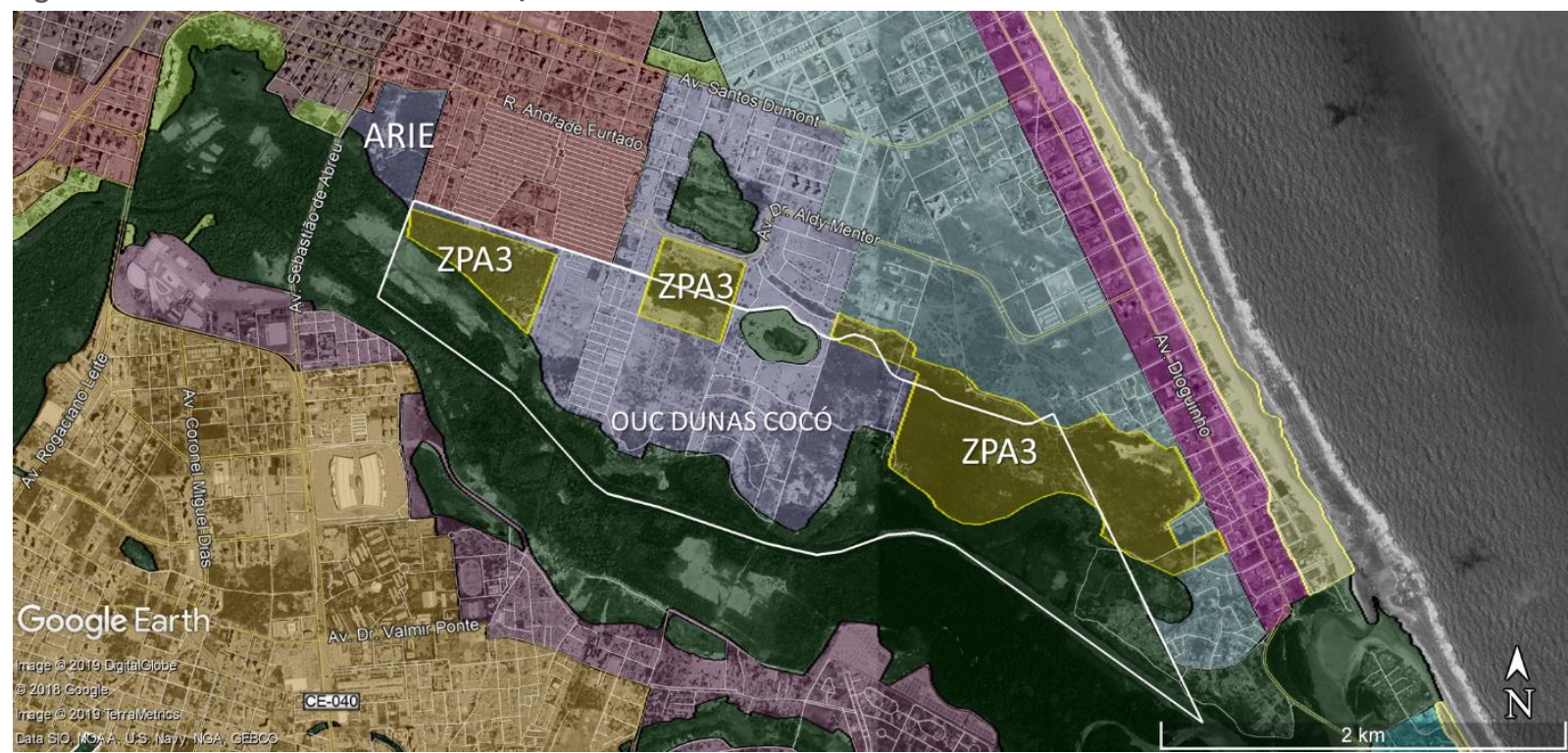

Fonte: Fortaleza/SEUMA, 2018. Sistematização: Rosa, 2018.

\section{Proposta de alteração dos índices das Zonas do PDPfor}

Segundo o Estatuto da cidade, o artigo $228^{194}$ do PDP, e o art. 4ำ da Lei em questão, "A edificação decorrente do acréscimo de área construída deverá obedecer aos parâmetros de uso e ocupação previstos na legislação urbanística para a zona de sua implantação" (FORTALEZA, 2015). Subtende-se, assim, que o I.A. máximo ${ }^{195}$ disposto no Plano Diretor não

\footnotetext{
194 Art. 228. O potencial construtivo poderá ser transferido para imóveis situados para qualquer zona onde o índice de aproveitamento máximo é superior ao básico, desde que aprovado pelo órgão competente do Município de Fortaleza (PDP, 2009, art. 228).

195 Índice de aproveitamento máximo: é aquele que determina a área total de construção permitida em cada zona da cidade, sendo o resultado do somatório entre o índice de aproveitamento básico e as áreas de construção acrescidas a partir da transferência do direito de construir e/ou da outorga onerosa (PDP, 2009, art. 190, V).
} 
pode ser ultrapassado. Esse também é o entendimento de Barros et. al. (2010) ao comentar o instrumento, segundo o Estatuto da Cidade:

Por meio desse instrumento, o proprietário pode exercer em outro local o direito de construir, seja em outro terreno de sua propriedade, seja transferindo ou alienando para um terceiro. Em ambos os casos, deve ser respeitado o coeficiente de aproveitamento máximo do local onde será exercido o direito de construir e as demais regras previstas no Plano Diretor [...] (BARROS; CARVALHO; MONTANDON, 2010, p. 1010).

Esta condicionante pode, em muitos casos, inviabilizar a aplicação do instrumento em Fortaleza, devido ao fato de que para quase toda a cidade o I.A. básico é quase, ou, igual ao I.A. máximo. Esta "coincidência" entre os dois índices deve-se em grande parte à pressão do setor imobiliário e da construção civil do município no período de discussão e aprovação do Plano Diretor Participativo (PDP) na Câmara ${ }^{196}$.

Das 12 zonas do Município onde é permitido construir, apenas 3 delas possuem diferenças entre o valor definido para o I.A. básico e o I.A. máximo, todas as demais apresentam o mesmo índice. Sem mencionar que, nos três casos onde existe uma diferença, esta é relativamente bem pequena. Na Zona de Ocupação Prioritária 2 (ZPO2), o índice passa de 2,00 para 3,00; já nas Zonas de Ocupação Moderada 1 e 2 (ZOM 1 e ZOM 2) esta diferença é de apenas 0,5. Na primeira, passa de 2,0 para 2,5 e na segunda, de 1,0 para 1,5 (Quadro 11).

Desse modo, o empenho do município em regulamentar o instrumento aparenta ser um esforço desnecessário, já que os empreendedores teriam pouco interesse neste, pois estes já têm o direito de construir até o I.A. máximo para quase toda a cidade. Para o município, em termos de arrecadação, o instrumento em questão poderia render bem menos do que a aplicação, por exemplo, do IPTU progressivo. O mesmo vale para o instrumento da Outorga Onerosa Sobre o Direito de Construir que será analisada no próximo ponto.

Quadro 11. Comparativo entre os I.A. básico e máximo definidos pelo Plano Diretor Participativo (2009)

\begin{tabular}{|l|r|r|}
\hline ZONAS & I.A. BÁSICO & I.A. MÁXIMO \\
\hline ZPA & 0,0 & 0,0 \\
\hline ZIA-sabiag. & 0,5 & 0,5 \\
\hline ZIA-Cocó & 1,5 & 1,5 \\
\hline
\end{tabular}

196 Entrevistas revelam que, durante o processo de discussão do PDP, representantes do setor imobiliário de Fortaleza tentaram negociar com representantes da sociedade civil, movimentos e academia, a troca de demarcação de ZEIS por aumento de índice de aproveitamento em determinadas áreas. Outro fato é que mesmo sem emendas, os I.A. indicados no PL do PDP que entrou na Câmara, são diferentes dos que saíram impressos na publicação da Lei no Diário Oficial. No caso os I.A. iniciais eram mais baixos. 


\begin{tabular}{|l|r|r|}
\hline ZIA-P.Futuro & 2,0 & 2,0 \\
\hline ZRA & 0,6 & 0,6 \\
\hline ZOP 1 & 3,0 & 3,0 \\
\hline ZOP 2 & $\underline{\mathbf{2 , 0}}$ & $\underline{\mathbf{3 , 0}}$ \\
\hline ZOC & 2,5 & 2,5 \\
\hline ZRU 1 & 2,0 & 2,0 \\
\hline ZRU 2 & 1,5 & 1,5 \\
\hline ZOM 1 & $\underline{\mathbf{2 , 0}}$ & $\underline{\mathbf{2 , 5}}$ \\
\hline ZOM 2 & $\underline{\mathbf{1 , 0}}$ & $\underline{\mathbf{1 , 5}}$ \\
\hline ZOR & 1,0 & 1,0 \\
\hline
\end{tabular}

Fonte: FORTALEZA, 2009. Plano diretor Participativo. Organização Sara V. Rosa, 2017. Em destaque, as únicas zonas que possuem I.A. básico menores do que o I.A. máximo.

Todavia, o município, juntamente com a Procuradoria Geral do Município (PGM), CPPD e SINDUSCON, aparentemente, já vem desenhando uma solução para esse impasse, a qual resultou em uma minuta de lei que dá poderes ao município de alterar o zoneamento do PDP e na nova Lei de Uso e Ocupação do Solo (LUOS) atualmente na câmara para votação. Esta hipótese fica clara durante leitura da Ata da CPPD que discutiu a minuta da Lei de Transferência do Direito de Construir:

O representante do SINDUSCON, Sr. Gama deu início ao processo de discussão demandando que no Art. 12 fosse inserido um prazo para a regulamentação da Lei pelo Poder Executivo, e em seguida solicitou que tendo em vista que algumas regiões o índice de aproveitamento básico está muito próximo do máximo, que se possível já encaminhar um projeto de lei alterando os índices da Zona de Ocupação Consolidada no Plano Diretor Participativo - PDP (FORTALEZA, 2014, p.6. Ata da 57ạ reunião da CPPD. Grifo meu).

Durante a fala do Secretário da CPPD, o representante do SINDUSCON, Sr. Gama interpelou e solicitou uma posição mais concreta da Presidente da CPPD, a Secretária Águeda Muniz, quanto ao encaminhamento da Lei que alterem o PDP, principalmente no que diz respeito aos índices (FORTALEZA, 2014, p.7. Ata da 57ạ reunião da CPPD).

Quanto à solicitação do representante do SINDUSCON, Sr. Gama no que diz respeito às alterações nos índices, a Presidente da CPPD, a Secretária Águeda Muniz afirmou que estarão na revisão da Lei de Uso e Ocupação do Solo - LUOS, e que ainda neste primeiro semestre será dado início ao processo de discussão sobre a revisão da LUOS (FORTALEZA, 2014, p.7. Ata da 57ạ reunião da CPPD).

Posteriormente, no dia 22 de abril de 2015, foi realizada reunião da CPPD em cuja pauta constava a mencionada minuta de lei que altera o PDP ${ }^{197}$, questionada pelo representante do SINDUSCON, um ano antes, na reunião do dia 5 de fevereiro de 2014.

\footnotetext{
197 "Fechamento da Minuta Pretendida de Alteração ao PDPfor", tal qual consta como pauta em ata.
} 
A leitura das atas e o acompanhamento de reuniões posteriores apontam para a ideia de que a pretensão do município era subdividir as zonas existentes, conferindo a estas, novos parâmetros urbanos, incluindo o índice de aproveitamento. Tudo indica que a intenção era que estas zonas já fossem apresentadas dentro do pacote de revisão da Lei de Uso e Ocupação do Solo (LUOS). Porém, aparentemente, apesar do documento da ata não ser muito claro, a representante da PGM alertou, ou se deu conta, que a LUOS não poderia alterar o zoneamento, nem os índices destes.

A saída então era a referida "Lei que altere o PDP, especialmente seus índices", todavia, a proposta feita pelo município não agradou muito os representantes do SINDUSCON.

\begin{abstract}
Não havendo questionamentos sobre o assunto, prosseguiu a reunião propondo uma leitura da Minuta Pretendida de Alteração ao PDPfor, pauta da reunião passada, quando na oportunidade foram entregues cópias do documento para apreciação dos presentes [...] (FORTALEZA, 2014, p.6. Ata da 66a reunião da CPPD).

O representante do SINDUSCON, Sr. Gama questionou o trecho da Minuta que trata da autorização dada ao Município para promover as subdivisões, seria decreto ou lei? [...] Ainda sobre a autorização, o Sr. Gama do SINDUSCON, levantou a possibilidade de grande risco por estar concedendo ao município um "cheque em branco" ao permitir que sejam feitas alterações no PDPfor, citou que precisava cautela no momento de fazer estas solicitações (FORTALEZA, 2014, p.6. Ata da 66a reunião da CPPD).

A Representante da PGM, Fernanda Diógenes esclareceu que esta seria uma Lei Complementar e ressaltou que a regulamentação de vários aspectos do PDPfor é feita pela Lei de Uso e Ocupação do Solo (LUOS), só que a LUOS não pode criar outras zonas dentro das que já existem no PDPfor, uma vez que ela é apenas uma lei que regulamenta. Daí a necessidade de elaboração do Projeto de Lei Complementar autorizando a criação destas novas zonas [..] (FORTALEZA, 2014, p.6 e 7. Ata da 66a reunião da CPPD).
\end{abstract}

Aparentemente, o que incomodava os representantes do SINDUSCON é que a "Minuta de Lei que Altera o PDP", não especificava as alterações, simplesmente entregava o poder ao município de alterar o Plano Diretor e sem prazo de vigência:

Art. 1․ Fica o Município autorizado a subdividir as Macrozonas de que trata o Plano Diretor Participativo de Fortaleza (PDPFOR) em função das suas especificidades e considerando os elementos elencados no art. 58 do referido Plano.

Art. 2o. - Esta subdivisão visa:

I- A regulamentação dos instrumentos normativos dispostos no art. 305 do Plano Diretor Participativo de Fortaleza;

II- Atender às diretrizes contidas no Título III - Do Ordenamento Territorial - Capítulo I - Do Macrozoneamento, especialmente as previstas no art. 57 do Plano Diretor Participativo de Fortaleza; 
III- A delimitação de novas Zonas, sem prejuízo do que estabelecem os arts. 148, 151, 158 e 164 do Plano Diretor Participativo de Fortaleza.

Art. 3‥ Poderão ser alterados os parâmetros de ocupação das Macrozonas em função das especificidades da subdivisão, em obediência ao disposto no art. 305, inciso II, do Plano Diretor Participativo de Fortaleza, e para fins de efetiva aplicação dos Instrumentos de Política Urbana previstos no Capítulo X, Título III - Do Ordenamento Territorial, do Plano Diretor Participativo.

(FORTALEZA, 2015. Minuta de Lei que altera o Plano Diretor).

A Minuta de lei, de apenas 4 artigos, daria total poder ao executivo de alterar o zoneamento e seus parâmetros, sem prazo definido e sem especificar como isso poderia ser feito. $\mathrm{E}$ a preocupação do SINDUSCON está exatamente neste ponto. O zoneamento poderia ser alterado de acordo com os interesses do SINDUSCON, mas nada garantia. Uma gestão mais progressista, mais à esquerda, ou a própria gestão atual, poderia, por exemplo, reduzir o potencial construtivo de algumas zonas da cidade. Inclusive, uma das ideias que vem sendo falada pelos técnicos do município é a necessidade de que todo o I.A. básico seja igual a 1 , para que o município possa se utilizar dos instrumentos de Transferência do Direito de Construir e Outorga Onerosa do Direito de Construir e arrecadar recursos para os cofres públicos.

Isso fica mais claro em ata de reunião da CPPD realizada no dia 22 de março de 2014:

O representante do SINDUSCON, Sr. Gama solicitou a palavra e citou que no $6^{\circ}$ (sexto) parágrafo da página número 7 (sete) da ata da 57ạ reunião da CPPD constam que:

"O Secretário da CPPD, Sr. Francisco consentiu com a proposta, e sugeriu que na proposta o índice que deve ser alterado é o coeficiente básico, e que em um determinado momento a Cidade de Fortaleza terá que discutir novamente os índices do PDP, pois da forma como está definida é um prejuízo tremendo para a cidade. $\mathrm{E}$ que seja elaborado um estudo consistente redefinindo os índices básico e máximo".

E que o SINDUSCON não concorda com a proposta do Secretário da CPPD, o Arq. Francisco Sales, sendo contra a alteração do índice básico, tendo em vista ter sido uma grande defesa pleiteada pelo SINDUSCON nas discussões do Plano Diretor Participativo - PDP e um direito adquirido, cabendo à Prefeitura estudar quais as áreas poderiam ser elevados os índices máximos se pagando o solo criado para a prefeitura, e que a proposta do SINDUSCON não é que seja alterado o índice básico.

(FORTALEZA, 2014, p. 2. Ata da 58a reunião da CPPD. Grifos meus).

A referida minuta, que permite o Município alterar o zoneamento, não foi aprovada ainda, nem as referidas subdivisões foram feitas no Projeto de Lei da LUOS enviado à Câmara. Todavia, o PL da LUOS vem com criação de vinte novas Zonas Especiais de Dinamização Urbana 
e Socioeconômica (ZEDUS), cobrindo mais de $12 \%{ }^{198}$ do território com novos parâmetros urbanos. Não sabemos tampouco se o município fará vistas grossas e transferirá potencial para terrenos mesmo que leve a I.A. acima do máximo para a zona, como já tem feito na aplicação da Outorga Onerosa. O mesmo repetimos para os CEPACS emitidos.

\section{Sobre a Comissão Permanente de Avaliação do Plano Diretor (CPPD)}

A Comissão Permanente de Avaliação do Plano Diretor é um órgão consultivo de colegiados ligado diretamente ao Prefeito do Município de Fortaleza. Foi criada na Lei Orgânica do Município (art. 160), versão anterior, da década de 90, a qual definiu e atribuiu a regulamentação e detalhamento de seu funcionamento à elaboração de lei posterior.

Art. 160. A comissão de avaliação permanente do plano diretor de desenvolvimento urbano é órgão colegiado, autônomo e ligado diretamente ao Prefeito Municipal, em que é garantida a participação das entidades representativas de categorias profissionais.

Parágrafo único. A lei disporá a composição, atribuições, organizações e funcionamento de comissão de avaliação permanente do plano diretor de desenvolvimento urbano. (FORTALEZA, Lei Orgânica do Município, s/da, art. 160)

Em 1992, o Plano Diretor do Município (FORTALEZA, 1992, art.99), fazendo referência à Lei Orgânica, incorpora a Comissão ao seu texto e já lhe atribui algumas funções, dentre elas a avaliação do Plano Diretor, bem como a revisão, complementação, e avaliação das leis relativas aos Planos Diretores Setoriais; Lei de Parcelamento, Uso e Ocupação do Solo; e Código de Obras e de Postura. O PDDU definiu também que todas as decisões da CPPD deveriam ser submetidas ao aval do Prefeito.

A lei que regulamenta a CPPD é aprovada apenas em 1995, Lei 7.813 de 30 de outubro ${ }^{199}$, e, em 1996, o então prefeito da época, A. E. Cambraia, assina decreto com o regimento interno

\footnotetext{
198 Dados obtidos através de análise em parceria entre o Laboratório de Estudos da Habitação - LEHAB, o Laboratório de Estudo das Relações Humano-Ambientais da Unifor - LERHA, mandato Ecos, e outros profissionais para apresentação na Câmera sobre o PL da LUOS.

199 Lei no 7.813, de 30 de outubro de 1995. Dispõe sobre a composição, atribuições, organização e funcionamento da comissão Permanente de Avaliação do Plano Diretor-CPPD, e dá outras providências.
} 
da Comissão ${ }^{200}$. Além das atribuições já definidas pela Lei Orgânica, fica então estabelecido como competência da CPPD:

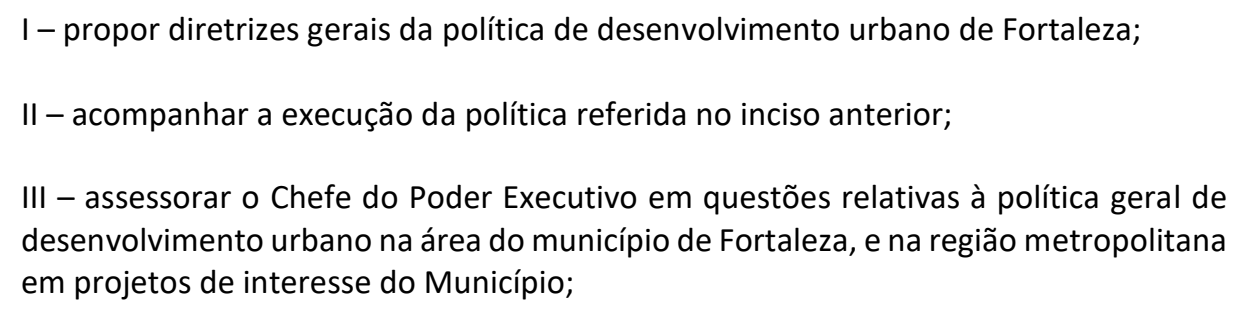

Os órgãos e Entidades que compõe a CPPD são os definidos na lei supracitada (art. 2º, 1995) e são praticamente os mesmos até o presente, com exceção dos membros natos, devido à criação e extinção de secretárias e órgãos municipais que mudaram nas reformas administrativas ocorridas nestes 10 anos.

Assim, como membros natos, foram definidos ao todo 10 órgãos municipais, os quais eram inicialmente: Instituto de Planejamento do Município - IPLAM; Secretaria do Controle Urbano e Meio Ambiente - SPLAM; Secretaria de Transportes do Município - STM; Procuradoria Geral do Município - PGM; Secretaria de Finanças do Município - SEFIN; Secretaria de Serviços Públicos - SSP; Empresa Municipal de Limpeza e Urbanização - EMLURB; Superintendência Municipal de Obras e Viação - SUMOV; Fundação Cultural de Fortaleza - FCF; Comissão de implantação de Projetos Habitacionais de Interesse Social e Infraestrutura Urbana - COMHAB.

Como membros presentes, foram definidas 10 entidades, a saber: Câmara Municipal de Fortaleza - CMF; Instituto de Arquitetos do Brasil - IAB-CE; Associação de Geógrafos do Brasil - AGB-CE; Associação das Empresas Construtoras do Ceará - ASSECON; Sindicato da Indústria da Construção Civil do Ceará - SINDUSCON (em sistema de rodízio com a ASSECON); Clube dos Diretores Lojistas - CDL; Associação Comercial do Ceará - ACC; Associação Brasileira de Engenharia Sanitária - ABES; Universidade Federal do Ceará - UFC; Federação de Bairros e

\footnotetext{
200 Decreto no 9.978, de 07 de novembro de 1996. Dispõe sobre o regimento interno da Comissão Permanente de Avaliação do Plano Diretor - CPPD e dá outras providências.
} 
Favelas, em sistema de rodízio com a União das Comunidades da Grande Fortaleza (FORTALEZA, 1995, art. 2ㅇ).

Com o novo Plano Diretor Participativo de Fortaleza, elaborado após o Estatuto da Cidade (2001), havia-se a pretensão de extinção da CPPD, pois ele garantia um controle social bem democrático, uma vez que as entidades foram escolhidas pelo Município, sendo metade das cadeiras ocupadas por órgãos municipais. Para se ter uma ideia, o único representante de movimentos e/ou comunidades da comissão, é a Federação de Bairros e Favelas, movimento que, já alguns anos, não tem atuação nenhuma no município e continua ocupando um lugar.

Para se adequar à Lei do Estatuto da Cidade, o PDP estabelece a criação do Conselho Municipal de Desenvolvimento Urbano (CMDU), baseado na estrutura proposta pelo Ministério das Cidades (MCidades) para o Conselho Nacional das Cidades, o qual deveria garantir a representatividade da sociedade civil e cujas entidades representantes deveriam ser eleitas, de forma transparente, durante a Conferência Nacional das Cidades. Deste modo, o texto do Plano Diretor (art.305) estabeleceu um prazo de seis meses para que o Município criasse o CMDU 201 .

Importante destacar que, em 2011, durante a gestão de Luzianne Lins, o município tentou, por meio de Lei Complementar (Lei 101/2011), substituir todas as funções do CMDU, atribuídas no Plano Diretor, ao CONCIDADE (Conselho Municipal da Cidade), que seria implementado posteriormente, na gestão Roberto Cláudio, porém, fora do modelo de participação e gestão democráticas definidos pelo MCidades. Todavia, essa alteração do Plano Diretor foi vetada pelo fato da Lei Orgânica do Município prever em seu art. 203 “[...] apenas a existência do Conselho Municipal de Desenvolvimento Urbano - CMDU como detentor da competência deliberativa nas questões relativas a gestão democrática da cidade, mediante sua composição paritária entre Poder Público e sociedade" (FORTALEZA, 2012, p.2).

Desde então, a CPPD, tanto na gestão da Luizianne, como na do Roberto Cláudio, tem assumido todas as atribuições do CMDU, desrespeitando o prazo imposto pelo Plano Diretor, bem como as diretrizes de conselhos democráticos trazidas pelo Estatuto da Cidade.

201 VIII - lei municipal específica que trata do Conselho Municipal de Desenvolvimento Urbano, no prazo de até 6 (seis) meses (FORTALEZA, Art.305, 2009) 
Em 2013, depois de reforma administrativa, na primeira gestão do prefeito Roberto Cláudio ${ }^{202}$ (Lei 137, de 08 de janeiro de 2013) 203, por meio de decreto (13.262/2013), o município estabelece nova composição dos membros natos da CPPD, que passa a ser: Secretaria de Urbanismo e Meio Ambiente SEUMA; Instituto de Planejamento e Urbanismo e Meio Ambiente - IPLANFOR; Secretaria Municipal de Infraestrutura - SEINF; Secretaria de Desenvolvimento Econômico - SDE; Procuradoria Geral do Município - PGM; Secretaria Municipal de Finanças - SEFIN; Secretarias Regionais I, II, III, IV, V e VI; Autarquia Municipal de Trânsito - AMC, tendo a SEUMA como presidente nato da Comissão, no nome de sua secretária, a arquiteta Maria Águeda P. C. Muniz, e o arquiteto Francisco das Chagas do Vale Sales, como secretário executivo ${ }^{204}$. (FORTALEZA, 2013b).

Paralelamente, o prefeito Roberto Cláudio lançou, em setembro de 2013, o projeto do Conselho da Cidade. Quando anunciado, foi nomeado também como Conselho dos Notáveis, ou "Conselhão", como também ficou conhecido, pelo fato de ter seus membros escolhidos pelo Prefeito por "notório saber".

[...] a proposta da gestão era a criação de um "Conselhão" de caráter consultivo, com dezenas de entidades representadas, assessorado por um grupo de "notáveis" e que contemplaria todas as pautas que permeavam os embates municipais: educação, mobilidade, saúde, meio ambiente, moradia, entre outros setores. Houve resistência dos movimentos do campo da reforma urbana presentes nessas discussões (FBFF, CMP, Cearah Periferia, para citar alguns), que afirmaram a necessidade de manutenção do ConCidades conforme o Nacional, deliberativo, com as pautas definidas das políticas urbanas e com a representação dos seis segmentos (movimentos populares; ONGs; empresários; poder público; trabalhadores e entidades profissionais, acadêmicas e de pesquisa). Após esse embate, o processo de construção da proposta ficou estanque, sendo retomado apenas após o fim da Copa (PINHEIRO, 2014, p. 115).

\footnotetext{
202 Roberto Cláudio, candidato do PSB, foi eleito em 2012, assumindo seu primeiro mandato de 2013 a 2016, durante o qual mudou para o partido PROS e depois PDT, ao qual permanece filiado ainda hoje. Foi reeleito em 2016, assumindo novo mandato, iniciado no ano de 2017.

203 É nesta reforma administrativa que foi criada a então Secretaria de Urbanismo e Meio Ambiente, SEUMA, a qual passou a somar as atribuições da SEMAN e da SEPLA, mais as atribuições relativas a urbanismo provenientes da SEINF, além de outras alterações (FORTALEZA, 2013). Depois disso, ainda foi realizada mais uma reforma administrativa, quando então a HABITAFOR passa a ser Secretaria, Lei Complementar no 0176, de 19 de dezembro de 2014.

${ }^{204}$ A SEUMA passa, a partir da reforma administrativa de 2013, a presidiar os demais conselhos do Município, como o CGS (Conselho Gestor da Sabiaguaba) e o COMAM (Conselho de Meio Ambiente Municipal).
} 
O Projeto de Lei do Conselho da Cidade (Conselho dos notáveis) foi então enviado pelo prefeito para a Câmara em fevereiro de 2014, e teve a Lei aprovada em julho de $2014^{205}$, na qual lhe foram definidas as seguintes atribuições:

I - assessorar o chefe do Poder Executivo Municipal na formulação de políticas, indicações normativas e ações governamentais;

II - debater, orientar e apreciar propostas de políticas públicas e reformas estruturais submetidas pelo chefe do Poder Executivo Municipal;

III - sugerir, propor, elaborar e apresentar ao chefe do Poder Executivo Municipal relatórios, estudos, projetos, acordos e pareceres, reunindo as contribuições dos diversos setores da sociedade civil;

IV - organizar, promover e acompanhar debates acerca das medidas necessárias para a promoção do desenvolvimento econômico, social e ambiental da cidade.

(Art. 2으, FORTALEZA, 2014, LEI 10232)

O Conselho dos Notáveis tomou posse em abril de $2015^{206}$, e, segundo entrevista com a Secretária Águeda Muniz (2015), este se reúne com o prefeito a cada seis meses. Todavia, até hoje não se percebe grande movimentação, nem atuação desse, se existe, é mais interna, somente com o prefeito e equipe específica.

Importante destacar que, em 2015, a prefeitura aprovou três leis que regularizam os instrumentos Outorga Onerosa de Alterar o Uso do Solo e a Transferência do Direito de Construir ${ }^{207}$, bem como lei de Regularização de Edificações Irregulares, que funciona como uma "anistia", mediante pagamento a ser calculado, para construções inadequadas quanto aos parâmetros, porte, e usos definidos pelo Plano Diretor ${ }^{208}$. Essas três leis serão analisadas no próximo ponto deste capítulo, mas, de antemão, adiantamos que elas trazem distorções quanto ao conteúdo dos instrumentos, principalmente com relação a lei da Outorga, e levam a flexibilização urbana a um ponto de total desconsideração da legislação urbana, por intermédio da aprovação da Comissão Permanente do Plano Diretor - CPPD e pagamento.

\footnotetext{
205 O Conselho das Cidades, órgão consultivo, de assessoramento do prefeito, tomou posse apenas em 22 de abril de 2015, é composto por mais de 100 pessoas escolhidas pelo gestor, e tem previsão de reunir-se apenas de 6 em 6 meses (PINHEIRO, 2014, p. 115).

206 Diário do Nordeste. Disponível em: <diariodonordeste.verdesmares.com.br/cadernos/cidade/prefeitura-lanca-projetode-acoes-para-fortaleza-1.1274763>.

207 Outorga onerosa de alteração de uso do solo: LEI № 10.335, DE 01 DE ABRIL DE 2015; Transferência do Direito de Construir: LEI 10.333, DE 1 DE ABRIL DE 2015.

208 Regularização de edificações: LEI 10.334, DE 1 DE ABRIL DE 2015.
} 
O exposto acima trouxe para a CPPD, nos últimos dois anos, um poder de decisão sobre o território muito alto, diria até um poder de legislar sobre o uso e a ocupação do solo. Para cada projeto que entra para análise na CPPD são definidos para o seu terreno novas taxas de ocupação e permeabilidade, novos índices de aproveitamento e gabaritos máximos, novos recuos, novas frações do lote, novos usos permitidos, entre outros, e o município fica "resguardado", prosseguiu os trâmites legais para aprovação dos projetos.

Tão grave quanto a postura do município de legitimar a CPPD, é a postura de dizer que ela é o CMDU. Isso foi perceptível em entrevistas feitas com a secretária da SEUMA, onde foi afirmado que a CPPD é o CMDU, e na 6ạ Conferência Municipal das Cidades, realizada em junho de 2016, onde o município tentou validar ficha, que deveria ser entregue ao Ministério das Cidades, afirmando que Fortaleza possuía um Conselho de Desenvolvimento Urbano.

Neste contexto, nos últimos anos, passaram pela CPPD diversos temas para análise e aprovação, dos quais destacamos:

- Projeto de lei da Outorga onerosa de alteração de uso do solo: LEI № 10.335, DE 01 DE ABRIL DE 2015;

- Projeto de lei de Transferência do Direito de Construir: LEI 10.333, DE 1 DE ABRIL DE 2015;

- Projeto de lei de Regularização de edificações: LEI 10.334, DE 1 DE ABRIL DE 2015;

- Minuta de decreto sobre a Outorga Onerosa de Alteração do Uso do Solo;

- Análise prévia de projetos "especiais" com pedidos de Outorga do Direito de Construir e de Alterar o Uso do Solo;

- Projetos de Lei de Operações Urbanas Consorciadas. 


\title{
3.2. OUTORGA ONEROSA DO DIREITO DE CONSTRUIR E DO DIREITO DE ALTERAR USO DO SOLO
}

\author{
Outorga Onerosa de Alteração de Uso do Solo - Lei no \\ 10.335, de 01 de abril de 2015 e lei no 10.431, de 22 de \\ dezembro de $2015^{209}$
}

Neste ponto, serão analisadas duas leis que tratam da regulamentação do instrumento da Outorga Onerosa de Alteração do Uso do Solo, Lei Complementar 10.335 (de 01 de abril de 2015) e Lei 10.431 (de22 de dezembro de 2015), bem como uma minuta de decreto formulada na tentativa de regulamentar as leis supracitadas (Quadro 12).

Quadro 12. Enquadramento da Minuta de Decreto em análise. Fonte: Lei 10.335/2015; lei 10.431/2015; minuta de decreto de 2016.

\begin{tabular}{|c|c|c|c|}
\hline Lei & & Data & Descrição \\
\hline $\begin{array}{l}\text { LEI } \\
10.335\end{array}$ & $\mathrm{~N}^{\circ}$ & $01 / 04 / 2015$ & $\begin{array}{l}\text { Dispõe sobre a outorga onerosa de alteração de uso do solo que trata o art. } 222 \text { da Lei Complementar } \\
\text { n 0062/09, que institui o Plano Diretor Participativo, e dá outras providências. Regulamenta que a } \\
\text { Outorga Onerosa pode ser aplicada a todo o macrozonemento urbano. }\end{array}$ \\
\hline $\begin{array}{l}\text { LEI } \\
10.431\end{array}$ & № & $22 / 12 / 2015$ & $\begin{array}{l}\text { Altera a Lei } 10.335 \text {. Acrescentou: } \$ 50 \text { - excepcionalmente, desde que analisado pela SEUMA e aprovado } \\
\text { pelo COMAM, poderá ser admitida a alteração de uso nos empreendimentos classificados como } \\
\text { projetos especiais, localizados na macrozona de proteção ambiental e inseridos na zona de interesse } \\
\text { Ambiental (ZIA) e Zona de Recuperação Ambiental (ZRA). }\end{array}$ \\
\hline $\begin{array}{l}\text { Minuta } \\
\text { decreto } \\
\text { outorga } \\
\text { onerosa }\end{array}$ & & $\begin{array}{l}\text { Entrou } \\
\text { discussão na CPPD } \\
\text { em março de } 2016\end{array}$ & $\begin{array}{l}\text { Regulamenta as Leis no } 10.335 \text {, de } 01 \text { de abril } 2015 \text { e no } 10.431 \text {, de } 22 \text { de dezembro de } 2015 \\
\text { disciplinando o procedimento administrativo da Outorga Onerosa de Alteração de Uso do Solo, } \\
\text { estabelecendo condições de adequabilidade das atividades limites dos parâmetros urbanísticos e } \\
\text { critérios para o cálculo do valor da contrapartida. Altera os parâmetros, índices urbanísticos e usos } \\
\text { possíveis em áreas de proteção ambiental através da outorga. }\end{array}$ \\
\hline PL & & 2017 & Transforma a minuta do decreto anterior em projeto de lei \\
\hline
\end{tabular}

Fonte: Fortaleza, 2015. Organização própria.

A Outorga Onerosa do Direito de Construir e a Outorga Onerosa de Alteração do Uso do Solo são instrumentos regulamentados pelo Estatuto da Cidade (Lei Federal no 10.257/2001), no qual o município pode dar a concessão para que um proprietário, mediante contrapartida paga ao poder público municipal, construa acima do coeficiente de aproveitamento básico, até o limite do coeficiente máximo ${ }^{210}$, estabelecidos no Plano Diretor (outorga onerosa do

\footnotetext{
209 Para a análise dessa Lei foram fundamentais as discussões ocorridas dentro do LEHAB, com a participação de integrantes da Associação dos Geógrafos Brasileiros - AGB, e do Parecer do advogado Henrique Botelho Frota, do Instituto Brasileiro de Direito Urbanístico - IBDU.

210 “O limite é fixado pelo coeficiente de aproveitamento máximo, acima do qual nenhum projeto poderá ser aprovado ainda que mediante contrapartida. Sem que a legislação urbanística municipal diferencie esses dois índices (básico e máximo), a aplicação da outorga onerosa do direito de construir fica inviabilizada" (BOTELHO, 2016).
} 
direito de construir), ou que o proprietário, também mediante contrapartida, mude o uso do solo definido pelo município de determinada área da cidade, mediante pagamento (outorga onerosa de alteração do uso do solo) 211.

Estes instrumentos deveriam, em tese, dotar o município de ferramentas para induzir o crescimento e desenvolvimento da cidade para áreas de seu interesse e, ao mesmo tempo, colher benefícios e redistribuí-los para áreas da cidade menos privilegiadas. Porém, vale destacar que a aplicação da outorga onerosa do direito de construir aumenta o potencial construtivo, que, por sua vez, pode levar ao adensamento construtivo das áreas onde esse instrumento é aplicado. Já a outorga onerosa de alteração do uso do solo pode flexibilizar os tipos de uso e assim trazer empreendimentos de maior porte e/ou maior impacto social, econômico e ambiental.

Assim sendo, o município deve prever cuidadosamente quais as áreas que poderão ter esses instrumentos aplicados e já pré-dimensionar o coeficiente de aproveitamento máximo que pode ser atingido, dentre outros parâmetros, de modo a não sobrecarregar o sistema de infraestrutura da cidade, como redes de água, esgoto, energia, coleta de lixo, sistema viário e transporte público. Deve também ter cuidado redobrado com as áreas ambientalmente frágeis, se possível, evitar a utilização destes instrumentos nestas, já que em tais áreas o objetivo é controlar o adensamento e uso do solo, de modo a minimizar os impactos ambientais. Tudo isto deve ser definido no plano diretor do município, segundo o estabelecido pelo Estatuto da Cidade, Lei no 10.257/2001, art. 28, 29 e 42.

“[...] fica claro que a legislação federal atribuiu ordem de importância diferenciada entre o plano diretor e as demais leis municipais. Somente àquele cabe a determinação do âmbito territorial de incidência dos instrumentos, não podendo as demais leis, nisso incluída até mesmo a lei de uso e ocupação do solo, autonomamente ampliar ou modificar essa previsão" (FROTA, 2016, p. 13).

Em 2015, foi aprovada pelo município de Fortaleza lei específica que regulamenta a outorga onerosa de alteração do uso do solo (Lei n 10.335/2015). Esta lei, aprovada no dia 10 de abril foi modificada pela lei № 10.431/2015, aprovada no dia 22 de dezembro do mesmo ano. A principal modificação foi a inclusão das Zonas de Proteção Ambiental do zoneamento de Fortaleza como zonas passíveis de aplicação do instrumento em questão. Não bastasse a

\footnotetext{
${ }^{211}$ Ver Art. 28 e 29 da Lei Federal no 10.257/2001.
} 
inclusão de zonas não definidas pelo Plano Diretor ${ }^{212}$, a lei citada junta o instrumento de outorga onerosa de alteração do uso do solo com o de direito de construir, ao definir que na outorga de alteração do uso do solo está prevista também a alteração do coeficiente de aproveitamento, esvaziando a outorga onerosa do direito de construir e confundindo os dois instrumentos. ${ }^{213}$

Parece meio confuso, e realmente é. Rigorosamente, o município regulamentou apenas um instrumento, a Outorga Onerosa do Direito de Alterar o Uso do Solo, porém Ihe atribuiu os atributos da Outorga Onerosa do Direito de Construir, como se os dois instrumentos fossem

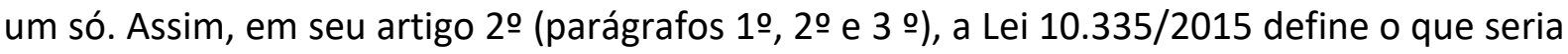
a "alteração de uso":

§ 10 Considera-se alteração de uso a mudança dos índices urbanos na implantação das atividades, nos termos previstos nos arts. 18, 19 e 20 da LUOS.

$\S 20$ Considera-se também alteração de uso a inclusão de um novo uso ou tipo de atividade não previsto para a unidade imobiliária, mantendo-se o uso previsto nas normas de edificação, uso e gabarito vigentes.

§ 30 Em qualquer das situações, se a desconformidade com a legislação de uso e ocupação do solo se restringir à autorização de construir acima do coeficiente básico, o pagamento de contrapartida pelo beneficiário será calculada de acordo com o disposto no art. 220 do PDP.

(FORTALEZA, 2015, ART. 2. Lei 10.335/2015)

Sobre os incisos acima Frota $(2016$, p.9) afirma:

A previsão do § 10, no entanto, revela-se contraditória ao estabelecer que a alteração de uso consiste na possibilidade de mudança dos índices urbanos. Ainda mais inadequado é o § 3o, que admite situações em que a alteração de uso poderá se restringir a "construir acima do coeficiente básico" (sic). O dispositivo claramente

\footnotetext{
212 Resolução CONCIDADES n. 34/2005: Art. 4o Nos termos do art. 42, inciso II do Estatuto da Cidade, caso o plano diretor determine a aplicação dos instrumentos: direito de preempção, outorga onerosa do direito de construir e de alteração de uso, operações urbanas e a transferência do direito de construir; estes só poderão ser aplicados se tiverem sua área de aplicação delimitada no Plano Diretor.

Parágrafo único. Na exposição dos motivos, o Plano Diretor deverá apresentar a justificativa de aplicação de cada um dos instrumentos previstos no art. 40 desta Resolução, com vinculação às respectivas estratégias e objetivos.

Lei Federal no 10.257/2001 - Estatuto da Cidade: Art. 30. Lei municipal específica estabelecerá as condições a serem observadas para a outorga onerosa do direito de construir e de alteração de uso, determinando:

I - a fórmula de cálculo para a cobrança;

II - os casos passíveis de isenção do pagamento da outorga;

III - a contrapartida do beneficiário.

213 Sobre a Lei $n^{\circ} 10.335 / 2015$, Botelho $(2016$, p. 14) afirma: “A leitura comparativa das duas normas revela disparidades, com a inclusão de zonas na legislação ordinária que não estão previstas no plano diretor. A circunstância demonstra que o legislador municipal não se deteve com atenção aos limites impostos pelo Estatuto da Cidade e pelo Plano Diretor Participativo, tendo produzido uma lei ordinária que viola preceito básico da política urbana. Diante disso, outra não pode ser a conclusão senão pela ilegalidade e consequente inaplicação dos dispositivos que extrapolam a competência da lei específica".
} 
confunde o instrumento que deveria regulamentar com o da outorga do direito de construir, desviando a finalidade estabelecida pelo Estatuto da Cidade e pelo PDPFor. Essa confusão tem reflexos em toda a regulamentação, marcando com vício insanável inclusive a minuta de Decreto Municipal sob análise.

Todavia, o Plano Diretor (2009) é tão claro com relação à alteração de uso e o direito de construir serem distintos que, quando lista os instrumentos prioritários por zona, ele coloca em linhas e com numeração separada a outorga do direito de construir e a da outorga de alterar o uso do solo. Fica claro que são dois instrumentos distintos, podendo em uma única zona aplicar os dois, somente um ou nenhum (ver Anexo 01 e Quadro 11).

Quadro 13. Indicação do uso da Outorga Onerosa de Alteração do Uso e do Direito de Construir para o macrozoneamento urbano, segundo PDP 2009

\begin{tabular}{|c|c|c|c|c|c|c|c|c|}
\hline ZOP 1 & ZOP 2 & $z O C$ & ZRU 1 & ZRU 2 & ZOM 1 & ZOM 2 & ZOR & ZO \\
\hline $\begin{array}{l}\text { Outorga } \\
\text { onerosa de } \\
\text { alteração de } \\
\text { uso. }\end{array}$ & $\begin{array}{l}\begin{array}{l}\text { Outorga } \\
\text { onerosa do } \\
\text { direito de }\end{array} \\
\underline{\text { construir; }}\end{array}$ & $\begin{array}{l}\text { Outorga } \\
\text { onerosa do } \\
\text { direito de } \\
\text { construir: } \\
\text { Outorga } \\
\underline{\text { onerosa de }} \\
\text { alteração de } \\
\text { uso. }\end{array}$ & - & $\begin{array}{l}\text { Outorga } \\
\text { onerosa de } \\
\text { alteração de } \\
\underline{\text { uso. }}\end{array}$ & 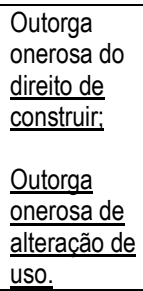 & $\begin{array}{l}\begin{array}{l}\text { Outorga } \\
\text { onerosa do } \\
\text { direito de } \\
\underline{\text { construir; }}\end{array}\end{array}$ & & 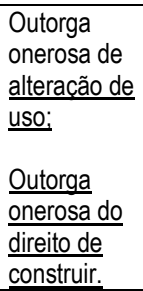 \\
\hline
\end{tabular}

Elaboração própria a partir do PDP de 2009.

Além de confundir os dois instrumentos entre si, caso a Lei tratasse também da Outorga Onerosa do Direito de Construir, assim mesmo estaria desvirtuando o instrumento, ao permitir que este seja aplicado sobre outros parâmetros urbanos, além do índice de aproveitamento, como definem o Estatuto da Cidade e o Plano Diretor.

Um terceiro problema é que a Lei 10.335/2015 estende a aplicação do instrumento à toda a Macrozona Urbana do Município, enquanto no PDP a Outorga de Alteração do Uso é permitida somente para a Zona de Ocupação Prioritária 1 (ZOP1), Zona de Ocupação Consolidada (ZOC), Zona de Recuperação Urbana 2 (ZRU2), Zona de Ocupação Moderada 1 (ZOM1) e Zona de Orla (ZO); e a Outorga do Direito de Construir para a Zona de Ocupação Prioritária 2 (ZOP2), Zona de Ocupação Consolidada (ZOC), Zona de Ocupação Moderada1 e 2 ZOM 1 e 2 e Zona de Orla (ZO) (Quadro 13).

Essa ampliação da área de aplicação do instrumento traz entre seus principais problemas o desrespeito as diretrizes do PDP 214 , incluindo a aplicação de um instrumento que incentiva a

\footnotetext{
214 "Sobre a questão, importante reafirmar que o Estatuto da Cidade traçou a moldura geral do instrumento, estabelecendo que as áreas de incidência da outorga onerosa, tanto de alteração de uso quanto do direito de construir, devem ser previstas na lei que instituir o plano diretor do município (Arts. 28 e 29). Tal exigência é reforçada pelo Art. 42 da mesma lei federal,
} 
ocupação e maior densidade em áreas sem infraestrutura como a Zona de Ocupação Restrita - ZOR, contrariando os objetivos definidos para esta, que buscam restringir a ocupação 215 . Além de regulamentar a aplicação da compra de potencial construtivo em zonas onde, da forma como o PDP foi alterado na sua publicação, não se tem potencial construtivo disponível, pois o I.A. básico é igual ao máximo. De acordo com o PDP, como foi mostrado anteriormente, as únicas zonas que teriam possibilidade de aplicação de outorga sobre o índice de aproveitamento são a Zona de Ocupação Prioritária 2, e as zonas de ocupação moderada 1 e 2.

Não sendo suficiente a aplicação do instrumento em zonas de ocupação restrita, o município, em 22 de dezembro de 2015, por meio da Lei 10.431, ampliou a Outorga de Alteração de Uso definida pela Lei 10.335, do mesmo ano, a qual permite a alteração dos parâmetros urbanos, como explicado, para o Macrozoneamento Ambiental, excluindo apenas a Zona de Preservação Ambiental.

\begin{abstract}
A leitura comparativa das duas normas revela disparidades, com a inclusão de zonas na legislação ordinária que não estão previstas no plano diretor. A circunstância demonstra que o legislador municipal não se deteve com atenção aos limites impostos pelo Estatuto da Cidade e pelo Plano Diretor Participativo, tendo produzido uma lei ordinária que viola preceito básico da política urbana. Diante disso, outra não pode ser a conclusão senão pela ilegalidade e consequente inaplicação dos dispositivos que extrapolam a competência da lei específica (FROTA, 2016, p.14. Grifo meu).
\end{abstract}

Importante destacar que a elaboração das leis que regem o uso e a ocupação do solo, estudadas neste capítulo, possuem uma forte influência do Sindicato da Indústria da Construção Civil - SINDUSCON. O caso, por exemplo, da aprovação de uma lei nove meses depois da regulamentação da Outorga Onerosa de Alteração do Uso do Solo, ampliando a aplicação do instrumento para o Macrozoneamento Ambiental, mesmo contrariando matéria de lei, pode ter sido uma cobrança da instituição mencionada, como pode ser observado em relatos das atas da CPPD:

O representante do SINDUSCON, Sr. Gama propôs que o procedimento a ser seguido fosse de acordo com a primeira opção sugerida e questionou qual a opinião da Prefeitura quanto à restrição de se ficar só na Macrozona Consolidada, se a Prefeitura

ao determinar como conteúdo obrigatório dos planos diretores as disposições referentes à outorga onerosa, dentre outros instrumentos" (FROTA, 2016, p. 12).

${ }^{215}$ Art. 108. São objetivos da Zona de Ocupação Restrita (ZOR): I - inibir, controlar e ordenar os processos de transformações e ocupações urbanas de modo a evitar inadequações urbanísticas e ambientais; II - implantar ou complementar a infraestrutura básica apenas nas áreas ocupadas; III - conter a expansão e a ocupação urbanas (FORTALEZA, 2009. PDP) 
acha que é possível que todo e qualquer projeto vai ter de passar, quer queira, quer não, pela análise da Comissão da CPPD.

O Secretário da CPPD, o Arq. Francisco Sales expôs que primeiro o Estatuto da Cidade disse que o Plano Diretor tem que fixar as áreas onde será aplicado, então trata-se de uma exigência legal, segundo nós estamos tratando de Projetos Especiais, e nenhum deles estaria em áreas de interesse ambiental, mas sempre há uma novidade, daí surge um equipamento, como por exemplo o Mirante, onde o fato de estar junto a uma área de interesse ambiental está atrelada à sua finalidade, não estando previsto nos projetos especiais. Mas em princípio é necessário estabelecer onde será avaliado, ou seja, a Macrozona de Ocupação Urbana, porque estamos tratando de Projetos Especiais, entretanto sempre irá acontecer situações de formas diferenciadas.

(FORTALEZA, 2014, p. 8. Ata da 58a reunião da CPPD).

Fora todos estes pontos acima, as duas leis apresentam diversos outros problemas, como o de não conter o conteúdo mínimo exigido pelo Estatuto da Cidade, como a fórmula de cálculo para a aplicação da outorga. O Plano Diretor não define a forma de contrapartida para a Outorga de Alteração do Uso do Solo, sendo esta a principal questão que demandava uma lei específica para a regulamentação do instrumento, a qual não foi atendida nas duas leis.

Durante reunião da CPPD sobre a minuta da primeira lei, houve o debate sobre a forma de contrapartida para o município, que seria em dinheiro e calculada por engenheiro contratado pelo próprio interessado privado (FORTALEZA, 2014, p. 2. Ata da 58a reunião da CPPD). Proposta que seria inadequada, visto que o interessado privado tem interesse de pagar o menor valor possível.

Tentou-se sanar esta omissão da forma de contrapartida por meio de decreto, o qual não foi sancionado devido a diversas críticas do LEHAB e AGB, por meio de pareceres técnicos. A seguir, a Minuta do Decreto é analisada, tentando dar mais ênfase às implicações para as áreas de proteção e preservação ambiental.

\section{Minuta do Decreto da Outorga Onerosa de Alteração do Uso do Solo}

Art. 10 Este Decreto disciplina o procedimento administrativo da Outorga Onerosa de Alteração de Uso do Solo, instituída no Município de Fortaleza através da Lei Complementar no 062, de 02 de fevereiro de 2009, e regulamentada pelas Leis no 10.335, de 01 de abril de 2015 e no 10.431, de 22 de dezembro de 2015 e estabelece condições de alteração de uso e dos parâmetros urbanísticos e alteração da adequabilidade das atividades e critérios para o cálculo do valor da contrapartida a ser prestada pelo beneficiário. (FORTALEZA, 2016. Minuta de Decreto).

A presidente da CPPD, Águeda Muniz, iniciou a reunião cumprimentando a todos e prosseguiu a pauta da reunião, acrescentou dizendo que esse mês terá uma reunião de CPPD extra que provavelmente acontecerá no dia 31 de março deste ano 
justamente para ter o critério a ser adotado quando aos parâmetros máximos a serem permitidos no processo de Outorga Onerosa, assim como a base de cálculos (FORTALEZA, 2016, p.2. Ata da 75a reunião da CPPD).

A citação acima corresponde ao primeiro parágrafo do relato da Ata da 75a reunião da CPPD, que tinha como pauta a discussão da Minuta de Decreto de Outorga Onerosa de Alteração do Uso do Solo. Além do fato da reunião da CPPD contar com a presença da secretária e a reunião ser aberta por ela, o que não é comum, o relato de sua fala apresenta dois pontos gravíssimos que serão melhor discutidos a seguir.

O primeiro corresponde à discussão de quais seriam os parâmetros máximos a serem permitidos no processo de Outorga Onerosa, o que é um absurdo, pois leis maiores já o definem. Em sua essência, a Outorga Onerosa do Direito de Construir incide sobre o índice de aproveitamento básico até o máximo disposto no plano diretor. Assim, não existem parâmetros máximos a serem discutidos. Existe um parâmetro, o I.A. máximo e não existe discussão, pois o I.A. máximo já está estabelecido no plano diretor. Na verdade, não deveria existir parâmetro nenhum, pois a Lei $10.335 / 2015$, sobre a qual incide o decreto analisado, trata da Outorga Onerosa de Alteração do Uso do Solo e não da do Direito de Construir, como debatido anteriormente.

O segundo ponto corresponde à base de cálculo para aplicação da Outorga. Outra incongruência, já que a forma de pagamento deveria ser definida em lei específica, como estabelecem o Estatuto da Cidade e o Plano Diretor do Município, não cabendo a um decreto cobrir essa função.

Assim, a partir de análise realizada pelo $L E H A B, A G B$ e do parecer elaborado por Henrique Frota (2016), do IBDU, é possível elencar diversos problemas observados no Decreto da Outorga Onerosa de Alteração do Uso do Solo, além dos dois destacados a princípio, dos quais apresentamos de forma resumida:

1. A Minuta do Decreto está embasada na Lei da Outorga Onerosa de Alteração do Uso do Solo (Lei 10.335/2015), que, como foi problematizado anteriormente, trata-se de uma lei com diversos vícios e irregularidades, a qual teve seu caráter de constitucionalidade negado por Frota (2016) e reiterado aqui nesta análise. 
2. A Minuta proposta apresenta matérias de lei que não poderiam ser definidas através de um decreto 216 :

a. Traz alterações de parâmetros e índices definidos no Plano Diretor. Permite inclusive a alteração do Índice de Aproveitamento até duas vezes acima do definido pelo Plano Diretor. Decretos não podem alterar o Plano Diretor. Isso é matéria de lei complementar, o que torna o decreto inconstitucional.

b. Trata de parcelamento do solo urbano, propondo remembramento, desmembramento e reloteamento nas áreas de interesse ambiental, o que é matéria privativa de lei, e altera o PDP.

c. Traz fórmula para cálculo do valor da contrapartida devida pelos empreendedores em troca da outorga de alteração de uso. Este conteúdo deveria ser tratado na lei específica do instrumento (Lei Municipal $\mathrm{n}$. 10.335/2015). Assim, além da violação do art. 30 do Estatuto da Cidade (Lei Federal 10.257/2001), por não trazer seu conteúdo mínimo ${ }^{217}$, o município traz a fórmula para cálculo dentro de um decreto, sendo isto matéria de lei, não de decreto.

3. O texto da Minuta aumenta o potencial construtivo e altera o uso do solo (altera o uso, aumenta o coeficiente de aproveitamento, a taxa de ocupação e o gabarito, e permite remembramento de lotes) em área de proteção ambiental e em toda a zona urbana do município. Assim, o decreto tenta permitir que áreas onde se deveria ter um controle da densidade, de construção e do tipo de uso, de modo a promover a recuperação ambiental, passem a ser alvo de grandes empreendimentos, que podem provocar um maior impacto ambiental.

4. Outro ponto é que os instrumentos que permitem a compra de potencial construtivo, como a outorga onerosa, não podem nunca ultrapassar o coeficiente de aproveitamento máximo estabelecido pelo plano diretor. Esse decreto, e a lei anterior da outorga onerosa, lei

\footnotetext{
216 Os Decretos Municipais são modalidades de regulamentos administrativos executivos e, como tais, destinam-se à fiel execução das leis. Seu conteúdo não pode contrariar ou ultrapassar os limites legais, devendo-se restringir a aspectos operacionais e de procedimentos (FROTA, 2016, p. 21).

${ }^{217}$ A lei municipal específica da outorga onerosa de alteração de uso deve prever as condições para aplicação do instrumento, contendo no mínimo: I - a fórmula de cálculo para a cobrança; II - os casos passíveis de isenção do pagamento da outorga; III - a contrapartida do beneficiário (Art. 30, Lei Federal no 10.257/2001) (FROTA, 2016, p. 21).
} 
10.335/2015, alteram o coeficiente construtivo acima do máximo estabelecido pelo plano diretor para o macrozoneamento urbano e para a Zona de Recuperação Ambiental - ZRA.

5. Vale também destacar que as áreas da cidade que podem ter esse instrumento aplicado, a outorga onerosa, devem ser identificadas pelo Plano Diretor. A lei que vem regulamentar esse instrumento deve fazer seguindo o Plano Diretor, deste modo, deve seguir a implementação do instrumento somente nas áreas apontadas pelo Plano Diretor. Porém, as leis 10.335/2015 e 10.431/2015 ampliam as áreas da cidade que podem ter esse instrumento aplicado, inclusive para áreas de proteção ambiental.

Para fechar esse ponto sobre a minuta, citamos abaixo um trecho do relato da fala de arquiteto da Coordenadoria de Desenvolvimento Urbano - COURB na reunião da CPPD, com a presença da Secretária do Conselho, discutindo o decreto, o qual faz parecer que estão, na verdade, discutindo o zoneamento de um novo plano diretor e não um decreto administrativo:

Sobre as Zonas de Proteção Ambiental, iniciamos pela ZIA da Praia do Futuro, novamente temos uso residencial, residencial multifamiliar, de acordo com a Via Arterial e demais vias. Nós estamos de alguma forma tentando estabelecer uma fração que também viabilize uma Outorga Onerosa, não tendo um grande impacto para a área, tendo em vista que essas áreas tem um aspecto ambiental muito forte, mas também que viabilize de alguma forma uma ocupação moderada, uma ocupação verticalizada. No uso do não residencial, proporcionamos usos que não estavam sendo possibilitados, seja pelo tipo de via, estamos possibilitando novos usos de acordo com a adequabilidade. Referente as áreas ambientais, permanece com a taxa de permeabilidade. No caso do uso para os do Futuro imóveis situados na ZIA da Praia e a parte do parcelamento, estamos possibilitando devido aos tamanhos de quadra; e essas quadras ainda estarem totalmente desocupadas uma possibilidade de novo reloteamento, remembramento, desmembramento para que as pessoas possam inserir equipamentos maiores, desde que respeitem a quadra máxima, lembrando que nessa necessidade possivelmente vamos ter desafetação de vias para possibilitar esses equipamentos.

Na Zona de Proteção Ambiental da ZIA da Sabiaguaba, estamos proporcionando o uso multifamiliar, uso residencial e não residencial, os não residenciais com as vias coletoras, também de acordo com adequabilidade de via, de acordo com as tabelas na LUOS, nos Anexos 8 e 9; e estamos na ZIA da Sabiaguaba vendo a possibilidade de remembramento e desmembramento da mesma forma, [...] estamos proporcionando para essa área até uma quadra superior aos $250 \mathrm{~m}^{2}$, desde que atendidas a todas as demandas ambientais e também passar pelo Conselho Gestor da Sabiaguaba - CGS.

Na Zona de Recuperação Ambiental [...] os índices até onde o máximo que seria índice 1 taxa de ocupação de 33 a 40 objeto de Outorga e altura máxima atual de todos os prédios, onde pode ir até no máximo $15 \mathrm{~m}$, estamos proporcionando $30 \mathrm{~m}$ com a Outorga Onerosa.

(FORTALEZA, 2016, p. 22 e 23. Ata da 75으 reunião da CPPD). 
Minuta de decreto de outorga onerosa de alteração de uso altera características essenciais da APA da Sabiaguaba ${ }^{218}$

[...] vamos imaginar a ZIA da Sabiaguaba que tem ainda grandes glebas que se quer foram loteadas, não foram objeto de loteamento, e que ali alguém queira implantar um resort, ou um grande hotel com campo de golf, pois tem ambiência para esse tipo de equipamento, estamos possibilitando que equipamentos como resorts ou algo diferenciado possam se instalar naquela área, estamos proporcionando para essa área até uma quadra superior aos $250 \mathrm{~m}^{2}$ [...] (FORTALEZA, 2016, p.23. Ata da 75o reunião da CPPD).

O território da Sabiaguaba está situado entre o Rio Cocó e o Rio Pacoti e, segundo o PDPFor, é composto por dois bairros: a Sabiaguaba, que corresponde a toda porção ao lado direito da Av. Sabiaguaba, e o bairro Edson Queiroz, que pega a porção mais próxima do Rio Cocó até a sua foz, lado esquerdo da pista Av. Sabiaguaba, antigamente também parte do primeiro bairro. Este território é inteiramente formado por zonas de proteção ambiental, incidindo sobre ele as três categorias definidas pelo PDPFor: 1) Zona de Preservação Ambiental, 2) Zona de Interesse Ambiental e 3) Zona de Recuperação Ambiental. A primeira corresponde à preservação permanente, não podendo, a princípio, ter construções e edificações em seu interior. As duas seguintes já permitem um maior uso e a presença de edificações, porém com restrições ao tipo de uso e aos parâmetros urbanísticos, como pode ser observado no Quadro 14.

Quadro 14. Definição, objetivos e instrumentos previstos pelo PDPFor para as Zonas de proteção ambiental ZIA e ZRA. Fonte: Fortaleza/PDPfor, 2009

\begin{tabular}{|c|c|c|c|}
\hline & Definição segundo o PDPfor & Objetivos segundo o PDPfor & Instrumentos previstos segundo o PDPFor \\
\hline ZIA & $\begin{array}{l}\text { Art. 72. A Zona de Interesse } \\
\text { Ambiental (ZIA) } \\
\text { corresponde às áreas } \\
\text { originalmente impróprias à } \\
\text { ocupação do ponto de vista } \\
\text { ambiental, áreas com } \\
\text { incidência de atributos } \\
\text { ambientais significativos em } \\
\text { que a ocupação ocorreu de } \\
\text { forma ambientalmente } \\
\text { inadequada. }\end{array}$ & $\begin{array}{l}\text { I - compatibilizar a conservação } \\
\text { dos sistemas ambientais com uso } \\
\text { sustentável dos recursos naturais; } \\
\text { II - qualificar os assentamentos } \\
\text { existentes, de forma a minimizar } \\
\text { os impactos decorrentes da } \\
\text { ocupação indevida do território } \\
\text { elevando os níveis da qualidade } \\
\text { ambiental; } \\
\text { III - disciplinar o processo de uso } \\
\text { e ocupação do solo; } \\
\text { IV - assegurar a sustentabilidade } \\
\text { dos recursos naturais; } \\
\text { V - regular o uso admissível } \\
\text { dessas áreas, de modo a } \\
\text { compatibilizar com os objetivos de } \\
\text { conservação da natureza; } \\
\text { VI - promover educação }\end{array}$ & $\begin{array}{l}\text { I - instrumentos de regularização } \\
\text { fundiária; } \\
\text { II - direito de preempção; } \\
\text { III - direito de superfície; } \\
\text { IV - estudo de impacto de vizinhança } \\
\text { (EIV); } \\
\text { V - estudo ambiental (EA). }\end{array}$ \\
\hline
\end{tabular}

${ }^{218}$ Texto original elaborado pela autora para relatório em parceria com outros autores sobre a Sabiaguaba. Relatório não publicado. 


\begin{tabular}{|c|c|c|c|}
\hline & & $\begin{array}{l}\text { ambiental; } \\
\text { VII - promover a regularização } \\
\text { fundiária, em especial nas áreas de } \\
\text { interesse social classificadas como } \\
\text { ZEIS, garantindo a qualidade } \\
\text { ambiental. }\end{array}$ & \\
\hline ZRA & $\begin{array}{l}\text { Art. 67. A Zona de } \\
\text { Recuperação Ambiental } \\
\text { (ZRA) compõe-se por áreas } \\
\text { parcialmente ocupadas e } \\
\text { com atributos ambientais } \\
\text { relevantes que sofreram } \\
\text { processo de degradação, e } \\
\text { tem como objetivo básico } \\
\text { proteger a diversidade } \\
\text { ecológica, disciplinar os } \\
\text { processos de ocupação do } \\
\text { solo, recuperar o ambiente } \\
\text { natural degradado e } \\
\text { assegurar a estabilidade do } \\
\text { uso dos recursos naturais, } \\
\text { buscando o equilíbrio } \\
\text { socioambiental. }\end{array}$ & $\begin{array}{l}\text { I - promover a conservação e } \\
\text { recuperação ambiental de áreas } \\
\text { indevidamente utilizadas e/ou } \\
\text { ocupadas; } \\
\text { II - qualificar os assentamentos } \\
\text { existentes, de forma a minimizar } \\
\text { os impactos decorrentes da } \\
\text { ocupação indevida do território } \\
\text { elevando os níveis da qualidade } \\
\text { ambiental; } \\
\text { III - controlar e disciplinar os } \\
\text { processos de uso e ocupação do } \\
\text { solo a fim de assegurar a } \\
\text { estabilidade do uso dos recursos } \\
\text { naturais; } \\
\text { IV - proteger ambientes naturais } \\
\text { onde se assegurem condições para } \\
\text { a existência ou reprodução de } \\
\text { espécies ou comunidades da flora } \\
\text { e da fauna local; } \\
\text { V - promover a regularização } \\
\text { fundiária nas áreas ocupadas pela } \\
\text { população de baixa renda, } \\
\text { definidas como ZEIS; } \\
\text { VI - promover a recuperação } \\
\text { ambiental de terras ocupadas } \\
\text { irregularmente mediante Termo } \\
\text { de Compromisso. }\end{array}$ & $\begin{array}{l}\text { II lianos de gestão; } \\
\text { II - direito de superfície; } \\
\text { IV - estudo de impacto de vizinhança } \\
\text { (EIV); } \\
\text { V - direito de preempção; } \\
\text { VI - instrumentos de regularização } \\
\text { fundiária; } \\
\text { VII - transferência do direito de construir. }\end{array}$ \\
\hline
\end{tabular}

Fonte: FORTALEZA/PDP, 2009. Organização própria.

A este cenário de proteção, soma-se duas unidades de conservação do sistema SNUC (Lei Federal n. 9.985/2000), criadas antes da aprovação do PDPFor. A primeira corresponde ao Parque Natural Municipal das Dunas de Sabiaguaba - PNMDS (decreto 11.986/2006) e a segunda, à área de Proteção da Sabiaguaba - APA da Sabiaguaba (decreto 11.987/2006). Sobre as Unidades de Conservação, vale destacar que:

“[...] as unidades de conservação sobrepõem-se ao zoneamento urbano, sendo plenamente possível que alterem as normas definidoras do direito de construir constantes na legislação municipal. Assim, ao serem criados, o Parque Natural Municipal das Dunas e a Área de Proteção Ambiental da Sabiaguaba modificaram imediatamente a regulação do uso do solo urbano na região, sobrepondo-se ao Plano Diretor de Desenvolvimento Urbano e à Lei de Uso e Ocupação do Solo, então vigentes (PLANO DE MANEJO, 2010, p. 216). 
Figura 85. APA da Sabiaguaba e Zoneamento Ambiental segundo PDP 2009

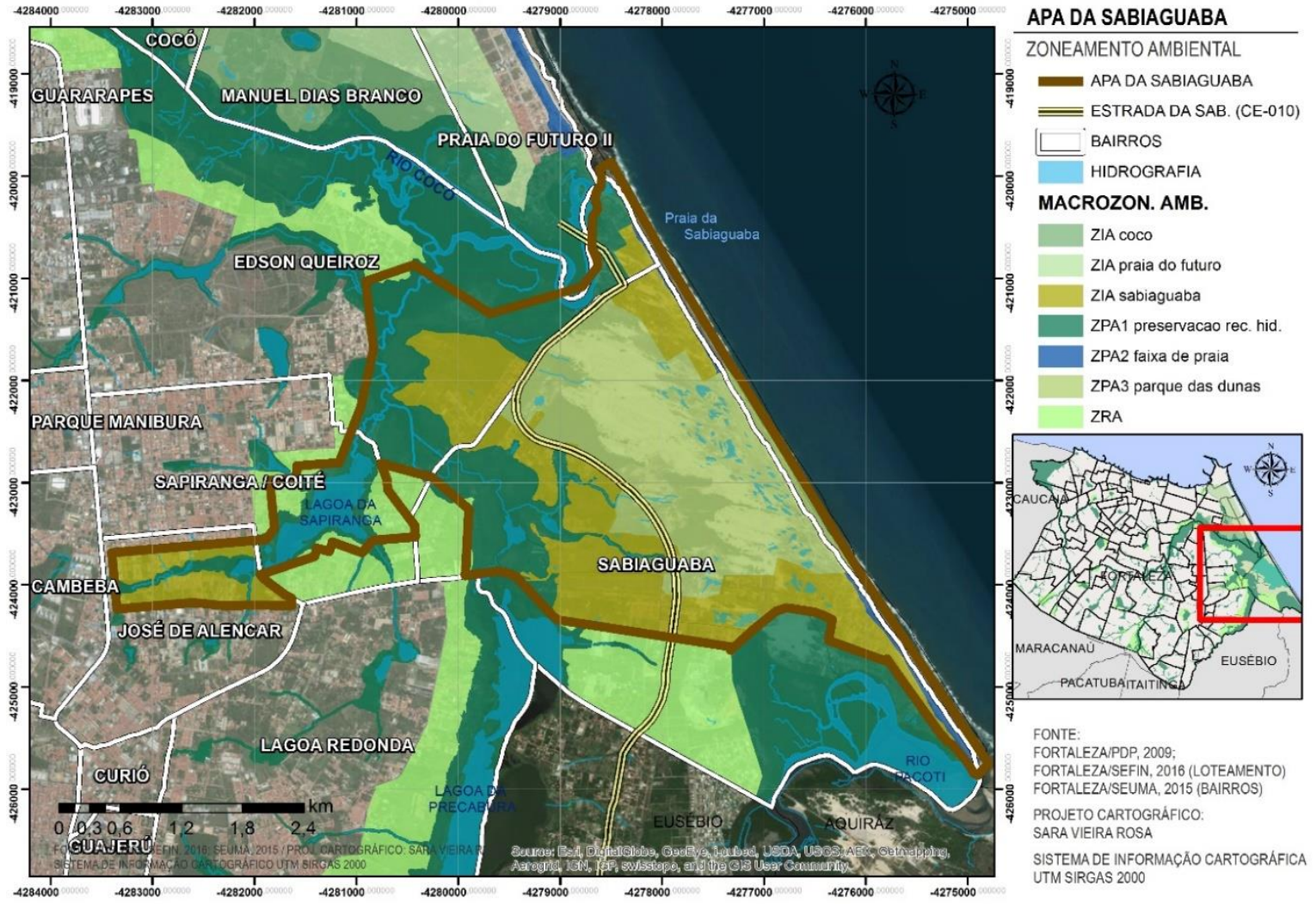

Fonte: FORTALEZA, 2009/PDP. Elaboração Sara V. Rosa

O plano de manejo da APA da Sabiaguaba e do PNMDS considera que o PDPFor de 2009 contempla essas duas unidades de conservação e propõe parâmetros urbanísticos já adequados para a mesmas, ao delimitar as Zonas de Preservação Ambiental (ZPA) e Zonas de Interesse Ambiental (ZIA) da Sabiaguaba. Assim, o Plano de manejo estabelece que os parâmetros urbanísticos para estas áreas da APA e PNMDS devem seguir os já estabelecidos no PDPFor.

Assim sendo, uma vez que o PDPFor não coloca a outorga como um instrumento previsto para as zonas de proteção ambiental, entende-se, a partir do que já foi comentado, que a aplicação desse instrumento e a alteração de parâmetros definidos na lei, em 2009, para estas áreas, é indevida e inconstitucional, mesmo que por meio de lei e menos ainda por meio de decreto.

Especificamente para a Zona de Recuperação Ambiental, a minuta coloca:

Minuta de decreto municipal de outorga onerosa de alteração do uso do solo Art. $10 \mathrm{Na}$ Zona de Recuperação Ambiental - ZRA:

$\S 1$ 을 Admite-se o uso Residencial Multifamiliar, nas condições estabelecidas pelo Artigo 2으, Parágrafo 60 da Lei no 10.431/2015;

I - será admitida a alteração dos seguintes parâmetros de ocupação: 
a) índice de aproveitamento máximo: de 0,6 a 1,0;

b) taxa de ocupação: de $33 \%$ a $40 \%$;

c) taxa de ocupação do subsolo: de $33 \%$ a $40 \%$;

d) altura máxima da edificação: de 15,00m (quinze metros) a 30,00m (trinta metros).

II - será considerada a área do lote mínimo de $300 \mathrm{~m}^{2}$ (trezentos metros quadrados), que corresponderá a Fração do Lote.

III - deverá ser respeitada a taxa de permeabilidade estabelecida na Lei Municipal n062/2009 (PDP);

IV - será admitida a construção de apenas um pavimento subsolo.

$\S 2$ Para os usos não residenciais, classificados como Projetos Especiais, autoriza-se o uso da Outorga Onerosa de Alteração do Uso do Solo:

I - em Vias Locais, admitindo-se as atividades adequadas, de acordo com o Anexo 8 e 9 da Lei no 7.987/1996 (LUOS) para Vias Locais;

II - em Vias Coletoras, admitindo-se as atividades adequadas, de acordo com o Anexo 8 e 9 da Lei no 7.987/1996 (LUOS) para Vias Coletoras.

Já para a Zona de Interesse Ambiental da Sabiaguaba, o texto da minuta afirma que mudança nos parâmetros urbanísticos não serão permitidas, todavia permite, além da alteração de uso, o remembramento, desmembramento e o reloteamento, com tamanhos de quadras superiores ao máximo permitido pela LUOS vigente à época (Lei de Uso e Ocupação do Solo lei 7.987/1996).

Minuta de decreto municipal de outorga onerosa de alteração do uso do solo

Art. 7ํ Na Zona de Proteção Ambiental ZIA - Sabiaguaba:

§1 Para os usos não residenciais classificados como Projetos Especiais, autoriza-se o uso da Outorga Onerosa de Alteração do Uso do Solo desde que a proposta do empreendimento seja analisada e aprovada pelo Conselho Gestor da Sabiaguaba CGS:

I - em Vias Locais, admitindo-se as atividades adequadas, de acordo com os Anexos 8 e 9 da Lei no 7.987/1996 (LUOS) para Vias Locais;

II - em Vias Coletoras, admitindo-se as atividades adequadas, de acordo com os Anexos 8 e 9 da Lei no 7.987/1996 (LUOS) para Vias Coletoras.

III - não será admitida a alteração dos parâmetros urbanísticos.

Art. 8ㅇ Para os imóveis situados na ZIA - Sabiaguaba, será avaliada a possibilidade do remembramento, desmembramento e reloteamento, admitindo-se dimensões superiores à quadra máxima prevista na Lei no 7.987/1996 (LUOS), desde que a proposta do empreendimento seja analisada e aprovada pelo Conselho Gestor da Sabiaguaba - CGS.

Deste modo, com relação à Sabiaguaba, a minuta prevê a alteração dos parâmetros urbanísticos previstos para a ZRA, incluindo o aumento do coeficiente máximo estabelecido 
no Plano Diretor de Fortaleza, violando, assim, a legislação. Também extrapola a competência do ato normativo (decreto) ao tratar de remembramento, desmembramento e reloteamento.

Não bastasse considerar a possibilidade do remembramento, desmembramento e reloteamento para ZIA, e através de decreto, a minuta o faz considerando que o valor máximo da quadra pode ultrapassar o valor máximo estabelecido na Lei de Uso e Ocupação do Solo. Assim, o município desconsidera a legislação existente e abre a possibilidade para a implantação de equipamentos de grande porte que ocupem grandes extensões e que, por sua vez, são considerados de maior impacto, onde não existe limite de quadra e este poderá ser negociado entre o município e o empreendedor.

Uma vez classificado como projeto especial, passa a valer quase todo tipo de empreendimento, incluindo de hotéis a atividades mineradoras e insalubres, como aterros, a depender de análise do município.

Por último, além das irregularidades apontadas acima, é importante destacar os diferentes interesses que estão em jogo. Essa minuta de decreto aumenta o potencial construtivo e altera o uso do solo de áreas protegidas das dunas da Praia do Futuro e da APA da Sabiaguaba para empreendimentos do setor imobiliário. Ao mesmo tempo, é prevista a retirada de famílias pobres da área que foi definida como limite do Parque do Cocó, sem qualquer projeto para o reassentamento destas. Algumas destas famílias vivem nestas áreas há várias gerações, com grande vínculo com o Rio Cocó, como a pesca, e dificilmente serão reassentadas no padrão de casas unifamiliares térreas dentro da APA, onde o lote mínimo exigido é de $300 \mathrm{~m}^{2}$. Então o discurso ambiental passa a ser válido como justificativa para retirada de populações mais pobres, mas não é justificativa para retirada nem impedimento de chegada das populações mais ricas, como destacado anteriormente na fala de servidor da prefeitura, onde fica claro qual o tipo de perfil de morador a que se quer destinar a área "[...] vamos imaginar a ZIA da Sabiaguaba [...] e que ali alguém queira implantar um resort, ou um grande hotel com campo de golf, pois tem ambiência para esse tipo de equipamento [...](FORTALEZA, 2016, p.23. Ata da 75 reunião da CPPD). 
Figura 86. Vista da CE 010 em construção, sentido Sabiaguaba-Eusébio.

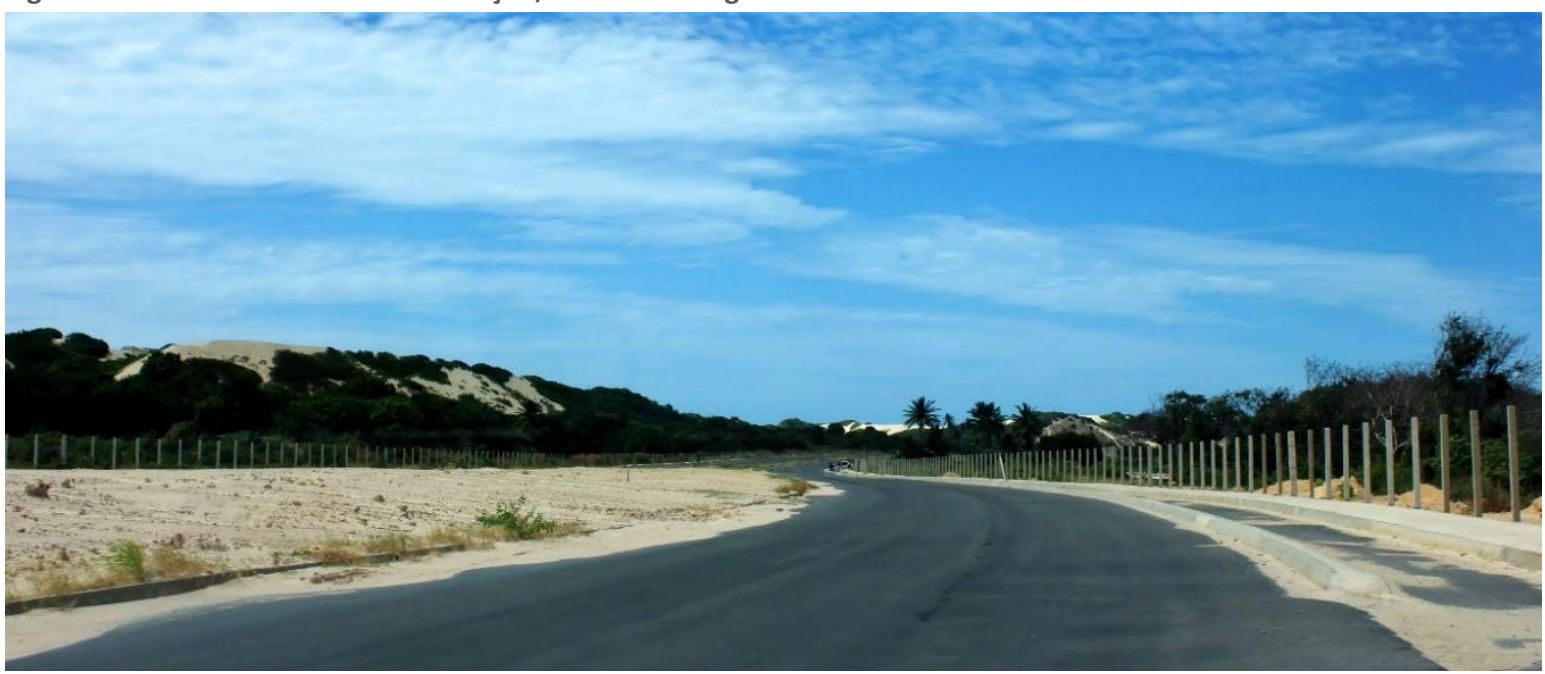

Foto: Sara V. Rosa, 2016. Foto tirada no dia 03 de set 2016.Local: CE 010 (estrada da Sabiaguaba em construção), faixa da direita sentido Sabiaguaba-Eusébio. A esquerda, Parque das Dunas da Sabiaguaba, canteiro central (areia), faixa da direita.

Figura 87. Vista de terrenos a venda dentro do Parque das Dunas da Sabiaguaba cortado pela CE 010

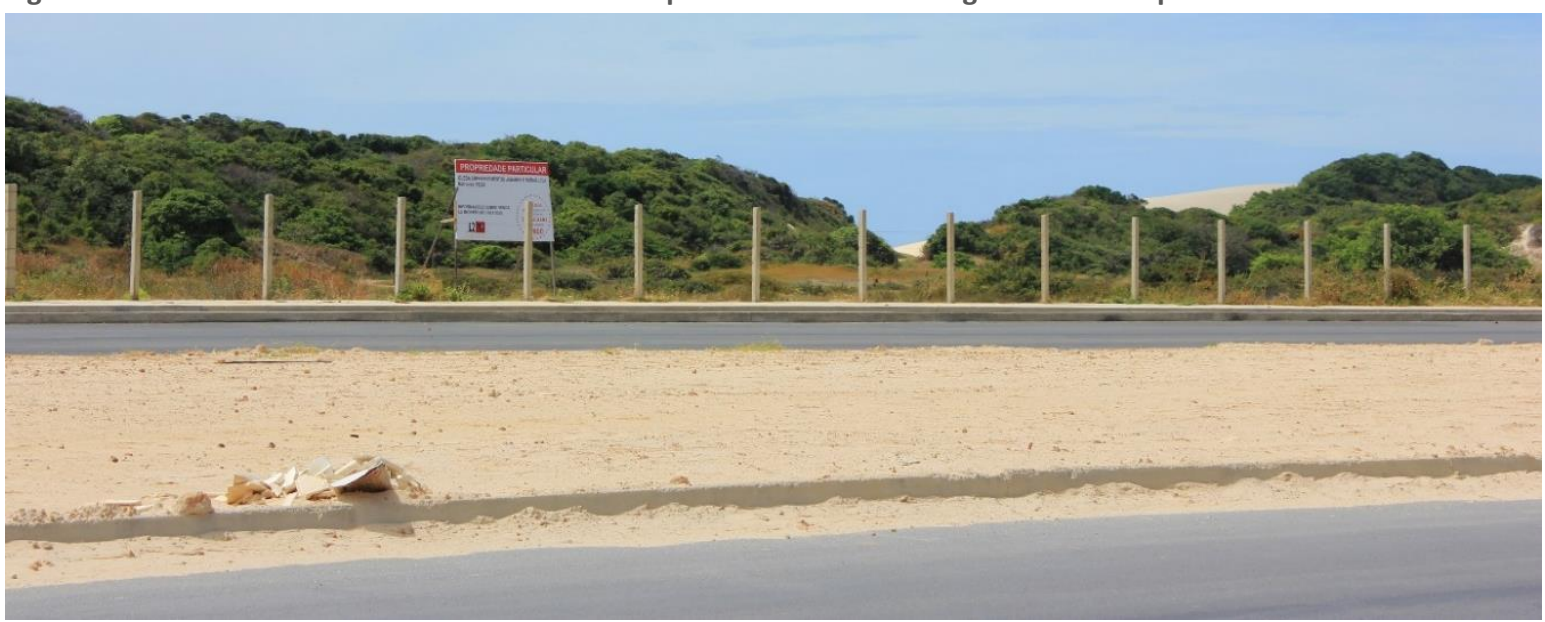

Foto: Sara V. Rosa, 2016. Foto tirada no dia 03 de set 2016. Local: CE 010 (estrada da Sabiaguaba em construção). Ao fundo parte do Parque das Dunas da Sabiaguaba com Placa indicando que o terreno é propriedade privada e telefone de contato para venda ("Gleba Empreendimentos Urbanos e Rurais LTDA. Informações sobre venda: L2 imóveis")

Figura 88. Ocupações recentes na beira da CE 010 em construção.

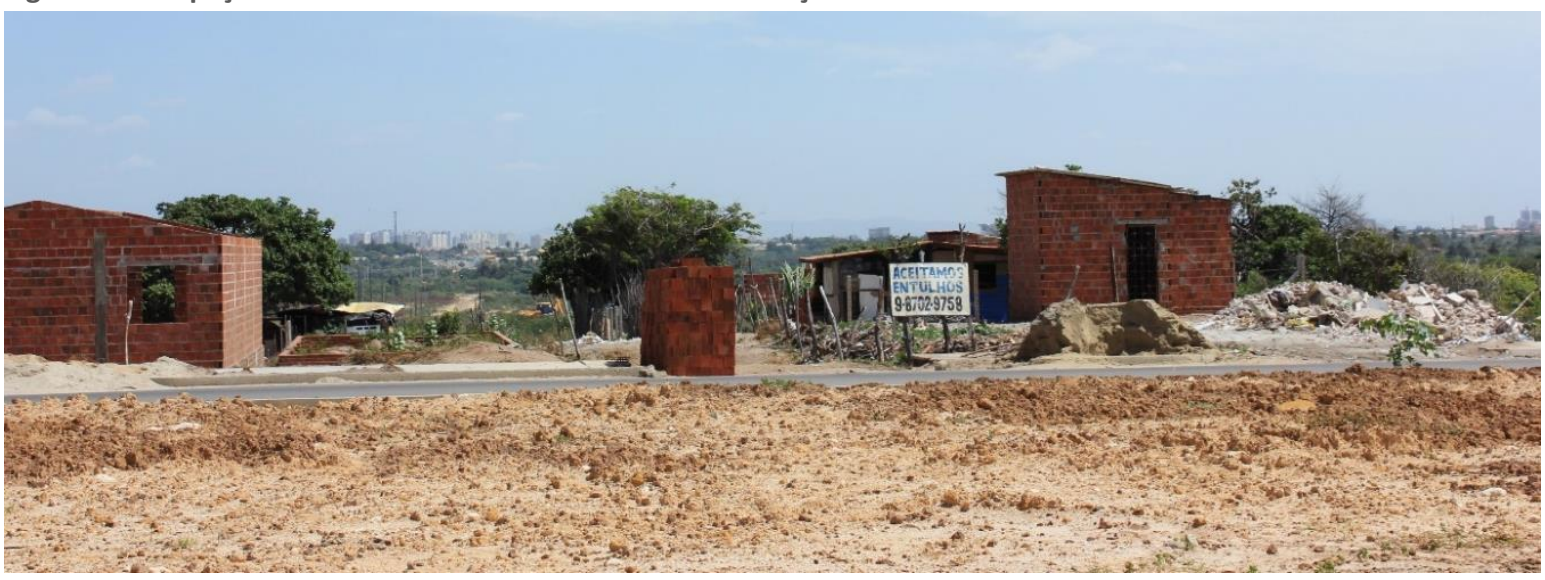

Foto: Sara V. Rosa, 2016. Foto tirada no dia 03 de set 2016. Local: beira da CE 010 mostrando uma das ocupações recentes da área. 
Figura 89. Vista de parte do Parque das Dunas da Sabiaguaba da CE 010.

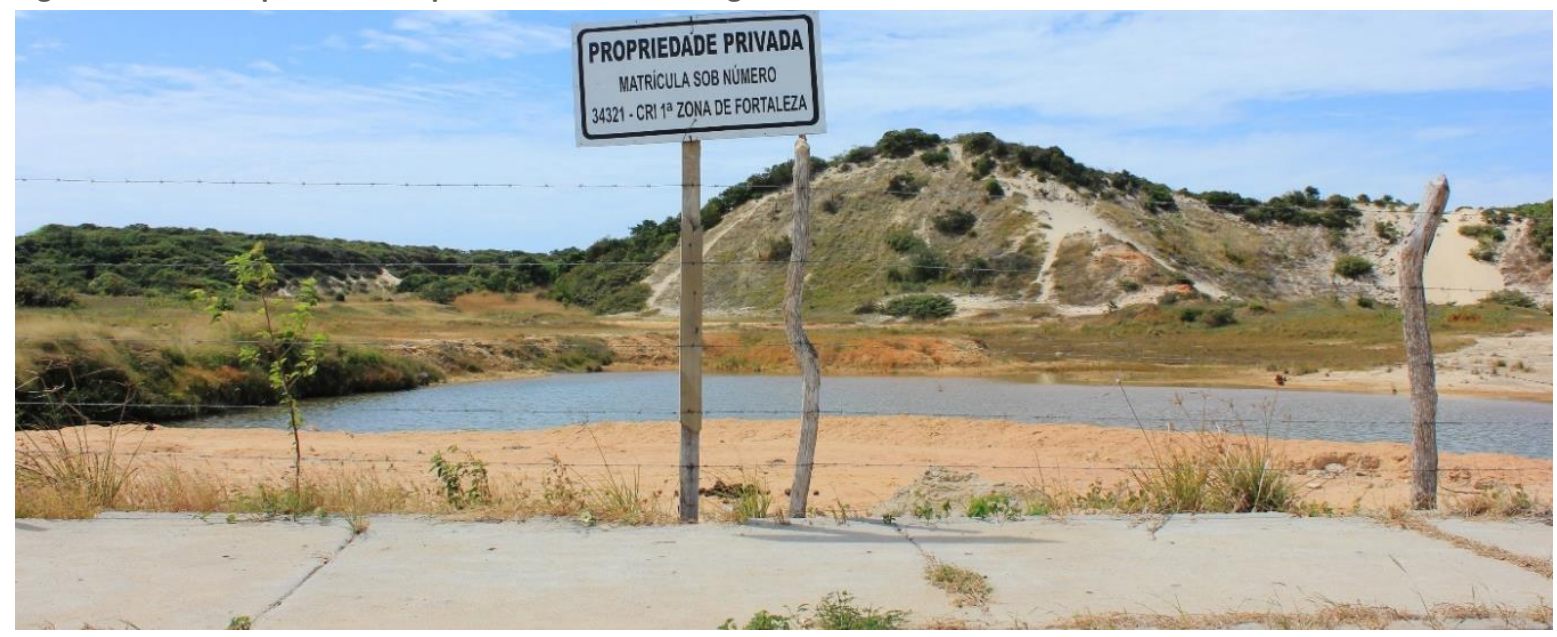

Foto: Sara V. Rosa, 2016. Foto tirada no dia 03 de set 2016. Local: beira da CE 010 (estrada da Sabiaguaba em construção) olhando para parte do Parque das Dunas da Sabiaguaba.

Em 2017 o município transformou a minuta do decreto que ampliava e flexibilizava o uso da Outorga em projeto de Lei enviado à Câmara. 
EVOLUÇÃO DA LIBERAÇÃO DE VENDA DE I.A. POR MEIO DE OUTROGA ONEROSA A PARTIR DA REGULAMENTAÇÃO DE FORTALEZA

ONDE REALMENTE É POSSÍVEL

A COMPRA DE I.A POR MEIO

DE OUTORGA DE ACORDO

COM O PDP E ESTATUTO

ZOP2, ZOM1, ZOM2

ONDE O MUNICÍPIO LIBEROU

PARA ACOMPRA DE I.A. POR

MEIO DE OUTORGA COM A

LC 10.335/2015

ZOP2, ZOM1, ZOM2 +

ZOP1, COC, ZRU2, ZO

ONDE O MUNICÍPIO LIBEROU

PARA ACOMPRA DE I.A. POR

MEIO DE OUTORGA COM A

LC $10.335 / 2015$ + LC 10.431/2015

ZOP2, ZOM1, ZOM2 +

ZOP1, COC, ZRU2, ZO +

ZRA, ZIA

ONDE O MUNICÍPIO PASSARÁ

A LIBERAR A COMPRA DE I.A.

POR MEIO DE OUTORGA COM

A APROVAÇÃO DO PROJETO DE

LEI QUE JÁ ESTÁ NA CÂMARA

ZOP2, ZOM1, ZOM2 +

ZOP1, ZOC, ZRU2, ZO +

ZRA, ZIA +

ZRU1, ZOR

(TODO O ZONEAMENTO COM

EXCEÇÃO DA ZPA)
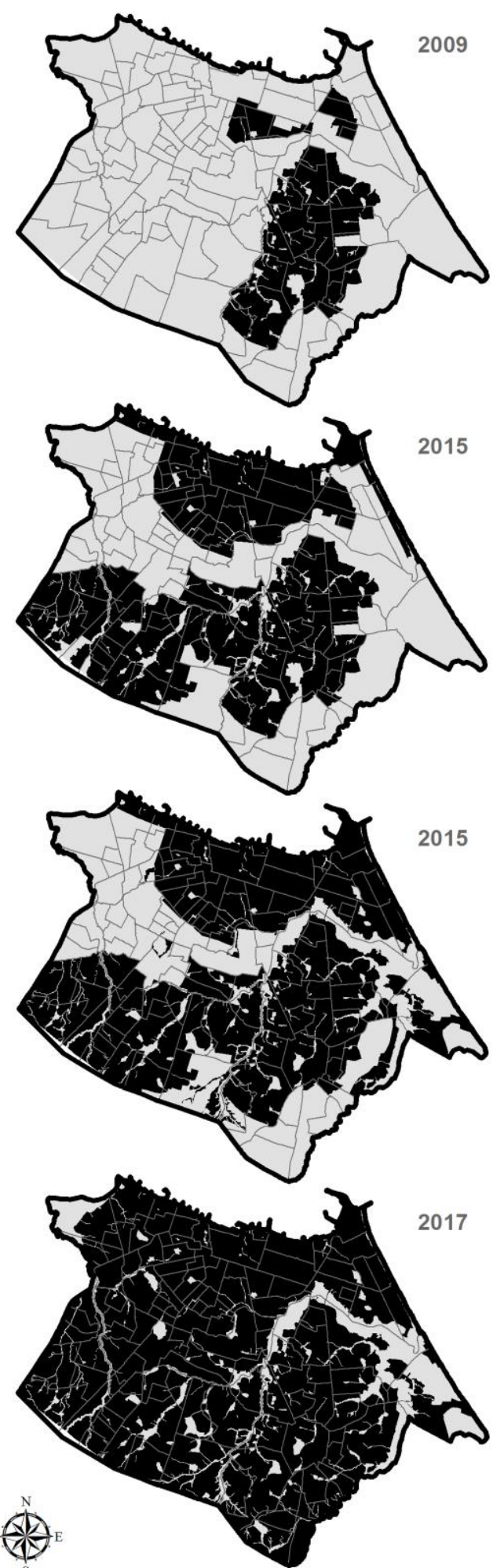

SISTEMA DE PROJEÇÃO GEOGRÁFICA UTM SIRGAS 2000

SISTEMA DE PROJEÇAO GEOGRAFICA UTM SIRGAS 2000
FONTE: FORTALEZA/PDP (2009); FORTALEZA/LEI 10.335 E 10.431 (2015); FORTALEZA/PL OUTORGA(2017)

ELABORAĈ́O: 


\subsection{AS NOVAS OPERAÇÕES URBANAS: A CIDADE COMO UMA GRANDE OPERAÇÃO URBANA}

A gestão do atual prefeito, Roberto Cláudio (PDT), pagou duas consultorias que envolviam OUC. Uma delas foi a elaboração do Plano Fortaleza 2040, que prevê OUCs, e a outra foi a empresa Quanta Consultoria LTDA, contratada especificamente para desenvolver propostas de OUCs. O recurso da contratação da empresa Quanta está inserida dentro do Programa Fortaleza Sustentável (PFCS), que tem financiamento internacional do Banco Internacional para Reconstrução e Desenvolvimento (BIRD) de setenta e três milhões de reais. Tanto as OUCs propostas pelo 2040 como as propostas pela Quanta foram reunidas com outras propostas de PPPs em um programa chamado Fortaleza Competitiva, divulgado em $2017^{219}$.

No caso da consultoria específica para o desenvolvimento de propostas de OUCs, o município destinou uma rubrica de $\mathrm{R} \$ 1.660 .000,00$ (um milhão e seiscentos e sessenta mil reais), dos quais $\mathrm{R} \$ 1.140 .000,00$ (um milhão cento e quarenta mil reais) só para a consultoria, para identificar novas OUCs, sendo o restante para contratação de consultores específicos para acompanhar a implementação de OUCs ${ }^{220}$. Neste mesmo pacote, estava destinado também um montante de $\mathrm{R} \$ 1.050 .000,00$ (um milhão e cinquenta mil reais) a consultoria para elaboração de estudos para avaliação de instrumentos urbanísticos para ampliação da receita municipal.

Podemos perceber que o aumento dos gastos públicos não é somente com a infraestrutura ou com os financiamentos de fundo público para essas operações e empreendimentos privados. Há também um investimento gigantesco tanto do corpo técnico do Estado que é mobilizado para desenvolver análises e leis específicas para atender a demandas específicas

\footnotetext{
219 Informações sobre o valor do empréstimo para PFCS retiradas de apresentação "Fortaleza Cidade Sustentável" feita pela prefeitura municipal de Fortaleza em 2017.

220 O projeto FCS possui um componente intitulado "Governança, Planejamento e Gestão Urbana e Ambiental" o qual possui dois subcomponentes: 1) Instrumentos de Planejamento e Controle Urbano e Ambiental; 2) Oportunidades de Negócios Urbanos. Os quais incluem a revisão e/ou regulamentação do Plano Diretor no primeiro, e Identificação, desenvolvimento, estruturação e implementação de OUCs no segundo. Dentro do total dos empréstimos do Programa são, dentre outras, as seguintes rubricas: Consultoria para avaliação e estudo de instrumentos urbanos para ampliação da receita do município: \$ 328.125,00; Consultoria para identificação das potencialidades das OUCs: US\$356.250,00 (R\$1.140.000,00); Consultor para acompanhamento da elaboração e implementação da OUC (urbanista): US\$60.000,00 (R\$192.000,00); Consultor para acompanhamento da elaboração e implementação da OUC (advogado): US\$52.500,00 (R\$168.000,00); Consultor para acompanhamento da elaboração e implementação da OUC (mercado imobiliário): US\$52.500,00 (R\$168.000,00). O Programa FCS tem a previsão de um orçamento de $\mathrm{R} \$ 146.600 .000,00$, sendo metade, $R \$ 73.300 .000,00$, empréstimo do BIRD, e a outra metade contrapartida do município (FORTALEZA, 2017).
} 
do capital imobiliário, como também há um outro montante de investimento em consultorias para realização de análises dessas áreas e para a construção do novo marco regulatório em si, para reestruturação regulatória urbana, como os estudos dos instrumentos urbanos.

Figura 90. Operações Urbanas Consorciadas aprovadas e propostas em Fortaleza

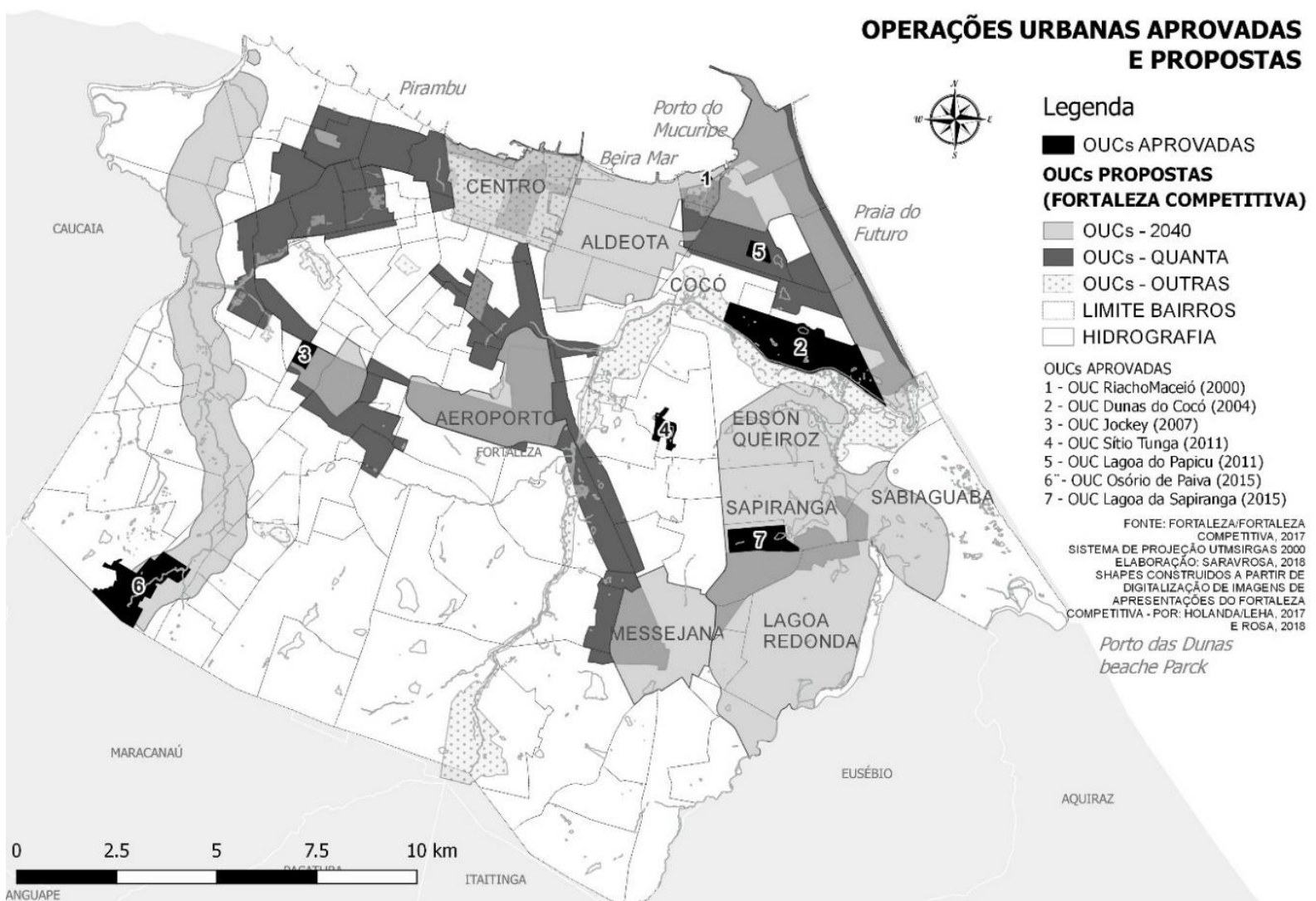

Fonte: Fortaleza Competitiva (FORTALEZA. 2017). Elaboração: Rosa (2018) a partir da digitalização das imagens do Fortaleza competitiva e digitalizações previas de Holanda/Lehab (2017).

As propostas de novas OUCs reunidas no Fortaleza Competitiva, juntamente com as 7 (sete) OUCs já aprovadas no município, retirando todas as sobreposições, totalizam mais de $170 \mathrm{~km}^{2}$ (aproximadamente metade do município). As novas OUCs propostas, diferente das aprovadas, são de grande porte, em muitos casos envolvendo vários bairros. Muitas delas continuam como as primeiras, associadas a recursos hídricos e sobre o macrozoneamento ambiental dos municípios, das quais podemos destacar do lado oeste da cidade a proposta de OUC para o Rio Maranguapinho, que recentemente recebeu a obra, ainda não finalizada, de urbanização do rio pelo Governo do Estado. Do lado leste, temos outra grande OUC proposta para o Rio Cocó, correspondente aos limites da recente Unidade de Conservação demarcada pelo Estado, o Parque do Cocó. A demarcação desta OUC é uma completa incógnita, pois toda sua poligonal corresponde à área de preservação permanente não restando, teoricamente e legalmente, áreas para intervenção e investimento do mercado imobiliário. Ainda no lado 
leste da cidade, temos outras propostas de OUC associadas a recursos naturais, como a do Riacho Maceió 2; as OUCs associadas à faixa de praia e dunas do Porto do Mucuripe e Praia do Futuro; a da Messejana que abrange o bairro inteiro, incorporando a Lagoa da Messejana, localizada no centro deste; e a OUC da Sabiaguaba, que incorpora a OUC já aprovada da Lagoa da Sapiranga e, apesar de englobar quase completamente os bairros Edson Queiroz, Sapiranga, José de Alencar e Lagoa Redonda, recebe o nome da Unidade de Conservação da APA da Sabiaguaba.

Recentemente, os produtos entregues pela Quanta consultoria foram disponibilizados no site da SEUMA (Secretaria de Urbanismo e Meio Ambiente de Fortaleza) e incluem a formulação de minutas de lei para seis OUCs escolhidas como prioritárias: OUC Centro-Oeste, OUC Eduardo Girão, OUC Litoral Central, OUC Maceió-Papicu, OUC Raquel de Queiroz, OUC LesteOeste. Assim como as OUCs já aprovadas, as novas trazem como proposta também a flexibilização dos parâmetros urbanísticos, incluindo o aumento de potencial construtivo e gabarito, e mudanças no zoneamento ambiental. Todavia, destaca-se que agora o porte dessas operações é expressivamente maior que o das primeiras.

Destas OUCs propostas, o município selecionou seis como operações prioritárias e para cada uma foi elaborado uma minuta de lei. As seis OUCs escolhidas foram a OUC Litoral Central, OUC Raquel de Queiroz, OUC Centro Oeste, OUC Eduardo Girão, e OUC Maceió-Papicu. Em todas estas há a presença também de recursos hídricos ou faixa de praia.

As estratégias de desregulamentação regulamentada permanecem trazendo novas flexibilizações para áreas de proteção e preservação, assim como estratégias de criação de natureza (fictícia) a imagem de uma natureza primeira. Na OUC litoral Central, por exemplo, há a supressão da Zona de Preservação Ambiental (ZPA) da faixa de praia, que passa de uma área não edificante a uma área com potencial construtivo de até cinco vezes a área do terreno. (I.A. = 5).

Já na OUC Eduardo Girão, existe por exemplo, proposta de empreendimento imobiliário vinculado a criação de lagoa artificial, próxima a antiga lagoa do Tauape, já soterrada pela ocupação urbana. Neste caso haveria a produção de uma natureza fictícia. Neste caso, como há produção, a valorização é real, e, é gerada pelo trabalho, não pela natureza em si, mas o fetiche da mercadoria nos faz enxergar somente a mercadoria e perdemos o processo de 
criação desta, fruto do trabalho humano. Então ao olho de quem vê a OUC, o valor adicional de um imóvel aí aparenta ser por conta do lago e das árvores, da área de lazer criada. Por conta do fetiche, enxergamos que a valorização gerada aí vem da natureza, mas sempre esteve na exploração do trabalho humano. Importante destacar que nesse caso em específico, o empreendimento proposto é em terreno público, do Batalhão do exército.

Em todos esses terrenos, aproximadamente metade do território do município, a simples oficialização da proposta de Operações Urbanas Consorciadas, mesmo ainda sem Lei aprovada, e sem implementação das propostas, já desencadeia um processo de valorização fictícia dos empreendimentos existentes, dos terrenos, e por sua vez, dos empreendimentos futuros. Elevando ainda mais o preço de monopólio da terra e da moradia, intensidicando os processos de desigualdade e segregação já existentes em Fortaleza.

Figura 91. Operações urbanas selecionadas pelo município como prioritárias

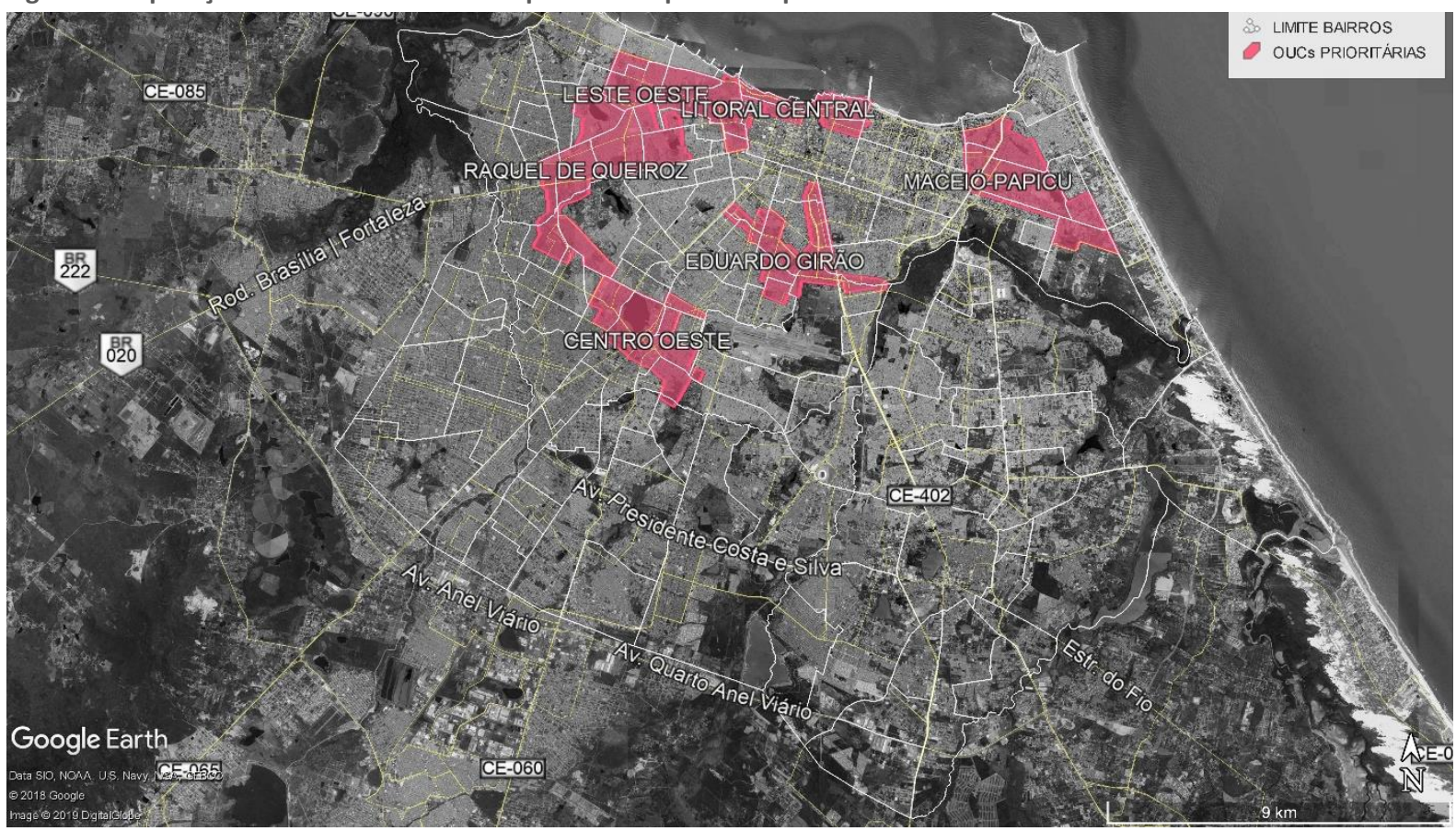

Elaboração: Sara V. Rosa, 2019. Fonte: Fortaleza/SEUMA, 2018 - KMZ "novas oportunidades de negócios". Software: googleEarth.

Figura 92. Ideia de OUC para área do 23 batalhão, ReCS Architects. Cliente: sinduscon

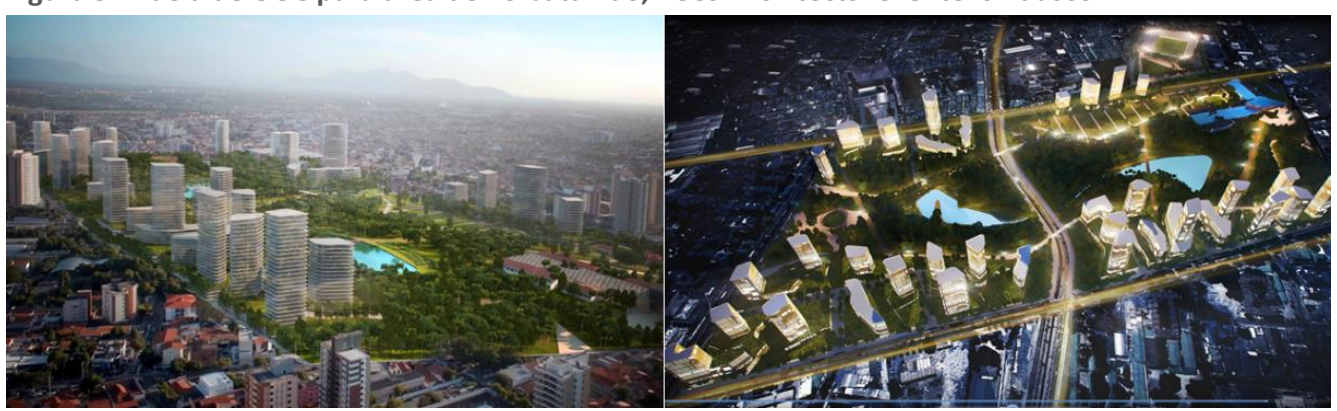

Fonte: http://www.recsarchitects.com/portfolio/parque-general-sampaio-masterplan/ 


\section{A VENDA DE IMÓVEIS TERRITORIAIS E PREDIAIS EM ÁREAS DE PROTEÇÃO E PRESERVAÇÃO AMBIENTAL EM FORTALEZA}

Como explicado na introdução, a identificação e análise da comercialização de imóveis dentro de áreas de proteção e preservação ambiental de Fortaleza foi realizada a partir da sistematização da base de dados do Imposto de Transferência de Bens e Imóveis (ITBI) ${ }^{221}$ obtida junto a Secretaria Municipal de Finanças de Fortaleza (SEFIN), para os anos de 2009 a setembro de 2016. Estes dados foram espacializados em mapas georeferenciados com o zoneamento do município e posteriormente separados por zonas, a partir daí, foram quantificados de acordo com as zonas do macrozoneamento ambiental (ZPA, ZIA, ZRA) e de acordo com algumas das informações contidas na base de dados originais (ano, bairro, tipo de imóvel - predial e territorial, padrão da edificação).

Deste modo, foi possível observar que, de fato, no município, vem sendo realizada a comercialização de imóveis dentro de áreas de proteção e de preservação ambiental, incluindo imóveis prediais dentro de ZPA (Zona de Preservação Ambiental). Foram realizados ao todo 7.547 cobranças de ITBI dentro de ZIA, ZRA e ZAP, das quais 1.206 só nesta última, sendo 728 prediais (Tabela 4) entre os anos de 2009 a setembro de 2016. Caso que pode ser apontado como um contrassenso, já que a prefeitura deveria estar inibindo e desapropriando construções nestas áreas destinadas à preservação dos ecossistemas e dos recursos naturais, e onde edificações não são permitidas ${ }^{222}$. Sendo possível observar inclusive a cobrança de imposto em imóvel edificado em fase de construção dentro da ZPA (Tabela 5).

Ao localizar esses imóveis, observa-se uma maior intensidade nas áreas de proteção ambiental do município do setor leste da cidade, área de maior crescimento do mercado imobiliário nas últimas décadas ${ }^{223}$ e também a área que concentra maior parte das áreas protegidas da cidade (Figura 94). Este fato pode ser uma das explicações para as crescentes alterações e tentativas

\footnotetext{
221 Base de dados da Secretaria Municipal de Finanças (SEFIN) do município de Fortaleza.

222 A cobrança de imposto de imóveis prediais em áreas de ZPA pode apontar para o fato da prefeitura ter ciência destes e de sua comercialização em áreas da cidade em que é proibida e edificação, mas termina por legitimar a presença destes.

$223 \mathrm{O}$ vetor da avenida Washington Soares tem concentrado grandes investimentos do mercado imobiliário principalmente voltados para classes média e alta. Essas observações foram constatadas também ao longo de pesquisas desenvolvidas junto ao professor Renato Pequeno desde 2008. Estas áreas apresentam ainda hoje grandes terrenos vazios cujos donos aguardam maior capitalização para investir.
} 
de alterações do marco legal urbano e ambiental do município e das flexibilizações pontuais através de operações urbanas consorciadas e aplicação de outorgas onerosas.

Estes registros do ITBI concentram-se principalmente nos anos de 2010 a 2013, período onde, apesar da crise econômica mundial, foi observado no Brasil um aquecimento do mercado imobiliário, parte, devido à injeção de subsídios pelo governo federal a partir do programa MCMV (Programa Minha Casa Minha Vida). Exceção feita aos ITBIs cobrados dentro da Zona de Preservação Ambiental (ZPA), com um maior número de registros entre 2014 e 2015. Aqui, cabe uma reflexão e investigação mais aprofundadas a posteriori dos motivos do aumento de cobranças de ITBI em ZPAs. Estará relacionado com a postura da atual gestão? Uma maior influência do neoliberalismo? Maior capacidade de registro da informação e cobrança de impostos? Crescente aumento da mercantilização destas áreas?

Figura 93

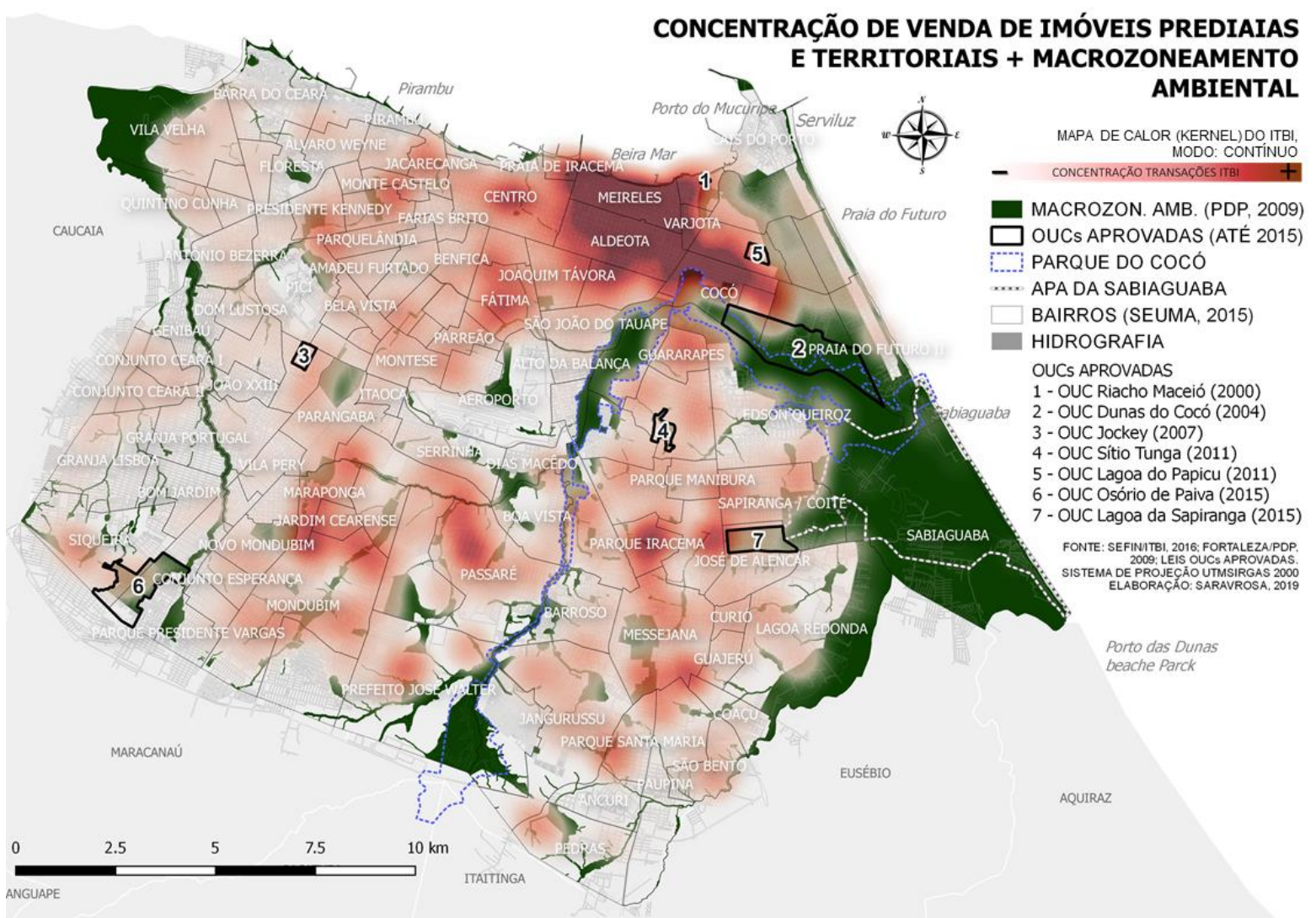

Elaboração: Rosa, 2018. Fonte: dados ITBI SEFIN, referentes aos anos 2009 a março de 2016. 
Figura 94. Cruzamento do zoneamento ambiental do PDP de Fortaleza com o número de registro de vendas de imóveis prediais e territoriais que deram entrada no ITBI entre os períodos de 2009 a setembro de 2016.

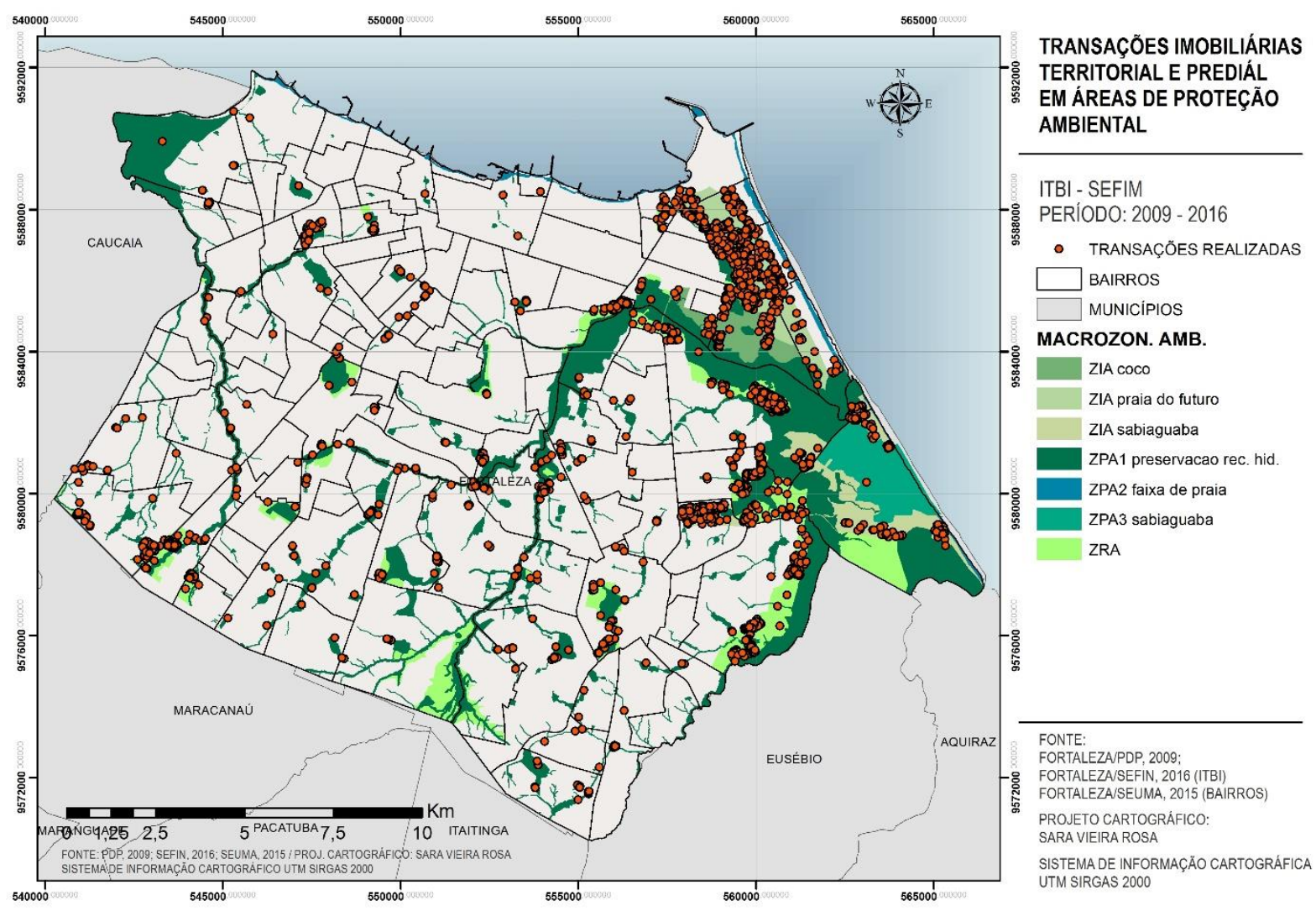

Fonte: SEFIN/ITBI, FORTALEZA/PDP, 2009. Elaborado por Sara Vieira Rosa, 2016.

Tabela 3. Total de imóveis registrados no ITBI dentro das zonas ambientais de Fortaleza, por ano de registro.

\begin{tabular}{lrrrrrrrrr} 
ZONA PDP2009 & $\mathbf{2 0 0 9}$ & $\mathbf{2 0 1 0}$ & $\mathbf{2 0 1 1}$ & $\mathbf{2 0 1 2}$ & $\mathbf{2 0 1 3}$ & $\mathbf{2 0 1 4}$ & $\mathbf{2 0 1 5}$ & $\mathbf{2 0 1 6 *}$ & Total Geral \\
ZIA & $\mathbf{2 7 8}$ & 574 & 512 & 380 & 416 & 242 & 273 & 76 & 2.851 \\
ZPA & 124 & 142 & 171 & 185 & 143 & 219 & 189 & 33 & 1.206 \\
ZRA & 488 & 355 & 695 & 453 & 509 & 483 & 370 & 137 & 3.490 \\
\hline Total Geral & $\mathbf{9 9 0}$ & $\mathbf{1 . 0 7 1}$ & $\mathbf{1 . 3 7 8}$ & $\mathbf{1 . 0 1 8}$ & $\mathbf{1 . 0 6 8}$ & $\mathbf{9 4 4}$ & $\mathbf{8 3 2}$ & $\mathbf{2 4 6}$ & $\mathbf{7 . 5 4 7}$
\end{tabular}

Fonte: SEFIN, 2016. Organização: Sara V. Rosa, 2016. * O ano de 2016 não contempla todos os meses, por isso não deve ser utilizado como parâmetro de comparação com os demais anos.

Tabela 4. Total de imóveis registrados no ITBI dentro das zonas ambientais de Fortaleza, por ano e tipo de imóvel.

\begin{tabular}{|c|c|c|c|c|}
\hline Rótulos de Linha & Predial & Territorial & Total Geral & \% Total Geral \\
\hline ZIA & 2.004 & 847 & 2.851 & $37,8 \%$ \\
\hline ZPA & 728 & 478 & 1.206 & $16,0 \%$ \\
\hline ZRA & 2.812 & 678 & 3.490 & $46,2 \%$ \\
\hline Total Geral & 5.544 & 2.003 & 7.547 & $100,0 \%$ \\
\hline
\end{tabular}

Fonte: SEFIN, 2016. Organização: Sara V. Rosa, 2016

Tabela 5. Tipo de ocupação do imóvel edificado vendido

\begin{tabular}{lrrrrr} 
Rótulos de Linha & ZIA & & ZPA & ZRA & \multicolumn{2}{c}{ Total Geral } \\
\hline Edificação & 1.775 & 712 & 2.396 & 4.883 \\
Em construção & 179 & 1 & 120 & 300 \\
Ruinas/demolição & 5 & & & 5 \\
SEM informação & 45 & 15 & 296 & 356 \\
\hline Total Geral & $\mathbf{2 . 0 0 4}$ & $\mathbf{7 2 8}$ & $\mathbf{2 . 8 1 2}$ & $\mathbf{5 . 5 4 4}$
\end{tabular}

Fonte: SEFIN, 2016. Organização: Sara V. Rosa, 2016 


\section{Venda de imóveis em Zona de Recuperação Ambiental (ZRA)}

Com 3.490 cobranças de ITBI, quase metade do que foi aplicado dentro das áreas de proteção e preservação ambiental, a Zona de Recuperação Ambiental (ZRA) foi a que teve o maior número de transações dentro do período analisado, incluindo áreas como as do mapa da Figura 94, justamente as áreas que o município está desconsiderando como áreas de proteção (ZRA Iguatemi e ZRA Cidade Ecológica), e áreas de realização de Operações Urbanas Consorciadas, como a do Riacho Maceió (bairro Mucuripe) e a da Osório de Paiva (bairros Siqueira e Canidezinho) e entorno da OUC da Lagoa da Sapiranga (ver mapas das Figura 96, Figura 97, e Figura 102Figura 99). Além destas áreas, também aparecem consideráveis números de registros nas ZRAs dos bairros de Messejana, Edson Queiroz, Lagoa Redonda, Cocó, Guararapes, e Presidente Kennedy (Figura 95).

Em todos estes casos, as ZRAs estão associadas a ZPAs de recursos hídricos, e em todos eles, com exceção dos bairros Presidente Kennedy e do Siqueira/Canidezinho, configuram bairros reconhecidos como de expansão do mercado imobiliário. O Presidente Kennedy (Figura 98), apesar de ser um bairro popular consolidado, recebeu no último ano um grande equipamento privado, o shopping RioMar e, associado a ele, diversas torres residenciais que estão sendo construídas ao norte, em terreno contiguo ao shopping, e ao sul, em áreas lindeiras à Av. Sargento Hermínio. Assim, o bairro entrou também no grupo dos bairros de expansão do mercado imobiliário, considerando a nova lógica de incorporação e transformações na produção imobiliária e do espaço de Fortaleza (RUFINO, 2016).

Já o bairro do Siqueira, além de bairro popular, é também periférico. Porém, desde 2014, o bairro está incluído no perímetro da Operação Urbana Consorciada Osório de Paiva (Figura 99), que aparentemente será mais voltada para a realização de empreendimentos do tipo comercial, como atacadões, devido a sua posição estratégica localizada em importante via de escoamento da cidade, Av. Gen. Osório de Paiva, que dá nome a OUC.

O caso da ZRA do Riacho Maceió (Figura 97), onde também se localiza a OUC Riacho Maceió, pode ser um caso interessante para maior aprofundamento devido às diversas alterações que foram feitas no zoneamento urbano e ambiental da área, desde o Plano Diretor de 1992, para possibilitar a implantação da operação. Esta é a última gleba ainda não ocupada por torres 
hoteleiras ou residenciais na área da Beira Mar, área de maior valorização imobiliária em Fortaleza.

Figura 95. Transações imobiliárias em área de ZRA - ITBI 2009 a setembro de 2016.

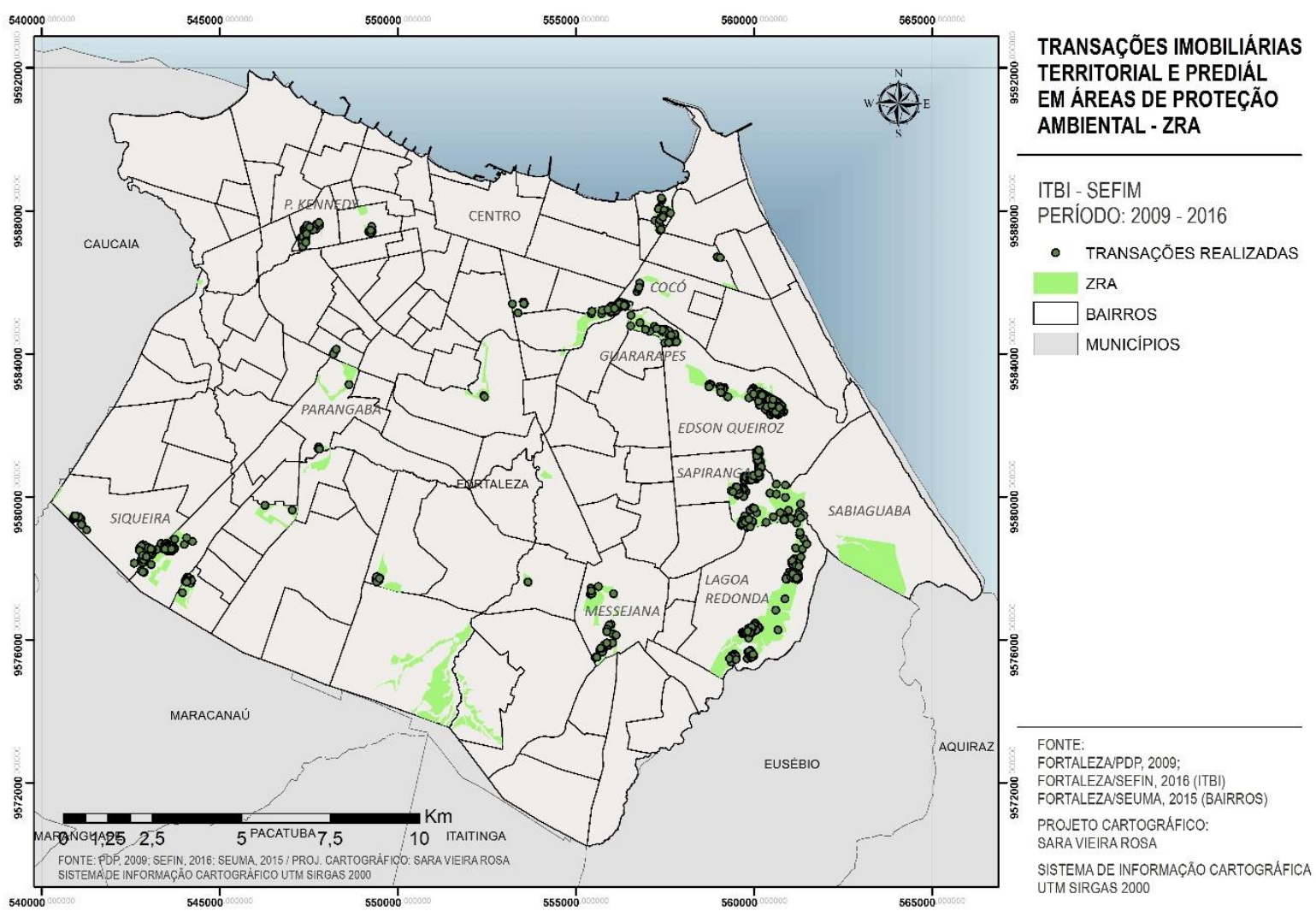

Fonte: SEFIN/ITBI, FORTALEZA/PDP, 2009. Elaborado por Sara Vieira Rosa, 2016 
Figura 96. Transações imobiliária territoriais e prediais nas ZRAs do Iguatem e Cocó e entorno.

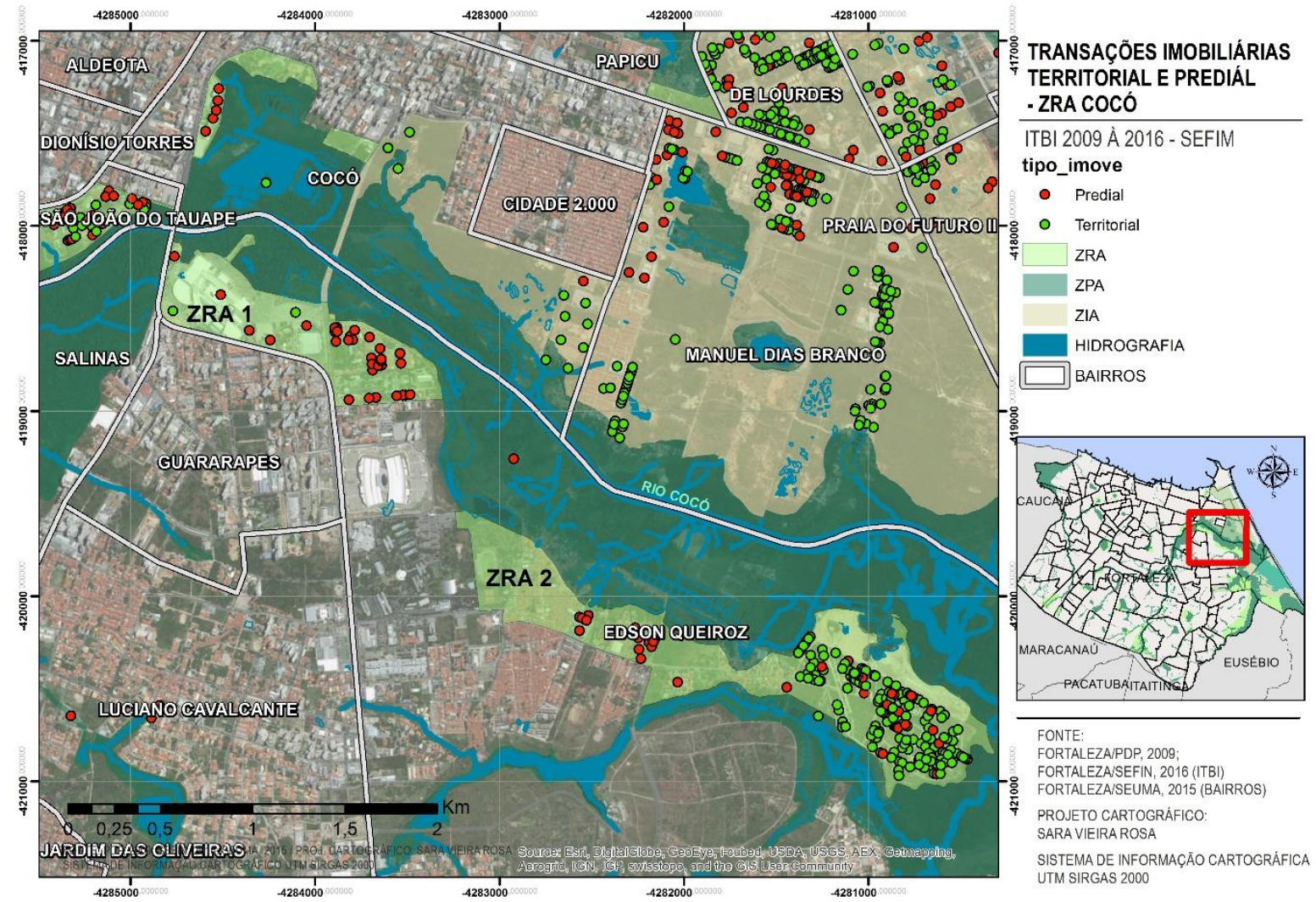

Fonte: SEFIN/ITBI, FORTALEZA/PDP, 2009. Elaborado por Sara Vieira Rosa, 2016

Figura 97. Transações imobiliária territoriais e prediais na área da OUC do Riacho Maceió e entorno.

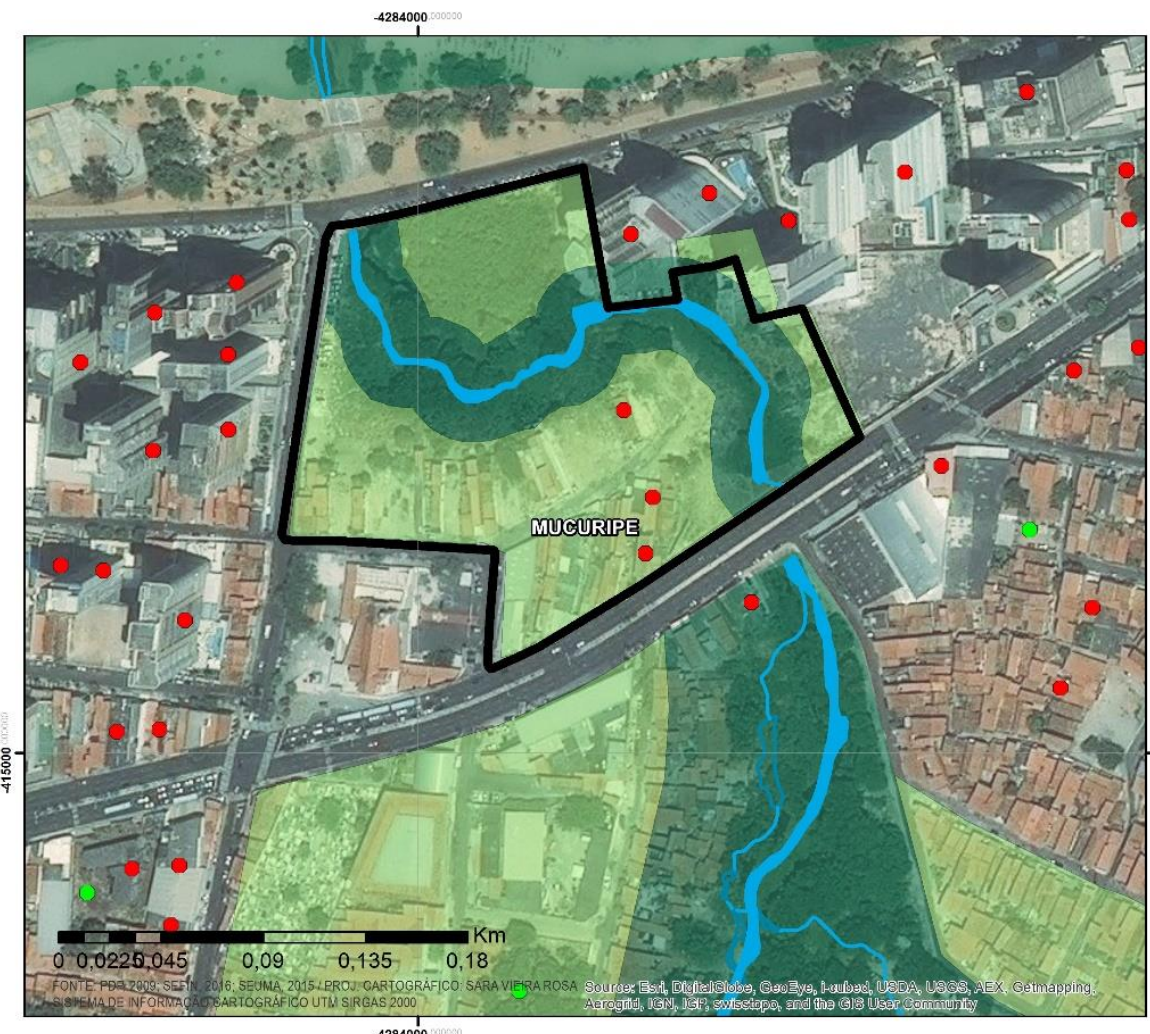

$-4284000$
TRANSAÇÕES IMOBILIÁRIAS TERRITORIAL E PREDIÁL - OUC RIACHO MACEIÓ

ITBI 2009 À 2016 - SEFIM

Tipo do Imóvel

- Predial

- Territorial

HIDROGRAFIA ZRA ZPA

ouc riacho maceió

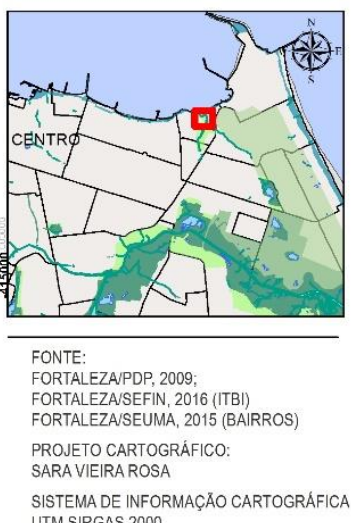

SISTEMA DE INFOR UTM SIRGAS 2000 
Figura 98. Transações imobiliária territoriais e prediais no bairro Presidente Kennedy e entorno.

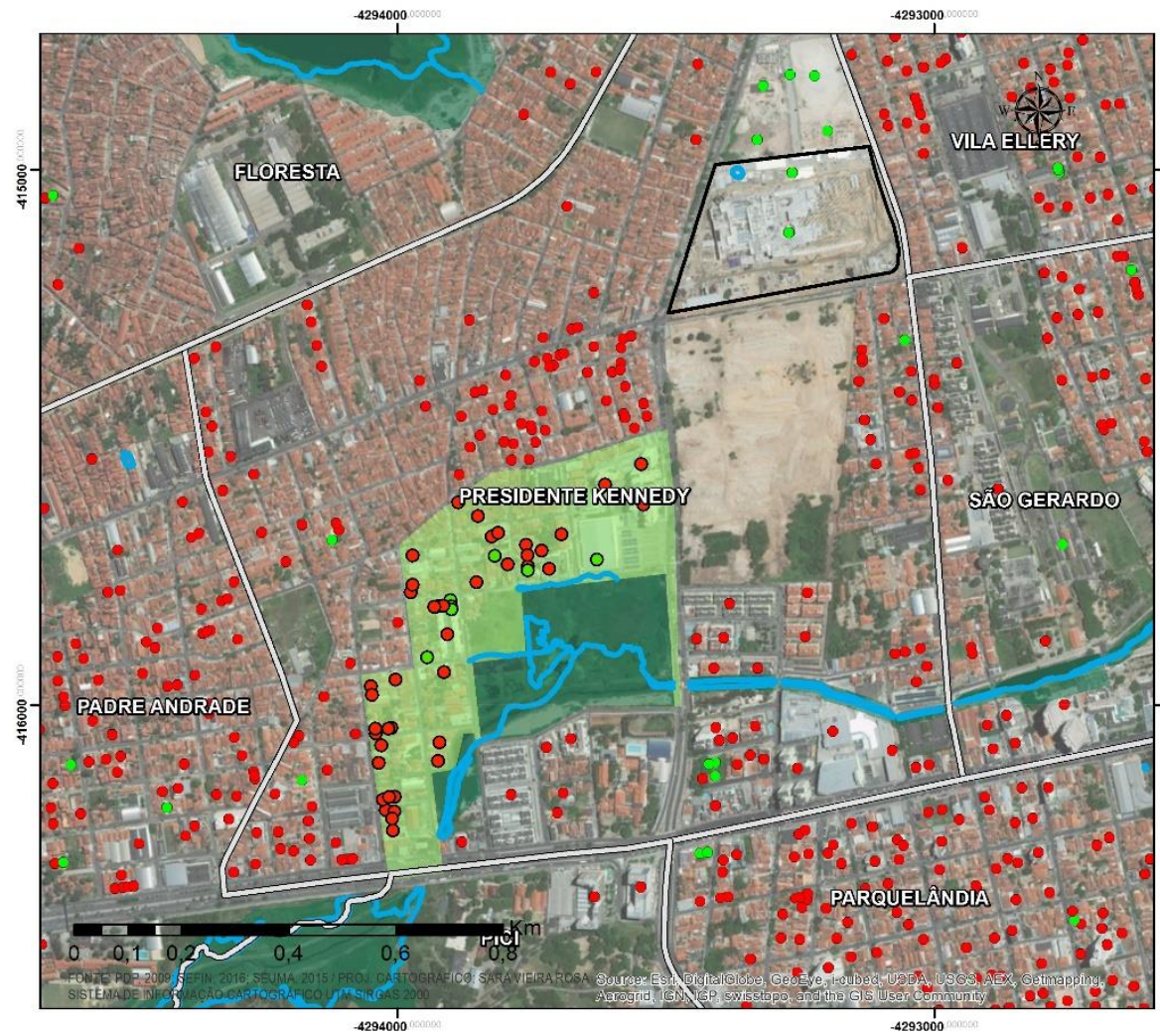

TRANSAÇÕES IMOBILIÁRIAS

TERRITORIAL E PREDIÁL - PRESIDENTE KENNEDY

ITBI 2009 À 2016 - SEFIM

紊 TIPO DO IMÓVEL

- Predial

- Territorial

ZRA

ZPA

HIDROGRAFIA

BAIRROS

SHOP. RIO MAR

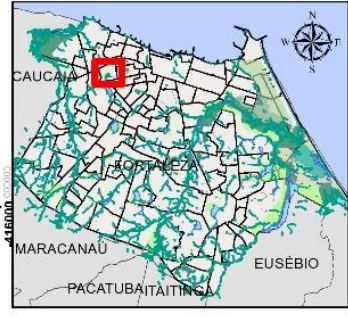

FONTE:

FORTALEZAIPDP, 2009;

FORTALEZASEFN, 2016 (ITBI)

PROJETO CARTOGRÁFICO:

SARAVIEIRAROSA

SISTEMA DE INFORMAÇÃO CARTOGRÁFICA UTM SIRGAS 2000

Fonte: SEFIN/ITBI, FORTALEZA/PDP, 2009. Elaborado por Sara Vieira Rosa, 2016

Figura 99. Transações imobiliária territoriais e prediais na área da OUC Osório de Paiva e entorno.

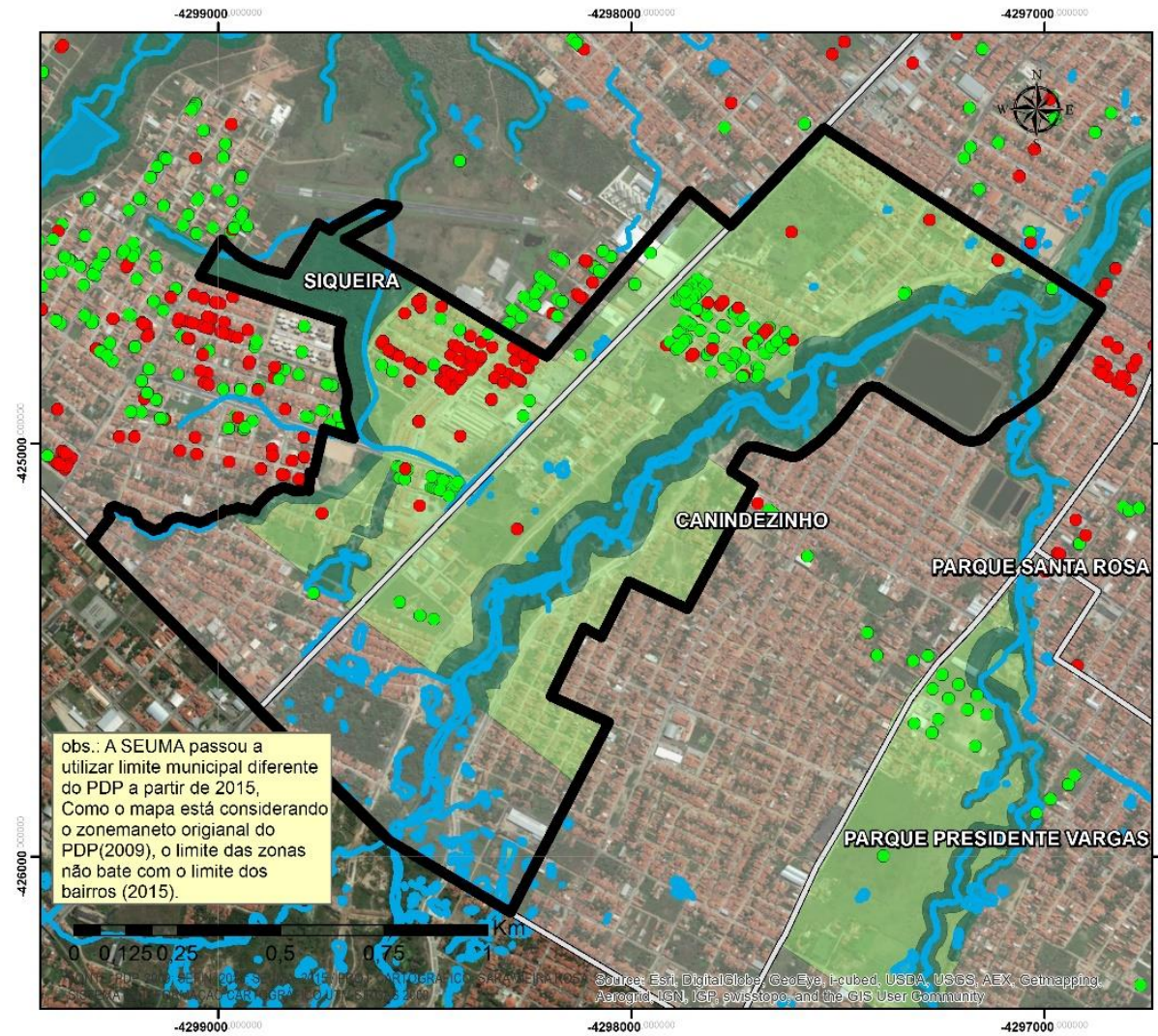

TRANSAÇÕES IMOBILIÁRIAS

TERRITORIAL E PREDIÁL - OUC OSÓRIO DE PAIVA

ITBI 2009 A 2016 - SEFIM

Tipo do Imóvel

- Predial

- Territorial ZRA

ZPA

HIDROGRAFIA

OUC OSÓRIO DE PAIVA $\square$ BaIRROS

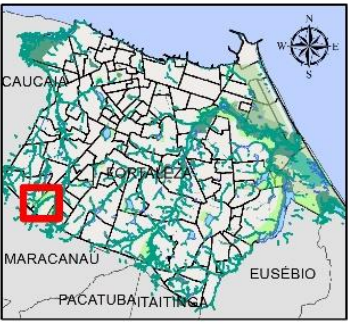

FONTE:
FORTALEZAPDP, 2009 ;

FORTALEZAIPDP, 2009;

FORTALEZASEUMA, 2015 (BAIRROS

PROJETO CARTOGRÁFICO:

SARA VIEIRAROSA

SISTEMA DE INFORMAÇÃO CARTOGRAFICA UTM SIRGAS 2000

Fonte: SEFIN/ITBI, FORTALEZA/PDP, 2009. Elaborado por Sara Vieira Rosa, 2016 


\section{Vendas de imóveis em Zona de Interesse Ambiental (ZIA)}

A Zona de Interesse ambiental (ZIA) também teve um número expressivo de comercializações de imóveis no período analisado, 2.851 , dos quais 2 mil estão registrados como prediais. É importante ressaltar aqui que, quando falamos em 2 mil imóveis, não estamos nos referindo a 2 mil empreendimentos ou edifícios diferentes, pois a base de dados trabalhada registra os imóveis individualmente. Assim, se em um mesmo edifício residencial foram comercializados 90 apartamentos, a base de dados terá 90 registros para o mesmo edifício.

Como o Zoneamento Ambiental do PDP demarca zonas de interesse ambiental apenas no setor leste da cidade, ZIA da Praia do Futuro, ZIA do Cocó, e Zia da Sabiaguaba, é aí onde estão concentrados estes 2 mil casos (Figura 100). É importante destacar que grande parte destas ZIAs, como a da Praia do Futuro, são áreas de preservação permanente (APP), segundo legislação federal (Código Florestal), por se tratar de área de dunas com vegetação, sendo assim, não deveriam ser permitidas construções nessas áreas. Todavia, as diferentes gestões do município vêm sendo omissas, permitindo e licenciando empreendimentos nessas áreas de dunas.

Figura 100. Transações imobiliárias em área de ZIA - ITBI 2009 a setembro de 2016

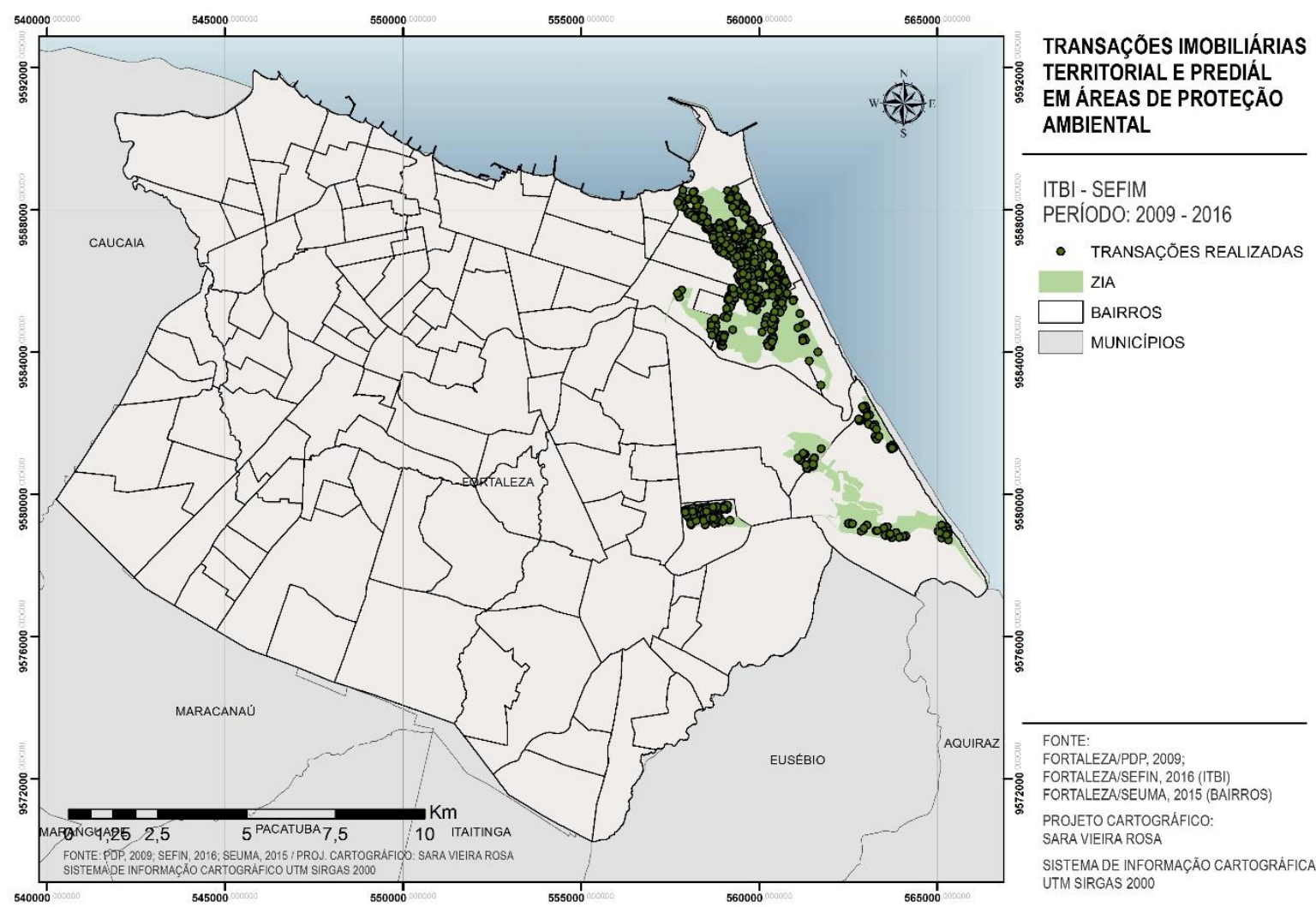

Fonte: SEFIN/ITBI, FORTALEZA/PDP, 2009. Elaborado por Sara Vieira Rosa, 2016 
Figura 101. Transações imobiliárias em área de ZIA da Praia do Futuro e Cocó - ITBI 2009 a setembro de 2016

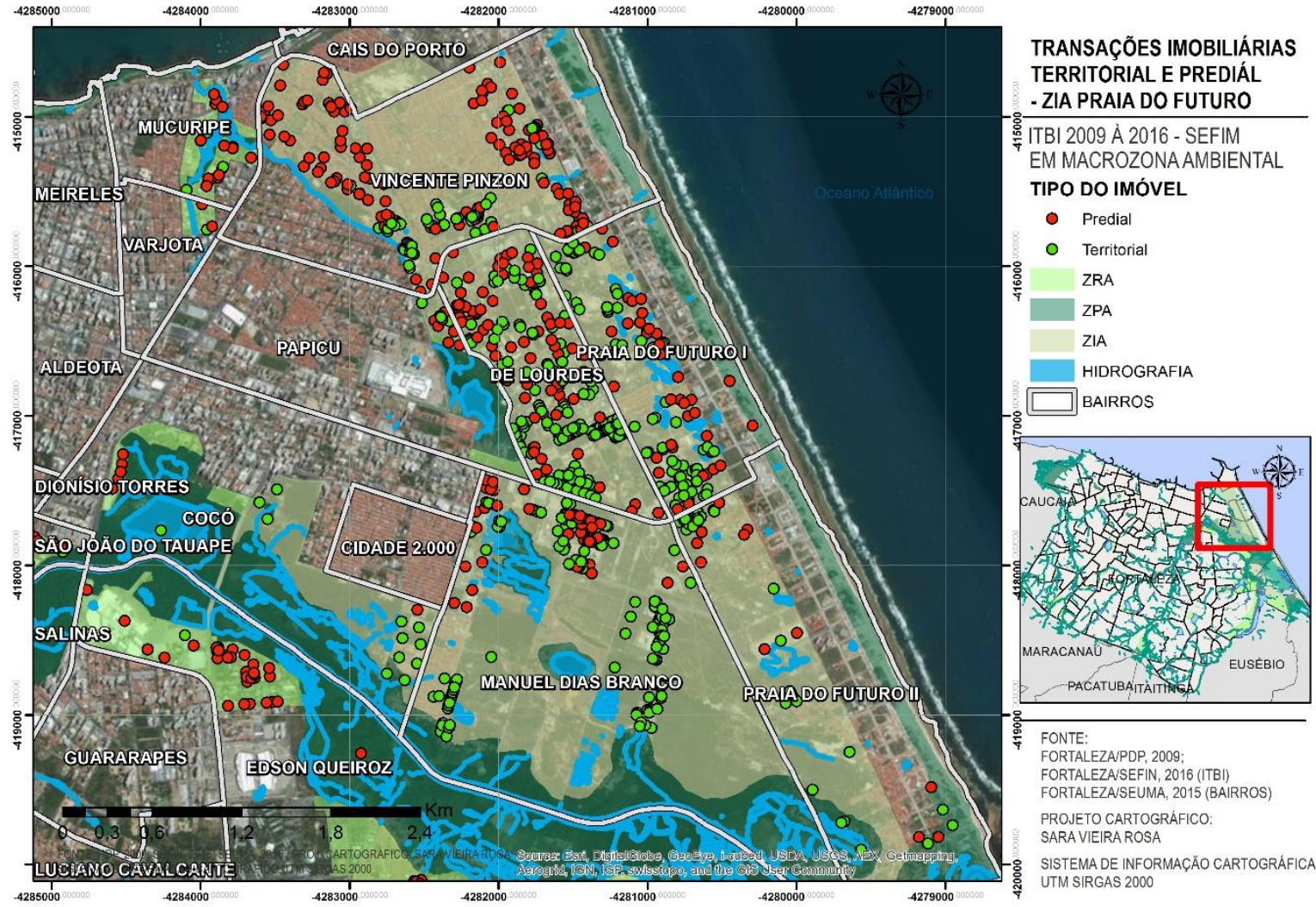

Fonte: SEFIN/ITBI, FORTALEZA/PDP, 2009. Elaborado por Sara Vieira Rosa, 2016

Figura 102. Transações imobiliárias em área da OUC da Lagoa da Sapiranga - ITBI 2009 a setembro de 2016

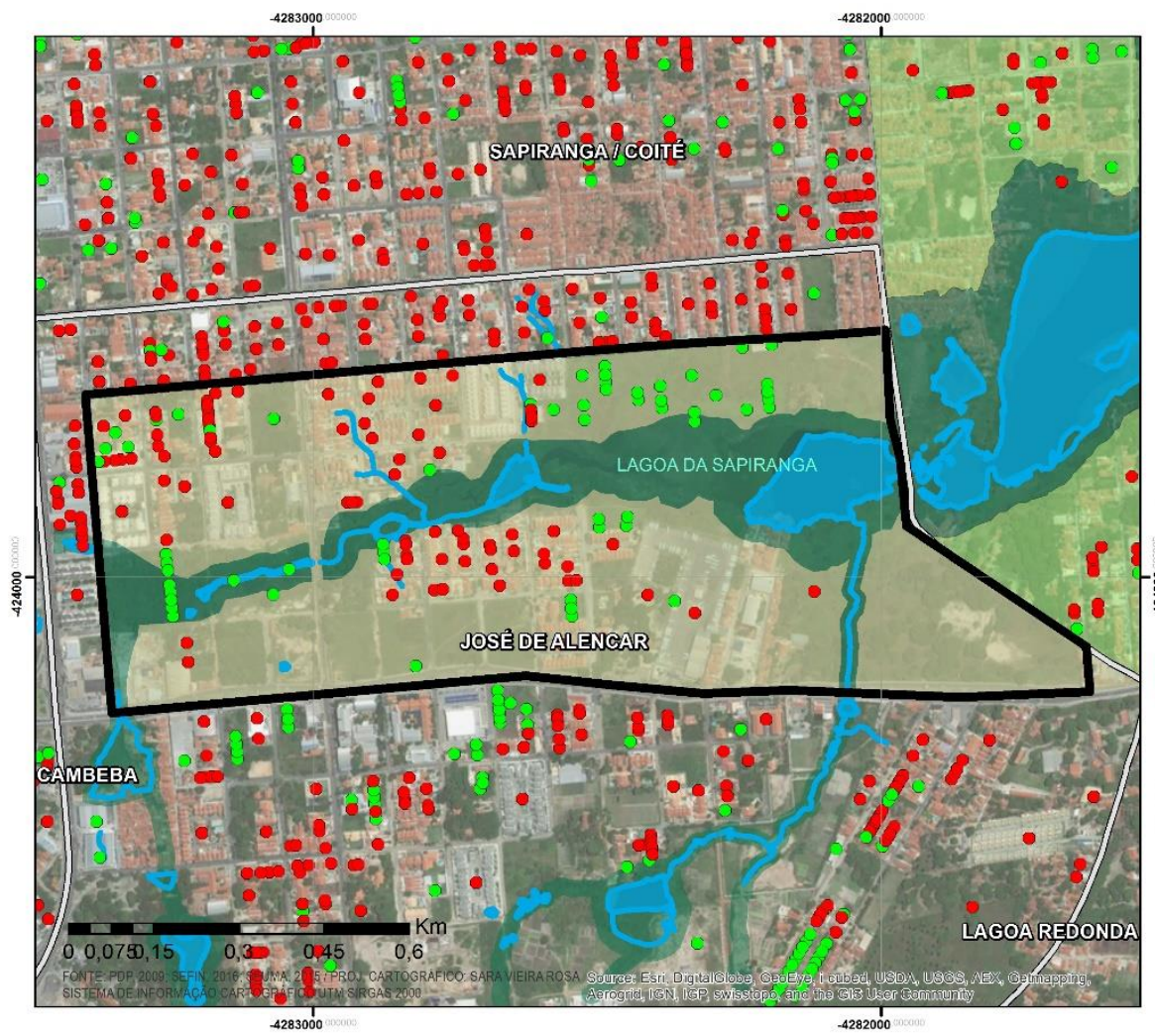

TRANSAÇÕES IMOBILIÁRIAS TERRITORIAL E PREDIÁL - OUC LAGOA DA SAPIRANGA

ITBI 2009 A 2016 - SEFIM Tipo do Imóvel

- Predial

- Territorial

ZRA

ZPA

ZIA

HIDROGRAFIA

ouc lagoa da sapiranga BAIRROS

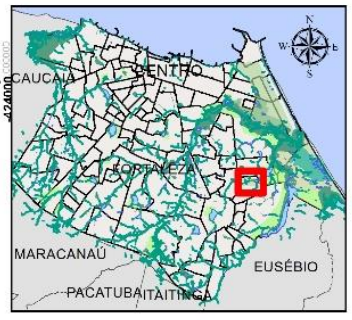

FONTE:

FORTALEZAPDP, 2009:

FORTALEZASEFIN, 2016 (ITBI)

FORTALEZASEUMA, 2015 (BAIRROS)

PROJETO CARTOGRÁFICO:

SARAVIEIRA ROSA

SISTEMA DE INFORMAÇÃO CARTOGRÁFICA UTM SIRGAS 2000

Fonte: SEFIN/ITBI, FORTALEZA/PDP, 2009. Elaborado por Sara Vieira Rosa, 2016 
Na Figura 101, é possível observar a distribuição destes casos de vendas de imóveis prediais e territoriais nas ZIAs da Praia do Futuro e Cocó. A área mais próxima ao Rio Cocó, ZIA do Cocó, onde se percebe maior presença de venda de imóveis territoriais, é a área que concentra o maior número de terrenos vazios e de dunas mais preservadas, ainda com vegetação - dunas fixas (Figura 103). A área vem sendo palco de diversos conflitos socioambientais envolvendo a demarcação do Parque do Cocó e colocando em debate atores do governo do estado, do governo municipal, entidades civis, ONGS do movimento ambiental e comunidades. Também são atores importantes desse conflito os foreiros e proprietários de terras, mas estes últimos não aparecem nas esferas de debate público, tornando-se de certa maneira invisibilizados.

O outro local da ZIA que também chama a atenção é o trecho da ZIA da Sabiaguaba, onde está localizado a OUC da Lagoa da Sapiranga, aprovada em 2015 (Figura 102), no qual é possível observar inclusive a venda de lotes dentro da ZPA. É importante destacar que toda a ZIA da Sabiaguaba está inserida na Unidade de Conservação APA da Sabiaguaba criada em 2006, e que até hoje não teve seu plano de manejo implementado.

Figura 103.Dunas da ZIA do Cocó.

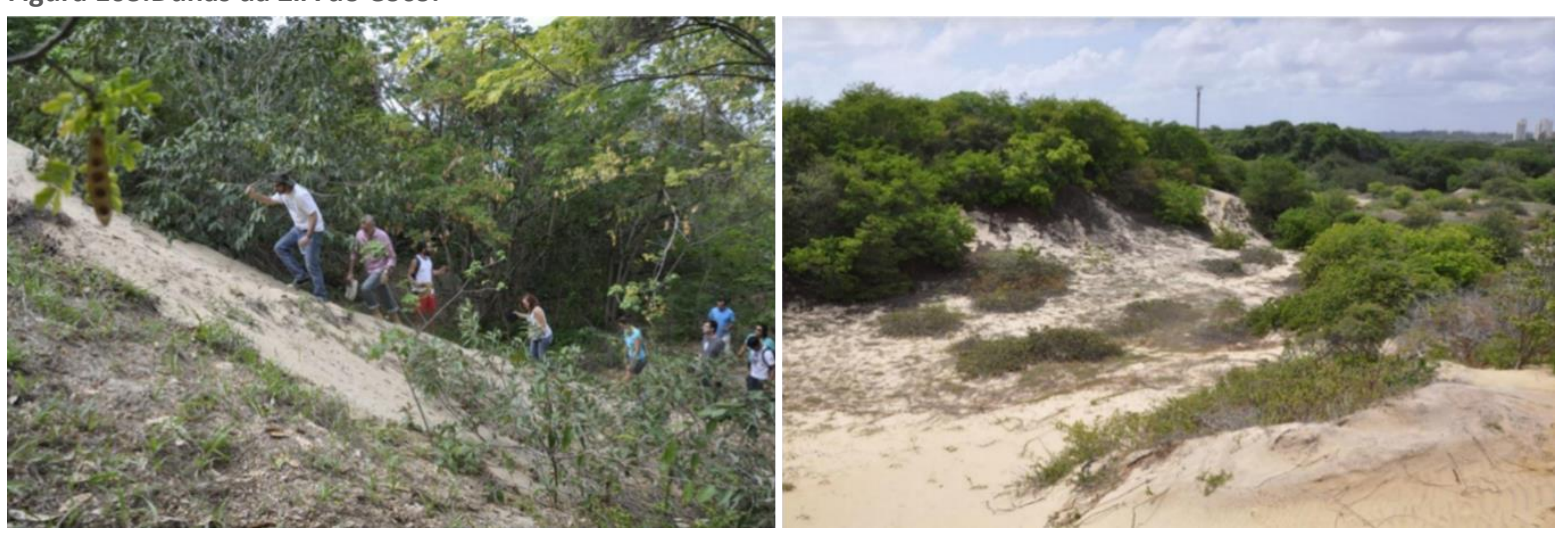

Fonte: Plano de Manejo: AIRE dunas do Cocó, 2014

Na Figura 104, é possível observar a localização da venda de imóveis prediais e territoriais em toda a extensão da ZIA da Sabiaguaba. O loteamento desta, na sua parte mais próxima à faixa de praia é bem antigo, datando da década de 1960, porém nunca logrou uma ocupação plena, o que contribuiu para a preservação da região, sendo a Sabiaguaba e seu entorno imediato, hoje, a área de Fortaleza que ainda preserva um importante exemplar de campo de dunas, com presença do ecossistema de manguezal e de restinga (Figura 105). 
Figura 104. Transações imobiliárias na ZIA e APA da Sabiaguaba - ITBI 2009 a setembro de 2016

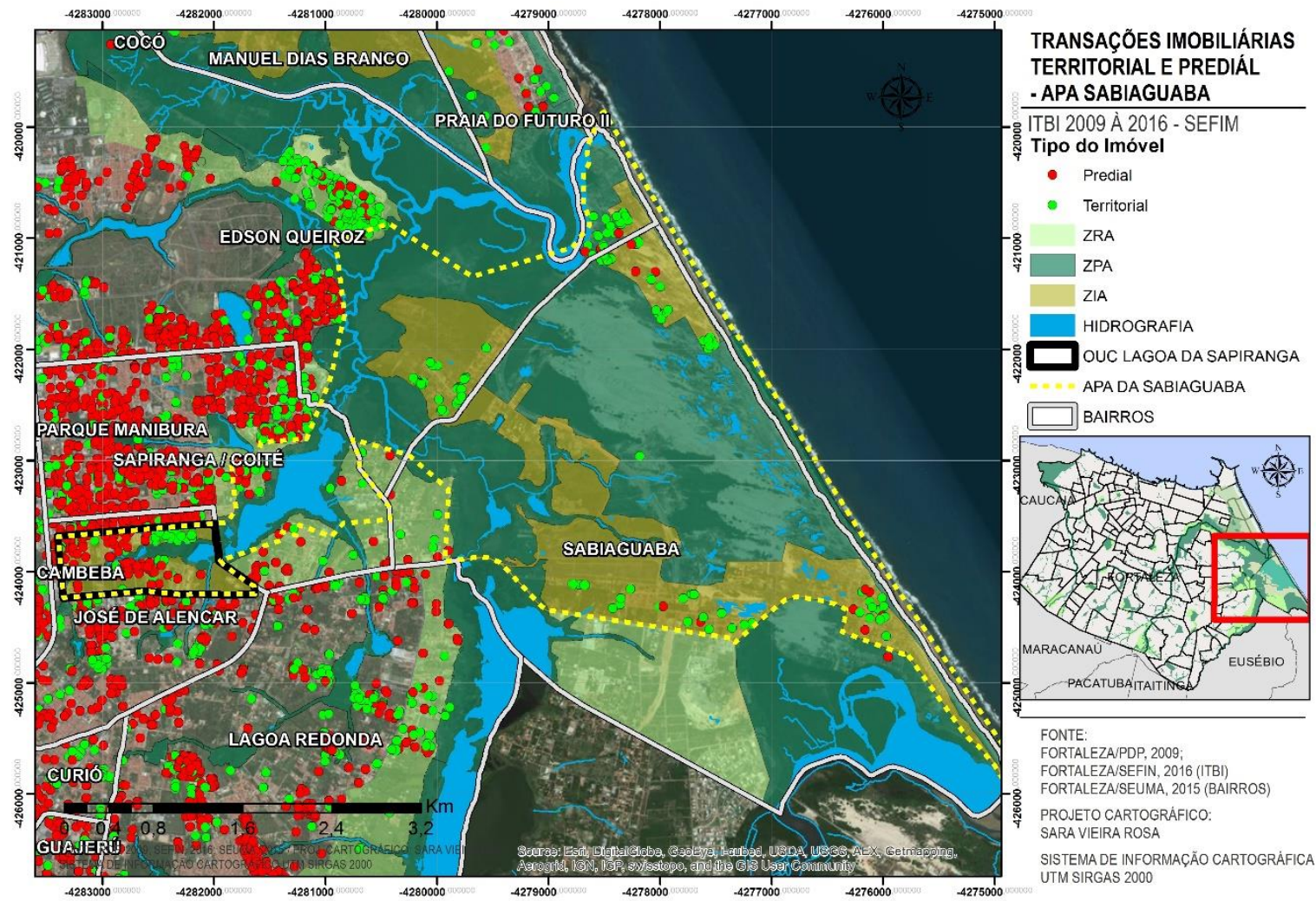

Fonte: SEFIN/ITBI, FORTALEZA/PDP, 2009. Elaborado por Sara Vieira Rosa, 2017

Figura 105. Dunas da APA da Sabiaguaba.
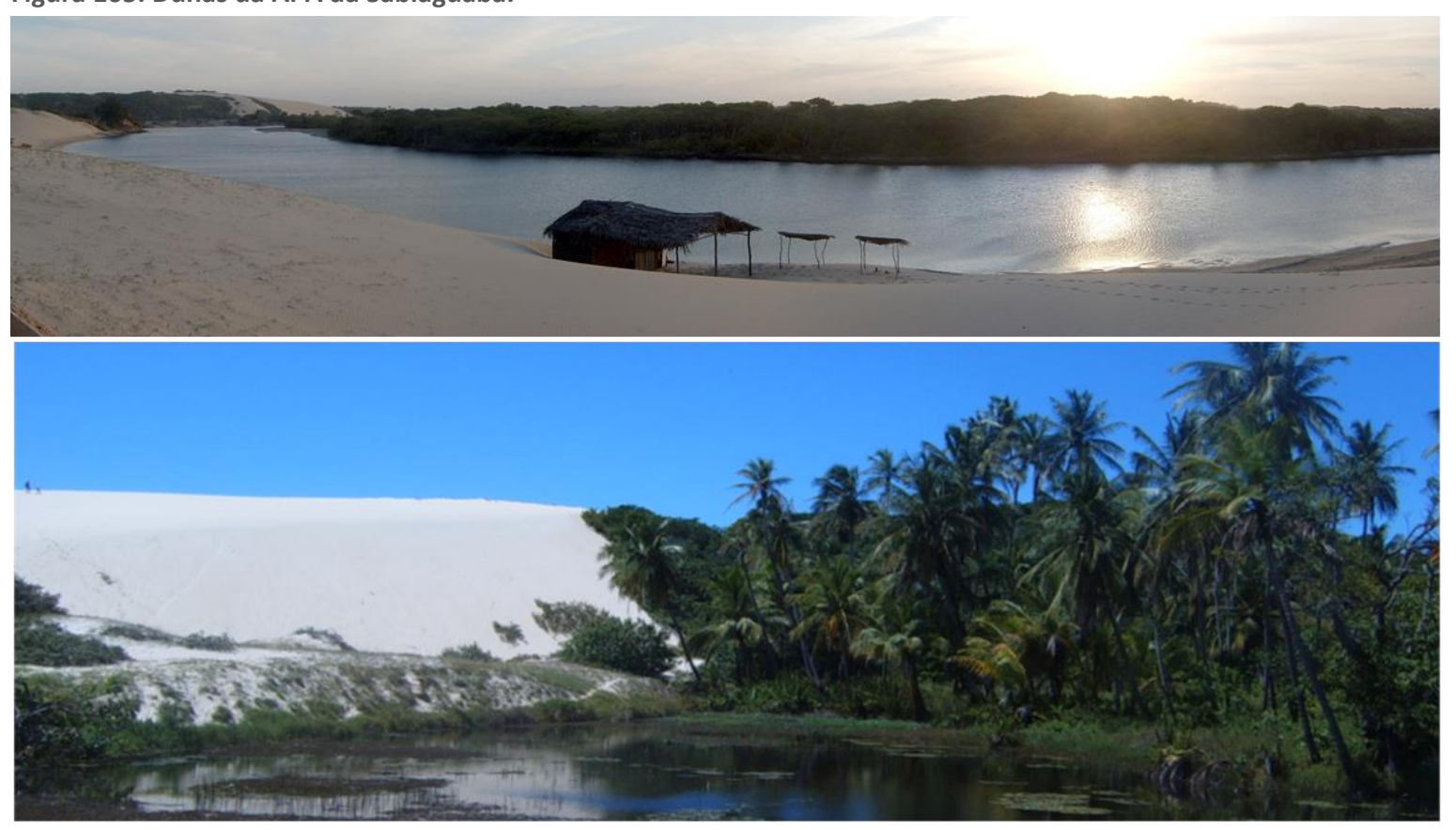

Fonte: Sara Vieira Rosa, 2008 
Figura 106. Imóveis territoriais a venda na Sabiaguaba.

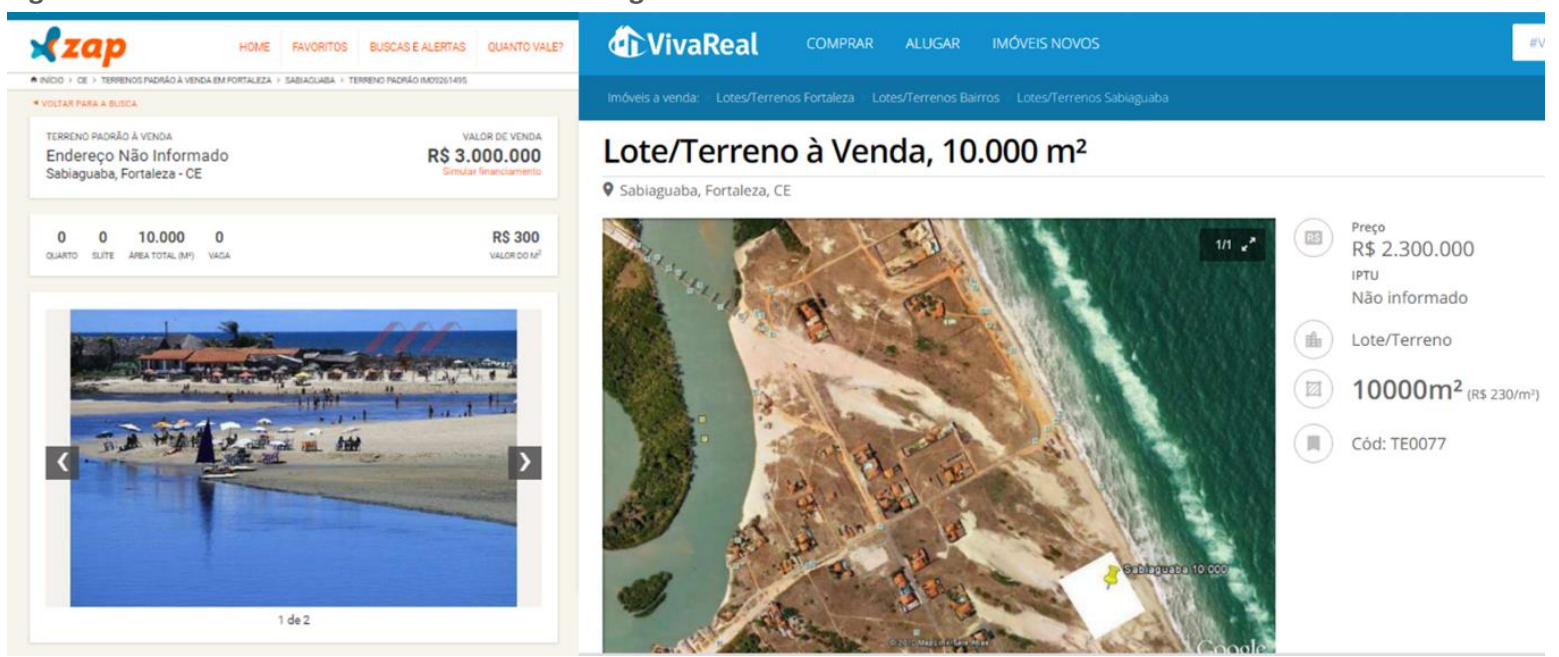

Fonte: vivareal, 2016; Zap imóveis, 2016. http://www.vivareal.com.br/imovel/lote-terreno-sabiaguaba-bairros-fortaleza10000m2-venda-RS2300000-id-52950032/; www.zapimoveis.com.br

\section{Venda de imóveis em Zonas de Preservação Ambiental (ZPA)}

Como já foi mencionado e mostrado em mapas, existem casos de comercialização de terrenos e edifícios dentro da Zona de Preservação Ambiental (ZPA) em Fortaleza. Estes ocorrem de forma dispersa ao longo de toda a zona, como se pode verificar no mapa da Figura 108. Ao todo, foram 1.206 Impostos de Transferência sobre Imóvel cobrados de 2009 até setembro de 2016, dos quais 728 estão registrados como imóveis prediais (Tabela 4 e Tabela 5).

Se considerarmos apenas os que tiveram registro de construção da edificação após a data de publicação da Lei do Plano Diretor, treze de março de 2009, este número cai para 429 (ver Figura 94). Número bem menor, mas ainda relevante, principalmente considerando que muitas destas áreas já eram zonas de preservação permanente segundo o Plano Diretor anterior (PDDU de 1992), ou mesmo áreas de APP segundo legislação federal. Assim, mesmo as construções anteriores a 2009 poderiam já estar em áreas não edificantes.

Para este trabalho, fizemos algumas aproximações nas áreas da ZPA abrangidas pela APA da Sabiaguaba e Cocó, cruzando com a planta de loteamentos do município. Assim, foi possível identificar os lotes e ter uma melhor ideia do impacto destes imóveis na ZPA. A escolha destas áreas como exemplos neste momento deve-se ao fato dessas áreas terem sido palco de conflitos ambientais durante todo o ano de 2016, durante o processo de tentativa de demarcação do Parque do Cocó e retirada de população ribeirinha (com o intuito de "preservação") e processos de tentativa de flexibilização da legislação urbana e ambiental do 
município nesta área. Além de serem as principais áreas ambientalmente frágeis mais preservadas da cidade.

Com a análise e acompanhamento do processo, foi possível observar três questões (ou problemas) relevantes: (1) tentativas do município de flexibilizar (leia-se alterar) os parâmetros da ZIA da Sabiaguaba, que fica dentro da APA da Sabiaguaba e serve como proteção da ZPA, por meio de decreto, o que é extremamente grave, pois decretos não podem alterar lei; (2) flexibilização a ZPA por meio da nova Lei de Uso e Ocupação do Solo, que deveria regulamentar o PDP e não alterá-lo; (3) e o recebimento de pagamentos de imposto predial sobre venda de imóveis (ITBI) dentro da Zona de Preservação Ambiental.

Na Figura 109 e na Figura 110, é possível observar os lotes vendidos, e registrados pela SEFIN através do ITBI, dentro da ZPA, já na foz do Rio Cocó. Ao mesmo tempo, com a tentativa de demarcação do Parque do Cocó, pelo governo do Estado, o poder público vem forçando a retirada de uma comunidade tradicional que vive há décadas na foz do Rio Cocó, área de ZPA.

Outra ação do governo municipal que chama atenção é a construção de uma estrada, asfaltada, com porte de rodovia, cruzando a APA da Sabiaguaba e passando por cima da ZPA do rio Cocó e da ZPA que corresponde ao Parque das Dunas da Sabiaguaba. Essa rodovia, em construção, ligará a Praia do Futuro ao quarto anel viário que circunda o limite sul do município cortando, além de grandes glebas de preservação e proteção ambiental da Sabiaguaba, grandes glebas também do município vizinho, Euzébio, que vem, ao longo das últimas décadas, despontando como expansão do mercado imobiliário de Fortaleza voltado para a classe média. Percebe-se assim que, além de um eixo de ligação, a nova obra viária abre caminho para a entrada de novas terras nos mercados imobiliários de Fortaleza e Região Metropolitana, que ainda não tinham valor de mercado competitivo.

Todavia, a estrada também abriu frente para novas ocupações informais que estão sendo realizadas na ZIA e ZPA, dentro da APA (Figura 107). Segundo funcionários da SEUMA, estas ocupações estão sendo realizadas sob comando de organizações criminosas que financiam pessoas para a construção das casas. Pretende-se, mais adiante, investigar melhor a origem e formação dessas ocupações, pois processos semelhantes vêm ocorrendo em outras partes da cidade, também em áreas de preservação ambiental. 
Figura 107. Ocupações ao longo da Rodovia que está sendo aberta pelo município na APA da Sabiaguaba.

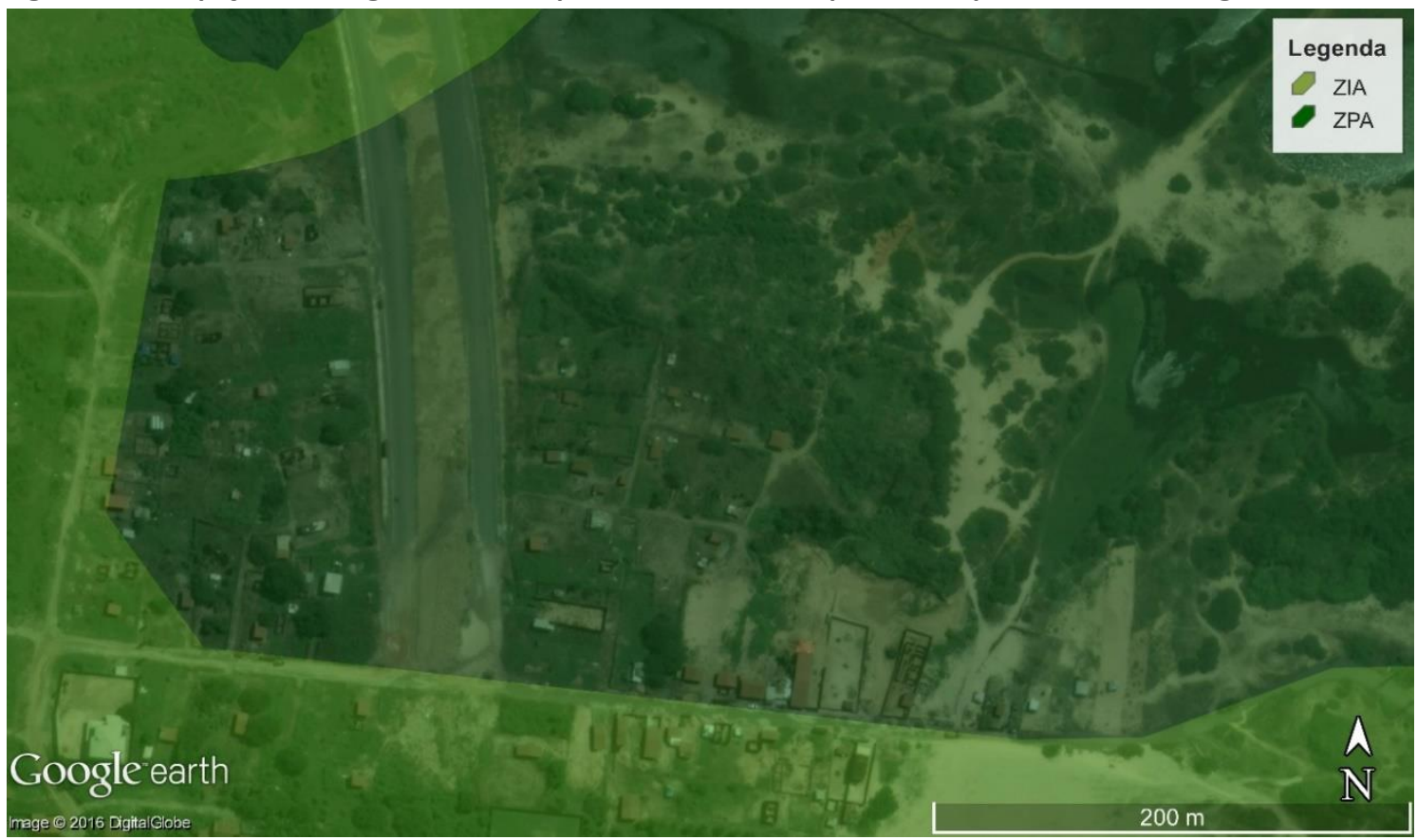

Fonte: Google Earth, 2006 (22/07/2016)

Figura 108. Transações imobiliárias em área de ZPA - ITBI 2009 a setembro de 2016

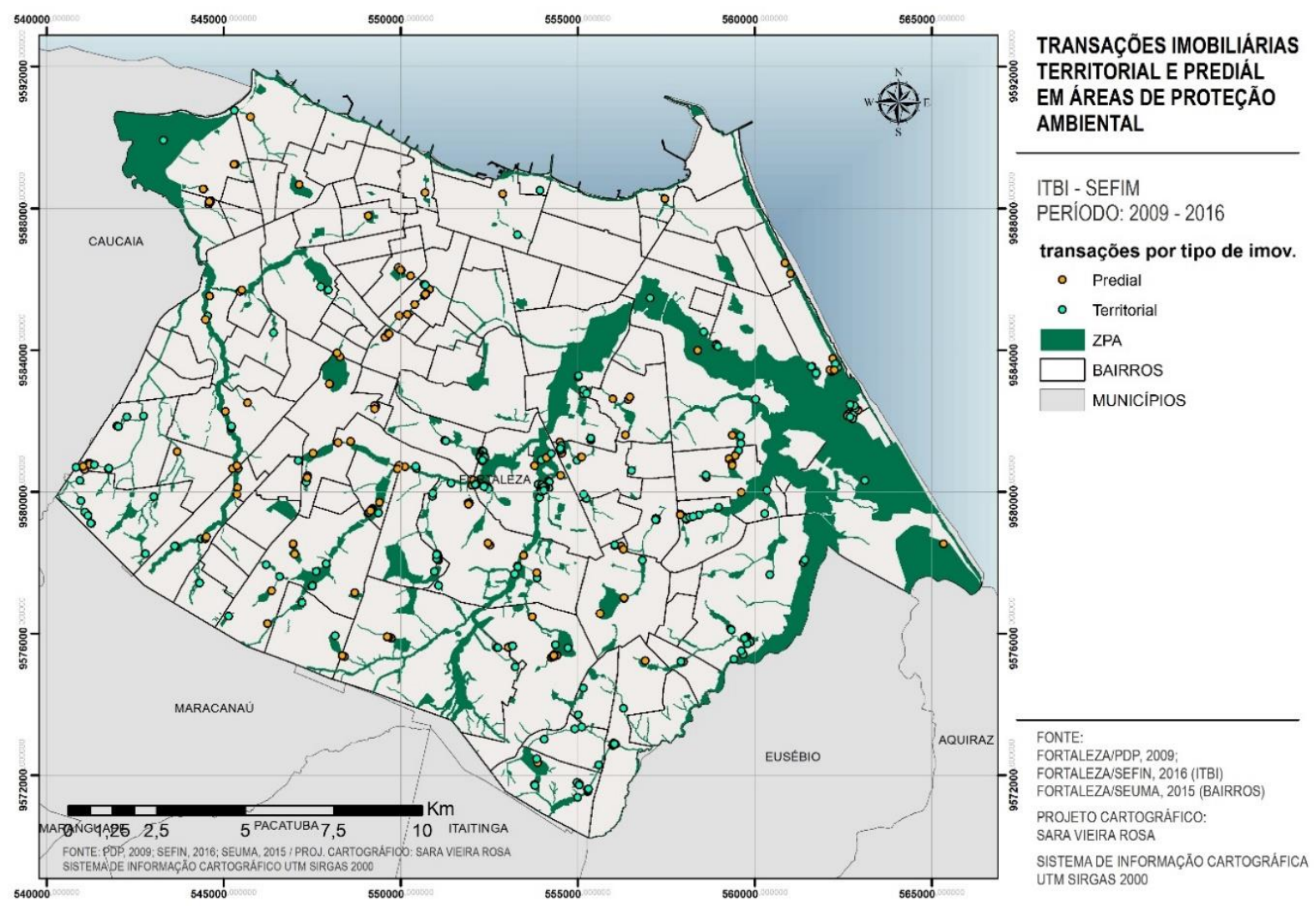

Fonte: SEFIN/ITBI, FORTALEZA/PDP, 2009. Elaborado por Sara Vieira Rosa, 2016 
Figura 109. Identificação dos lotes com cobrança de ITBI na ZPA da Sabiaguaba, foz do rio Cocó.

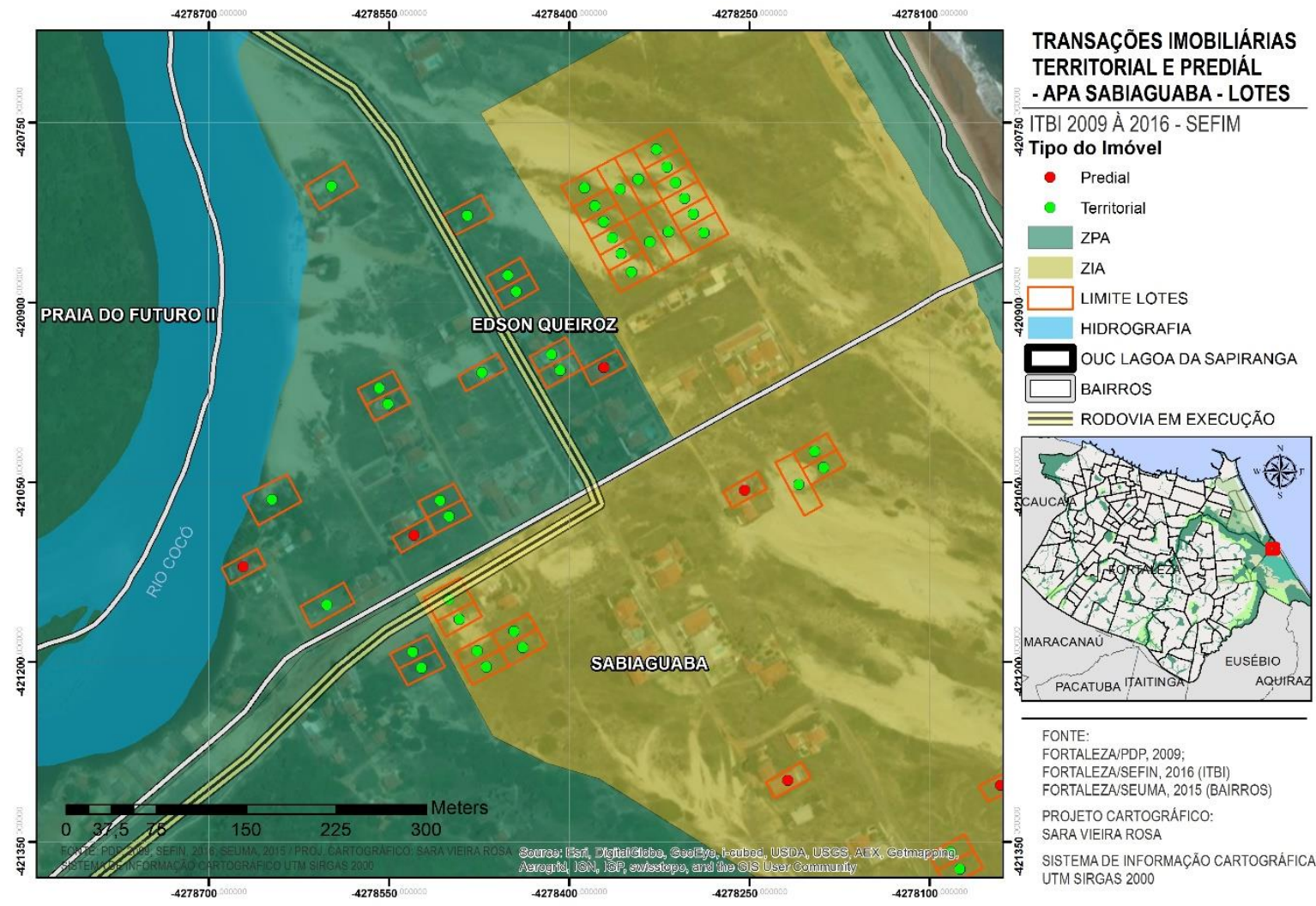

Fonte: SEFIN/ITBI, FORTALEZA/PDP, 2009. Elaborado por Sara Vieira Rosa, 2016. ITBI 2009 a setembro de 2016.

Figura 110. Identificação dos lotes com cobrança de ITBI na ZPA e APA da Sabiaguaba. ITBI 2009 a set. de 2016.

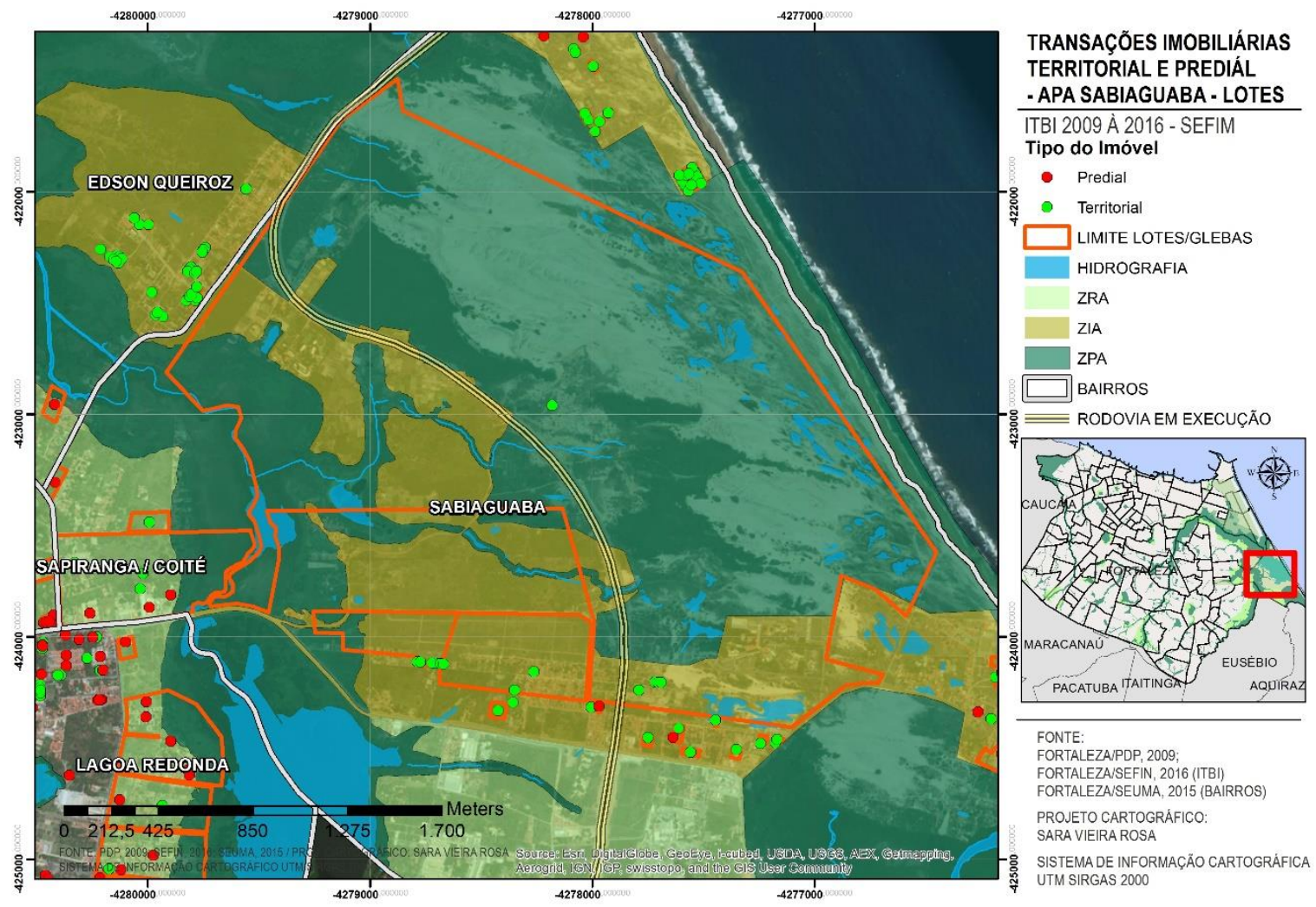

Fonte: SEFIN/ITBI, FORTALEZA/PDP, 2009. Elaborado por Sara Vieira Rosa, 2016 
Figura 111. Transações imobiliárias territorial e predial dentro da APA da Sabiaguaba

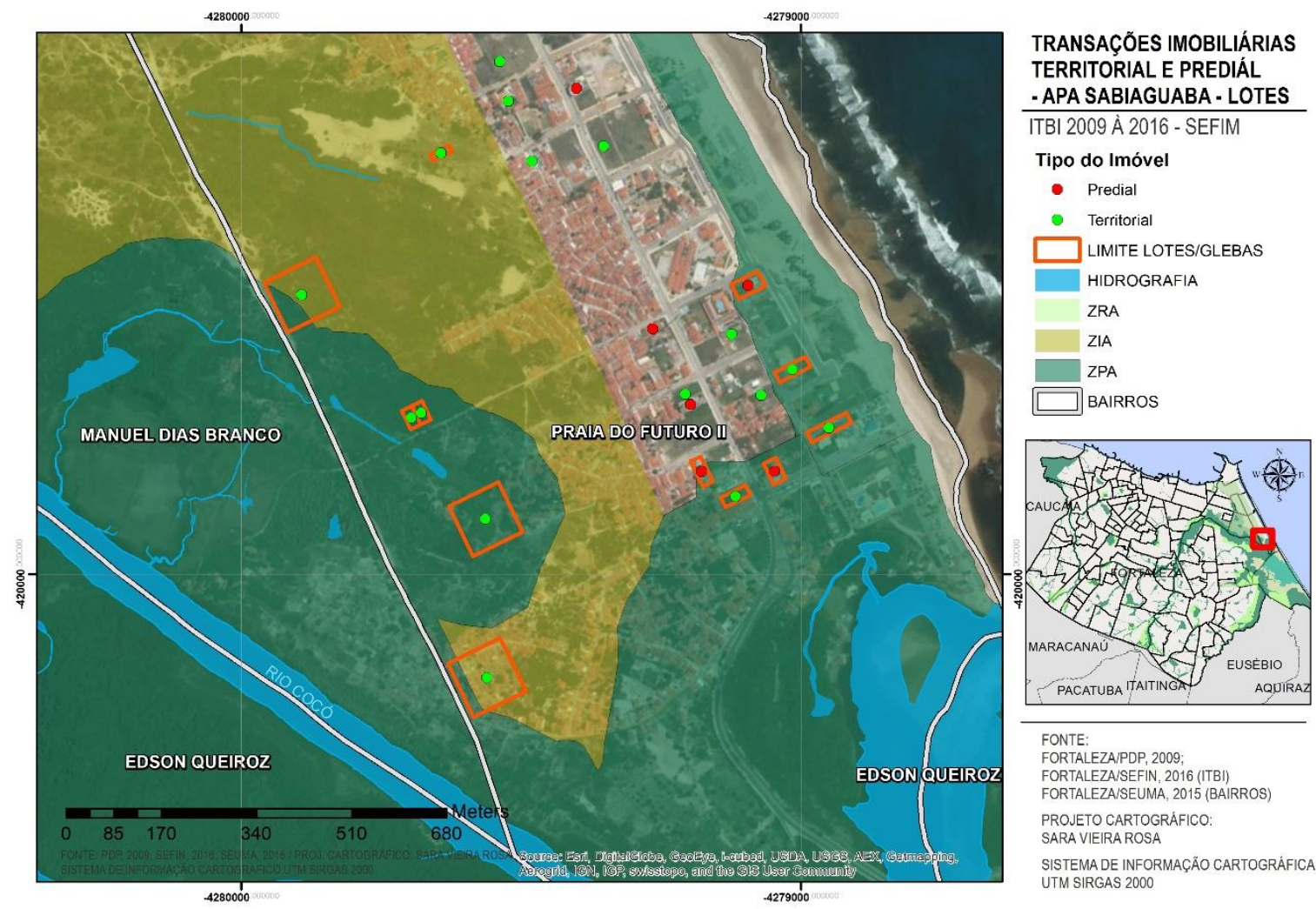

Fonte: SEFIN/ITBI, FORTALEZA/PDP, 2009. Elaborado por Sara Vieira Rosa, 2016

Inadequação dos imóveis edificados em áreas de proteção

As áreas de proteção ambiental de Fortaleza, ZIA e ZRA, permitem a construção de edificações com parâmetros específicos, segundo já explicitado. Todavia parte dos imóveis identificados com a ajuda da base de dados do ITB foram construídos desrespeitando estes parâmetros.

Para exemplificar, utilizaremos como análise a altura estimada das edificações construídas após a data de publicação do Plano Diretor Participativo (13 de março de 2009). Esta informação foi filtrada a partir do que estava registrado na base de dados do ITBI, como ano de construção do imóvel e a altura. As alturas foram estimadas a partir do número de pavimentos de cada edifício, considerando um pé-direito de $3 \mathrm{~m}$.

É importante fazer a ressalva de que o corte temporal das construções realizadas após a aprovação do PDP não garante que todos os imóveis construídos dentro de ZPA estejam 
ilegais, pois o PDP traz no Art. $320^{224}$ a possibilidade dos projetos aprovados previamente à publicação da lei serem regidos pela legislação antiga.

Ressalta-se também que a base do ITBI, como já mencionado, possui algumas falhas. Ao verificar o número de pavimentos, podem ser observados imóveis registrados como prediais, porém com 0 pavimentos, e por outro lado também se verifica o caso de imóveis territoriais com mais de 1 pavimento. Como estes casos eram poucos, considerou-se que não prejudicaria a informação. $O$ intuito desta primeira análise é apontar a ocorrência de processos e ter uma noção da sua incidência, mais do que quantificar precisamente os casos irregulares. Ainda assim, considera-se possível trabalhar com a base de forma quantitativa, considerando que existirá uma margem de erro.

O Quadro 16 mostra a informação do número de imóveis prediais construídos após a aprovação do PDP2009, com cobrança de ITBI nas zonas de Interesse Ambiental, Recuperação Ambiental e Preservação Ambiental, organizada pelo número de pavimentos da edificação. Já no Quadro 15, separamos a altura máxima da edificação segundo o PDP de 2009 e o número de pavimentos estimados correspondente à altura máxima.

Quadro 15. Parâmetros urbanos das zonas de proteção ambiental segundo PDP 2009

\begin{tabular}{|l|r|r|r|r|r|} 
ZONAS & ZPA & ZIA-sabiag. & ZIA-Cocó & ZIA-P.Futuro & ZRA \\
\hline ALTURA MÁXIMA DA EDIF. & 0,0 & $15 \mathrm{~m}$ & $48 \mathrm{~m}$ & $48 \mathrm{~m}$ & $15 \mathrm{~m}$ \\
Número de pavimentos estimados & 0 & 5 & 16 a 17 & 16 a 17 & 5 \\
\hline
\end{tabular}

Fonte: FORTALEZA/PDP, 2009. Organização: Sara V. Rosa, 2016

Quadro 16. Total de imóveis prediais registrados na Base de dados do ITBI após a aprovação do PDP (13/03/2009) por número de pavimentos da edificação.

\begin{tabular}{|c|c|c|c|c|}
\hline Número de Pavimentos & ZIA & ZPA & ZRA & Total Geral \\
\hline 0 & 59 & 4 & 266 & 329 \\
\hline 1 & 23 & 120 & 299 & 442 \\
\hline 2 & 242 & 112 & 332 & 686 \\
\hline 3 & 39 & & 1 & 40 \\
\hline 4 & & 13 & 7 & 20 \\
\hline 5 & 75 & 180 & & 255 \\
\hline 6 & 220 & & & 220 \\
\hline 7 & 23 & & & 23 \\
\hline 9 & 56 & & & 56 \\
\hline
\end{tabular}

\footnotetext{
${ }^{224}$ Art. 320. Os processos de aprovação de projetos arquitetônicos, pedido de alvará de construção/reforma, pedidos de alteração de projetos e os processos de consulta prévia, a exceção dos que envolvam áreas de ZEIS 3, conforme localizações indicadas no Anexo 5 (Mapa 5), cujos requerimentos vierem a ser potocolizados até o início da vigência desta Lei, e desde que encaminhados juntamente com os projetos necessários à sua análise, poderão, à opção do interessado, reger-se pela legislação vigente à época. (FORTALEZA, PDP, ART.320, 2009)
} 
Fonte: SEFIN, 2016. Organização: Sara V. Rosa, 2016

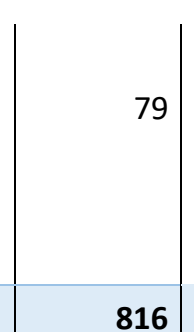

816

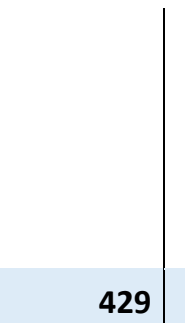

429
118

Segundo as informações analisadas, foram construídas dentro de ZPA, após a aprovação do Plano Diretor, 429 imóveis prediais, em uma área onde a taxa de ocupação e altura são 0. Caso existam edifícios verticais, alguns destes casos podem ser referentes à mesma edificação, porém, como as registradas não ultrapassam mais de 5 pavimentos, não serão estes muitos casos. Já nas áreas de ZIA e ZRA, os casos de registros referentes a um mesmo edifício podem ser vários devido à existência aí de edifícios de grande altura com mais de 16 andares.

A Zona de Interesse Ambiental possui parâmetros diferentes para Sabiaguaba, Cocó e Praia do Futuro, com 15 metros para a primeira e 48 para as demais. Pelas imagens aéreas e conhecimento da área, sabemos que na ZIA da Sabiaguaba não existem, atualmente, construções com mais de 15 metros, assim que fizemos o corte nos $48 \mathrm{~m}$ e os possíveis casos identificados correspondem a edifícios nas demais ZIAs. No total, são 79 casos registrados com 17 pavimentos, número de pavimentos limite dependendo da altura do pé-direito.

Já a Zona de Recuperação Ambiental, que deveria comportar edifícios de no máximo 15m, o equivalente aproximadamente a 5 pavimentos, é a que apresenta a maior quantidade de registro de imóveis em desconformidade com a lei vigente. Foram registrados 313 imóveis com mais de 16 pavimentos, ou seja, com mais de $44 \mathrm{~m} / 48 \mathrm{~m}$. Muitos destes, como já comentado, correspondem a um mesmo edifício vertical, como no exemplo da Figura 112, onde um mesmo edifício possui 118 registros. 
Figura 112. Iguatemi Tower

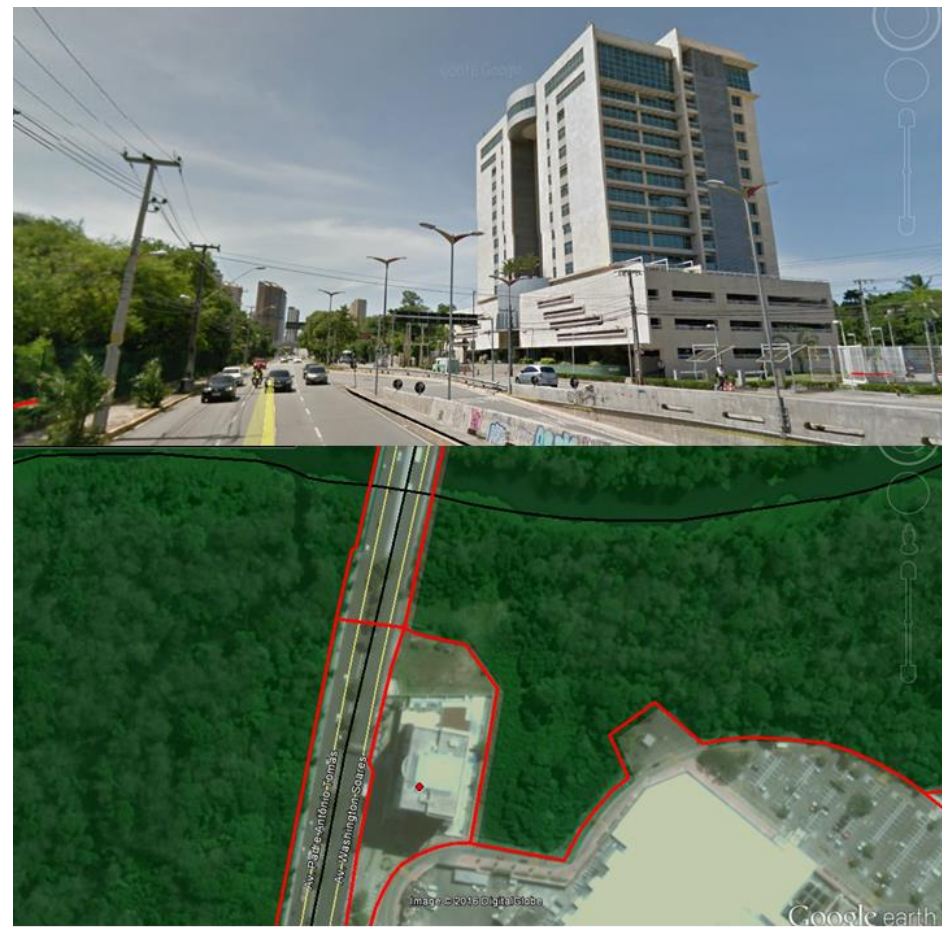

ZRA - Iguatemi tower

№ de unidades vendidas com

registro no ITBI: 118

Exercício de cobrança do ITBI: 2011 e 2016

Data de construção: 08/10/2010

Uso: Comercial

Tamanhos das salas: $16 \mathrm{~m}$ e $98 \mathrm{~m}$ a $125 \mathrm{~m}$

Valor base de venda para cálculo do

ITBI: $100 \mathrm{mil}\left(16 \mathrm{~m}^{2}\right)$ e $330 \mathrm{mil} \mathrm{a} 835 \mathrm{mil}$

Número de unidades do empreendimento: 262

Número de pavimentos: 16

Grupo Jereissati, incorporador do empreendimento

Altura aproximada: $44 m$ a $48 m$

Fonte: Google Earth e Google Street View

O padrão dos imóveis prediais vendidos dentro das áreas de proteção ambiental

Além da forte comercialização de terrenos e imóveis prediais em áreas de proteção ambiental, incluindo comercialização de edificações em áreas de ZPA, que não deveriam ter construções, é interessante também observar o padrão dessas construções, identificando assim um possível perfil de população foco para a comercialização nessas áreas.

O padrão das construções foi observado a partir da base de dados do ITBI, utilizando a classificação feita pela SEFIN para estes imóveis para efeito de estimativa do cálculo do imposto cobrado. A Secretaria classifica os imóveis edificados de acordo com o tamanho, número de compartimentos e material empregado na construção. Assim, quanto maior e quanto mais sofisticados forem os materiais, o valor de venda será mais caro e também o imposto cobrado. A Secretaria define 12 classes diferentes para o padrão da edificação. São estas: baixo nível 1,2, e 3; normal 1, 2 e 3; alto nível 1,2, e 3; luxo 1,2, e 3. Para completar a análise, também foram observadas algumas destas edificações a partir de visitas aos locais, imagens aéreas e google streetview. 
A sistematização dessas informações levou à conclusão que existe um perfil de cliente para estas áreas que seria a classe média, média alta, e alta, visto que mais de $77 \%$ das comercializações de imóveis no período analisado foram de imóveis alto nível e luxo (Quadro 17 e Tabela 6).

Quadro 17. Padrão das edificações que tiveram ITBI cobrados em áreas de proteção ambiental no período de 2009 a setembro de 2016 segundo a SEFIN

\begin{tabular}{|c|c|c|c|c|}
\hline Rótulos de Linha & ZIA & ZPA & ZRA & \\
\hline Alto nível 1 & 214 & 138 & 435 & 787 \\
\hline Alto nível 2 & 456 & 137 & 406 & 999 \\
\hline Alto nível 3 & 586 & 249 & 708 & 1.543 \\
\hline Baixo nível 1 & 88 & & 32 & 120 \\
\hline Baixo nível 3 & 1 & 3 & 1 & 5 \\
\hline Luxo 1 & 235 & 13 & 139 & 387 \\
\hline Luxo 2 & 171 & & 404 & 575 \\
\hline Luxo 3 & 1 & & & 1 \\
\hline Normal 1 & 5 & 10 & 11 & 26 \\
\hline Normal 2 & 69 & 42 & 52 & 163 \\
\hline Normal 3 & 57 & 134 & 373 & 564 \\
\hline (Vazio) sem informação & 121 & 2 & 251 & 374 \\
\hline Total Geral & 2.004 & 728 & 2.812 & 5.544 \\
\hline
\end{tabular}

Tabela 6

$\begin{array}{lrrr} & \text { Alto nível + luxo } & \text { Normal + Baixo Nível } & \text { Vazio } \\ \text { Total } & 4292 & 878 & 374 \\ \% & 77,42 & 6,75\end{array}$



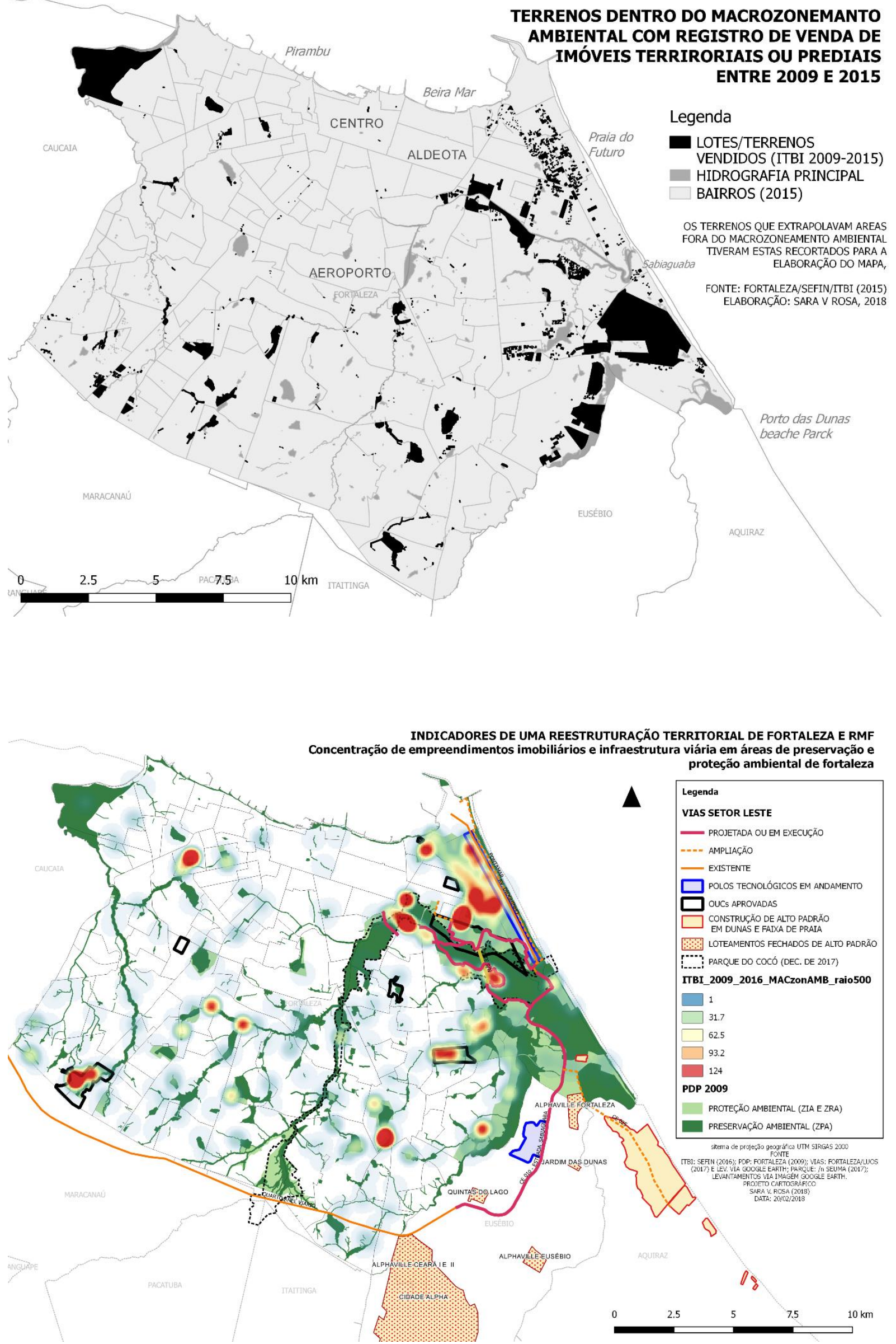


\subsection{CONSIDERAÇÕES FINAIS DO CAPÍTULO 03}

A partir da observação das estratégias atuais do mercado imobiliário de acumulação e valorização, percebe-se que a legislação e o planejamento urbano têm funcionado como uma importante ferramenta capaz de instrumentalizar o espaço (natureza) como meio de valorização fictícia do capital. Estratégias viáveis devido ao maior imbricamento do Estado e do Setor privado.

No contexto atual, não interessa tanto, como antes, o que é produzido no imobiliário, nem se de fato é realmente produzido, uma vez que os empreendimentos, por meio de Sociedades de Propósito Específico, e, especialmente, a própria terra são instrumentalizados como capital fictício $^{225}$, a alimentam o mercado de ações de empresas e fundos financeiros. A valorização fictícia da natureza, mesmo sem a concretização futura da produção, representa um aumento da renda, no presente.

Assim, esses processos atuais em Fortaleza onde observa-se a ampliação e intensificação de instrumentos urbanos como propostas de OUC para metade do município, possibilidade de aplicação de Outorga Onerosa para todos os parâmetros urbanos e em todo o território, emissão de Certificados de Potencial Adicional de Construção (CPACs), passam a ser mais interessantes que a construção em si, pois alimentam processos de valorização fictícia, ao mesmo tempo que são um reflexo da incorporação da lógica da financeirização e da dimensão do fictício para o território e para a gestão da cidade.

${ }^{225}$ Maiores detalhes da instrumentalização da terra como capital fictício ver ALDIGUERI, 2017. 


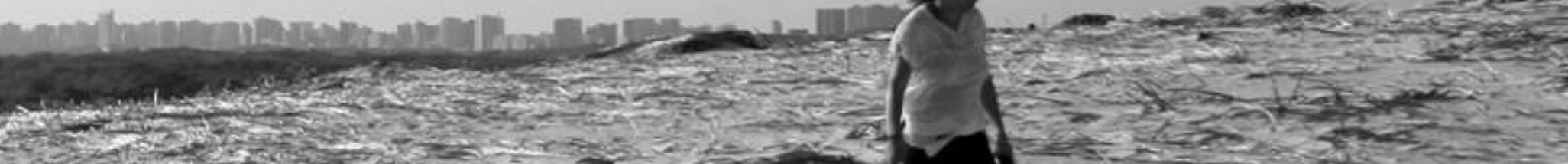

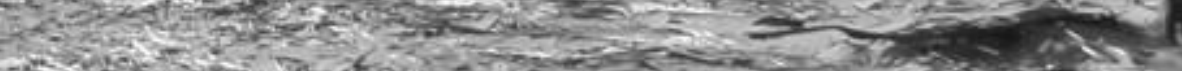

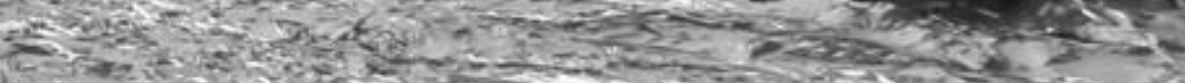

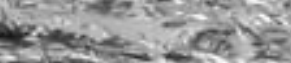

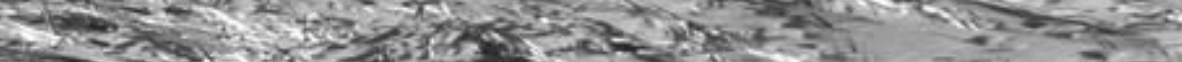

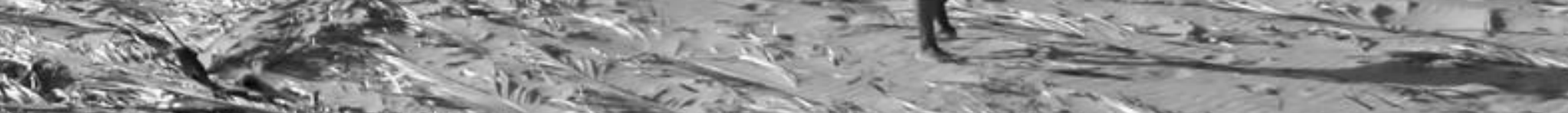

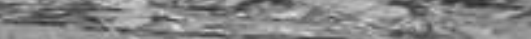

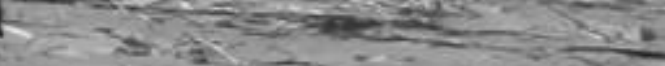

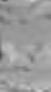

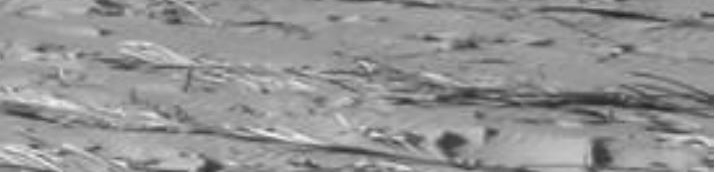
Q

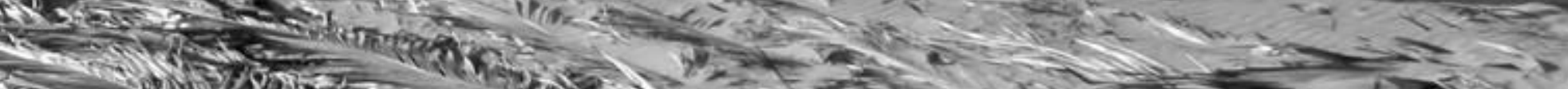

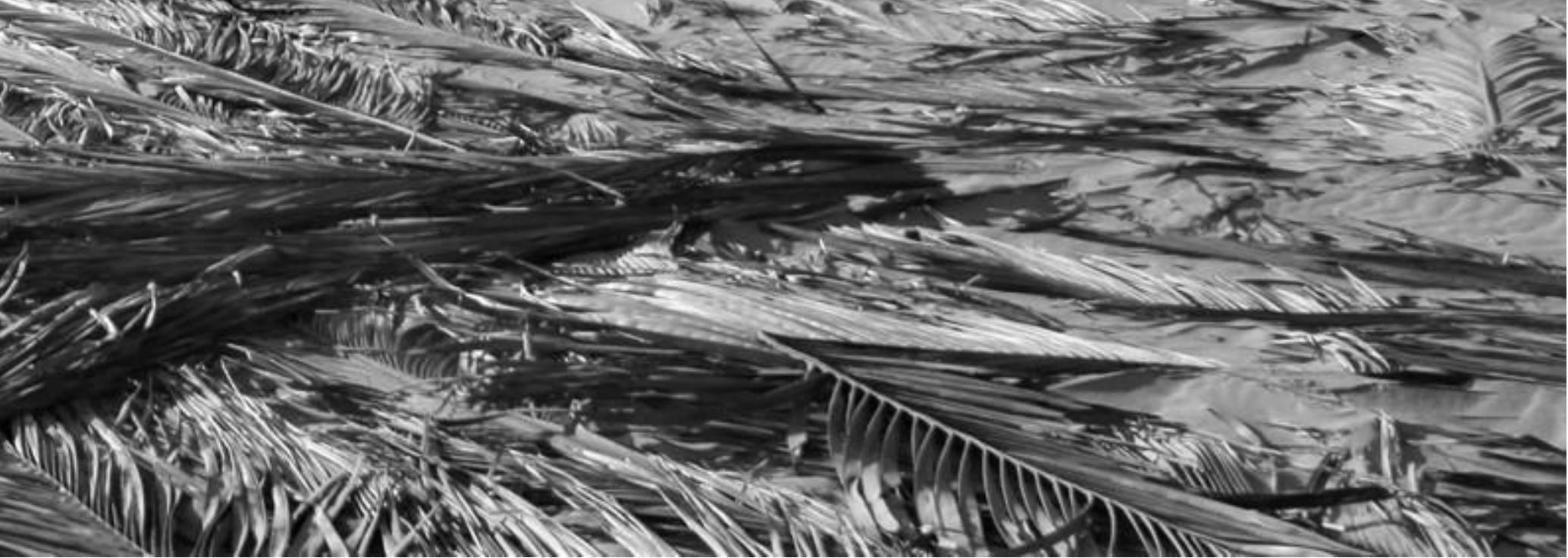

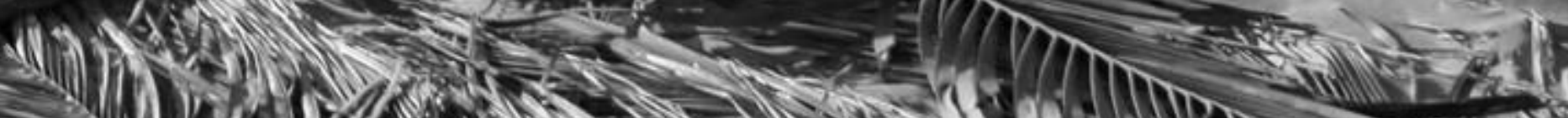
HII 
ACUMULAÇÃO E "VALORIZAÇÃO” PELA NATUREZA NO PROCESSO DE PRODUÇÃO CAPITALISTA DA CIDADE DE FORTALEZA

FOTO: SARA VIERA ROSA, 2017

VISTA DO PARQUE DAS DUNAS DA SAIAGUABA

LOCAL: DUNAS DA SABIAGUABA - PARUE DAS DUNAS DA SABIAGUABA - FORTALEZA, CE

Página 294 | CAP. 03 - INTENSIFICAÇÃO E APERFEIÇOAMENTO DAS ESTRATÉGIAS 


\section{CONSIDERAÇÕES FINAIS}

Iniciamos o primeiro capítulo da tese resgatando processos de acumulação por espoliação no Brasil e Ceará que foram essenciais para a formação das bases da sociedade capitalista europeia e brasileira. Ao longo do capítulo, observa-se que a Natureza, incluindo a terra e o homem, tem um papel essencial nesse processo. A acumulação inicial (primitiva), se dá justamente pela apropriação privada, roubo e exploração de ambos.

No século XX, a apropriação privada da terra, em Fortaleza, concentra-se nas mãos de poucos sob a forma da moderna propriedade privada. O loteamento dessas terras passa a ser uma atividade importante e expande horizontalmente a cidade, deslocando populações, soterrando lagoas, encobrindo dunas e desviando rios, mesmo que não exista demanda com capacidade de pagamento para ocupar esses lotes. Assim, os grandes marcos naturais, como rios mais volumosos, dunas, são neste momento barreiras que contêm e impedem a expansão urbana, a expansão dos loteamentos. A natureza é compreendida por estes proprietários de terra e rentistas como barreiras a serem superadas e incorporadas como riqueza entesourada e renda. Desta forma, ao mesmo tempo em que a natureza se apresenta como possibilidade de renda, ela é barreira, e ao mesmo tempo que que é barreira, é possibilidade de renda.

A postura então foi de dominá-la, de transformar locais não propícios à ocupação e construção, como dunas móveis, áreas de inundação (planícies flúvio-marinhas, fluviais, lacustres), e até mesmo o leito de lagoas e rios em terrenos propícios à construção e obtenção de renda, ou em avenidas-canais que, ao mesmo tempo que dão acesso a essas terras, contêm as águas, possibilitando que os lotes lindeiros sejam ocupados. Nos termos de Lefevbre (1999) podemos destaca uma negação da natureza pela indústria e pela cidade e a transformação da primeira natureza em segunda natureza, a cidade, o urbano. A renda imobiliária, neste momento, era obtida de forma extensiva e envolvendo processos de espoliação que capturam riquezas comuns, sem ou com o aval do Estado, ilegais, ou, já legalizados pelo direito à moderna propriedade privada, mas sempre imorais.

Essa postura alienada de dominação da Natureza, destaca uma das contradições mais importantes do capitalismo. No constante processo de obter seu próprio pressuposto, 
apropriação privada de riqueza a ser convertida em capital, o capital destrói os elementos capazes de lhe oferecer riqueza, a natureza (terra e homem).

A partir daí, em especial a partir da segunda metade do século $X X$, correntes ecológicas começam a ganhar mais destaque e a natureza começa a ser uma questão no processo de produção das cidades brasileiras e para o Estado, que passa a normatizar o uso e ocupação do solo, restringindo direitos de propriedade privada em prol da conservação ambiental. A natureza antes negada, passa a ser afirmada, seja por seu valor de uso, por seu valor intrínseco, seja como recurso, e seja também pelo seu valor de troca.

Assim, a natureza agora, legalmente afirmada, do ponto de vista do rentista e do capitalista imobiliário, passa a ser não só uma barreira física à possibilidade de renda, apesar de ser ela mesma o mecanismo da obtenção de renda, como também uma barreira legal. Todavia, no mundo das mercadorias, só tem validade social o que pode ser trocado enquanto mercadoria. Deste modo, a natureza afirmada não é natureza socialmente reconhecida como natureza. O não reconhecimento social da natureza enquanto natureza facilita as estratégias de superação dessas barreiras legais e a transformação da natureza em mercadoria.

Uma vez assumida a forma fantasmagórica de mercadoria, a natureza passa a ter validade social enquanto valor (fictício). Uma vez assumida a forma de valor (fictício), passa inclusive a ser produzida (natureza inventada) com aparência de uma primeira natureza e a geração de valor, antes fictício e capitalizado, passa a ser valor real produzido por meio da exploração do trabalho humano (também natureza).

As estratégias de acumulação de valor vão se sobrepondo, aperfeiçoando-se a partir de formas de capitalização de valor e produção de valor, tendo a natureza como meio para isto. Porém, estas duas formas sempre são pressupostas de acumulação de riqueza comum por espoliação.

Na modernidade, essas estratégias estão sendo viabilizadas e potencializadas por meio do planejamento urbano e por formas cada vez mais aperfeiçoadas de desregulamentação regulamentadas. Dessa forma, o Estado continua a ter um papel fundamental, se não ainda mais importante, e a legalidade colocada por este nos processos contribui ainda mais para obscurecer os processos de exploração e sobretudo de espoliação aí contidos. 
Do começo ao fim desta tese, foram destacados processos de acumulação por espoliação que envolvem a natureza, representada tanto pelo meio biofísico que sustenta a vida, como pelo ser humano, também natureza. Estes processos ajudam a demostrar que o sistema capitalista foi gerado, e é sustentado, por processos espoliativos e de capitalização de valor, mais do que de exploração e produção de valor. Por mais que haja um aperfeiçoamento da extração de mais-valia no processo produtivo do setor imobiliário, o produto final sempre está preso à terra (natureza), que se concretiza enquanto mercadoria por meio da capitalização de valor.

Tais processos ajudam a perceber também que, tanto no processo de produção como no de capitalização de valor, há uma destruição do meio biofísico que sustenta a vida e do próprio homem. Mesmo quando o capital "cria" natureza, ele o faz destruindo-a. Podemos relembrar aqui, para exemplificar, o caso da criação do Parque do Riacho Maceió. A justificativa do projeto é pautada em um discurso de que o local estava poluído e degradado, todavia a implementação do parque implicou o desmatamento de mata ciliar e este permaneceu poluído. Implicou também na a expulsão de moradores que guardavam uma relação de uso com o riacho. Assim, o parque, natureza inventada, natureza fictícia (LEFEVBRE, 1999), é também meio de exclusão e segregação. A natureza antes negada, agora afirmada enquanto valor, é negada para parcelas da população. Com bem afirmou Harvey, "o capital nunca hesitou em destruir as pessoas, quando se trata de lucrar" ( HARVEY, 2016, p. 232)

Essa destruição da natureza, incluindo o ser humano, em prol da geração de capital, ocorreu na acumulação primitiva, descrita no primeiro capítulo, e continua ocorrendo nos dias atuais, como mostrado nos capítulos dois e três. Para exemplificar, podemos relembrar das mortes de idosos, pelo impacto de serem removidos de seus lares, relatadas pelos antigos moradores do terreno da OUC do Riacho Maceió, como também, fugindo dos casos trabalhados na tese, o recente rompimento da barragem de exploração de minério na cidade de Brumadinho-MG. Em ambos os casos houve destruição do homem e da natureza, apesar que no caso do riacho Maceió a produção do parque mascara esse processo.

Rufino (2) observa, a partir do predomínio da forma imobiliária de incorporação, um "deslocamento do predomínio de relações de exploração para o predomínio de relações de espoliação - imobiliária, urbana e potencialmente financeira" (p. 313). Assim, 
complementando a ideia da autora, se consideramos a espoliação em um espectro mais amplo, considerando que em todos os processos de espoliação, seja imobiliária, urbana, financeira, o sujeito espoliado é o ser humano e a natureza (lembrando que o primeiro também é aqui considerado natureza), a espoliação sempre esteve presente, e em alguns períodos predominou sobre a exploração. É uma espiral formada pela espoliação e exploração que acompanha a espiral do sobrepreço e acumulação de capital.

Relembrando o primeiro momento de formação do mercado imobiliário em Fortaleza, até década de 1970, este foi quase que puramente espoliação. A conformação do mercado de loteamentos foi precedida pelo roubo e apropriação privada da terra. Primeiramente, esta passou a ser comercializada apenas em lotes, sem construção nenhuma, e praticamente sem infraestrutura alguma (capitulo 01). Ou seja, o proprietário, a partir de uma riqueza roubada (terra), obtém renda sem produzir nenhum valor. Como não existe produção de valor, a renda obtida pelo proprietário é capitalizada, sugada, de outros processos de produção de valor, ou adiantadas a partir de créditos bancários com base na perspectiva futura de produções de valores. Nesta situação, a espoliação prevalece enormemente sobre a exploração. Quando ocorre produção neste período, a construção do imóvel dá-se principalmente por encomenda, neste caso, o valor gerado é realizado principalmente na forma de valor de uso.

Quando o mercado imobiliário se desenvolve e deixa de ser apenas um mercado de terra, mas passa a ser também um mercado da construção, começa-se então a gerar mais-valia a partir do tempo abstrato da força de trabalho necessária para a construção desses imóveis. Mas não podemos esquecer que o preço final desse imóvel construído englobará também a renda paga ao proprietário da terra. Assim, a forma mercadoria desse imóvel construído mascara não só a exploração do trabalhador no processo de construção, mas também a apropriação privada de uma riqueza comum e a capitalização do valor necessário para pagar a renda da terra, ou seja, mascara também processos de espoliação.

Assim, no segundo e no terceiro capítulos, ainda que o foco seja a aparente valorização de capital pela natureza, valorização fictícia, porém real na aparência, mas que por não ser real na essência, realiza-se, na verdade, como capitalização de valor, implica, portanto, mais em processos espoliativos que de exploração. Além disso, apesar de serem casos mais recentes, eles combinam estratégias de acumulação nos moldes da "chamada acumulação primitiva", incluindo a apropriação privada de terras públicas, onde nem sempre fica clara a legalidade 
desses processos; a apropriação privada e a mercantilização de terras que haviam sido desmercantilizadas; e a expulsão de população que se apropriava destas terras enquanto valor de uso para moradia e subsistência.

O caso da Sabiaguaba, que atravessa parte da tese, e onde é possível comprovar a descendência indígena da população da Boca da Barra, expulsa na chegada do loteamento de veraneio e ameaçada recentemente (com futuro ainda incerto) pela demarcação do novo Parque do Cocó, exemplifica bem como a população espoliada no passado é a mesma do presente. Nossa dívida com os povos originários está sempre crescendo.

Nota-se, assim, que em um primeiro momento a estratégia de acumulação por espoliação no Ceará, e a formação da moderna propriedade privada implicaram a fixação do homem, nômade, em um território reduzido, como exemplificado no caso dos povos indígenas abordado no capítulo 01, enquanto que, na atualidade, as novas estratégias de acumulação por espoliação e manutenção da moderna propriedade privada forçam o homem a constantes mudanças do local de seu habitat, formando populações urbanas nômades ${ }^{226}$.

Por fim, destacamos que no capitalismo, desde seu início, "o lado abstrato chega a ser mais importante que o lado concreto" (Jappe, apud Pereira, 2017, p. 182). O capitalismo sempre esteve capitalizando valor de outros setores produtivos, e principalmente valor futuro. A cada fase ele vai aprimorando estratégias de potencializar a capitalização, deixando a geração seguinte sempre refém de produzir valor necessário no presente e valor capitalizado no passado. $\mathbf{O}$ capital se apropria privativamente não só da natureza, incluindo o ser humano, mas se apropria privativamente também do tempo. O que torna a possibilidade de encontrar uma outra forma de sistema de organização diferente do capitalismo uma tarefa praticamente, se não, impossível. Pois, mesmo que consigamos a árdua e difícil tarefa de romper com o fetiche da mercadoria e suplantar a alienação, como aponta Mészaros ( 2016), nosso futuro já está capturado. Nossos filhos e netos terão que produzir valor necessário para a produção de seus tempos e para pagar o débito do valor fictício capitalizado no nosso tempo.

Não só nosso trabalho futuro é capitalizado hoje. O consumo dos recursos naturais que sustentam a vida também é capitalizado no presente sob a forma de valor fictício. Ao

${ }^{226} \mathrm{O}$ destaque dado aqui para essa dualidade nômade-fixo versus fixo-nômade foi apontado como contribuição da colega Camila Aldigueri. 
capitalizar valor futuro também há uma captura de natureza futura. Natureza que será transformada e consumida nos processos de produção do futuro para realização do valor capitalizado no presente.

Com o advento do capital financeiro, que é fictício, sob o capital imobiliário, que como descrito ao longo da tese, é baseado em grande medida em capitalização de valor, o fictício se exacerba no nosso tempo. A capitalização de valor, antes, muito pautada na capitalização a partir da produção de mais-valia do entorno - como a construção de infraestrutura ou a construção de equipamento ancora - passa a ser, em grande medida, pautada na capitalização de uma possibilidade futura de produção de mais-valia. Nesse processo, a construção social do que é natureza, e do que deve ser ou não protegido, preservado e valorado entra como importante categoria, assim como os marcos legais e instrumento urbano como OUCs, têm se demostrado como importante estratégia de materialização (fictícia) dessa possível produção futura que já garante renda no presente.

O problema é que esse processo capitalização de valor, que não existe, fica acumulado nas mãos de poucos, que conseguem obter renda, no presente, a partir do ônus de toda a sociedade que passa a sofrer de forma mais intensa processos de espoliação urbana, imobiliária, financeira, e porque não, espoliação da natureza também? Além de ter que produzir mais valor no futuro por meio da exploração da sua força de trabalho. Processos, estes, que recaem principalmente na população mais pobre e na população que teve que arcar com a acumulação primitiva, em especial os negros e índios, contribuindo para o acirramento do quadro de desigualdade e segregação de Fortaleza. 



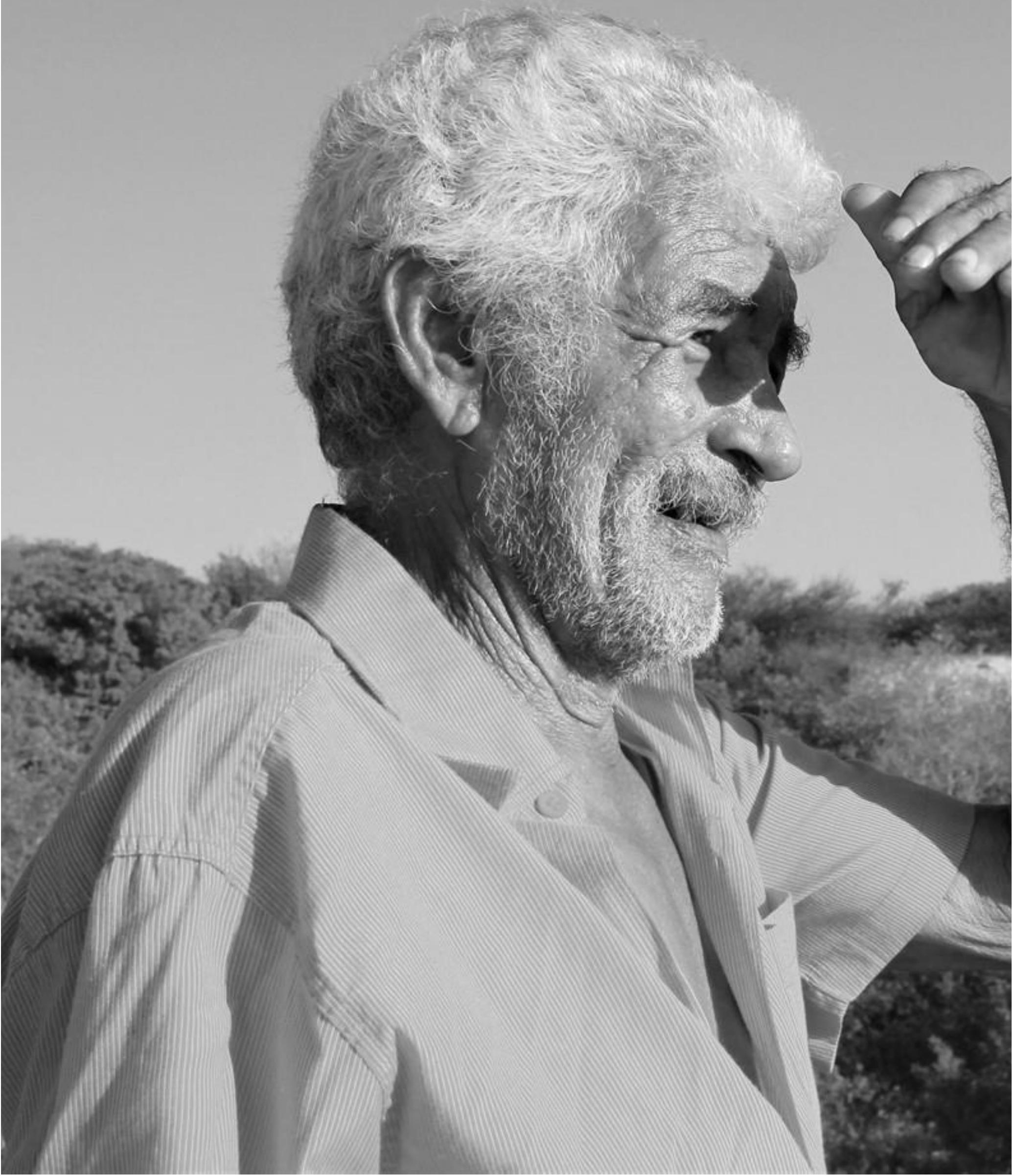




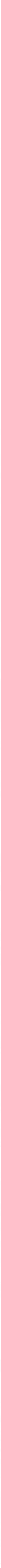


ACUMULAÇÃO E "VALORIZAÇÃO” PELA NATUREZA NO PROCESSO DE PRODUÇÃO CAPITALISTA DA CIDADE DE FORTALEZA

FOTO: SARA VIERA ROSA, 2017

PESCADOR DA BOCA DA BARRA OLHANDO O HORIZONTE

LOCAL: DUNAS DA SABIAGUABA - PARUE DAS DUNAS DA SABIAGUABA - FORTALEZA, CE 


\section{REFERÊNCIAS BIBLIOGRÁFICAS}

ACCIOLY, V. M. Planejamento, Planos Diretores e epansão urbana: Fortaleza 1960-1992. Salvador: Universidade Federal da Bahia, 2008. Tese apresentada ao Programa de Pósgraduação em Arquitetura e Urbanismo, Faculdade de Arquitetura, Universidade Federal da Bahia, como requisito parcial para a obtenção do grau de Doutora em Arquitetura e Urbanismo.

ACOSTA, A. O bem-viver: uma oportunidade para outros mundos. Tradução de Tadeu Breda. São Paulo: Autonomia Literária, Elefante, 2016. 264 p.

ALBUQUERQUE, C. C. G. Regimes de exceção e mobilização das mais-valias fundiárias: o caso das operações urbanas consorciadas de Fortaleza - cE. São Paulo: Mackenzie, 2015. Tese de Doutorado apresentada apresentada ao Programa de Pós-graduação da Universidade Presbiteriana Makenzie para obtenção de título de doutor em Arquitetura e Urbanismo..

ALDIGUERI, C. Metamorfoses da terra na produção da cidade e da favela em fortaleza. São Paulo: USP, 2017. Tese apresentada a Faculdade de Arquitetura e Urbanismo da Universidade de São Paulo para obtenção do título de Doutor em Ciências. Área de Concentração: Habitat. Orientador: Prof. Doutor Paulo César Xavier Pereira. Exemplar revisado e alterado.

ALDIGUERI, C. Metamorfoses da terra na produção da cidade e da favela em fortaleza. Tese apresentada a Faculdade de Arquitetura e Urbanismo da Universidade de São Paulo para obtenção do título de Doutor em Ciências. São Paulo: USP, 2017.

ANDRADE, M. J. D. S. Fortaleza em perspectiva histórica: poder e iniciativa privada na apropriação e produção material da cidade (1810 - 1933). São Paulo: USP, 2012. Tese de doutorado apresentada a FAUUSP. São Paulo, 2012.

ANDRADE, M. J. F. D. S.; JUCÁ NETO, C. R. A lógica da configuração da rede urbana cearense no século XIX. ENAMPARQ, São Paulo, 2014. III Encontro da Associação Nacional de Pesquisa e Pós-graduação em Arquitetura e Urbanismo: arquitetura, cidade e projeto: uma construção coletiva.

ANTUNES, T. D. O. 1863: o ano em que um decreto - que nunca existiu - extinguiu uma população indígena que nunca deixou de existir. Aedos, v. 4, Jan/Jul 2012. n. 10. 
BRASIL. Decreto n. 426 de 24 de julho de 1845. Contém o Regulamento ácerca das Missões de catechese, e civilisação dos ìndios. Coleção de Leis do Império do Brasil, Rio de Janeiro, 1845. Disponivel

em: <http://legis.senado.leg.br/legislacao/ListaTextoSigen.action?norma=387574\&id=14390167 \&idBinario=15771126\&mime=application/rtf>. Publicação Original [Coleção de Leis do Império do Brasil de 31/12/1845 - vol. 001] (p. 81, col. 1).

BRASIL. Lei no 601, de 18 de setembro de 1850. Dispõe sobre as terras devolutas do Império. Governo do Planauto, Rio de Janeiro, 1850. Disponivel em: <http://www.planalto.gov.br/ccivil_03/LEIS/LIM/LIM601.htm>.

BRASIL. Decreto no 1.318, de 30 de janeiro de 1854. Manda eecutar a Lei no 601 de 18 de setembro de 1850. Governo do Planauto, Rio de Janeiro, 1854. Disponivel em: <http://www.planalto.gov.br/ccivil_03/decreto/Historicos/DIM/DIM1318.htm>.

BRASIL. Código florestal brasileiro - lei n 4771 de 1965. [S.I.]: [s.n.], 1965.

CEARÁ. Decreto no 15.274, de 25 de maio de 1982. [S.I.]: [s.n.], 1982. Disponivel em: $<$ http://www.mpce.mp.br/wp-

content/uploads/2015/12/Coletanea_de_legislacao_ambiental-2007-Cear\%C3\%A1.pdf>. Acesso em: fevereiro 2019. Dispõe sobre as faixas de 1a e 2 2 Categorias de que tratam os art. 3a e 4a da Lei no 10.147, de 1ㅇ de dezembro de 1977, estabelecidas, especificamente, as áreas de proteção dos recursos hídricos do Município de Fortaleza.

CEARÁ. Lei complementar n.o 144, DE 04.09.14, D.0. 08.09.14. Fortaleza: [s.n.], 2014.

CECHIN, Andrei. A natureza como limite da economia: a contribuição de Nicholas GeorgescuRoegen. São Paulo: Ed. Senac São Paulo; EDUSP, 2010.

CHESNAIS, F.; SERFATI, C. "Ecologia" e condições físicas da reprodução social: alguns fios condutores marxistas. Crítica Marxista, São Paulo, n. 16, p. 39-75, março 2003. ISSN 01049321.

DANTAS, E. W. C.; SILVA, J. B. D. A formação histórica da metrópole e principais tendências de desenvolvimento. In: PEQUENO, R. Como anda Fortaleza. Rio de Janeiro: Letra Capital: Observatório das Metrópoles, 2009. Cap. 1, p. 1-39. 
DOM JOÃO VI, P. R. Carta Régia de 13 de maio de 1808. Manda fazer guerra aos indios Botocudos. Coleção de Leis do Império do Brasil - 1808, Página 37 Vol. 1 (Publicação Original), $1808 . \quad$ Disponivel em: <http://www2.camara.leg.br/legin/fed/carreg_sn/anterioresa1824/cartaregia-40169-13maio-1808-572129-publicacaooriginal-95256-pe.html>.

FERRARA, L. N. O lugar da natureza na produção do espaço metropolitano: do metabolismo urbano para o imobiliário financiro. In: PEREIRA, P. C. Imediato, global e total na produção do espaço: a financeirização da cidade de São Paulo no século XXI. São Paulo: FAUUSP, 2018. p. 137-160.

FOLADORI, Guillermo. O metabolismo com a natureza. Crítica Marxista. p. 105-117, s/d.

FORTALEZA. Lei 7.061 de 16 de janeiro de 1992. Fortaleza: [s.n.], 1992. Plano Diretor de Desenvolvimento integrado da Região Metropolitana de Fortaleza, PLADIRF.

FORTALEZA. Lei no 7.987, de 23 de Dezembro de 1996. Fortaleza: [s.n.], 1996. Lei de Uso e Ocupação do Solo do Município de Fortaleza.

FORTALEZA. Lei complementar no 062, de 02 de fevereiro de 2009. Fortaleza: [s.n.], 2009. Institui o Plano Diretor Participativo do Município de Fortaleza e dá outras providências.

FORTALEZA. Plano de Manejo do Parque Natural Municipal das Dunas de Sabiaguaba (PMNDS)) e da Área de Proteção Ambiental de Sabiaguaba (APA). Fortaleza: [s.n.], 2010. Disponivel em: <https://urbanismoemeioambiente.fortaleza.ce.gov.br/images/urbanismo-emeio-ambiente/planejamento/plano_de_manejo_da_sabiaguaba.pdf>. Equipe técnica: MEIRELES, J. et.al.

FORTALEZA. Plano local de habitação de interesse social de Fortaleza (PLHISfor). Fortaleza: [s.n.], 2012.

FORTALEZA. Lei Orgânica do Município. Fortaleza: [s.n.], sd. Disponivel em: <http://legislacao.fortaleza.ce.gov.br/index.php/Lei_Orgânica_do_Município>. Versão atualizada e disponível no site da PGM. Ultima atualizaçao: Emenda à LOM Nº14/201721/02/2017. 
GONÇALVES, T. E.; GONÇALVES, D. D. S. L.; CAETANO, F. A. D. O. Transformações no meio urbano a partir dos shoppings centers: uma abordagem geográfica da educação ambiental em Fortaleza-CE. Caminhos de Geografia, Uberlândia, 16, n. 54 , junho 2015. 239-253. Disponivel em:

<http://www.seer.ufu.br/index.php/caminhosdegeografia/article/download/26839/16883>.

GONDIM, L. M. D. P. Meio ambiente urbano e questão social: habitação popular em áreas de preservação ambiental. Caderno CRH, Salvador, v. 25, n. 64, p. 115-130, Jan./Abr 2012. Disponivel em: <http://www.scielo.br/scielo.php?pid=S010349792012000100009\&script=sci_abstract\&tlng=pt>.

HARVEY, D. O novo imperialismo. Tradução de Adail Sobral e Maria Stela Gonlçalves. 2. ed. São Paulo: Loyola, 2004.

HARVEY, D. Para entender o Capital. Livro I. Tradução de Rubens Enderle. 1. ed. São Paulo: Boitempo, 2013.

HARVEY, D. 17 contradições e o fim do capitalismo. Tradução de Rogério Bettoni. 1. ed. São Paulo: Boitempo, 2016.

HARVEY, D. A loucura da razão econômica: Marx e o capital no século XXI. Tradução de Artur Renzo. 1. ed. São Paulo: Boitempo, 2018. ISBN 9788575596432.

HIDALGO, R. et al. Aguas de ficción a la carta: la producción de naturaleza como nich de renta. Bienes comunes y espacio urbano en torno de las crystal laggons. In: ROSAS, A.; MATURANO, R. G.; HIDALGO, R. Expresión territoial de la fragmentación y segregación. México: Praxis Digital 9 - Universidad Autónoma del Estado de Morelos, 2016. p. 13-30.

HOLANDA, B.; ROSA, S. V. Anos de Operações urbanas em Fortaleza: um olhar a partir das diferentes gestões e da flexibilização urbana. XVII ENANPUR, São Paulo, 2017a.

HOLANDA, B.; ROSA, S. V. Las asociaciones público-privadas y el desarrollo urbano. Análisis de ilegalidades en la creación de operaciones urbanas consorciadas en fortaleza, ceará-brasil. Entretextos, León, n. 26, p. 29-46, agosto - noviembre 2017b. ISSN 2007-5316. Disponivel em: <http://entretextos.leon.uia.mx/num/26/PDF/Entretextos-26.pdf>. ano 9, Universidad Iberoamericana León. 
JARAMILLO, S. Las formas de producción del espácio construído en Bogotá. In: PRADILLA, E. Ensayos sobre el problema de la vivienda en México. Ciudad de México: Latina Annablume, 1982. p. $149-212$.

JUNIOR, C. T. D. C. Valorização do Capital na produçao imobiliária: distanciamento entre o preço da moradia e o do salario. In: PEREIRA, P. C. X. Imediato, global e total na produção do espaço: a financeirização da cidade de São Paulo no século XXI. São Paulo: FAUUSP, 2018. p. 40-54.

Disponivel

em:

<http://www.livrosabertos.sibi.usp.br/portaldelivrosUSP/catalog/book/302>.

KOWARICK, L. A Espoliação Urbana. São Paulo: Paz e Terra, 1979.

LEFEBVRE, H. A revolução urbana. Tradução de Sérgio Martins. Belo Horizonte: UFMG, 1999. 3 a reimpressão (2008). Título original: La Révolution Urbaine (1970).

LENCIONI, S. Acumulação primitiva: um processo atuante na sociedade contemporânea. Confins [Online] - Revista francobrasilera de geografia, v. 14, 22 março 2012. ISSN 10.4000/confins.7424. Disponivel em: <https://journals.openedition.org/confins/7424>.

LENCIONI, S. Metrópole e sua lógica capitanista atual face ao regime de acumulação patrimonial. Mercator, Fortaleza, v. 14, n. 4, p. 149-158, dezembro 2015. Disponivel em: <www.scielo.br/pdf/mercator/v14nspe/1984-2201-mercator-14-04-spe-0149.pdf>. Acesso em: 25 nov. 2018.

LIMA, F. A. D.; MARQUESAN, F. F. S. Terras indígenas no Ceará: uma história de lutas e resistência. Revista Brasileira de Estudos Latino-Americano - RABELA, v. 7, n. 3, p. 488-509, setembro/dezembro $2017 . \quad$ Disponivel em: <https://rebela.emnuvens.com.br/pc/article/download/365/716>.

MARICATO, E. Metrópole na periferia do capitalismo: ilegalidade desigualdade e violência. $\begin{array}{lllll}\text { São } & \text { Paulo: } & \text { [s.n.], } & 1995 . & \text { Disponivel }\end{array}$ <http://fau.usp.br/depprojeto/labhab/biblioteca/textos/maricato_metrperif.pdf>. MARTÍNEZ ALIER, J. O ecologismo dos pobres: conflitos ambientais e lingugens de valoração. Tradução de Maurício Waldman. 1. ed. São Paulo: Contexto, 2009. 
MARX, K. O Capital: crítica da economia política. [S.I.]: Boitempo, v. Livro I O processo de produção do capital, 1934.

MARX, K. O Capital. Crítica da economia política. São Paulo: Nova Cultura, v. II, 1985. Livro II. O Processo de Circulação do Capital. Coordenação Paul Singer. Editado por Friedrich Engels.

MARX, K. Grundrisse: Manuscritos econômicos de 1857-1858: Esboços da crítica da economia política. Tradução de Nélio Schneider (colaboração de Alice Helga Werner e Ruduger Hoffman) Mario Duayer. 1. ed. São Paulo: Boitempo, 2011. Traduzido do original: karl Marx Okonomische Manuskripte 1857/58, Berlim, Dietz, 1976 e 1982.

MARX, K. O Capital crítica da economia política. Tradução de Rubens Enderle. Livro I O processo de produção do capital. São Paulo: Boitempo, v. I, Tomo II, 2013a.

MARX, K. O capital: critica da economia política. Livro III: O processo global da produção capitalista. São Paulo: Boitempo, 2017.

MÁXIMO, F. R. C. C. Moradia, arquitetura e cidade: mudanças e permanências na produção da habitação social no espaço urbano metropolitano de Fortaleza. São Carlos: USP, 2012. Dissertação apresentada para obtenção de título de mestre ao Instituto de rquitetura e Urbanismo da Universidade de São Paulo.

MELO, J. R. D. A política indigenista no amazonas e o serviço de proteção aos índios: 19101932. Manaus: [s.n.], $2007 . \quad$ Disponivel em: <http://livros01.livrosgratis.com.br/cp102834.pdf>. Dissertação de mestrado apresentada ao Programa de Pós-Graduação em Sociedade e Cultura naAmazônia da Universidade Federal da Amazônia, sob a orientacão do Prof. Dr. Alfredo Wagner Berno de Almeida.

MÉSZÁROS, I. A teoria da alienação em Marx. Tradução de Nélio Schneider. São Paulo: Boitempo, 2016.

MOURA, R. C. D. Habitação de Interesse Social em Fortaleza-CE pós Ministério das Cidades: análise das intervensões promovidas pelo governo municiapal. Fortaleza: USP, 2017. Dissertação apresentada ao Programa de Pós-Graduação em Arquitetura e Urbanismo da Universidade de São Paulo para obtenção de título de mestre em Ciências, Programa de Arquitetura e Urbanismo. 
MUNOZ, J. R. El concepto de intercâmbio orgánico entre naturaleza e ser humano: una aproximación marxológica. Astrolabio. Revista Internacional de Filosofia. N.6. p. 16-25, 2015. NAREDO, J. M. La economía en evolución: invento e reconfiguración de la economía en los siglos XVIII y XIX y sus consecuencias actuales. Manuscritos, 22, 2004. P. 83-117, 2004.

NAREDO, J. M. La reconciliación virtual entre economía y ecología en el nuevo desarrollismo ecológico. Papeles. n. 100, 2005/08, 2007.

NAREDO, J. M. La ideologia económica en la historia y el medio ambiente. [S.I.]: [s.n.], 2016. Nota do autor: Este texto reescribe a posteriori la conferencia inaugural con la que intervine en el VIII Simposio de la Sociedad Latinoamericana y Caribeña de Historia Ambiental (SOLCHA) que tuvo en Puebla, México, el 3 de agosto de 2016.

NORPAR. Operação Urbana Consorciada: Parque Foz do Riacho Maceió. Fortaleza: [s.n.], sd. NORPAR; FORTALEZA. Operação Urbana Consorciada Parque Foz do Riacho Maceió. Fortaleza: [s.n.], sd.

PEQUENO, R. Como anda Fortaleza. Rio de Janeiro: Letra Capital: Observatório das Metrópoles, 2009.

PEQUENO, R. et al. Implicações da financeirização do desenvolvimento urbano na estruturação da Cidade de Fortaleza. 560 Congreso Internacional de Americanistas (ICA), Salamanca, 2018. Trabalho apresentado no eixo temático: Producción inmobiliária, financiarización y luchas socioespaciales en America Latina. Artigo relaizado para a apresentação ainda nao publicado.

PEQUENO, R.; FREITAS, C. F. S. Desafios para implementação de Zonas Especiais de Interesse Social em Fortaleza. Caderno Metrópoles, São Paulo, v. 14, n. 28, p. 485-505, jul/dez 2012. Disponivel

em: <http://cadernosmetropole.net/system/artigos/arquivos/000/000/244/original/cm28_245.p df?1474650655>.

PEREIRA, P. C. X. Espaço, técnica e construção: o desenvolvimento das técnicas construtivas e a urbanização do morar em São Paulo. São Paulo: Nobel, 1988. 
PEREIRA, P. C. X. Preço e valor na financeirização da produção do espaço. In: FERREIRA, A.; RUA, J.; MATOS, R. C. D. O espaço e a metropolização: codidiano e ação. 1. ed. São Paulo: Consequência, 2017. Cap. 7, p. 696.

PIRES, R. B. W. Fetichismo religioso, fetichismo da mercadoria, fetichismo sexual: transposições e conexões. Revista De Antropologia, São Paulo, 57, n.1, 11 nov. 2014. 347391.

PÍREZ, P. Las heterogéneas formas de producción y consumo de la urbanización latinoamericana. QUID 16, Buenos Aires, n. 6, p. 131-167, 2016. Disponivel em: <https://publicaciones.sociales.uba.ar/index.php/quid16/article/view/2085>. Revista del área de Estudios Urbanos del Instituto de Investigaciones Gino Germani de la Facultad de Ciencias Sociales (UBA).

POLANYI, K. o mercado auto-regulável e as mercadorias fictícias: trabalho, terra e dinheiro.. In: POLANYI, K. A grande transformação: as origens de nossa época. Rio de Janeiro: Ed. Campus, 1980. p. 81-88.

POVO, O. Fundo compra $15 \%$ do shopping Iguatemi Fortaleza. O POVO, Fortaleza, 30 setembro 2018. Disponivel em: <https://www.opovo.com.br/jornal/dom/2018/09/fundocompra-15-do-shopping-iguatemi-fortaleza.html>.

ROSA, S. V. El buen-vivir en Chiloé. Elaboración de un Indicador de Desarrollo Sustentable de Tercera Generación. Santiago: [s.n.], 2011. Disponivel em: <http://estudiosurbanos.uc.cl/images/tesis/2011/MHM_SVieira.pdf>. Tesis presentada para optar al grado académico de Magíster en Asentamientos Humanos y Medio Ambiente del Instituto de Estudios Urbanos y Territoriales de la Pontificia Universidad Católica de Chile. Profesor Guía: Jonathan Barton.

ROSA, S. V.; PEQUENO, R.; SILVA, H. S. A. D. Panorama dos primeiros empreendimentos entregues do Programa MCMV da faixa 1 na Região Metropolitana de Fortaleza (RMF). Congresso Internacional de Sustentabilidade e Habitação de Interesse Social - CHIS, Porto Alegre, abril 2014. Anais do evento.

RUFINO, B. A Incorporação da metrópole: transformações na produção imobiliária e do espaço na Fortaleza do século XXI. São Paulo: Annablume, 2016. 332 p. 
SALES, V. C. Oaisagem dunar em área urbana consolidada: natureza, ciência e política no espaço urbano de Fortaleza, Brasil. Sociedade e Natureza, Uberlândia, n. 22, p. 447-459, dezembro 2010.

SÁNCHEZ, Juan Fernando Arango. Evolución del papel de la naturaleza en el estudio económico: desde los autores preclásicos hasta la Escuela Neoclásica, 2014.

SANTOS, E. D. O. Produção do espaço, habitação e circuito imobiliário em fortaleza-ce: temporalidades e espacialidades no eixo sudeste de valorização da metrópole. Fortaleza: UFC, 2015. Tese apresentada ao Curso de Doutorado em Geografia do Programa de Pós-Graduação em Geografia da Universidade Federal do Ceará, como parte dos requisitos para obtenção do título de Doutor em Geografia. Área de concentração: Dinâmica Ambiental e Territoria.

SCHMIDT, A. El concepto de naturaleza en Marx. Tradução de Julia M. T. Ferrari de Prieto y Eduardo Prieto. Madrid: Siglo XXI Espana, 2011. 244 p.

SEMA, G. D. E. D. C.-S. D. M. A. . Criação de Unidades de Conservação do Rio Cocó. Fortaleza: Governo do Estado do Ceará, sd. Disponivel em: <http://webcache.googleusercontent.com/search?q=cache:8zMMCk2NslkJ:www.sema.ce.g ov.br/attachments/article/45074/RELATORIO\%2520T\%25C3\%2589CNICO\%2520CRIA\%25C3 \%2587\%25C3\%25830\%2520DE\%2520UNIDADES\%2520DE\%2520CONSERVA\%25C3\%2587\%2 5C3\%25830\%2520DO\%2520RIO\%2520COC>.

SILVA, A. C. M. A propriedade privada da terra e a produção de novas espacialidades na cidade de fortaleza. São Paulo: USP, 2000. Dissertação (mestrado) - Centro de Ciências e Tecnologia, Mestrado academico em geografia, Universidade Estadual de São Paulo.

SILVA, A. R. C. D. Construção da nação e escravidão no pensamento de José Bonifácio: 17831823. Campinas: UNICAMP/IFCH, 1996. Disponivel em: <http://repositorio.unicamp.br/jspui/handle/REPOSIP/280198>. Dissertação de Mestrado apresentada ao Departamento de História do Instituto de Filosofia e Ciências Humanas da Universidade Estadual de Campinas.

SILVA, I. B. P. D. Vilas de índio no Ceará Grande: a dinâmica local na implantação do Diretório Pombalino, Fortaleza. Departamento de Ciências Sociais - UFC. 
SOARES, J. M. B. Parque Ecológico do Cocó: a produção do espaço urbano no entorno de áreas de proteção ambiental. Fortaleza: UFC, 2005. Disponivel em: <http://www.repositorio.ufc.br/bitstream/riufc/16354/1/2005_dis_jmbsoares.pdf>. Dissertação apresentada à Coordenação de Mestrado em Desenvolvimento e Meio Ambiente da Universidade Federal do Ceara para a obtenção do título de mestre em Desenvolvimento em Meio ambiente.

ZANELLA, M. et al. Vulnerabilidade socioambiental de Fortaleza. In: COSTA, M. C. L.; DANTAS, E. Vulnerabilidade socioambiental na região metropolitana de Fortaleza. Fortaleza: Edições UFC, 2009. p. 191-216. 


\section{APÊNDICES}




\section{Nota metodológica: Georreferenciamento Carta da}

\section{Cidade de Fortaleza e Arredores de 1945 - levantada e desenhada pelo Serviço de Geografia do Exército}

O material original foi obtido na biblioteca do curso de arquitetura da UFC. Constitui ao todo 8 folhas com levantamento cartográfico da cidade de Fortaleza em 1945 e seus arredores realizado pelo Serviço de Geografia do Exército. O georreferenciamento para posterior trabalho da imagem sobrepondo-a a informações cartográficas originais procedeu da seguinte forma.

1) Cada folha da carta foi fotografada individualmente com câmera fotográfica digital semiprofissional e em alta qualidade;

2) Com auxilio de software de tratamento de imagens procedeu-se com a união das folhas em um único arquivo obtendo-se a carta completa. Esta foi salva como arquivo de imagem .tif;

3) No software de geoprocessamento Quantum Gis (Qgis), utilizou-se o plugin J Rectifier que permite o georreferenciamento de imagens a partir de pontos de controle. 0 shape utilizado como base para os pontos de controle foi o das quadras da cidade de Fortaleza com sistema de projeção UTM SIRGAS 2000, zona 24 sul;

4) Inicialmente foram estabelecidos 10 pontos de controle. Modo de transformação utilizado foi o Polynominal 1, resampling nearest;

5) Em seguida procedeu-se estabelecendo novos pontos de controle na tentativa de obter o melhor georreferenciamento possível, considerado que a imagem georreferenciada é uma colagem de partes de um mapa impresso antigo e apresenta assim bastante distorções e dificuldades em estabelecer pontos de controle.

Figura 113. Interface mostrando o processo de marcação dos pontos de controle

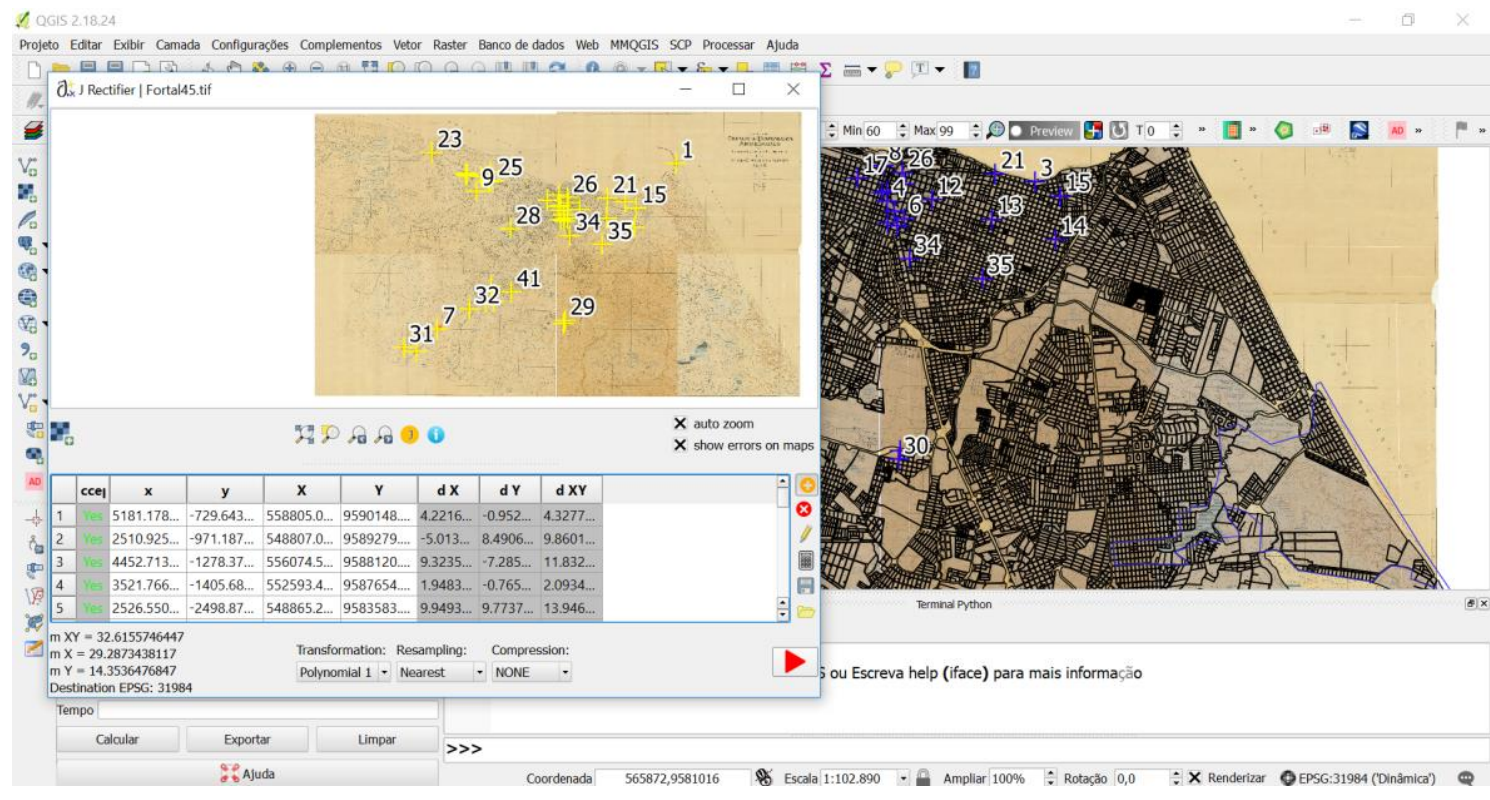

Elaboração: Sara V. Rosa, 2018. Software Qgis, plugin J Rectifier. 
Figura 114. Relatório gerado automaticamente pelo J Rectifier descrevendo e identificando os pontos de controle e opções escolhidas para o georreferenciamento.

\section{Rectification Report}

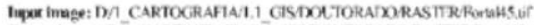

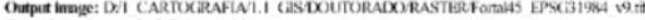

Geereferencing methut. Pulymmin

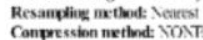

Destimation ERSG: 31984

Requed pothes namber: 3

Meliercurent:

$\mathrm{mIXY}=31.1549510623, \mathrm{mX}-28.0639970434, \mathrm{~m} \mathrm{Y}-13.5281659086$
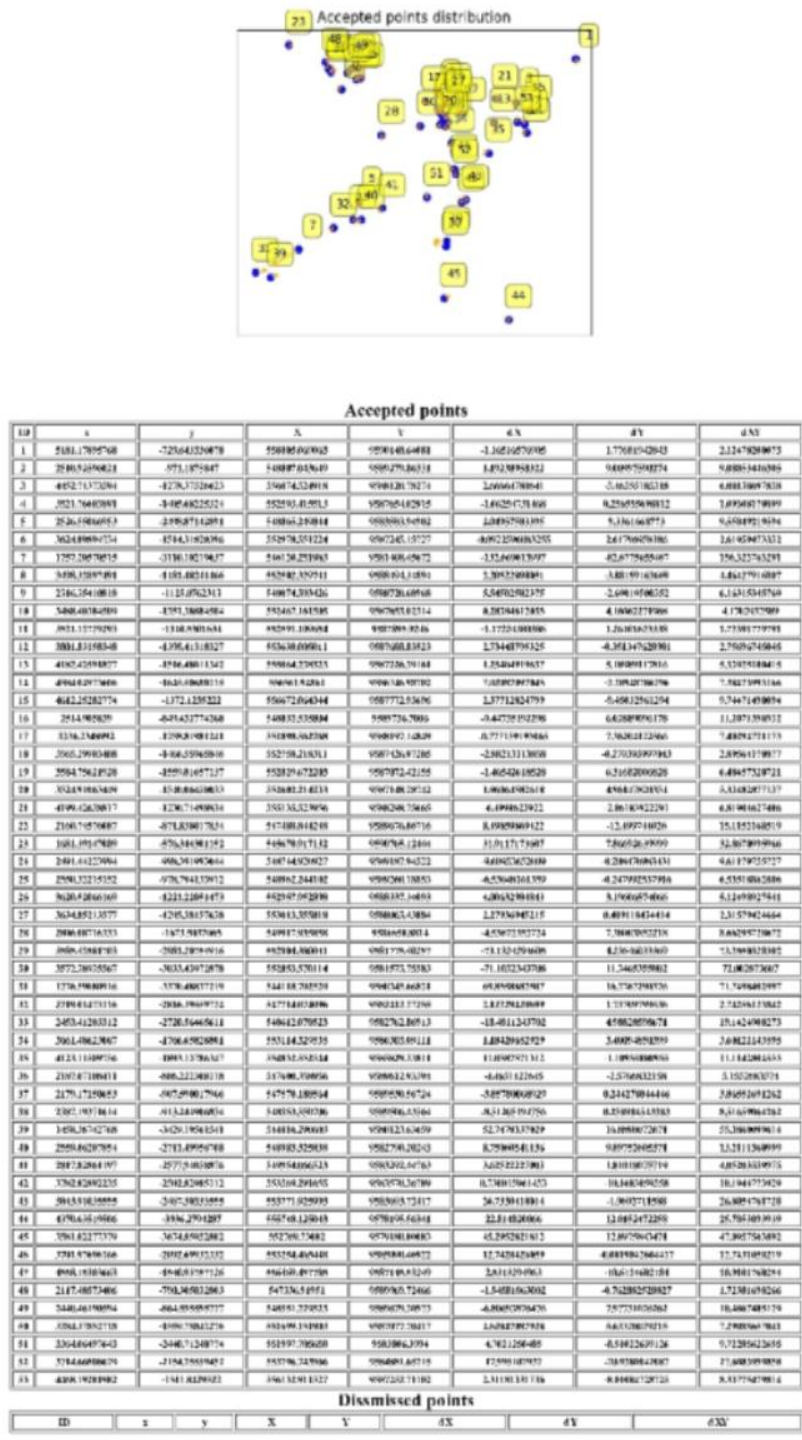
1I. Nota metodológica: Atualização base SIG de loteamentos da PMF a partir de cartografias

A Base da Prefeitura possui muitos loteamentos em que não se tem o ano de aprovação do loteamento. Para efeito da tese buscou-se complementar essa informação quando possível. A atualização foi feita pela década aproximada já que nem sempre se podia ter a data exata e aprovação do loteamento.

1) Abriu-se o shape dos loteamentos em um projeto novo no Qgis. Iniciou-se o modo de edição e foram criadas duas novas colunas tipo texto na tabela de atributos deste. A primeira coluna criada foi para a inserção das décadas de cada loteamento e a segunda para inserção da fonte. Para os casos dos loteamentos que possuíam data na base original, procedeu-se com o preenchimento da coluna década de acordo com estas datas.

2) Como referência, foi inserido também os raster (imagem em formato tif.) da Carta de Fortaleza e Arredores de 1945, e do mosaico de imagens de 1958 já previamente georreferenciados.

3) A partir destas duas imagens observou-se quais loteamentos existiam na base sem datas e que já apareciam com o parcelamento executado nas imagens referencias, já com o sistema viário, e adotou-se a década referência destes mapeamentos para estes. Década de 40 e década de 50 respectivamente.

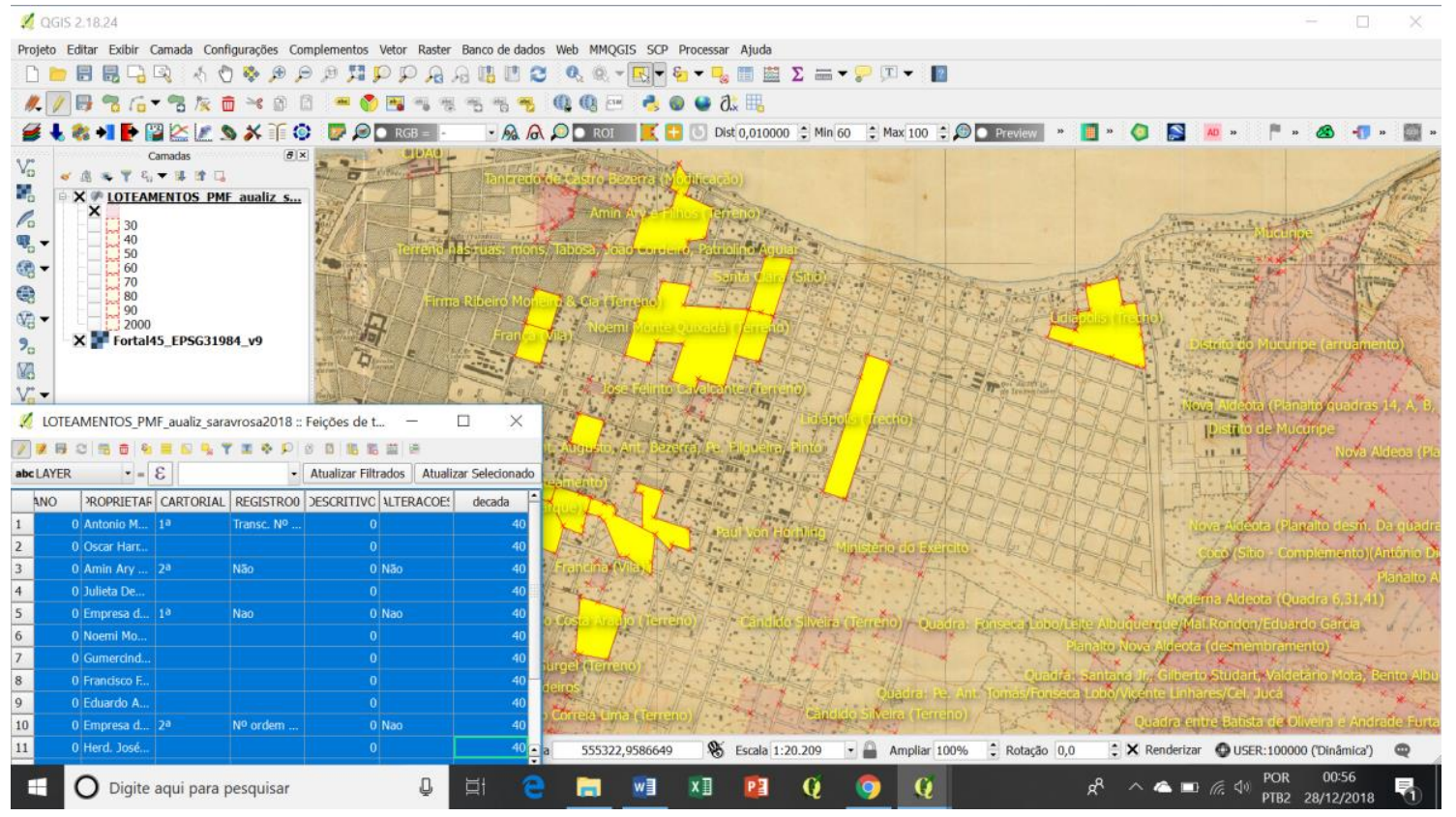

Casos em que apenas uma pequena porção do suposto loteamento aparecia parcelada, com arruamento já implementado, optamos por deixar sem atualizar a data poruque levantavam 
dúvida se todo o terreno havia tido loteamento e parcelamento aprovado e só implementaram uma pequena parte ou se hava tido algum desmembramento do terreno e só uma arte havia sido parcelada.

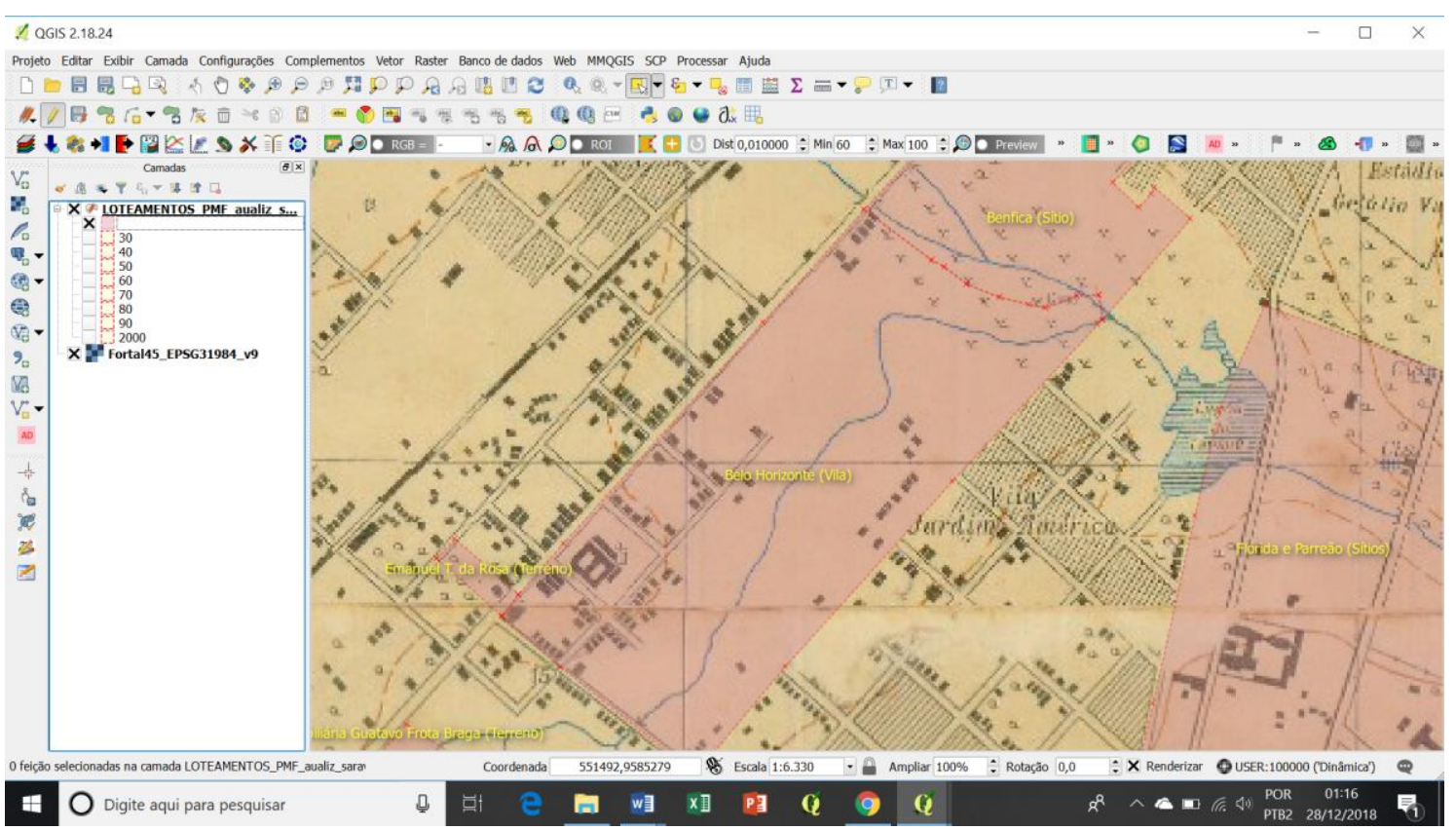

Alguns casos foram atualizados a partir de plantas de loteamentos encontradas com a data de aprovação, como foram os casos dos loteamentos na Sabiaguaba. Outros ainda foram atualizados pela história do bairro, como o caso do conjunto Ceará, em que se colocou a década do início da construção do conjunto. 


\section{II. Nota metodológica: Levantamento empreendimentos de empresas de capital fechado e capital aberto.}

Inicialmente foi feito uma listagem, a partir dos trabalhos de campo e conhecimento local, das principais empresas imobiliárias atualmente atuantes em Fortaleza considerando o volume e porte dos seus empreendimentos.

Pra os nomes listados foi realizado a identificação do CNPJ de cada empresa e, em seguida, realizada pesquisa junto a Junta Comercial do Ceará e consulta de CNPJ à Receita Federal (http://www.segs.com.br/segs-uteis/consultar-cnpj.html). Este procedimento permitiu identificar a natureza jurídica de cada empresa, identificando assim se possuíam capital fechado ou aberto, bem como as atividades principais das mesmas, o que permitia saber se esta atuava apenas na área da construção ou também na área da incorporação.

Também foi verificado se na lista de classificação setorial das empresas e fundos negociados na bm\&fbovespa existia alguma vincula ao setor da construção/imobiliária atuante em Fortaleza.

Foram identificados ao todo $\mathrm{X}$ empresas de capital aberto atuando no setor imobiliário de Fortaleza e no entorno imediato (Aquiraz, Maracanaú e Caucaia): Cyrella, Direcional, MRV, Gavisa, Helbor, Rodobens, Rossi, Tecnisa, Viver.

Foram levantados os empreendimentos das seguintes empresas de Capital fechado: BSPAR, Diagonal, JCPM, Moura Dubeux.

Quadro 18. Exemplo levantamento inicial.

\begin{tabular}{|c|c|c|c|c|c|c|}
\hline & receita & junta & receita & junta & receita & junta \\
\hline $\begin{array}{l}\text { nome empresarial - Razão } \\
\text { Social }\end{array}$ & CNPJ & CNPJ & $\begin{array}{l}\text { Natureza } \\
\text { Jurídica }\end{array}$ & $\begin{array}{l}\text { Nat. } \\
\text { Jurid. }\end{array}$ & $\begin{array}{l}\text { Estad } \\
0\end{array}$ & $\begin{array}{l}\text { Estad } \\
0\end{array}$ \\
\hline $\begin{array}{l}\text { BROOKFIELD CENTROOESTE } \\
\text { EMPREENDIMENTOS IMOBILIARIOS } \\
\text { S.A. }\end{array}$ & 04.123.616/000100 & & S/A Fechada & & GO & \\
\hline $\begin{array}{l}\text { BSPAR CONSTRUCOES E } \\
\text { INCORPORACOES LTDA }\end{array}$ & $11.849 .176 / 000139$ & & $\begin{array}{l}\text { Socied. } \\
\text { Empresarial } \\
\text { Limitada }\end{array}$ & & CE & \\
\hline BSPAR INCORPORACOES S/A & $09.365 .538 / 000174$ & & S/A Fechada & & $\mathrm{CE}$ & \\
\hline C ROLIM ENGENHARIA LTDA & $35.094 .382 / 000144$ & $35094382 / 0001-44$ & $\begin{array}{l}\text { Socied. Empresária } \\
\text { Limitada }\end{array}$ & LTDA & CE & \\
\hline $\begin{array}{l}\text { COMPANHIA DIAS DE SOUZA } \\
\text { COMERCIO INDUSTRIA }\end{array}$ & $07.614 .092 / 000149$ & 07614092/0001-49 & $\begin{array}{l}\text { Sociedade } \\
\text { Anônima Fechada }\end{array}$ & S/A-FECH & CE & \\
\hline CONSTRUTORA COLMEIA S/A & $06.048 .417 / 000100$ & & S/A Fechada & & CE & \\
\hline $\begin{array}{l}\text { CONSTRUTORA E INCORPORADORA } \\
\text { NASSAU LTDA }\end{array}$ & $11.168 .945 / 000133$ & & $\begin{array}{l}\text { Sociedade } \\
\text { Empresária } \\
\text { Limitada }\end{array}$ & & $\mathrm{PE}$ & \\
\hline
\end{tabular}




\begin{tabular}{|c|c|c|c|c|c|c|}
\hline CONSTRUTORA GRANITO LTDA & $07.134 .125 / 000153$ & & $\begin{array}{l}\text { Sociedade } \\
\text { Empresária } \\
\text { Limitada }\end{array}$ & & CE & \\
\hline CONSTRUTORA INTEGRAL LTDA & $18.576 .660 / 000180$ & & $\begin{array}{l}\text { Sociedade } \\
\text { Empresária } \\
\text { Limitada }\end{array}$ & & $M G$ & \\
\hline CONSTRUTORA INTEGRAL LTDA EPP & $14.088 .634 / 000152$ & & $\begin{array}{l}\text { Sociedade } \\
\text { Empresária } \\
\text { Limitada }\end{array}$ & & MT & \\
\hline CONSTRUTORA MARQUISE S A & $07.950 .702 / 000185$ & & S/A Fechada & & CE & \\
\hline $\begin{array}{l}\text { CONSTRUTORA MOTA MACHADO } \\
\text { LTDA }\end{array}$ & $07.282 .783 / 000192$ & & $\begin{array}{l}\text { Sociedade } \\
\text { Empresária } \\
\text { Limitada }\end{array}$ & & $\mathrm{CE}$ & \\
\hline CONSTRUTORA PLACIC LTDA & 05.535.398/000184 & 05535398/0001-84 & $\begin{array}{l}\text { Sociedade } \\
\text { Empresária } \\
\text { Limitada }\end{array}$ & LTDA & $\mathrm{CE}$ & \\
\hline $\begin{array}{l}\text { DIAGONAL EMPREENDIMENTOS E } \\
\text { ENGENHARIA LTDA }\end{array}$ & $06.880 .884 / 000100$ & 06880884/0001-00 & $\begin{array}{l}\text { Sociedade } \\
\text { Empresária } \\
\text { Limitada }\end{array}$ & LTDA & $\mathrm{CE}$ & \\
\hline DIRECIONAL ENGENHARIA S/A & $16.614 .075 / 000100$ & & S/A Aberta & S/A-ABER & $M G$ & MG \\
\hline $\begin{array}{l}\text { EIT EMPRESA INDUSTRIAL TECNICA } \\
\text { SA }\end{array}$ & $08.402 .620 / 000169$ & 08402620/0001-69 & S/A Fechada & LTDA & $\mathrm{CE}$ & $\mathrm{CE}$ \\
\hline ENGEXATA ENGENHARIA LTDA & $07.654 .734 / 000133$ & & $\begin{array}{l}\text { Sociedade } \\
\text { Empresária } \\
\text { Limitada }\end{array}$ & & CE & \\
\hline $\begin{array}{l}\text { GOLDSZTEIN CYRELA } \\
\text { EMPREENDIMENTOS IMOBILIARIOS } \\
\text { S/A }\end{array}$ & $08.074 .750 / 000110$ & & S/A Fechada & & $\mathrm{SP}$ & \\
\hline IDIBRA PARTICIPAÇÕES S.A & $\begin{array}{l}06.258 .768 / 0007- \\
31\end{array}$ & & & & & \\
\hline JOCKEY CLUBE CEARENSE & 07.845.191/000131 & & Associação Privada & & CE & \\
\hline $\begin{array}{l}\text { LPS FORTALEZA CONSULTORIA DE } \\
\text { IMOVEIS LTDA }\end{array}$ & $09.352 .067 / 000160$ & & $\begin{array}{l}\text { Sociedade } \\
\text { Empresária } \\
\text { Limitada }\end{array}$ & & CE & \\
\hline $\begin{array}{l}\text { MAGIS INCORPORACOES E } \\
\text { CONSTRUCOES LTDA }\end{array}$ & $08.954 .184 / 000130$ & & $\begin{array}{l}\text { Sociedade } \\
\text { Empresária } \\
\text { Limitada }\end{array}$ & & CE & \\
\hline $\begin{array}{l}\text { MD CE NOVA ALDEOTA } \\
\text { CONSTRUCOES LTDA. }\end{array}$ & $13.673 .987 / 000157$ & & $\begin{array}{l}\text { Sociedade } \\
\text { Empresária } \\
\text { Limitada }\end{array}$ & & CE & \\
\hline $\begin{array}{l}\text { MOURA DUBEUX ENGENHARIA E } \\
\text { EMPREENDIMENTOS S/A }\end{array}$ & $01.420 .682 / 000154$ & $01.420 .682 / 000154$ & S/A Fechada & S/A-ABER & $\mathrm{PE}$ & CE \\
\hline $\begin{array}{l}\text { MRV ENGENHARIA E PARTICIPACOES } \\
\text { SA }\end{array}$ & $08.343 .492 / 000120$ & $\begin{array}{l}08.343 .492 / 0014- \\
44\end{array}$ & S/A Aberta & S/A-FECH & MG & $\mathrm{CE}$ \\
\hline $\begin{array}{l}\text { NORPAR NORDESTE } \\
\text { EMPREENDIMENTOS E } \\
\text { PARTICIPACOES S.A }\end{array}$ & $02.457 .106 / 000144$ & & S/A Fechada & & CE & \\
\hline NOVAES ENGENHARIA EIRELI & $15.613 .223 / 000100$ & $15613223 / 0001-00$ & $\begin{array}{l}\text { Empresa Individual } \\
\text { de } \\
\text { Responsabilidade } \\
\text { Limitada }\end{array}$ & LTDA & $\mathrm{CE}$ & \\
\hline $\begin{array}{l}\text { PORTO FREIRE ENGENHARIA E } \\
\text { INCORPORACAO LTDA }\end{array}$ & 01.064.644/000106 & & $\begin{array}{l}\text { Sociedade } \\
\text { Empresária } \\
\text { Limitada }\end{array}$ & & CE & \\
\hline RIOMAR SHOPPING FORTALEZA S.A & $12.039 .513 / 000195$ & & S/A Fechada & & $\mathrm{PE}$ & \\
\hline ROSSI RESIDENCIAL SA & $61.065 .751 / 000180$ & 61065751/0010-71 & S/A Aberta & S/A-FECH & SP & CE \\
\hline $\begin{array}{l}\text { TECSA EMPREENDIMENTOS E } \\
\text { PARTICIPACOES S/A }\end{array}$ & $07.667 .538 / 000101$ & & S/A Fechada & & $\mathrm{CE}$ & \\
\hline $\begin{array}{l}\text { TERRA BRASILIS PARTICIPACOES E } \\
\text { EMPREENDIMENTOS LTDA. }\end{array}$ & $\begin{array}{l}03.968 .482 / 0001- \\
66\end{array}$ & & $\begin{array}{l}\text { Socied. Empresária } \\
\text { Limitada }\end{array}$ & & $\mathrm{CE}$ & \\
\hline
\end{tabular}

Elaboração própria, 2017. Fonte: Pesquisa CNPJ Receita Federal e Junta Comercial.

Uma vez identificada as empresas, foi realizada pesquisa na internet, nos sites das empresas e em imobiliárias para identificar empreendimentos lançados ou em construção por cada empresa. Cada empreendimento foi localizado, a partir de seu endereço, utilizando a 
ferramenta do GoogleEarth e georreferenciado. Nesta Etapa contou-se com a ajuda da equipe do LEHAB.

Os pontos de cada empreendimento por empresa georreferenciados no GoogleEarth foram salvos no formato KMZ e KML e utilizando o software Qgis foram transformados em Shapefile e a partir daí utilizados como capa vetorial de informação para elaboração de mapas temáticos.

Figura 115. Levantamento empreendimentos de empresas de capital fechado

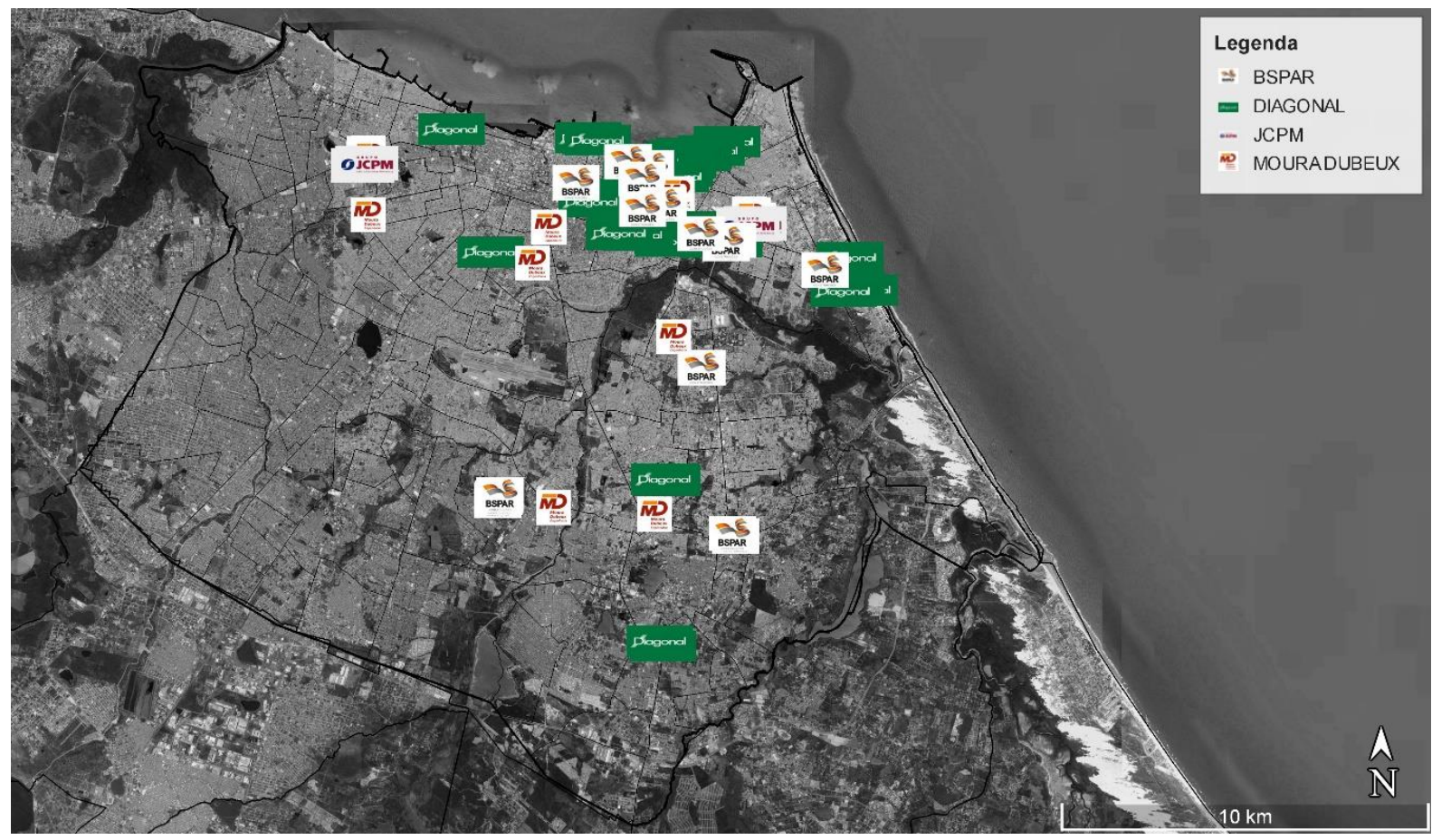

Fonte: Lehab (2017). Elaboração: Moura e Rosa/lehab, 2017. 
Figura 116. Levantamento empreendimentos de empresa de capital aberto

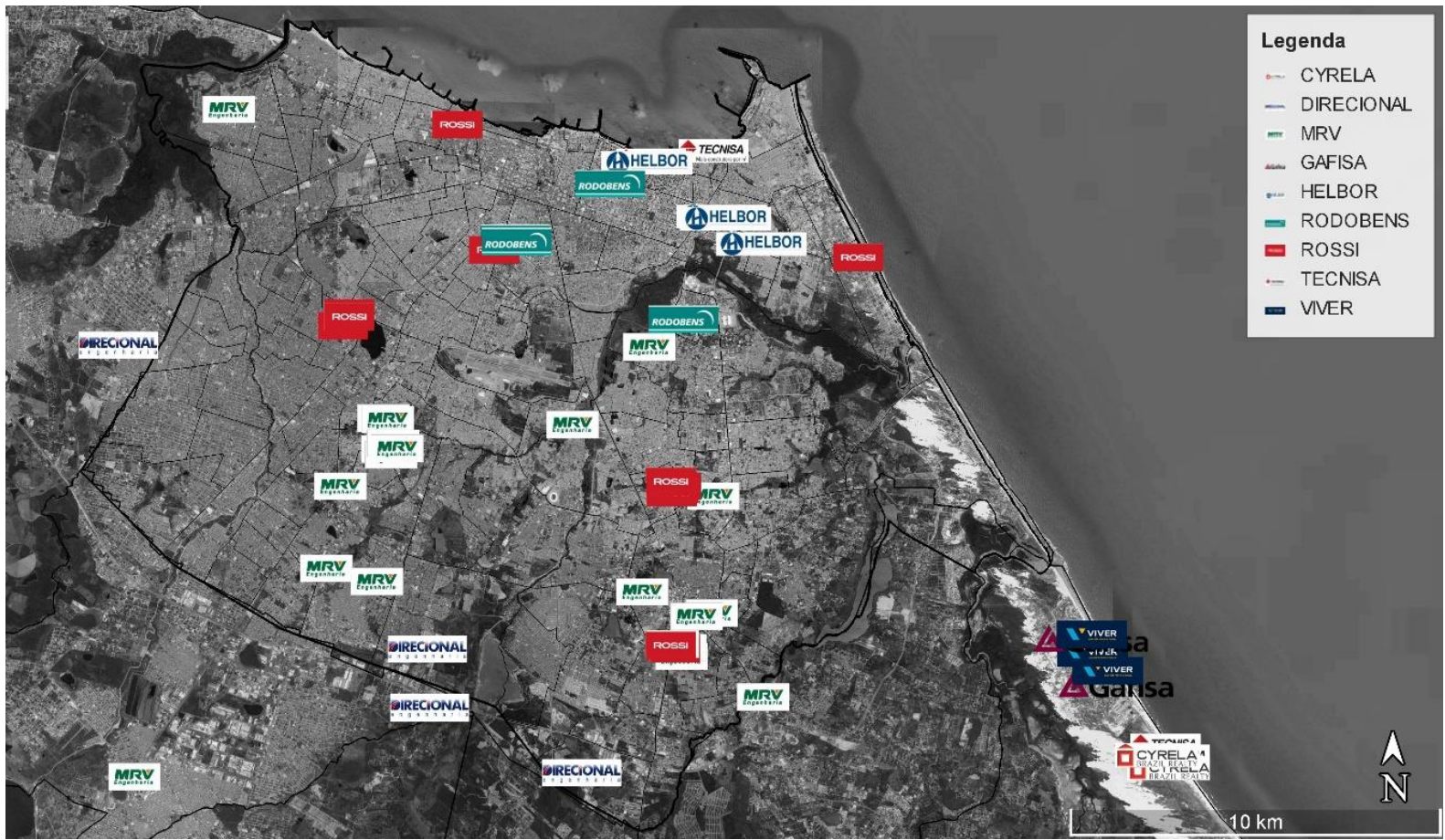

Fonte: Lehab (2017). Elaboração: Moura e Rosa/lehab, 2017.

Figura 117. Levantamento empreendimentos de empresa de capital aberto tipo incorporação

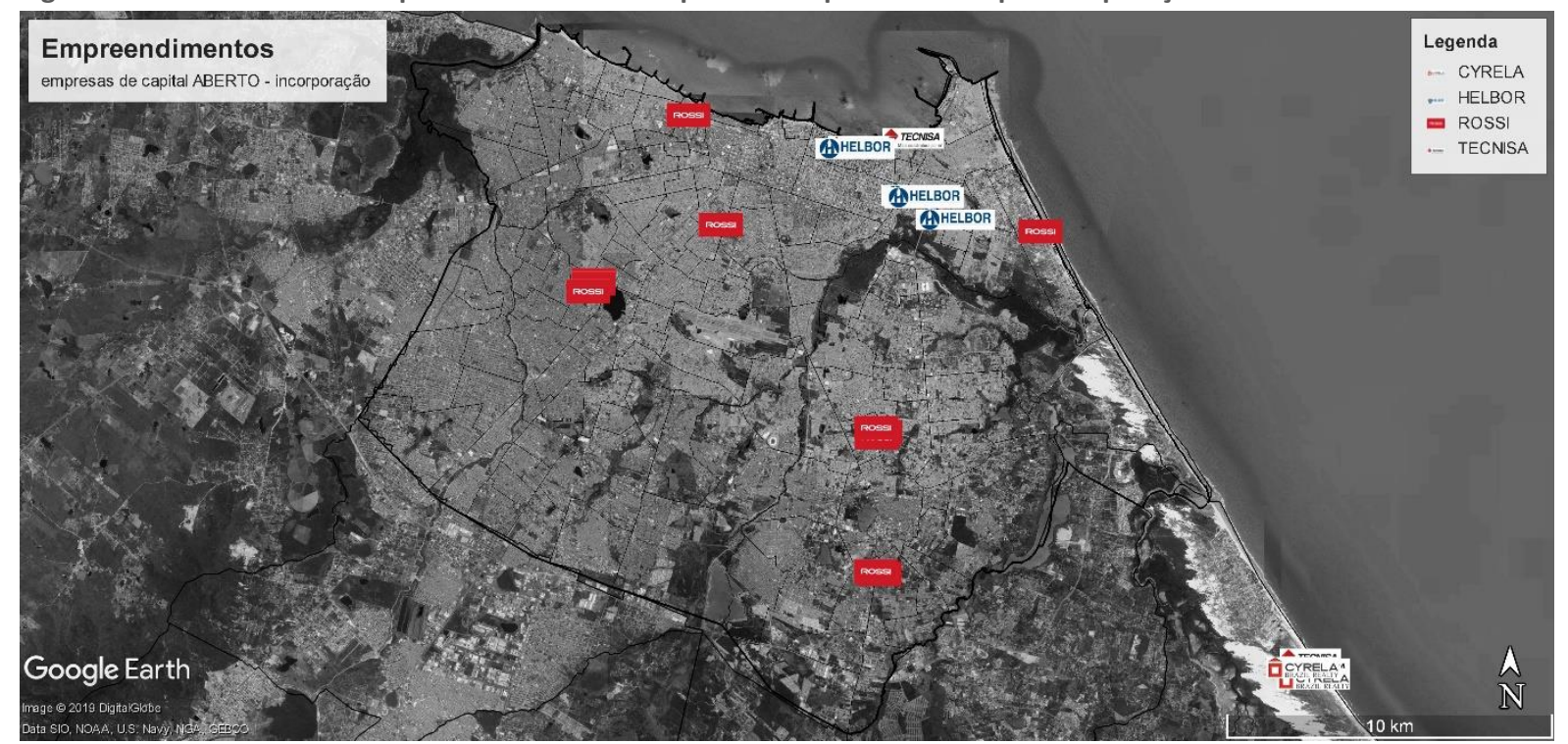

Fonte: Lehab (2017). Elaboração: Moura e Rosa/lehab, 2017. 
Figura 118. Levantamento empreendimentos de empresa de capital aberto tipo construção

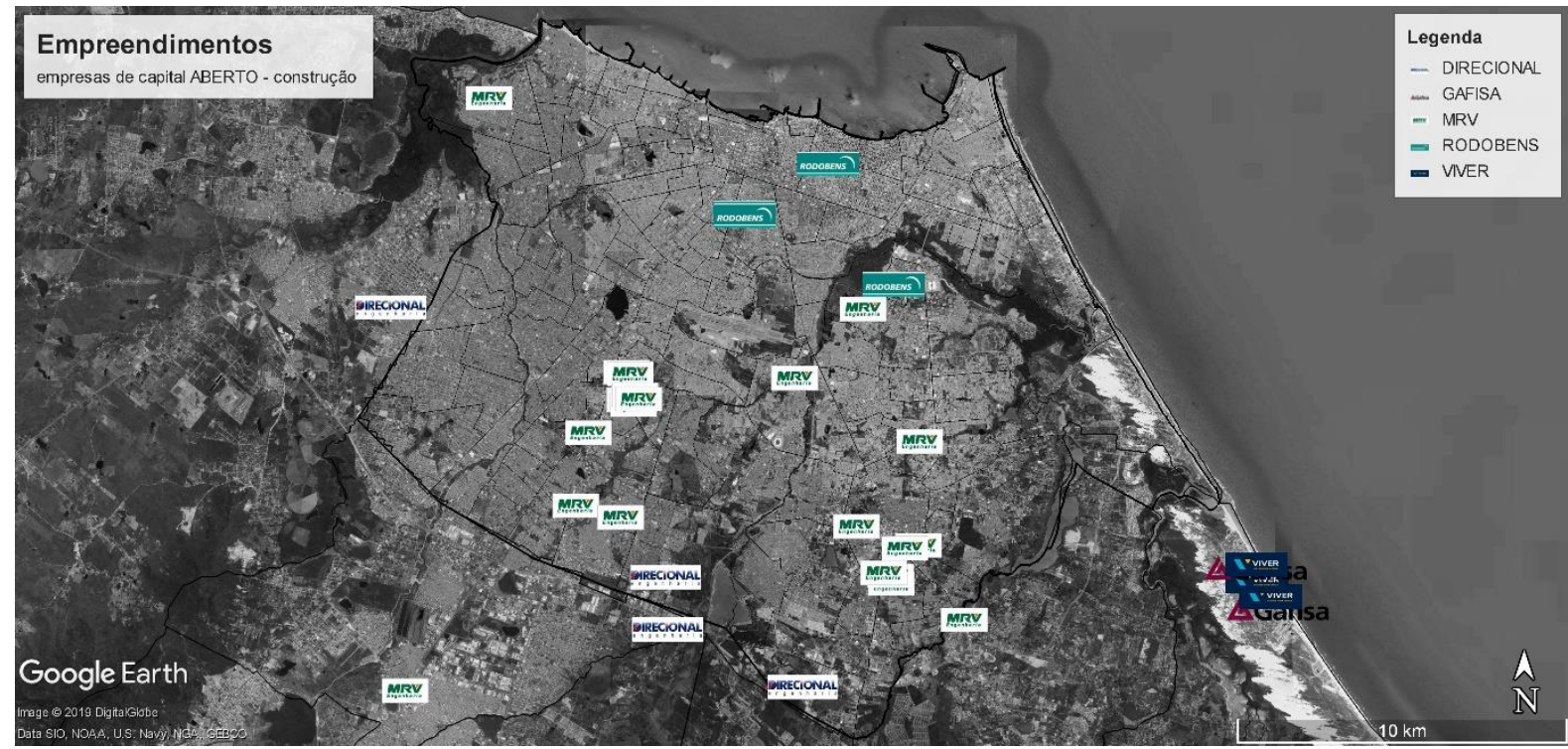

Fonte: Lehab (2017). Elaboração: Moura e Rosa/lehab, 2017. 
IV. Nota metodológica: Identificação da supressão das duas áreas de ZRA do Cocó do mapa de zoneamento divulgados pela SEUMA.

No momento que foi identificado que o mapa apresentado no projeto de Lei da LUOS não contemplava duas áreas de ZRA importantes procedeu-se inicialmente com levantamento e análise das leis complementares aprovadas até então, e consulta via e-mail à secretaria de urbanismo e meio ambiente do município (SEUMA).

Como não foi encontrada lei complementar que suprimisse essas áreas e a resposta da SEUMA foi que realmente andaram circulando dois mapas, mas que o oficial era o que não tinha as ZRAs e esse era o que havia sido aprovado com o Plano Diretor de 2009, procedeu-se com a espacialização das coordenadas geográficas de toda a zona de ZRA publicada em anexo a Lei do Plano Diretor no Diário Oficial do Município de 13 de março de 2009.

Para a espacialização das coordenadas transformou-se inicialmente o arquivo PDF em arquivo TXT e com o auxílio de programas de sistema de informação geográfica foram especializados todos os pontos e em seguida construída as poligonais formadas pelos pontos das coordenadas, constatando-se que as duas áreas de ZRA localizadas abaixo da ZPA do Rio Cocó, uma na altura do Iguatemi e outra na altura do loteamento Cidade Ecológica. 

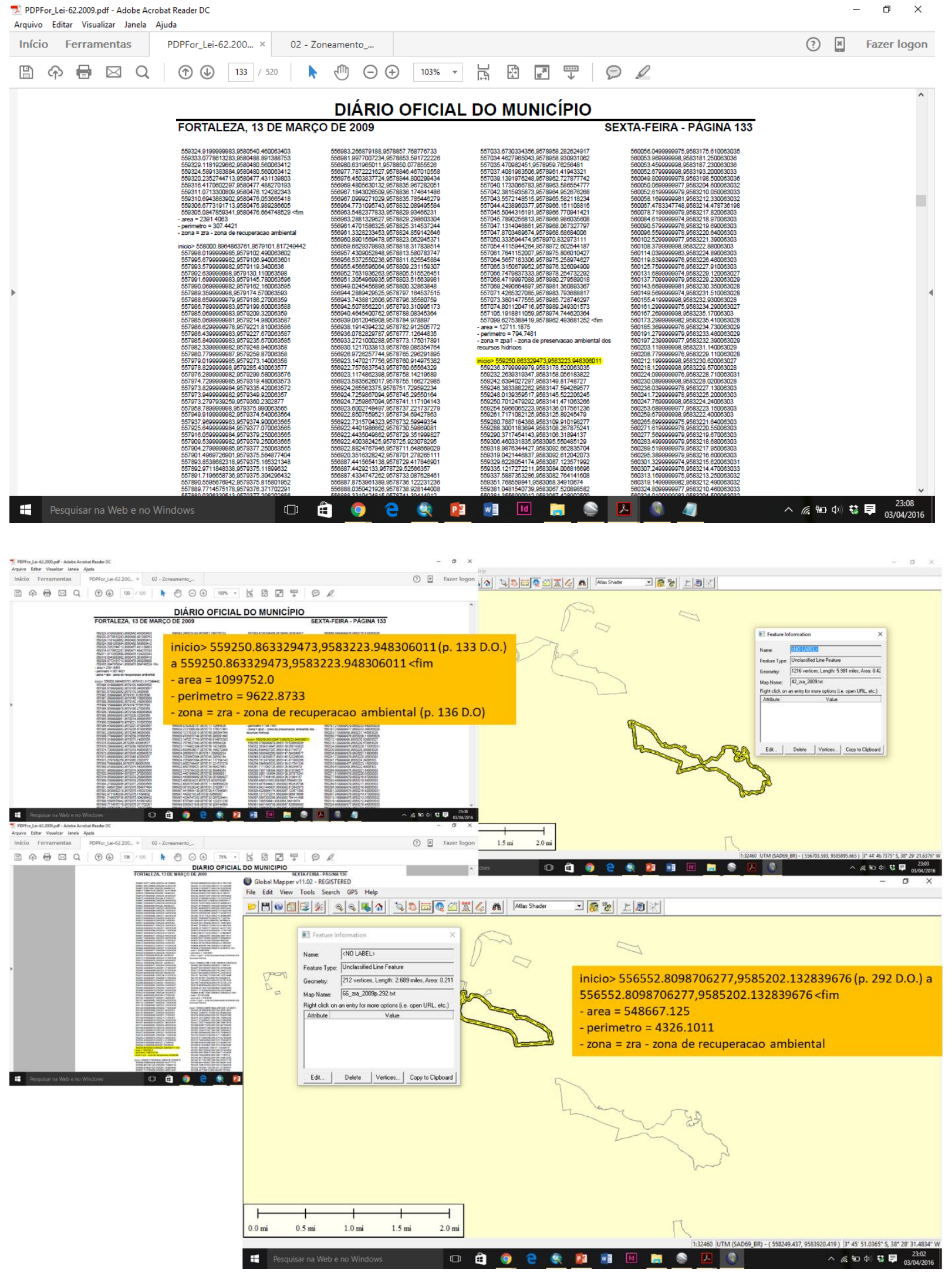

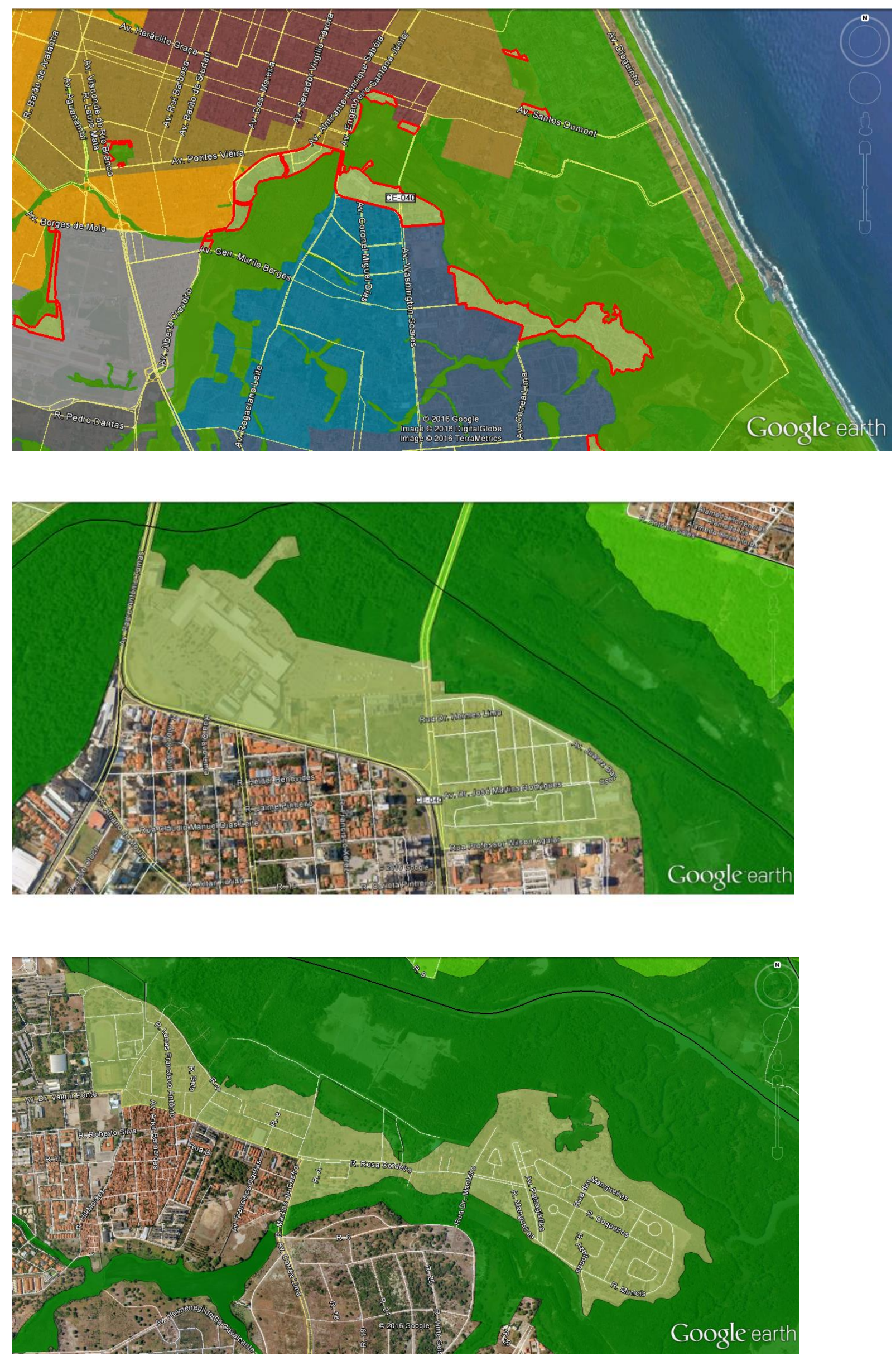


\section{Roteiro das entrevistas realizadas.}

As entrevistas realizadas, ocorreram, na sua maioria, com a utilização de roteiros semiestruturados para guiar os pontos que haviam interessem e serem abordados, porém, algumas foram realizadas sem roteiro algum com o objetivo que a conversa ocorresse com mais fluidez e permitisse que o entrevistado seguisse suas memórias. Abaixo, destacamos as principais.

- Secretária de Urbanismo e Meio Ambiente de Fortaleza, Águeda Muniz, entrevista realizada no dia no dia 21/11/2016, com a equipe do LEHAB (Renato Pequeno, Valeria Pinheiro, Sara V. Rosa e Breno Holanda - com roteiro de entrevista semiestruturado)

- Empresa Terra Brasilis (OUC Riacho Maceió), entrevista realizada no dia no dia; 24/10/2016, com a equipe do LEHAB (Renato Pequeno, Valeria Pinheiro, Sara V. Rosa e Breno Holanda - com roteiro de entrevista semiestruturado);

- Ex-morador da Comunidade Areias. Entrevista realizada no dia 25/01/2017 pela equipe do LEHAB (Valéria Pinheiro, Sara v. Rosa e Breno Holanda). (com roteiro de entrevista semiestruturado);

- Morador da comunidade Areias. Entrevista realizada no dia 25/01/2017 pela equipe do LEHAB (Valéria Pinheiro, Sara v. Rosa e Breno Holanda). (com roteiro de entrevista semiestruturado);

- Moradora antiga do Mucuripe e entorno imediato da OUC do Riacho Maceió. Entrevista realizada no dia 29/10/2016, por Sara V. Rosa e Camila Aldigueri (com roteiro de entrevista semiestruturado);

- Moradores das últimas casas dentro da poligonal da OUC do Riacho Maceió, realizada no dia 29/10/2016, por Sara V. Rosa e Camila Aldigueri (com roteiro de entrevista semiestruturado).

- Moradora antiga do Mucuripe - entorno da OUC do Riacho Maceió. Entrevista realizada por Sara V. Rosa e Breno Holanda (sem roteiro de entrevista);

- Ex-moradora da rua Senador Machado removida pela OUC do Riacho Maceió. Entrevista Realizada no dia 15/07/2017 pela equipe do LEHAB (Aline Medeios e Sara v. Rosa); 
- Moradores e pescadores da comunidade Boca da Barra - Sabiaguaba, realizada por Sara V. Rosa (sem roteiro de entrevista).

Foram realizadas outras entrevistas juntamente com a equipe do Lehab ou individualmente, além de conversas mais informais, que apesar de não entrarem diretamente na tese, contribuíram como pesquisa exploratória para a definição da mesma.

Ressalta-se que a entrevista concedida por moradores da comunidade Paufinim foi concedida a integrante da equipe do LEHAB e a autora desta tese não participou, todas as demais ela esteve presente tanto no momento de elaboração do roteiro como na aplicação da entrevista.

A seguir, os roteiros semiestruturados das principais entrevistas realizadas:

\section{ROTEIRO ENTREVISTA SEMIESTRUTURADA - TERRA BRASILIS}

Entrevista realizada no dia no dia 24/10/2016, com a equipe do LEHAB (presentes: Renato Pequeno, Valeria Pinheiro, Sara V. Rosa e Breno Holanda - com roteiro de entrevista semiestruturado)

1) Qual o histórico da empresa. Como ela se formou e no que tem atuado? (se ela não falar, perguntar sobre a relação com a Norpar)

2) Existe experiência anterior da empresa com a formulação e realização de OUC?

3) A empresa tem experiências externas que influenciam sua atuação? Existe influência externa para este tipo de projeto e operação? Quais? (não entendi... não vai pegar mal essa pergunta?) Para sintetizar sugiro a seguinte questão: Há referenciais de OUC que a empresa toma como modelos a serem reproduzidos?

4) A OUC do Riacho Maceió foi a primeira que a empresa participou? Estão desde o princípio da operação?

5) Qual a origem da concepção da OUC adotada para o Riacho Maceió? Quem teve a ideia?

6) Quais os diferentes agentes envolvidos? 
7) Quais as suas responsabilidades? (lembrar que o Parque do Riacho Maceió só se efetivou em 2014 e a terra brasilis (nopar) supostamente deveria gerir esse parque por 10 anos.)

8) Quais os seus benefícios obtidos pela empresa através desta OUC?

9) Quem fez o projeto? Quais os condicionantes para o seu desenvolvimento? (Achei semelhante a pergunta 5 , não?)

10) Como analisa o atual plano diretor municipal frente à implementação de OUCs?

11) Qual a articulação institucional para implementar a OUC?

12) Com que setor da prefeitura se deram as negociações? Como se deu?

13) Quais os mecanismos de financiamento?

14) Houve uma estratégia de marketing para esta OUC? Como ela foi composta?

15) Qual o modelo de governança?

16) Quais as formas de participação?

17) Quais as principais alterações decorrentes da OUC na estruturação da área?

18) Quais os impactos sociais, econômicos, ambientais e políticos desta OUC?

19) Como se dá o envolvimento com as comunidades situadas nas proximidades?

20) Quais os principais aspectos positivos desta OUC?

21) Quais as dificuldades enfrentadas para a sua implementação?

22) Como o setor imobiliário avalia o uso das OUCs no planejamento e na gestão?

23) Considera que as OUCs são um bom negócio para a empresa e para a cidade? Por que? (aqui eu perguntaria separado... primeiro pra empresa... deixa eles falarem... depois pra cidade...)

24) A empresa pretende realizar outras OUCs? Quais as oportunidades locais? (acho que aqui ou em alguma pergunta antes devíamos ampliar pra perguntar sobre outras oportunidades de parceria público privadas).

\section{ROTEIRO DE ENTREVISTA SEMIESTRUTURADO - SEUMA - AGDA MUNIZ}

Entrevista realizada em 21/11/2016 pela equipe do LEHAB (presentes: Renato Pequeno, Valéria Pinheiro, Breno Holanda e Sara V Rosa).

Resgate... Outras duas entrevistas, a primeira tratando do PMCMV e a segunda no início da pesquisa que trata do Direito à Cidade. Estamos numa nova fase em que buscamos 
compreender o processo de financeirização da política urbana, pretendendo entender como o complexo financeiro imobiliário interfere na restruturação da cidade.

1) As gestões Roberto Cláudio e Camilo Santana apostam muito na parceria público privada como uma solução viável e vantajosa para Fortaleza. Por que? Qual a sua opinião como urbanista e como gestora?

2) Considerando o seu olhar e sua prática como especialista no tema, é possível apontar uma tipologia para os instrumentos de indução do desenvolvimento urbano? (Empreendimentos privados com ou sem Outorgas; OUCs; PPPs; Licitações... algum outro tipo considerando a realidade local?

3) Além da OUCs existem outras parcerias público privadas realizadas ou em negociação em Fortaleza? Quais?

4) Como a gestão avalia a oportunidade de implementar PPPs? Há áreas prioritárias? Como acontece a negociação com o setor privado? Vocês os procuram ou são procurados?

5) Quando a entrevistamos ano passado, você falou da implantação de um programa que identificaria 10 OUCs para as quais seriam realizados estudos de viabilidade econômica e ambiental e seus respectivos projetos de lei? Como se encontra este programa? Elas serão implementadas? Quais seriam?

6) Passados 4 anos de comando a frente da SEUMA, seria possível arriscar quais seriam essas 10 áreas em Fortaleza?

7) Qual o perfil do investidor pretendido?

8) Comparando os instrumentos da OUC e as Outorgas onerosas do direito de construir e de alteração do uso do solo, qual você acha mais interessante para a cidade? Por que?

9) Como se dá atualmente a contratação das OUCs/parcerias público privadas em Fortaleza? Quem toma a iniciativa? Prefeitura lança proposta para que o setor privado manifeste seu interesse? Ou o setor privado que procura a prefeitura? Prefeitura procura segmentos específicos para dialogar?

10) Durante sua apresentação no Fórum Adolfo Herbster, você disse que Fortaleza não tem fôlego para grandes OUCs e que talvez essas nem sejam as melhores formas de 
intervenção na cidade. Gostaríamos de saber qual é o modelo de OUCs que você considera ideal? E quais seriam os instrumentos ideais para a nossa realidade?

11) Considerando o papel maior de Fortaleza como município polo da RMF, você considera possível uma OUC / PPP que venha ser promovida por mais de um município da RMF?

12) Em São Paulo e Rio é comum observar o emprego de recursos do FGTS nas OUCs, como você avalia este procedimento? aqui temos algo do tipo?

13) Até hoje em Fortaleza os CEPACS não foram utilizados. Entretanto vimos que na OUC da Sapiranga pretende-se utilizar estes certificados. Como funcionariam na OUC da Sapiranga? Qual a ligação da CEPAC com o direito de construir proposto na lei da OUC?

14) Quem são os empreendedores privados das OUCs da Sapiranga? Como se dará a contrapartida da construção do parque? Quem irá construir nesse caso em que não se tem a identificação do agente privado?

15) E no caso da OUC Osório de Paiva. Por que o Atacadão / Carrefour não aparece no corpo de texto da Lei já que este foi o principal empreendimento/interessado na OUC?

16) Como funcionam os conselhos gestores das OUCs? Há uma normativa que estabelece as condições para o seu funcionamento? Quem participa? Composição? Que atribuições possuem? Qual a periodicidade das reuniões?

17) O que está sendo pensado para o centro da cidade? Há a previsão de uma OUC para la? (informação de um mapa da prefeitura)

18) Por falar em LUOS, como se deu a montagem da proposta final? como você avalia a versão que foi para a câmara? (pergunta sobre as ZEDUS)

19) Considerando o novo projeto de lei da LUOS em vias de discussão junto à CMF? Qual o papel das ZEDUS? Elas interferem na identificação das OUCs / PPPs previstas/

20) Como ficaria a sobreposição da OUC / PPP com as duas ZEDUS previstas para o Centro? Essas ZEDUS não inviabilizariam o possível ganho do município/da cidade que poderia ser obtido com a OUC?

21) Como tem funcionado a incorporação de contrapartidas do privado e do setor público nas OUCs que não estavam previstas em lei? (não entendi!!!)

22) Observamos que das 7 OUC propostas 5 delas encontram-se quase que inteiramente em áreas de proteção ambiental. Qual sua opinião sobre isso? A natureza estaria agregando valor a esses empreendimentos? 
23) Segundo o plano diretor de 2009, as ZEIS da Praia do Futuro têm sua implementação condicionada ao uso das OUCs. Qual teria sido a grande dificuldade para a sua implementação em conjunto?

24) Passados os 5 anos de resgate das ZEIS do tipo vazio pelo setor imobiliário, como prossegue este processo?

25) Tendo em vista as Outorgas Onerosas até aqui implementadas, existe algum cadastro ou ferramenta que possibilite o acesso às informações referentes às outorgas até hoje contratadas?

26) É possível ter uma estimativa dos ganhos totais em contrapartidas e o que foi arrecadado com as OUC?

27) Uma vez que ela informou que o Fortaleza 2040 serviria como base do plano diretor em 2019, como que o plano interage com as PPP? Pretende-se apontar as novas OUCs no próprio plano?

28) Quais os critérios adotados para a delimitação das OUCs? No caso da OUC do Papicu, foi apresentada a expansão dos limites no último Fórum Adolfo Herbster? Qual a justificativa?

29) Foi percebido que durante as gestões da Luizianne, as 3 OUCs aprovadas tinham entes privados definidos, a maioria não continha assentamentos precários, tinham cerca de 200 mil metros quadrados cada e em apenas uma delas tinha, no seu limite, áreas de macrozoneamento ambiental (ainda que a lei impedisse a ocupação dentro da ZPA). Quais são as críticas que a prefeitura faz a esse modelo e a que a senhora julga que tenha sido o motivo para que os padrões das OUCs tenham sido alterados na gestão do Roberto Claudio.

\section{ROTEIRO DE ENTREVISTA SEMIESTRUTURADO PARA MORADOR DA ÁREA DE INSERÇÃO DA \\ OUC DO RIACHO MACEIÓ (últimos moradores e moradora antiga do entorno)}

Entrevista realizada no dia 29/10/2016, por Sara V. Rosa e Camila Aldigueri.

1) Quanto tempo você mora aqui?

2) Como era quando você chegou? Como foi se dando o processo de ocupação da área?

3) Haviam pessoas morando antes de vocês? 
4) Já haviam sofrido algum tipo de pressão para sair da área antes da OUC do Riacho Maceió?

5) Como ficaram sabendo da OUC do Riacho? Como vocês e o resto da comunidade reagiram a isso?

6) Houve resistência das pessoas que moravam em permanecer no local?

7) Como foi o processo de resistência? Existiu desde o início? Como foi no final? Teve alguma ação coletiva dos moradores? Teve alguma associação de moradores formada? Constituição de liderança, ligação á movimento social?

8) Como foi o processo de negociação pelas indenizações? As pessoas estavam concordando? Queriam ficar? Qual o valor médio inicial das negociações? Quando foram iniciadas? Houve algum tipo de pressão para que os moradores cedessem a negociação e saíssem? O que acontecia com as casas já desocupadas?

9) Quem negociava com os moradores? Empresa? Prefeitura? Como essa pessoa se identificava?

10) A prefeitura participou da intermediação dessas negociações?

11) Qual o papel da prefeitura dentro de todo o processo da OUC?

12) Você tem notícias dos moradores que saíram? Sabe como eles estão?

13) Porque você e sua família ficaram até hoje?

14) Qual a sua opinião da OUC?

\section{ROTEIRO ENTREVISTA SEMIESTRUTURADA PARA EX-MORADOR E ATUAL MORADOR DA COMUNIDADE DAS AREIAS}

Entrevista realizada no dia 25/01/2017 pela equipe do LEHAB (Valéria Pinheiro, Sara v. Rosa e Breno Holanda.

1) LEHAB: Apresentar-se; explicar pesquisa.

2) Pedir que ele se apresente: nome, idade, onde mora, o que faz... - Conta um pouco da tua história de vida a partir dos teus locais de moradia

3) Sobre a comunidade DAZAREIAS: (perguntas podem variar um pouco a depender se ele ainda mora lá...)

- Com você chegou lá? 
- O que sabe sobre a formação da comunidade?

- Quem eram/são pessoas de referência por lá?

- Quais os principais problemas da comunidade?

- Quais as coisas mais legais da comunidade?

- Existe organização comunitária?

- Já foram ameaçados de remoção?

- Antes do Rio Mar, houve alguma grande obra pública ou privada por aqui?

- Como ficaram sabendo do projeto do Rio Mar? Quem os comunicou?

- Como a comunidade recebeu a notícia?

- Como foi a execução do projeto? Que fatos marcaram?

- Com quem do poder público ou privado a comunidade tinha contato, sobre a obra?

- O que mudou após o fim da obra?

- Qual sua avaliação sobre a obra?

- (tentar contatos de pessoas das comunidades vizinhas...)

4) Demais perguntas norteadoras:

- Como um tema tão complexo como financeirização da política pública chega aos movimentos? Ele chega?

- Os movimentos e conseguem de alguma forma visualizar o tema da financeirização e o impactos desta na cidade e nas suas pautas de lutas, mesmo que indiretamente?

- Como estes complexos financeiros multiusos impactam os moradores da área do entorno? Surgem resistências as alterações que estes provocam no território? Estas resistências são mais dos moradores, ou de movimentos organizados? Estes têm ciência desses processos mais globais de financeirização?

- Quais são as resistências e insurgências dentro do processo de reestruturação urbana neoliberal? São resistências ou são processos de place makers? Estamos terminando de acabar com o Estado?

- Como podemos contribuir para desvendar esses processos para os movimentos e moradores? 


\section{ROTEIRO ENTREVISTA SEMIESTRUTURADA - MORADOR PAUFININHO}

Entrevista realizada em 11/05/2017 por Valéria Pinheiro (lehab)

1) LEHAB: Apresentar-se; explicar pesquisa. Pracinha da ciclofaixa

2) Pedir que ele se apresente: nome, idade, onde mora, o que faz... - Conta um pouco da tua história de vida a partir dos teus locais de moradia

3) Sobre a comunidade PAUFINNIHO: (perguntas podem variar um pouco a depender se ele ainda mora lá...)

- Com você chegou lá?

- O que sabe sobre a formação da comunidade?

- Quem eram/são pessoas de referência por lá?

- Quais os principais problemas da comunidade?

- Quais as coisas mais legais da comunidade?

- Existe organização comunitária?

- Já foram ameaçados de remoção? (Perguntar do episódio do ano passado - protesto dos moradores queimando objetos na rua)

- Antes do Rio Mar, houve alguma grande obra pública ou privada por aqui?

- Como ficaram sabendo do projeto do Rio Mar? Quem os comunicou?

- Como a comunidade recebeu a notícia?

- Como foi a execução do projeto? Que fatos marcaram?

- Com quem do poder público ou privado a comunidade tinha contato, sobre a obra?

- O que mudou após o fim da obra?

- Qual sua avaliação sobre a obra?

- (Tentar contatos de pessoas das comunidades vizinhas...)

4) Demais perguntas norteadoras:

- Como um tema tão complexo como financeirização da política pública chega aos movimentos? Ele chega?

- Os movimentos e conseguem de alguma forma visualizar o tema da financeirização e o impactos desta na cidade e nas suas pautas de lutas, mesmo que indiretamente?

- Como estes complexos financeiros multiusos impactam os moradores da área do entorno? Surgem resistências as alterações que estes provocam no território? Estas 
resistências são mais dos moradores, ou de movimentos organizados? Estes têm ciência desses processos mais globais de financeirização?

- Quais são as resistências e insurgências dentro do processo de reestruturação urbana neoliberal? São resistências ou são processos de place makers? Estamos terminando de acabar com o Estado?

- Como podemos contribuir para desvendar esses processos para os movimentos e moradores?

\section{ROTEIRO ENTREVISTA SEMIESTRUTURADA PARA MOORADORA DO RIACHO MACEIÓ - (moradores removidos)}

LEHAB - 15/07/2017

1) Conte um pouco da história da rua Senador Machado. De onde as pessoas vieram? Quando? Como foi o processo de ocupação do local.

2) Onde você morava antes?

3) Como era quando você chegou no riacho Maceió? Como foi se dando o processo de ocupação da área? Haviam pessoas morando antes de vocês?

4) Quantos anos morou na rua Senador Machado? Quantas famílias haviam na rua?

5) Como ficaram sabendo da Operação Urbana do Riacho Maceió? Como vocês e o resto da comunidade reagiram a isso?

6) Como foi o processo a partir que foi divulgado que teriam que sair do local? Quando isso se iniciou?

7) Houve resistência? Houve gente que não queria sair? Houve mobilização dos moradores para permanecer ou para lutar por melhores indenizações?

8) Como foram as negociações com a construtora?

9) Qual o valor médio das indenizações que foram pagas? Se não se importar, por quanto foi vendida a casa? Quando foi vendida?

10) A Prefeitura participou das negociações de alguma forma?

11) Como foi a atuação da prefeitura durante todo esse processo?

12) Já haviam sofrido algum tipo de pressão para sair da área antes da OUC do Riacho Maceió? Se sim, quando foi e o como foi? 
13) Atualmente você mora na comunidade do Saporé? Porque escolheu ela como o novo lugar de sua residência? Se considerava da comunidade do Saporé? Por que?

14) Na comunidade do Saporé, já ocorreram pressões de remoção?

15) Qual a sua opinião sobre a Operação Urbana do Riacho Maceió?

16) Você acha que a construção do prédio da Operação pode trazer alguma consequência para o entorno? 
VI. Instrumentos por zona do macrozoneamento urbanos de Fortaleza, segundo o Plano Diretor Participativo de Fortaleza, PDP-2009.

Quadro 19. Instrumentos indicados pelo PDP para cada zona, macrozoneamento ambiental e zonas especiais de interesse social

\begin{tabular}{|c|c|c|c|c|c|}
\hline ZPA & RA & ZIA & EIS 1 & ZEIS 2 & ZEIS 3 \\
\hline $\begin{array}{l}\text { I - plano de manejo; } \\
\text { II - plano de gestão; } \\
\text { III - estudo ambiental } \\
\text { (EA); } \\
\text { IV - estudo de impacto } \\
\text { de vizinhança (EIV); } \\
\text { V - direito de preempção. }\end{array}$ & $\begin{array}{l}\text { I - planos de manejo; } \\
\text { II - planos de gestão; } \\
\text { III - direito de superfície; } \\
\text { IV - estudo de impacto } \\
\text { de vizinhança (EIV); } \\
\text { V _ _ direito de } \\
\text { preempção; } \\
\text { VI - instrumentos de } \\
\text { regularização fundiária; } \\
\text { VII - transferência do } \\
\text { direito de construir. }\end{array}$ & $\begin{array}{l}\text { I - instrumentos de } \\
\text { regularização } \\
\text { fundiária; } \\
\text { II - direito de } \\
\text { preempção; } \\
\text { III - direito de } \\
\text { superfície; } \\
\text { IV - estudo de } \\
\text { impacto } \\
\text { vizinhança (EIV); de } \\
\text { V - estudo } \\
\text { ambiental (EA). }\end{array}$ & $\begin{array}{l}\text { I — concessão de uso especial } \\
\text { para fins de moradia; } \\
\text { II - usucapião especial de } \\
\text { imóvel urbano; } \\
\text { III - concessão de direito real } \\
\text { de uso; } \\
\text { IV - autorização de uso; } \\
\text { V - cessão de posse; } \\
\text { VI - plano integrado de } \\
\text { regularização fundiária; } \\
\text { VII - assistência técnica e } \\
\text { jurídica gratuita; } \\
\text { VIII - direito de superfície; } \\
\text { IX - direito de preempção }\end{array}$ & $\begin{array}{l}\text { I - concessão de uso especial } \\
\text { para fins de moradia; } \\
\text { II - usucapião especial de } \\
\text { imóvel urbano; } \\
\text { III - concessão de direito real } \\
\text { de uso; } \\
\text { IV - autorização de uso; } \\
\text { V - cessão de posse; } \\
\text { VI - plano integrado de } \\
\text { regularização fundiária; } \\
\text { VII - assistência técnica e } \\
\text { jurídica gratuita; } \\
\text { VIII - direito de superfície; } \\
\text { IX - direito de preempção. }\end{array}$ & $\begin{array}{l}\text { I - parcelamento, edificação e utilização } \\
\text { compulsórios; } \\
\text { II - IPTU progressivo no tempo; } \\
\text { III - desapropriação para fins de reforma } \\
\text { urbana; } \\
\text { IV - consórcio imobiliário; } \\
\text { V - direito de preempção; } \\
\text { VI - direito de superfície; } \\
\text { VII - operações urbanas consorciadas; } \\
\text { VIII - transferência do direito de construir; } \\
\text { IX - abandono; } \\
\text { X - plano de intervenção. }\end{array}$ \\
\hline
\end{tabular}


Quadro 20. Instrumentos indicados pelo PDP para cada zona, macrozoneamento urbano

\begin{tabular}{|c|c|c|c|c|c|c|c|c|}
\hline ZOP 1 & ZOP 2 & ZOC & ZRU 1 & ZRU 2 & ZOM 1 & ZOM 2 & ZOR & Zo \\
\hline $\begin{array}{l}\text { I- parcelamento, } \\
\text { edificação e utilização } \\
\text { compulsórios; }\end{array}$ & $\begin{array}{l}\text { - parcelamento, } \\
\text { edificação e utilização } \\
\text { compulsórios; }\end{array}$ & $\begin{array}{l}\text { I - parcelamento, } \\
\text { edificação e utilização } \\
\text { compulsórios; }\end{array}$ & $\begin{array}{l}\text { I - parcelamento, } \\
\text { edificação e utilização } \\
\text { compulsórios; }\end{array}$ & $\begin{array}{l}\text { I - parcelamento, } \\
\text { edificação e utilização } \\
\text { compulsórios; }\end{array}$ & $\begin{array}{l}\text { I - parcelamento, } \\
\text { edificação e utilização } \\
\text { compulsórios; }\end{array}$ & $\begin{array}{l}\text { I - parcelamento, } \\
\text { edificação e utilização } \\
\text { compulsórios; }\end{array}$ & $\begin{array}{l}\text { I - direito de } \\
\text { preempção; }\end{array}$ & $\begin{array}{l}\text { l }- \text { parcelamento, } \\
\text { edificação e utilização } \\
\text { compulsórios; }\end{array}$ \\
\hline $\begin{array}{l}\text { II - IPTU progressivo } \\
\text { no tempo; }\end{array}$ & $\begin{array}{l}\text { II - IPTU progressivo } \\
\text { no tempo; }\end{array}$ & $\begin{array}{l}\text { II - IPTU progressivo } \\
\text { no tempo; }\end{array}$ & $\begin{array}{l}\text { II - IPTU progressivo } \\
\text { no tempo; }\end{array}$ & $\begin{array}{l}\text { II - IPTU progressivo } \\
\text { no tempo; }\end{array}$ & $\begin{array}{l}\text { II - IPTU progressivo } \\
\text { no tempo; }\end{array}$ & $\begin{array}{l}\text { II - IPTU progressivo } \\
\text { no tempo; }\end{array}$ & II-direito de superfície; & $\begin{array}{l}\text { II - IPTU progressivo } \\
\text { no tempo; }\end{array}$ \\
\hline $\begin{array}{l}\text { III - desapropriação } \\
\text { mediante pagamento } \\
\text { por títulos da divida } \\
\text { pública; } \\
\text { IV - direito de } \\
\text { preempção; }\end{array}$ & $\begin{array}{l}\text { III - desapropriação } \\
\text { mediante pagamento } \\
\text { por títulos da divida } \\
\text { pública; } \\
\text { IV - direito de } \\
\text { preempção; }\end{array}$ & $\begin{array}{l}\text { III - desapropriação } \\
\text { mediante pagamento } \\
\text { por títulos da divida } \\
\text { pública; } \\
\text { IV - direito de } \\
\text { preempção; }\end{array}$ & $\begin{array}{l}\text { III - desapropriação } \\
\text { mediante pagamento } \\
\text { por títulos da dívida } \\
\text { pública; } \\
\text { IV - direito de } \\
\text { preempção; }\end{array}$ & $\begin{array}{l}\text { III - desapropriação } \\
\text { mediante } \\
\text { por títulos da da dívida } \\
\text { pública; } \\
\text { IV - direito de } \\
\text { preempção; }\end{array}$ & $\begin{array}{l}\text { III - desapropriação } \\
\text { mediante } \\
\text { por títulos da da dívida } \\
\text { pública; } \\
\text { IV - direito de de } \\
\text { preempção; }\end{array}$ & $\begin{array}{l}\text { III - desapropriação } \\
\text { mediante pagamento } \\
\text { por títulos da divida } \\
\text { pública; } \\
\text { IV - direito de } \\
\text { preempção; }\end{array}$ & $\begin{array}{l}\text { III - estudo de impacto } \\
\text { de vizinhança (EIV); } \\
\text { IV - estudo ambiental } \\
\text { (EA); }\end{array}$ & $\begin{array}{l}\text { III - desapropriação } \\
\text { mediante pagamento } \\
\text { por títulos da dívida } \\
\text { pública; } \\
\text { IV - direito de } \\
\text { preemp̧̧ão; }\end{array}$ \\
\hline $\begin{array}{l}\text { V-direito de } \\
\text { superfície; }\end{array}$ & $\begin{array}{l}\mathrm{V}-\text { direito de } \\
\text { superficie; }\end{array}$ & $\begin{array}{l}V_{\text {superfície; }} \text { direito de }\end{array}$ & $\begin{array}{l}\mathrm{V}-\text { direito de } \\
\text { superfície; }\end{array}$ & $\begin{array}{l}V \quad-\quad \text { direito de } \\
\text { superficie; }\end{array}$ & $\begin{array}{l}V \quad-\quad \text { direito de } \\
\text { superfície; }\end{array}$ & $\begin{array}{l}V_{\text {superfície; }} \text { direito de }\end{array}$ & $\begin{array}{l}V-\text { Zona Especial de } \\
\text { Interesse Social (ZEIS). }\end{array}$ & $\begin{array}{l}\text { V - direito de } \\
\text { superficie; }\end{array}$ \\
\hline $\begin{array}{l}\mathrm{VI} \text { - transferência do } \\
\text { direito de construir; }\end{array}$ & $\begin{array}{l}\mathrm{VI} \text { - outorga onerosa } \\
\text { do direito de construir; }\end{array}$ & $\begin{array}{l}\mathrm{VI} \text { - outorga onerosa } \\
\text { do direito de construir; }\end{array}$ & $\begin{array}{l}\mathrm{VI} \text { - operação urbana } \\
\text { consorciada; }\end{array}$ & $\begin{array}{l}\mathrm{VI} \text { - operação urbana } \\
\text { consorciada; }\end{array}$ & $\begin{array}{l}\mathrm{VI} \text { - outorga onerosa } \\
\text { do direito de construir; }\end{array}$ & $\begin{array}{l}\mathrm{VI} \text { - outorga onerosa } \\
\text { do direito de construir; }\end{array}$ & & $\begin{array}{l}\mathrm{VI} \text { - operação urbana } \\
\text { consorciada; }\end{array}$ \\
\hline $\begin{array}{l}\text { VII - operação urbana } \\
\text { consorciada; }\end{array}$ & $\begin{array}{l}\mathrm{VII} \text { - transferência do } \\
\text { direito de construir; }\end{array}$ & $\begin{array}{l}\mathrm{VII} \text { - transferência do } \\
\text { direito de construir; }\end{array}$ & $\begin{array}{l}\text { VII - consórcio } \\
\text { imobiliário; }\end{array}$ & $\begin{array}{l}\text { VII - consórcio } \\
\text { imobiliário; }\end{array}$ & $\begin{array}{l}\mathrm{VII} \text { - transferência do } \\
\text { direito de construir; }\end{array}$ & $\begin{array}{l}\mathrm{VII} \text { - transferência do } \\
\text { direito de construir; }\end{array}$ & & $\begin{array}{l}\text { VII - consórcio } \\
\text { imobiliário; }\end{array}$ \\
\hline $\begin{array}{l}\text { VIII — consórcio } \\
\text { imobiliário; }\end{array}$ & $\begin{array}{l}\text { VIII - operação } \\
\text { urbana consorciada; }\end{array}$ & $\begin{array}{l}\text { VIII _- consórcio } \\
\text { imobiliário; }\end{array}$ & $\begin{array}{l}\text { VIII - estudo de } \\
\text { impacto de vizinhança } \\
\text { (EIV); }\end{array}$ & $\begin{array}{l}\text { VIII - estudo de } \\
\text { impacto de vizinhança } \\
\text { (EIV); }\end{array}$ & $\begin{array}{l}\text { VIII - operação } \\
\text { urbana consorciada; }\end{array}$ & $\begin{array}{l}\text { VIII - operação } \\
\text { urbana consorciada; }\end{array}$ & & $\begin{array}{l}\text { VIII - estudo de } \\
\text { impacto de vizinhança } \\
\text { (EIV); }\end{array}$ \\
\hline $\begin{array}{l}\text { IX - estudo de impacto } \\
\text { de vizinhança (EIV); }\end{array}$ & $\begin{array}{l}\text { IX } \\
\text { imobiliário; }\end{array}$ & $\begin{array}{l}\text { IX - estudo de impacto } \\
\text { de vizinhança (EIV); }\end{array}$ & $\begin{array}{l}\text { IX - estudo ambiental } \\
(\mathrm{EA}) ;\end{array}$ & $\begin{array}{l}\text { IX - estudo ambiental } \\
\text { (EA); }\end{array}$ & $\begin{array}{ll}\text { IX } & \text { consórcio } \\
\text { imobiliário; } & \end{array}$ & $\begin{array}{l}\text { IX - consórcio } \\
\text { imobiliário; }\end{array}$ & & $\begin{array}{l}\text { IX - estudo ambiental } \\
\text { (EA); }\end{array}$ \\
\hline $\begin{array}{l}X \text { - estudo ambiental } \\
(\mathrm{EA})\end{array}$ & $\begin{array}{l}\mathrm{X} \text { - estudo de impacto } \\
\text { de vizinhança (EIV); }\end{array}$ & $\begin{array}{l}\mathrm{X}-\text { estudo ambiental } \\
\text { (EA); }\end{array}$ & $\begin{array}{l}\text { X - Zona Especial de } \\
\text { Interesse Social (ZEIS); }\end{array}$ & $\begin{array}{l}\text { X - Zona Especial de } \\
\text { Interesse Social (ZEIS); }\end{array}$ & $\begin{array}{l}X \text { - estudo de impacto } \\
\text { de vizinhança (EIV); }\end{array}$ & $\begin{array}{l}\text { X - estudo de impacto } \\
\text { de vizinhança (EIV); }\end{array}$ & & $\begin{array}{l}\text { X - Zona Especial de } \\
\text { Interesse Social (ZEIS); }\end{array}$ \\
\hline $\begin{array}{l}\text { XI —ZZona Especial de } \\
\text { Interesse Social (ZEIS); }\end{array}$ & $\begin{array}{l}\mathrm{XI} \text { - estudo ambiental } \\
(\mathrm{EA}) ;\end{array}$ & $\begin{array}{l}\text { XI - Zona Especial de } \\
\text { Interesse Social (ZEIS); }\end{array}$ & $\begin{array}{l}\mathrm{XI} \text { - instrumentos de } \\
\text { regularização fundiária; }\end{array}$ & $\begin{array}{l}\mathrm{XI} \text { - instrumentos de } \\
\text { regularização fundiária; }\end{array}$ & $\begin{array}{l}\mathrm{XI} \text { _ estudo ambiental } \\
(\mathrm{EA}) ;\end{array}$ & $\begin{array}{l}\mathrm{XI} \text { - estudo ambiental } \\
\text { (EA); }\end{array}$ & & $\begin{array}{l}\mathrm{XI} \text { - instrumentos de } \\
\text { regularização fundiária; }\end{array}$ \\
\hline $\begin{array}{l}\mathrm{XII} \text { - instrumentos de } \\
\text { regularização fundiária; }\end{array}$ & $\begin{array}{l}\text { XII — Zona Especial de } \\
\text { Interesse Social (ZEIS); }\end{array}$ & $\begin{array}{l}\text { XII - instrumentos de } \\
\text { regularização fundiária; }\end{array}$ & $\begin{array}{l}\text { XII - outorga onerosa } \\
\text { de alteração de uso. }\end{array}$ & $\begin{array}{l}\text { XII - outorga onerosa } \\
\text { de alteração de uso. }\end{array}$ & $\begin{array}{l}\text { XII - Zona Especial de } \\
\text { Interesse Social (ZEIS); }\end{array}$ & $\begin{array}{l}\text { XII - Zona Especial de } \\
\text { Interesse Social (ZEIS). }\end{array}$ & & $\begin{array}{l}\text { XII - outorga onerosa } \\
\text { de alteração de uso; }\end{array}$ \\
\hline $\begin{array}{l}\text { XIII - outorga onerosa } \\
\text { de alteração de uso. }\end{array}$ & $\begin{array}{l}\text { XIII - instrumentos de } \\
\text { regularização fundiária. }\end{array}$ & $\begin{array}{l}\text { XIII - outorga onerosa } \\
\text { de alteração de uso. }\end{array}$ & & & $\begin{array}{l}\text { XIII - instrumentos de } \\
\text { regularização fundiária; } \\
\text { XIV - outorga onerosa } \\
\text { de alteração de uso. }\end{array}$ & & & $\begin{array}{l}\text { XIII- outorga onerosa } \\
\text { do direito de construir. }\end{array}$ \\
\hline
\end{tabular}




\section{Obrigações do setor público e setor privado que}

\section{assinam as Operações}

\section{Quadro 21. Obrigações do setor público e setor privado que assinam as Operações}

\section{Setor publico}

Aproveitamento (IA), liberada para ocupação da Quadra 01, constante do Anexo 02 desta Lei, a área de $2.435,61 \mathrm{~m} 2$ (dois mil, quatrocentos e trinta e cinco metros e sessenta e um centímetros quadrados) correspondente à parte da área a ser doada para implantação da via pública paisagística, respeitados os demais índices de ocupação previstos na legislação vigente;

D a) reanalisar os projetos de parcelamento existentes na área da Operação u Urbana Consorciada Dunas do Cocó, redefinindo a localização das áreas $\mathrm{n}$ públicas, compreendendo as vias, áreas verdes e institucionais; b) a estabelecer diretrizes para as áreas não parceladas inseridas na área da s Operação Urbana Consorciada Dunas do Cocó em consonância com o disposto nesta Lei ou na Lei de Parcelamento do Solo em vigor, respeitando d as diretrizes do sistema viário constante do Anexo 02; c) elaborar o projeto

- do Parque Linear do Cocó e das vias incluídas na área da Operação Componentes do Sistema Viário Estrutural;

J a) Desafetar as áreas públicas inseridas no Loteamento Parque São - Cristóvam, compreendendo $19.889,96 \mathrm{~m}^{2}$ de ruas e $20.152,00 \mathrm{~m}^{2}$ de área

c de praça. b) Permitir que quando do parcelamento da gleba objeto da k matrícula no 62.858 do CRI da 3a Zona desta capital, as áreas públicas, verde, institucional e fundo de terra no valor de $27.536,81 \mathrm{~m}^{2}$, doadas y antecipadamente, sejam agrupadas em um único terreno para possibilitar a implantação do Hospital da Mulher; c) Permitir a utilização pelo Jockey

C Clube Cearense dos seguintes indicadores urbanos; índice de

aproveitamento de 1.7 para ZU4.2 e 1.5 para AEA-3 e fração do lote igual a 100 para a ZU4.2 e AEA-3, os demais indicadores permanecem os

b definidos na Lei no 7987/96, não sendo permitido a utilização da fração do lote reduzida na área, como compensação pelo recebimento da doação da área de $7.125,25 \mathrm{~m}^{2}$.

\section{Setor privado}

a) aquisição e doação ao Município de Fortaleza de um terreno de $17.874,91 \mathrm{~m} 2$ (dezessete mil, oitocentos e setenta e quatro metros e noventa e um centímetros quadrados), compreendendo $14.693,49 \mathrm{~m} 2$ (quatorze mil, seiscentos e noventa e três metros e quarenta e nove centímetros quadrados) para implantação da área do Parque e $3.181,42 \mathrm{~m} 2$ (três mil, cento e oitenta e um metros e quarenta e dois centímetros quadrados) para o Sistema Viário Básico; b) aquisição e desocupação dos imóveis, tais como prédios, benfeitorias e posses, localizados na Rua Senador Machado, lado norte, bem como aqueles existentes na área destinada ao Parque; c) implantar e executar, às suas expensas, a infraestrutura e urbanização do Parque e da via paisagística de acesso, conforme projeto elaborado pela Secretaria Municipal de Desenvolvimento Territorial Urbano e Meio Ambiente (SMDT); d) manutenção, conservação e limpeza do Parque pelo período de 10 (dez) anos, contado a partir de sua implantação.

a) submeter à aprovação do Município os projetos de parcelamento e reparcelamento e ocupação dos terrenos inseridos na área da Operação Urbana Consorciada; b) doar ao Município, quando do parcelamento, reparcelamento ou reloteamento, as áreas públicas, as áreas destinadas ao sistema viário, áreas verdes e institucionais na mesma metragem do loteamento inicial; c) implantar e executar, às suas expensas, toda a infraestrutura e urbanização da área de acordo com as diretrizes definidas pelo Poder Público Municipal, de acordo com o disposto nesta Lei; d) manter, sem quaisquer encargos financeiros ou indenizatórios para o Poder Público, todas as áreas de proteção e de preservação especial definida nos incisos I e II do art. 6으 desta Lei, como espaço de interesse ambiental e paisagístico; e) responder pelos custos de manutenção, conservação, administração e limpeza das áreas definidas na alínea " $d$ " deste artigo, pelo prazo de 10 (dez) anos, contados da data da assinatura do convênio, tudo previamente aprovado por laudo expedido por técnicos da Secretaria Municipal de Meio Ambiente e Controle Urbano (SEMAM).

a) promover o reloteamento do Parque São Cristóvam e o loteamento da gleba objeto da matrícula no 62.858 do CRI da 3a Zona desta capital, conforme diretrizes emitidas pela SEINF, constantes do Anexo II do presente protocolo. b) Doar o Município as áreas públicas relativas aos $25 \%$ incidente na gleba objeto da matrícula no 62.858 do CRI da 3a Zona desta capital cuja área total é de $110.147,24 \mathrm{~m}^{2}$; que representa uma área a ser doada de $27.536,81 \mathrm{~m}^{2}$; c) Doar, por ato de liberalidade, ao município a área de $7.125,25 \mathrm{~m}^{2}$ com o fim de integrar área total de

$75.092,02 \mathrm{~m}^{2}$ do Hospital da Mulher; d) Permutar $26.749,84 \mathrm{~m}^{2}$ de área do terreno inserido no perímetro onde será construído o Hospital da Mulher por área equivalente pertencente ao município inserida no loteamento Parque São Cristóvam localizada em área externa ao referido perímetro; e) Implantar o sistema viário definido nas diretrizes emitidas pela SEINF constantes no Anexo II, que incidirão no terreno do Jockey Clube Cearense na sua totalidade; f) Em caso de unificação de matricula, obrigase o conveniado a fazer a doação direta ao Município de Fortaleza da área total de $75.092,02 \mathrm{~m}^{2}$ resultante das obrigações descritas nos itens supra. 
S a) transferência, mediante permuta, para a empresa FCM Comercial Ltda, i da titularidade do terreno com área de $32.237,00 \mathrm{~m} 2$ (trinta e dois mil, $\mathrm{t}$ duzentos e trinta e sete etros quadrados), de propriedade do Município de i Fortaleza (área institucional vinculada ao Loteamento Alpha Village), - localizado na Avenida Pindorama, conforme anexo 02, objeto da matrícul no 55.897 do Cartório de Registro de Imóveis da 1a Zona da Comarca de

T $\quad$ Fortaleza; pela permuta 0 Municipio de Fortaleza receberá o imóve u descrito na alínea a do inciso II deste artigo; b) objetivando viabilizar n implantação da Operação Urbana Consorciada Sítio Tunga, fica autorizada

a utilização, no empreendimento imobiliário residencial multifamiliar que

a se pretende implantar no Sítio Tunga, dos seguintes indicadores urbanísticos, mantidos todos os demais previstos na Lei Complementar $n$ 0062/2009 (PDP): i) fração do lote igual a 100m2 (cem metros quadrados); e ii) índice de aproveitamento (I.A.) previsto na Lei para a Zona Urbana onde se localiza o Sítio Tunga, aplicável sobre a área total de $103.240,10 \mathrm{~m} 2$ (cento e três mil, duzentos e quarenta metros e dez centímetros quadrados), nesta compreendida a área edificável de $97.618,46 \mathrm{~m} 2$ (noventa e sete mil, seiscentos e dezoito metros e quarenta e seis centímetros quadrados), resultante final de propriedade da FCM Comercia Ltda e e a área edificável de $5.621,64 \mathrm{~m} 2$ (cinco mil, seiscentos e vinte e um metros e sessenta e quatro centímetros quadrados), a ser doada ao Município de Fortaleza, de que trata a alínea b do inciso II deste artigo; c) fica autorizada a manutenção da integridade da gleba do Sítio Tunga, numa área total de $213.377,00 \mathrm{~m} 2$ (duzentos e treze mil, trezentos setenta e sete metros quadrados), resultante da área atual de $203.044,70 \mathrm{~m} 2$ (duzentos e três mil, quarenta e quatro metros e setenta centímetros quadrados), acrescida de $32.237,00 \mathrm{~m} 2$ (trinta e dois mil, duzentos e trinta e sete metros quadrados), recebidos pela permuta de que trata a alínea a retro, e reduzida em $21.904,70 \mathrm{~m} 2$ (vinte e um mil, novecentos e quatro metros e setenta centímetros quadrados), em razão da doação para o Município de Fortaleza objetivando a implantação de um parque público urbano, de que trata a alínea c do inciso II; a) alocar a quantia de $\mathrm{R} \$ 1.680 .000,00$ (um milhão, seiscentos e oitenta mil reais) para aquisição de terreno localizado na Avenida Presidente Juscelino Kubitschek, lado par, no bairro Passaré, entre o Hospital Sarah Kubitschek e o Cemitério Parque da Paz, objeto da matrícula no 59.680 do Cartório de Registro de Imóveis da 2a Zona da Comarca de Fortaleza, com área real de $27.116,79 \mathrm{~m} 2$ (vinte e sete mil, cento e dezesseis metros e setenta e nove centímetros quadrados) (no registro constam $34.831,53 \mathrm{~m} 2$ ), cuja titularidade será transferida para o Município de Fortaleza, mediante permuta com o terreno a que se refere a alínea a do inciso I deste artigo, e que se destinará à implantação, pela Fundação HABITAFOR, de programa de habitação social; b) alocar a quantia de R\$1.046.388,00 (um milhão, quarenta e seis mil, trezentos e oitenta e oito reais), mediante a transferência, por doação, para o Município de Fortaleza, de área com $21.904,70 \mathrm{~m} 2$ (vinte e um mil, novecentos e quatro metros e setenta centímetros quadrados), conforme descrita no anexo 04 , contígua à já existente Área Verde 04 (20.500,00m2), esta oriunda do Loteamento Alpha Village, no bairro Luciano Cavalcante; a área a ser doada ao Município tem os seguintes limites e confrontações, no sentido anti-horário: ao sul, por onde mede 170,00m (cento e setenta metros), com a atual área institucional, de que trata a alínea a do inciso I deste artigo; a leste, por onde mede $88,96 \mathrm{~m}$ (oitenta e oito metros e noventa e seis centímetros), por um segmento que inicia na extremidade do limite sul da porção ora descrita, e segue em direção nordeste, formando um ângulo interno de $90^{\circ}$ (noventa graus) até encontrar a quadra 05 do Loteamento Alpha Village; ao norte, por onde mede $243,38 \mathrm{~m}$ (duzentos e quarenta e três metros e trinta e oito centímetros), em 4 (quatro) segmentos consecutivos que extremam, respectivamente, com parte da quadra $05(64,79 \mathrm{~m})$, com a Área Verde $04(104,00 \mathrm{~m})$, com o final da rua local situada a leste da quadra $01(32,97 \mathrm{~m})$ e com os lotes 24 e 25 da quadra $01(41,62 \mathrm{~m})$, sendo todas essas referências vinculadas ao Loteamento Alpha Village; e, ao norte, por onde mede $153,88 \mathrm{~m}$ (cento e cinquenta e três metros e oitenta e oito centímetros), em segmento curvilíneo, com a Avenida Pindorama, fechando a poligonal; c) alocar a quantia de $\mathrm{R} \$ 500.000,00$ (quinhentos mil reais), através da construção de parque público urbano, na gleba de $42.404,70 \mathrm{~m} 2$ (quarenta e dois mil, quatrocentos e quatro metros e setenta centímetros quadrados), formada pela reunião da área a ser doada ao Município com a Área Verde 04, ambas referidas na alínea b anterior; o programa de investimentos na construção do parque público urbano, conforme projeto a ser elaborado pela Secretaria Municipal de Desenvolvimento Urbano e Infraestrutura (SEINF), contemplará os seguintes itens: retificação e limpeza do terreno, incluindo o canal nele existente; construção de gradil e de pontes sobre o canal; pavimentação de passeios, iluminação e instalação de equipamentos de descanso, lazer e diversão - bancos de alvenaria e concreto, pistas de cooper, playgrounds, ciclovia, quadra poliesportiva e quadra de vôlei de praia; d) alocar a quantia de $\mathrm{R} \$ \mathbf{6 0 0 . 0 0 0 , 0 0}$ (seiscentos mil reais) na execução dos trabalhos de limpeza e manutenção do parque público urbano de que trata a alínea anterior, que deverão ser executados sob a responsabilidade das empresas FCM Comercial Ltda. e BROOKFIELD MB Empreendimentos Imobiliários S.A., pelo período de 10 (dez) anos, contados da data de sua implantação; e) alocar a quantia de $\mathrm{R} \$ 1.622 .547,95$ (um milhão, seiscentos e vinte dois e mil, quinhentos e quarenta e sete reais e noventa e cinco centavos), para execução das obras de terraplanagem, compactação, pavimentação, urbanização e iluminação da Avenida Pindorama, no bairro Luciano Cavalcante, numa extensão de $800 \mathrm{~m}$ (oitocentos metros), com caixa de $24,00 \mathrm{~m}$ (vinte e quatro metros), compreendendo 2 (duas) pistas de rolamento, canteiro central com pista de desaceleração para acesso ao empreendimento e passeios, devidamente pavimentados, conforme projeto a ser elaborado pela Secretaria Municipal de Desenvolvimento Urbano e Infraestrutura (SEINF); f) alocar a quantia de $\mathrm{R} \$ 319.025,79$ (trezentos e dezenove mil, vinte e cinco reais e setenta e nove centavos), para execução das obras de pavimentação, urbanização e iluminação de 2 (dois) trechos de vias locais, como indicado no anexo 02, numa extensão total de $230,00 \mathrm{~m}$ (duzentos e trinta metros), com 14,00m (quatorze metros) de largura, sendo $9,00 \mathrm{~m}$ (nove metros) de pista de rolamento e $5,00 \mathrm{~m}$ (cinco metros) de passeios $(2 \times 2,5 \mathrm{~m})$, conforme projeto a ser elaborado pela Secretaria Municipal de Desenvolvimento Urbano e Infraestrutura (SEINF); g) alocar a quantia de $\mathrm{R} \$ 30.000,00$ (trinta mil reais), que serão destinados à realização de sondagens e de ajustes nos projetos arquitetônico e complementares de engenharia das habitações sociais que serão implementadas pela Fundação HABITAFOR no imóvel de que trata a alínea a deste inciso; h) implantar e executar, às suas expensas, toda a infraestrutura e urbanização da área alcançada por esta operação urbana consorciada, em conformidade com as diretrizes estabelecidas pelo poder público municipal através desta Lei; i) adotar medidas visando à proteção e à recuperação das áreas de preservação permanente situadas na área abrangidas por esta OUC; j) realizar Estudo de Impacto de Vizinhança e, se necessário, estudo ambiental, conforme estabelecido pelo inciso VII do art. 244 da Lei Complementar no 0062/2009 (PDP); k) proceder ao licenciamento ambiental de todas as obras executadas em decorrência da implantação desta OUC junto à Secretaria Municipal do Meio Ambiente 
L a) redefinição e aprovação do uso do solo e de seu parcelamento das antigas quadras $12,13,14,16,17,18,20$, 21 e 22 em lote 10, com área g total de $114.030,48 \mathrm{~m}^{\wedge} 2$, para construção de grande centro comercial; b) - redefinição e aprovação do uso do solo e de seu parcelamento de parte a das antigas quadras 6 e 9 para criação do lote 1, com área de $6.948,34 \mathrm{~m}^{2}$. d c) redefinição e aprovação do uso do solo e de seu parcelamento das partes - das antigas quadras 6 e 9 para criação do lote 2, com área de 7.963,90 $\mathrm{m}^{\wedge} 2$; d) redefinição e aprovação do uso do solo e de seu parcelamento de parte P da antiga quadra 9 para criação do lote 3 , com área de $3.796,71 \mathrm{~m}^{2}$; e) a redefinição e aprovação do uso do solo e de seu parcelamento de parte da p antiga quadra 9 para criação do lote 4 , com área de $3.660,00 \mathrm{~m}^{\wedge} 2$; f) redefinição e aprovação do uso do solo e de seu parcelamento de parte da antiga quadra 9, para criação do lote 5 , com área de $2.623,00 \mathrm{~m} \mathrm{~m} \mathrm{~m}^{\wedge} 2 \mathrm{~g}$ ) u redefinição e aprovação do uso do solo e de seu parcelamento de parte da antiga quadra 7 , para criação do lote 6 , com área de $6.118,00 \mathrm{~m}^{2} ; \mathrm{h}$ ) redefinição e aprovação do uso do solo e de seu parcelamento de parte da antiga quadra 7 , para criação do lote 7 , com área de $6.289,64 \mathrm{~m}^{\wedge} 2$; i) redefinição e aprovação do uso do solo e de seu parcelamento de parte da antiga quadra 10 , para criação do lote 8 , com área de $6.152,80 \mathrm{~m}^{\wedge 2}$; j) redefinição e aprovação do uso do solo e de seu parcelamento de parte da antiga quadra 10 para criação do lote 9 , com área de $6.117,13 \mathrm{~m}^{2}$; k) promover o licenciamento das obras caracterizadas como contrapartidas dos investidores privados localizadas fora do perímetro;

L a) Definir o programa de necessidade do Parque Urbano da Lagoa da Sapiranga, no trecho objeta desta OUC; b) Elaborar Projeto Executivo do

d Parque Urbano da Lagoa da Sapiranga, no trecho objeto desta OUC; c)

a Definir as diretrizes de arruamento local para o entorno; d) Estabelecer diretrizes para as áreas não parceladas inseridas na área da OUC; e) Definir

S terrenos a serem objetos de contrapartida da iniciativa privada para

a implantação de trecho; f) Definir equipamentos públicos a serem

p implantados; g) Elaborar projeto e executar obras complementares de infraestrutura urbana (drenagem e pavimentação) necessárias à $r$ implantação do parque; h) Definir o estoque de Potencial Construtivo da a área contida no perímetro da OUC, a ser adquirida onerosamente por n proprietários e empreendedores interessados na operação, segundo as

g regras da Outorga Onerosa do Direito de Construir; i) Aprovar, licenciar e

a fiscalizar os projetos em acordo com esta Lei e que estejam inseridos dentro desta OUC.

- a) Elaborar diagnóstico e plano de ocupação para a área da operação urbana consorciada; b) elaborar plano de arborização para a área desta

ó OUC; c) estabelecer diretrizes para as áreas não parceladas inseridas na área da operação urbana consorciada Osório de Paiva em consonância com esta lei e com a lei de parcelamento do solo em vigor, respeitado as diretrizes do sistema viário; d) definir diretrizes de arruamento para as áreas objeto de loteamentos irregulares; e) definir os equipamentos

d públicos a serem implanta- dos; f) elaborar projeto e executar obras

e complementares de infraestrutura urbana (drenagem e pavimentação); g) indicar a localização dos imóveis a serem doados pela iniciativa privada a

P título de contrapartida, nos termos desta OUC; h) aplicar os instrumentos a do estatuto da cidade, para os terrenos inseridos na área delimitada nesta OUC, onde estes se fizerem necessário; i) aprovar, licenciar e fiscalizar os v projetos inseridos na área desta operação urbana consorciada, de acordo

a com esta lei; j) elaborar e implementar estudos e plano de recuperação ambiental de todo o recurso hídrico da microbacia c- 8.2 , de flora e fauna, contido na poligonal desta OUC;

Fonte: Lei de cada OUC a) complementar, quando necessário, as obras de micro e macrodrenagem iniciadas no programa sanear i, e obras necessárias a melhoria do sistema público de distribuição d'água e coleta de esgoto na área objeto da operação urbana consorciada, bem como a melhoria do sistema de coleta de lixo, com vistas a atender plenamente a demanda gerada pelo empreendimento; b) realizar estudo de impacto de vizinhança, de impacto sobre o trânsito e, se necessário, estudo ambiental; c) requerer o licenciamento ambiental das obras que serão executadas nas áreas em decorrência da implantação desta operação urbana consorciada, junto a secretaria municipal do meio ambiente e controle urbano (SEMAM); d) submeter à apreciação da SEMAM o estudo de impacto de vizinhança e de impacto sobre o trânsito, para análise e aprovação, devendo o último ser levado também a autarquia municipal de trânsito, serviços públicos e cidadania de fortaleza (AMC)

a) Submeter à aprovação do Município os projetos de parcelamento ou de regularização fundiária e de uso e ocupação dos terrenos inseridos na área da OUC; b) Doar ao Município, quando do parcelamento, as áreas destinadas ao sistema viário, Áreas Verdes e Institucionais, em conformidade com as diretrizes estabelecidas pela SEUMA; c) Implantar e executar, às suas expensas, toda a infraestrutura e urbanização das áreas previstas no projeto de parcelamento de acordo com o disposto nesta Lei; d) Efetuar o pagamento dos valores calculados pelo Poder Público relativos à aplicação dos instrumentos previstos nesta Lei; e) Implantar, em parceria com o Poder Público, o reflorestamento das margens dos recursos hídricos inseridos na área da presente OUC; f) Implantar medidas mitigadoras exigidas quando da aprovação de Projetos Especiais; g) Responsabilizar-se pelas medidas compensatórias estabelecidas quando do Licenciamento Ambiental.

a) submeter a aprovação do município os projetos de parcelamento ou de regularização fundiária e de uso e ocupação dos terrenos inseridos na área da operação urbana consorciada; b) doar ao município; quando do parcelamento, as áreas públicas destinadas ao sistema viário, áreas verdes, e institucionais, e fundo de terra e, em caso de reparcelamento, estas áreas na mesma quantidade dos loteamentos originais, em conformidade com as diretrizes estabelecidas pela SEUMA; c) implantar, e executar, as suas expensas, toda a infraestrutura e urbanização da área de acordo com as diretrizes definidas pelo poder público municipal, na forma disposta nesta lei; d) implementar em cooperação com o município, o plano de arborização, incumbindo ao conveniado a manutenção do plantio por um período mínimo de 2 (dois) anos; e) efetuar o pagamento das contrapartidas devidas ao poder público, relativas à aplicação dos instrumentos previstos nesta lei, ou executar as obras dos equipamentos prioritários estabelecidos no plano de ocupação, mediante aprovação do município; f) implantar medidas mitigadoras e compensações ambientais exigidas quando da aprovação de projetos especiais; g) responsabilizar-se pelas medidas compensatórias estabeleci- das quando do licenciamento ambiental; h) implantar, em parceria com o poder público, o reflorestamento das margens dos recursos hídricos inseridos na área da presente OUC. 
VIII. Mapas extras - dinâmica da produção imobiliária de mercado

Figura 119. Concentração de transações de imóveis prediais segundo dados do ITBI (2009 a março de 2016)

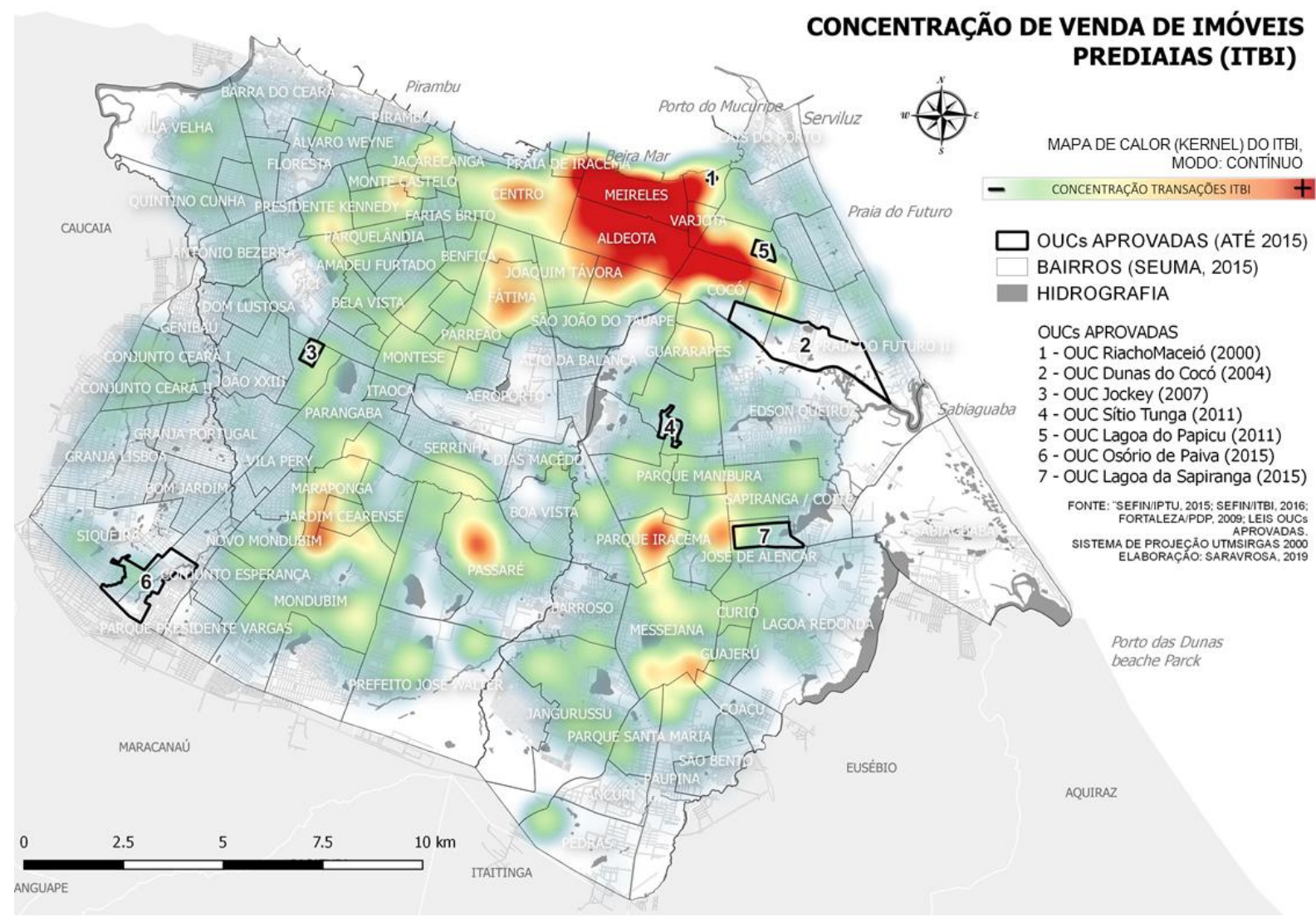

Elaboração: Rosa, 2019. Fonte: FOTALEZA/SEFIN, 2016. Dados do IBI referentes aos anos de 2009 a março de 2016. 
Figura 120. Concentração de transações de imóveis prediais segundo ITBI ao longo da Av. Santos Dumont.

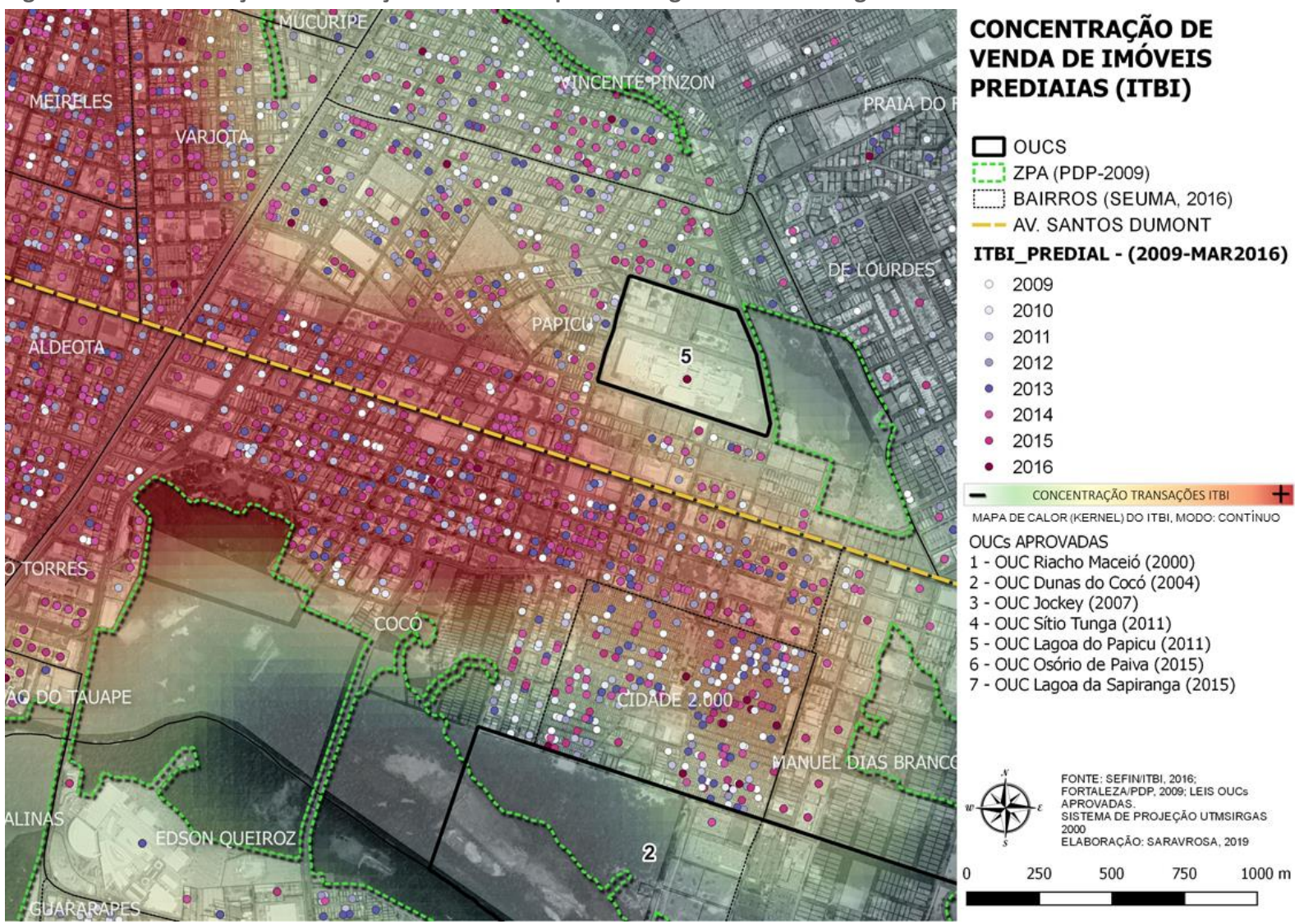

Elaboração: Rosa, 2019. Fonte: FOTALEZA/SEFIN, 2016. Dados do IBI referentes aos anos de 2009 a março de 2016.

Figura 121. Concentração de transações de imóveis prediais segundo ITBI /Av. W. Soares/Luc. Cavalcante

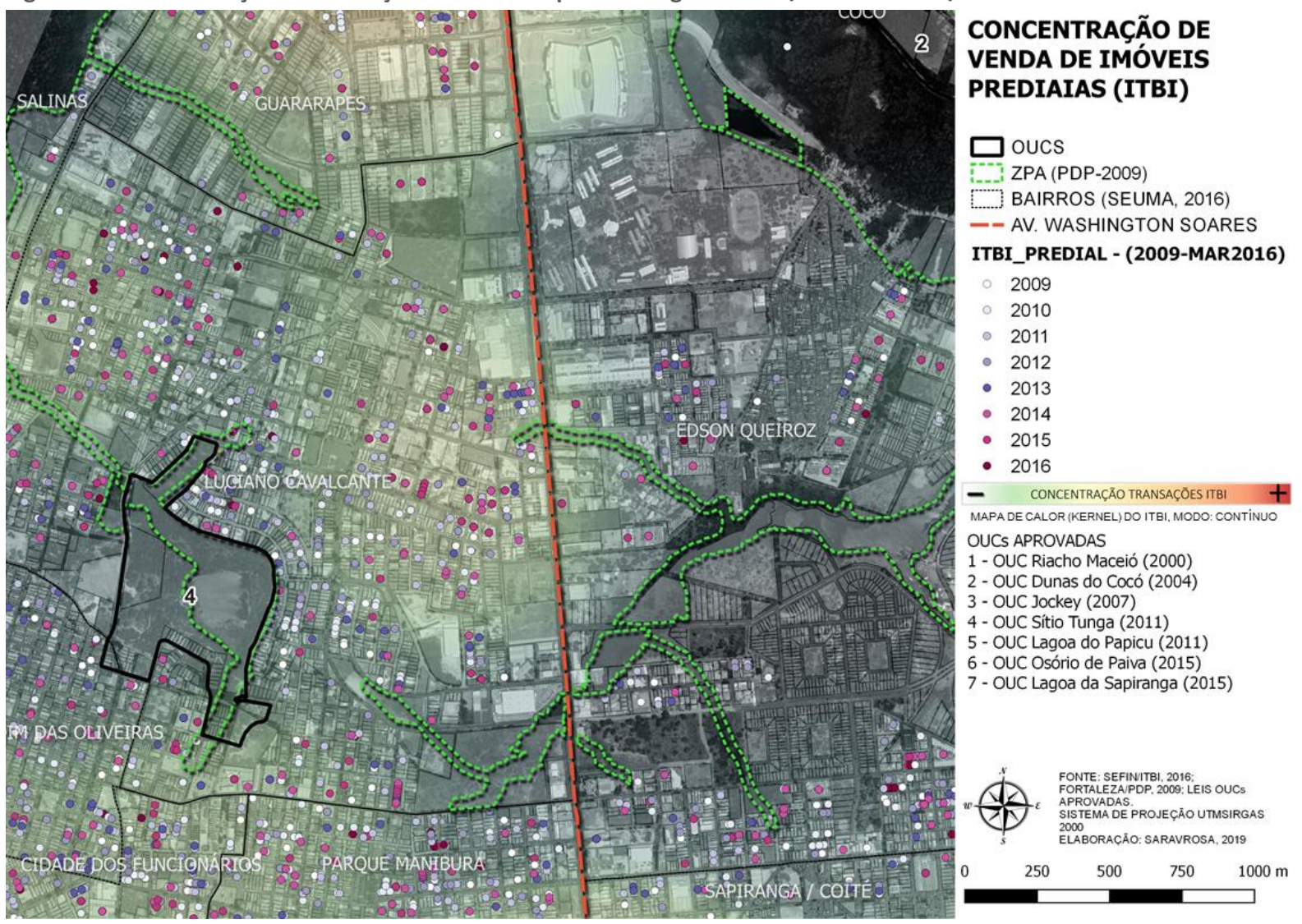

Elaboração: Rosa, 2019. Fonte: FOTALEZA/SEFIN, 2016. Dados do IBI referentes aos anos de 2009 a março de 2016. 
Figura 122. Concentração de transações de imóveis prediais segundo dados do ITBI /Av. W. Soares/Sapiranga e Cambeba.

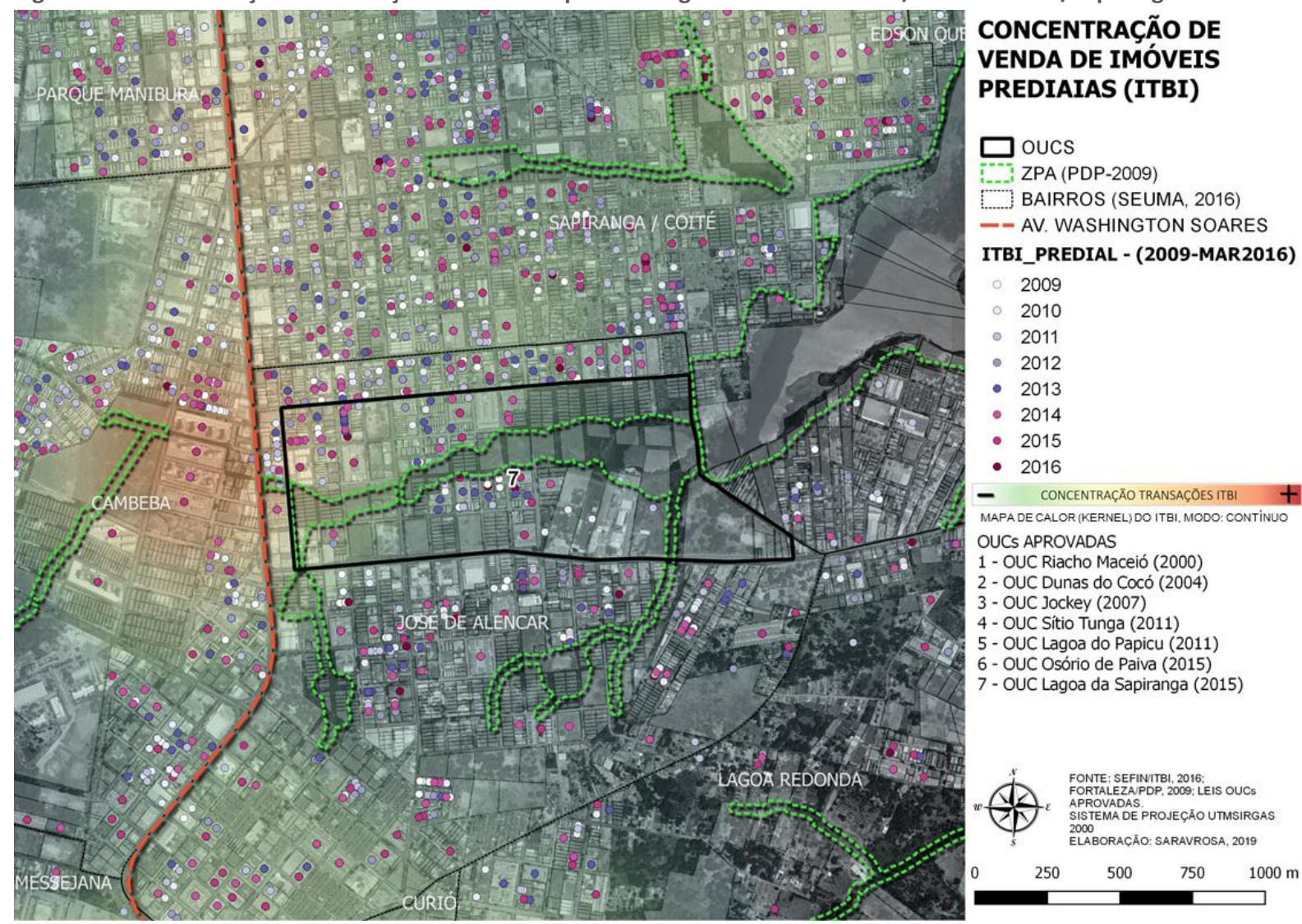

Elaboração: Rosa, 2019. Fonte: FOTALEZA/SEFIN, 2016. Dados do IBI referentes aos anos de 2009 a março de 2016. 
Apêndice 04.

Figura 123. Diferença do limite municipal do PDP-2009 para 2015

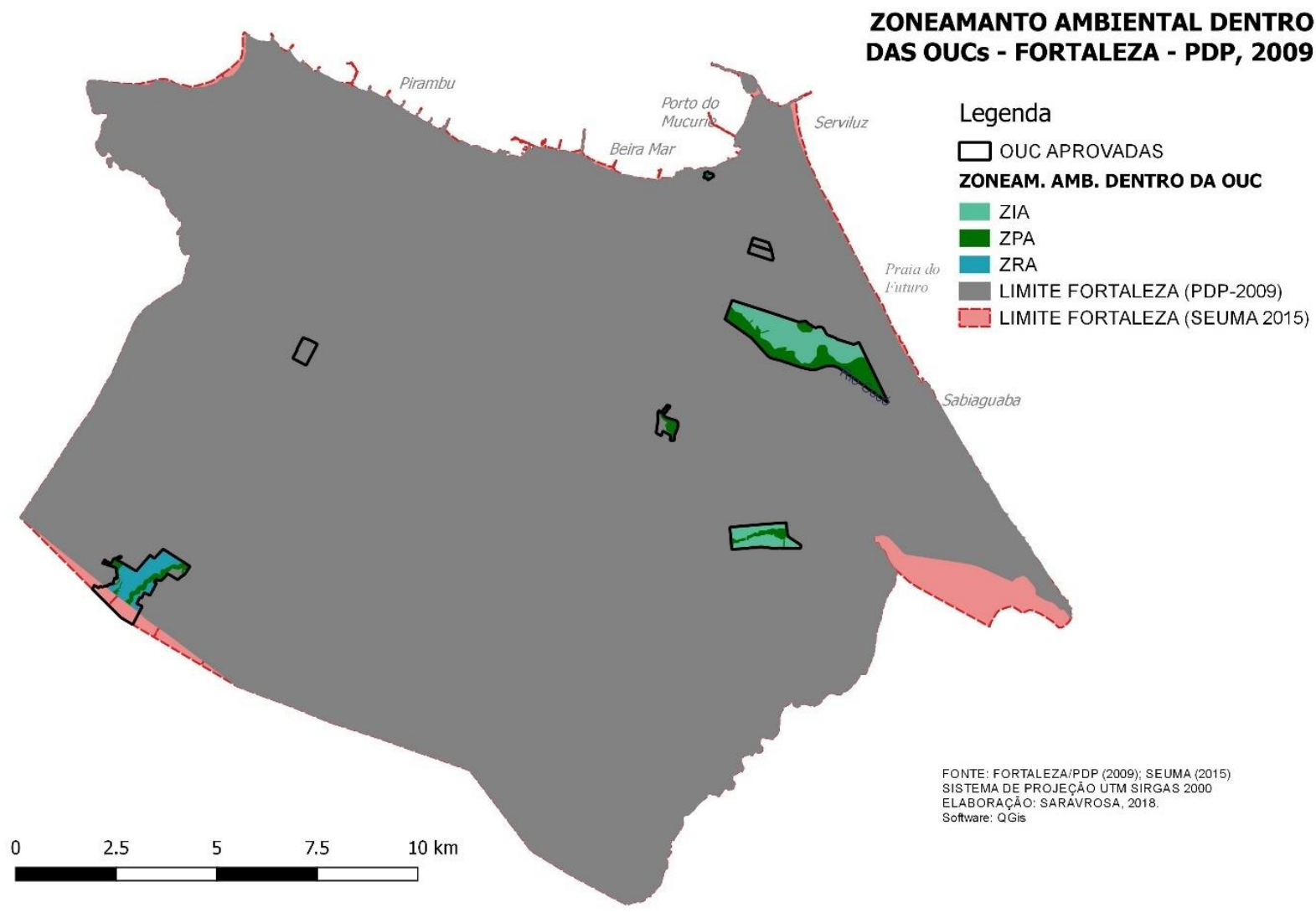


ANEXOS 


\section{Decreton. 426 de 24 de julho de 1845 - Regulamento acerca das missões de catechese e civilização dos índios.}

Fonte:

http://legis.senado.leg.br/legislacao/ListaTextoSigen.action?norma=387574\&id=14390167\&idBinario=15771126\&mime=ap plication/rtf

\section{DECRETO N. 426 - DE 24 DE JULHO DE 1845}

\section{Contém o Regulamento ácerca das Missões de catechese, e civilisação dos ludios.}

Hei por bem, Tendo ouvido o Meu Conselho de Estado, Mandar que se observe o Regulamento seguinte:

Art. 1ํ Haverá em todas as Provincias um Director Geral de Indios, que será de nomeação do Imperador. Compete-lhe:

$\S 1^{\circ}$ Examinar o estado, em que se achão as Aldêas actualmente estabelecidos; as occupações habituaes dos Indios, que nellas se conservão; suas inclinações e propensões; seu desenvolvimento industrial; sua população, assim originaria, como mistiça; e as causas, que tem influido em seus progressos, ou em sua decadencia.

$\S$ 2을 Indagar os recursos que offerecem para a lavoura, e commercio, os lugares em que estão collocadas as Aldêas; e informar ao Governo Imperial sobre a conveniencia de sua conservação, ou remoção, ou reunião de duas, ou mais, em uma só.

$\S 3^{\circ}$ Precaver que nas remoções não sejão violentados os Indios, que quizerem ficar nas mesmas terras, quando tenhão bem comportamento, e apresentem um modo de vida industrial, principalmente de agricultura. Neste ultimo caso, e emquanto bem se comportarem, Ihes será mantido, e ás suas viuvas, o usufructo do terreno, que estejão na posse de cultivar.

§ 4ํIndicar ao Governo Imperial o destino que se deve dar ás terras das Aldêas que tenhão sido abandonadas pelos Indios, ou que o sejão em virtude do $\S 2^{\circ}$ deste artigo. O proveito, que se tirar da applicação dessas terras, será empregado em beneficio dos Indios da Provincia.

§ 5 - Indagar o modo por que grangeão os Indios as terras, que Ihes tem sido dadas; e se estão occupadas por outrem, e com que titulo.

$\S 6^{\circ}$ Mandar proceder ao arrolamento de todos os Indios aldeados, com declaração de suas origens, suas linguas, idades, e profissões. Este arrolamento será renovado todos os quatro annos.

$\S 7$ Inquerir onde ha Indios, que vivão em hordas errantes; seus costumes, e linguas; e mandar Missionarios, que solicitará do Presidente da Provincia, quando já não estejão á sua disposição, os quaes lhes vão pregar a Religião de Jesus Christo, e as vantagens da vida social.

§ 8을 Indagar se convirá fazel-os descer para as Aldêas actualmente existentes, ou estabelecel-os em separado; indicando em suas informações ao Governo Imperial o lugar onde deve assentar-se a nova Aldêa.

§ 9ํㅡㄹiligenciar a edificação de Igrejas e de casas para a habitação assim dos Empregados da Aldêa, como dos mesmos Indios.

$\S 10$. Distribuir pelos Directores das Aldêas, e pelos Missionarios, que andarem nos lugares remotos, os objectos que pelo Governo Imperial forem destinados para os Indios, assim para a agricultura, ou para o uso pessoal dos mesmos, como mantimentos, roupas, medicamentos, e os que forem proprios para attrahir-lhes a attenção, excitar-lhes a curiosidade, e despertar-Ihes o desejo do trato social; requisitando-os do Presidente da Provincia, segundo as Instrucções que tiver do Governo Imperial. 
$\S$ 11. Propôr ao Presidente da Provincia a demarcação, que devem ter os districtos das Aldêas, e fazer demarcaras terras que, na fórma do $\S 15$ deste artigo e do $\S 2^{\circ}$, forem dadas aos Indios. Se a Aldêa já estiver estabelecida, e existir em lugar povoado, o districto não se estenderá além dos limites das terras originariamente concedidas á mesma.

$\S 12$. Examinar quaes são as Aldêas que precisão de ser animadas com plantações em commum, e determinar a porção de terras que deve ficar reservada para essas plantações, assim como a porção das que possão ser arrendadas, quando, attenta ainda a pequena população, não possão os Indios aproveital-as todas.

$\S 13$. Arrendar por tres annos as terras, que para isso forem destinadas, procedendo ás mais miudas investigações, sobre o bom comportamento dos que as pretenderem, e sobre as posses que tem. Nestes arrendamentos não se comprehende a faculdade de derrubar matos, para o que será necessario o consenso do Presidente, que será expresso no contracto, com declaração dos lugares onde os possão derrubar.

$\S 14$. Examinar quaes são as Aldêas, onde, pelo seu adiantamento, se possão aforar terras para casas de habitação; informar ao Governo Imperial com o quantitativo do fôro; e aforal-as segundo as Instrucções, que receber. Não são permittidos aforamentos para cultura.

$\S 15$. Informar ao Governo Imperial ácerca daquelles Indios, que, por seu bom comportamento e desenvolvimento industrial, mereção se lhes concedão terras separadas das da Aldêa para suas grangearias particulares. Estes Indios não adquirem a propriedade dessas terras, senão depois de doze annos, não interrompidos, de boa cultura, o que se mencionará com especialidade nos relatorios annuaes; e no fim delles poderão obter Carta de Sesmaria. Se por morte do concessionario não se acharem completos os doze annos, sua viuva, e na sua falta seus filhos, poderão alcançar a sesmaria, se, além do bom comportamento, e continuação de boa cultura, aquella preencher o tempo que faltar, e estes a grangearem pelo duplo deste tempo, com tanto que este nem passe de oito annos, e nem seja menos de quinze o das diversas posses.

$\S 16$. Dar licença ás pessoas que quizerem ir negociar nas Aldêas novamente creadas, com estabelecimento ou fixo, ou volante; e retiral-a, quando o julgar conveniente. Quanto ás que já estão estabelecidas, examinará quaes as que estão nas circumstancias de precisarem desta protecção; e as declarará sujeitas a esta disposição, com dependencia de approvação Imperial.

$\S$ 17. Representar ao Presidente da Provincia a necessidade que possa haver de alguma força militar, que proteja as Aldêas, a qual poderá ter um Regulamento especial.

§ 18. Propor á Assembléa Provincial a creação de Escolas de primeiras Letras para os lugares, onde não baste o Missionario para este ensino.

$\S 19$. Empregar todos os meios licitos, brandos, e suaves, para atrahir Indios ás Aldêas; e promover casamentos entre os mesmos, e entre elles, e pessoas de outra raça.

$\S$ 20. Esmerar-se em que Ihes sejão explicadas as maximas da Religião Catholica, e ensinada a doutrina Christã, sem que se empregue nunca a força, e violencia; e em que não sejão os pais violentados a fazer baptisar seus filhos, convindo attrahil-os á Religião por meios brandos, e suasorios.

$\S 21$. Cuidar na introducção da vaccina nas Aldêas, e facilitar-Ihes todos os soccorros nas epidemias.

$\S 22$. Corresponder-se com os Missionarios, de quem receberá todos os esclarecimentos para a catechese e civilisação dos Indios, providenciando no que couber em suas faculdades; e com todas as Autoridades, por quem possa ser auxiliado.

§ 23. Vigiar na segurança, e tranquillidade das Aldêas, e seus districtos, requerendo, ou constituindo procurador para requerer perante as Justiças, e requisitando das Autoridades competentes as providencias necessarias.

$\S 24$. Indagar se nas Aldêas, e seus districtos, morão pessoas de caracter rixoso, e de máos costumes, ou que introduzão bebidas espirituosas, ou que tenhão enganado aos Indios com lesão enorme; e fazel-as expulsar até cinco leguas fóra dos limites dos districtos.

$\S 25$. Informar-se dos meios de subsistencia, que tem as Aldêas, para providenciar que não sobrevenha alguma fome, que seja causa de que os Indios abalem para os matos, ou se derramem pelas Fazendas, e Povoações.

$\S 26$. Promover o estabelecimento de officinas de Artes mecanicas, com preferencia das que se prestão ás primeiras necessidades da vida; e que sejão nellas admittidos os Indios, segundo as propensões, que mostrarem.

$\S 27$. Indagar quaes as producções do lugar de mais facil cultura, e de mais proveito; esmerando-se em fazer adoptar aquelle genero de trabalho, e modo de vida, que offereça mais facilidade, e a que os Indios mais promptamente se acostumem. 
§ 28. Exercer toda a vigilancia em que não sejão os Indios constrangidos a servir a particulares; e inquerir se são pagos de seus jornaes, quando chamados para o serviço da Aldêa, ou qualquer serviço publico; e em geral que sejão religiosamente cumpridos de ambas as partes os contractos, que com elles se fizerem.

§ 29. Vigiar que não sejão os Indios avexados com exercicios militares, procurando que se lhes dê aquella instrucção, que permittir o seu estado de civilisação, suas occupações diarias, e seus habitos e costumes, os quaes não devem ser aberta, e desabridamente contrariados.

$\S 30$. Fiscalizar as rendas das Aldêas, quaesquer que sejão as suas fontes; e exercer vigilante inspecção sobre as producções das lavouras, pescas, e extracções de drogas, e de outro qualquer ramo de industria, e em geral sobre todos os objectos destinados para o uso, e consumo das Aldêas.

$\S 31$. Applicar os dinheiros, e outros quaesquer objectos, segundo as necessidades das Aldêas, e na conformidade das ordens do Governo Imperial, dando uma conta circumstanciada todos os annos, e todas as vezes que uma urgente necessidade o obrigue a fazer alguma despeza extraordinaria, da applicação, que houver resoluto.

$\S 32$. Servir de Procurador dos Indios, requerendo, ou nomeando Procurador para requerer em nome dos mesmos perante as Justiças, e mais Autoridades.

§ 33. Propôr ao Presidente da Provincia o Director da Aldêa, o Thesoureiro, Almoxarife e o Cirurgião, preferindose para estes empregos os casados aos solteiros; suspender os tres ultimos, e em geral a todos os que estão empregados no serviço das Aldêas, nomeando interinamente quem os substitua, e dando parte immediatamente ao Presidente, ou ao Director da Aldêa, segundo pertencer a nomeação ao primeiro, ou ao segundo.

$\S 34$. Organizar a Tabella dos vencimentos dos Pedestres, e dos salarios dos officiaes de officios, que estiverem ao serviço das Aldêas; e leval-a ao conhecimento do Governo Imperial para sua approvação.

§ 35. Approvar, e mandar pôr em execução provisoriamente a Tabella, organizada pelos Directores das Aldêas, dos jornaes, que devem ganhar os Indios, que forem chamados para o serviço das mesmas, ou qualquer outro serviço publico; levando-a ao conhecimento do Governo Imprial para sua final approvação.

$\S 36$. Propor ao Governo Imperial os Regulamentos especiaes para o regimes das Aldêas, e as instrucções convenientes para o desenvolvimento de sua industria; tendo attenção ao estado de civilisação dos Indios, sua indole, e caracter; ás necessidades dos lugares, em que se acharem ellas estabelecidas; ás produções do Paiz, e ás proporções, que o mesmo offerece para o seu adiantamento moral, e material.

§ 37. Apresentar todos annos ao Governo Imperial o Orçamento da receita e despeza das Aldêas, e um Relatorio circumstanciado do seu estado em população, instrucção, e industria, com exposição miuda da execução das disposições deste Regulamento; exigindo dos Directores das Aldêas outros iguaes, que o habilitem a esclarecer o Governo sobre os progressos, ou decadencia das mesmas, e as causas, que para isso tem concorrido; e apontando as providencias, que convenha ser adoptadas.

§ 38. Expor ao Governo Imperial os inconvenientes, que tenha encontrado na execução deste Regulamento, e de outros, que houver de fazer; indicando as medidas, que julgar apropriadas para se conseguir o grande fim da catechese, e civilisação dos Indios.

Art. 2ํHaverá em todas as Aldêas um Director, que será de nomeação do Presidente da Provincia, sobre proposta do Director Geral. Compete-lhe:

$\S 1^{\circ}$ Informar ao Director Geral a necessidade, que possa haver de trabalhos em commum, e a natureza destes; assim como sobre a parte dos productos desses trabalhos, que deva reservada para o uso commum dos Indios.

$\S 2^{\circ}$ Designar as terras, que devem ficar reservadas para as plantações em comum, depois de determinada a porção, que o deve ser pelo Director Geral; assim como as que devem ficar para as plantações particulares dos Indios, e as que possão ser arrendadas, art. $1^{\circ} \S 2^{\circ}$.

§ 3ํㅡㄴ Inspeccionar essas plantações ou outros quaesquer trabalhos da Aldêa; e procurar consumo aos seus productos, depois de feitas as reservas necessarias.

$\S 4^{\circ}$ Nomear quem substitua o Thesoureiro, ou Almoxarife, nos impedimentos imprevistos, e de caso repentino.

$\S 5^{\circ}$ Nomear os Indios para as plantações, ou outros trabalhos em commum, ou para qualquer serviço publico; procurando repartir o trabalho com igualdade, e ir de accordo, quanto ser possa, com o Maioral dos mesmos Indios.

$\S 6$ 6azer entregar ao Thesoureiro, ou Almoxarife, os productos dos trabalhos dos Indios, os objectos obtidos em troca dos que forem vendidos, o dinheiro pertencente á Aldêa, qualquer que seja sua origem, e em geral todos os objectos destinados para a aldêa. 
$\S 7^{\circ}$ Distribuir os objectos, que forem applicados pelo Director Geral para os trabalhos communs, e particulares dos Indios; e os que forem destinados para animar, e premiar os Indios já aldeados, e attrahir os que ainda o não estejão.

$\S 8^{\circ}$ Applicar os dinheiros, e mais objectos, segundo as determinações do Director Geral; podendo, em casos urgentes, gastar, sob sua responsabilidade, do dinheiro, que houver em caixa, até a quantia de cem mil réis, de que dará conta ao mesmo Director para sua approvação.

§ 9o Nomear, suspender, e despedir os Pedestres, e officiaes de officios, que estiverem ao serviço da Aldéa, e determinar o serviço, que devem fazer.

$\S 10$. Vigiar sobre a segurança, e tranquilidade da Aldêa, e seu districto; podendo, em caso, menores, reter em prisão, até seis dias, o que a perturbar, sendo Indio; e não sendo, fazel-o expulsar para fóra da Aldêa, e até do seu districto: e em casos maiores, prender e remetter ás Justiças ordinarias com todas as indicações que esclareção a verdade.

$\S 11$. Requerer ás Autoridades policiaes contra os que, tendo sido expulsos em virtude do paragrapho antecedente, ou do $\S 24$ do art. 1丷, se estabelecerem dentro dos limites declarados no Mandado de despejo, ou não queirão obedecer a este.

$\S 12$. Ter debaixo de suas ordens a força militar que se houver de mandar collocar na Aldêa, e seu districto; representando a necessidade, que della possa haver, ao Director Geral, conformando-se com as instrucções que receber e com o Regulamento especial do $\S 17$ do art. $1^{\circ}$.

$\S 13$. Alistar os Indios, que estiverem em estado de prestar algum serviço militar, e acostumal-os a alguns exercicios, animando com dadivas aos que mostrarem mais gosto e zelo pelo serviço, e tendo todo o cuidado em que não se desgostem por excesso de trabalho. Dará uma conta circumstanciada ao Director Geral das disposições que encontrar para ser levada ao conhecimento, do Governo Imperial, que resolverá sobre, a opportunidade de se crearem algumas Companhias, as quaes poderão ter uma organização particular.

§ 14. Procurar que sejão demarcadas as terras dadas aos indios, e proceder á demarcação das porções das mesmas, que, em virtude deste Regulamento, tenhão de ser demarcadas dentro dos seus limites.

$\S 15$. Esmerar-se em que as festas tanto civis como religiosas se fação com a maior pompa, e apparato, que ser possa; procurando introduzir nas Aldêas o gosto da musica instrumental.

$\S 16$. Servir de Procurador dos Indios, podendo nomear quem faça as suas vezes para requerer perante as Justiças, e outras Autoridades.

$\S 17$. Dar parte todos os trimestres ao Director Geral dos acontecimentos mais notaveis na Aldêa, e fazer um relatorio annual do estado em que se ela acha, com declaração da execução, que tem tido as disposições deste Regulamento, e com o orçamento da receita e despeza para o anno seguinte.

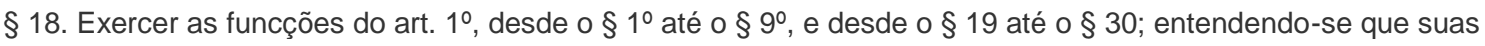
faculdades são restrictas á Aldêa de que é Director; e que em lugar do Presidente, ou Governo Imperial, deve dirigir-se ao Director Geral da Provincia.

\section{Art. 3ำ Ao Thesoureiro compete:}

$\S 1^{\circ}$ Receber os dinheiros pertencentes a Aldêa, qualquer que seja a origem d'onde provenha, recolhendo-os em uma caixa, de que o Director da Aldêa terá uma chave; assim como receber todos os objectos, que forem destinados para o serviço, e uso da Aldêa.

$\S 2^{\circ}$ Ter a seu cargo a escripturação, e contabilidade, para o que terá os livros proprios, fornecidos pela Fazenda Publica.

§ 3ํA Ajudar ao Director da Aldêa na sua correspondencia, particularmente na confecção dos mappas estatisticos.

$\S 4^{\circ}$ Fazer os pagamentos, e entregar os objectos, que estiverem debaixo de sua guarda, segundo as ordens que receber do Director Geral, e as determinações do Director da Aldêa.

$\S 5^{\circ}$ Dar todos os annos uma conta circumstanciada ao Director Geral de todos os dinheiros e objectos que houver recebido; dos empregos, que fez; e das ordens que os autorizárão.

§ 60 Escrever em todos os actos, que houverem de ser remettidos ás Justiças, e nos termos das demarcações das porções de terras, a que houver de proceder o Director da Aldêa dentro dos limites das terras da Aldêa.

$\S 7^{0}$ Substituir o Director da Aldêa em seus impedimentos imprevistos, e de caso repentino dando parte immediatamente ao Director Geral para prover interinamente. 
Art. 4 Quando o estado da Aldêa não exiba um Tesoureiro, um Almoxarife receberá todos os objectos que forem destinados para a Aldêa, e os entregará segundo as ordens do Director da mesma, dando annualmente conta ao Director Geral; e o Director da Aldêa receberá os dinheiros que á mesma pertencerem.

Art. 5 $\mathrm{O}$ Cirurgião tem a seu cargo a botica, e os instrumentos cirurgicos; e cuidará da enfermaria com um Enfermeiro, que será um dos Pedestres, que proporá ao Director da Aldêa.

Art. 6 Haverá um Missionario nas Aldêas novamente creadas, e nas que se acharem estabelecidas em lugares remotos, ou onde conste que andão Indios errantes. Compete-lhe:

$\S 1^{0}$ Instruir aos Indios nas maximas da Religião Catholica, e ensinar-Ihes a Doutrina Christã.

$\S 2^{\circ}$ Servir de Parocho na Aldêa, e seu districto, emquanto não se crear parochia.

$\S 3^{\circ}$ Fazer o arrolamento de todos os Indios pertencentes á Aldêa, e seu districto, com declaração dos que morão nas Aldêas, e fóra dellas; dos baptisados, idades e profissões; e dos nascimentos, e obitos, e casamentos: para o que Ihe serão fornecidos os livros pelo Bispo Diocesano, pela caixa das Obras Pias.

§ 4ํㅡㄹ parte ao Bispo Diocesano, por intermedio do Director Geral da Provincia, do estado espiritual da Aldêa; representando as necessidades que encontrar e apontando as providencias que the parecerem mais proprias para occorrer a ellas.

§ 5ำ Representar ao Director Geral, por intermedio do da Aldêa, a necessidade que possa haver de outro Missionario, que o ajude, principalmente se houver nas vizinhanças Indios errantes, que seja mister chamar á Religião e sociedade.

$\S 6$ Ensinar a ler, escrever e contar aos meninos, e ainda aos adultos, que sem violencia se dispuzerem a adquirir essa instrucção. substituir

$\S 7^{\circ}$ Substituir ao Director da Aldêa, quando esteja impedido o Thesoureiro, e nos casos, em que este o póde

Art. $7^{\circ}$ A creação de Thesoureiro, Almoxarife, cirurgião, dependerá do estado, em que se achar a Aldêa, e da sua importancia; e do lugar, em que estiver collocada: sobre o que o Director Geral informará ao Governo Imperial para resolver. O Cirurgião poderá servir de Thesoureiro, e as circumstancias o permittirem. Seus vencimentos, e os dos Missionarios serão fixados segundo as informações dos Directores Geraes.

Art. 8 A creação dos Pedestres e officiaes de officios; seu numero, salario, organização, e a natureza dos officios, dependeráõ das circumstancias locaes, segundo as informações dos Directores Geraes.

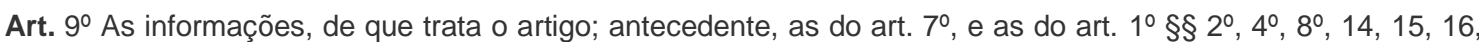
34, 35, 36, e 37, serão transmittidas ao Governo Imperial por intermedio do Presidente da Provincia, que as acompanhará com as observações convenientes.

Art. 10. Nos impedimentos do Director Geral o Presidente da Provincia nomeará quem o substitua; e nos impedimentos do Director da Aldêa, que não serão imprevistos, e de caso repentino, fará a nomeação o Director Geral.

Art. 11. Emquanto servirem, terão a graduação honoraria o Director Geral de Brigadeiro, o Director da Aldêa de Tenente Coronel, e o Thesoureiro de Capitão; e usaráõ do uniforme, que se acha estabelecido para o Estado Maior do Exercito.

José Carlos Pereira de Almeida Torres, Conselheiro de Estado, Ministro e Secretario de Estado dos negocios do Imperio, assim o tenha entendido e faça executar despachos necessarios. Palacio do Rio de Janeiro em vinte e quatro de Julho de mil oitocentos quarenta e cinco; vigesimo quarto da Independencia e do Imperio.

Com a Rubrica de Sua Magestade o Imperador.

José Carlos Pereira de Almeida Torres. 
II. Planta XXXXXXXXXXXX

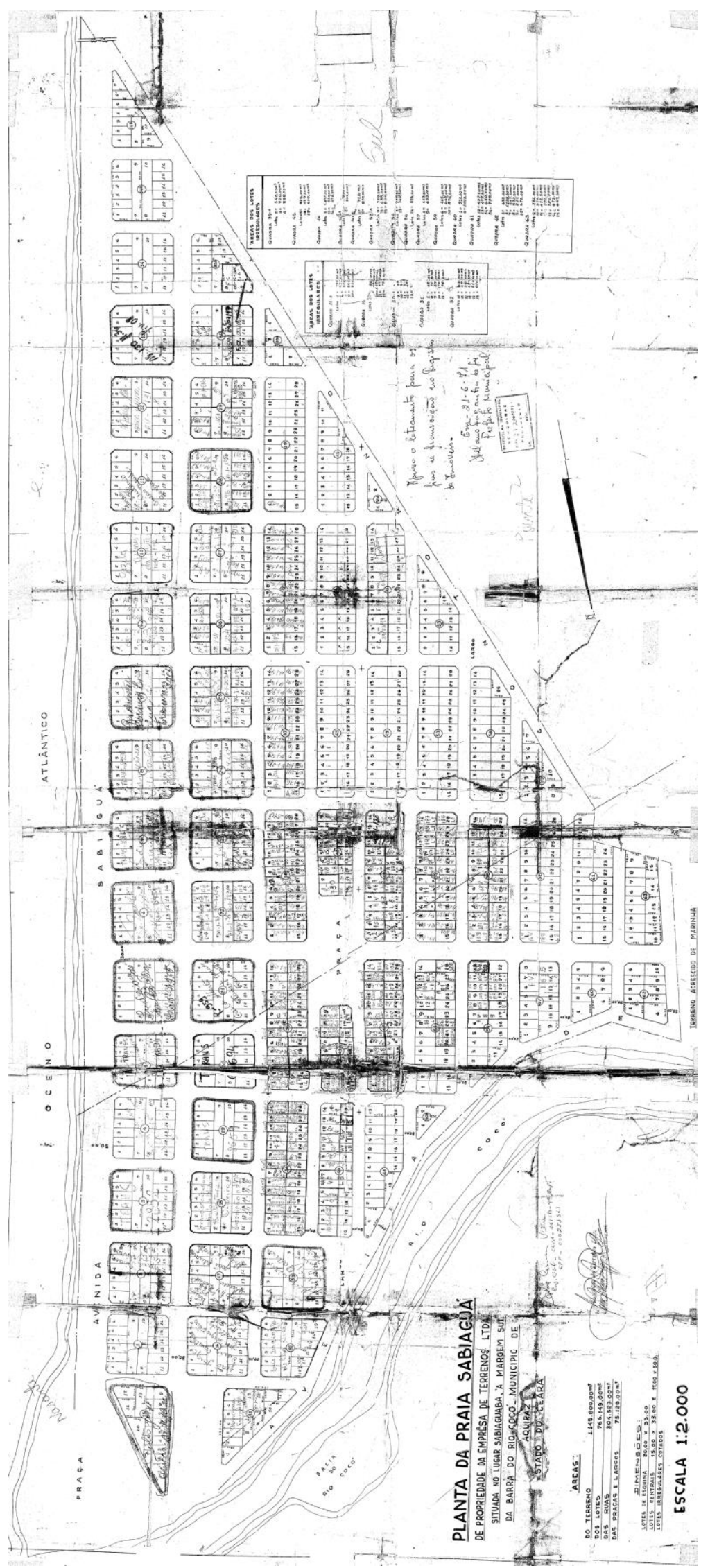


III. Planta XXXX

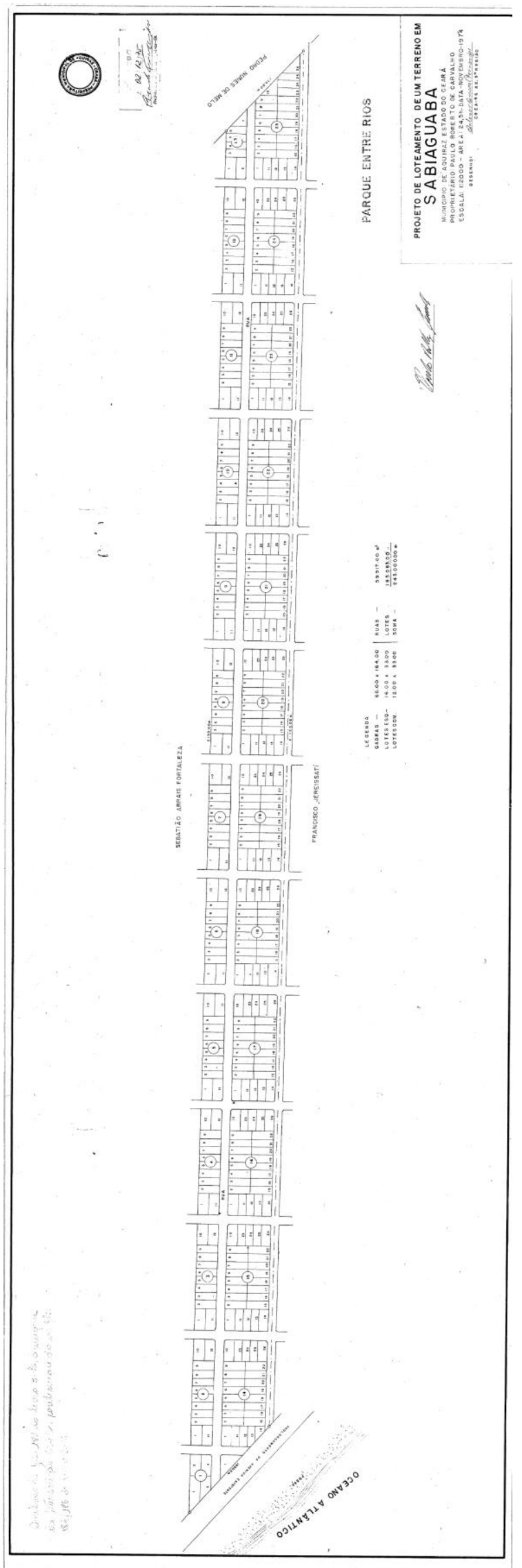




\section{OUCs e macrozoneamento ambiental do PDP-2009 atualizado e disponibilizado pela SEUMA em 2015}

Figura 124. Localização das OUC frente ao zoneamento ambiental do município segundo Zoneamento do PDP-2009 atualizado pela SEUMA em 2015.

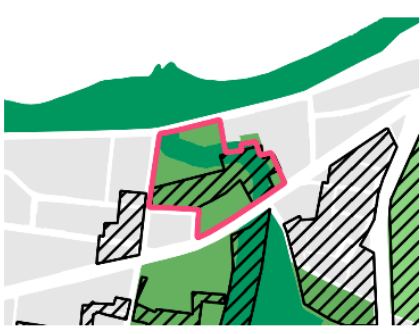

OuC Riacho Maceió

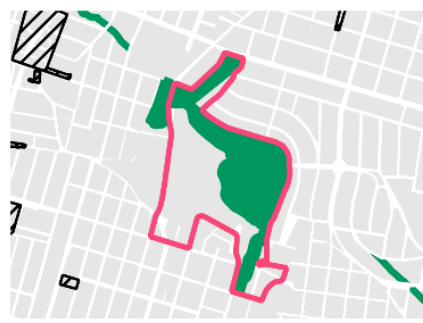

OuC Sítio Tunga

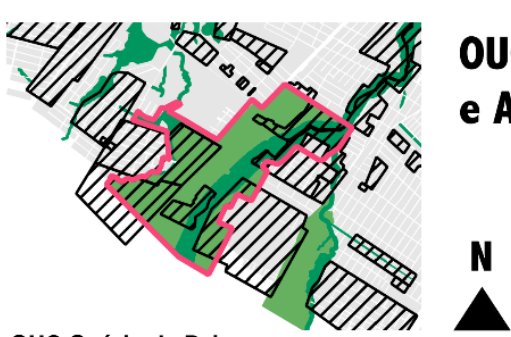

ouc Osório de Paiva

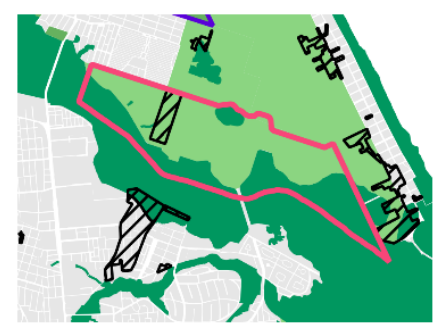

OuC Dunas do Cocó

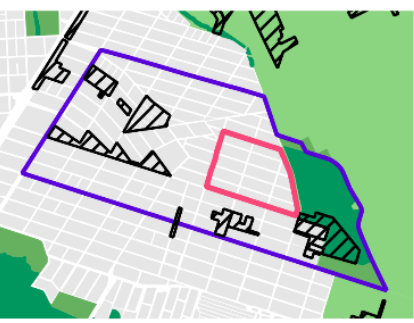

OUC Lagoa do Papicu

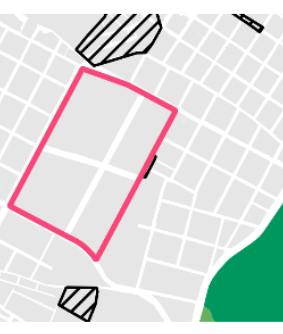

ouc Jockey Clube

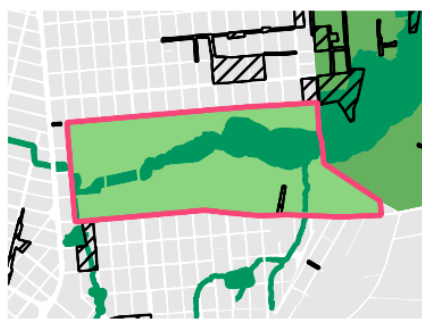

ouc Sapiranga

\section{OUCs - Macrozoneamento ambiental}

\section{e Assentamentos Precários}

Fonte: SEUMA (2015); PLHIS (2013); SEFIN (2015); LEHAB (2016)

Sistema de projeção: SIRGAS 2000_24S Realização: LEHAB/Holanda (30/out/2017)

\section{LEGENDA}

Zoneamento Ambiental

ZIA

ZPA

ZRA

Quadras

Z7 Assentamentos precários

$\square$ Limite das OUCs

$\square$ Límite expandido das OUCs

Fonte: HOLANDA; ROSA, 2017. SEUMA, 2015/PDP, 2009; leis de criação das Operações Urbanas. Elaboração: HOLANDA/LEHAB, 2016. Mapa elaborado a partir do zoneamento do Plano Diretor Participativo (Lei № 62 de 2009), segundo base de dados disponibilizada pela Secretaria de Urbanismo e Meio Ambiente, SEUMA, em 2015. 
Figura 125. IBI por valor e outorgas

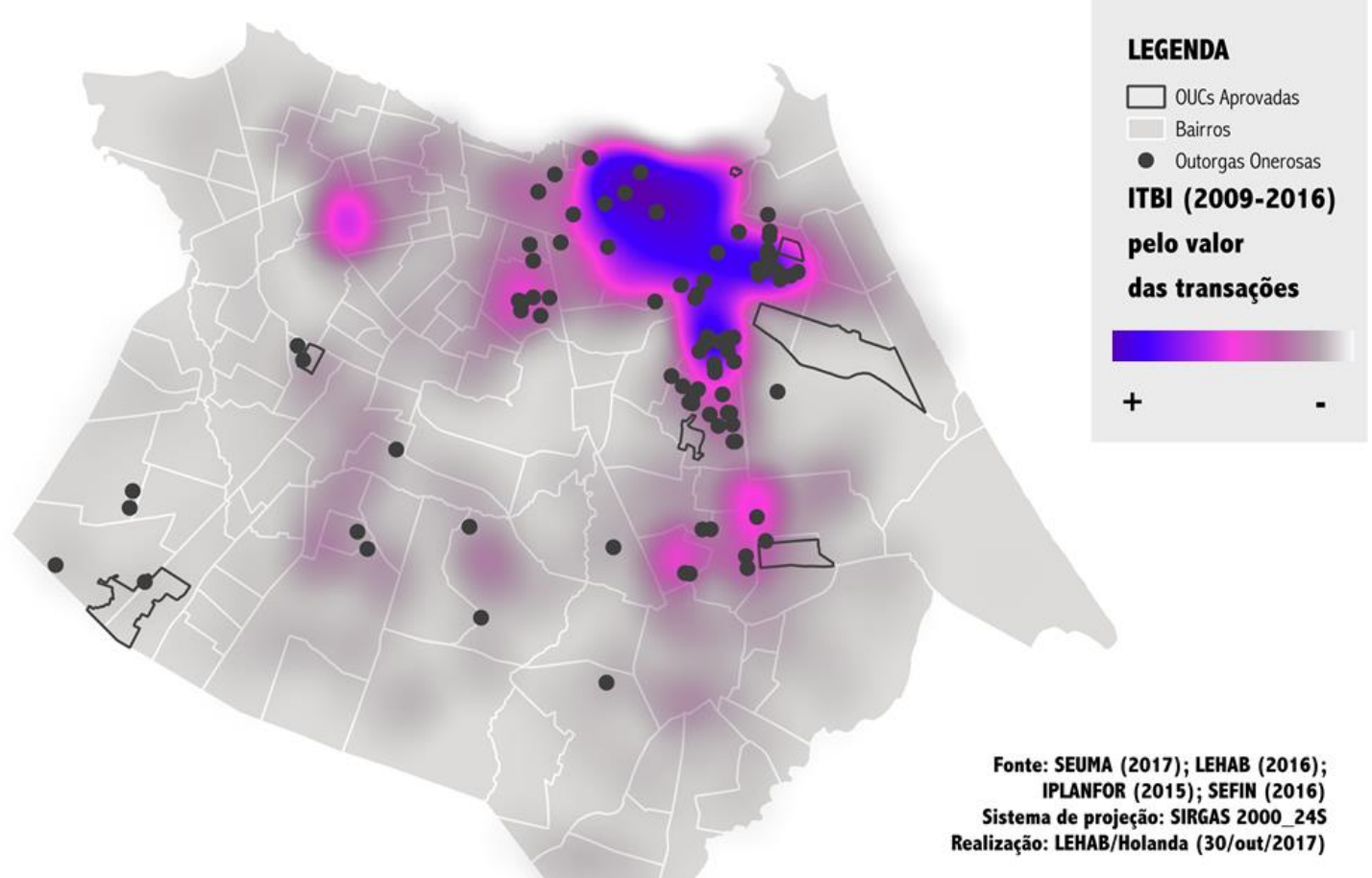

N

0 aquecimento do mercado imobiliário 